WSRC-TR-94-0159

Rev. 1

\title{
Dynamic Compaction Facility Test Report (U)
}

March 1994

Scott R. McMullin

Scott A. Dendler

Environmental Restoration Department

Westinghouse Savannah River Company

Savannah River Site

Aiken, SC 29808

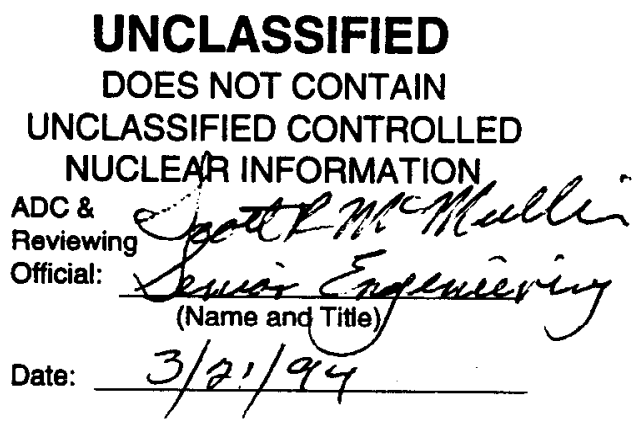

Prepared for the U. S. Department of Energy under Contract No. DE-AC09-89R18035. 
This document was prepared in conjunction with work accomplished under Contract No.

DE-AC09-89SR18035 with the U.S. Department of Energy.

\section{DISCLAIMER}

This report was prepared as an account of work sponsored by an agency of the United States Government. Neither the United States Government nor any agency thereof, nor any of their employees, makes any warranty, express or implied, or assumes any legal liability or responsibility for the accuracy, completeness, or usefulness of any information, apparatus, product or process disclosed, or represents that its use would not infringe privately owned rights. Reference herein to any specific commercial product, process or service by trade name, trademark, manufacturer, or otherwise does not necessarily constitute or imply its endorsement, recommendation, or favoring by the United States Government or any agency

thereof. The views and opinions of authors expressed herein do not necessarily state or reflect those of the United States Government or any agency thereof.

This report has been reproduced directly from the best available copy.

Available for sale to the public, in paper, from: U.S. Department of Commerce, National Technical Information Service, 5285 Port Royal Road, Springfield, VA 22161, phone: (800)

553-6847, fax: (703) 605-6900, email: orders@ntis.fedworld.gov online ordering: http://www.ntis.gov/ordering.htm

Available electronically at http://www.doe.gov/bridge

Available for a processing fee to U.S. Department of Energy and its contractors, in paper, from: U.S. Department of Energy, Office of Scientific and Technical Information, P.O. Box 62, Oak Ridge, TN 37831-0062, phone: (865 ) 576-8401, fax: (865) 576-5728, email: reports@ adonis.osti.gov 


\section{Table of Contents}

Executive Summary $\ldots \ldots \ldots \ldots \ldots \ldots \ldots \ldots \ldots \ldots \ldots \ldots \ldots \ldots \ldots$

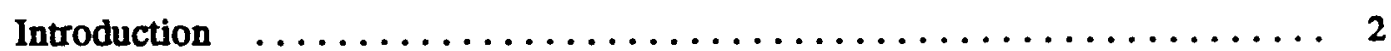

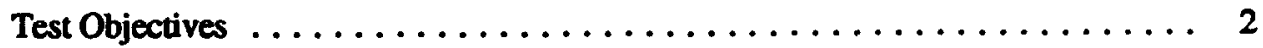

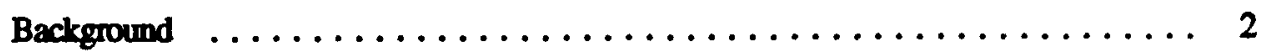

Organizational Elements $\ldots \ldots \ldots \ldots \ldots \ldots \ldots \ldots \ldots \ldots \ldots \ldots \ldots \ldots \ldots \ldots$

Construction $\ldots \ldots \ldots \ldots \ldots \ldots \ldots \ldots \ldots \ldots \ldots \ldots \ldots \ldots \ldots \ldots \ldots, 4$

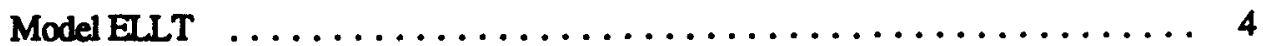

Kaolin Clay Cap $\ldots \ldots \ldots \ldots \ldots \ldots \ldots \ldots \ldots \ldots \ldots \ldots \ldots \ldots \ldots \ldots$

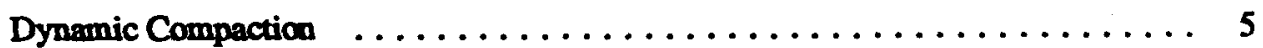

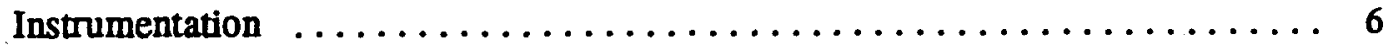

Characterization and Comparison of Kaolin Clay Caps ............ 6

Impact Velocity Survey and Energy Measurements $\ldots \ldots \ldots \ldots \ldots \ldots$

Vibratory Ground Motion Monitoring Program .............. 7

Inelastic Deformation Monitoring $\ldots \ldots \ldots \ldots \ldots \ldots \ldots \ldots \ldots$

Post - Compaction Infiltration Monitoring $\ldots \ldots \ldots \ldots \ldots \ldots \ldots \ldots$

Data Evaluation and Observations $\ldots \ldots \ldots \ldots \ldots \ldots \ldots \ldots \ldots \ldots$

Non - Invasive Characterization of the DCF vs. MWMF Kaolin Clay Caps . . . . 9

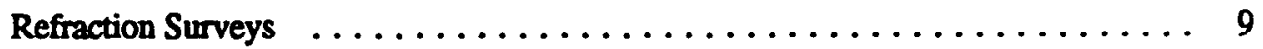

Spectral Analysis of Shear Wave Analysis $\ldots \ldots \ldots \ldots \ldots \ldots \ldots \ldots \ldots$

Impact Velocity Calibration Results $\ldots \ldots \ldots \ldots \ldots \ldots \ldots \ldots \ldots \ldots$

Natural Soil Strong Motion Sensor Baseline $\ldots \ldots \ldots \ldots \ldots \ldots \ldots \ldots$

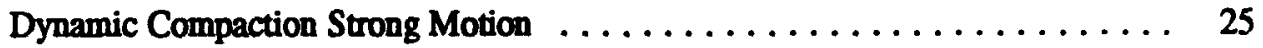

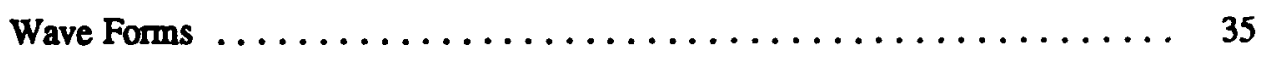

Inelastic Deformation Test Results $\ldots \ldots \ldots \ldots \ldots \ldots \ldots \ldots \ldots \ldots$

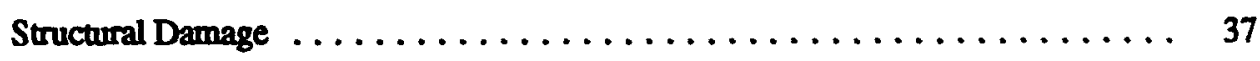

Hydraulic Conductivity Measurements $\ldots \ldots \ldots \ldots \ldots \ldots \ldots \ldots \ldots \ldots, 38$

Buried Waste Compaction Evaluation $\ldots \ldots \ldots \ldots \ldots \ldots \ldots \ldots \ldots \ldots$

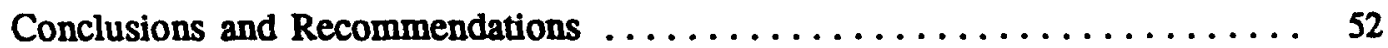

Non-Invasive Characterization $\ldots \ldots \ldots \ldots \ldots \ldots \ldots \ldots \ldots \ldots \ldots \ldots \ldots$

Vibratory Impacts and Buffer $\ldots \ldots \ldots \ldots \ldots \ldots \ldots \ldots \ldots \ldots \ldots \ldots$

Hydraulic Conductivity of Kaolin Clay $\ldots \ldots \ldots \ldots \ldots \ldots \ldots \ldots \ldots$

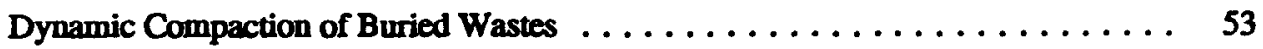

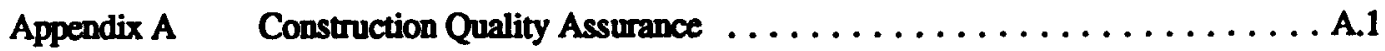

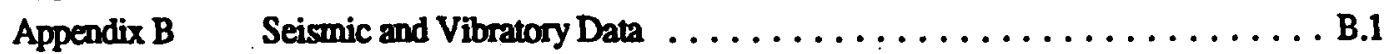

B.1 Spectral Analysis of Shear Wave Data $\ldots \ldots \ldots \ldots \ldots \ldots \ldots \ldots$ B.1

B.2 Low-Strain Test Data . . . . . . . . . . . . . . . B.42

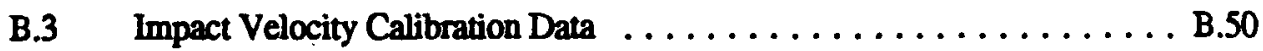

B.4 Strong Motion Sensor Baseline Data .............. B.76 
Appendix C Seismic and Vibratory Data $\ldots \ldots \ldots \ldots \ldots \ldots \ldots \ldots \ldots . \ldots \ldots$

Appendix D Post Test Data . . . . . . . . . . . . . . . . . . . . . .

\section{List of Tables}

Table 1. Shear Wave Velocities for Kaolin Clay, Comparing the DCF and the MWMF. 17

Table 2. Summary Data For Primary, Secondary, and Tertiary Production Drops ..... 25

Table 3. A Comparison Between The Natural Ground Baseline And The Production

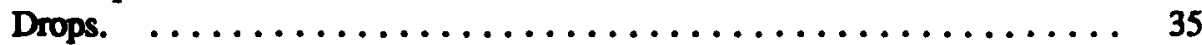

Table 4. Statistical Analysis For SDRI Testing Of Hydraulic Conductivity, DCF Test Cap $\ldots \ldots \ldots \ldots \ldots \ldots \ldots \ldots \ldots \ldots \ldots \ldots \ldots$

\section{List of Figures}

Figure 1 Generalized Layout for the Measurement of Instantaneous Velocity at Impact During Dynamic Compaction Activities . . . . . . . . . . 7

Figure 2 Sample Readout from Strong Motion Instrumentation $\ldots \ldots \ldots \ldots \ldots \ldots$

Figure $3 \quad$ P- and S- Wave Seismic Refraction Survey for DCF Site SR1 . . . . . . . . 12

Figure 4 P- and S-Wave Seismic Refraction Survey for the MWMF Horseshoe Site .............................. 12

Figure 5 P- and S- Wave Seismic Refraction Survey for the MWMF Concrete Ditch Site

Figure 6 Histogram Count of the SASW Layers Within a Shear Wave Velocity Range for the DCF Test Site . . . . . . . . . . . . . . . . . . . . 14

Figure 7 Thickness Weighted S- Wave Velocity Values for each Test Location at the DCF Test Site . . . . . . . . . . . . . . . . . . . . . 14

Figure 8 Histogram Count of the SASW Layers Within a Shear Wave Velocity Range for the MWMF Site $\# 1 \ldots \ldots \ldots \ldots \ldots \ldots \ldots \ldots \ldots \ldots$

Figure 9 Thickness Weighted S- Wave Velocity Values for each Test Location at

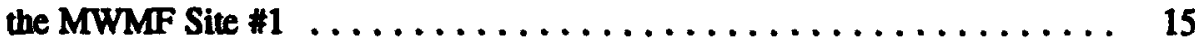

Figure 10 Histogram Count of the SASW Layers Within a Shear Wave Velocity

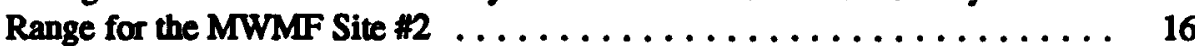

Figure 11 Thickness Weighted S- Wave Velocity Values for each Test Location at

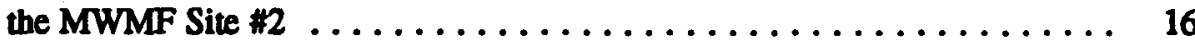

Figure 12 Dynamic Compaction Test Drop Locations and Test Site Layout . . . . . . . 18

Figure 13 Plot of Peak Particle Velocity Versus Distance From Drop Site for the Natural Ground Calibration Drops ..................... 19

Figure 14 Locations for all Strong Motion Sensors for A' Drop Locations . . . . . . . . . 20

Figure 15 Locations for all Strong Motion Sensors for B' Drop Locations . . . . . . . . 21

Figure 16 Locations for all Strong Motion Sensors for C' Drop Locations . . . . . . . . . 22

Figure 17 Locations for all Strong Motion Sensors for TERTIARY Drop

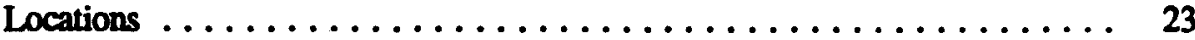

Figure 18 Peak Particle Velocity Versus Scaled Energy Factor for all Drop Locations at the DCF Test Facility . . . . . . . . . . . . . . . . . 
Figure 19 Comparison Between the PPV Attenuation Curves for the Natural Ground Versus the Composite for all Production Drops ........... . 26

Figure 20 Tabulation of the Maximum Observed Peak Particle Velocities for all

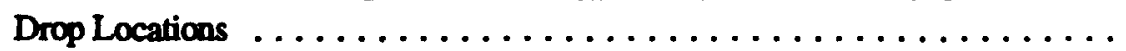

Figure 21 Peak Particle Velocities Versus Scaled Energy Factor for all First Drops

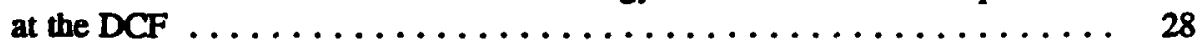

Figure 22 Peak Particle Velocities Versus Scaled Energy Factor for all Second Drops at the DCF . . . . . . . . . . . . . . . . . . . . .

Figure 23 Peak Particle Velocities Versus Scaled Energy Factor for all Third Drops at the DCF . . . . . . . . . . . . . . . . . . . 30

Figure 24 Peak Particle Velocities Versus Scaled Energy Factor for all Primary Drops at the DCF . . . . . . . . . . . . . . . . . . . . 31

Figure 25 Peak Particle Velocities Versus Scaled Energy Factor for all Secondary Drops at the DCF . . . . . . . . . . . . . . . . . . . .

Figure 26 Peak Particle Velocities Versus Scaled Energy Factor for all Tertiary Drops at the DCF $\ldots \ldots \ldots \ldots \ldots \ldots \ldots \ldots \ldots \ldots \ldots \ldots \ldots$

Figure 27 Drop Area A Versus Drop Area B .................... 34

Figure 28 Plot of the Vertical Displacement Versus Distance From Impact for Natural, Undisturbed Soils . . . . . . . . . . . . . . . . . 36

Figure 29 Comparison of Actual Wave Form Between Natural Ground, Beginning Tertiary Drop, and Final DCF Test Drop ............... 37

Figure 30 Schematic Showing Suspected Mechanism for Subsidence Failure to the Kaolin Clay Cap $\ldots \ldots \ldots \ldots \ldots \ldots \ldots \ldots \ldots \ldots \ldots \ldots \ldots, 38$

Figure 31 Graph Presenting Threshold Limits for Structural Damage as a Function of Peak Particle Velocity Versus Frequency U.S. Bureau of

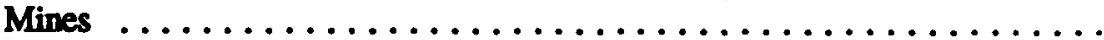

Figure 32 Plot of Dry Density Versus Moisture Content for DCF As Built Quality Assurance Test Data . . . . . . . . . . . . . . . . . . 40

Figure 33 Plot Displaying the Locations for the Six Sealed Double-Ring Infiltrometers . . . . . . . . . . . . . . . . . . . . . .

Figure 34a Plot of Variations in Hydraulic Conductivity, Location $\mathrm{W}-\mathrm{N}$ on the

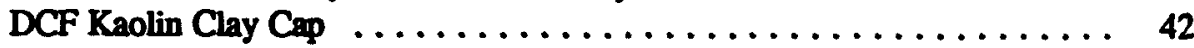

Figure 34b Plot of Variations in Hydraulic Conductivity, Location W - C on the

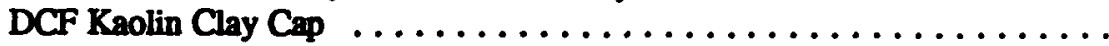

Figure 35a Plot of Variations in Hydraulic Conductivity, Location W - S on the DCF Kaolin Clay Cap . . . . . . . . . . . . . . . . .

Figure 35b Plot of Variations in Hydraulic Conductivity, Location $\mathrm{E}-\mathrm{N}$ on the DCF Kaolin Clay Cap $\ldots \ldots \ldots \ldots \ldots \ldots \ldots \ldots \ldots \ldots \ldots \ldots$

Figure 36a Plot of Variations in Hydraulic Conductivity, Location E - C on the DCF Kaolin Clay Cap $\ldots \ldots \ldots \ldots \ldots \ldots \ldots \ldots \ldots \ldots$

Figure 36b Plot of Variations in Hydraulic Conductivity, Location E - S on the DCF Kaolin Clay Cap $\ldots \ldots \ldots \ldots \ldots \ldots \ldots \ldots \ldots$

Figure 37 Log- log Plot Comparing Altenuation of PPV Versus Distance Between the Natural Ground Baseline and the PRimary, Secondary, and Tertiary Drops . . . . . . . . . . . . . . . . . . . . . . 
WSRC-TR-94-0159.

Rev. 1

March 21, 1994

Dynamic Compaction Report

Figure 38 Westerly Edge of Excavated B-25 Boxes, Sbowing the Difference in Between Compaction Zones A and B . . . . . . . . . . . . . . 47

Figure 39 Plot of the Influence of Stress With Depth, Using the Boussinesq Equation .............................. 49

Figure 40 Plot of Scaled Energy Versus Depth, Compared With Slocombe Correlations For Soil $\ldots \ldots \ldots \ldots \ldots \ldots \ldots \ldots \ldots \ldots \ldots \ldots$

Figure 41 Plot comparing the Drops With Respect to the Change in Crater Depth .... 50 
Rev. 1

\section{Executive Summary}

The primary objective for the Dynamic Compaction Facility (DCF) test was to determine if dynamic compaction of buried low-level waste trenches would cause damage or failure to the adjacent Mixed Waste Management Facility (MWMF) closure system. A second objective was to quantify the success of dynamic compaction in consolidated buried B-25 boxes containing lowlevel waste. To accomplish these objectives, the DCF test program constructed a full-scale model of an engineered low level trench, containing B-25 boxes full of simulated waste. A 3-ft thick kaolin clay cap, modeling the as-built characteristic of the MWMF, was constructed adjacent to this trench. The buried waste was dynamically compacted with instrumentation to monitor the vibratory effects. At the conclusion of the drop testing, the kaolin clay cap hydraulic conductivity was measured, using Sealed Double-Ringed Infiltrometers (SDRD). Following the dynamic testing, the compacted B-25 boxes were excavated and the degree of compaction quantified.

The regulatory driver for the DCF test is the Solvent Rag Settlement Agreement between the U.S. Department of Energy (DOE) and the South Carolina Department of Health and Environmental Control (SCDHEC). This agreement mandates the closure of portions of the Savannah River Site (SRS) burial grounds as a mixed waste management facility under the Resource Conservation Recovery Act (RCRA). In response to this mandate, the first closure phase was completed in 1991 with the Mixed Waste Management Facility (MWMF) certification. The next closure phase is referred to as the Low-Level Radioactive Waste Disposal Facility (LLRWDF).

Noninvasive characterization was performed using the Spectral Analysis of Shear Waves method, evaluating the quality of the DCF model as compared to MWMF. The test results indicated that the MWMF clay cap was drier and stiffer than the newly constructed DCF clay cap. While the same clay and specifications were used for both, the difference in mechanical properties can be attributed to desiccation and aging. The reaching impact from desiccation cannot be quantified with the current data, but could potentially impact the regulatory quality of the closure.

Vibrations from dynamic compaction could potentially damage the existing MWMF kaolin clay cap. The industry standard threshold for damage to plaster structures is 2.0 inches per second (in/s), peak particle velocity (PPV). While this value is a conservative value for kaolin clay, it provides a target baseline. Using this $2.0 \mathrm{in} / \mathrm{s}$ threshold, evaluating the attenuation of PPV versus distance indicates a limiting distance of $33 \mathrm{ft}$ for natural ground. There is uncertainty regarding the comparative response of the DCF to the MWMF kaolin clay caps (i.e., apparent brittleness of the MWMF cap). The conservative approach is to apply a 1.50 factor of safety to the limiting distance. The reasonable and recommended buffer is $50 \mathrm{ft}$ between the drop locations and the MWMF kaolin cap.

The barrier material used in regulated closures must meet the $10-07 \mathrm{~cm} / \mathrm{sec}$ hydraulic conductivity criterion. This value is the threshold for failure when evaluating barrier performance. To validate the buffer between dynamic compaction activities and the MWMF, the DCF kaolin cap was instrumented using six SDRI. The results of these in situ studies measured no appreciable change in hydraulic conductivity for the DCF cap.

Evaluatation of the dynamic compaction success by excavating the compacted wastes, provided valuable insight; improving the quality of future closures. The traditional SRS success criterion was a $6 \mathrm{ft}$ displacement or 20 consecutive drops, which ever came first. Observations early in the test indicating this criterion was inadequate allowing modifications to be made to the test plan. Excavating and measuring the reduction in void ratio for the traditional criterion demonstrated the lack of compaction to the bottom tier of boxes. As a result, a new criterion for success is recommended. The recommendation is to implement a success criterion based upon the change in crater depth per drop. This criterion is two consecutive drops with a change in crater depth of no greater than $0.2 \mathrm{ft}$. 
Rev. 1

\section{Introduction}

\section{Test Objectives}

This report presents the construction, testing, and data evaluation for the Dynamic Compaction Facility (DCF). DCF construction and testing will be discussed, followed by a synthesis of the data collected, and concluded with test result evaluation. The following discussion will present a brief overview of the test objectives, the background, and the organizational elements.

The DCF test was performed to determine if dynamic compaction of buried low level waste trenches would induce damage or failure to the adjacent Mixed Waste Management Facility (MWMF) closure system. The second objective was to measure how successfully dynamic compaction consolidated buried B-25 boxes containing low-level waste.l

To accomplish these objectives, the DCF test program constructed a full-scale model of an engineered low level trench (ELLT), containing B-25 boxes full of simulated wastes. A 3-ft thick kaolin clay cap, modeling the as-built characteristics of the MWMF, was constructed adjacent to this trench. To dynamically compact the buried B-25 boxes, a 20-ton steel encased, concrete weight was dropped repeatedly from $50 \mathrm{ft}$ in the air. Instrumentation monitored the effects of this dynamic compaction on the kaolin clay cap. At the conclusion of the drop testing, Sealed Double-Ring Infiltrometers (SDRI) were used to measure the kaolin clay hydraulic conductivity. Then, the compacted B- 25 boxes were excavated to measure the degree of compaction.

\section{Background}

SRS burial ground receives low-level waste generated during production activities. This facility, located between the $F$ and $H$ separation areas, covers approximately 120 acres. The waste has been deposited in the burial ground has evolved over the years. Before 1985, low-level radioactive waste was randomly dumped into disposal trenches, with little or no containerization. After 1985, ELLTs were constructed to hold waste contained in low-carbon steel boxes, called B-25's. The design function of these boxes was to help handle and transport LLRW.

Over time, this facility received solvent wipe rags containing small amounts of organic solvents. Burying these wipe rags violated the waste disposal permit. This violation was resolved through the Solvent Rag Settlement Agreement between DOE and SCDHEC. This agreement mandates that portions of the SRS burial grounds be closed as a mixed waste management facility under RCRA.

In response to this mandate, the first closure phase was completed in 1991, with the MWMF certification. This interim closure covered 58 acres of dynamically consolidated trenches with a 3-ft thick kaolin clay cap, followed by $2 \mathrm{ft}$ of topsoil and vegetative cover.

The next closure phase is referred to as the LLRWDF. Covering approximately 34 acres, the LLRWDF closure consists predominately of ELLTs, containing low-grade, carbon-steel B-25 boxes filled with low-level radioactive waste. Historically, these boxes contain approximately $10 \%$ - 50\% void space, which must be reduced to minimize settlement potential and to ensure closure cap longevity.

To effect buried waste consolidation and stabilization, dynamic compaction was selected, provided it did not damage existing structures and permitted facilities. To this end, the DCF test was conceived and conducted. 


\section{Organizational Elements}

The DCF test and test facility design were accomplished through two simultaneous efforts. Under the direction of Westinghouse Savannah River Company Environmental Restoration Department (WSRC-ERD), Bechtel Savannah River Incorporated (BSRI) Design Engineering provided the design and construction specifications for the facility. 2 The second effort again under WSRCERD's direction of, EBASCO Services Incorporated (EBASCO) designed and implemented the instrumentation plan. ${ }^{3}$ As part of this task order, EBASCO compiled the resulting test data into a workable form for WSRC-ERD to interpret and evaluate.4

DCF construction was performed by BSRI. Using onsite forces, BSRI excavated the model ELLT; filled, placed, and backfilled the B-25 boxes; and constructed the kaolin clay cap. Additionally, the 20-ton, steel-encased, concrete weight was fabricated onsite. 


\section{Construction}

\section{Model ELLT}

ELLT is a terminal receptor of low-level waste containerized in low-grade, carbon-steel boxes, called B-25's. The B-25 boxes are usually stacked four high inside the trench. Trenches at SRS contain up to 100,000 boxes. After placement, the boxes are backfilled and buried under approximately $4 \mathrm{ft}$ of soil.

The SRS standard specifications for ELLT construction were reflected in the project construction specifications. 2 The DCF ELLT was designed to contain 165 B-25 boxes, and an access ramp. The sides of the trench were cut back to minimize slope failure and to allow safe entry.

Prior to placement, the B-25 boxes were randomly filled with simulated waste. These clean, simulated wastes characterized the types of materials buried in the burial grounds. This included metal, wood, soil, and protective clothing. The boxes were randomly hand filled with variable densities and then placed in a random configuration in a $6 \times 7 \times 4$ box matrix.

After the boxes were placed, the excavation was backfilled, hand compacting the soil against the boxes to ensure intimate contact. The backfilled soil was compacted as close as possible to the natural density of undisturbed soil. As with the burial grounds, the model ELLT was buried under $4 \mathrm{ft}$ of overburden.

The CT Main Company was subcontracted to analyze the MWMF as-built moisture density relationships for each constructed lift These values were synthesized into representative targetmoisture density values for the constructing the DCF kaolin clay cap.2 This was done to provide a more representative target moisture-density relationship, increasing the probability for a representative model.

To ensure a representative model clay was procured from the same vendor that provided it for the MWMF, samples were taken and analyzed prior to purchase, ensuring clay quality and compatibility with the test design.

After the excavation and recompaction of a 4-ft subgrade base, the kaolin clay was spread in 8-in. thick lifts. The clay for each lift was pulverized the into 1/4-in. clods, mixing with water until moisture content target range was achieved. The lift was then compacted using a CAT 815B at a specified number of passes to achieve the target-range density. Quality assurance testing verified that the target moisture density specification was met.

After constructing the kaolin clay cap, 6 in. of topsoil was compacted on top of the kaolin clay to protect and preserve the clay moisture. This 6 -in. thickness deviated from the standard $2 \mathrm{ft}$ at the MWMF, but did not impact the test results. 


\section{Dynamic Compaction}

The MWMF project dynamic compaction weight and drop-height was designed after extensive testing. This testing determined an optimal configuration of an $8 \mathrm{ft}$ diameter 20-ton weight dropped from $42 \mathrm{ft}$. The success criteria were established at a 6-ft displacement or 20 drops, which ever came first. The DCF program modeled this existing standard.

The dynamic compaction weight was fabricated onsite by casting a reinforced concrete weight, encased in 1/4-in. steel shell. After fabrication and curring, the weight was found to be 42,000 lbs.

Providing the energy level anticipated during production is critical in modeling actual conditions. Production cranes are assumed to be $90 \%$ efficient. Using the 20-ton weight from $42 \mathrm{ft}$, this is interpreted to be 1.512 million ft-lbs. As described previously, the measured the efficiency for the DCF crane was 55\%. Back calculating the energy, the DCF 20 ton weight needed to be dropped from $50 \mathrm{ft}$ to approximate actual production energy. 


\section{Instrumentation}

To DCF test goals, a complete suite of instrumentation was identified and implemented. This suite of instrumentation collected data supporting preliminary characterization of the kaolin clay caps, impact velocity determination, strong motion, inelastic deformation, and in situ permeability. The different instrumentation elements were installed and operated in accordance with the Instrumentation Plan: Dynamic Test Facility, Final Report, prepared by EBASCO 3 . The data acquisition was divided into six basic elements, which are briefly outlined below.

\section{Characterization and Comparison of Kaolin Clay Caps}

DCF and the MWMF kaolin clay caps similarities are a basic premise to the DCF test program. To quantify and calibrate the as-built similarities and dis-similarities, nondestructive field geophysical studies were implemented. These studies determined the relative physical properties of the DCF clay cap and the existing MWMF closure system prior initiating dynamic compaction work. Two different techniques were implemented and are described below.

These two methods were P- and S- wave seismic refraction and Spectral Analysis of Shear Waves (SASW). Both methods were used at DCF and MWMF. The P- and S- wave seismic refraction placed seismographs in a linear array across the sampling area. A 1- ton weight was dropped from $10 \mathrm{ft}$ as an energy source. Testing was performed in natural, undisturbed soil areas, across the long axis of the DCF clay cap and across the MWMF clay cap. Refraction data acquisition was not optimal because the surface soils had a higher shear wave velocity than the underlying soils. This condition did not cause effective refraction of the energy wave and prevented sampling of the underlying soils. This testing did, however, measure the shear wave velocities in the surface soils, serving as a redundant check of the SASW.

The SASW is based upon measuring surface waves propagating in layered elastic media. The surface wave velocity varies with frequency in a layered system. 5 The variation is called dispersion. A dispersion curve is created by plotting the surface wave velocity versus the wavelength. Using established relations, the surface wave velocities determined from the dispersion curves can be used to estimate sherr wave velocities for the same materials. Generally, a stiffer material will have a higher shear wave velocity, while a less stiff material will have a lower shear wave velocity. The material's stiffness is a function of the bulk density and the moisture content. In turn, these values are reflected in the Young's Modulus of Elasticity and the Poisson's Ratio for the material. By knowing these values for both the DCF and the MWMF closure material, a correlation can be developed to help extrapolate the DCF results to the MWMF.

\section{Impact Velocity Survey and Energy Measurements}

Dynamic compaction is performed by hoisting a weight to a specified height, then releasing the weight in free-fall until impact with the target material. Each crane has an inherent efficiency factor, which is a function of the internal friction for the cable spool, brake configuration, and associated pulleys. Production cranes are designed to minimize this internal friction, thus, maximizing the impact energy. Production cranes and may attain an efficiency factor between 80 90\%.

To realistically model production cranes and actual closure LLRWDF conditions, the efficiency of the DCF crane must be measured and differences calibrated. The impact velocity survey and energy measurements were designed to measure the energy at impact compared to the free-fall energy described through Newton's Law. To achieve this evaluation, instrumentation was designed to measure the actual impact velocity of the dynamic compaction weight. The ratio between the actual impact velocity and the velocity computed from the ideal equation for kinetic energy provides the efficiency factor for the DCF crane (Appendix B.3). 
WSRC-TR-94-0159

Rev. 1

March 21, 1994

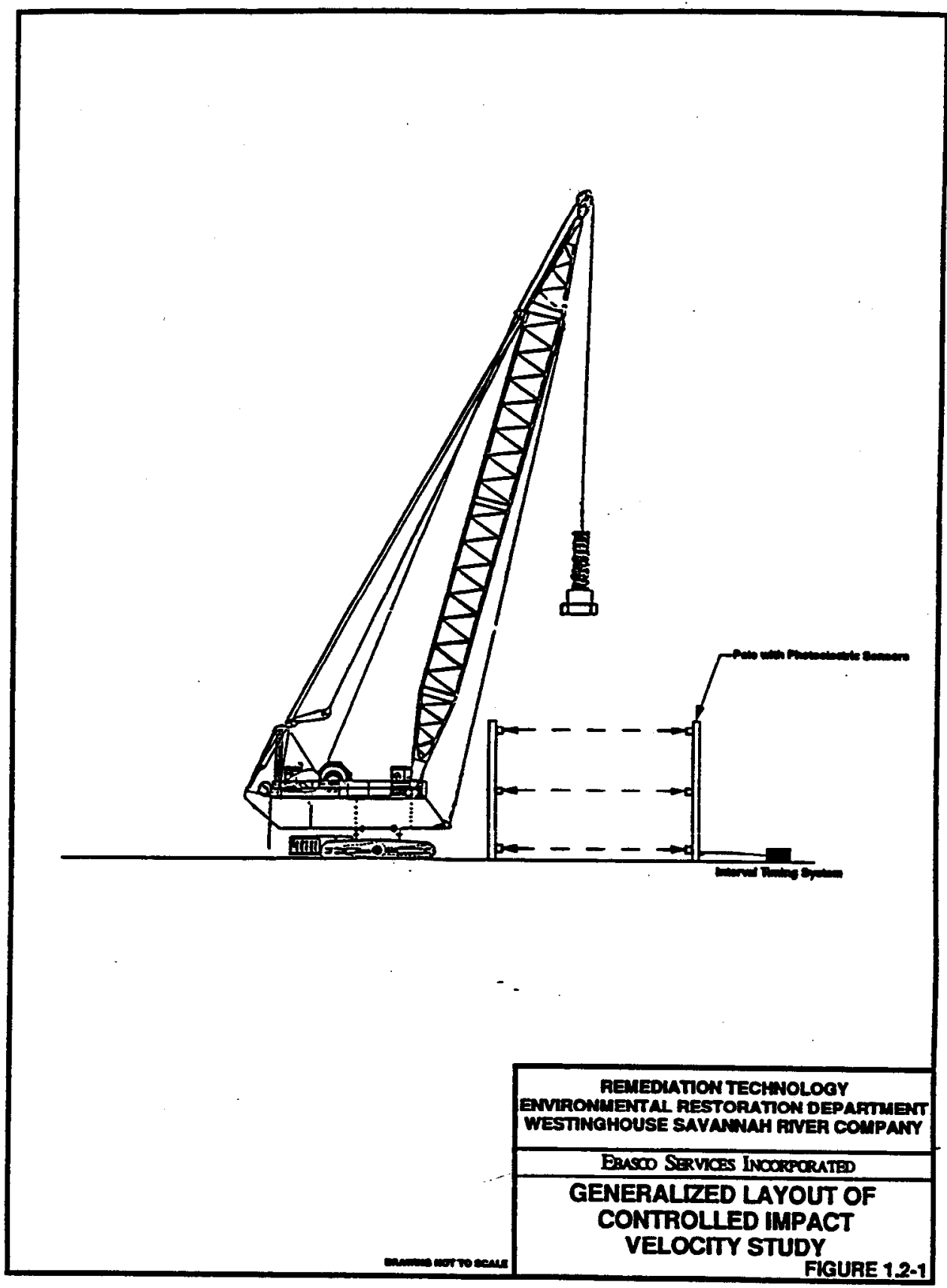

Figure 1 Generalized layout for the measurement of instantaneous velocity at impact during dynamic compaction activities. 
Rev. 1

To make these measurements, a series of laser diode photoelectric cells were mounted along two vertical poles at predetermined heights (Figure 1). As the weight fell downward, it sequentially broke a series of photocell beams at several predetermined beights above the ground surface. The interval between each successive break was recorded. Since the beams were located a known distance apart, the impact velocity and interval crane efficiency could be calculated. Determining instantaneous impact velocity is then a simple matter of extrapolation, using the quantities measured in the photocell gates.

The efficiency factor was measured during the preliminary drops prior to the actual compaction of the test waste matrix. Data evaluation measurements determined that the drop height for the DCF test should be increased from $42 \mathrm{ft}$ to $50 \mathrm{ft}$ to provide compactive energy similar to that anticipated during actual production.

\section{Vibratory Ground Motion Monitoring Program}

The key determination for the DCF test is to compare the range of vibratory ground motion with the changes in hydraulic conductivity. Literature indicates that $67 \%$ of the vibratory ground motion from dynamic compaction is manifest in the form of shear or surface waves. ${ }^{6}$ Additionally, the frequency normally ranges between 5 and $200 \mathrm{~Hz}$. A common method to measure and express these shear waves is to measure the peak particle velocity (PPV). The PPV is the instantaneous velocity at a point on the ground and provides the best evaluation of vibrations relative to potential structural damage.

To measure the PPV, strong motion sensors were set at predetermined locations on the kaolin clay cap and the surrounding undisturbed ground. The normal threshold values were set at 0.2 inches per second (in/s). Historical research and testing by the U.S. Burean of Mines has set the threshold limit for damage to structures at $2.0 \mathrm{in} / \mathrm{s}$.

A subcontractor provided 43 strong motion sensors for measurements during the DCF testing. Readouts from these instruments provided the following information:

- PPVs in the longitudinal, transverse, and vertical axis (inches per second)

- peak displacements in the longitudinal, transverse, and vertical axis (inches)

- peak particle accelerations in the longitudinal, transverse, and vertical axis (g)

- frequency, in the longitudinal transverse, and vertical axis (hz)

- the resultant peak particle velocity (inches per second)

- peak sound in decibels and pounds per square inch

- a graphical display of the vibrations in the longitudinal, transverse, and vertical axis

- a comparison with the US Bureau of Mines standard for damage to structures

Figure 2 presents a copy of a typical readout from a strong motion sensor. These data were measured for each dynamic compaction weight drop at each instrument location. The vibratory data for these locations determine the PPV dissipation across the DCF for each drop.

\section{Inelastic Deformation Monitoring}

As the DCF waste matrix is dynamically consolidated, there is a high potential for a resulting inelastic deformation. This deformation may be manifest through the lateral movement of the waste materials, causing the surrounding ground to either heave or subside. Either of these movements could potentially induce cracking and failure to the kaolin clay cap. To monitor the inelastic deformation, survey monuments were placed at predetermined locations surrounding the waste matrix. These brass caps, embedded in concrete, were surveyed based on the SRS coordinate system measuring the $X, Y$, and $Z$ positions. Periodically during the DCF test, these positions were remeasured, with the final positions determined at the conclusion of the dynamic compaction phases of the DCF testing program. 


\section{Rev. 1}
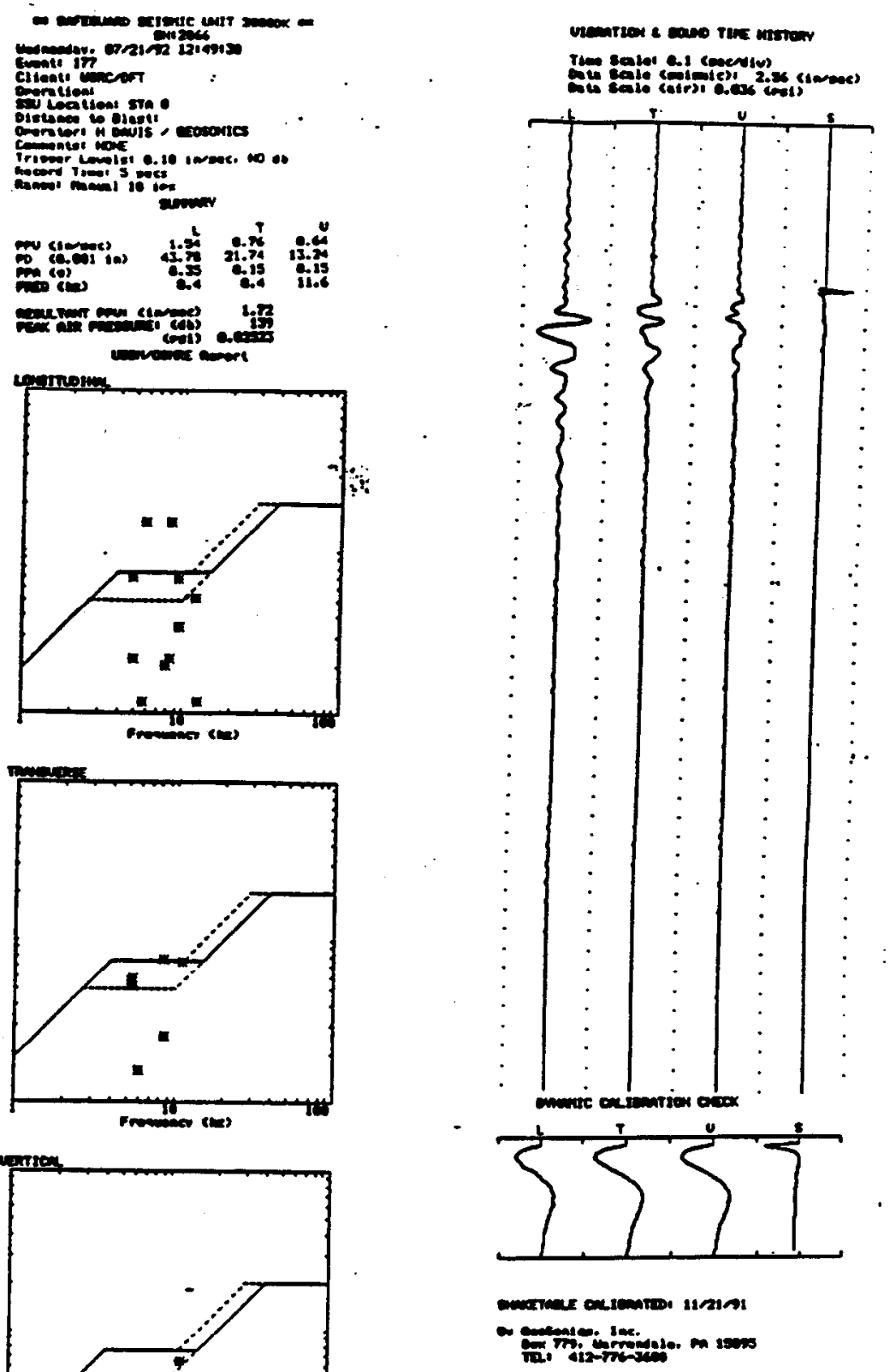

Figure 2 Sample readout from strong motion instrumentation. Note that the plots are representative of the U.S. Bureau of Mines threshold criterion. The distance from the drop location is $15 \mathrm{ft}$. 


\section{Postcompaction Infiltration Monitoring}

The hydraulic conductivity of a waste site cover system is a key regulatory element. Any damage reflected on the MWMF closure cap by the dynamic compaction of the LIRWDF closure, will be manifest through changes in hydraulic conductivity (leaking). The second critical measurement for the DCF test is the hydraulic conductivity.

To accomplish this, a preliminary evaluation of the vibratory monitoring identified areas of high, medium, and low impact on the DCF kaolin cap. The Sealed Double-Ringed Infiltrometer (SDRD), designed by Drs. Stephen Trautwein of Houston, TX and David Daniels of the University of Texas chosen to measure the hydraulic conductivity. Six SDRIs were embedded in the DCF kalin clay, with three placed in areas of high probability of impact, one placed in an area of medium probability of impact, and the remaining two placed in areas of low probability of impact. 


\section{Data Evaluation and Observations}

\section{Noninvasive Characterization of the DCF vs. MWMF Kaolin Clay Caps}

A basic premise to the Dynamic Compaction Facility (DCF) test program is that the kaolin clay caps for both the DCF and the MWMF closure are structurally and mechanically similar. Because the MWMF closure system is a regulated closure, sampling and evaluation must be noninvasive and nondestructive. To meet these criteria and to determine the similarities between the two systems, the Spectral Analysis of Shear Waves (SASW) technique and the seismic refraction surveys were selected. During the DCF test design and construction, the intent was to emulate the specifications and as-built characteristics of the MWMF. As a reiteration, these efforts included purchasing the same clay and constructing the model cap to the same moisture/density relationship. Data included in Appendix A demonstrate the details of these efforts. An evaluation of these techniques and their results are presented herein.

The DCF kaolin cap was built from the same materials and to the same specifications as the MWMF closure cap. Theoretically, the DCF and the MWMF closure cap in situ properties should be virtually identical. The data quantitatively compare the in situ properties represented by the relative stiffness of each cap. This stiffness is represented by the accumulative shear wave velocities for each layer and material, using the seismic refraction and a SASW survey.

\section{Refraction Surveys}

P- and S-wave seismic refraction surveys were conducted on a limited basis at DCF and at two MWMF locations. These surveys consisted of a symmetrical array of strong motion sensors collecting data at a distance from the point of impact of a 1000-lb weight dropped from $10 \mathrm{ft}$ high. These limited seismic refraction surveys measured only the fast, direct $P$ - and $S$-wave velocities of the surface layer.

A linear, least-squares line was fitted through the seismic P- and S-wave refraction data for the three sites tested, as shown in figures 3,4 , and 5 . These figures show a good data fit and a high correlation between $\mathrm{r}_{2}$ values ranging from 0.977 to 0.997 , with 1.0 representing a perfect correlation. The straight lines of these plots, without any faster, shorter time, refracted arrivals, indicate that the overlying topsoil and/or shallowest portions of the cap are faster than the rest of the underlying clay cap at the three sites tested. Consequently, while providing an estimate of near surface velocities of the soil cover and perhaps the shallowest kaolin clay, these data did not provide any definitive information on the velocity for the kaolin clay caps. Seismic wave velocities were generated by calculating the slope inverse of the lines, accounting for the vertical time scale in milliseconds. Compressional wave velocities for the surface layer using this refraction data were determined to be $1360 \mathrm{fps}$ at the DCF location and 1580 and $1620 \mathrm{fps}$ at the two MWMF locations. Calculation of the Poisson's ratios for each location suggests a value of 0.33 value for the surface layer for the DCF and 0.18 to 0.19 for the MWMF sites.

These studies confirm that the surface materials at both the DCF and the MWMF caps have higher seismic velocity values than the underlying kaolin clay caps. These limited seismic refraction surveys only measured the fast, direct P-and S-wave velocities of the surface layer. The measured direct shear wave velocities were generally comparable to those predicted by the SASW surveys. 
P. and S- Wave Sci. ic Refraction Survey

DTF Sitc SR 1 across SASW Sites 7, 8 \& 9

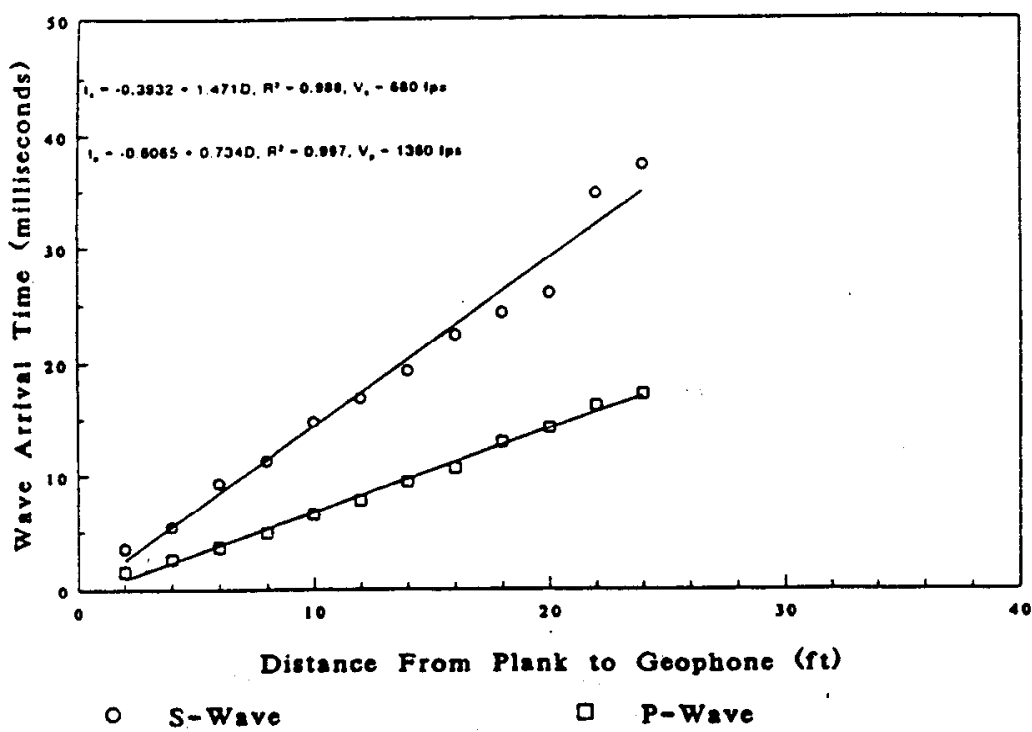

Figure 3 P- and S- Wave seismic refraction survey for DCF site SR1.

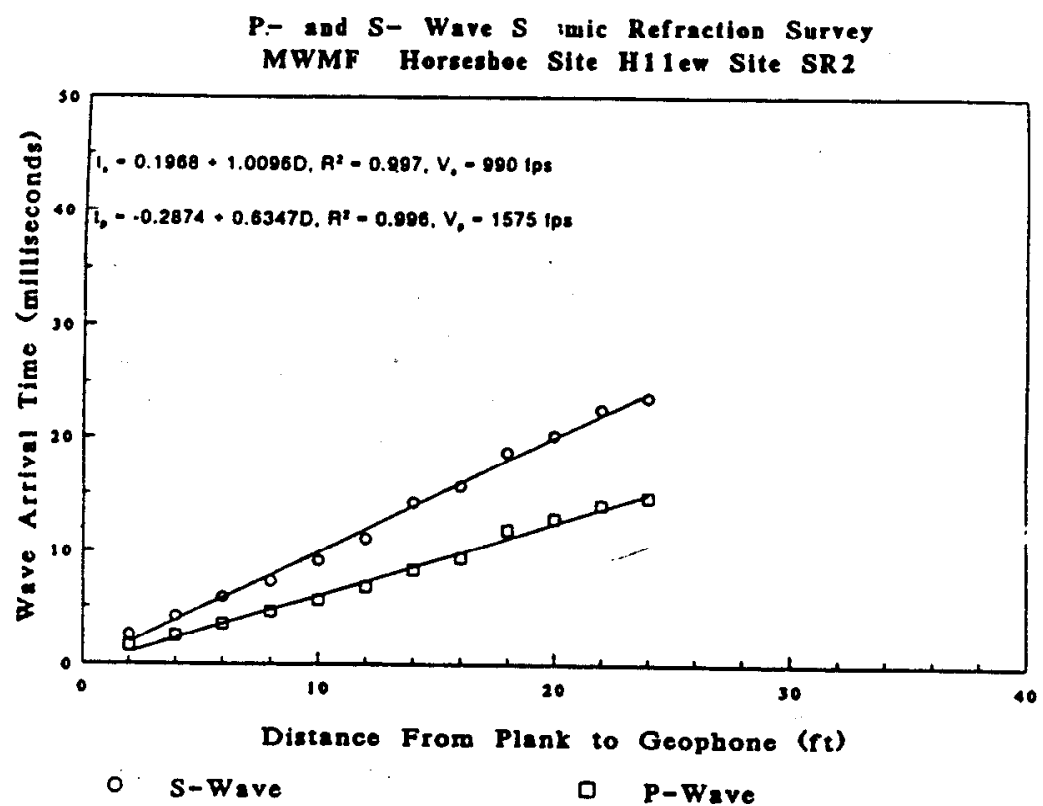

Figure 4 P- and S- Wave seismic refraction survey for the MWMF Horseshoe site. 


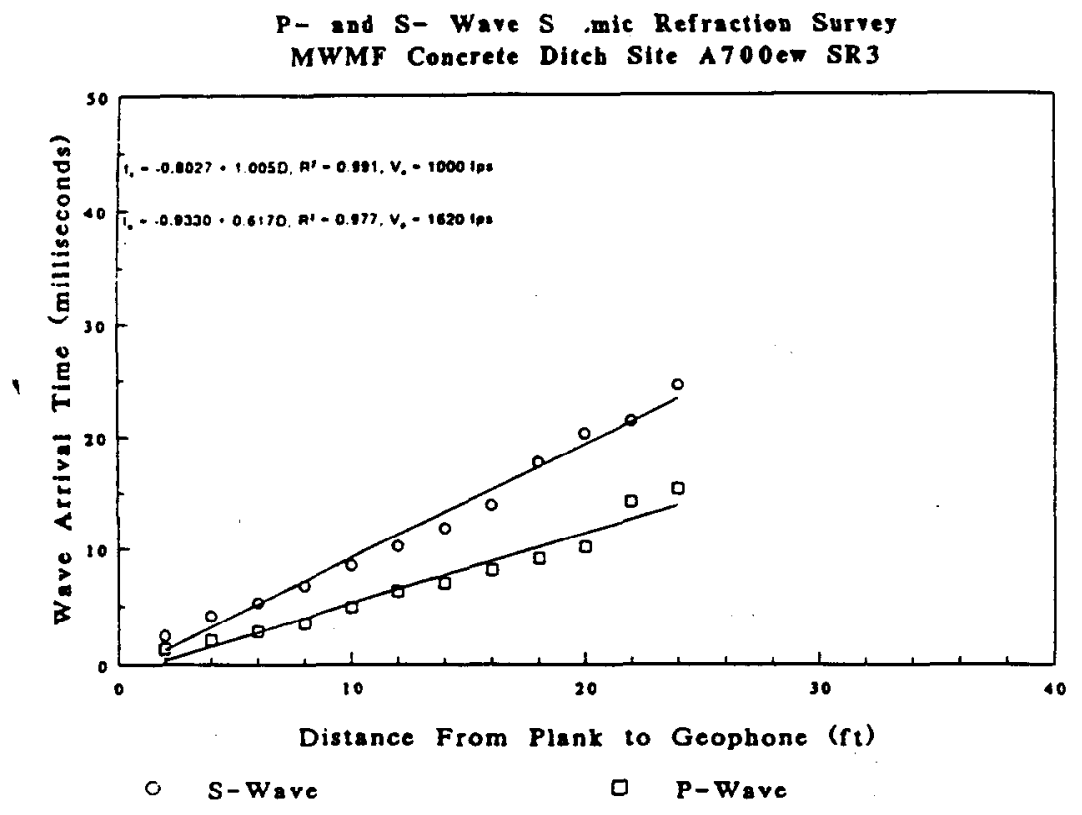

Figure 5 P- and S- Wave seismic refraction survey for the MWMF concrete ditch site.

\section{Spectral Analysis of Shear Wave Analysis}

The SASW uses a 3-Dimensional forward modeling technique to generate values for interpretation. The data provide the following information by model layer number from the surface down:

- layer thickness in units of feet

- an assumed compression wave velocity in units of feet per second

- shear wave velocity in units of feet per second

- an assuned Poisscon's ratio

- an assumed mass density in units of $1 \mathrm{~b}-\mathrm{sec}^{2} / \mathrm{ft}^{4}$

The shear wave velocities and layer thicknesses were adjusted and 2-D and 3-D forward modeling computer analyses performed until a reasonable match was obtained between the 3-D theoretical and experimental dispersion curves.

The DCF SASW data fall into three general categories: relatively high velocity soil or kaolin over lower velocity kaolin; uniform velocity within the soil and kaolin clay; and relatively low velocity soil or kaolin over a higher velocity kaolin. The SASW method identified the approximate thickness and shear wave velocity for each layer. Plots of the 3-D theoretical and experimental dispersion curves and the theoretically determined shear wave velocity versus depth profile are presented in Appendix B.1.

The SASW studies successfully measured the shear wave velocities of the underlying laolin clays. Results indicate a mean shear wave velocity about 350 fps for the DCF kaolin clay cap zone. In comparison, mean shear wave velocities range from 500 to 550 fps for the MWMF kaolin clay cap zone. Shear wave velocities appear to be similar at the southeastern and northwestern portions of the MWMF cap. 
Rev. 1

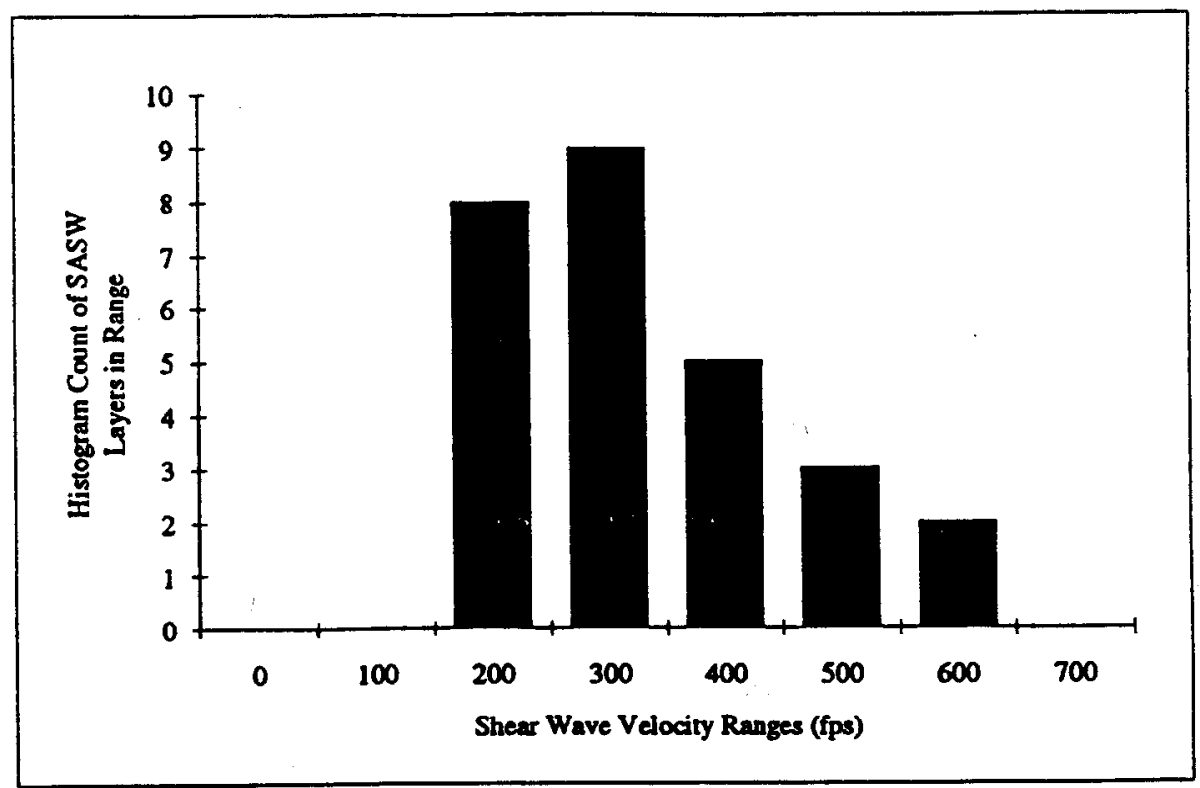

Figure 6 Histogram count of the SASW layers within a shear wave velocity range for the DCF test site (after Olson).

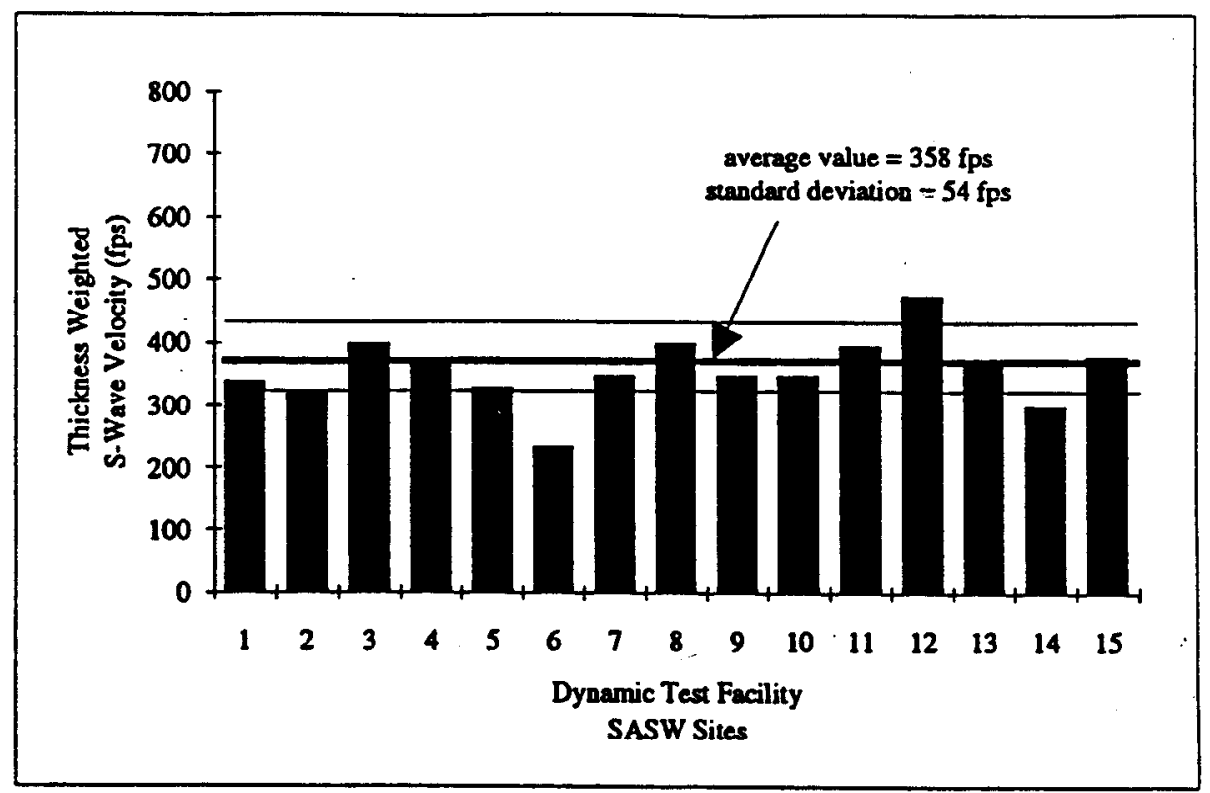

Figure 7 Thickness weighted S- Wave velocity values for each test location at the DCF test site (after Olson). 
WSRC-TR-94-0159

Rev. 1

March 21, 1994

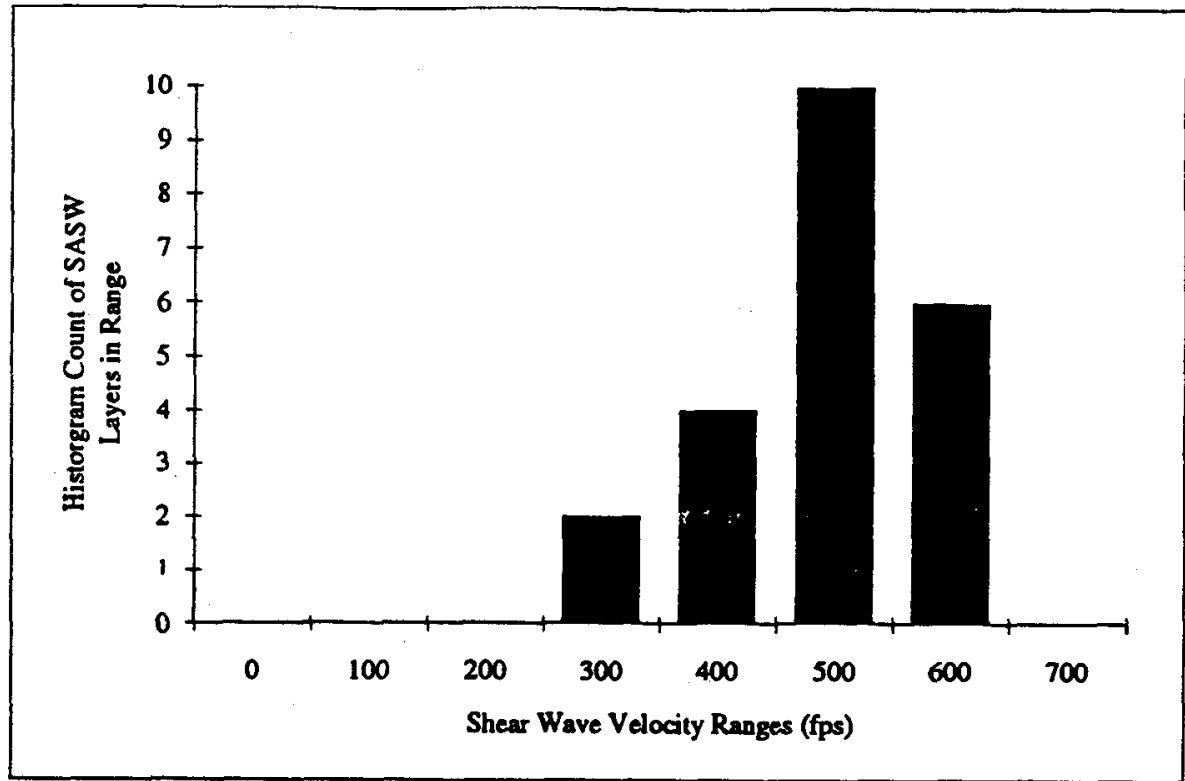

Figure 8 Histogram count of the SASW layers within a shear wave velocity range for the MWMF site \#1 (after Olson).

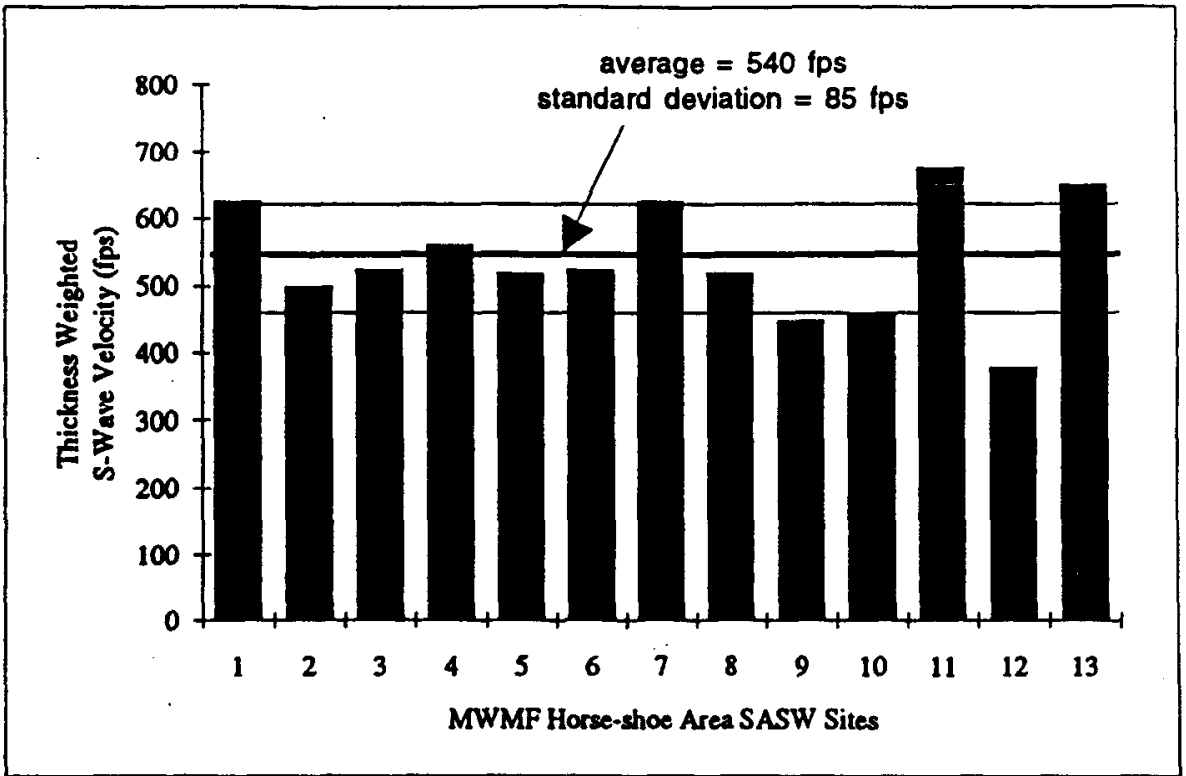

Figure 9 Thickness weighted S- Wave velocity values for each test location at the MWMF test site \#1 (after Olson). 
Rev. 1

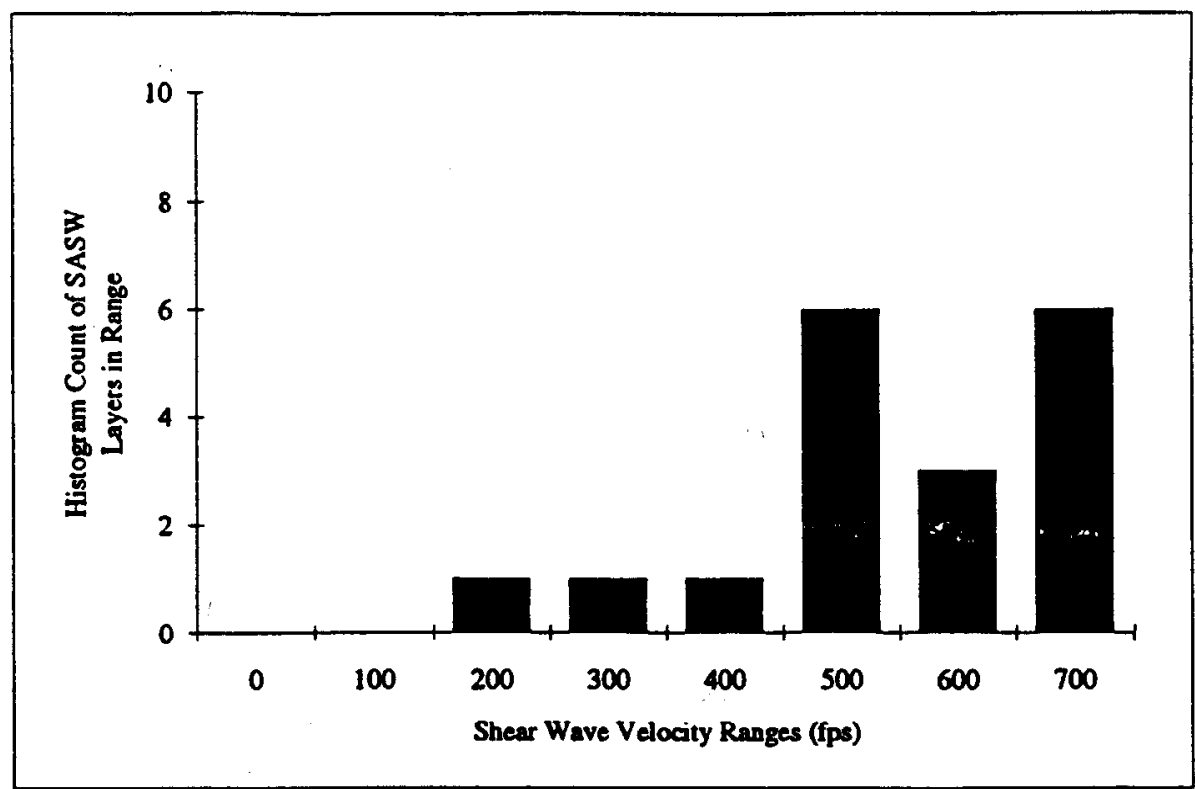

Figure 10 Histogram count of the SASW layers within a shear wave velocity range for the MWMF site \#2 (after Olson).

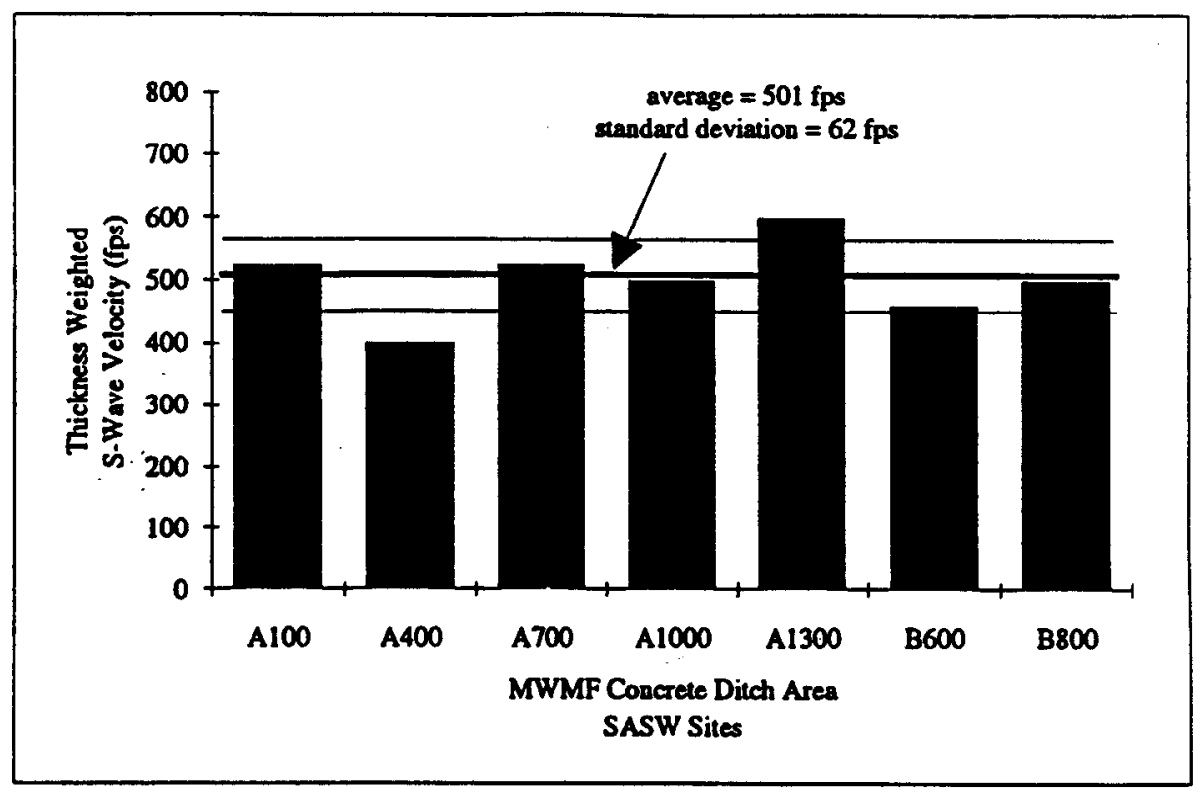

Figure 11 Thickness weighted S- Wave velocity values for each test location at the MWMF test site \#2 (after Olson). 
Rev. 1

Figures 6 through 11 analyze the SASW data. Figures 6, 8, and 10 are histograms of the kaolin layers versus the shear wave velocity in feet per second. To obtain a better understanding, these data were normalized using layer thickness and are presented in figures 7,9 , and 11. Table 1 summarizes this evaluation for each of the characteristic sample locations.

Table 1 Shear Wave Velocities For Kaolin Clay, comparing the DCF and the MWMF

\begin{tabular}{|c|c|c|c|}
\hline \multicolumn{4}{|c|}{ Shear Wave Velocity (Vs) } \\
\hline & Range (fps) & Mean (Fps) & Standard Deviation \\
\hline DCF & 200 to 680 & 350 & 57 \\
\hline MWMF-Site \#1 & 380 to 670 & 359 & 83 \\
\hline MWMF-Site \#2 & 380 to 650 & 502 & 60 \\
\hline
\end{tabular}

The layer thickness weighted shear wave velocities range between 300 and 450 fps for the DCF sites and $\mathbf{4 0 0}$ to $\mathbf{7 0 0}$ fps for the MWMF sites. The difference between the two testing areas means that the MWMF closure cap is dryer or more brittle than the DCF closure cap. The higher the moisture content of a material, the more the material dampens the shear waves, resulting in a slower shear wave velocity. Conversely, with a low moisture content, the shear wave velocity will be higher.

The higher shear wave velocity observed at the MWMF may be caused by aging effects, which include drying of the kaolin clay over the past several years. In several instances, the shear wave velocities similar to those observed at the MWMF were documented in the shallowest portions of the DCF cap, consistent with the drying model. Further more, at one DCF site, the soil cover was removed, exposing the kaolin clay and allowing it to dry for several hours. The shear wave velocity for this clay was virtually identical to the mean values obtained at the older and presumably drier MWMF cap. The results of these studies suggest that the younger, wetter DCF cap may be less brittle than the older, drier MWMF cap.

Note that the data at the natural soil calibration site and the MWMF were collected during dry conditions. In contrast, the low-strain data at the DCF cap were collected the day after a beavy rain when the shallow soils at the drop point were very wet. This may explain the observed differences. The fact that the MWMF closure system appears dryer than the newly constructed DCF cap can be attributed to aging and desiccation. The regulatory impacts resulting from this desiccation are not distinct at this time. However, a conservative interpretation would be that the DCF cap materials tend to attenuate seismic waves faster than the MWMF cap.

\section{Impact Velocity Calibration Results}

The focus for this phase of testing was to establish the efficiency of the crane used to hoist and drop the 20-ton weight. Figure 12 shows the location of each drop point, drop location type (primary, secondary, or tertiary), and sequence in which each drop was completed. To examine reproducibility of the crane drops and photocell measurements, Appendix B.3 summarizes the instantaneous velocity and average crane efficiency at photocell $3\left(v_{3}\right)$. The instantaneous velocity at photocell 3 averages $41.43 \mathrm{f} / \mathrm{s}$, with a standard deviation of $0.44 \mathrm{fU} / \mathrm{s}$. The average crane efficiency for all production drops is 0.555 (55.5\%), with a standard deviation of $0.015(1.5 \%)$. These results indicate a high degree of reproducibility for both the crane and the interval photocell measurement equipment. 
WSRC-TR-94-0159

Rev. 1

March 21, 1994

Dynamic Compaction Report

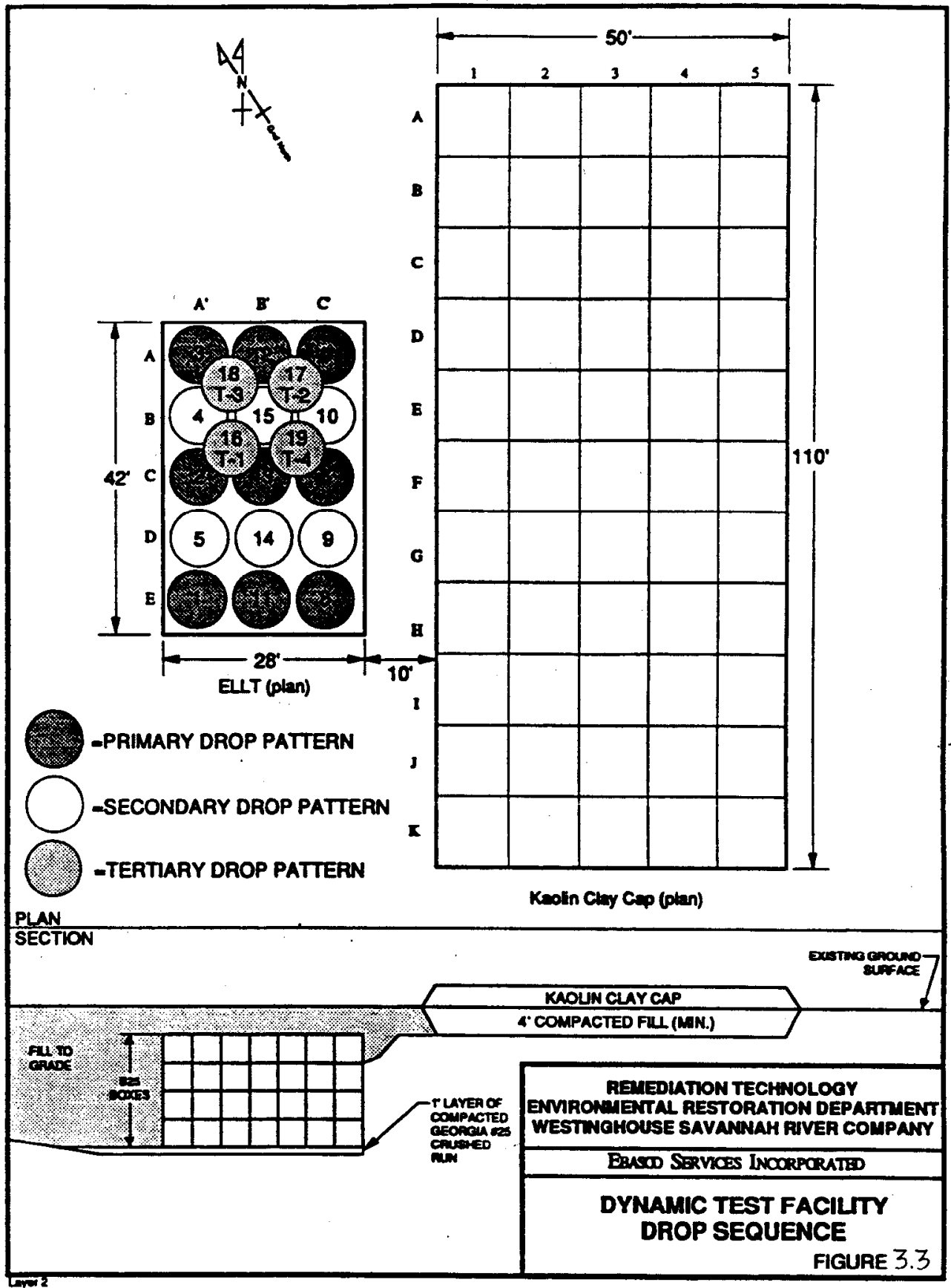

Figure 12 Dynamic Compaction Test drop locations and test site layout (after EBASCO). 
Rev. 1

\section{Natural Şoil Strong Motion Sensor Baseline}

The dynamic compaction weight was dropped on undisturbed natural ground to obtain a PPV baseline and to ensure that surrounding structures would not sustain damage during the test. To provide this assurance, strong motion sensors were placed adjacent to nearby structures prior to testing. During actual dynamic compaction testing, these instruments were seldom triggered. These instruments demonstrated that at distance, the dynamic compaction test generated less vibration near sensitive structures than passing trucks, construction equipment, and trains.

Initial preliminary drops were conducted beginning at $10 \mathrm{ft}$, followed by drops at increasing heights of $15,25,35,42$, and $50 \mathrm{ft}$. This incremental approach was taken to ensure that the DCF program would have no negative impacts on nearby, sensitive structures (i.e., steamline, highlevel transfer line and RCRA storage facility).

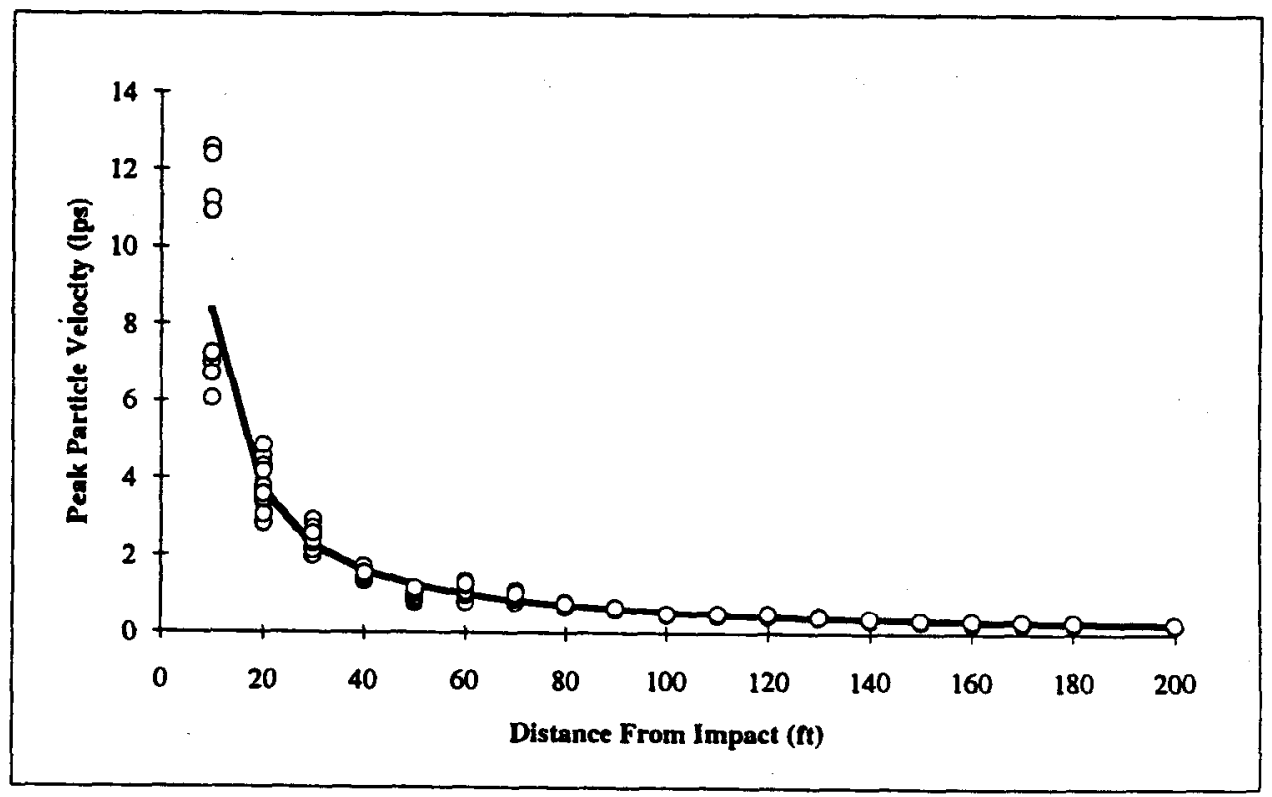

Figure 13 Plot of peak particle velocity versus distance from drop site for the natural ground, calibration drops. The regression curve provides an attenuation baseline for production drops.

Figure 13 plots the natural ground PPV against the distance from the drop point. This wellbehaved data set demonstrates the natural attenuation of the shear wave energy with distance. The best fit curve for this data shows that on natural ground, the PPV at a distance of $33 \mathrm{ft}$ from the impact site is below the $2 \mathrm{in} / \mathrm{s}$ threshold set by the U.S. Burpau of Mines. Calibration seismograph amay locations/configurations are presented in Appendix B.4. 
Rev. 1
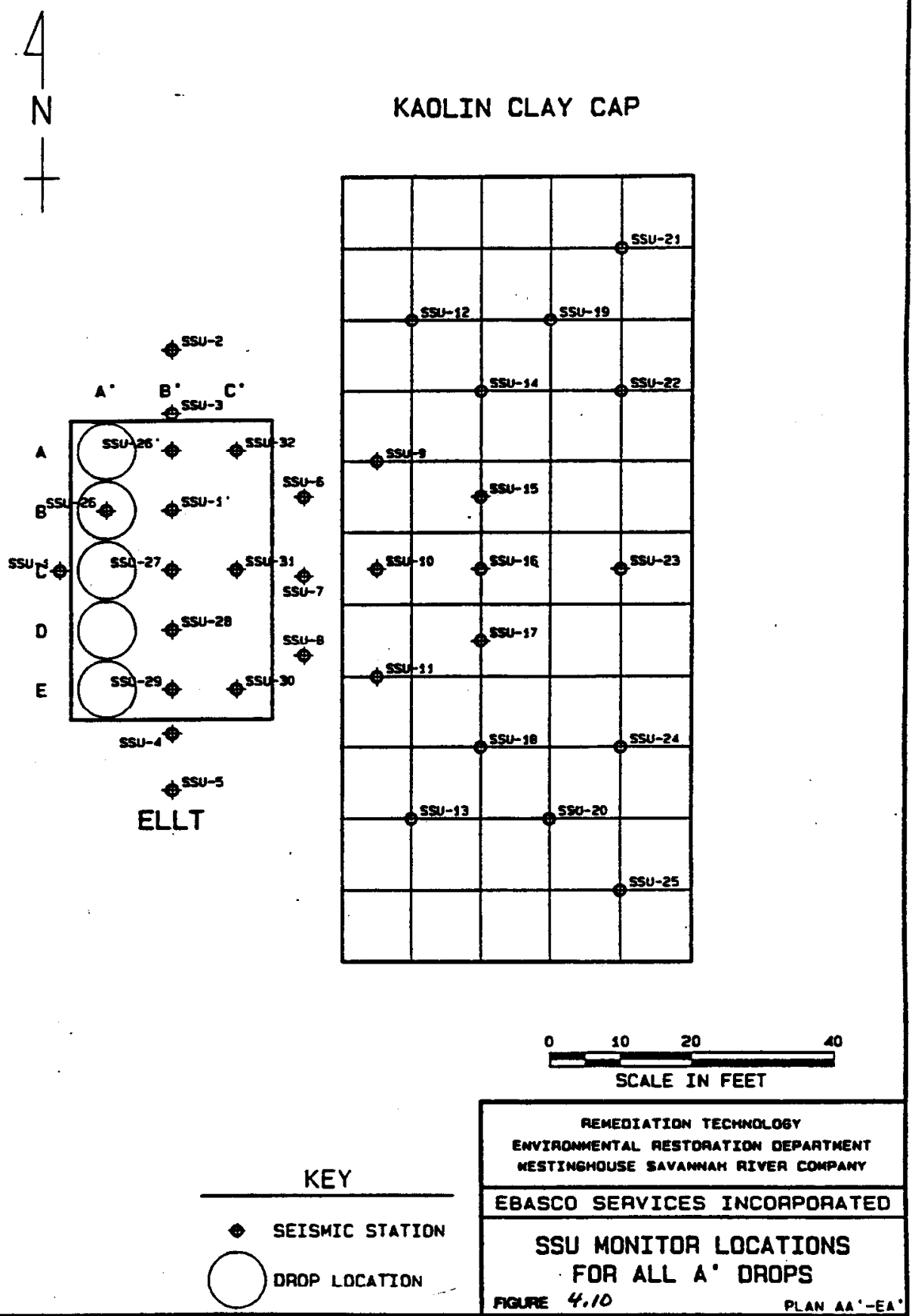

Figure 14 Locations for all strong motion sensors for $A^{\prime}$ drop locations. (After EBASCO). 
WSRC-TR-94-0159

Rev. 1

March 21, 1994

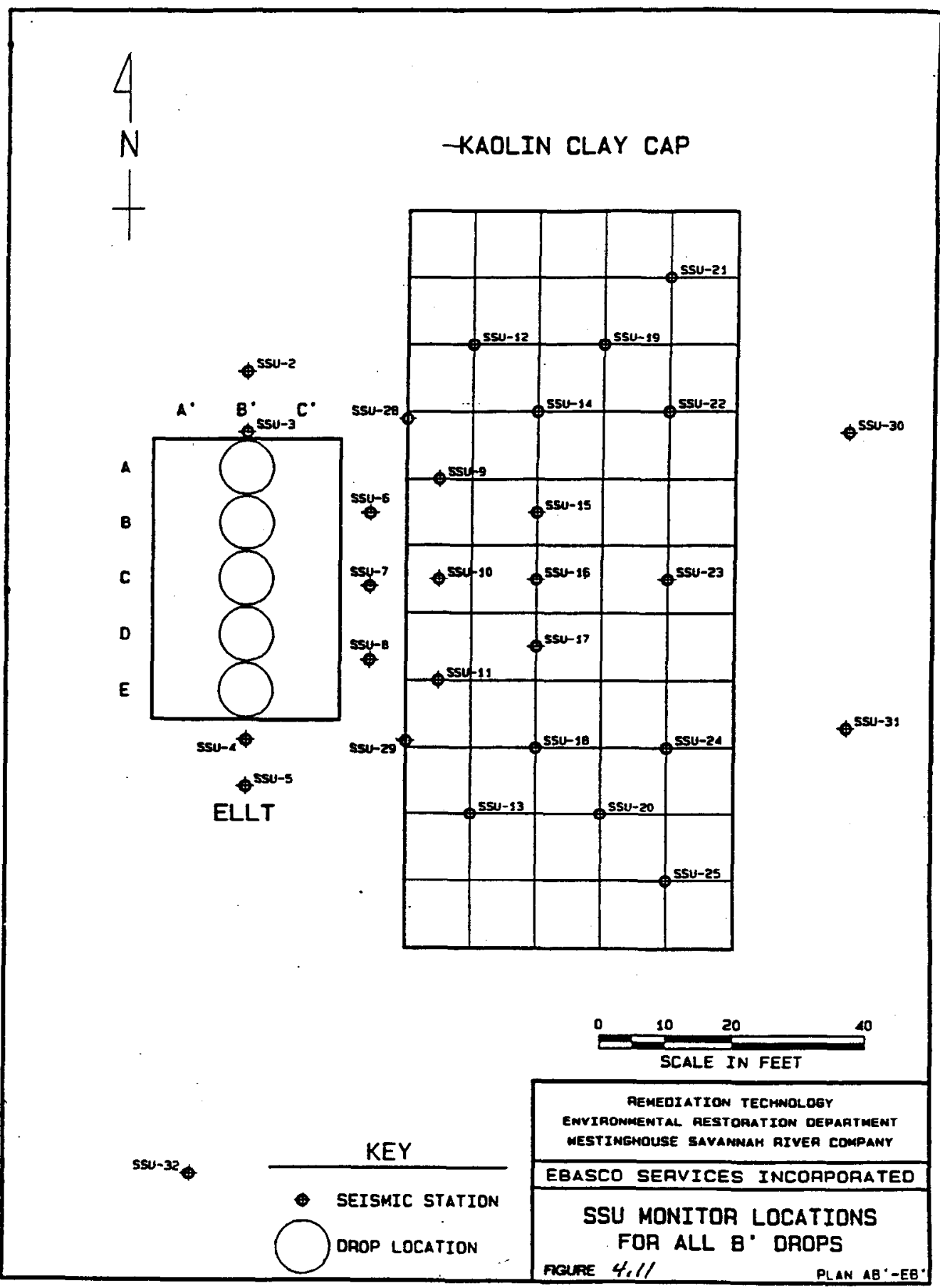

Figure 15 Locations for all strong motion sensors for B' drop locations. (After EBASCO). 
Rev. 1

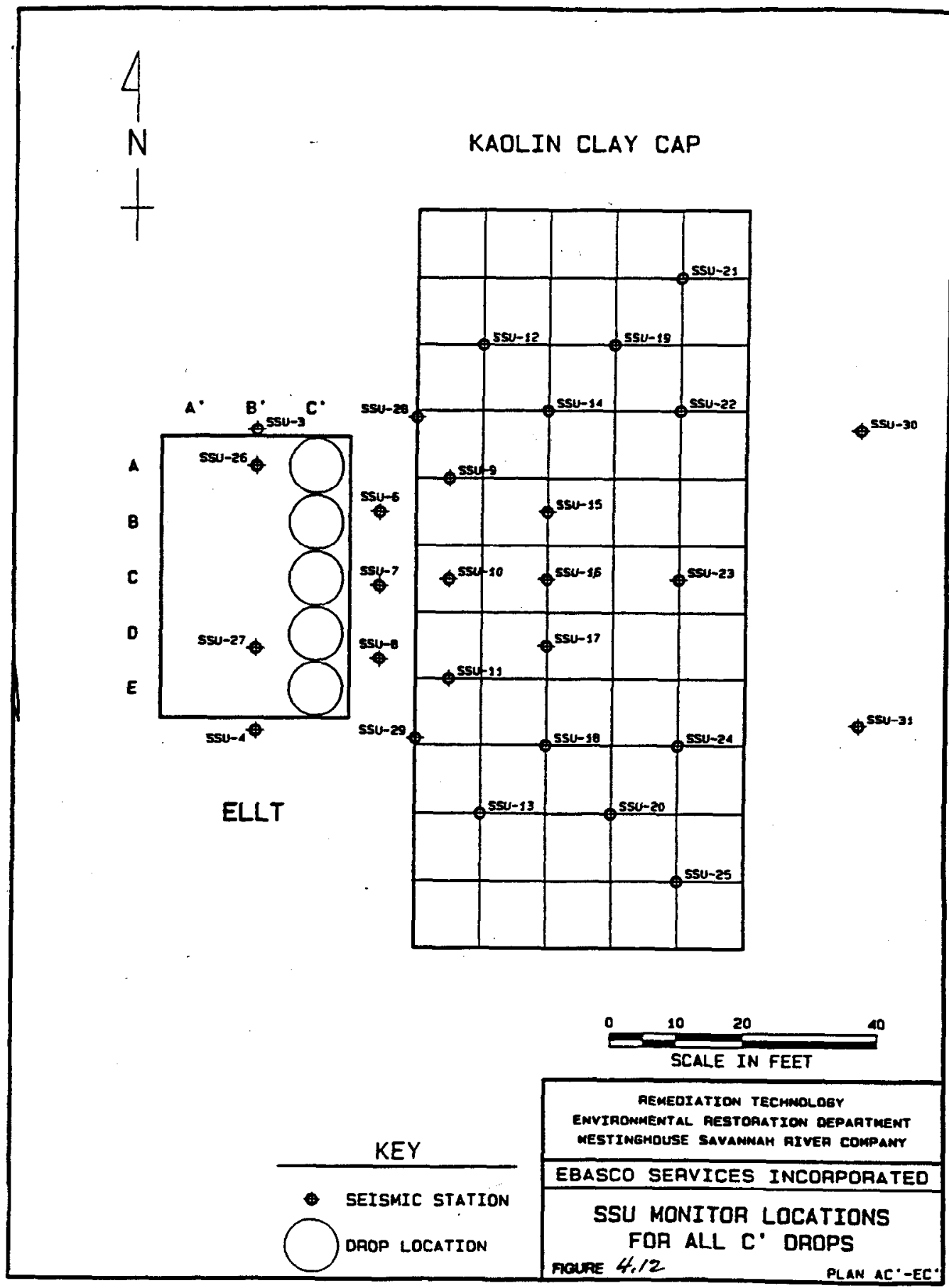

Figure 16 Locations for all strong motion sensors for $C^{\prime}$ drop locations. (After EBASCO). 
Rev. 1

March 21, 1994

4
+
+

KAOLIN CLAY CAP

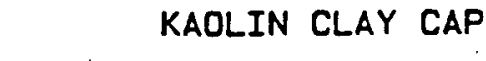

(1)

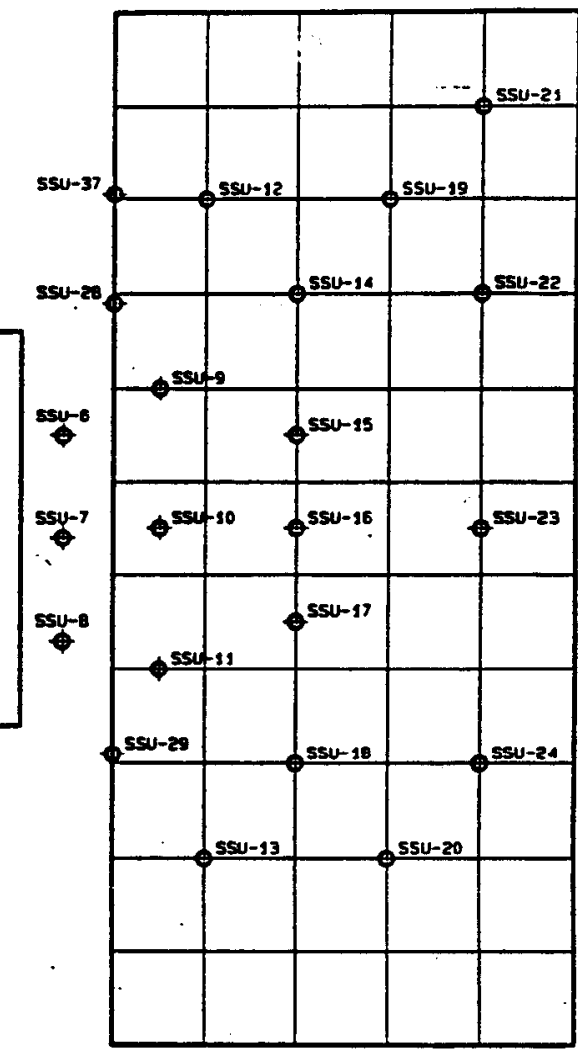

$\phi^{55 v-30}$

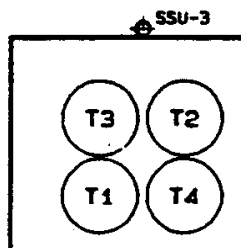

$\phi^{\text {sSU-33 }}$

ssu-A

$\phi^{\text {sSu-s }}$

ELLT

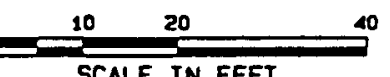

SCALE IN FEET

AEMEOTATION TECMNOLOEY ENVIAONKENTAL AESTOAATION DEPARTMENT

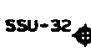

EBASCO SERVICES INCOAPORATED

SSU MONITOA LOCATIONS

FOR ALL TERTIARY DROPS FGURE 4.13 PLAN TI-TS

Figure 17 Locations for all strong motion sensors for TERTIARY drop locations. (After EBASCO). 


\section{PPV VERSUS SCALED ENERGY FACTOR}
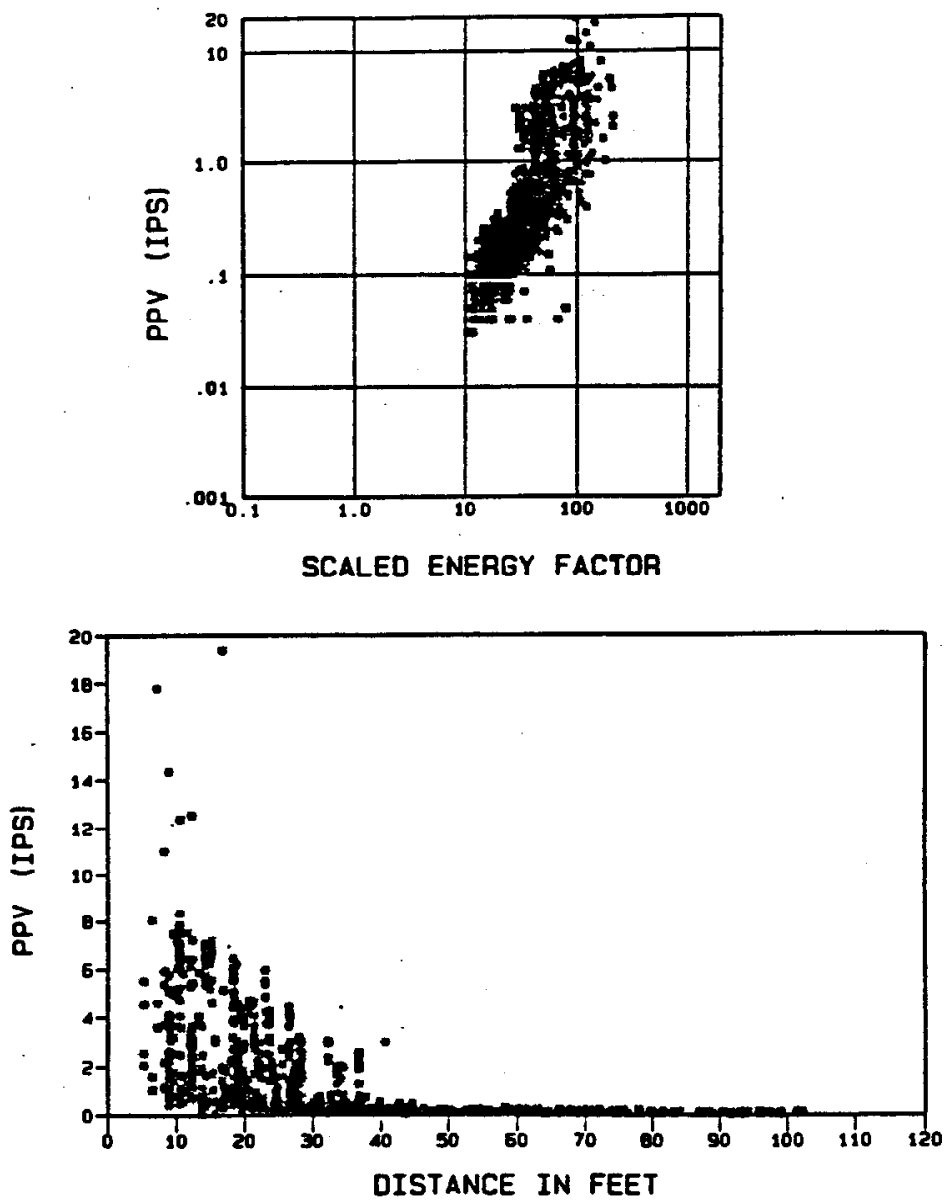

\begin{tabular}{|c|}
\hline 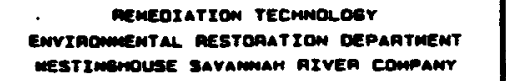 \\
\hline EBASCO SEAVICES INCORPOAATEO \\
\hline $\begin{array}{l}\text { PPV VERSUS SCALED ENERGY } \\
\text { FACTOR FOA ALL DAOPS AT DTF } \\
\text { FTEUAE SEF.OOJ }\end{array}$ \\
\hline
\end{tabular}

Figure 18 Peak particle velocity versus scaled energy factor for all drop locations at the DCF test facility. (After EBASCO) 
Table 2 Summary data for primary, secondary, and tertiary production drops.

\begin{tabular}{|c|c|c|c|c|c|c|c|c|c|}
\hline $\begin{array}{l}\text { Drop } \\
\text { Order }\end{array}$ & 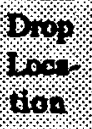 & $\frac{8}{30}$ & $\frac{1007}{100}$ & 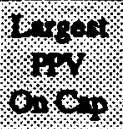 & 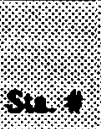 & 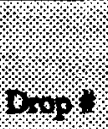 & 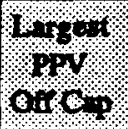 & $810 \%$ & 180,09 \\
\hline 1 & $\mathbf{E A}^{\prime}$ & Primary & 3 & 033 & 11 & $1 \%$ & 6.40 & 28 & 1 \\
\hline 2 & $C^{\prime}$ & Primary & 4 & 326 & 8 & 4 & 10.98 & 26 & 1 \\
\hline 3 & $\mathbf{A A}^{\prime}$ & Primary & 3 & $0 \% 8$ & 18 & $\%$ & 12.50 & 1 & 1 \\
\hline 4 & $\mathbf{B A}^{\prime}$ & Secondary & 5 & 386 & 8 & 3 & 5.75 & 1 & 1 \\
\hline 5 & $\mathbf{D A}^{\prime}$ & Secondary & 3 & 081 & 10 & \% & 5.46 & 27 & 1 \\
\hline 6 & $\mathrm{CC}^{\prime}$ & Primary & 4 & 806 & 10 & $\%$ & $7: 47$ & 7 & 1 \\
\hline 7 & $A C^{\prime}$ & Primary & 3 & $8 \%$ & 8 & 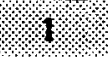 & 14.32 & 26 & 1 \\
\hline 8 & EC' & Primary & 3 & $\%$ & 20 & 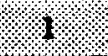 & 19.37 & 27 & 1 \\
\hline 9 & $\mathbf{D C}^{\prime}$ & Secondary & 4 & $10 \% \%$ & 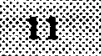 & 4 & 7.16 & 8 & 1 \\
\hline 10 & $\mathbf{B C}^{\prime}$ & Secondary & 4 & $108 \%$ & 9 & 3. & 7.22 & 26 & 2 \\
\hline 11 & EB' & Primary & 5 & $0 \% 1$ & 29 & 4 & 17.79 & 4 & 1 \\
\hline 12 & $\mathbf{A B}^{\prime}$ & Primary & 4 & 0.30 & 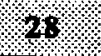 & 6 & 5.52 & 3 & 1 \\
\hline 13 & CB' & Primary & 5 & 813 & 36 & 8 & 5.85 & 7 & 1 \\
\hline 14 & DB' & Secondary & 8 & $0 \% 0$ & 19 & 4 & 3.98 & 7 & 1 \\
\hline 15 & BB' & Secondary & 10 & 102 & $\%$ & 8 & 4.76 & 7 & 1 \\
\hline 16 & $\mathbf{T} 1$ & Tertiary & 8 & $10 \% 6$ & 28 & 6 & 4.40 & 3 & 5 \\
\hline 17 & $\mathbf{T 2}$ & Tertiary & 11 & $6 \%$ & $8 \%$ & 8 & 7.05 & 6 & 4 \\
\hline 18 & $\mathbf{T 3}$ & Tertiary & 9 & 1865 & 28 & \% & 8.34 & 3 & 5 \\
\hline 19 & $\mathrm{~T} 4$ & Tertiary & 14 & 126 & 80 & 14 & 7.18 & 6 & 14 \\
\hline
\end{tabular}

\#Only 12 drops required to meet refusal criteria of $6 \mathrm{ft}$ crater depth

\section{Dynamic Compaction Strong Motion}

The buried waste matrix was consolidated using three principle drop pattems: primary, secondary, and tertiary. The intent of these patterns was to emulate production methods by consolidating the waste matrix, while minimizing lateral spread. Sixty-eight drops were performed at 15 primary and secondary drop locations, and 42 drops were performed at 4 tertiary locations from $50 \mathrm{ft}$ high. Consistency in drop height was maintained by placing a mark on the cable spool. The consistent impact velocity with small standard deviation verifies the consistency in drop height.

Summary data for the largest primary, secondary, and tertiary drops are given in Table 2. The location of stations that correspond to the largest or smallest PPV values given in Table 2 can be found in Figure 14 (all A' drops), Figure 15 (all B' drops), Figure 16 (all C' drops), and Figure 17 (all tertiary drops). 
There are many variables controlling the impact of vibrations induced by dynamic compaction. One is drop location, (i.e., primary, secondary, and tertiary). Another variable is the drop number at each location, (i.e., 1st, 2nd, or 3xd drop). A brief discussion of several graphical permutations of data combinations is given below.

Figure 18 presents data for all production drops and stations at the DCF. This includes seismograph stations on the DCF cap, the ELIT surface, areas surnounding the ELLT, and areas surrounding the DCF cap. Maximum PPV values from 5 to $40 \mathrm{ft}$ range from a maximum of 18 to $20 \mathrm{in} / \mathrm{s}$ near the point of tamper impact to less than $2 \mathrm{in} / \mathrm{s}$ near a 40-ft distance. Distances in excess of $40 \mathrm{ft}$ had PPVs typically less than $0.5-0.7 \mathrm{in} / \mathrm{s}$. Most of the scatter is from stations located off the DCF cap within the ELLT or surrounding soils. Figure 19 presents the attenuation curves for all the production drops, compered with the baseline from natural ground. The comparison suggests significantly higher attenuation values at the DCF.

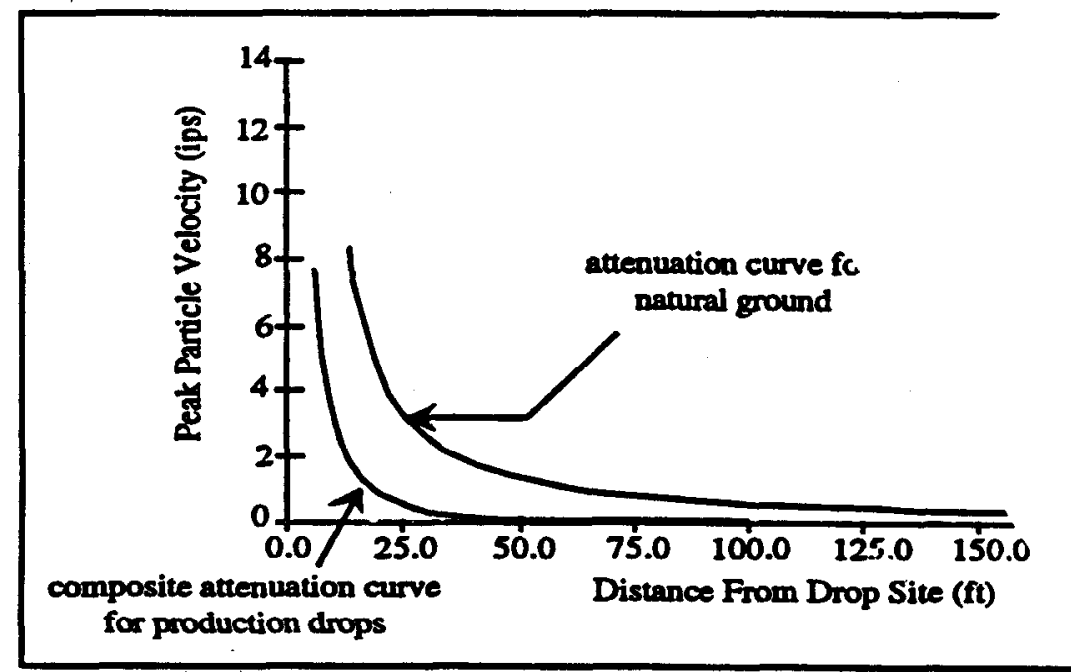

Figure 19 Comparison between the PPV attenuation curves for the natural ground versus the composite for all production drops.

The maximum observed PPV value for each seismograph station (for all production drops) is shown in Figure 20. The largest PPV values were recorded by stations located immediately adjacent to the impact area on the ELLT. Typical ELLT PPV values range from approximately 1 to $20 \mathrm{in} / \mathrm{s}$. For the same data set, the DCF cap had significantly lower PPV's, ranging from 2.0 in/s on the western side of the cap to about $0.2 \mathrm{in} / \mathrm{s}$ on the castern side. Figures 21, 22, and 23 illustrate the variability observed for the production drops by drop number. As illustrated, the highest PPV values are clearly associated with the first drop. This is because the first drop had to rupture the compacted soil cover that was placed over the EI.T. This sandy clay was extremely hard and its rupture resulted in very high PPV values at stations located near the impact point. Virtually all PPV values above 8 in/s occurred during the first drop. The effect of the sandy clay soil cover is less apparent for stations more than $20 \mathrm{ft}$ from the drop point. Figures 24, 25, and 26 present data for the primary, secondary, and tertiary production drops, respectively. These figures show that for stations within about $20 \mathrm{ft}$ of the drop point, the primary drops clearly resulted in higher ground motion levels. As discussed previously, the higher PPV 
Rev. 1
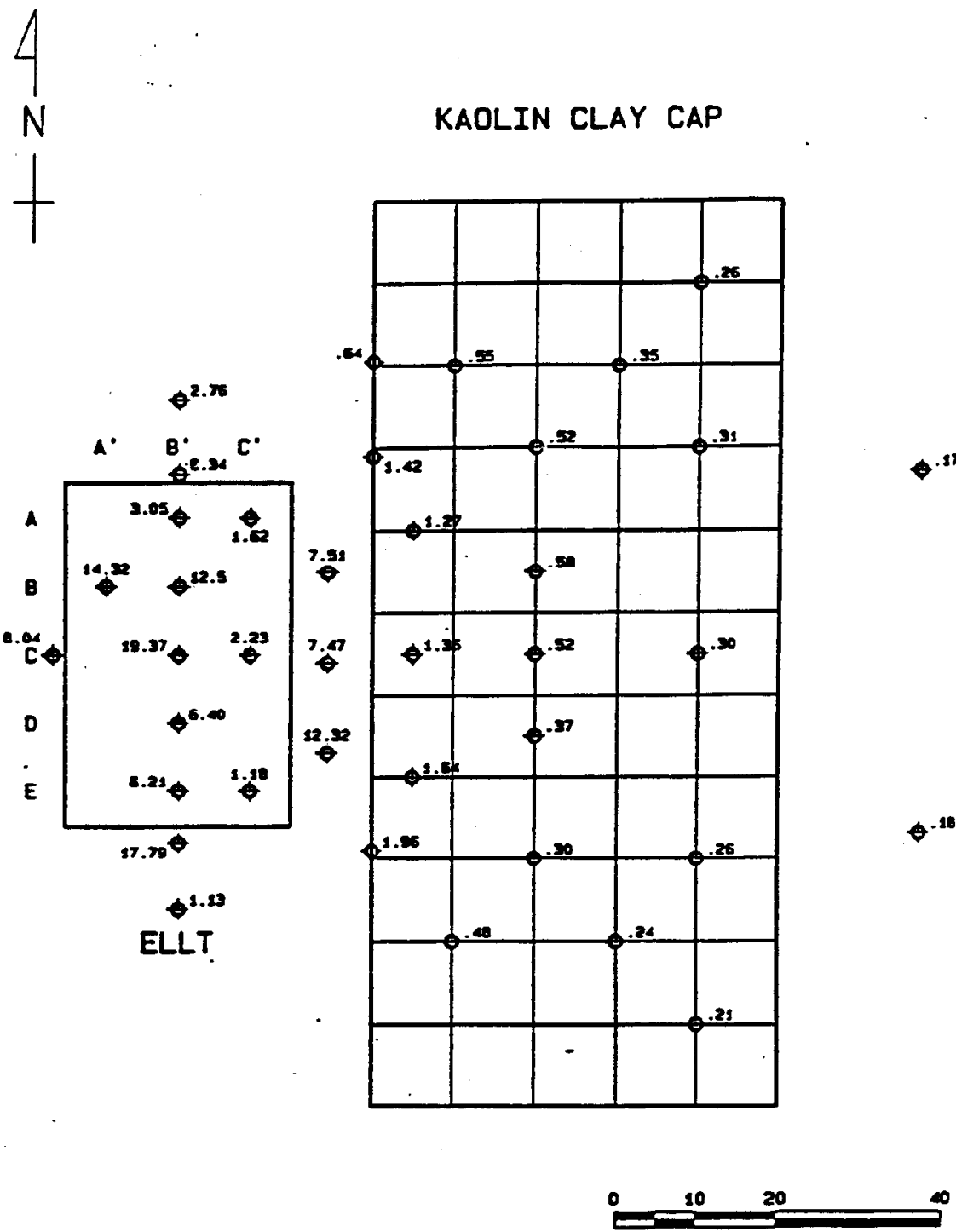

SCALE IN FEET

nemeozation tecmologr EAVIAOMEENTAL AESTOAATION DEPAATMENT westrmanouse savamak aIVEa company

$$
\varphi^{.25}
$$

NOTE: values represent the axiaun observed ppy (IPS) experienced at each seisaic station. The total number of orops experienced at each station varied.
EBASCO SERVICES INCOAPOAATED

MAXIMUM DBSEAVED PPV FOR ALL DROPS

Figure 20 Tabulation of the maximum observed peak particle veolocities for all drop locations. (After EBASCO) 
Rev. 1

\section{PPV VERSUS SCALED ENERGY FACTOR}
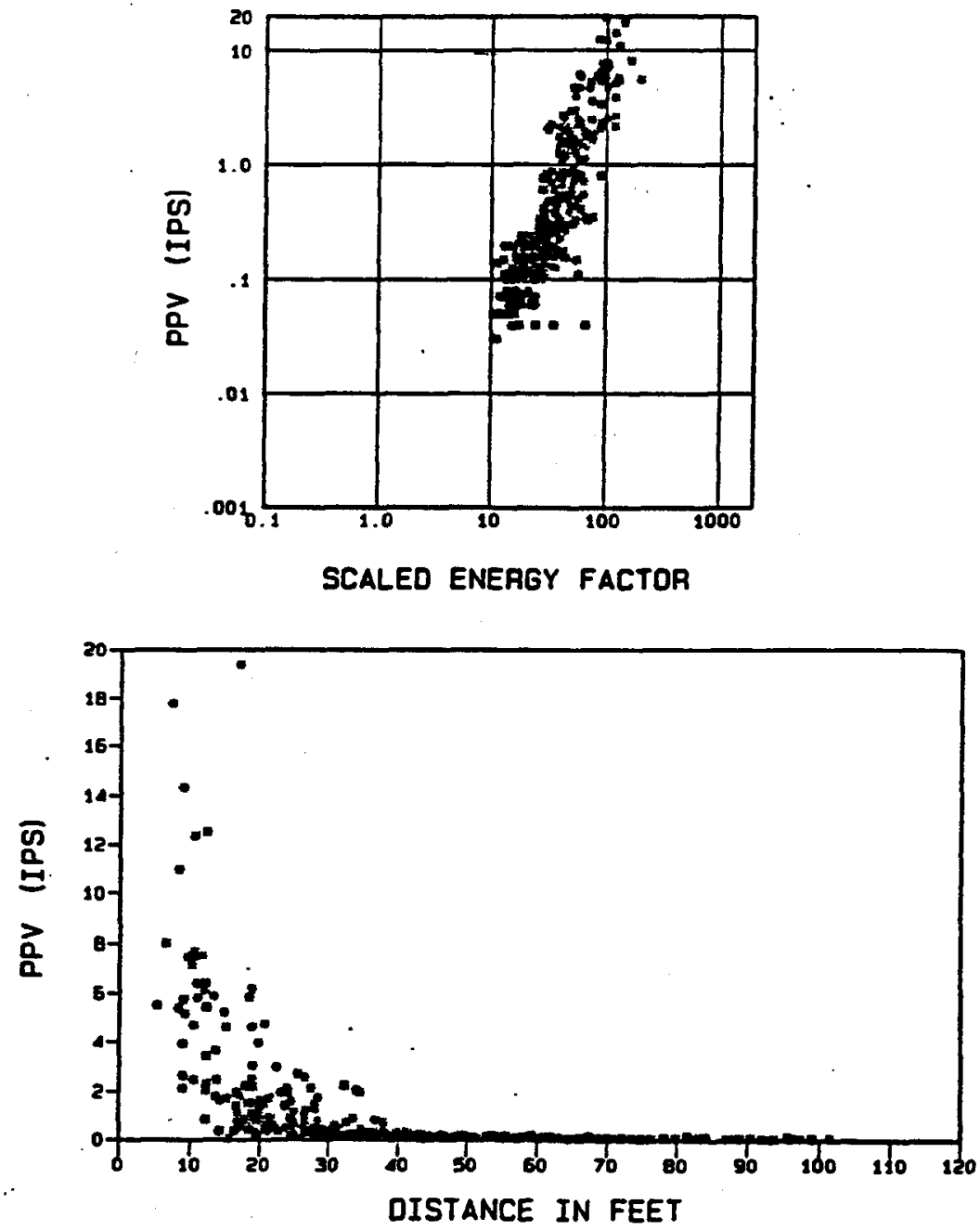

AEMEDzaTzON TECMmoLoer EMVIRONmENTAL RESTOAATZON DEPAGTWEAT mestrumenouse savamman arveA company

EBASCO SEAVICES INCOAPORATED

pPY VERSUS SCALED ENERSY

FACTOA FOR ALL FIRST DROPS AT DTF

FIOUne geF, OQE

Figure 21 Peak particle velocities versus scaled energy factor for all first drops at the DCF. (After EBASCO) 
WSRC-TR-94-0159

Rev. 1

March 21, 1994

\section{PPV VERSUS SCALED ENERGY FACTOR}
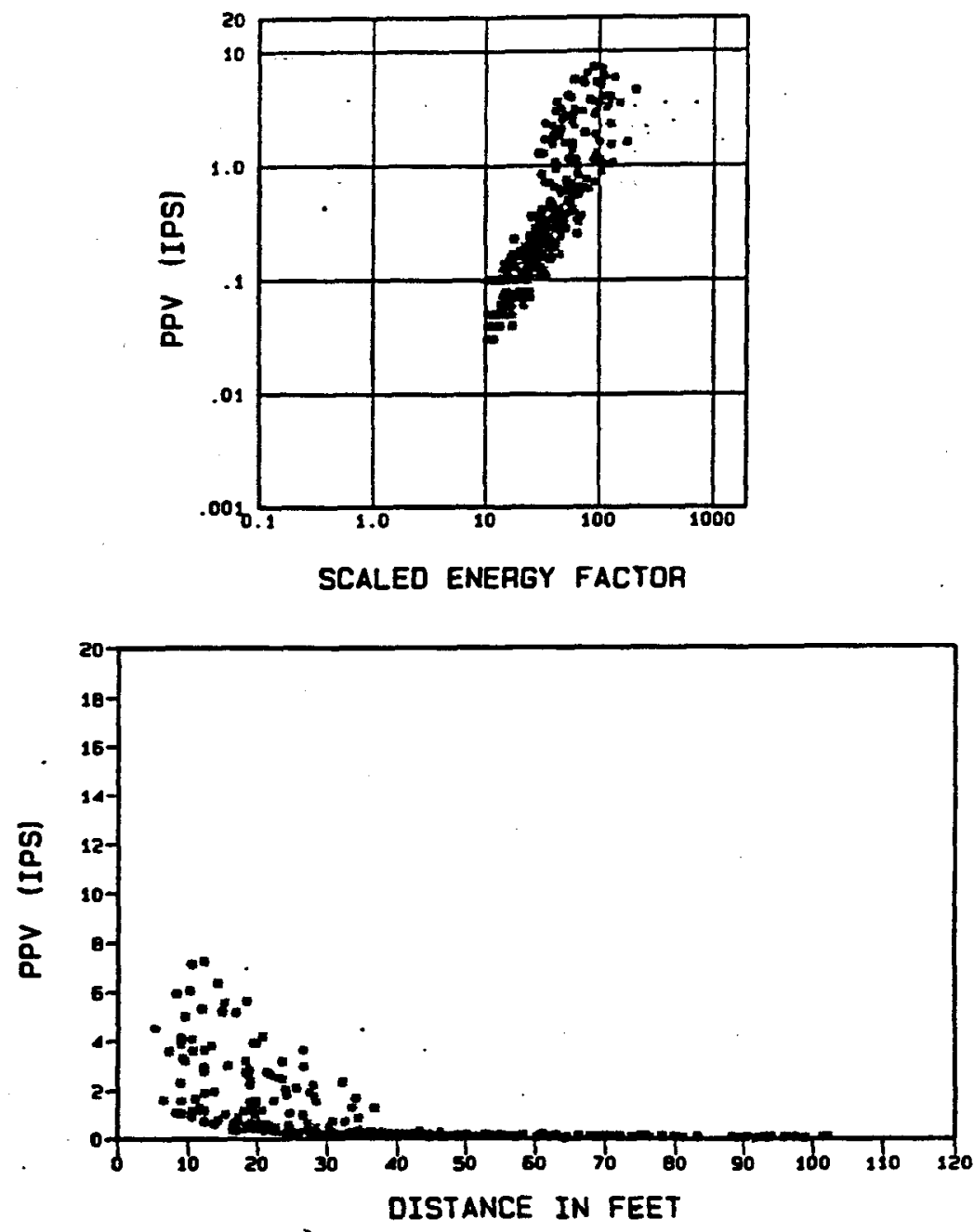

AEmentatzon TECmoloar ENVIAOMENTAL RESTORATION DEPAATMENT EBASCO SFRVICES INCOAPOAATED PPV VERSUS SCALEO ENEREY FACTOR FOR ALL SECOND oRops at DTF FIGUAE SEF. OOE

Figure 22 Peak particle velocities versus scaled energy factor for all second drops at the DCF. (After EBASCO) 
Rev. 1

\section{PPV VERSUS SCALED ENERGY FACTOR}
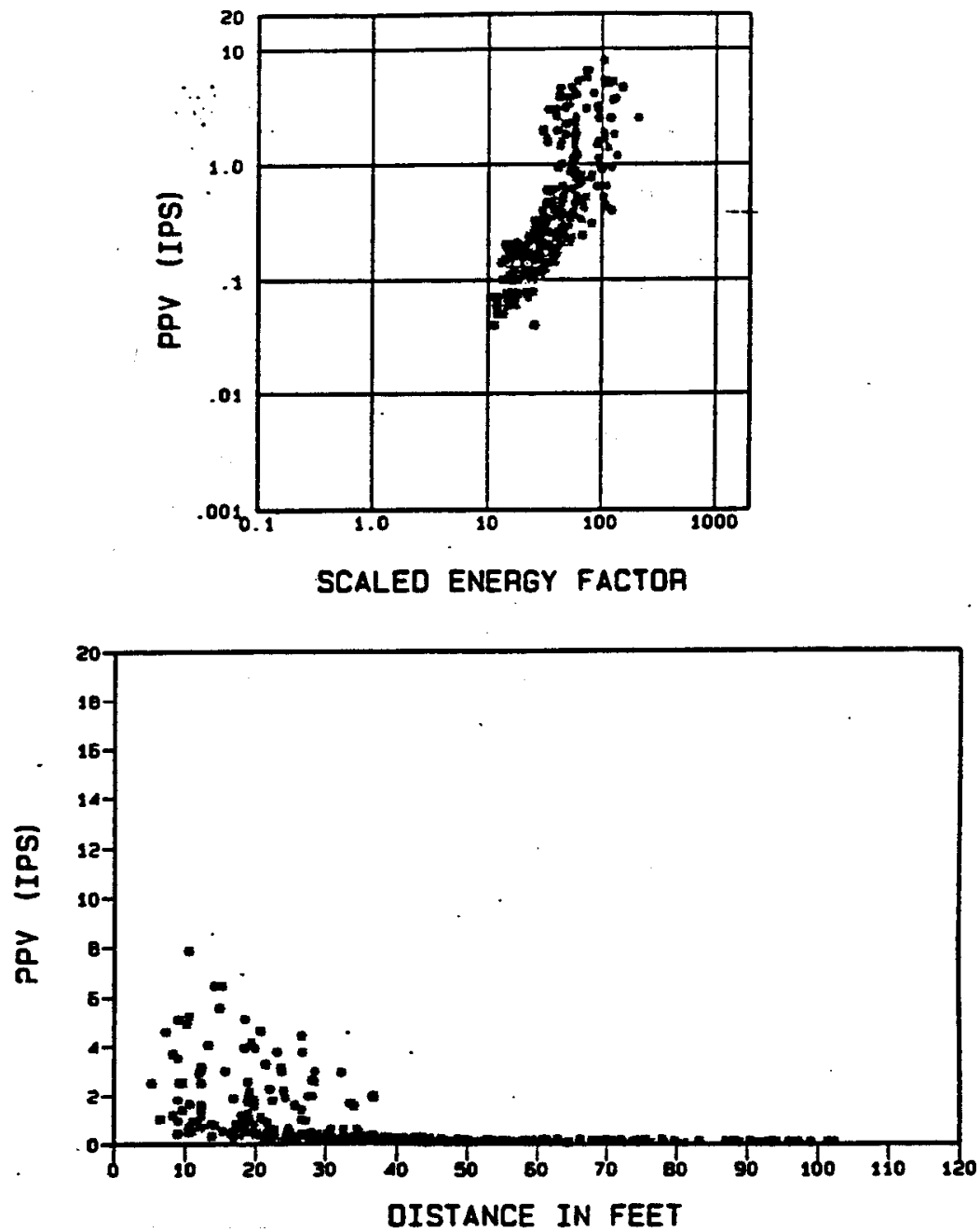

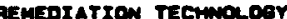

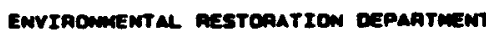
mestrnenouse savanuay arveg company

EBASCO SEAVICES INCOAPORATED

PPY VERSUS SCALED ENERGY

FACTOA FOR ALL THIRD OAOPS AT DTF

FIGUFE GEF, OD?

Figure 23 Peak particle velocities versus scaled energy factor for all third drops at the DCF. (After EBASCO) 
WSRC-TR-94-0159

Rev. 1

March 21, 1994

\section{PPV VERSUS SCALED ENERGY FACTOR}
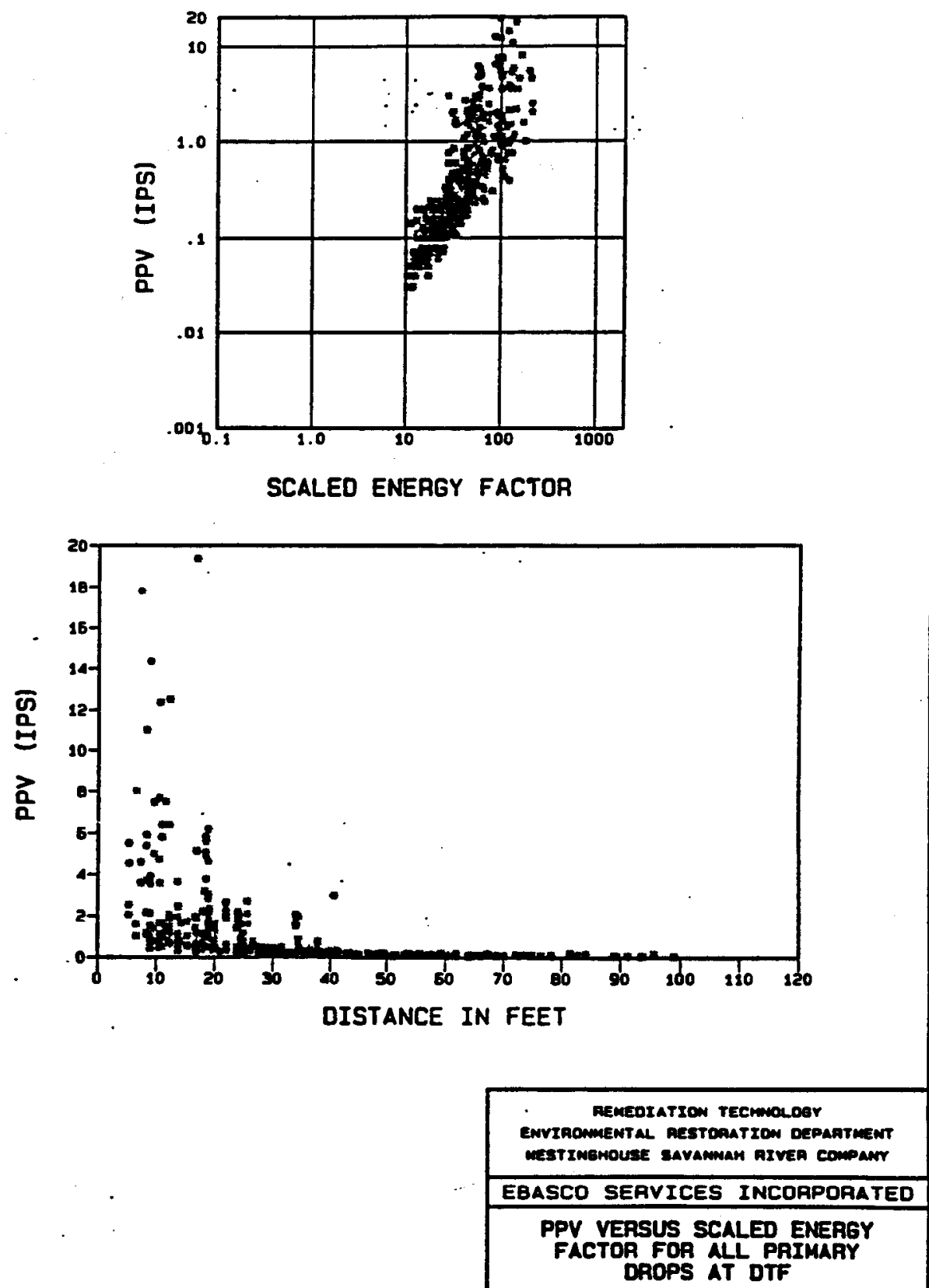

Figure 24 Peak particle velocities versus scaled energy factor for all primary drops at the DCF. (After EBASCO) 
Rov. 1

\section{PPV VERSUS SCALED ENERGY FACTOR}
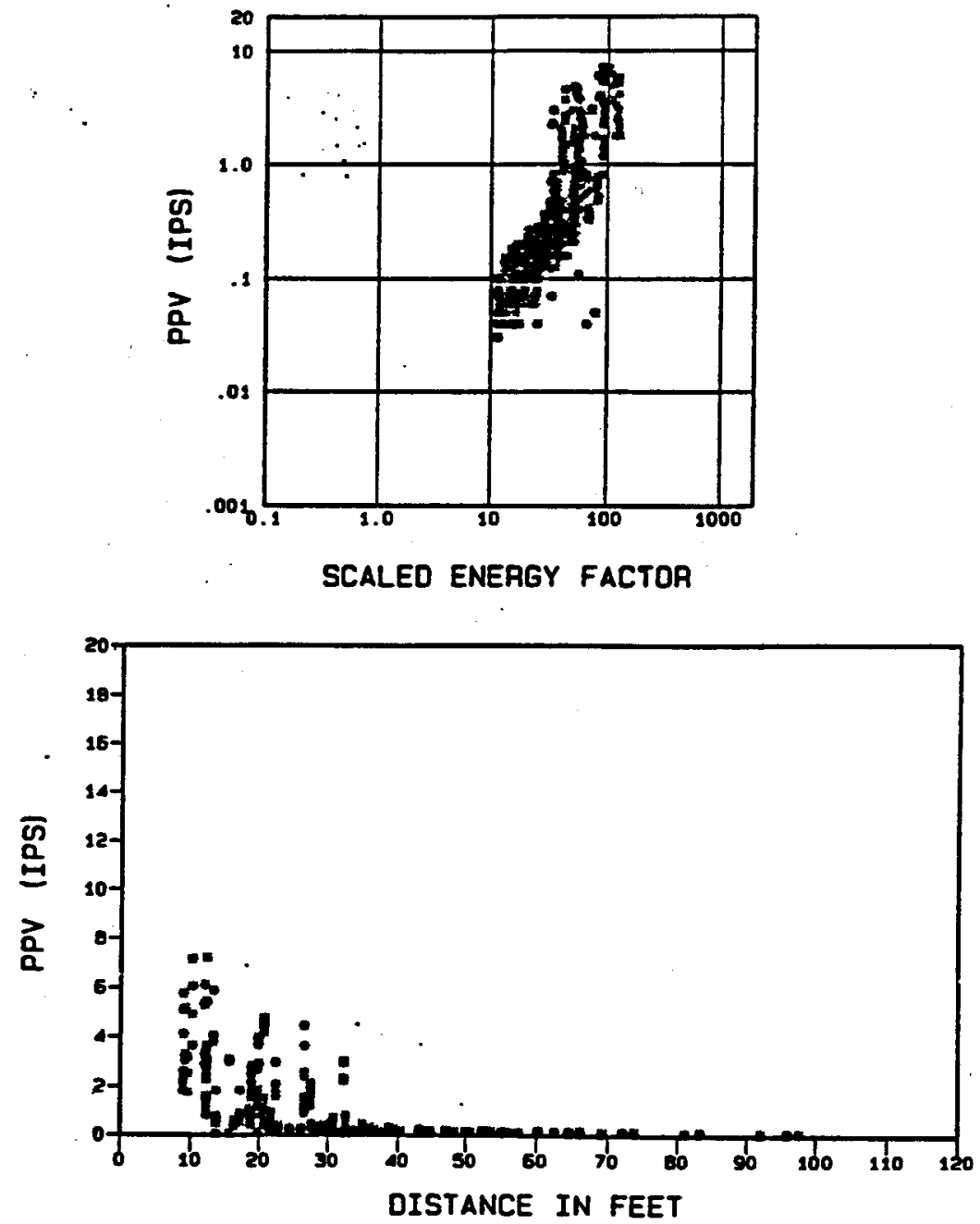

AEMEDTATYOU TECMmonogV

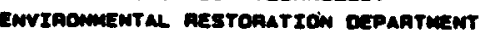
mestrmentouse savaman arvea company

EBASCO SERVICES INCORPOAATED

PPV VERSUS SCALED ENERGY

FACTOR FOR ALL SECONOARY DAOPS AT DTF

FIGUAE SEF OOE

Figure 25 Peak particle velocities versus scaled energy factor for all secondary drops at the DCF. (After EBASCO) 
WSRC-TR-94-0159

Rev. 1

March 21, 1994

\section{PPV VERSUS SCALED ENERGY FACTOR}
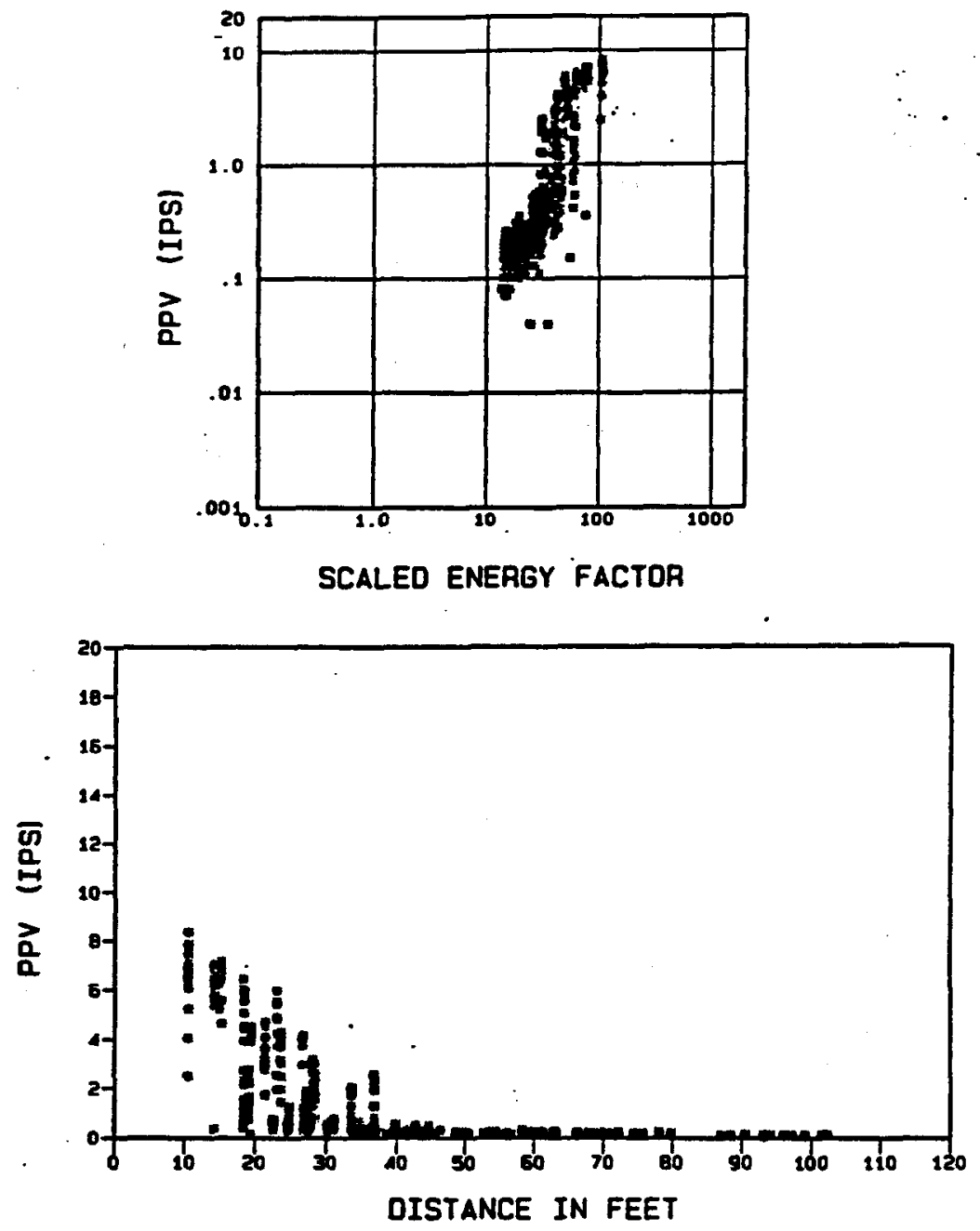

AENEOIATION TECMnOLOQ

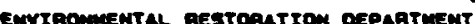
mestrmenouse savamum arvea company

EBASCO SEAVICES INCORPOAATEO

PPV VERSUS SCALED ENERGY

FACTOR FOR AL TERTIARY DAOPS AT DTF

FIGUAE SEF. OOC

Figure 26 Peak particle velocities versus scaled energy factor for all tertiary drops at the DCF. (After EBASCO) 
Rev. 1

values are primarily associated with the first drops that had to break through the compacted sandy clay cover of the ELIT. However, a close comparison of these figures shows that for stations in the 20 - $40 \mathrm{ft}$ distance range, the secoadary drops generally resulted in higher PPV values than the primary drops and the tertiary drops resulted in even higher values. For example, PPVs in excess of $3 \mathrm{in} / \mathrm{sec}$ are rare in the primary drop data set, but are very common for tertiary drops. This increase probably reflects the improvement the compaction process has had on the waste matrix, suggesting PPV values could potentially be used to monitor this improvement.

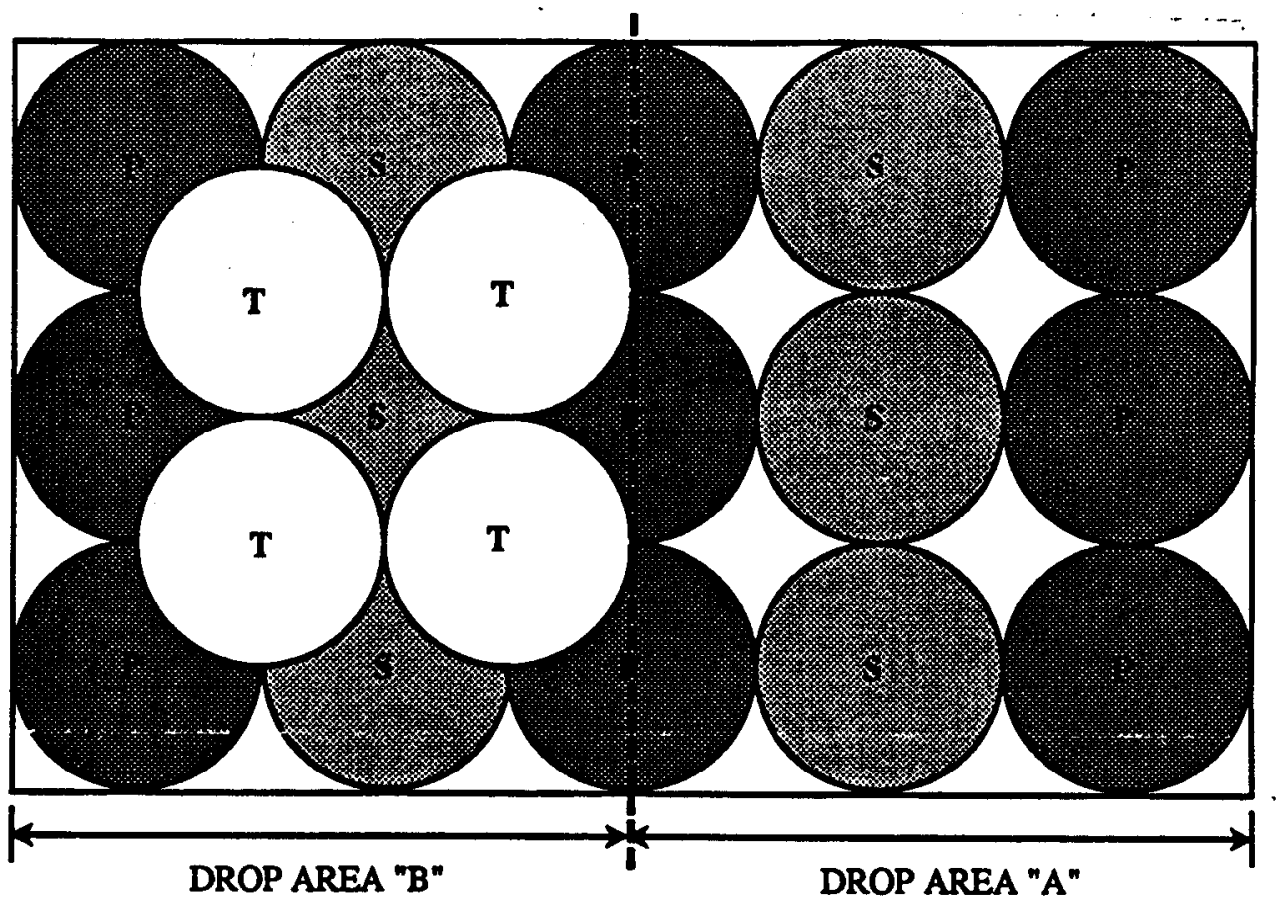

Figure 27 Drop area A was compacted to existing specifications while drop area B was over compacted to facilitate the generation of a new specifications.

During the early drop test phases, it became apparent that this was not the case, and the buried boxes were not being fully consolidated. To better evaluate and take advantage of instrumentation redundancy, the drop zone was divided into drop areas A and B (Figure 27). Drop area A was compacted using the traditional MWMF success criteria, while drop area B was compacted until very little improvement could be detected.

Table 3 presents a comparison between the displacements in the longitudinal, transverse, and vertical directions for the natural ground baseline and the DCF test. Note a marked decrease in vertical motion accompanied by an increase in displacements in the other directions. The data presented are the peak displacements, not the displacements at an instantaneous point in time. The instrumentation was oriented with the longitudinal direction corresponding with the long axis of the DCF test cap, and the transverse direction corresponding to the short axis. The wave forms generated by dynamic compaction propagate in a radial direction from the point of impact. 
Rev. 1

Table 3 A comparison between the natural ground baseline and the production drops. Table displays the percentage of total displacement in the longitudinal, transverse, and vertical directions.

\begin{tabular}{|c|c|c|c|c|c|c||}
\hline \multirow{2}{*}{$\begin{array}{c}\text { Drop } \\
\text { Location }\end{array}$} & \multicolumn{2}{|c|}{ Longitudinal } & \multicolumn{2}{c|}{ Transverse } & \multicolumn{2}{c|}{ Vertical } \\
\cline { 2 - 7 } & Average & St. Dev. & Average & St. Dev. & Average & St. Dev. \\
\hline Baseline & 40.6 & 1.4 & 1.0 & 2.7 & 58.3 & 1.5 \\
\hline$A^{\prime}$ & 29.6 & 4.0 & 18.8 & 4.2 & 51.6 & 3.9 \\
\hline B' $^{\prime}$ & 31.0 & 3.3 & 12.5 & 4.4 & 56.5 & 4.2 \\
\hline C'$^{\prime}$ & 49.7 & 3.5 & 17.8 & 4.3 & 32.5 & 1.9 \\
\hline D' $^{\prime}$ & 37.4 & 4.6 & 32.5 & 2.6 & 30.1 & 4.5 \\
\hline T1 & 36.0 & 2.1 & 10.0 & 2.1 & 54.0 & 2.5 \\
\hline T2 & 40.8 & 2.6 & 16.4 & 3.3 & 42.8 & 3.9 \\
\hline T3 & 34.8 & 2.3 & 18.7 & 4.3 & 46.6 & 1.7 \\
\hline T4 & 38.3 & 1.1 & 10.3 & 4.7 & 51.4 & 1.7 \\
\hline
\end{tabular}

Note: Values are expresced in percentage.

Understanding this principle and reexamining Table 5.3 shows that the percentages of true longitudinal and transverse displacement are severely distorted, compared with the natural ground baseline.

\section{Wave Forms}

To quantify the effects on the kaolin clay from vibrations induced by dynamic compaction, the physical effects of the wave form must also be considered. To understand the different wave forms and their effects, it is useful to consider a seismic event. With any seismic event, there are three basic types of elastic waves: the primary or $\mathrm{P}$-wave, the secondary or S-wave, and the surface wave. The P-waves travel the fastest through the medium, typically $5000 \mathrm{ft} / \mathrm{s}$. These wave forms alternatively compress and dilate the soil medium. The $S$-waves are slower, and as the waves propagate, they shear the medium sideways, normal to the direction of propagation. This motion may be both vertical and horizontal. The surface waves travel the slowest and are restricted to the near ground surface. Surface waves can be divided into two basic forms. The first is the Love wave motion, which is essentially the same as the S-wave, without the vertical component. The ground moves laterally back and forth. The second form is the Rayleigh wave. The Rayleigh wave produces a rolling motion, with both a horizontal and a vertical component. This motion can be described as an elliptical, retrograde motion.

Dynamic compaction energy manifests itself predominately as a Rayleigh type wave form6. Table 3 summarizes the percentage of total motion displayed as longitudinal, transfers, and vertical motion. Note that as the compaction process progresses, the ratios for longitudinal, transverse, and vertical displacements change. Woods 6 stated that $67 \%$ of the wave form motion is attributed to Rayleigh waves. Assuming the vertical motion is truly characteristic of Rayleigh waves, an analysis of the DCF test data establishes that $64 \%$ of the motion recorded for natural ground is Rayleigh waves. Note, however, that the standard deviation is high. Figure 28 presents the vertical displacement attenuation with distance for the natural ground baseline data. 


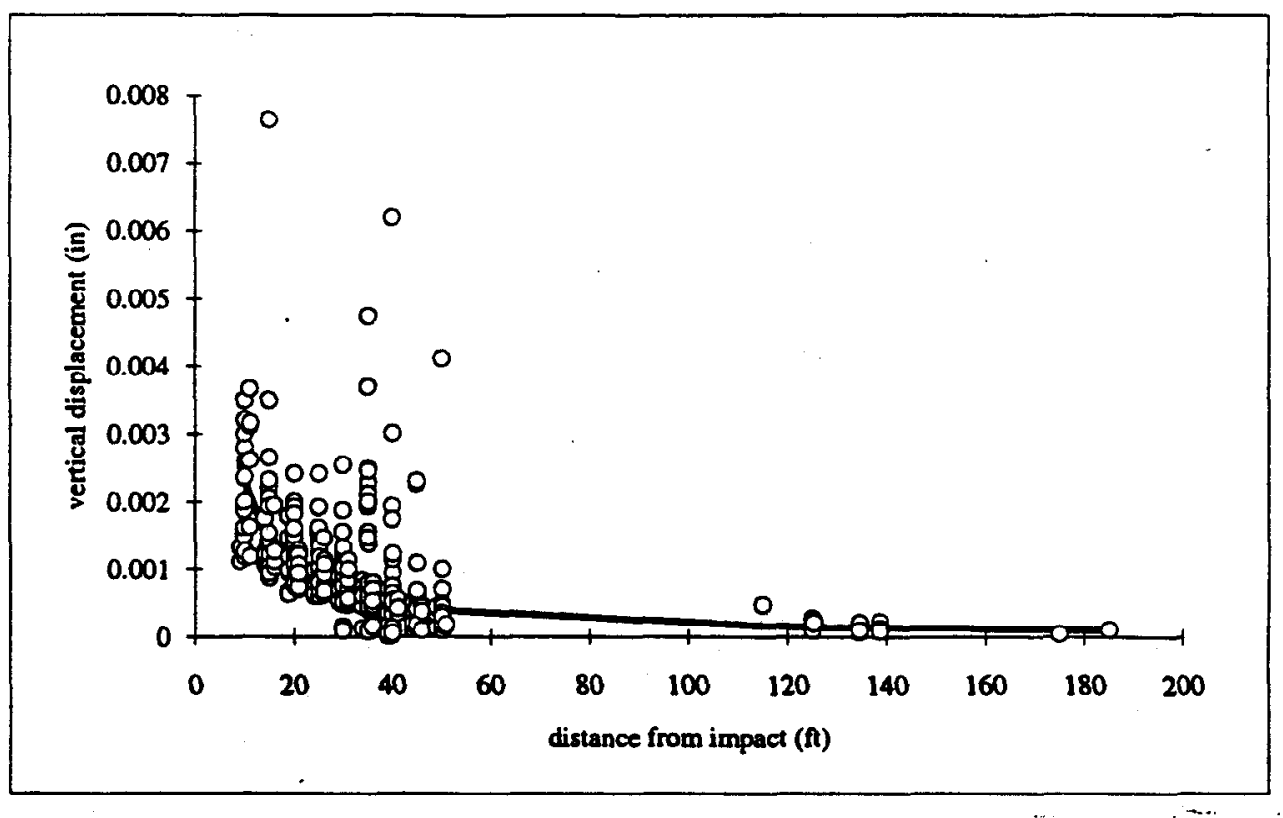

Figure 28 Plot of the vertical displacement versus distance from impact for natural, undisturbed soils.

If the medium has no material interface or surface, all the energy will be manifest as body waves or P- and S- waves. The surface waves occur with material interfaces and tend to travel along these surfaces. As these wave forms intersect a material boundary, they are reflected and refracted, converting some energy to other wave forms.

The basic premise that as the buried waste approached maximum density, the strong motion dispersion curve would approach the density established for natural, undisturbed soils was flawed. Figure 29 presents a comparison between the actual recorded wave forms.

The first that as wave forms move through a material interface, they are reflected and refracted. Through the interface, the wave form is transmuted into different wave forms. Additionally, when seismic waves are reflected and/or refracted, the phase of the wave is changed. These actions to greatly change the wave form behavior, explaining the deviations seen in Table 3.

In comparing the recorded wave forms for natural ground (Figure 29a) with those from production drops (Figure 29b and 29c), there are some distinct differences. Figure 29a is a relatively smooth sine curve with little interferences. Figures $29 \mathrm{~b}$ and $29 \mathrm{c}$ represent a wave record of combined wave forms. The arrows show, smaller, out of phase vibrations showing up with the primary wave pattern. These additional vibrations are different in frequency, amplitude, and phase than the record for natural ground. This is assumed to be the result of the fused layer acting as a diaphragm, vibrating within the soil.

The combined effects of the wave form transmutation and the additional vibrational sources account for the different displacement ratios for the production drops. The benefit of all this "confusion" is a reduced PPV and vertical displacement, both of which are the primary sources of damage to a structure. 


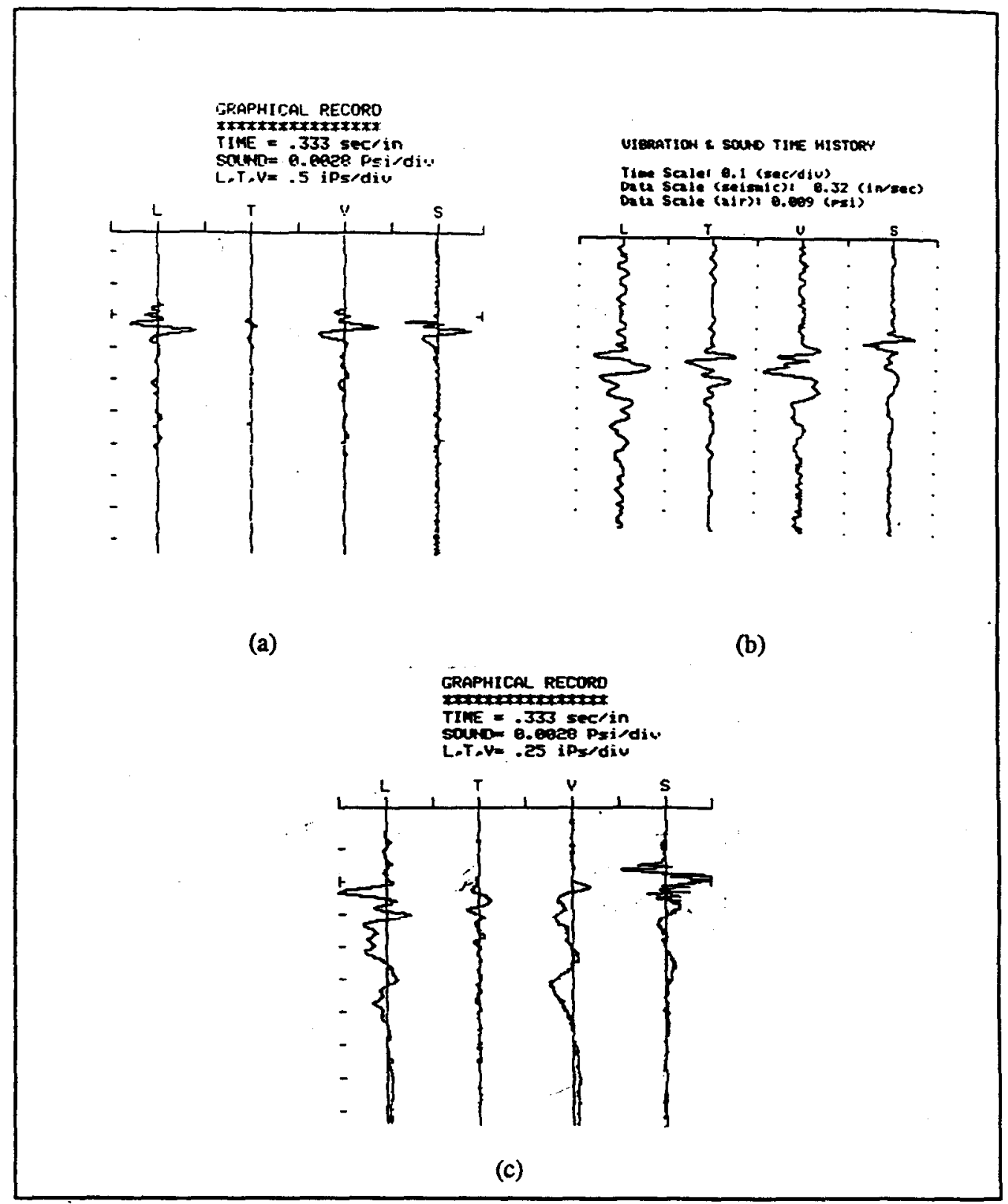

Figure 29 Comparison of actual wave form between (a) natural ground, (b) beginning tertiary drop, and (c) final DCF test drop. Note the difference in duration and wave shape. Tertiary drop records display a series of waves ranging from low to high frequencies. 
Rev. 1

\section{Inelastic. Deformation Test Results}

Twenty-two survey monuments were in and around the DCF test site to monitor heave place around the DCF. Of the 22 monuments, 10 were located on the perimeter of the ELLT, four on the westerly DCF cap edge, four on virgin ground east of the DCF cap, and four on virgin ground surrounding the ELLT. Monument locations were resurveyed after completing of the $A^{\prime}, C^{\prime}, B^{\prime}$, and tertiary drop locations. The only movement observed was local movement toward the compacted boxes. After excavating the topsoil cover for infiltrometer placement, observations indicate that this subsidence caused some damage to the kaolin cap. The lose of foundation support apparently caused a "hinging" effect in the clay, rupturing the cap along the crest of the side slope (Figure 30). This effect is sensible and expected, considering the degree of compaction applied to the buried boxes.

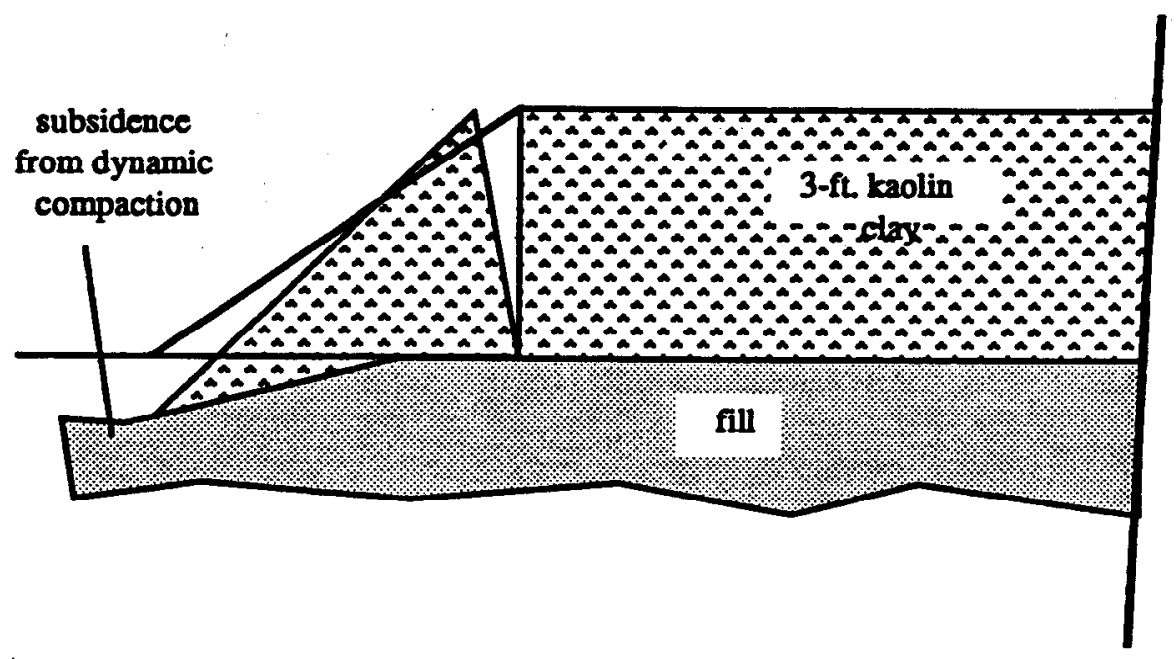

Figure 30 Schematic showing suspected mechanism for subsidence failure to the kaolin clay cap.

There is little literature describing threshold limits for damage to compacted kaolin clay. The University of Kentucky performed a series of static load tests to determine the arching strength of kaolin clay7. In these tests, Dr. Richard Warner determined that a $3 \mathrm{ft}$-thick-clay layer could span a 3-ft hole, and when the clay deflected 6 in., it would crack and fail. The U.S. Bureau of Mines (USBM) has conducted a series of tests to evaluate structural damage thresholds for explosives. Explosives generate wave forms similar to seismic events, and even more so like those from dynamic compaction. Figure 31 presents a graph generated by this USBM research. Note that the threshold limit is defined by the heavy line marked, (a), and is a function of the vibration frequency. Frequencies recorded for the DCF dynamic compaction ranged between 50 and $80 \mathrm{~Hz}$. At this frequency range, the threshold limit in PPV is 2 in/s. This value is conservative because it represents the threshold limit for damage to plaster structures. The compacted kaolin clay should have a much higher plastic range than a rigid structure and withstand higher vibrations without failure.

Another consideration is the definition of failure. For a rigid structure, failure might be cracking or even a catastrophic failure. For a regulated closure system, failure might be when the hydraulic conductivity exceeds $10 \mathrm{~m} \mathrm{~cm} / \mathrm{sec}$. Clays are considered thixotropic because they tend to repair 
WSRC-TR-94-0159

Rev. 1

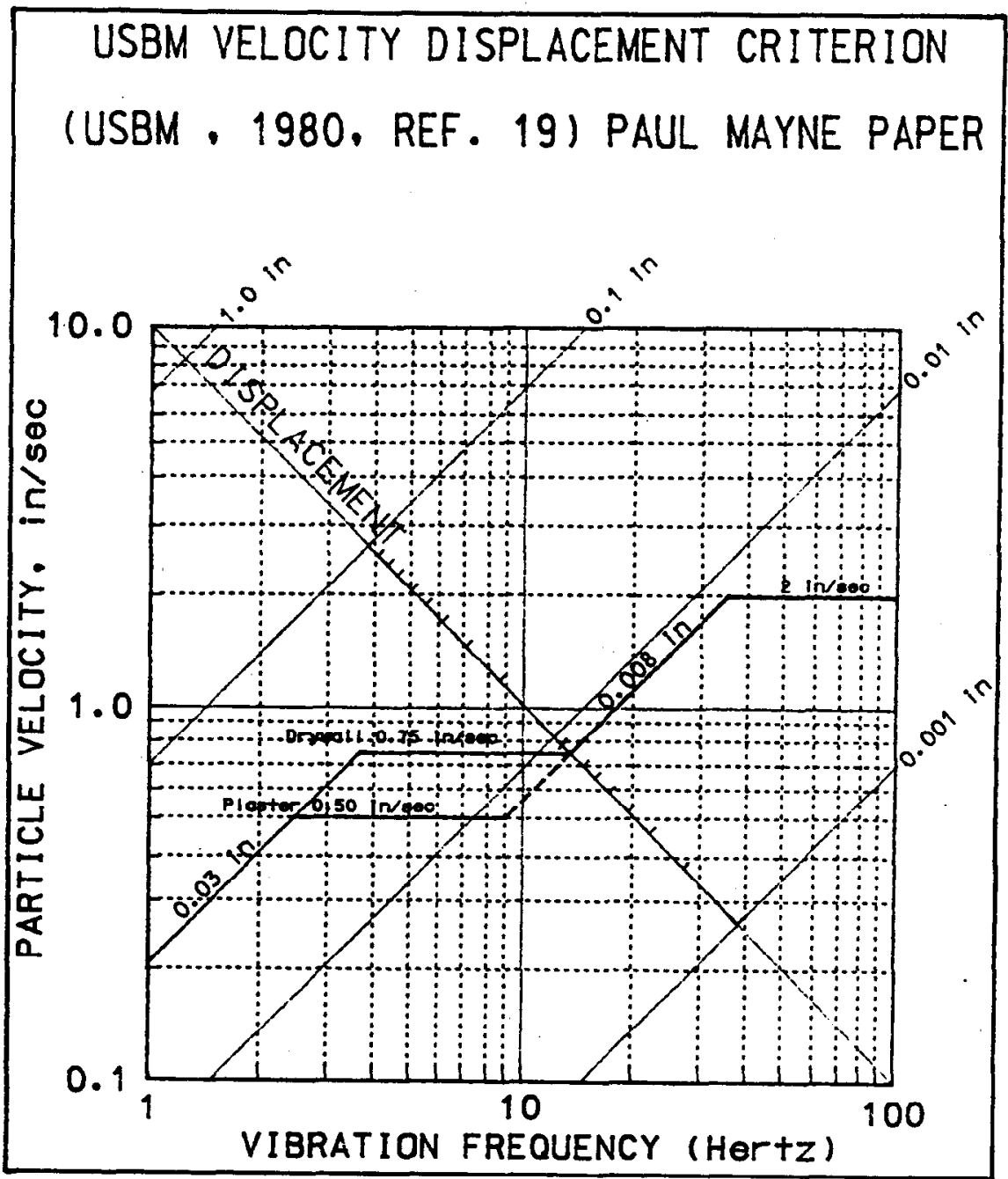

Figure 31 Graph presenting threshold limits for structural damage as a function of peak particle velocity versus frequency. (after U.S. Bureau of Mines)

themselves when minimally damaged. As part of this test, though not included herein, a helium injection system was employed to evaluate microfissuring. During compaction, helium was moving through the clay cap. However, by the next morning, there was no helium flux occurring. During the time between the two observations, the kaolin clay displayed thixotropic characteristics by recovering from microfissuring induced by the dynamic compaction.

\section{Hydraulic Conductivity Measurements}

At the conclusion of the active dynamic compaction phase, two data collection activities provided additional data. These two activities included evaluating the hydraulic conductivity and the success in consolidating the buried B-25 boxes.

Kaolin clay hydraulic conductivity was demonstrated prior to placing the MWMF closure system. Under subcontract to WSRC, Mueser-Rutledge, Inc., constructed nine test pads, using locally available kaolin clay. The test objectives were to identify a suitable source of clay, establish the in-place hydraulic conductivity, and to identify the characteristic soil parameters and construction methods. Methods modifying the proctor test were identified to ensure harmony with actual field 
Rev. 1

conditions. Finally, the test established that kaolin clay met or exceeded the required $10 \mathrm{rcm} / \mathrm{sec}$ hydraulic conductivity.

It was assumed that by constructing the kaolin clay cap to the Mueser-Rutledge specifications and by using the target moisture density values, the baseline hydraulic conductivity would met or exceed 10-07 cm/sec was considered. Conducting in situ permeability testing prior to dynamic compaction activities was eliminated because testing would cause saturation of the test cap, interfering with the propagation of shear waves across the cap. (Note that water will not transmit shear waves, and a high moisture content would dampen the shear wave energy.)

The ASTM D698-78 provided the optimal moisture density for the kaolin clay. Specifications, which included the CT Main target values for each lift, required the in-place moisture to range between 28 and $30 \%$ and the dry density to range between 90.0 and 95.0 pef. Figure 32 presents the as built moisture and density gradations, relative to the window of acceptability. In all cases, the target values were met. During construction, areas not meeting the specifications were reworked until the specifications were achieved.

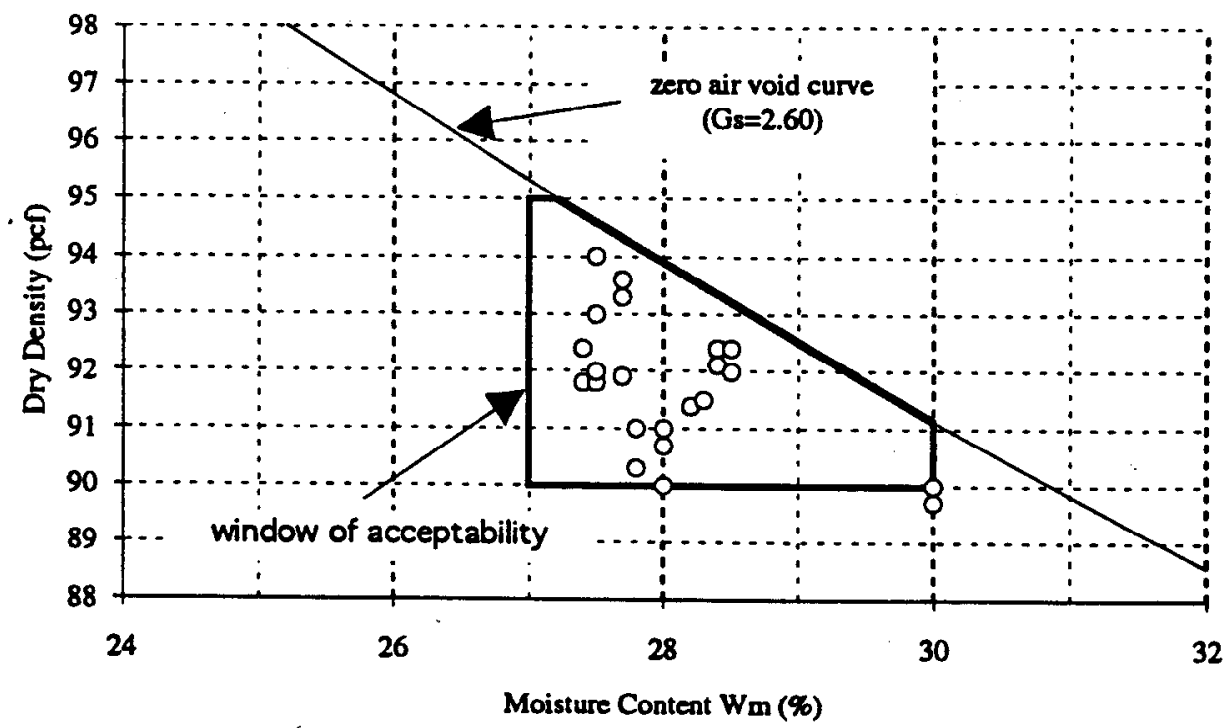

Figure 32 Plot of dry density versus moisture content for DCF as built quality assurance test data. Note that the window of acceptability was derived from the CT Main Corp. statistical analysis of the MWMF as built values.

As discussed previously, the hydraulic conductivity for a closure cap is a critical component for a RCRA closure. One of the purposes for the DCF is 10 determine any impacts on the MWMF kaolin closure system from dynamic compaction of the LLRWDF closure. The hydraulic conductivity was measured at the conclusion of dynamic testing to assist in making this determination. The instrument of choice is the SDRI, as discussed previously.

Postdynamic compaction analysis identified six sites on the DCF clay cap to be instrumented. Each of these sites was selected based upon a probability level for damage. Three sites were in high probability areas, one site was in a moderate probability area, and two were in low probability areas. Figure 33 shows the general locations tested.

Permeability testing was conducted between September 14, 1992, and January 8, 1993. During this time, each instrument was monitored with data collected regularly. Figures 34,35 , and 36 present a comparative composite for hydraulic conductivity for all instrumentation during the test. 
Rev. 1

March 21, 1994

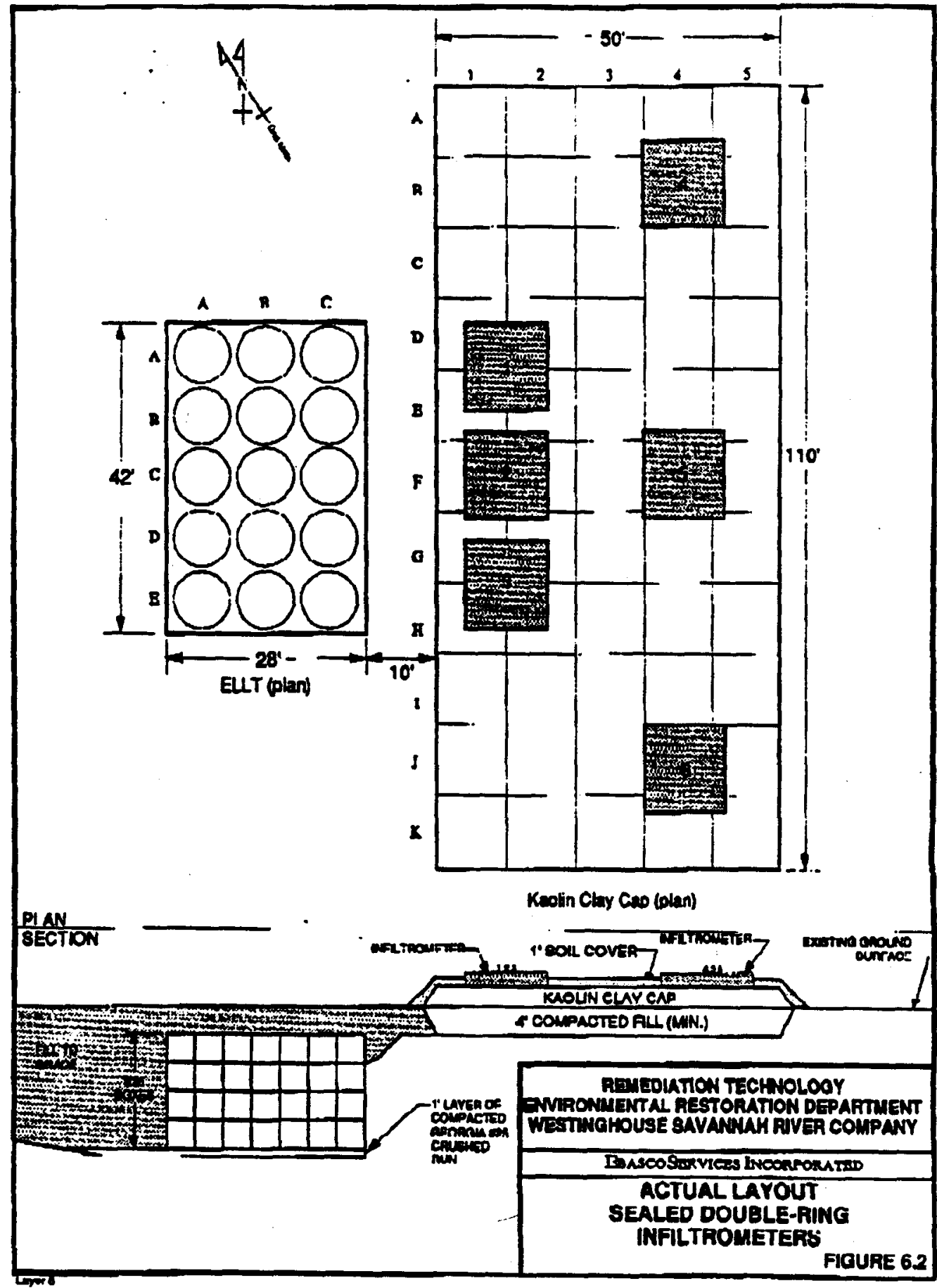

Figure 33 Plot displaying the locations for the six Sealed Double-Ring Infiltrometers.

Placement was based upon preliminary evaluation of vibration montioring data. SDRI 1 - 3 are in areas of high probability for damage, SDRI 5 is in an area of moderate probability for damage, and SDRI 4 and 6 are in areas of low probability for damage. (after EBASCO) 


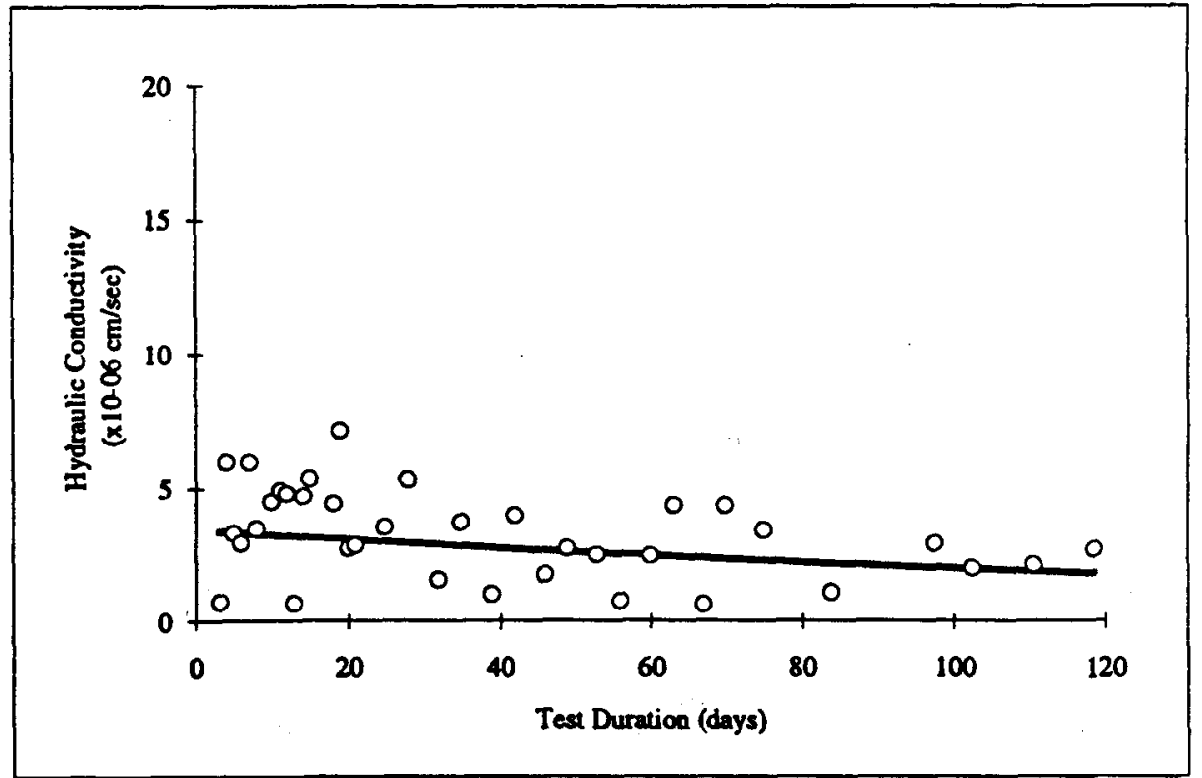

Figure 34-a Plot of variations in hydraulic conductivity, location $\mathrm{W}-\mathrm{N}$ on the DCF kaolin clay cap.

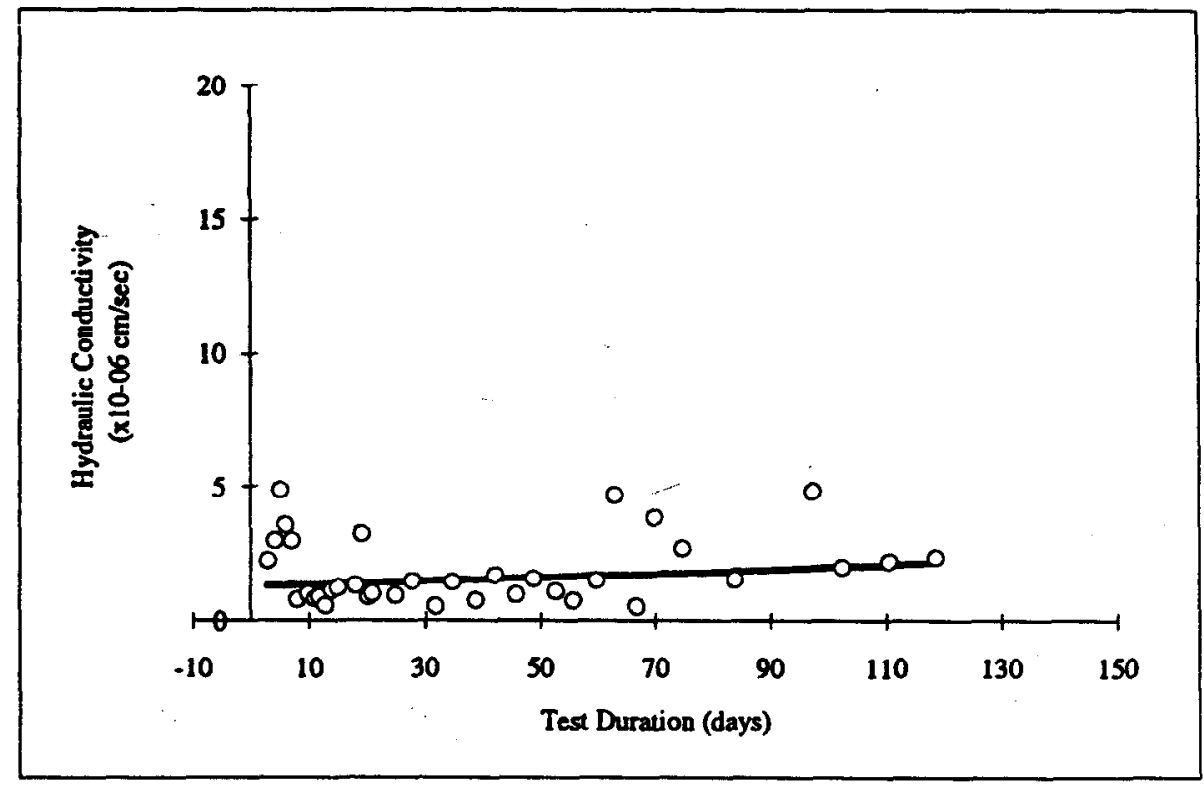

Figure 34-b Plot of variations in hydraulic conductivity, location W - C on the DCF kaolin clay cap. 
Rev. 1

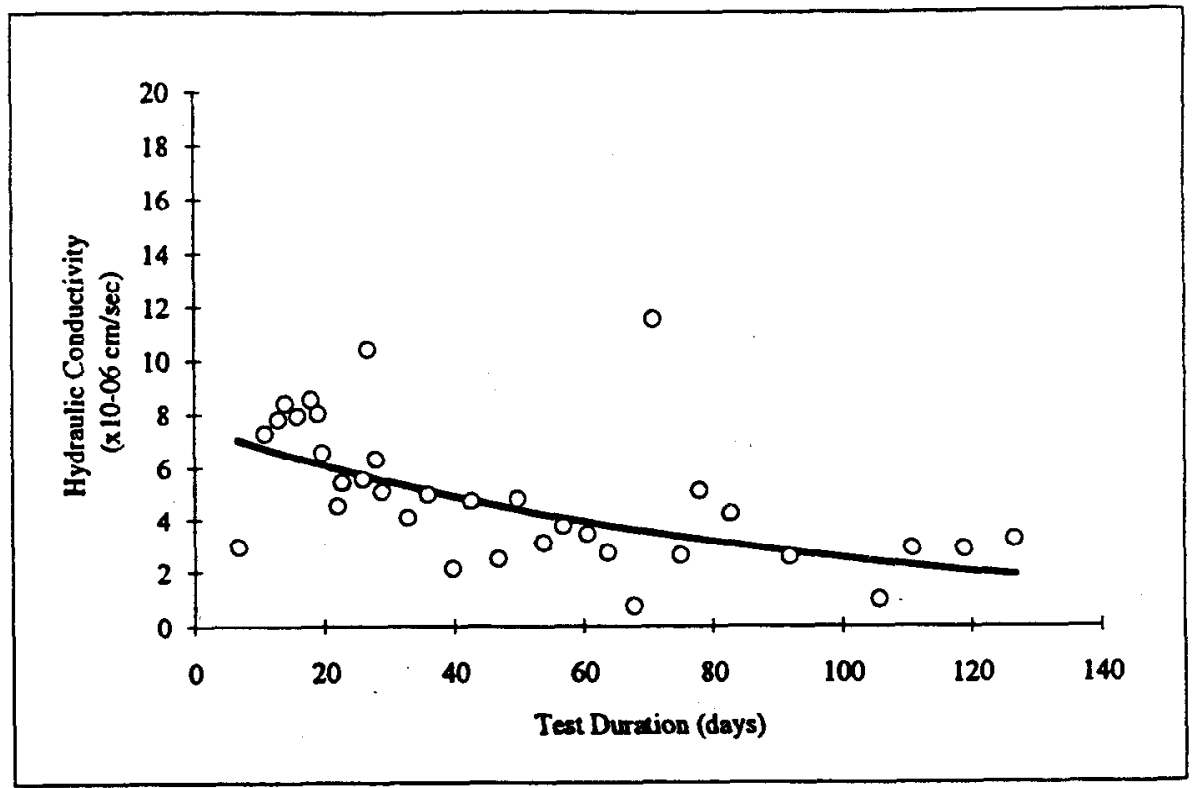

Figure 35-a Plot of variations in hydraulic conductivity, location W - S on the DCF kaolin clay cap.

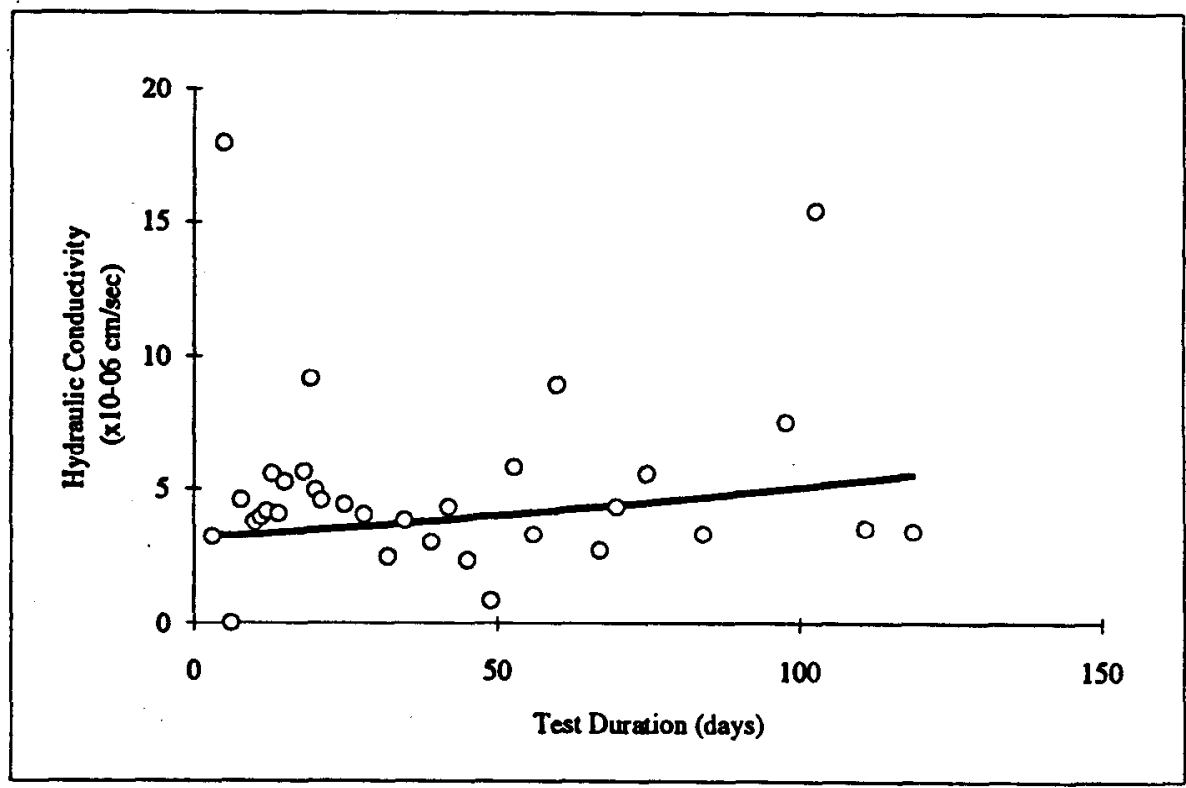

Figure 35-b Plot of variations in hydraulic conductivity, location E - N on the DCF kaolin clay cap. 


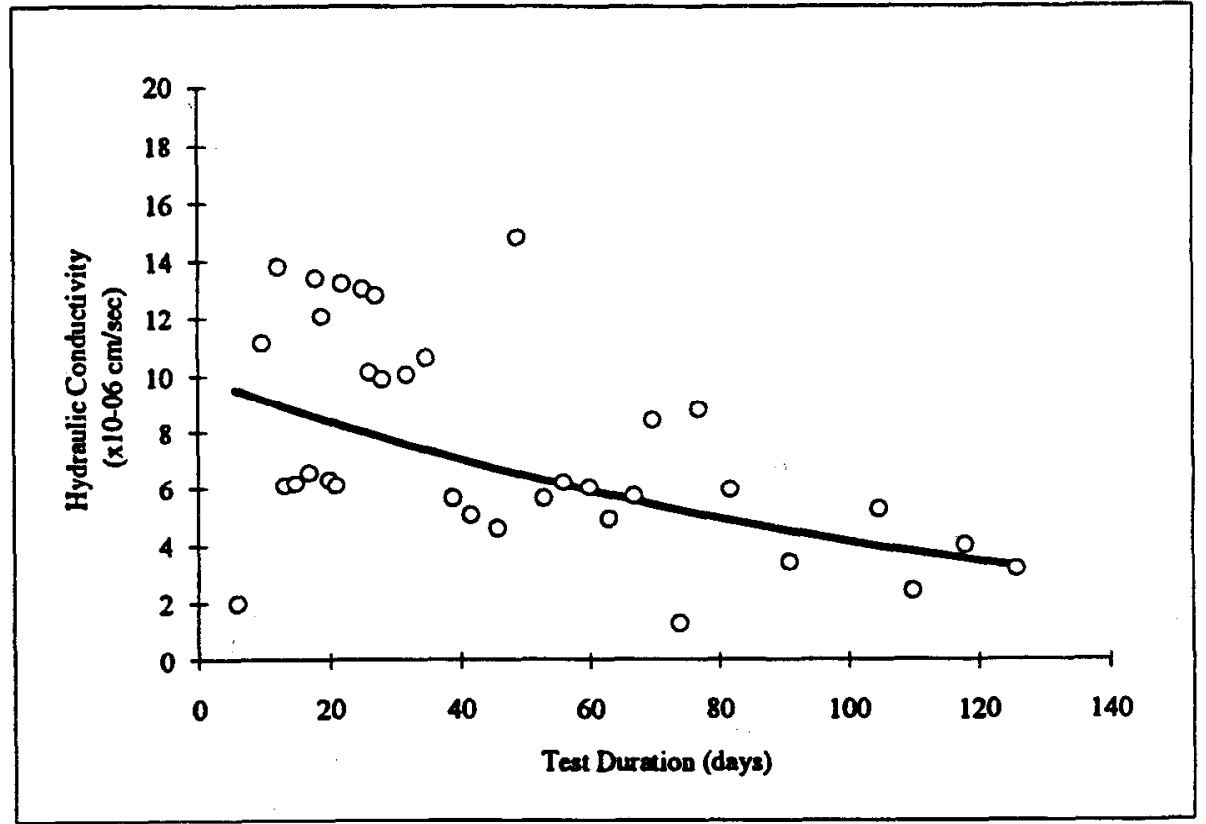

Figure 36-a Plot of variations in hydraulic conductivity, location E - C on the DCF kaolin clay cap.

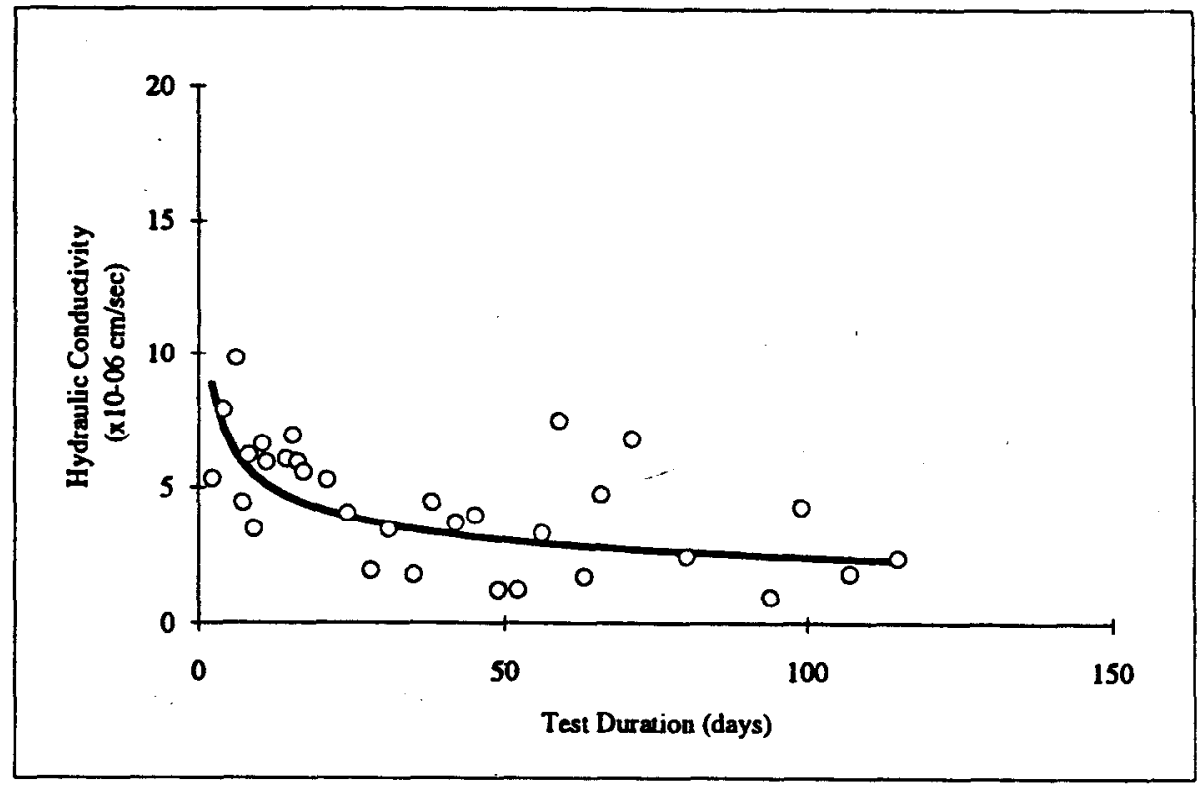

Figure 36-b Plot of variations in hydranlic conductivity, location E - S on the DCF kaolin clay cap. 
Rev. 1

Table 4 Statistical analysis for SDRI testing of hydraulic conductivity, DCF test cap.

\begin{tabular}{|c|c|c|c|c|c|c|c|}
\hline \multicolumn{3}{|c|}{ Areas Subjected to Higher Vibrations } & \multicolumn{3}{c|}{ Areas Subjected to Lower Vibrations } \\
\hline & $\begin{array}{c}\text { Test } \\
\text { Period }\end{array}$ & Average & $\begin{array}{c}\text { Standard } \\
\text { Deviation }\end{array}$ & & $\begin{array}{c}\text { Test } \\
\text { Period }\end{array}$ & Average & $\begin{array}{c}\text { Standard } \\
\text { Deviation }\end{array}$ \\
\hline W-N & Month 1 & 0.41 & 0.17 & E-N & Month 1 & 0.53 & 0.38 \\
\hline & Month 2 & 0.23 & 0.11 & & Month 2 & 0.39 & 0.23 \\
\hline & Month 3 & 0.26 & 0.13 & & Month 3 & 0.57 & 0.44 \\
\hline W-C & Month 1 & 0.53 & 0.38 & E-C & Month 1 & 0.95 & 0.37 \\
\hline & Month 2 & 0.39 & 0.23 & & Month 2 & 0.76 & 0.35 \\
\hline & Month 3 & 0.57 & 0.44 & & Month 3 & 0.48 & 0.23 \\
\hline W-S & Month 1 & 0.77 & 0.43 & E-S & Month 1 & 0.57 & 0.19 \\
\hline & Month 2 & 0.37 & 0.11 & & Month 2 & 0.34 & 0.19 \\
\hline & Month 3 & 0.35 & 0.28 & & Month 3 & 0.32 & 0.20 \\
\hline
\end{tabular}

This original work by Meuser-Rutledge established construction criteria that ensures compliance with RCRA requirements. The RCRA regulatory limit for hydraulic conductivity is $10-07 \mathrm{~cm} / \mathrm{sec}$. At the conclusion of the dynamic compaction phase, the DCF cap was instrumented with six SDRIs. These infiltrometers use a driving head to measure the in situ hydraulic conductivity. Note in figures 35a and $b$ and $36 \mathrm{a}$, there are data points exceeding the $10^{-07} \mathrm{~cm} / \mathrm{sec}$ limit. However, as the clay reaches a steady state, the average hydraulic conductivity is consistently below the regulatory limit. These deviations are attributed to variations in the quality of construction, seams between the clay panels, and localized preferential pathways. Pathways within the clay are usually lateral, resulting from constructing the clay cap with 8 in. lifts. As these pathways are filled with water, the water must work it's way through the compacted clay. This is recorded as a higher flux at the SDRI. Table 4 presents the statistical variation for each SDRI for each 30-day testing period. Generally, with a little deviation, the hydraulic conductivity decreases with time. This is consistent with the clay becoming saturated and reaching a steady state. Note that on a general evaluation, there is little variation between all the infiltrometers. All locations meet regulatorily required hydraulic conductivity.

DCF kaolin cap for approximately 120 days. A breakthrough of the kaolin clay occurred after about 60 days. After the breakthrough, the instruments reached a steady state condition, or free and constant flow through the kaolin clay. There were some obvious deviations in hydraulic conductivity over time that are interesting and noteworthy.

The first observation is a noticeable increase in hydraulic conductivity at the time of the breakthrough. This increase may be atuributed to an influence on the flux by the underlying, unsaturated soils. The negative pore pressure in the unsaturated soils could potentially exert a draw onto the steady state flux rate until enough of the underlying soils become saturated to negate this influence. The temporary increase in hydraulic conductivity was observed in all six instruments at or near the time of the breakthrough.

The second observation was a correlation between the changes in hydraulic conductivity and barometric pressure. As the barometric pressure changed, the steady state hydraulic conductivity was uniformly altered for all six SDRI's, simultaneously. This alteration ranged almost a full order of magnitude between the high and low points. This change can be attributed to an increase and/or decrease in the driving head under the influence of the barometric changes. 


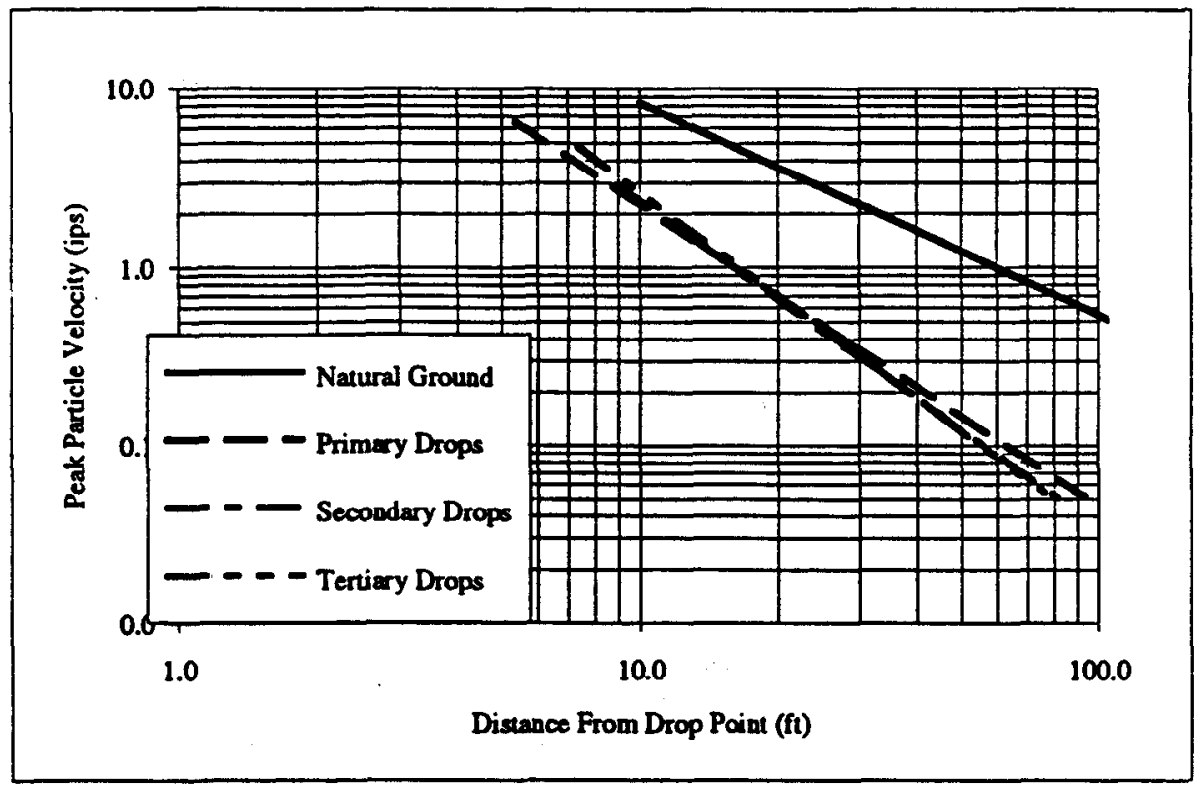

Figure 37 Log- log plot comparing attenuation of PPV versus distance between the natural ground baseline and the primary, secondary, and tertiary drops.

\section{Buried Waste Compaction Evaluation}

There were several key observations during dynamic compaction indicating that the buried wastes were not being consolidated. These were the differences in weight impact between the natural ground and the buried B-25 boxes; penetration of the weight into the buried wastes; and the small PPV's observed during impact. In response to these observations, the test plan was modified to establish drop zones A and B. Symmetry in the instrumentation allowed for this modification, without negatively impacting the test objectives. Drop area $A$ was compacted, using the traditional SRS success criterion of a $6 \mathrm{ft}$ displacement or 20 consecutive drops. Drop area B was overcompacted, using a primary, secondary, and tertiary drop pattern. Compaction was continued until the displacement appeared to be negligible.

Excavation of the consolidated B-25 boxes revealed that in both drop zones, there was a fused layer of boxes. This layer was formed by the lateral spread and interlocking of the compacted boxes. Failed boxes and materials were overlying each other so tightly that, in some cases, the cranes extracting the boxes tore the metal rather than separate the boxes.

This is supported by the divergence of the slope of attenuation from primary to secondary to tertiary drop sites on figure 37 (note that figure 37 has been plotted using a log-log scale to accentuate the relationship). The primary attenuation curve demonstrated a slope very similar to the baseline. As the fused layer formed, it absorbed energy, reducing the shear wave energy induced into the soil.

Additionally, the outside edges of the box matrix were not effectively consolidated. Apparently, the drop pattern did not overlap the exterior edge of the box matrix. The drop patterns were designed so that the distance between the center point of impact and the exterior edge was the radius of the weight. Failure to consolidate the box matrix edge may have contributed to the elastic nature of the fused box layer by providing supports to bridge the box matrix. Corrective action for future compactive efforts will ensure that the center point of the weight will impact on the exterior edge of the perimeter boxes. 

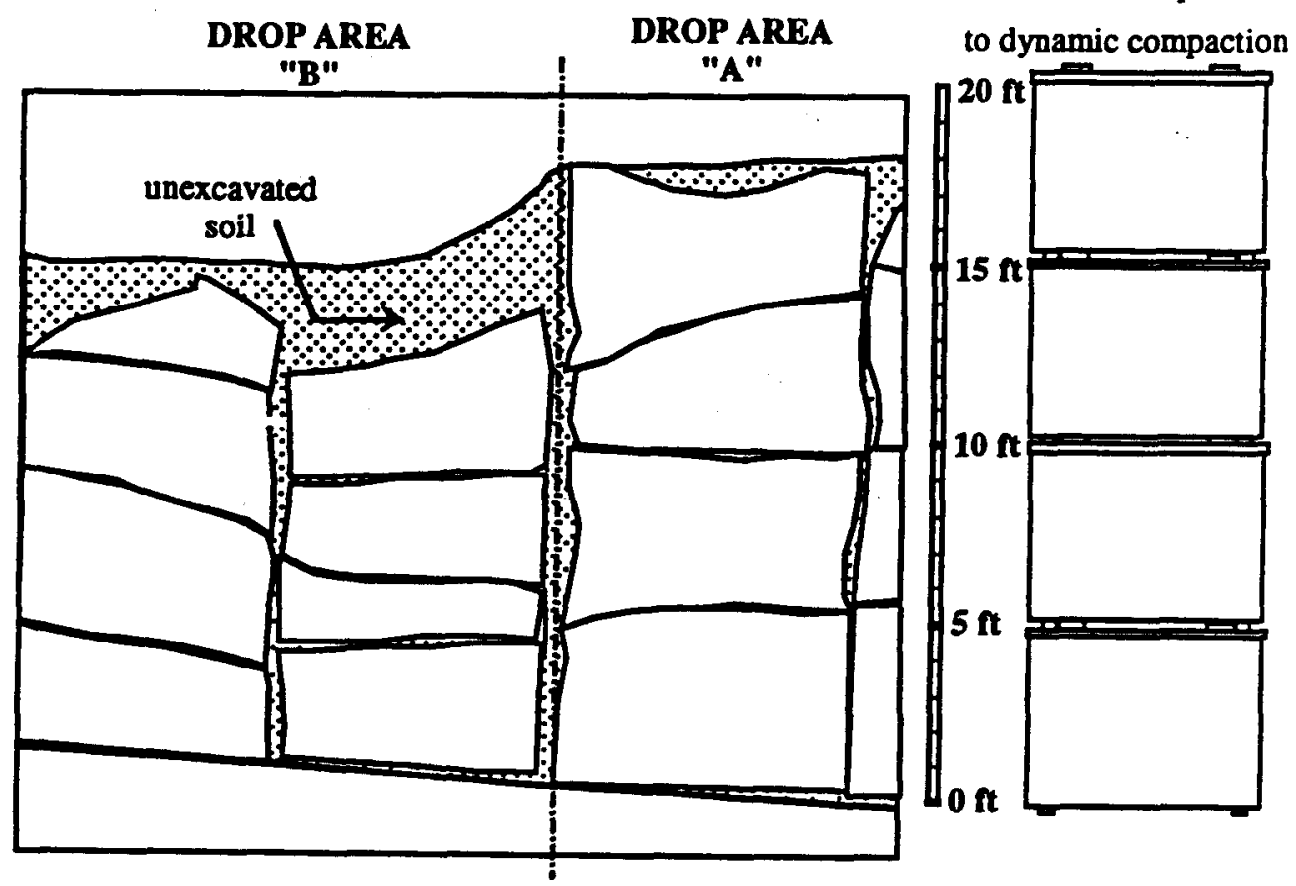

Figure 38 Westerly edge of excavated B-25 boxes, showing the difference in between compaction zones A and B.

The design purpose of B-25 boxes is to contain bow-level waste at the generation point, to protect workers, and to facilitate transportation to the burial site. These boxes were never intended to provide contain waste within a burial; however, they do, by default, help minimize waste migration. An excavation of the consolidated boxes revealed that dynamic compaction accelerated the corrosion rate of these low grade, carbon steel boxes by bending and tearing the metal and by breaking the protective paint bonds. As part of another corrosion study, three B-25 boxes were buried uncompacted at a nearby location. To provide a comparison, when the boxes were excavated, the Savannah River Technology Center concluded that these undisturbed boxes experienced no observable corrosion. The DCF boxes had been in the ground six months when excavated, while the corrosion study boxes had been buried four years. Corrosion of the DCF boxes exceeded that of the long-term study, demonstrating that dynamic compaction had accelerated box corrosion and degradation.

Consideration should be taken to evaluate the burial site and consolidation goals relative to the effect of corrosion on containment. If corrosion minimization is important, then dynamic compaction should be reconsidered.

Supporting the observation that the traditional SRS success criteria were not successfully consolidating the lower boxes, excavation provided a measured quantification of the box 
Rev. 1

densification. The boxes were excavated one by one, with measurements made of each dimension. The volume was compared with the initial volume to determine the percent compaction. The densification in drop area B was significantly more compacted than drop area A. Figure 38 shows the western side of the box matrix, with a sketch of the original configuration added for reference. Note that some of the bottom boxes in drop area $A$ show little consolidation, while the boxes in drop area B are much more compressed. Generally, boxes in drop area B were $30 \%$ more compacted than those in drop area $A$, with local variations.

Most questions were answered during the actual excavation and final measurements of the compacted boxes. Drop zone A (which utilized the traditional drop pattern and compaction criteria) had not been adequately consolidated. Some of the bottom boxes had only cursory damage, depending upon the containerized materials and the location within the matrix. Drop zone B, however, compacted with additional drops and drop locations, showed a much more thorough consolidation.

To support a new compaction criterion proposal, the depth of influence for the SRS dynamic compaction efforts needed to be calculated. With simplifying assumptions, the Boussinesq Equation ${ }^{8}$ was used to obtain an estimate of stress influence with depth. Note that this equation is independent of the material type.

The instantaneous velocity for each impact was measured as part of the DCF test program. Knowing this velocity, both the kinetic energy at impact and the negative acceleration were computed, using the standard equation for kinetic energy (1) and a change in velocity because of acceleration equation (2):

$$
\begin{gathered}
E=\frac{1}{2} m v^{2} \\
v=v_{0}+2 a\left(y_{1}-y_{0}\right)
\end{gathered}
$$

where:

$$
\begin{aligned}
& E=\text { energy at impact, } \\
& \left(y_{1}-y_{0}\right)=\text { differential displacement induced by impact of the weight, } \\
& m=\text { mass of the weight, and } \\
& v=\text { velocity of the weight }
\end{aligned}
$$

Once the negative acceleration was calculated, the stress induced at the surface by the impacting mass could be calculated using:

$$
p=\frac{m a}{\pi^{2}}
$$

where:

$$
\begin{aligned}
& \mathbf{p}=\text { stress, } \\
& \mathbf{m}=\text { mass of the weight, } \\
& \mathbf{a}=\text { negative acceleration, and } \\
& \mathrm{r}=\text { radius of the dynamic compaction weight. }
\end{aligned}
$$


Rev. 1

Once these basic equations were combined to estimate the stress induced at the surface by the dynamic compaction weight, the value was entered into the Boussinesq Equation for a circular load to quantify the induced stress with depth.

$$
\Delta p=q\left\{1-\frac{1}{\left[\left(\frac{r}{z}\right)^{2}+1\right]^{\frac{3}{2}}}\right\}
$$

where:

$$
\begin{aligned}
& \Delta p=\text { change in stress, } \\
& q=\text { induced stress, } \\
& r=\text { radius of the dynamic compaction weight, and } \\
& z=\text { depth of influence for which } \Delta p \text { is calculated. }
\end{aligned}
$$

Though the soil and the buried boxes are not elastic, homogeneous, and isotropic, equation (4) provides a reasonable estimate of stress influence with depth. Figure 39 was developed using the Boussinesq equation to plot the comparison between stress and depth of influence as a function of depth of differential displacements. The 3-ft displacement would relate to an average first drop in a primary pattern, while the 0.2 -ft change would relate to a late secondary/tertiary type drop. Note that assuming the top of the bottom tier of boxes is 14-ft deep, the initial change of 3-ft induces no significant stress depth within the box matrix. As the box matrix becomes more stiff, the differential displacement becomes smaller, increasing stress with depth. Clearly, at the 0.2-ft displacement, the bottom tier of boxes is being influenced.

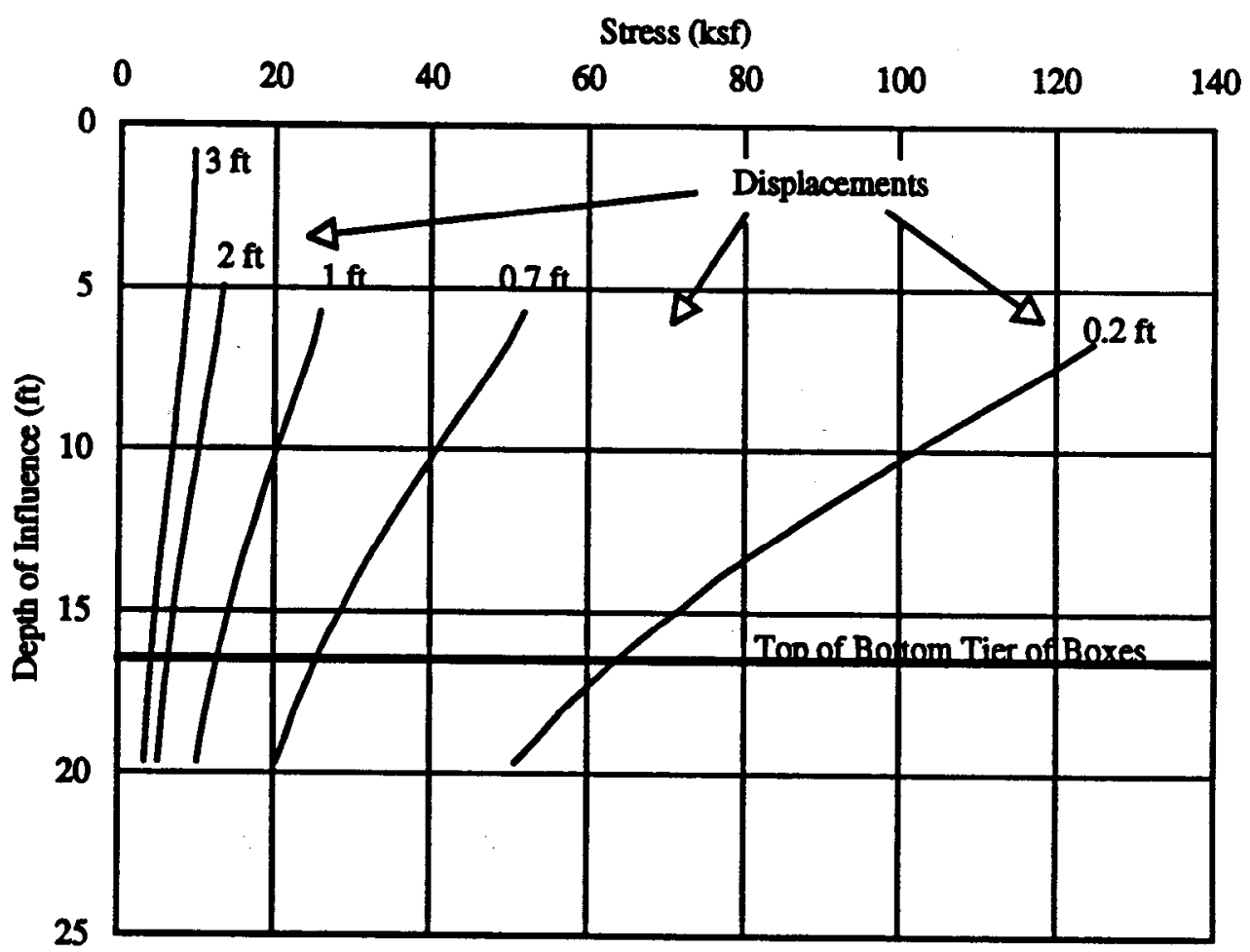

Figure 39 Plot of the influence of stress with depth, using the Boussinesq equation. 
Rev. 1

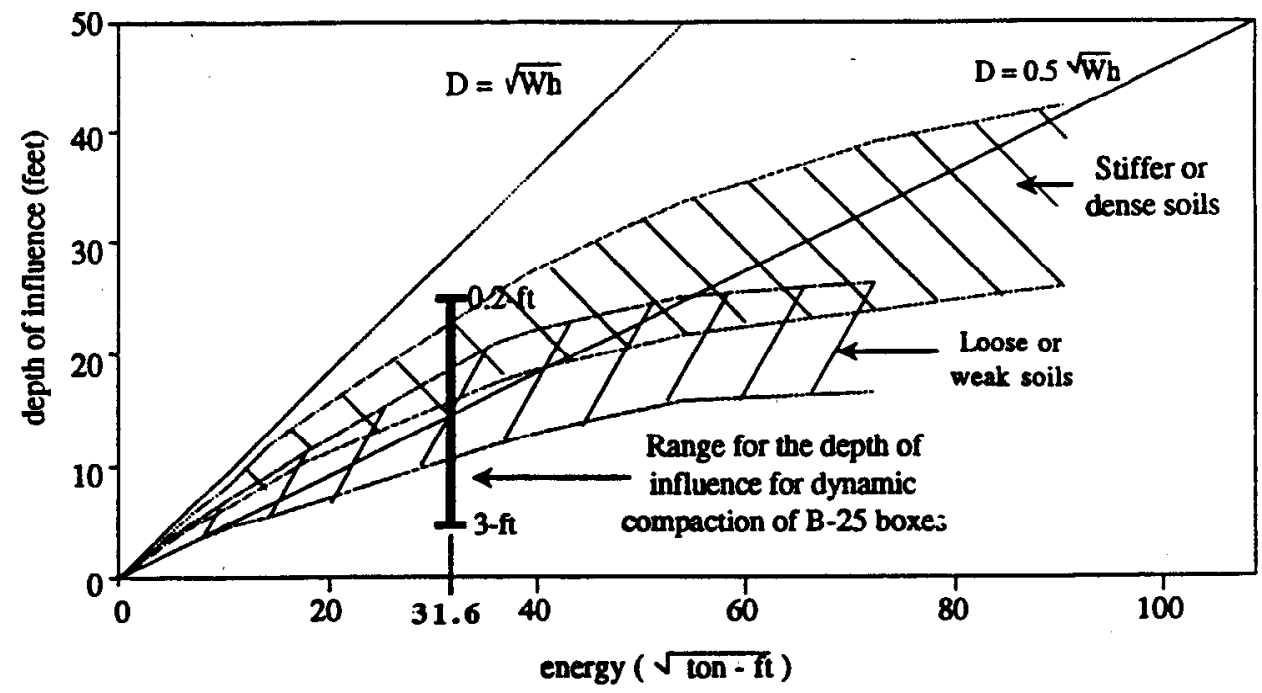

Figure 40 Plot of scaled energy versus depth, compared with Slocombe correlations for soil. (after Slocombe)

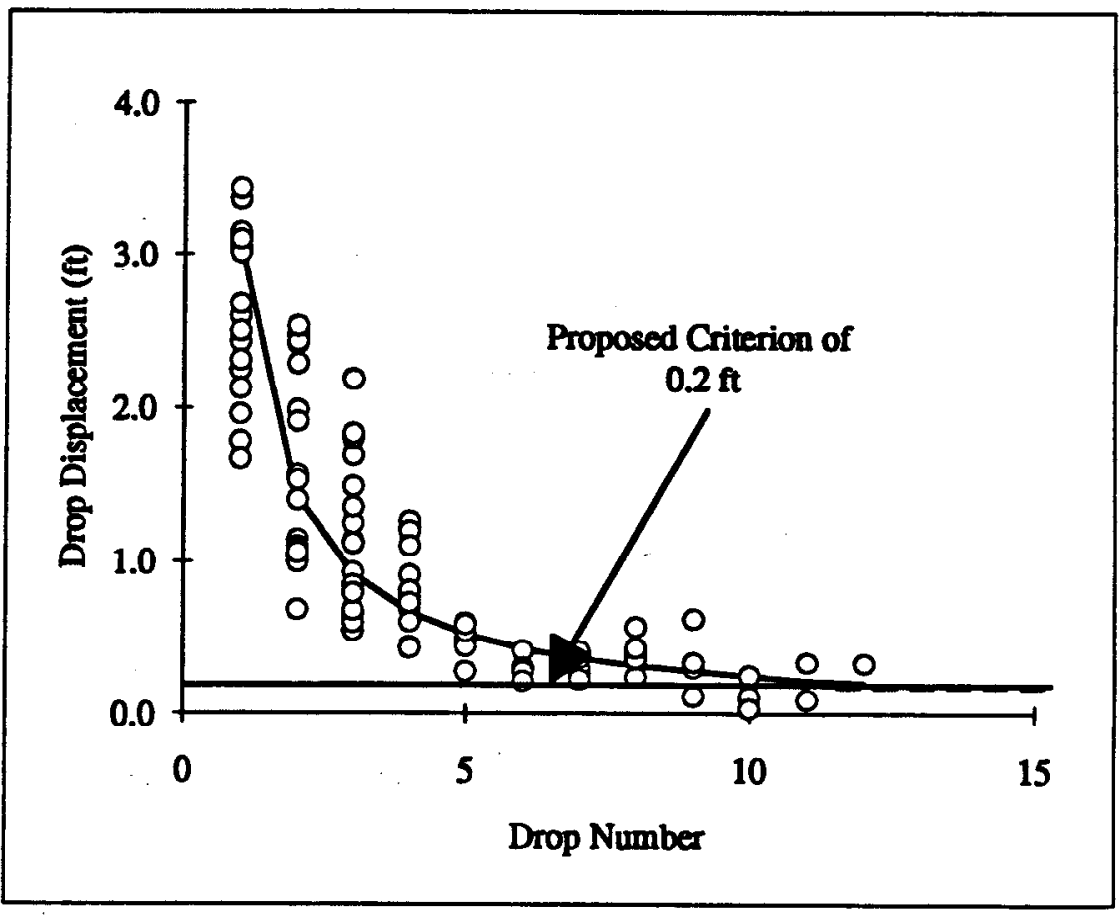

Figure 41 Plot comparing the drops with respect to the change in crater depth. 
WSRC-TR-94-0159

Rev. 1

March 21, 1994

Dynamic Compaction Report

With the simplifying assumptions and the liberty tren to apply the Boussinesq equation to this scenario, a relationship developed by Slocombe' was used to calibrate the model. Slocombe's model presents the depth of influence as a function of scaled energy, using historical data and provided ranges for stiff or dense soils and loose or weak soils. The average kinetic energy at impact for the test was $31.6 \mathrm{ft}-\mathrm{lb}$, at a computed differential displacement range between 3 and 0.2 $\mathrm{ft}$ This value was superimposed over the range of influence plotted on the Slocombe graph (Figure 40). The range of SRS data "fits" rather well over the data generated for soils. With this correlation, it is assumed that applying the Boussinesq equation provided a reasonable estimation of the depth of influence for the SRS dynamic compaction efforts.

There has been long discussions on the design purpose of B-25 boxes. The SRS design intent has been to contain low-level wastes at the generation point for worker protection and to facilitate transportation to the burial site. These boxes were never intended to provide containment within a burial. They do, however, by default, contribute to minimizing waste migration. Clearly, dynamic compaction accelerated the corrosion rate of these low-grade, carbon steel boxes. Consideration should be taken to evaluate the burial site consolidation goals and purposes relative to the effect of corrosion on containment. If corrosion minimization is important, then dynamic compaction of metal boxes should be reconsidered.

The final evaluation of dynamic compaction relative to consolidating buried B-25 boxes has generated a new success criteria based on a change in crater depth (displacement). Figure 41 is a plot comparing the drops with respect to the change in crater depth. The curve is best fit of all the drop data. This curve is approaching the asymptote at an approximate change in crater depth of 0.2 ft. The recommended criterion is two consecutive drops that change the crater depth no greater than $0.2 \mathrm{ft}$. Two consecutive drops at this criteria will ensure that no minor bridging of material occurs at the drop site. If the subsurface material bridge can withstand the energy given by two consecutive drops, then additional drops to destroy the bridge will most likely not be beneficial and therefore, not cost-effective. 
Rev. 1

\section{Conclușions and Recommendations}

\section{Non-Invasive Characterization}

The noninvasive characterization studies confirm that the surface materials at both the DCF and MWMF caps have higher seismic velocity values than the underlying kaolin clay caps. Consequently, the limited seismic refraction surveys only measured the fast, direct $P$ - and $S$-wave velocities of the surface layer. However, measured direct shear wave velocities were, in general, comparable to those predicted by the SASW surveys.

The SASW studies successfully measured shear-wave velocities of the underlying kaolin clays at both the DCF and MWMF. Results indicate a mean shear wave velocity on the of $350 \mathrm{fps}$ for the DCF kaolin clay cap, compared to 500 to $550 \mathrm{fps}$ for the MWMF kaolin clay cap. Shear wave velocities appear to be similar at the southeastern and northwestern portions of the MWMF cap.

The higher shear wave velocity observed at the MWMF may be because of aging effects, which would be caused by drying of the kaolin clay over the past several years. In several instances, shear wave velocities similar to those observed at the MWMF were documented in the shallowest portions of the DCF cap, consistent with the drying model. Further more, at DCF site 11, the soil cover was removed and the exposed kaolin clay dried for several hours. At this location, the measured shear wave velocity was nearly identical to the mean values obtained at the older, presumably drier MWMF cap.

The results of the noninvasive characterization program suggest that the younger DCF cap may be less brittle than the older MWMF caps. Because of this difference, the reasonable buffer between the production drop locations and the MWMF clay cap should be adjusted with a factor of safety. This adjustment will be discussed below.

An important consideration resulting from the noninvasive characterization is the utility of the measurements. Currently, the only postclosure monitoring is through sparsely spaced, surface settlement monitors. As the MWMF and other closure systems mature, the need for noninvasive monitoring and interrogating of these systems increases. A prohibitor to traditional geophysical methods was demonstrated with the refraction survey work outlined in this report. With a higher velocity overlying a slower velocity material, the ability to see the shallow material is limited. The SASW method has demonstrated an ability to interrogate the near surface materials without this bias. The recommendation is to continue research in using the SASW technique on a more broad base over the SRS closure systems. By performing this work, the ability to detect closure system failure will improve.

\section{Vibratory Impacts and Buffer}

The primary focus for the DCF test was to determine a suitable buffer distance between dynamic compaction impact points and the existing MWMF kaolin cap. This determination is nontrivial, complicated by waste configuration, different soil responses, and the definition of failure for a kaolin clay cap. As discussed earlier, the response of the heterogenous mass of buried B-25 boxes to dynamic compaction causes transmutation of the wave forms and the wave form energy. Measurements of the PPVs and on evaluation of the generated wave forms indicate a relatively high attenuation factor for the buried wastes. This high attenuation factor reduces the degree and amount of vibratory energy entering the soil matrix and the kaolin clay cap. Figure 19 compared the attenuation curve for natural ground with that for the composite of all production drops. To achieve the $2.0 \mathrm{in} / \mathrm{s}$ threshold for the production drops, the distance from the drop location to the buried waste is approximately $12 \mathrm{ft}$ For natural ground, this distance becomes $33 \mathrm{ft}$ As discussed previously, there is some uncertainty regarding the comparative response of the DCF to the MWMF kaolin clay caps, because the MWMF cap appears to be more brittle. The conservative approach and the recommendation made in this report are to assume the natural undisturbed ground 
WSRC-TR-94-0159

Rev. 1

March 21, 1994

Dynamic Compaction Report

response and then apply a safety factor of $1.50 \mathrm{ft}$ to the buffer distance. The reasonable and recommended buffer is $50 \mathrm{ft}$ between the drop locations and the MWMF kaolin cap.

\section{Hydraulic Conductivity of Kaolin Clay}

The hydraulic conductivity of a barrier material used in a regulated closure must meet the $10-07$ $\mathrm{cm} / \mathrm{sec}$ criteria. This value is the threshold for failure when evaluating barrier performance. To determine the buffer between dynamic compaction activities and the MWMF, the DCF kaolin cap was instrumented after dynamic compaction, using six SDRI. These instruments use an induced hydraulic head to measure in situ the bydraulic conductivity of a material. The results of these studies measured no appreciable change in hydraulic conductivity for the DCF cap, assuming the construction specifications and methods met the intent of the Meuser-Rutledge study.

The changes in hydraulic conductivity resulting from environmental and boundary conditions bad little impact on the generalized hydraulic conductivity for the kaolin clay. They do, bowever, raise the issue of absolute hydraulic conductivity and barrier performance over time. The SDRI instrumented were originally designed to test landfill liners. Simulating field conditions, the instruments employ a hydraulic driving bead to cause the water to penetrate the test material. For testing barrier material, however, the model breaks down. Most closure barrier designs minimize the driving head within the system by implementing drainage systems and vegetation. While the SDRI is the industry standard and EPA instrument of choice, there is some question as to the applicability to the barrier system scenario and whether the hydraulic conductivity is higher than actuality as the result of the driving head. The barrier systems are nonsaturated systems, which apparently respond to variations in environmental conditions. The design and testing of alternative instrumentation accounting for the unsaturated conditions may derive a more realistic value for a more broad base of closure materials. These additional materials may include more sandy clay materials available at SRS, which would translate into cheaper closure systems for environmental restoration projects. The recommendation is to investigate the observed phenomenons and develop a more realistic testing scenario.

\section{Dynamic Compaction of Buried Wastes}

Excavation of the compacted wastes to evaluate the dynamic compaction success provided valuable insight that will improve the quality of future closures. The observation of the need to improve success criteria and the formation of the fused layer, are both new and unique. As stated previously, the traditional SRS success criteria was a 6-ft displacement or 20 consecutive drops, which ever came first. The observations early in the test that these criteria were inadequate allowed modifications to the test plan and the success of the program. While the inadequacy in the success criteria was apparent for the B-25 boxes, it should not be construed to be inadequate for open slit trenches.

As the boxes were excavated, the measured reduction in void ratio for the traditional criteria demonstrated the general lack of compaction to the bottom tier of boxes. At the same time, the excavation of the overcompacted boxes determine the new SRS criteria of two consecutive drops with a change in crater depth of no greater than $0.2 \mathrm{ft}$ Two consecutive drops at this criteria will ensure that no minor bridging of material occurs at the drop site. If the subsurface material bridge can withstand the energy imparted by two consecutive drops, then additional drops to destroy the bridge will most likely not be beneficial and; therefore, not cost-effective.

An alternative to implementing the success criteria is to alter the weight shape, the weight mass, or the drop height. The recommended SRS criteria assume a flat bottom, and a 6-ft-diameter weight, weighing 20 tons. Altering the weight shape from flat bottomed to round or cylindrical would concentrate the force of impact, improving compaction at depth. Also, increasing the mass or drop height would also increase the compactive energy. These are design issues to addressed by the specific concerns for each site. 
Rev. 1

The test scenario assumed the buried boxes were stacked four high. Should this scenario change, then the direct assumptions and conclusions from this study may not be applicable.

The recommendation is to implement success criterion that are based upon the change in crater depth, per drop. This is a two consecutive drops with a change in crater depth of no greater than $0.2 \mathrm{ft}$. Additional consideration should be given to optimizing the weight shape to allow a more penetrating impact to break up any bridging and spanning by the compressed metal boxes. 
Rev. 1

1. S.R. McMullin. Test Program Plan for a Study: Aralysis of Changes in Permeability in a Kaolin Clay Cap when Subjected to Shear Waves Generated By Dynamic Compaction. Environmental Restoration Department, Westinghouse Savannah River Company, WERERG-920917, (1992).

2. Dynamic Compaction Test Facility, Design Drawings and Specifications, Engineering and Projects Division, C-CV-G-0006, 0007, \& 0008 and C-SPC-G-00041, Savannah River Site, Aiken, SC 29808 (1992).

3. Westinghouse Savannah River Company Project Engineering Services Contract Instrumentation Plan: Dynamic Test Facility. USDOE Technical Report WSRC-TR-94116, Savannah River Site, Aiken, SC 29808 (1992).

4. Dynamic Test Facility: Data Report (Text and Figures). USDOE Technical Report, WSRC-TR-94117, Rev. 1, Savannah River Site, SC 29808 (September 1992).

5. K.H. Stokoe, S.Nazarian, G.J. Rix, I. Sanchez-Salinero, J.C. Sheu, and YJ. Mok. "In Situ Seismic Testing of Hard-To-Sample Soils By Surface Wave Method". Proceedings, American Society of Civil Engineers, Specialty Conference on Earthquake Engineering and Soil Dynamics II - Recent Advances in Ground Motion Evaluation, Park City, Utah (Jume 1988).

6. R.D. Woods and L.P. Jedele. "Energy-Attenuation Relationships From Construction Vibrations". Vibration Problems, ASCE, (1987).

7. R.C. Warner. Clay Cap Subsidence demosntration project report for the Mixed Wastes Management Facility, Savannah River Plant, Submitted to E.I. DuPont de Nemours \& Company, Inc. (1982).

8. B.M. Das. Principles of Geotechrical Engineering, PWS Engineering, Boston, MA (1985).

9. B.C. Slocombe. “Dynamic Compaction," Ground Improvement, CRC Press, (1993).

10. Dobry, Ricardo and George Gazetas. "Dynamic Stiffness and Damping of Foundations By Simple Methods". Vibration Problems, ASCE, (1987).

11. S.G. Wright, K.H. Stokoe, and J.M. Roesset. "SASW Measurements At Geotechnical Sites Overlaid By Water". Dynamic Geotechnical Testing: Second Volume, STP 1213, R.J. Ebelhar, V.P. Drnevich, and B.L. Kutter, Eds., American Society for Testing and Materials, Philadelphia, PA (1995).

12. J.M. Roesset, D.W. Chang, and K.H. Stokoe. "Comparison of 2-D and 3-D Models for Analysis of Surface Wave Tests". Proceedings, Sth International Conference on Soil Dynamics and Earthquake Engineering, Karksuhe, Germany, (September 1991).

13. P.W. Mayne. "Ground Vibrations During Dynamic Compaction". Vibration Problems, ASCE, (1987).

14. R.F. Mera. Analytical Study And Inversion For The Spectral Analysis Of Surface Waves Method Master of Science in Engineering Thesis, The University of Texas at Austin (1991).

15. J.A. Bameich. "Vehicle Induced Ground Motion". Vibration Problems, ASCE, (1987). 
16. S. Ahmad and T.M. Al-Hussaini. "Simplified Design for Vibration Screening By Open and In-Filled Trenches". Journal of Geotechnical Engineering, Vol. 117, No. 1 , (January, 1991).

17. M. Vucetic and R. Dobry. "Effect of Soil Plasticity On Cyclic Response". Journal of Geotechnical Engineering, Vol. 117, No. 1, (January 1991).

18. R.F. Ballard Jr. "Determination of Soil Shear Moduli at Depth by In Situ Vibratory Techniques," Miscellaneous Paper No. 4-691, U.S. Army Engineering Waterways Experiment Station, Vicksburg, MS, (1964).

19. W.M. Ewing, W.S. Jardetzly, and F. Press. Elastic Waves in Layered Media, McGraw-Hill Book Company, Inc., New York, NY (1957).

20. N.A. Haskell. "The Dispersion of Surface Waves in Multilayered Media," Bulletin of the Seismological Society of America, Vol. 43, pp. 17-34, (1953).

21. S.W. Hull and E. Kausel. "Dynamic Loads in Layered Half-Spaces," Proceedings of the Sth Engineering Mechnics Division Specialty Conference, ASCE, Laramie, Wyoming, (1984).

22. R. Jones. "Insitu Measurement of the dynamic Properties of Soil by Vibration Methods," Geotectinique, Vol. 8, No. 1, pp. 1-21, (March, 1958).

23. R. Jones. "Surface Wave Technique for Measuring the Elastic Properties and Thickness of Roads: Theoretical Development," British Journal of Applied Physics, Volume 13, pp. 21 29, (1962).

24. E. Kausel and J.M. Roesset. "Stiffness Matrices for Layered Soils," Bulletin of the Seismological society of America, Vol. 71, pp 17-34, (1953).

25. W. Menke, W. Geophysical Data Analysis, Discrete Inverse Theory, Academic Press, Inc., (1984).

26. S. Nazarian. In Situ Determination of Elastic Moduli of Soil Deposits and Pavement Systems by Spectral-Analysis-of-Surface-Waves Method, Ph.D Dissertation, The University of Texas at Austin, 458 pp., (1984).

27. H.B. Seed, R.T. Wong, I.M. Idriss, and K. Tokimatsu. "Moduli and Damping Factors for Dynamic Analyses of Cohesionless Soils," Joumal of Geotechnical Engineering Division, Vol. 112, No. 11, ASCE, 17 pp., (1986).

28. K.H. Stokoe II, and S. Nazarian , "Use of Rayleigh Waves in Liquefaction Studies," Proceedines, Measurement and Use of Shear Wave Velocity for Evaluating Dynamic Soil Properties, Geotechnical Engineering Division, ASCE, pp. 1-14, (1985).

29. W.T. Thomson. "Transmission of Elastic Waves Through a Stratified Solid". Journal of Applied Physics, Vol. 21, pp 89-93, (1950).

30. C.Vrettos and B. Prange. "Evaluation of Insitu Effective Shear Modulus from Dispersion Measurements". Journal of Geotechnical Engineering Vol. 116. No. 10, pp. 1581-1585, (October, 1990). 


\section{Appendix A Construction Quality Assurance}

The success of the Dynamic Compaction Facility test is dependent upon the ability to model the actual field conditions. As described within this report, CT Main conducted a statistical analysis of the as-built moisture density values for the compacted kaolin clay used to construct MWMF closure system. These statistical values were input into the construction specifications.

Construction of a large, soil structure is not a precise endeavor. Specifications present a range of acceptable values for a construction target. Testing methods carry out a statistical approach to evaluating how well construction efforts meet the target range. Desiccation of the MWMF kaolin cap over the last three to four years is also variable, dependent upon the local conditions. These uncertainties introduce a degree of variability in how closely the DCF models the actual MWMF field conditions.

Construction efforts maximized the quality of the DCF model. Enclosed are copies of the quality assurance/quality control documentation. After review and evaluation, we determined that the kaolin clay cap was constructed as close to the MWMF as possible, meeting the test program goals.

Appendix A contains the quality assurance test data for the construction activities. 


\begin{tabular}{|c|c|c|c|c|c|c|c|c|c|c|c|}
\hline & A & B & $\mathrm{C}$ & D & $\mathbf{E}$ & $F$ & $\overline{\mathbf{G}}$ & $\mathrm{H}$ & $I$ & $J$ & \\
\hline 43 & & 4108 & 4-DATFS & $5 / 16 / 92$ & SOlL & $17.0 \%$ & $18.1 \%$ & 104.9 & 106.8 & 122.7 & 107.2 \\
\hline 44 & & 4108 & 4-DATFS & $5 / 16 / 92$ & SOIL & $16.4 \%$ & $18.1 \%$ & 99.8 & 106.8 & 116.9 & 107.2 \\
\hline 45 & & $\therefore$ & 6-DATFS & $5 / 18 / 92$ & SOlL & $16.6 \%$ & $18.1 \%$ & 105.5 & 106.2 & 123.0 & 124.2 \\
\hline 46 & & '- & 6-DATFS & $5 / 18 / 92$ & SOlL & $16.9 \%$ & $18.1 \%$ & 106.2 & 106.2 & 124.2 & 124.2 \\
\hline 47 & & $\because$ & 6-DATFS & $5 / 18 / 92$ & SOlL & $14.0 \%$ & $18.1 \%$ & 97.2 & 106.2 & 110.8 & 124.2 \\
\hline 48 & & $\because$ & 6-DATFS & $5 / 18 / 92$ & SOll & $13.8 \%$ & $18.1 \%$ & 91.6 & 106.2 & 104.2 & 124.2 \\
\hline 49 & & $\because$ & 6-DATFS & $5 / 18 / 92$ & SOlL & $16.3 \%$ & $18.1 \%$ & 97.8 & 106.2 & 113.7 & 124.2 \\
\hline 50 & & '. & 6-DATFS & $5 / 18 / 92$ & SOlL & $14.7 \%$ & $18.1 \%$ & 103.7 & 106.2 & 118.9 & 124.2 \\
\hline 51 & & 4105 & 2-DATFS & $5 / 19 / 92$ & SOIL & $15.7 \%$ & $19.2 \%$ & 98.7 & 107.8 & 114.2 & 128.5 \\
\hline 52 & & 4105 & 2-DATFS & $5 / 19 / 92$ & SOIL & $17.3 \%$ & $19.2 \%$ & 102.3 & 107.8 & 120.0 & 128.5 \\
\hline 53 & & 4105 & 2-DATFS & $5 / 19 / 92$ & SOIL & $19.4 \%$ & $19.2 \%$ & 107.6 & 107.8 & 128.5 & 128.5 \\
\hline 54 & $\mathrm{PRO} / \mathrm{SC}$ & 4105 & 2-DATFS & $5 / 19 / 92$ & SOIL & $20.3 \%$ & $19.2 \%$ & 105.1 & 107.8 & 126.4 & 128.5 \\
\hline 55 & & $\therefore$ & 5-DATFS & $5 / 20 / 92$ & SOIL & $16.9 \%$ & $18.1 \%$ & 107.1 & 110.0 & 125.2 & 107.2 \\
\hline 56 & & $\because$ & 5-DATFS & $5 / 20 / 92$ & SOIL & $17.7 \%$ & $18.1 \%$ & 101.7 & 110.0 & 119.7 & 107.2 \\
\hline 57 & & $\because$ & 5-DATFS & $5 / 20 / 92$ & SOlL & $15.1 \%$ & $18.1 \%$ & 110.1 & 110.0 & 126.7 & 107.2 \\
\hline 58 & & $\therefore$ & 5-DATFS & $5 / 20 / 92$ & SOIL & $13.4 \%$ & $18.1 \%$ & 111.7 & 110.0 & 126.7 & 107.2 \\
\hline 59 & & $\therefore$ & 5-DATFS & $5 / 20 / 92$ & SOIL & $16.5 \%$ & $18.1 \%$ & 110.0 & 110.0 & 128.2 & 107.2 \\
\hline 60 & & $\because$ & 5-DATFS & $5 / 20 / 92$ & SOlL & $17.0 \%$ & $18.1 \%$ & $9 \oint .7$ & 110.0 & 116.6 & 107.2 \\
\hline
\end{tabular}


TEPT *___

PROJ/AMO: $\quad 4794$

WORK PACKAGE NO: $92-W P W \cdot E C-023$ DA:COOL TWC: $\frac{9660}{\text { CONTRACTOR: - AXC:_ NA }}$

$925 R$ S-E-4744-1101-C-CV-G.

material descaiption:_ Kaoleal Clay A-LLET ACCEPTANCE CRITERIA: 95-\% COMPRCHON $92-95$ PCF

DATE TESTED: $6-28-92$ TEST NO. 65

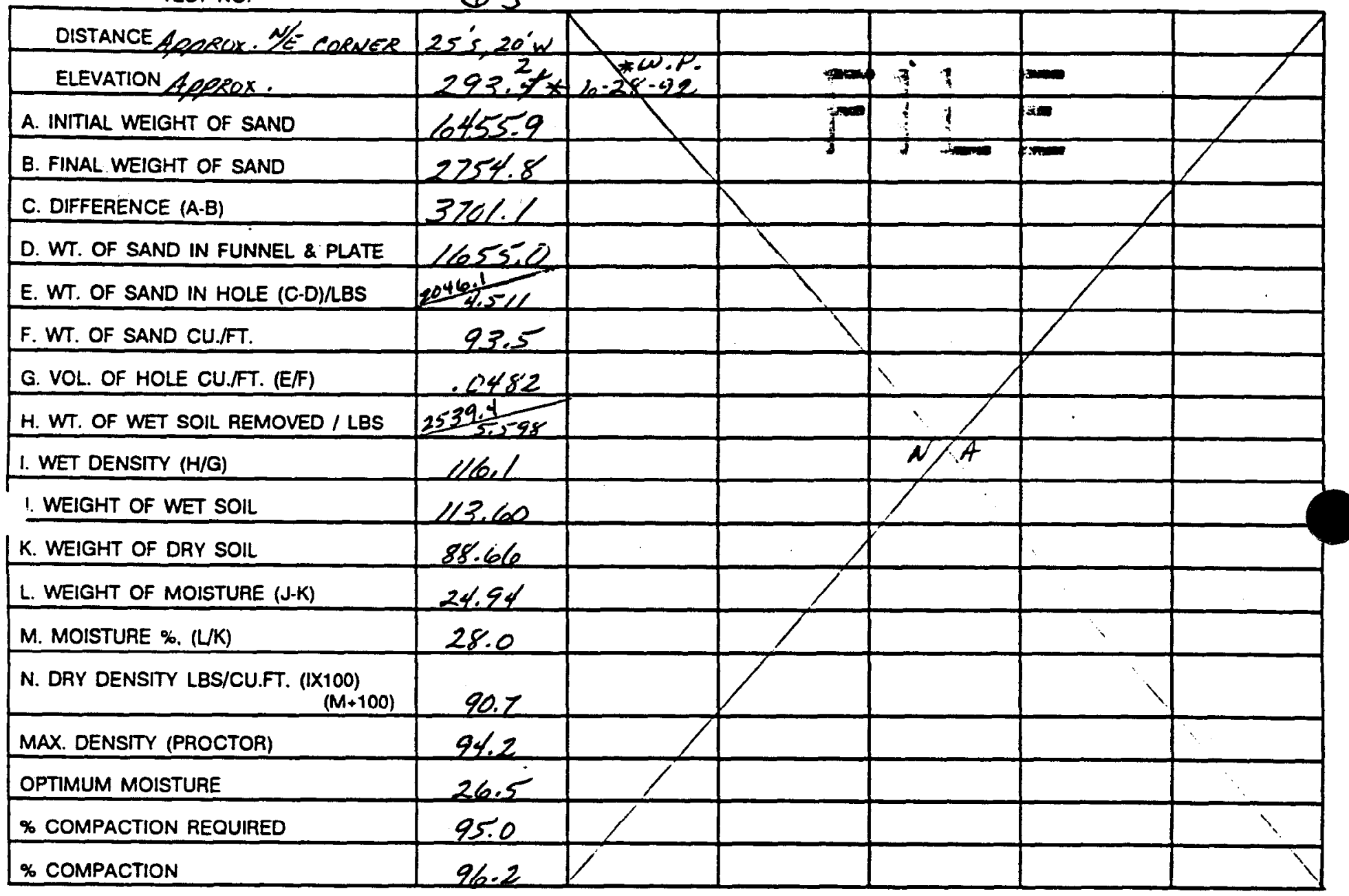

DENSITY PROCTOR REPORT : WER-ERC- $22-0544$ MOISTURE DETERMINATION: $\square$ ASTM D-2216 (, )

DESIGN CATEGORY:

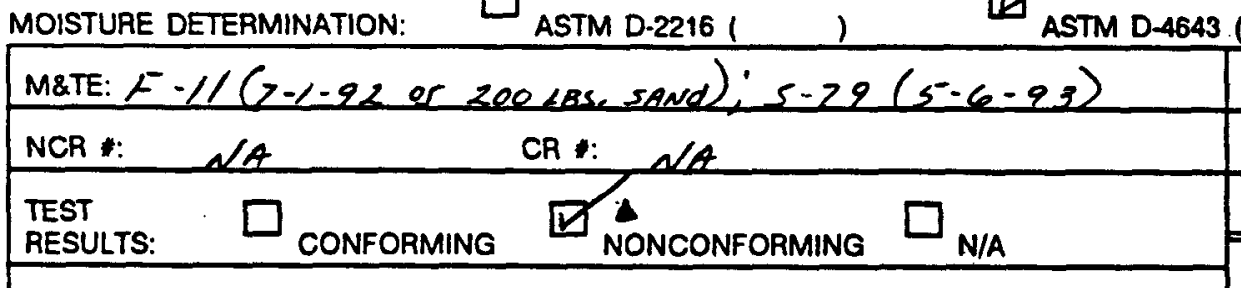

REMARKS: OFF/CIAL TEST 6.28.92 W.P.

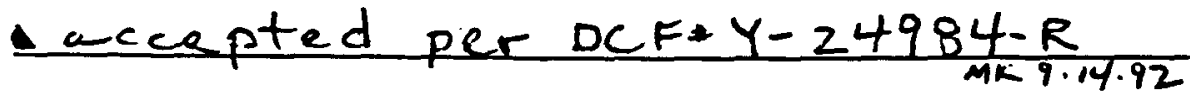
M.K Trale II 6.28 .92 INSPECTOR: Limman Pope fo. LEVEL: II DATE: 6.28 .92

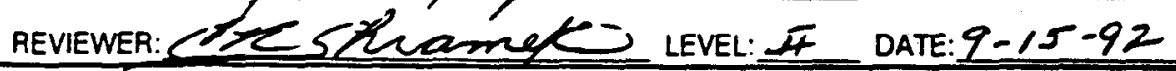

PROCEDURE: $C-Q C P-021$ REV: $Q$ PCN'S: $\quad N A$ SPECS: $C-5 P C-6-00041$ REV: 2 DCF'S: STANDARDS: 4 Mil 9.14 .92 
ERASCO SERVICES INCORPORATED

DETERMINATION OF WATER CONTENT

PAGE 2 OF 11

ASTM D-2216 ( )

PROJ/AMO: 4794

REPT \#:

$4 / 22$

DA: $200 /$ TWC: 9660 AXC: dA

LAB \#: $592-708$ DATE TESTED:

MATERIAL DESCRIPTION:

Kaolur Clay $\sim$ ASTM D-4643 (87)

WORK PACKAGE NO:: $92-W P W \cdot E C-023$ 922ReA- $-2-4794-1101-\mathrm{C}-\mathrm{CV}$ QCIR NO.: 6 -0006.0002

ACCPT. CAITERIA: AUG, $28-30 \%$

LOCATION:

Bucial Ground soits

DVaramic A- KEFT

\begin{tabular}{|c|c|c|c|c|c|c|c|}
\hline BOAlNG NHWEEA NENO No,'s & 1 & 2 & 4 & 5 & 6 & 4 & 5 \\
\hline SAMPLE NUMBER & 1 & 2 & 3 & 4 & 5 & 6 & 7 \\
\hline WT. OF WET SAMPLE + FAAE * * & 113,15 & 113.34 & 113,83 & 113.21 & 113.64 & 113.41 & 113.03 \\
\hline WT. OF DRY SAMPLE + FARE * & 87.40 & 87.03 & 87.91 & 86.93 & $85,4,5$ & 87.28 & 86.55 \\
\hline WEIGHT OF MOISTURE & 25.75 & 26.31 & 25.92 & 26.28 & 28.19 & $26 \cdot 13$ & 260.48 \\
\hline TARE WEIGHT & $\sqrt{A}$ & $\sqrt{A}$ & $N A$ & $N A$ & $N A$ & $\sqrt{A}$ & $N A$ \\
\hline WEHGHF-OF-DHY-SAMAPLE $*$ Z & 29.5 & 30.2 & 29.5 & 30.2 & $32 \cdot 9$ & 29.9 & 30.6 \\
\hline$\%$ MOISTURE ${ }_{\text {pownded }}$ ro $0.5 \%$ & 29.5 & 30.0 & 29.5 & 30.0 & 33.0 & 30.0 & 30.5 \\
\hline
\end{tabular}

\begin{tabular}{|c|c|c|c|c|c|c|}
\hline 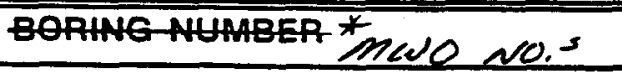 & 6 & 7 & 8 & 10 & & \\
\hline SAMPLE NUMBER & 8 & 9 & 10 & $\begin{array}{l}\text { SAND } \\
\text { CONE F.MI }^{-1}\end{array}$ & & \\
\hline WT. OF WET SAMPLE TAAE * & 113,30 & 113.32 & $13,3.5$ & $1 / 3.60$ & & \\
\hline WT. OF DRY SAMPLE + TAAE * & 88.93 & 88.50 & 84.50 & 88.66 & & \\
\hline WEIGHT OF MOISTURE & 24.37 & 24.82 & 29.01 & 24.94 & $2: 4$ & \\
\hline TARE WEIGHT & $\sqrt{A}$ & $\sqrt{A}$ & $N^{\prime} A$ & $N A$ & & \\
\hline 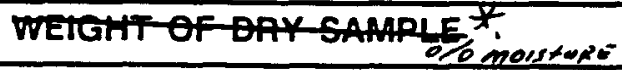 & 27.4 & 28.0 & 34.3 & 28.1 & & \\
\hline$\%$ MOISTURE Round ced to $0.5 \%$ & 27.5 & 28.0 & 34.5 & 28.0 & & \\
\hline
\end{tabular}

MINIMUM

SIZE SAMPLE $\square$ CONFORMING $\square$ NONCONFORMING REMARKS: $\sqrt{ }$

MORE THAN ONE SOIL TYPE: Ne

METHOD OF DRYING: $\square 230$ +/- 9 DEGREES F $\square$ OTHER:

MATERIAL (SIZE/AMOUNT) EXCLUDED FROM TEST:

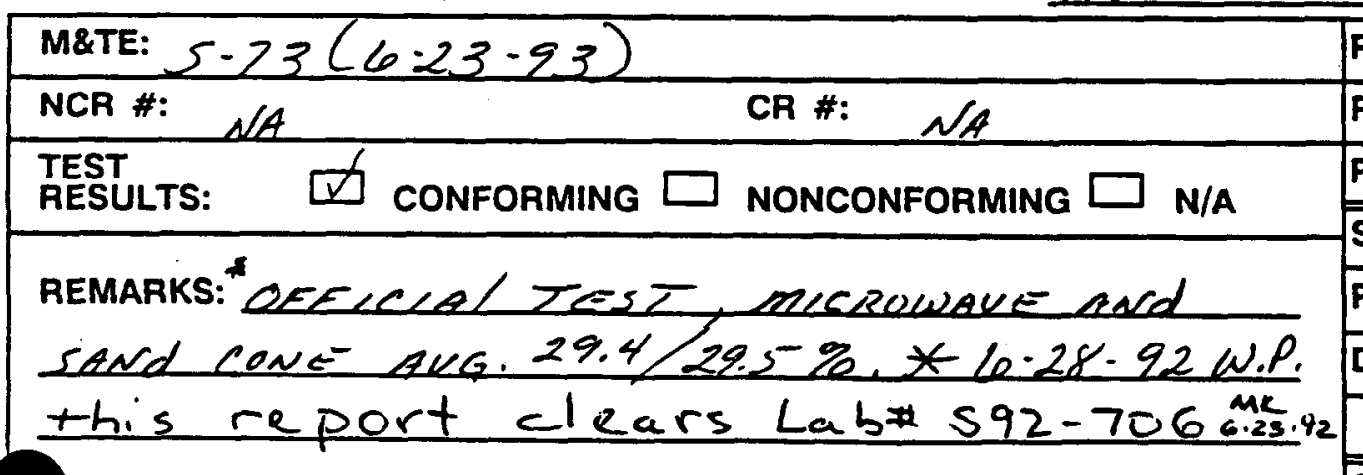

M.Koure

INSPECTOR:

REVIEWER:

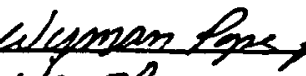

$2 \frac{1}{20} \mathrm{Cane}$
II

LEVEL:

LEVEL: I
6.28 .92

DATE: 6.28 .92 DATE: $q-15-92$
PROCEDURE: $C$-QCP-OZI REV: 0

PCN'S: NA

SPECS: C-SPC-G-00041

REV: 2

DCF'S:

N/A

STANDARDS:

DES. CAT: GS 


\section{FOR INFORMATION ONLY}

ASTM D-2216 ( )

PROJ/AMO: 4794

REPT \#: $\quad$ - $1 / 22$

DA: $\mathrm{COO/}$ TWC: 2660 AXC: NA

LAB \#: $592-708$ DATE TESTED: $1 e-28-92$

MATERIAL DESCRIPTION:

kaolea clac $\square$ ASTM D-4643 (87)

WORK PACKAGE NO.: q2-WPW-éc.023

QCIR NO: $92 \mathrm{Je} 5 \cdot \mathrm{E}-4794-1101-\mathrm{C} \cdot \mathrm{CV}-$

OCIR NO.: G-0006-0002

ACCPT. CRITERIA: AUG. $2 Y-30$

A.LET

LOCATION: BuRIR/ Genued sols Dyalanic Compactied

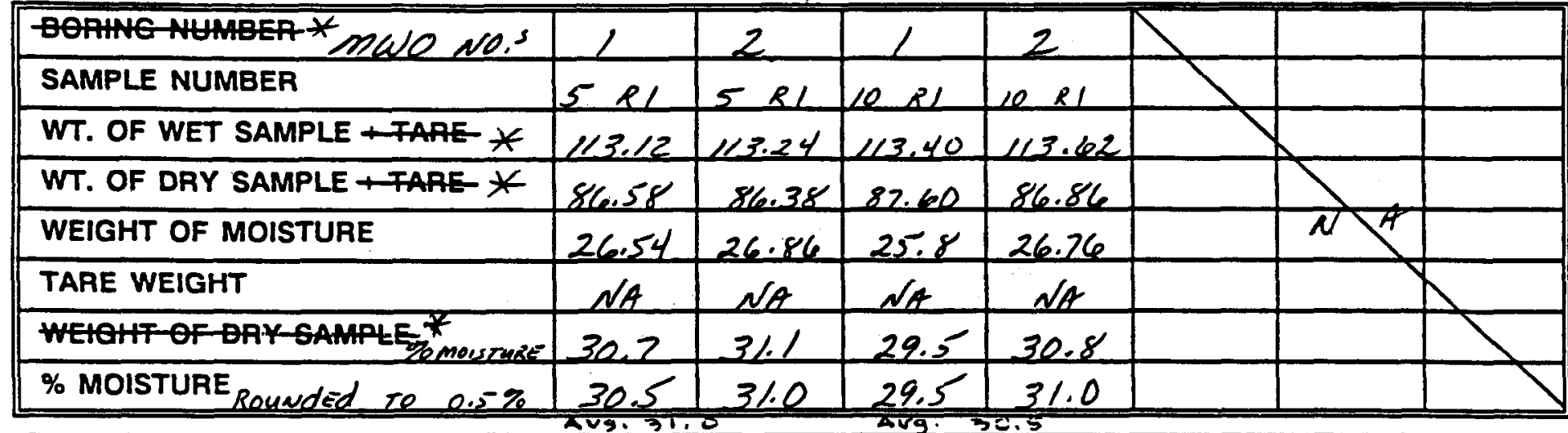

BORING NUMBER

SAMPLE NUMBER

WT. OF WET SAMPLE + TARE

WT. OF DRY SAMPLE + TARE

WEIGHT OF MOISTURE

TARE WEIGHT

WEIGHT OF DAY SAMPLE

$\%$ MOISTURE

MINIMUM

SIZE SAMPLE $\square$ CONFORMING $\square$ NONCONFORMING REMARKS: $N_{A}$

MORE THAN ONE SOIL TYPE: NO

METHOD OF DRYING: $\square 230$ +/- 9 DEGREES F

$\square$ OTHER: Malo

MATERIAL (SIZE/AMOUNT) EXCLUDED FROM TEST:

No

\begin{tabular}{|c|c|}
\hline METE: $5-73(10-23-93)$ & PROCEDURE: $C-Q C P-O 21$ \\
\hline NCR \#: NA & REV: 0 \\
\hline$\square$ NONCONFORMING [ & PCN'S: \\
\hline . & SPECS: $C-S P C-G-00041$ \\
\hline Z, DLCRQWUAVE and & REV: 2 \\
\hline SANd CeNE RKE. $29.4 / 285 \%$ * $20-28.92$ W.P. & DCF'S: \\
\hline this report clears lab $1592-7060.28 .72$ & $7 / 7$ \\
\hline & STANDARDS: \\
\hline $\begin{array}{ll}\text { II } & 6.28 .92 \\
L & \text { LEVEL: II DATE: } 6.28 .92\end{array}$ & - $/ / A$ \\
\hline DATE: $q-1592$ & DES. CAT: $G S$ \\
\hline
\end{tabular}


FOR INFORMATION ONLY

ASP $18-178(3 / 92)$

EBASCO SERVICES INCORPORATED

DETERMINATION OF WATER CONTENT

ATM D-2216 ( )

ASTM D-4643 (87)

PAGE

$\frac{\frac{4}{1} \text { of }}{\text { WPW-EC-O23 }} \frac{11}{28-30 \%}$

REPT \#: 4122 PROJ/AMO: 4794

DA: $\angle O D L$ NC: 9660 axe: NA

WORK PAC KA

LAB \#: $\$ 92-706$ DATE TESTED: 6.27 .92

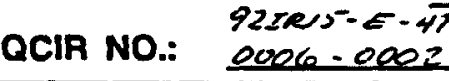

MATERIAL DESCRIPTION: Kaolin C. lay

LOCATION: Burial Ground Soils Dynamic Compaction

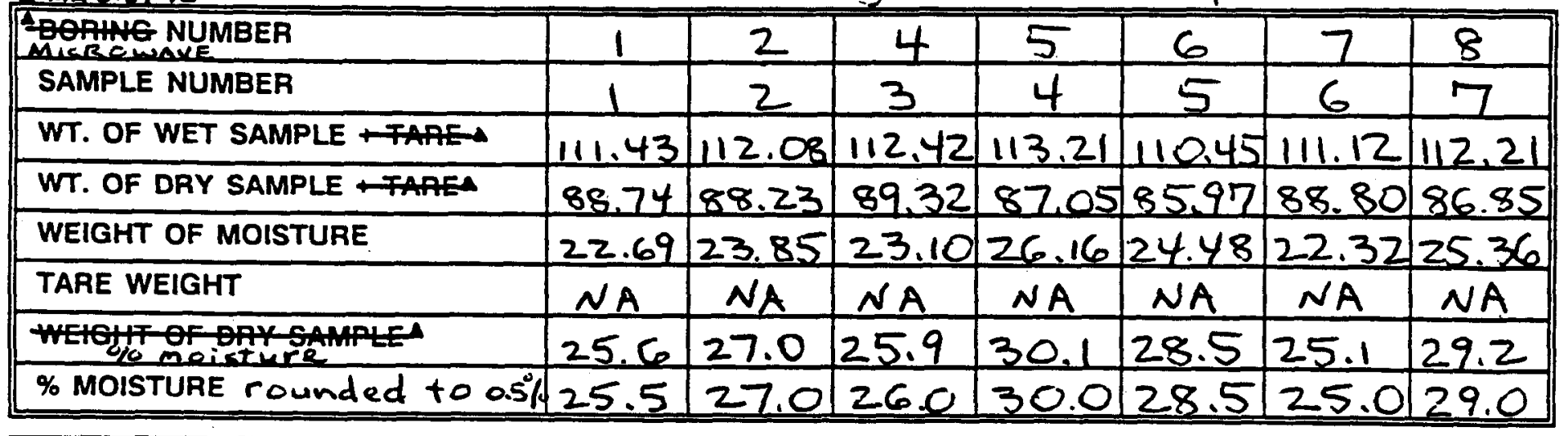

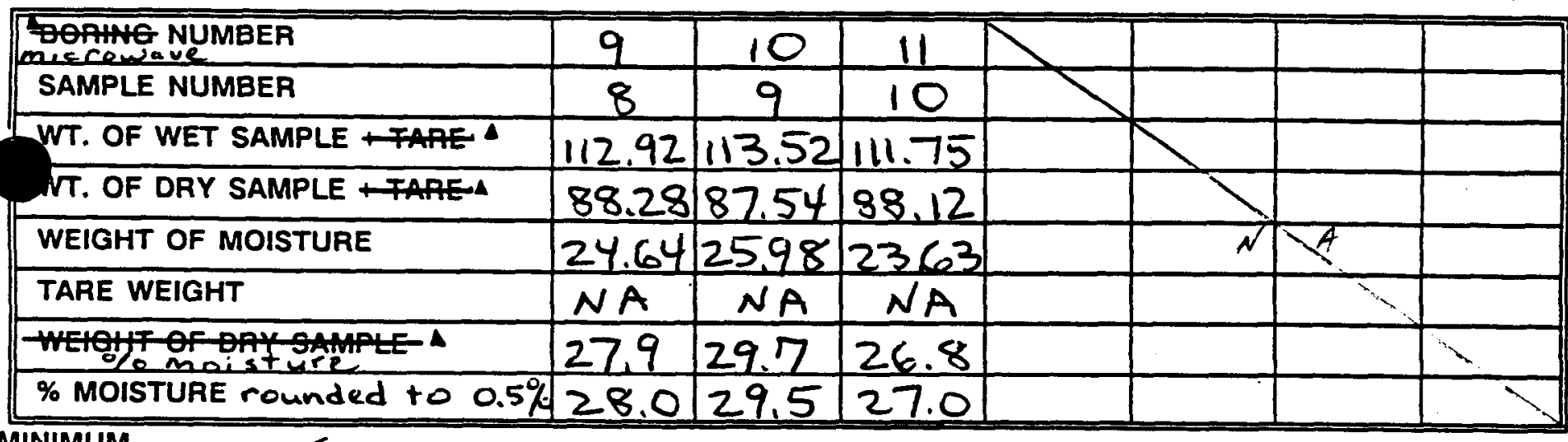

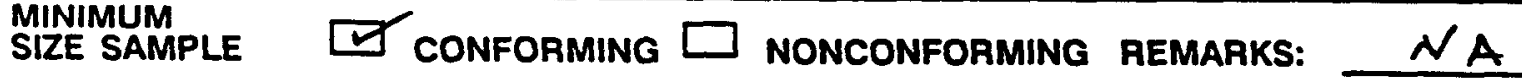
MORE THAN ONE SOIL TYPE: $\quad N O$

METHOD OF DRYING: $\square 230$ +/- 9 DEGREES F $\square$ OTHER: MU O

MATERIAL (SIZE/AMOUNT) EXCLUDED FROM TEST:

No

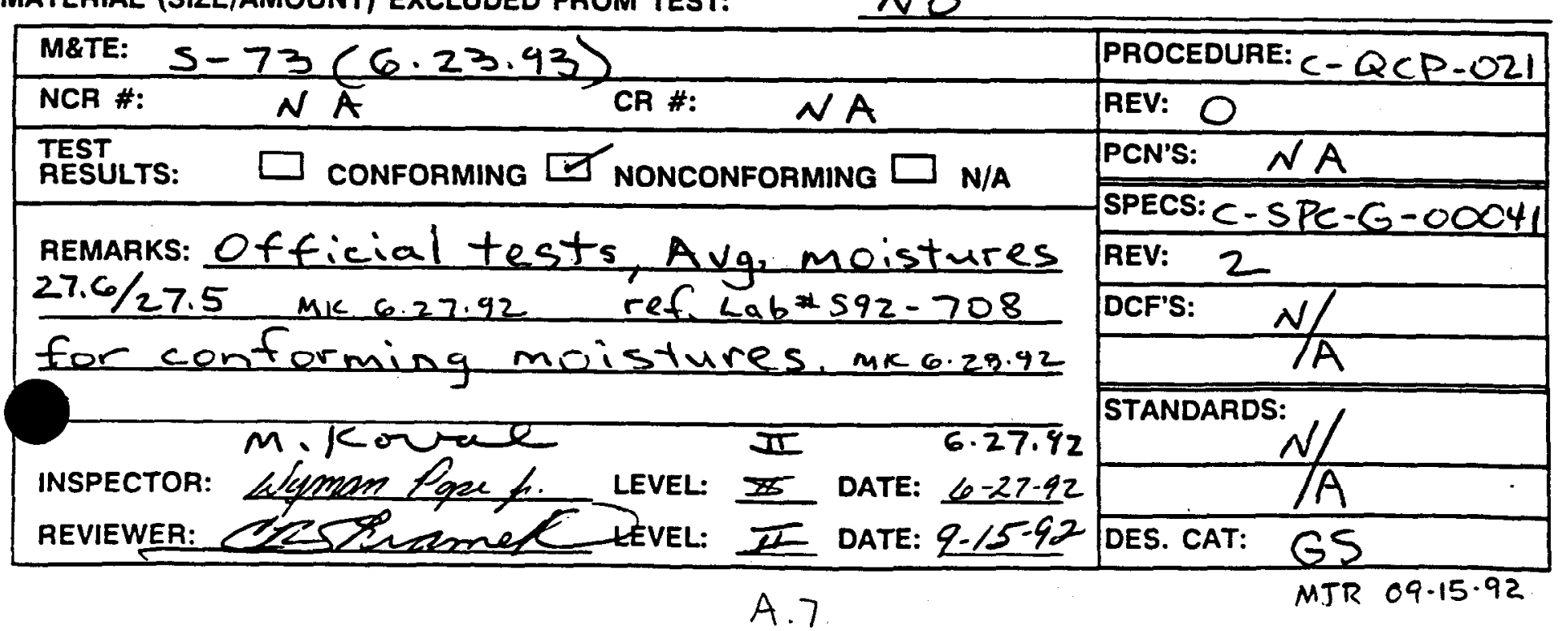




\section{FOR INFORMATION ONLY}

ASR 18-178 (3/92)

EBASCO SERVICES INCORPORATED

FILE ID* 80143

\section{DETERMINATION OF WATER CONTENT}

ASTM D-2216 ( )

PROJ/AMO: 4794

P.EPT \#:

$4 / 22$

DA: COOL TWC: Globo AXC: NA

DA: CoDL TWC: Globo AXC: NA

LAB \#: $\$ 92-700$ DATE TESTED: $\&-25=92$

MATERIAL DESCRIPTION:

Hoolur Slor
ASTM D-4643 (87)

WOAK PACKAGE NO.: 92-WPW-LC-OZ3

$922 \times 15=-4794-1101 \cdot \mathrm{C}^{2} \mathrm{CV}-$

QCIR NO.: $\quad g-0006-0002$

ACCPT. CRITERIA:

LOCATION: BueLel Geoued souls pulamec compection

\begin{tabular}{|c|c|c|c|c|c|c|c|}
\hline BOAHE NHMEEA MWO NOS & 1 & 2 & 11 & 4 & 5 & 6 & 7 \\
\hline SAMPLE NUMBER & $\angle$ & 2 & 3 & 4 & 5 & 6 & 7 \\
\hline WT. OF WET SAMPLE †AAE-* & $11.4 \gamma$ & 111.25 & 111.62 & 111.42 & 111.31 & 111.21 & 111.68 \\
\hline WT. OF DRY SAMPLE + TARE- * & 91.27 & 89.45 & 91.32 & 88.65 & 89.91 & 87.84 & 89.12 \\
\hline WEIGHT OF MOISTURE & 20.21 & $2 / .8$ & 20.25 & 22.77 & 21.4 & 23.37 & 22.56 \\
\hline TARE WEIGHT & NA & $\sqrt{A}$ & als & $N A$ & $N^{\prime} A$ & $N A$ & $\sqrt{A}$ \\
\hline WELEHT OF BAY SAMPLEF" & 22.1 & 24.4 & 22.2 & 25,2 & 23.8 & 26.6 & 253 \\
\hline \% MOISTURE Rounded te $0,5 \%$ & 22.0 & 24.5 & 22.0 & 25,5 & 24.0 & 26.5 & \\
\hline 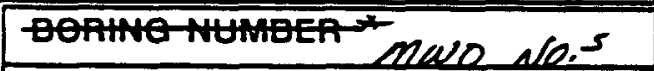 & 8 & 9 & 10 & & & & \\
\hline SAMPLE NUMBER & 8 & 9 & 10 & & & & \\
\hline WT. OF WET SAMPLE + TAAE* * & 111.89 & 111.68 & 111.79 & & & & \\
\hline WT. OF DRY SAMPLE + FAPE * & 88.21 & $82 \cdot 69$ & $8 \times .26$ & & & & \\
\hline WEIGHT OF MOISTURE & 23.68 & 23.99 & 23.03 & & $N$ & & \\
\hline TARE WEIGHT & ate & Na & $\sqrt{A}$ & & & & \\
\hline WEHOHT OF DAY-SAMPUE & 26.8 & $2 \geq 24$ & 25.9 & & & & \\
\hline$\%$ MOISTURE Rounde-d to $0.5 \%$ & 27.0 & $27,2^{-}$ & 26.0 & & & & \\
\hline
\end{tabular}

\section{MINIMUM}

SIZE SAMPLE

$\square$ CONFORMING

NONCONFORMING REMARKS:

MORE THAN ONE SOIL TYPE: $\quad$ Alo

METHOD OF DRYING: $\square 230$ +/- 9 DEGREES F

OTHER:

MATERIAL (SIZE/AMOUNT) EXCLUDED FROM TEST:

No

M\&TE: $5.73(6-23-93) \quad$ CR \#: NA
NCR \#: NA $\quad \square$ CONFORMING $\square$ NONCONFORMING $\square$ N/A
TEST
RESULTS: $\square$ C

REMARK: IAlEO ONCY TEST, *6-25-92 W.P. AlG. 25.1/25.0\% $\quad 6-25-92$ W.P.

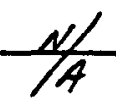

INSPECTOR: h.Kor hale REVIEWER:
II $\quad 6.25 .92$ LEVEL: $I 0$ DATE: $10-25=92$ LEVEL: $\%$ DATE: $9-15.92$
PROCEDURE: $C-Q C P-021$ REV: 0

PCN'S: NA

SPECS: $C-\operatorname{SPC}-G-00041$

REV: 2

DCF'S: N/A

STANDARDS:

N/A

DES. CAT: 'GS' 


\section{FUK INFURMATION ONLY}

ASR 18-178 (3/92)

FILE ID $\$ 80143$
EBASCO SERVICES INCORPORATED

DETERMINATION OF WATER CONTENT

\section{ASTM D-2216 ( )}

PROJ/AMO: 4794

DA: CROI TWC: G660 AXC: NA

LAB \#: 592 - 702 DATE TESTED: $6-27-92$

MATERIAL DESCRIPTION: KACLlea CloY

LOCATION:

Buela

$\square$ ASTM D-4643 (87)

PAGE $\frac{6}{\text { i OF } \frac{11}{\vdots}}$

WORK PACKAGE NO.: $\quad$ Q2-WPN-EC.023

S2TR5- $-0.4754-1101-C-C V-G$ QCIR NO.: e006-0002

ACCPT. CAITERIA:

Le

Compaction

L

\begin{tabular}{|c|c|c|c|c|c|c|c|}
\hline 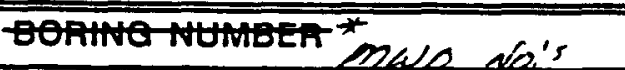 & $l$ & 2 & 4 & 5 & 6 & 7 & 8 \\
\hline SAMPLE NUMBER & 1 & 2 & 3 & 4 & 5 & 6 & 7 \\
\hline WT. OF WET SAMPLE + FAAE $*$ & 109.99 & 110.67 & 109.70 & 112.89 & 108.48 & 106.77 & $108.55^{-}$ \\
\hline WT. OF DRY SAMPLE + FAPE * & 810.32 & 82.85 & 82.44 & 90.60 & 85.96 & 82.21 & 83.32 \\
\hline WEIGHT OF MOISTURE & 23.62 & 22.82 & 22.26 & 22.29 & 22.52 & 24.06 & 25.23 \\
\hline TARE WEIGHT & $N_{A}$ & $N A$ & $\sqrt{A}$ & $\sqrt{A}$ & $N A$ & $\sqrt{A}$ & $\sqrt{n}$ \\
\hline WETEHT OF OAY SAMALE* & 27.3 & 26.0 & 25.5 & 24.6 & 26.2 & 291 & 30.3 \\
\hline$\%$ MOISTURE pounded To $0.5 \%$ & 27.5 & 26.0 & 25.5 & 24.5 & 26.0 & 290 & 30,5 \\
\hline
\end{tabular}

\begin{tabular}{|c|c|c|c|c|c|c|c|}
\hline DOAHG WHAEA * MWO ans & 9 & 10 & 11 & 1 & 2 & 4 & 5 \\
\hline SAMPLE NUMBER & 8 & 9 & 10 & II & 12 & 13 & 14 \\
\hline WT. OF WET SAMPLE + FAAE * & 108.26 & 107.77 & 111.99 & 108.52 & 107.44 & 109.78 & 113.95 \\
\hline VT. OF DRY SAMPLE + TAPE * & 83.66 & 82.25 & 86084 & 81.97 & 84.14 & 84.46 & 97.85 \\
\hline WEIGHT OF MOISTURE & 25.1 & 2552 & 25,15 & 26.6 & 233 & $25 \div 32$ & 26.1 \\
\hline TARE WEIGHT & $\sqrt{A}$ & $N_{t}$ & $N A$ & $N / A$ & $N A$ & $\sqrt{A}$ & $\sqrt{A}$ \\
\hline HEHOHT OF ORY SAMPLE & 30.0 & 31.0 & 29.0 & 32.4 & 27.7 & 30.0 & 29.7 \\
\hline$\%$ MOISTURE pounded to 0.5 & $30 \cdot 0$ & $3 / .0$ & 290 & 32.5 & 27.5 & 30.0 & 29.5 \\
\hline
\end{tabular}

\section{MINIMUM}

SIZE SAMPLE CONFORMING

NONCONFORMING REMARKS: NA

MORE THAN ONE SOIL TYPE: NO
METHOD OF DRYING:
$230+/-9$ DEGREES $F$
$\triangle$ OTHER:

MATERIAL (SIZE/AMOUNT) EXCLUDED FROM TEST:

alo

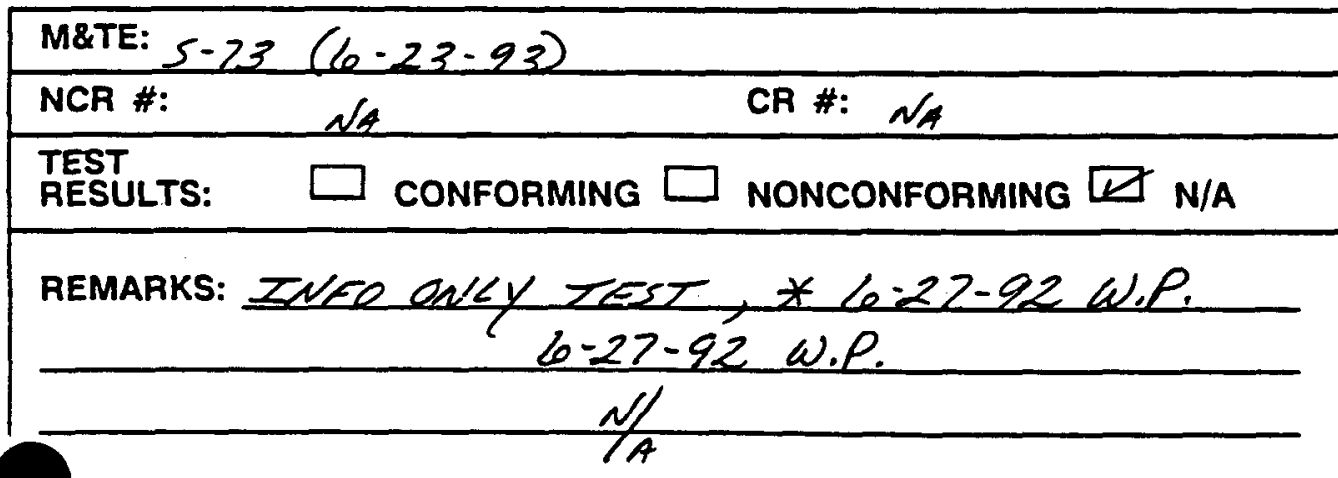

INSPECTOR:

M. 16 orral

REVIEWER:
II LEVEL: II DATE: 6.27 .92 LEVEL: 2 DATE: $9-15-92$
PROCEDURE: $(-Q P F-02)$ REV: 0

PCN'S:

SPECS: $P$ - SPC-G-0.04I

REV: 2

DCF'S:

N/2

STANDARDS:

N/A 
REPT \#: $4 / 22$ PROJ/AMO: 4794

DA: $\mathrm{COO} /$ TWC. 9600 AXC: NA

WORK PACKAGE NO:: q2-WPW-EC-023 OCIR NO. TZ2R'S-E-4794-1101-C-CUOCIR NO.: $\quad$ $2-0006-0002$

LAB \#: $592-702$ DATE TESTED: $10-22-92$ ACCPT. CRITERIA: NA MATERIAL DESCRIPTION: ${ }^{6.27 .90^{2}}$ KROLN ClaY iA-leE '

LOCATION: Buelel Geaund sols DYNamic compection

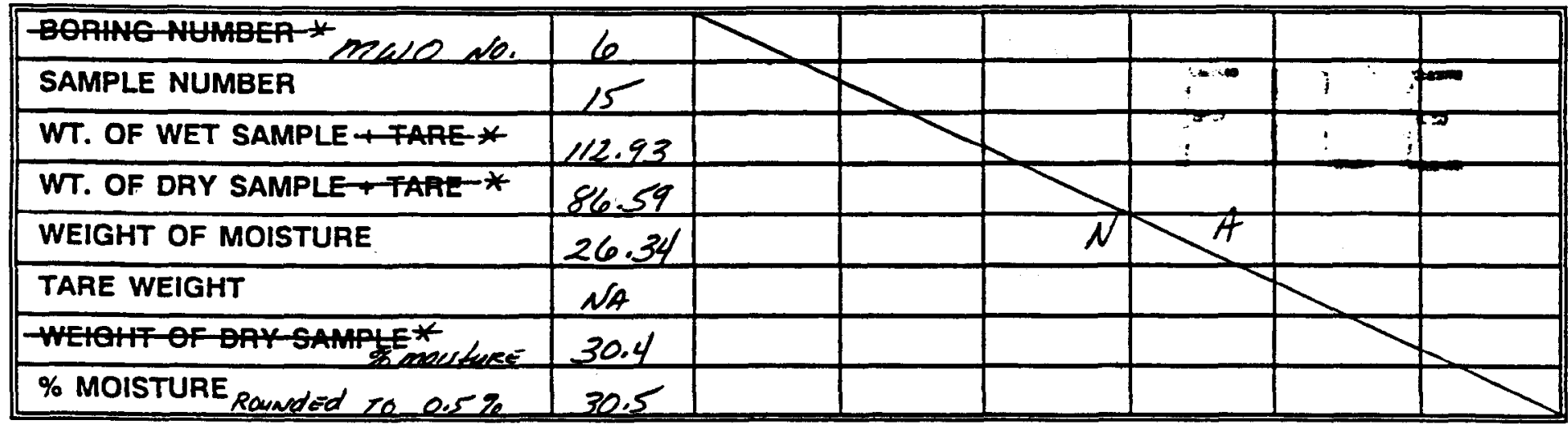

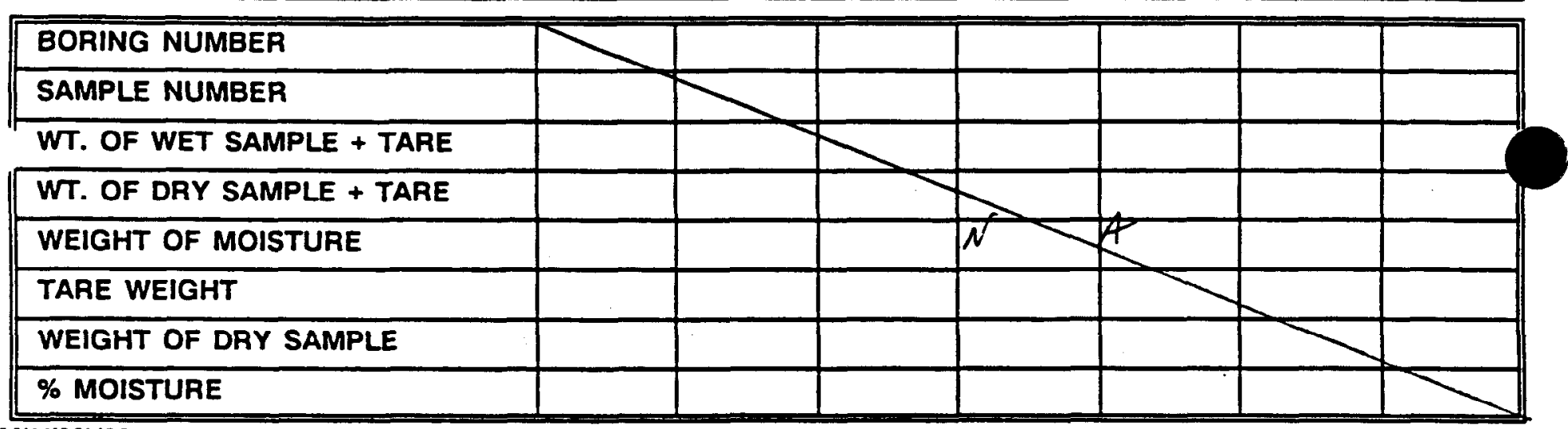

MINIMUM

SIZE SAMPLE

2 CONFORMING

NONCONFORMING REMARKS:

MORE THAN ONE SOIL TYPE:

METHOD OF DRYING: $\square 230+/-9$ DEGREES F

$\square$ OTHER: MWO

MATERIAL (SIZE/AMOUNT) EXCLUDED FROM TEST:

\begin{tabular}{|c|c|}
\hline$(6-23-93)$ & PROCEDURE: $C-Q C P-O Z 1$ \\
\hline CR \#: $N / A$ & REV: 0 \\
\hline$\square$ CONFORMING $\square$ NONCONFORMING $\square$ N/A & PCN'S: $\quad$ NA \\
\hline REMARKS: INEO eNly ZEST, *6-27-92 W. & $\begin{array}{l}\text { SPECS: } C \cdot S P C \cdot G-00041 \\
\text { REV: } 2\end{array}$ \\
\hline$\frac{6}{627-92 \text { w. p. }}$ & DCF'S: \\
\hline \& & $1 / 4$ \\
\hline $7 / 4$ & STANDARDS: \\
\hline 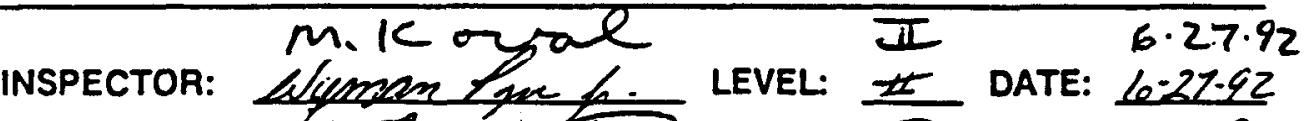 & \begin{tabular}{|r|r}
$/ 4$ \\
\end{tabular} \\
\hline REVIEWER: Cesthame/C LEVEL: DATE: $9-15-92$ & DES. CAT: \\
\hline
\end{tabular}




\section{FOR INFORMATION ONLY}

EBASCO SERVICES INCORPORATED

FILE ID $* 80143$

\section{DETERMINATION OF WATER CONTENT}

ASTM D-2216 ( )

$\square$ ASTM D-4643 (87)

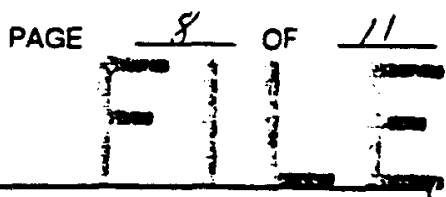

REPT \#: 4122

PROJ/AMO: YZZ4

DA: Cool TWC: 9660 MUC: NA

LAB \#: $\$ 92-705$ DATE TESTED: $12-27-92$

MATERIAL DESCRIPTION:

Krolin

Clev

WORK PACKAGE NO:: 92 -WPA-EC.023

925R, -E.4744-1101-C.CU-G. QCIR NO.: eeck-e002

LOCATION: BueIal Greuald sols ordomic compection

\begin{tabular}{|c|c|c|c|c|c|c|c|}
\hline GOAHONHAEA * MuO & 1 & 2 & 4 & 5 & 6 & 7 & 8 \\
\hline SAMPLE NUMBER & 1 & 2 & 3 & 4 & 5 & 6 & 7 \\
\hline WT. OF WET SAMPLE- TAAE- * & 113,50 & $1 / 3,47$ & 112,08 & 111.53 & $1 / 4.62$ & 112.09 & 111.61 \\
\hline WT. OF DAY SAMPLE + FAAEE * & 89.44 & 87.95 & 82.14 & 87.08 & 89.44 & 88.07 & 88.58 \\
\hline WEIGHT OF MOISTURE & 24.06 & 25.52 & 2494 & 24.45 & 25.18 & 24.02 & 23.03 \\
\hline TARE WEIGHT & $\sqrt{A}$ & $\sqrt{A}$ & NA & $\sqrt{A}$ & $\sqrt{A}$ & $\sqrt{A}$ & $\sqrt{A}$ \\
\hline 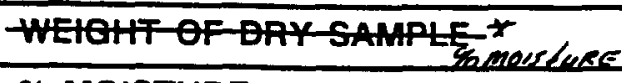 & 26.9 & 29.0 & 28.6 & 28.1 & 28.2 & 27.3 & 26.0 \\
\hline$\%$ MOISTURE Roundad to 0.520 & 27.0 & 29.0 & 28.5 & 28.0 & 28.0 & 22.5 & $26=$ \\
\hline
\end{tabular}

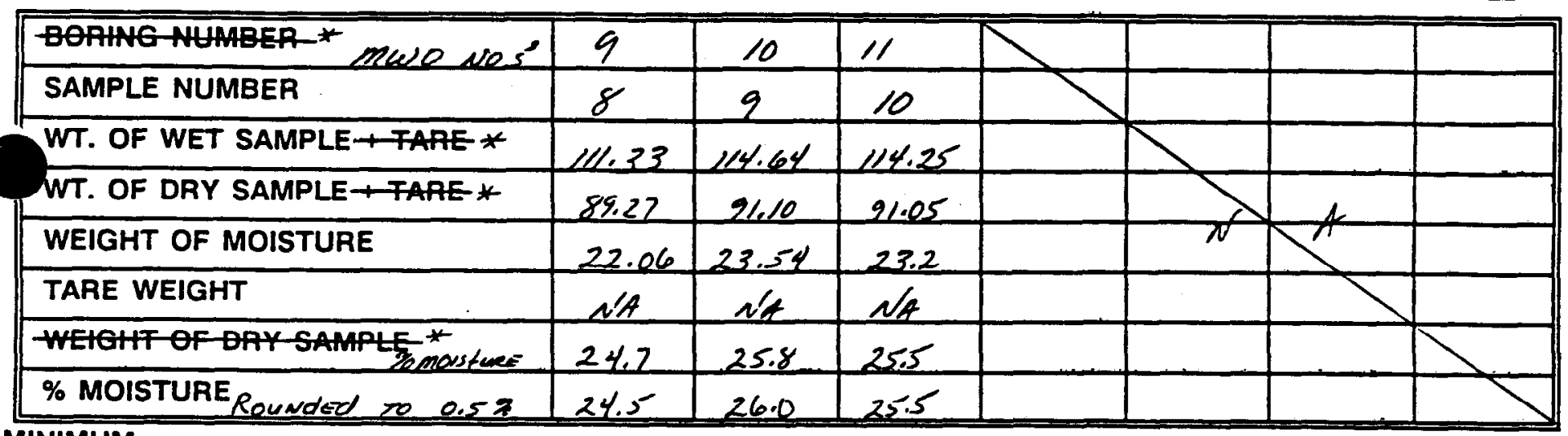

MINIMUM

$\square$ CONFORMING

NONCONFORMING REMARKS: NA

MORE THAN ONE SOIL TYPE: NO

METHOD OF DRYING: $\square 230$ +/- 9 DEGREES F $\square$ OTHER: MWO

MATERIAL (SIZE/AMOUNT) EXCLUDED FROM TEST:

No

$\begin{array}{ll}\text { M\&TE: } 5-73(6-23-93) & \\ \text { NCR \#: } \quad \text { CR \#: NA }\end{array}$

TEST

RESULTS: $\square$ CONFORMING $\square$ NONCONFORMING $\square$ N/A

REMARKS: INFO eN/F TEST, $* 6-27-92 w, P$. $6-27-92$ w.P.

$$
\text { N/A }
$$

\section{M.Krval}

INSPECTOR:

REVIEWER:
M.K II

tyom tam

Rutionet DATE: $6.27 \cdot 92$ LEVEL: I DATE: $9-15.97$
PROCEDURE: $C \cdot Q C P-021$

REV: 0

PCN'S:

SPECS: C-SPC-G-00041

REV: 2

DCF'S:

$\pi / 4$

STANDARDS

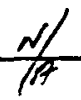




\section{FUK IIVTUKIVIAIIUIV UIVLI}

ASR $18.178(3 / 92)$

FILE ID $\$ 80143$
EBASCO SERVICES INCORPORATED

DETERMINATION OF WATER CONTENT

$\square$ ASTM D-4643 (87)
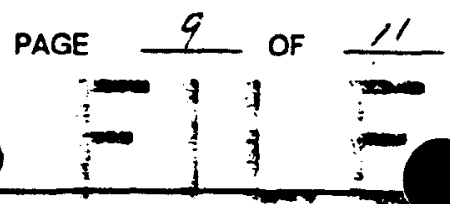

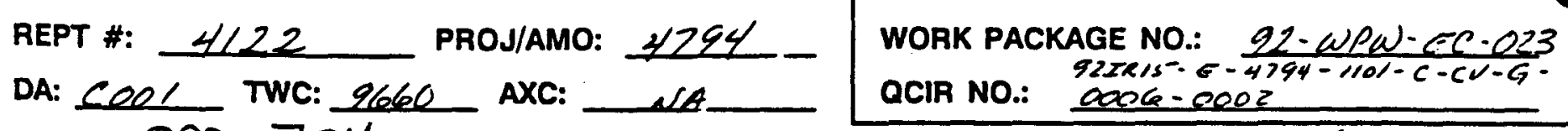

LAB \#: $592-704$ DATE TESTED: $k-27-92$ ACCPT. CRITERIA: N NA

MATERIAL DESCRIPTION: HAOLN CLAV A-LET

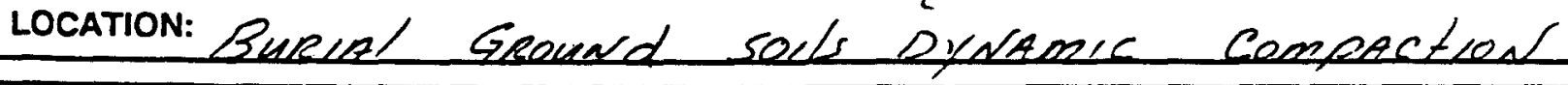

\begin{tabular}{|c|c|c|c|c|c|c|c|}
\hline BOAHONHMBEA " MUNO $\mathrm{NO}^{5}$ & $\angle$ & 2 & 4 & 5 & 6 & 7 & \\
\hline SAMPLE NUMBER & $L$ & $\angle B$ & 2 & $2 B$ & 3 & $3 B$ & \\
\hline WT. OF WET SAMPLE †AAE* $*$ & 112.33 & 112.17 & $11 / 63$ & 411.81 & 112,76 & 112.67 & \\
\hline WT. OF DRY SAMPLE + FARE * & 85.40 & 36.14 & 85.72 & 85.58 & 89.56 & 87.98 & \\
\hline WEIGHT OF MOISTURE. & 26.43 & $2 / 0.03$ & 25.91 & 26.23 & 23.2 & 24.69 & \\
\hline TARE WEIGHT & NA & $N A$ & $\sqrt{4}$ & $N A$ & $\sqrt{A}$ & $\sqrt{4}$ & \\
\hline WEIGHT OF OAY SAMPISE* & 30.8 & 30.2 & 30.2 & 30.6 & 25,9 & 28.1 & \\
\hline$\%$ MOISTURE Rounded to 0.59 & 310 & 30.0 & 30.0 & 30.5 & 26.0 & 28.0 & \\
\hline
\end{tabular}

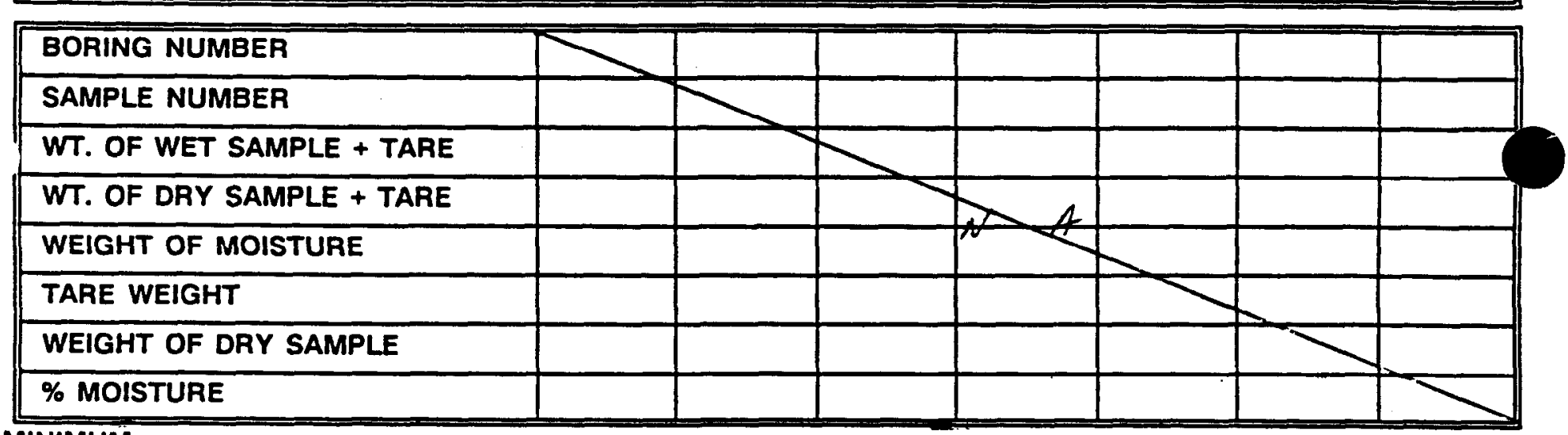

MINIMUM SAMPLE $\square$ CONFORMING $\square$ NONCONFORMING REMARKS: $N$

MORE THAN ONE SOIL TYPE: $\sqrt{ }$

METHOD OF DRYING: $\square 230+/-9$ DEGREES F $\square$ OTHER: 2 230

MATERIAL (SIZE/AMOUNT) EXCLUDED FROM TEST:

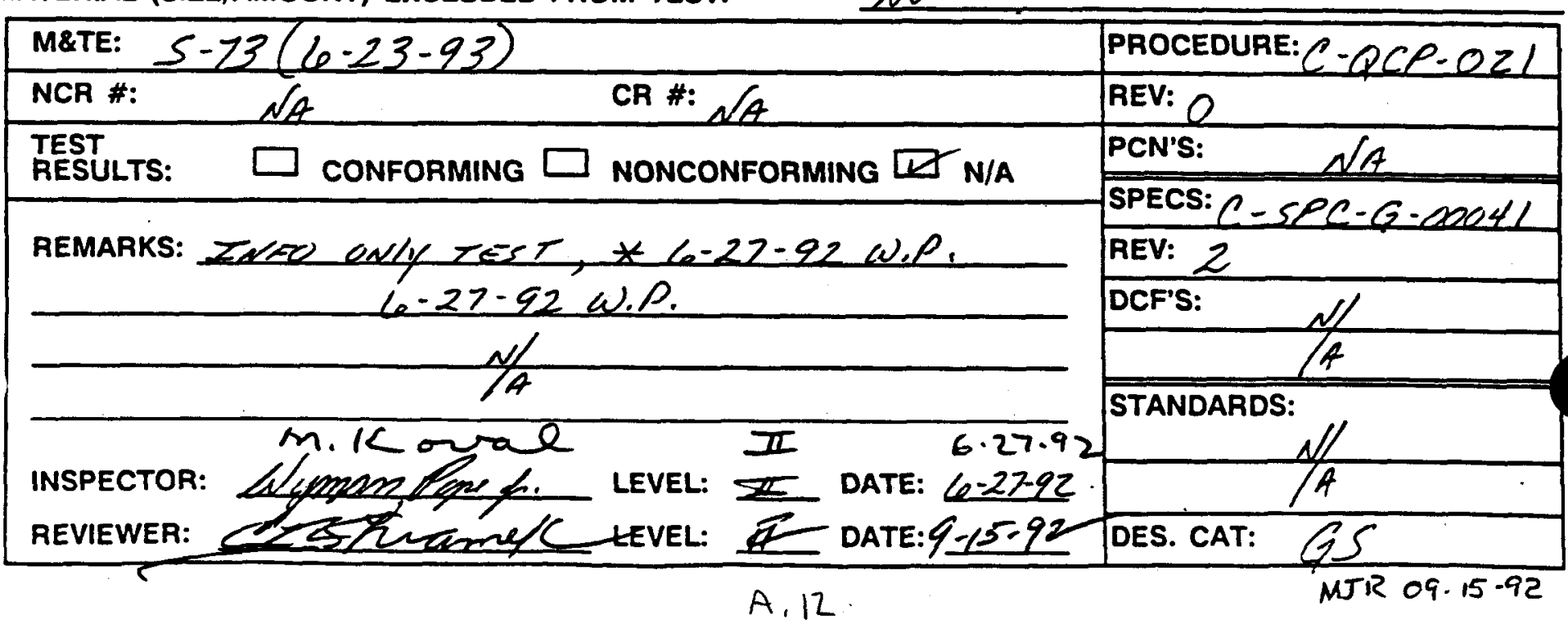


FOR INFORMATION ONLY

ASR 18-178(3/92)
FILE ID $\$ 80143$

EBASCO SERVICES INCORPORATED

DETERMINATION OF WATER CONTENT

ATM D-2216 ( )

$\square$ ASTM D-4643 (87)

PAGE 10 OF 11

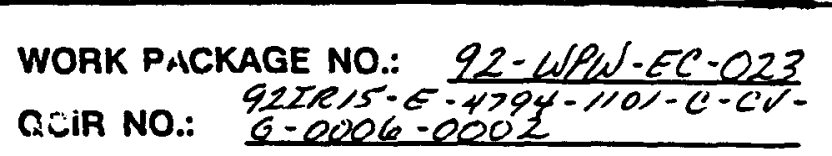

REPT \#: $4 / 22$ PROJ/AMO: 4724

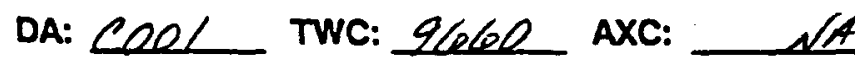

LAB \#: $592-703$ DATE TESTED: lo -22-92 ACCPT. CRITERIA:

MATERIAL DESCRIPTION: KOLa Clay A-LLF

LOCATION: BuRIAL GROUNA SEMS DVNAMIC LOMPRCLION

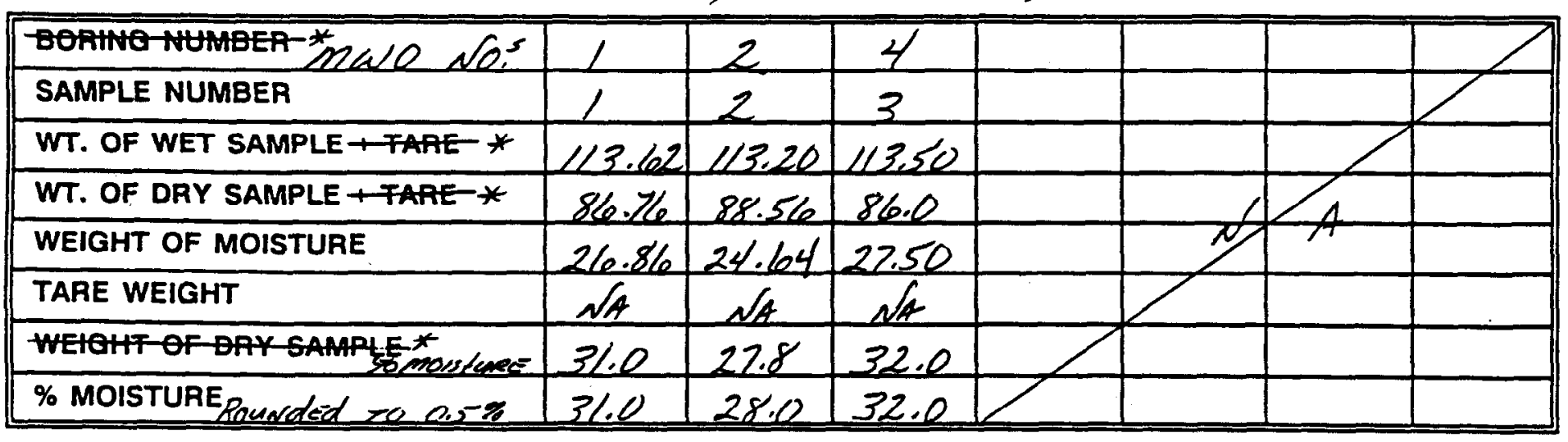

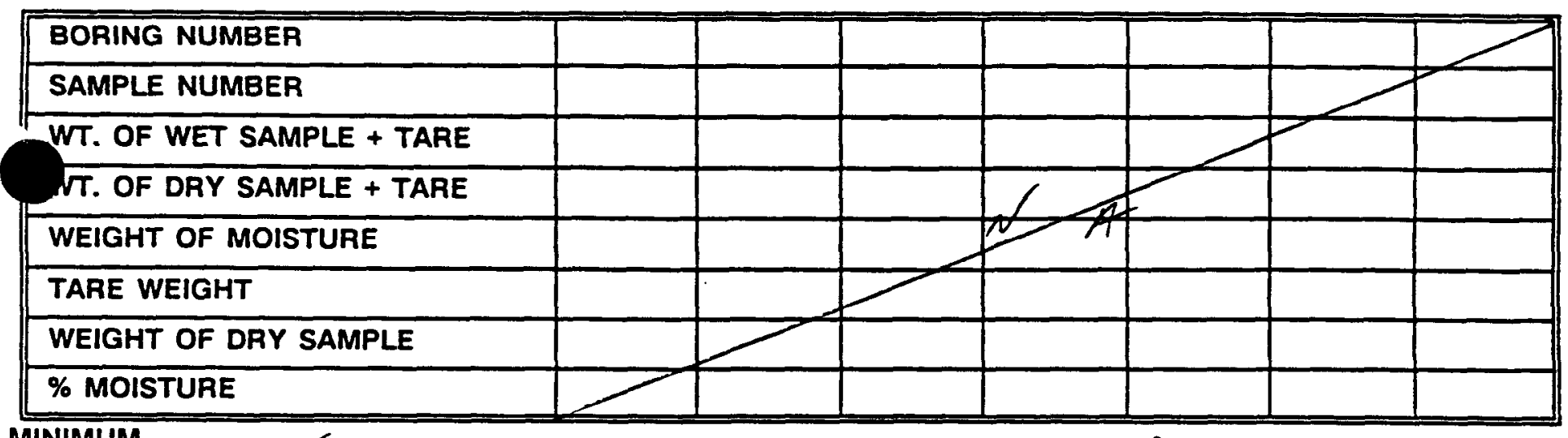

MIZE SAMPLE $\square$ CONFORMING $\square$ NONCONFORMING REMARKS: $\Lambda / A$ MORE THAN ONE SOIL TYPE: $N O$

METHOD OF DRYING: $\square 230+1-9$ DEGREES F $\square$ OTHER: MOO

MATERIAL (SIZE/AMOUNT) EXCLUDED FROM TEST: $\quad 1 / 0$

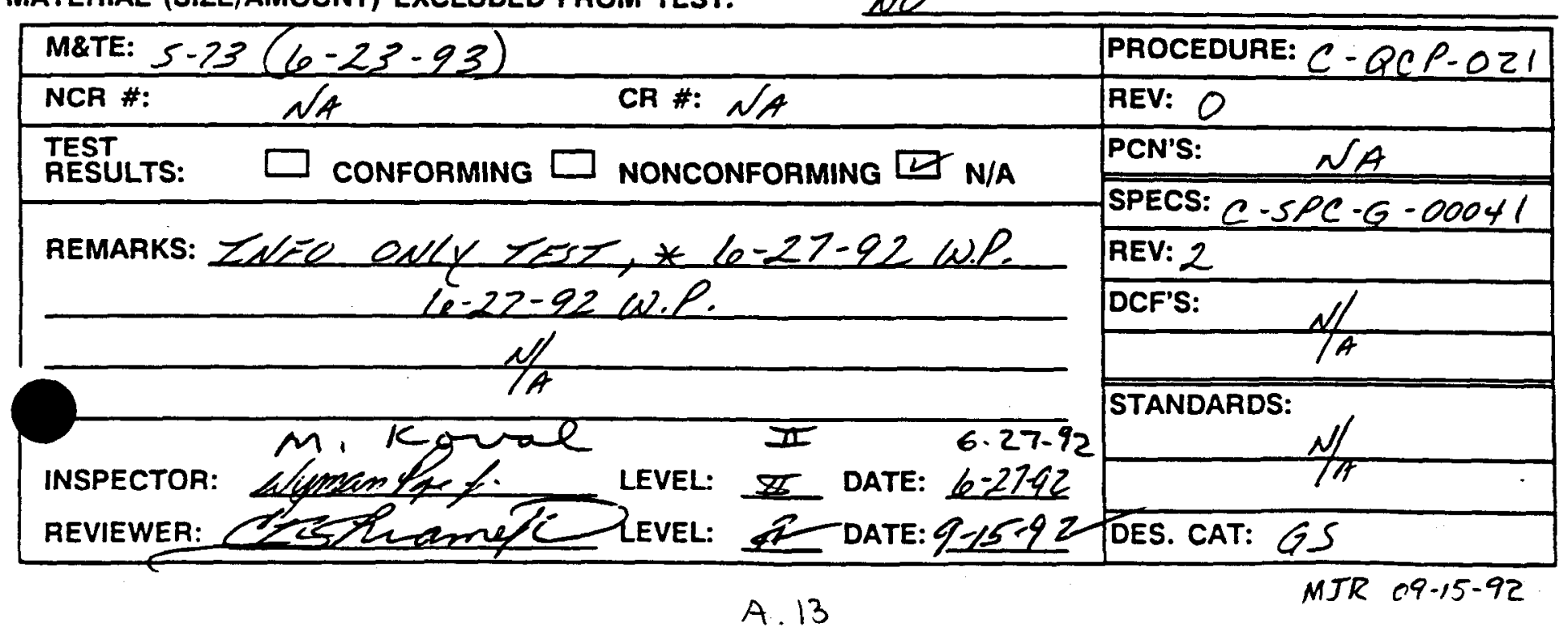




\section{FOR INFORMATION ONLY}

\section{DETERMINATION OF WATER CONTENT}

\section{ASTM D-2216 ( )}

PROJ/AMO: $4 Z G 4$

REPT \#: $\quad$ H/22

DA: COOL TWC: Glele AXC: NA

LAB \#: $\$ 92-707$ DATE TESTED: $10-28-92$

MATERIAL DESCRIPTION: KAOLLA ClAK

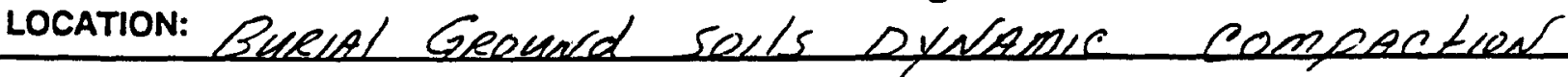

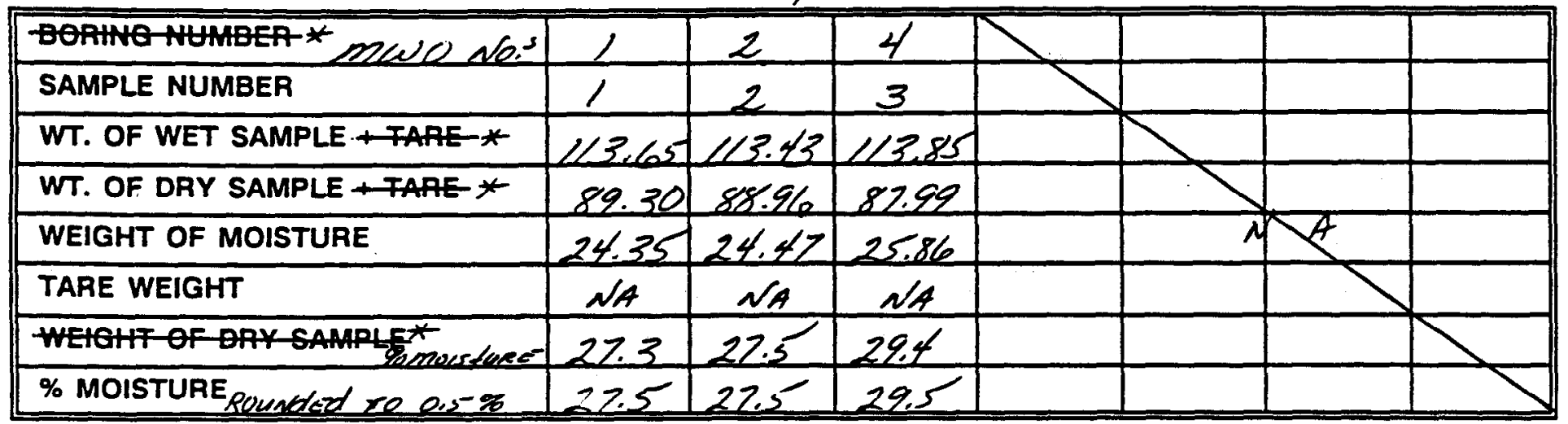

\begin{tabular}{|l|l|l|l|l|l|l|l|}
\hline BORING NUMBER & & & & & & \\
\hline SAMPLE NUMBER & & & & & & & \\
\hline WT. OF WET SAMPLE + TARE & & & & & & & \\
\hline WT. OF DRY SAMPLE + TARE & & & & & \\
\hline WEIGHT OF MOISTURE & & & & & & & \\
\hline TARE WEIGHT & & & & & & & \\
\hline WEIGHT OF DRY SAMPLE & & & & & & & \\
\hline$\%$ MOISTURE & & & & & & & \\
\hline
\end{tabular}

MINIMUM

SIZE SAMPLE $\square$ CONFORMING $\square$ NONCONFORMING REMARKS:

MORE THAN ONE SOIL TYPE: NO

METHOD OF DRYING: $\square 230+/-9$ DEGREES F $\square$ OTHER: $M$ MUC

MATERIAL (SIZE/AMOUNT) EXCLUDED FROM TEST:

\begin{tabular}{|lcl}
\hline M\&TE: & $5.73(6-23-93)$ & \\
\hline NCR \#: & $N A$ & CR \#: NA
\end{tabular}

TESTULTS: $\square$ CONFORMING $\square$ NONCONFORMING $\square$ N/A

REMARKS: INET aNY TEST, *6:28.92 W.P. $6-28-92$ w.

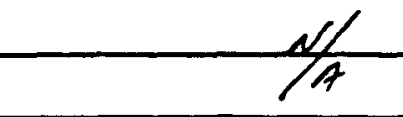

m.K on rale

II 6.25 .92

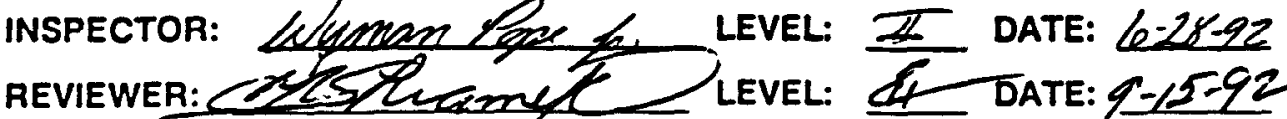

PROCEDURE: $C-Q C P-021$

REV: 0

PCN'S: NA

WORK PACKAGE

ACCPT. CAITEHIA: 


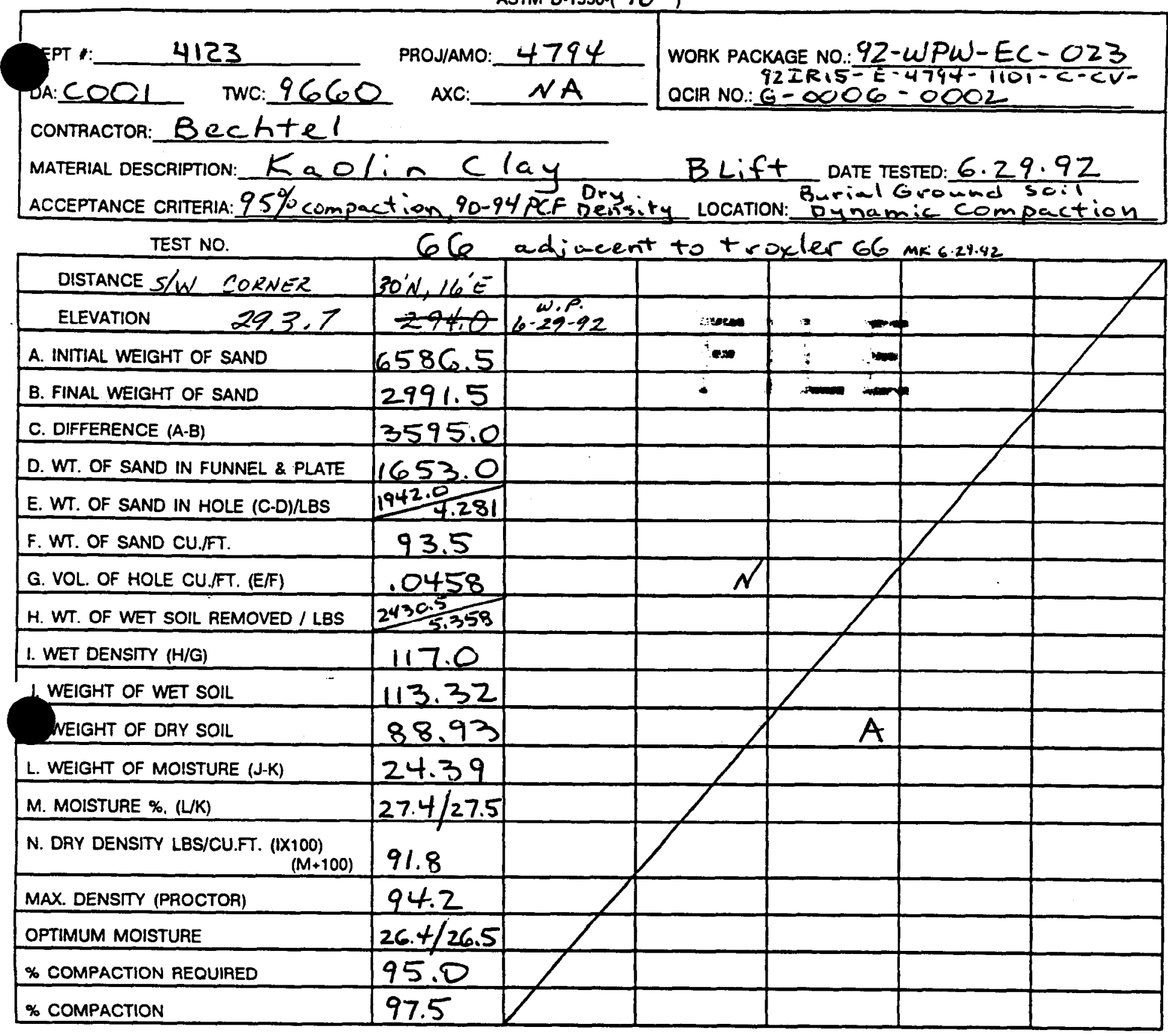

DENSITY PROCTOR REPORT :UER-ERC-92-0544.

DESIGN CATEGORY:_ GS

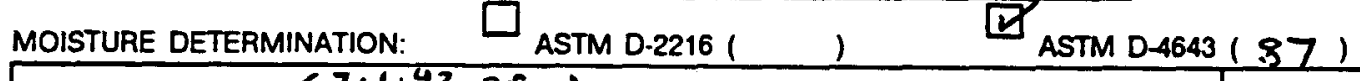

\begin{tabular}{|c|c|}
\hline M\&TE: $F-10\left(\begin{array}{c}7.1142 \text { or } \\
20016 \text { s sand }), 5-79(5.6 .93)\end{array}\right.$ & PROCEDURE: $C-Q C P-021$ \\
\hline NCR : $\quad N A \quad$ CR : $\quad N A$ & REV: 0 \\
\hline TEST $\square$ DECIUTC. $\square$ & PCN'S: $\quad N A$ \\
\hline & SPECS: $C-S P C-G-00041$ \\
\hline REMARKS: & REV: \\
\hline & $N /$ \\
\hline 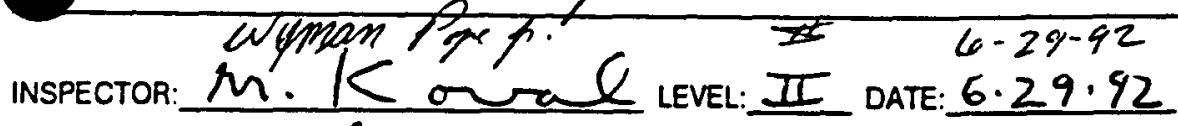 & STANDARDS: \\
\hline 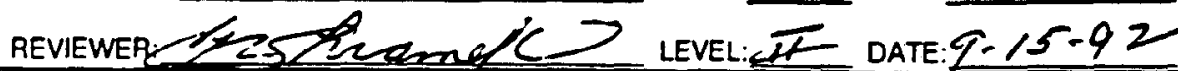 & \\
\hline
\end{tabular}


FOR INFËR̆YIÁTION̄ ONLY

ASR 18-180 (3/92)
FILE ID 80145

EBASCO SERVICES INCORPORATED

PAGE 2 OF $\&$

MOISTURE \& DENSITY TESTS USING SURFACE PROBES

ASTI D-2922 $\left(81 B / H_{0}\right)$

REPT \#: $\frac{4123}{412}$ PROJ/AMO: $\frac{4794}{\text { WORK PACKAGE NO.:92-WPW-EC-O23 }}$

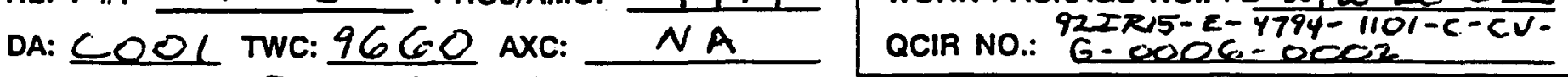
CONTRACTOR: Bechtel

MATERIAL DESCRIPTION: Kaolin Clay

aCCePtance CRITERIA: $95 \%$ compaction, $90-94$ PCF Dry Density DRAWINGS) \& REV(S): $\mathrm{c}-\mathrm{CV}-\mathrm{G}-0006 \mathrm{k} / \mathrm{i}$

Location: Burial Ground Soils Dynamic Compaction - B Lift TEST NO.

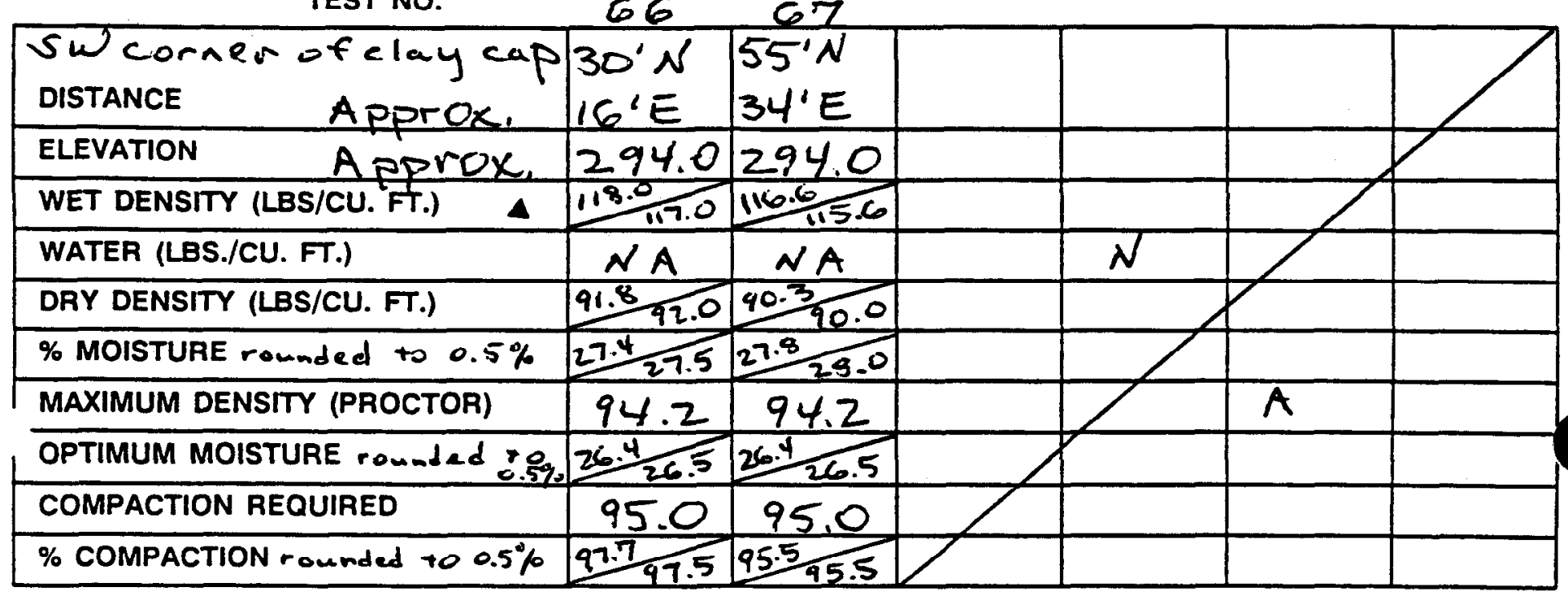

TROXLER \#: 7 MODEL: 3440 SERIAL \#: 17494

DENSITY PROCTOR REPT \#: WER-ERC-92-0544 DESIGN CAT: GS

DENSITY: AVERAGE OF LAST 4 STANDARD COUNTS (No): 3832

DAILY STANDARD COUNTS (Ns): $\quad 3853$

MOISTURE: AVERAGE OF LAST 4 STANDARD COUNTS (No): 604

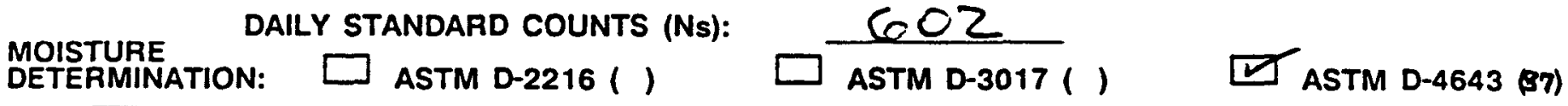

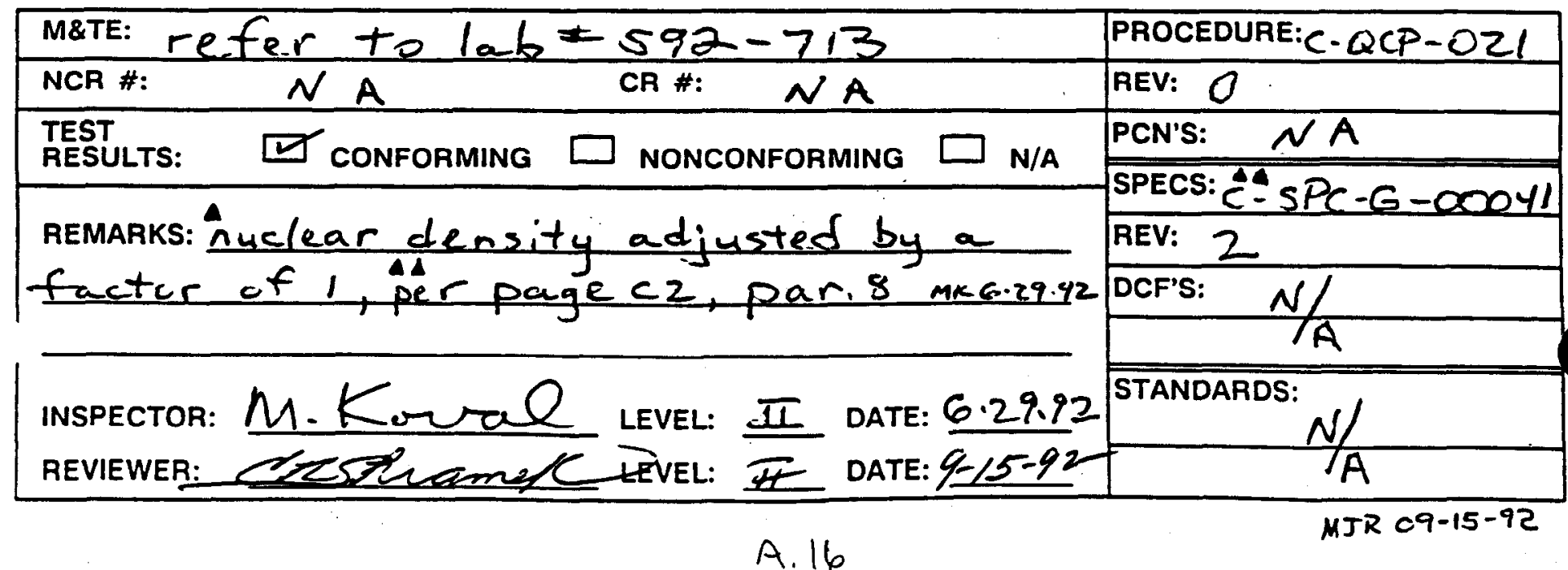


REPT \#: 4123 PROJ/AMO: 4794

DA: $C O O 1$ TWC: 9660 AXC: NA

LAB \#: $592-709$ DATE TESTED: 6.29 .92 ACCPT. CRITERIA:

MATERIAL DESCRIPTION: Kaolin Clay B Lift

WORK PACKAGE NO:: 92-WPW-EC-O23

QCIR NO. 92IR15-E-4794-1101-C-CV

QCIR NO.: $\quad$ - $0006-0002$

LOCATION: Burial Ground Soils Dynamic Compaction

\begin{tabular}{||l|c|c|c|c|c|c|c|}
\hline SAMPLE NUMBER & 1 & 2 & 4 & 5 & 6 & 7 & 8 \\
\hline WT. OF WET SAMPLE & 1 & 2 & 3 & 4 & 5 & 6 & 7 \\
\hline WT. OF DRY SAMPLE & 112.80 & 112.21 & 114.41 & 112.49 & 112.86 & 113.38 & 113.25 \\
\hline WEIGHT OF MOISTURE & 90.85 & 89.28 & 92.50 & 90.93 & 91.73 & 92.18 & 91.43 \\
\hline TARE WEIGHT & 21.95 & 22.93 & 21.91 & 21.56 & 21.13 & 21.20 & 21.82 \\
\hline & NA & NA & NA & NA & NA & NA & NA \\
\hline$\%$ MOISTURE rOUnded TO $0.5 \%$ & 24.0 & 25.5 & 23.5 & 23.5 & 23.0 & 23.0 & 24.0 \\
\hline
\end{tabular}

AOAHAE NUMBEA

micremuve

SAMPLE NUMBER

WT. OF WET SAMPLE + TAPEA

JT. OF DAY SAMPLE + FAPE-A

WEIGHT OF MOISTURE

TARE WEIGHT

WE HOHF OF OAY SAMPLEA

$\%$ MOISTURE rounded to $0.5 \%$

\begin{tabular}{|c|c|c|c|c|c|c|}
\hline 9 & 10 & 11 & & & & \\
\hline 8 & 9 & 10 & & & & \\
\hline 111.38 & 112.50 & 113.92 & & & & \\
\hline 91.12 & 91.44 & 92.07 & & & & \\
\hline 20.26 & 21.06 & 21.85 & & & & \\
\hline$N A$ & $N A$ & $N A$ & & & & \\
\hline 22.2 & 23.0 & 23.7 & & & & \\
\hline 22.0 & 23.0 & 23.5 & & & & \\
\hline
\end{tabular}

MINIMUM SAMPLE $\square$ CONFORMING $\square$ NONCONFORMING REMARKS: $\mathcal{N}$

MORE THAN ONE SOIL TYPE: No

METHOD OF DRYING: $\square 230+/-9$ DEGREES F

OTHER: MWO

MATERIAL (SIZE/AMOUNT) EXCLUDED FROM TEST:

No

\begin{tabular}{l}
\hline M\&TE: $5-73(6.23 .43)$ \\
\hline NCR \#: $\quad$ CR \#: NA \\
\hline TEST \\
RESUTS: $\square$ cONFORMING $\square$ NONCONFORMING $\square$ N/A \\
REMARKS: tests taken for in fo only. \\
Avg, $23.5 \%$ m/K 6.29 .92 \\
\hline
\end{tabular}

INSPEC

INSPECTOR:

$\ln \cdot 1<$ mal

REVIEWER:
Llomen tor

Excriande
II

LEVEL:

LEVEL:
6.29 .92

DATE: $6-29 \cdot 42$

I DATE: $9-15-92$
PROCEDUAE: $C-Q C P-021$

REV: $O$

PCN'S: $N A$

SPECS: $C-S P C-G-00041$

REV: 2

DCF'S: $\quad N /$

STANDARDS:

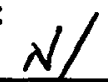

DES. CAT: GS 


\section{TUK INFURMATION ONLY}

ASR 18-178 (3/92)

EBASCO SERVICES INCORPORATED

FILE ID $* 80143$

DETERMINATION OF WATER CONTENT

ASTM D-2216 ( )

ASTM D-4643 (87)

REPT \#: 4123 PROJ/AMO: 4794

DA: ceel TWC: GleGe AXC: dA

LAB \#: $\$ 92-710$ DATE TESTED: $6-29-92$ ACCPT. CRITERIA:

WORK PACKAGE NO.: $92-W Q W-E C-023$

922R15.6-4794-1101-C-CV-

QCIR NO: $\quad 4$-0006-0002

MATERIAL DESCRIPTION: KAOLN CloY B.LIET

LOCATION: Bureal Greand souts oracanic compretrod

\begin{tabular}{|c|c|c|c|c|c|c|c|}
\hline BOAHONHAEA* MWO & 1 & 2 & 4 & 1 & 2 & 4 & 5 \\
\hline SAMPLE NUMBER & 1 & 2 & 3 & 4 & 5 & be & 7 \\
\hline WT. OF WET SAMPLE —AAE * & 113,48 & 113,10 & 13.85 & 113,46 & 113,15 & 13.02 & 125 \\
\hline WT. OF, DRY SAMPLE + TAAE * & 89.24 & 87.03 & 89.60 & 88.20 & 89.60 & 87.34 & 90.61 \\
\hline WEIGHT OF MOISTURE & 24.24 & 26.07 & 24.25 & 25.26 & 23.55 & 25.68 & 22.94 \\
\hline TARE WEIGHT & $\sqrt{A}$ & $\sqrt{A}$ & $N A$ & NA & NA & $N A$ & $\sqrt{A}$ \\
\hline 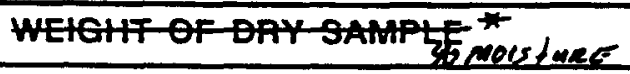 & 27.2 & 30.0 & 27.1 & 28.6 & 26.3 & 29.4 & 25,3 \\
\hline$\%$ MOISTURE Rounded to as\% & 22.0 & 30.0 & 27.0 & 28.5 & 26.5 & 29.5 & 25.5 \\
\hline
\end{tabular}

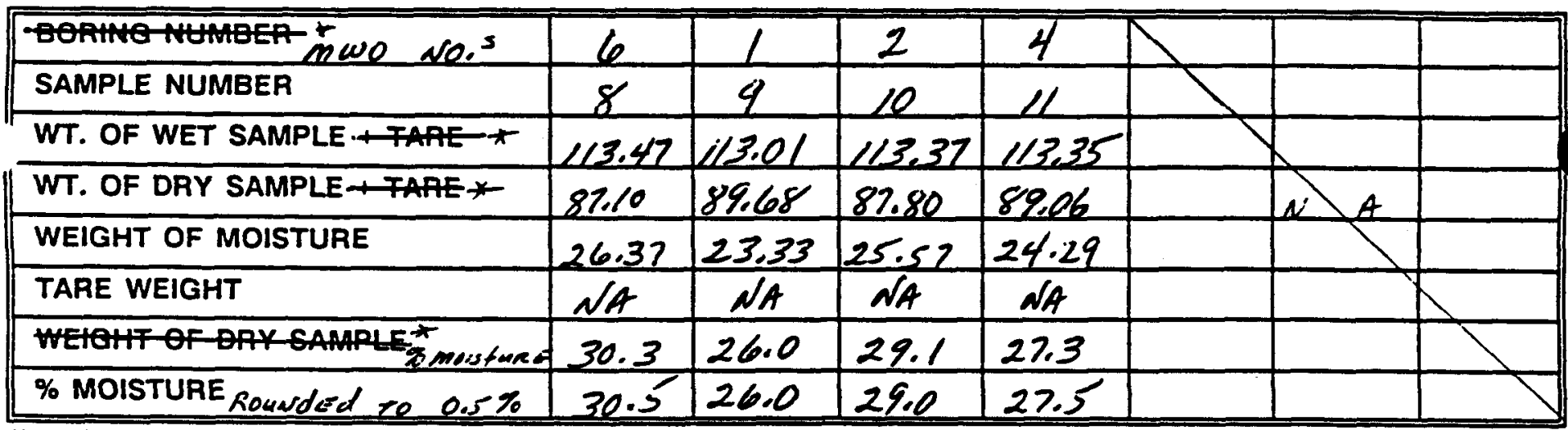

MINIMUM

SIZE SAMPLE $\square$ CONFORMING $\square$ NONCONFORMING REMARKS:

MORE THAN ONE SOIL TYPE: $\quad \alpha O$

METHOD OF DRYING: $\square 230$ +/- 9 DEGREES F $\square$ OTHER: MWO

MATERIAL (SIZE/AMOUNT) EXCLUDED FROM TEST:

M\&TE: $5-23(6-23 \cdot 93)+6-29-92$ W.P.

NCA \#: $\quad \sqrt{A} \quad$ CR \#: NA

TEST

TESTULTS: $\square$ CONFORMING $\square$ NONCONFORMING $\square$ N/A

REMARKS: ZAFO ONly TEST, * 6-29-92 w.P. QVG, $28 \%$ le 29-92 a.p.

$$
\text { N/A }
$$

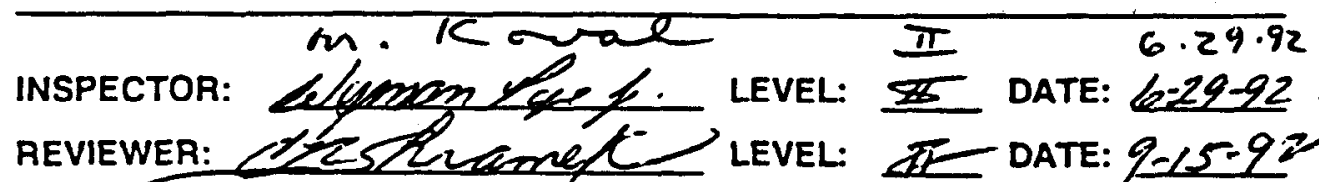

PROCEDURE: $C-Q C P-021$

REV: 0

PCN'S:

SPECS: C-SPC-G-00041

REV: 2

DCF'S: N/A

STANDARDS: 
REPT \#: $\frac{4123}{4}$ PROJ/AMO: 4794 DA: $\mathrm{COO1}$ "TWC: 9660 AXC: NA LAB \#: $592-711$ DATE TESTED: $6.29-92$ MATERIAL DESCRIPTION: Krelear elley

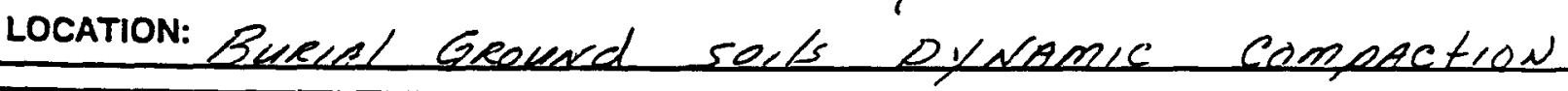

\begin{tabular}{|c|c|c|c|c|c|c|c|}
\hline 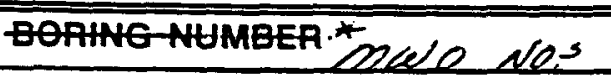 & 1 & 2 & 4 & 5 & 6 & 7 & 8 \\
\hline SAMPLE NUMBER & 1 & 2 & 3 & 4 & 5 & 6 & 7 \\
\hline WT. OF WET SAMPLE - TARE-* & 113,15 & 112.52 & 113.16 & 113.13 & 114,23 & 114.97 & 113,74 \\
\hline WT. OF DAY SAMPLE + TAAE- * & 87.26 & 84.62 & 87.64 & 88.44 & 88.14 & 88.55 & 88.12 \\
\hline WEIGHT OF MOISTURE & 25.89 & 27.9 & 25.52 & 24.68 & 26.09 & 26.42 & 25.62 \\
\hline TARE WEIGHT & NA & $N A$ & $N A$ & Na & $N_{A}$ & $N A$ & NA \\
\hline WETOHF-OF-OAK SAMAPLEF & 29.7 & 32.9 & 29.1 & 27,9 & 29.6 & 29.8 & 29.1 \\
\hline$\%$ MOISTURE Roudden $z$ & 29.5 & 33.0 & 29.0 & 28.0 & 29,5 & 30.0 & 29.0 \\
\hline
\end{tabular}

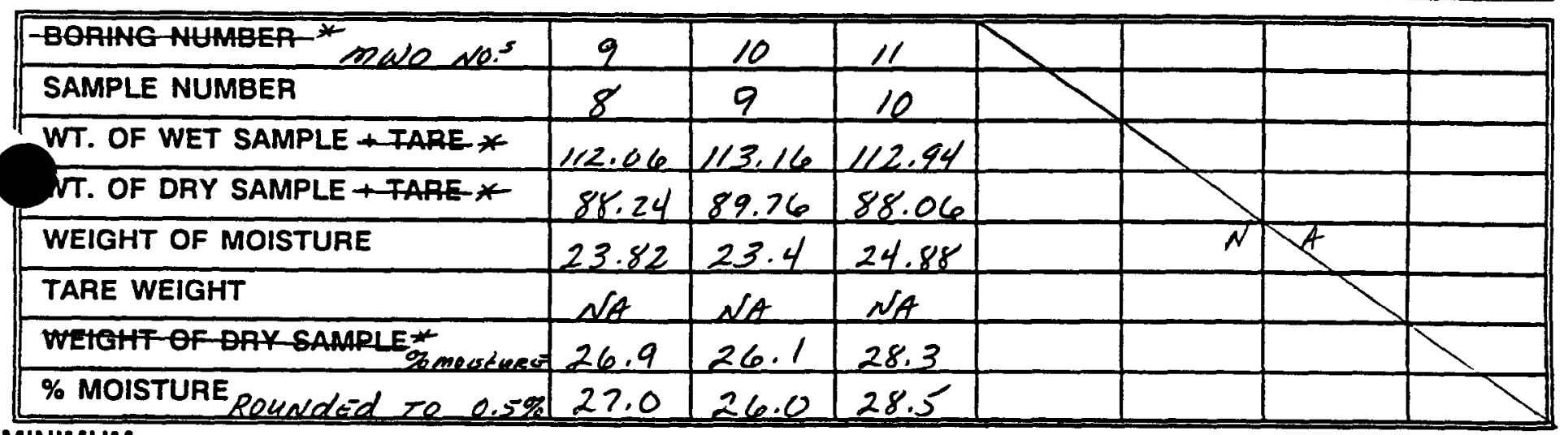

MINIMUM

SIZE SAMPLE $\square$ CONFORMING $\square$ NONCONFORMING REMARKS: $\perp_{A}$ MORE THAN ONE SOIL TYPE: N'O
METHOD OF DRYING:
$230+/-9$ DEGREES $F$
OTHER: MWO

MATERIAL (SIZE/AMOUNT) EXCLUDED FROM TEST:

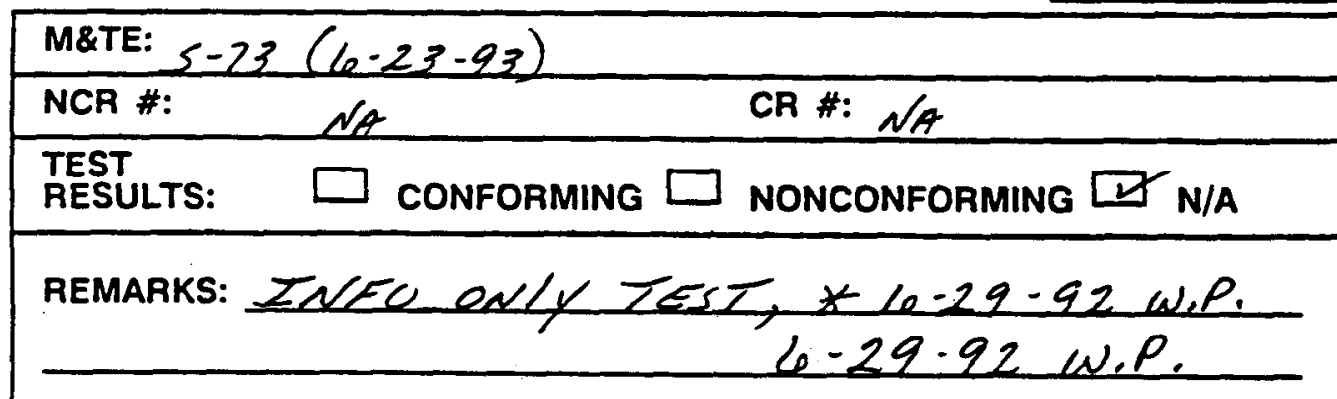

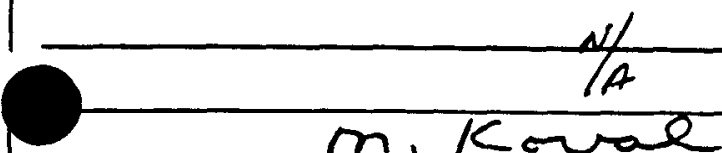

INSPECTOR: Lieman foce h.

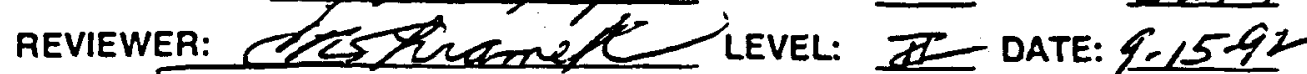

WORK PACKAGE NO:: $92-W P W-E C-023$ $925 R / 5=-E-4794-1101-C-C V-1$ $6-0006-0002$ NA 
FOR INFORMATION ONLY

ASP $18-178(3 / 92)$
FILE ID 180143
EBASCO SERVICES INCORPORATED

DETERMINATION OF WATER CONTENT

ASTI D-2216 ( )
ASTI D-4643 (ST)

PAGE

PROJ/AMO: 4794

DA: $\angle 001$ TWA: 9600 AC: NA

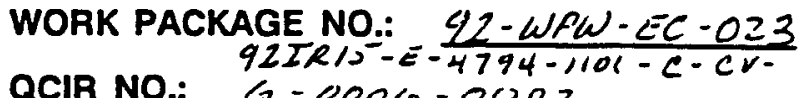

LAB \#: \$92-712 DATE TESTED: $6-30-92$

ACPT. CRITERIA:

MATERIAL DESCRIPTION:

Kola Clay

NA

LOCATION: BuRIAl GROUNd SOLS DYNAMIC COMPACtION

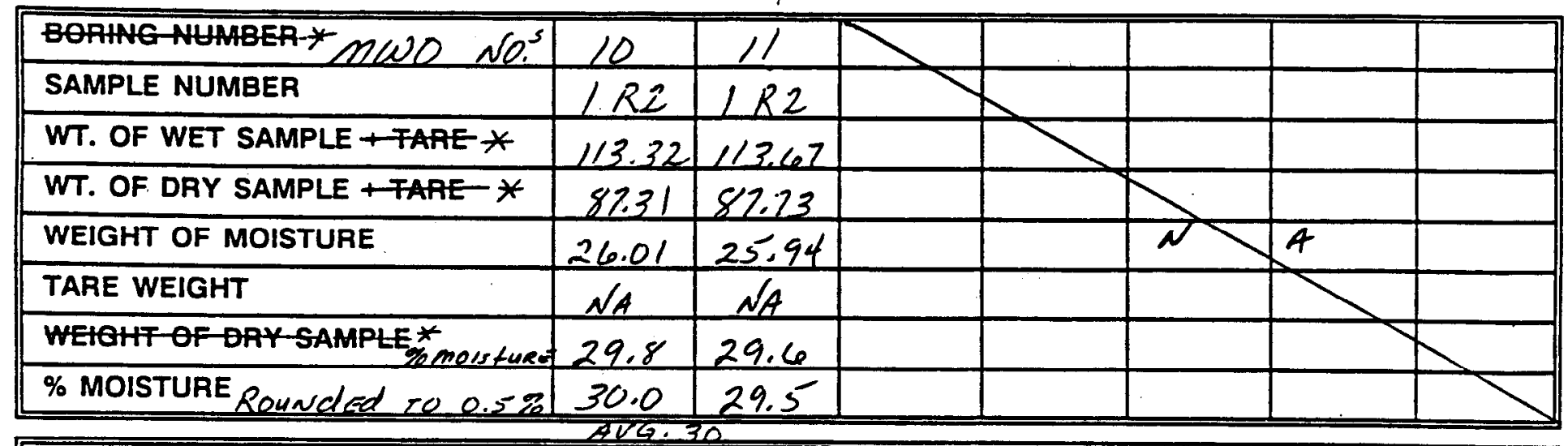

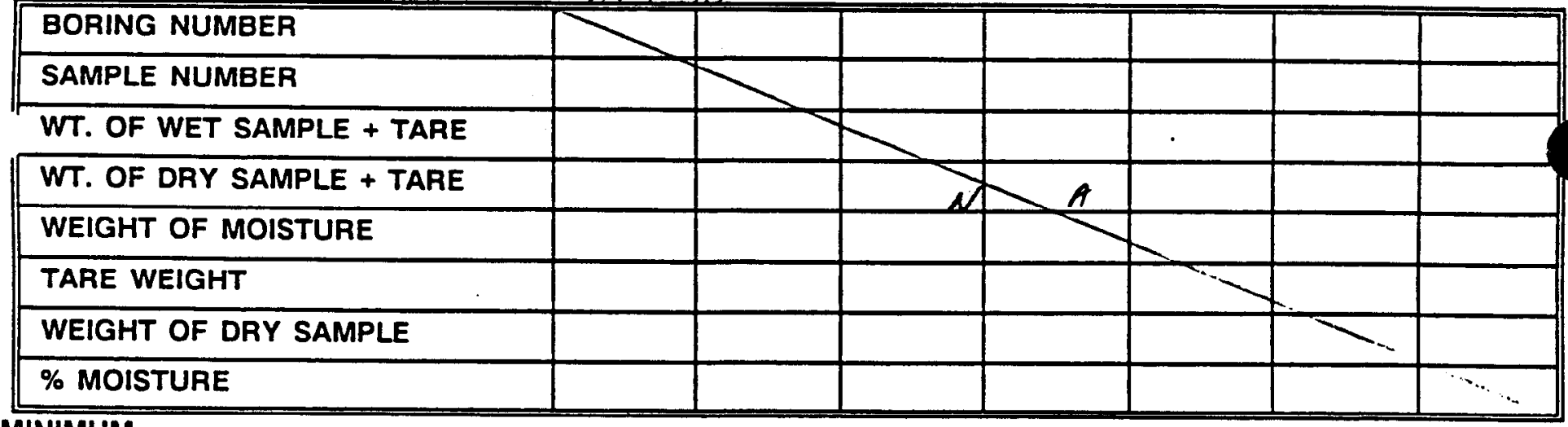

MINIMUM

SIZE SAMPLE $\square$ CONFORMING $\square$ NONCONFORMING REMARKS: $N A$

MORE THAN ONE SOIL TYPE: NO

METHOD OF DRYING: $\square 230+1-9$ DEGREeS F $\square$ OTHER: M WU

MATERIAL (SIZE/AMOUNT) EXCLUDED FROM TEST:

Lo

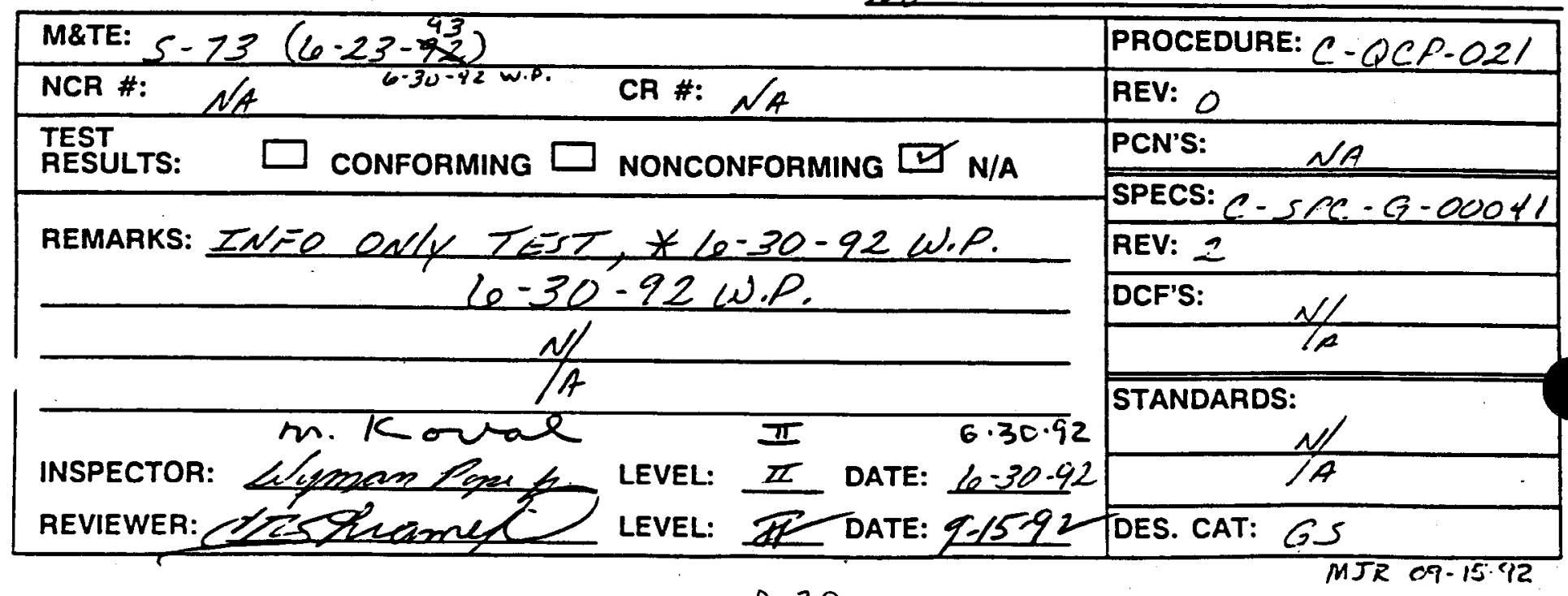

A 70 


\section{FOR INFORMATION ONLY}

ASR 18-178 (3/92)

FILE ID $* 80143$

\section{EBASCO SERVICES INCORPORATED}

DETERMINATION OF WATER CONTENT

$\square$ ASTM D-4643 (87)

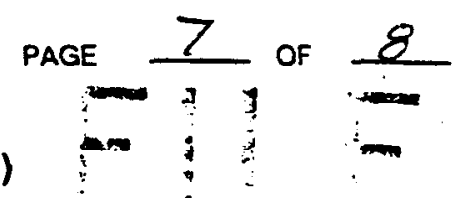

REPT \#: 4123

PROJ/AMO:

DA: COOL TWC: 5660 AXC:

LAB \#: $592-712$ DATE TESTED **6-30-42

MATERIAL DESCRIPTION:

Kadin Clay

WORK PACKAGE NO.: $\quad$ 21-WPW-EC.023 QCIR NO: $\quad 922 R 15 \cdot E-4744-1101-C \cdot C r-G-$ OCIR NO.: neOle-0002

ACCPT. CRITERIA: B-LIFT LOCATION: Bueiel Ground soils Dyatamic compactical

\begin{tabular}{|c|c|c|c|c|c|c|c|}
\hline BOAHG HUMBEA ORWO NO.- & 1 & 2 & 4 & 5 & 6 & 9 & 1 \\
\hline SAMPLE NUMBER & 1 & 2 & 3 & 4 & 5 & $\begin{array}{l}\operatorname{sand} \text { Sest } \\
\operatorname{con} E-10\end{array}$ & 6 \\
\hline WT. OF WET SAMPLE + FAAE * $*$ & 113,53 & 113.62 & 113.49 & 43.10 & 113.52 & 113.32 & 113.21 \\
\hline WT. OF DRY SAMPLE + FARE * & 41.20 & 87.70 & 88.45 & 88.78 & 85.94 & 88,93 & 85,44 \\
\hline WEIGHT OF MOISTURE & 22.33 & 25.92 & 25.04 & 24.32 & 22.58 & $24 \cdot 39$ & 27.77 \\
\hline TARE WEIGHT & $a / A$ & $\sqrt{A}$ & $N A$ & $\sqrt{A}$ & $\sqrt{A}$ & $N A$ & $N A$ \\
\hline WETOHF-OF BAY-SAMPLEE-* & 24,5 & 29.6 & 28,3 & 27.4 & 32,1 & 27.4 & 32.5 \\
\hline$\%$ MOISTURE Pounded zo $0.5 \%$ & 24.5 & 29.5 & 28.5 & 27.5 & 32.0 & 27.5 & 32.5 \\
\hline
\end{tabular}

\begin{tabular}{|c|c|c|c|c|c|c|c|}
\hline BOAHHG HWABER EMWO NO.5 & 2 & 4 & 5 & 1 & 2 & 7 & 8 \\
\hline SAMPLE NUMBER & 7 & 8 & NUC & 9 & 10 & $\angle R I$ & $|R|$ \\
\hline WT. OF WET SAMPLET-TAFE $*$ & 113,41 & 113,37 & 113.84 & 113.92 & 113.22 & 113,18 & 113.42 \\
\hline WT. OF DRY SAMPLE + TARE * & 89.18 & 86.37 & 89.10 & 86.90 & 8276 & 90.43 & 90,55 \\
\hline WEIGHT OF MOISTURE & 24.23 & 27.0 & $24 \cdot 74$ & 27.02 & 25.46 & 22.75 & 2.87 \\
\hline TARE WEIGHT & NA & $\sqrt{4}$ & $\sqrt{A}$ & NA & $N / A$ & $N A$ & $\sqrt{A}$ \\
\hline WETGHT-OF-DRY SAMPLEX & 27.2 & 31.3 & 27.8 & 31.1 & 29.0 & 25.2 & 25.3 \\
\hline \% MOISTURE Rounded to $0.5 \%$ & 27.0 & 31.5 & 28.0 & 31.0 & 29.0 & 25.0 & 25.5 \\
\hline
\end{tabular}

MINIMUM

SIZE SAMPLE

TCONFORMING

MORE THAN ONE SOIL TYPE: $\triangle \mathcal{L}$

METHOD OF DRYING: $\square 230$ +/- 9 DEGREES $F$

NONCONFORMING REMARKS: N/A AUG. $28-30$ 
ASR $18-178(3 / 92)$

FILE ID $\$ 80143$

\section{FOR INFORMATION ONLY}

EBASCO SERVICES INCORPORATED

DETERMINATION OF WATER CONTENT

ASTM D-4643 (87)

PAGE 8 OF $\&$

ASTM D-2216 ( )

PROJ/AMO: 4794

REPT \#: 4123

DA: $\mathrm{COOL}$ TWC: 96600 AXC: NA

LAB \#: $592-713$ DATE TESTED: $10-30.92$

MATERIAL DESCRIPTION:

Kadur clay.
WORi, PACKAGE NO:: $92-\omega f W-E C-023$

92 IRIs- $5-4794-1101-C-C V-$ QCIR NO.: G.0006.0002

ACCPT. CRITERIA: ALG. $28-30 \%$ $B-\angle, E$

LOCATION: BuRLAl Geouid sols DYalame compaction

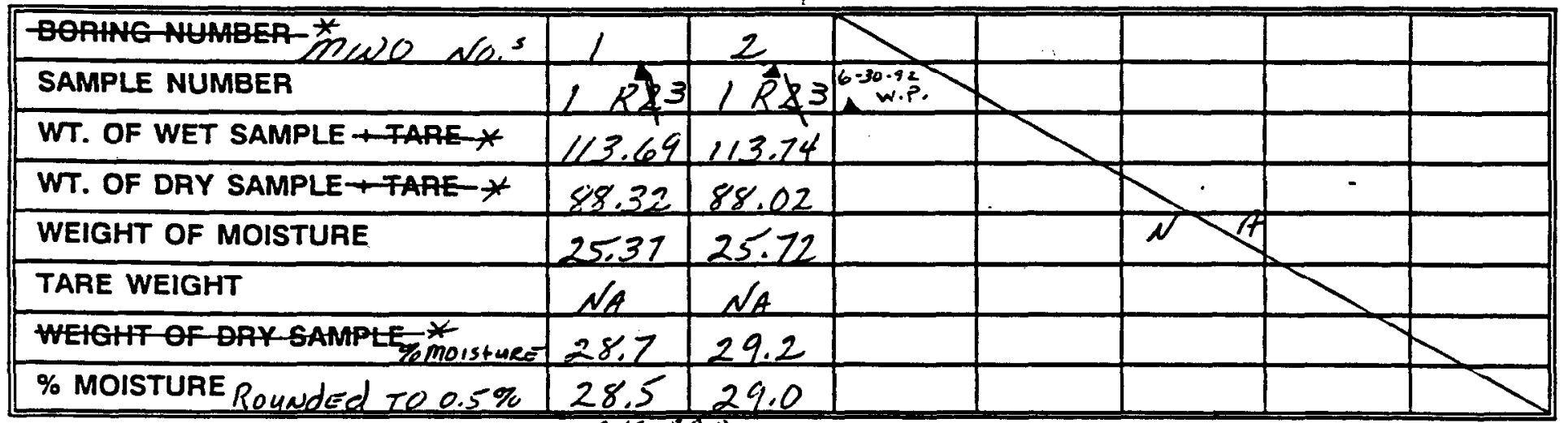

\section{BORING NUMBER}

SAMPLE NUMBER

WT. OF WET SAMPLE + TARE

WT. OF DRY SAMPLE + TARE

WEIGHT OF MOISTURE

TARE WEIGHT

WEIGHT OF DRY SAMPLE

$\%$ MOISTURE

MINIMUM

SIZE SAMPLE

$\square$ CONFORMING

AKG.29,0

MORE THAN ONE SOIL TYPE: Ne

METHOD OF DRYING: $\square 230+/-9$ DEGREES F

$\square$ OTHER: $\mathrm{mWL}$

MATERIAL (SIZE/AMOUNT) EXCLUDED FROM TEST:

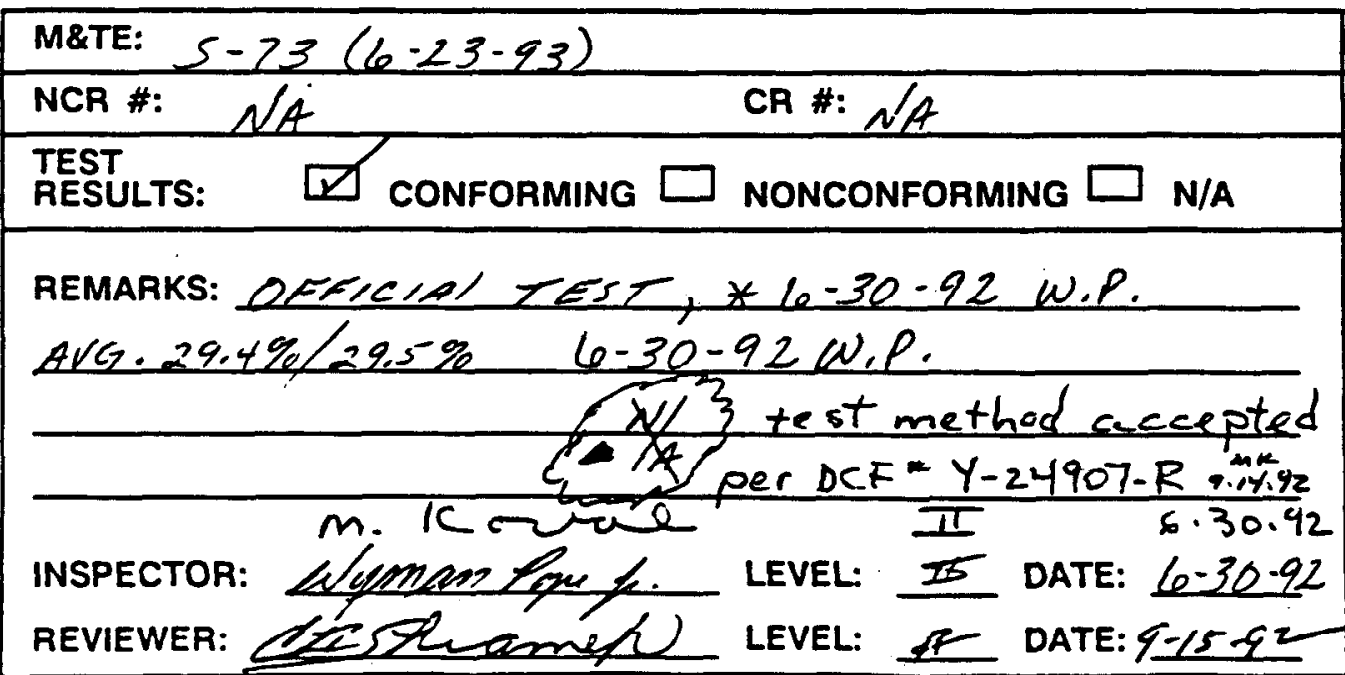

The above tests clear tests 1 and $1 R /$

PROCEDURE: $C-\angle P C P-021$

REV: 0

PCN'S:

SPECS: $C-S A C-G-00041$

REV: $\mathcal{2}$

DCF'S:

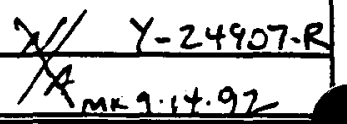

STANDARDS

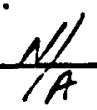

DES. CAT: GS

$M R 9.14 .92$

MTR $09-15-92$ 


\section{MOISTURE \& DENSITY TESTS USING SURFACE PROBES} ASTM D-2922 ( 81 R/\%0)

REPT \#: $\frac{4125}{4}$ PROJ/AMO: 4794

DA: $C O O L$ TWC: $96 G O$ AXC: NA

CONTRACTOR: Bechtel

MATERIAL DESCRIPTION: Kaolin Clay

acceptance criteria: $95 \%$ compaction; $90-94$ PCF Dry Density

DRAWING(S) \& REV(S): $\quad \mathrm{C}-\mathrm{CV}-\mathrm{G}-000 \mathrm{R} / \mathrm{I}$

LOCATION: Burial Ground Soils Dynamic Compaction-CLift TEST NO.

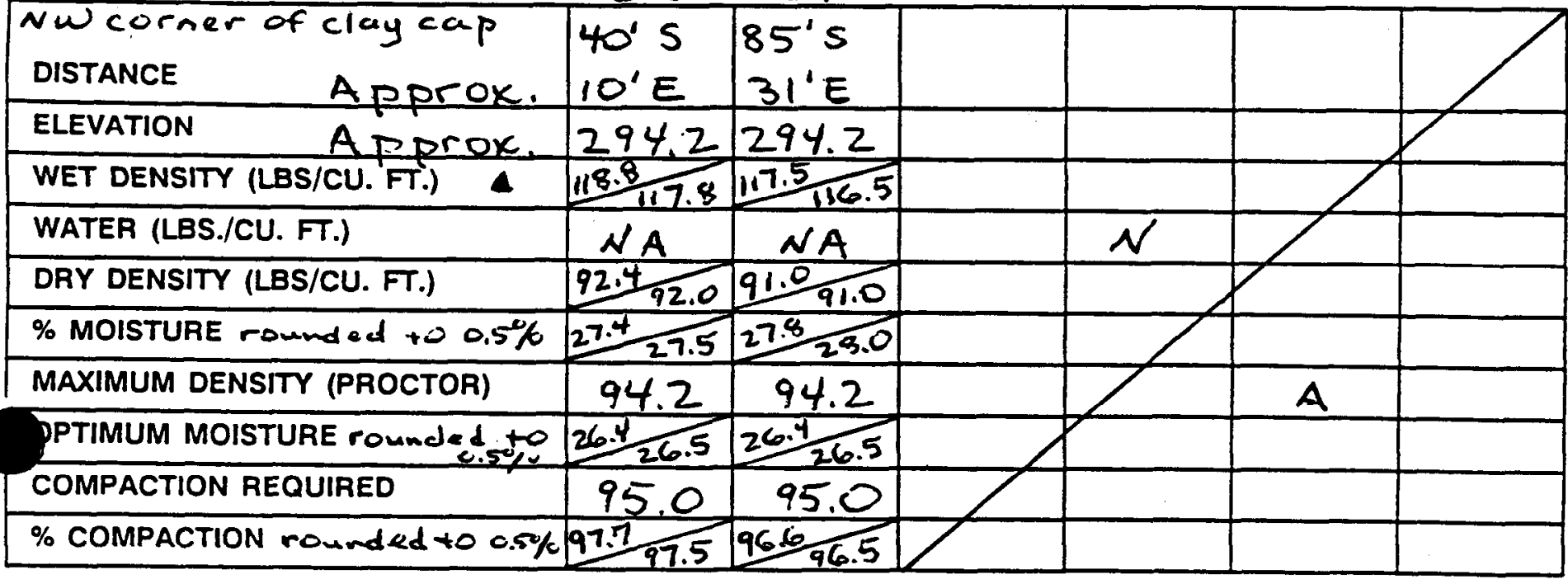

TROXLER \#: 7 MODEL: 3440 SERIAL \#: 17494

DENSITY PROCTOR REPT \#: WER-ERC-92-0544 DESIGN CAT: GS

DENSITY: $\quad$ AVERAGE OF LAST 4 STANDARD COUNTS (No):

3838

DAILY STANDARD COUNTS (Ns): $\quad 3790$

MOISTURE: AVERAGE OF LAST 4 STANDARD COUNTS (No): 603

MOISTURE DAILY STANDARD COUNTS (Ns): 605

DETERMINATION: $\square$ ASTM D-2216 () $\square$ ASTM D-3017 ()

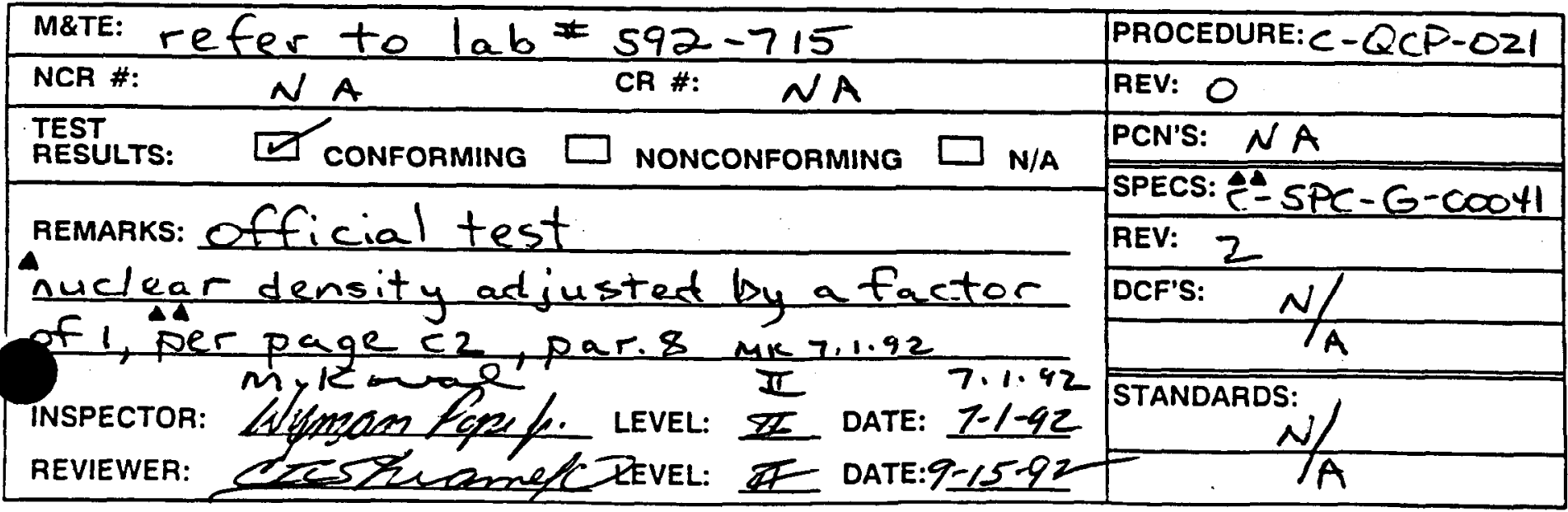


FOR INFORMATION ONLY

ASR 18-178 (3/92)

FILE ID $\$ 0143$
EBASCO SERVICES INCORPORATED

DETERMINATION OF WATER CONTENT

ATM D-2216 ( )
PAGE

ASTM D-4643 (87)
PROJ/AMO: 4794

DA: 6001 TWC: glee AXC: NA
WORK PACKAGE NO.:

$921 R 15-2=-4794-1101-C-\bar{C} V-$

LAB \#: $597-7 / 5$ DATE TESTED: $7-1-92$ ACPT. CRITERIA: AVG. $28-30$

MATERIAL DESCRIPTION: KaOliN Clay C-LIET

LOCATION: BuRIAl GRound sols DYAlamiC COMPACHION

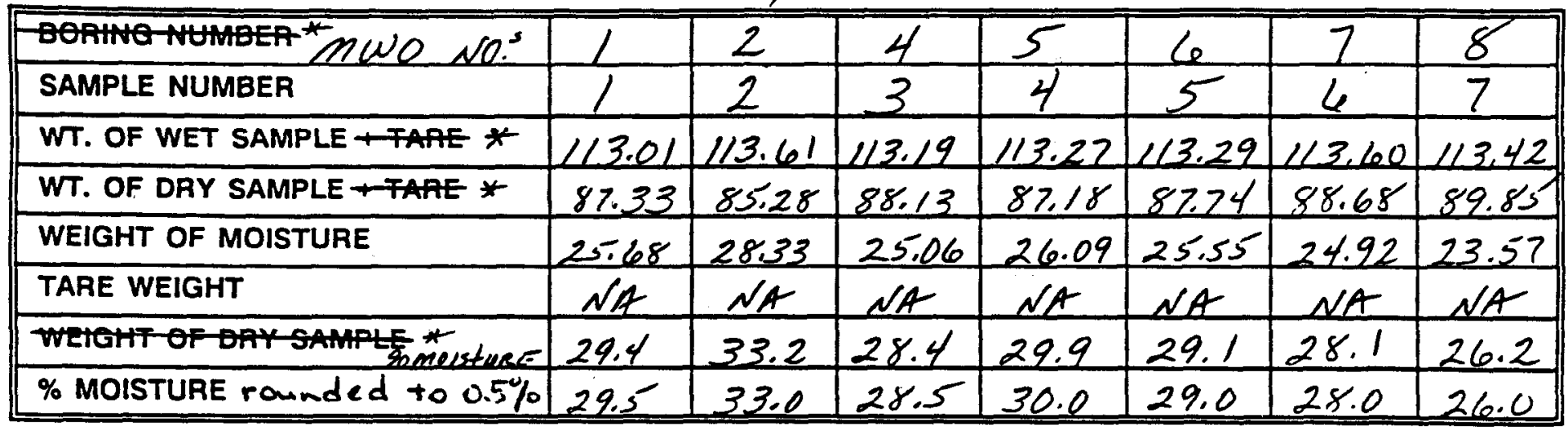

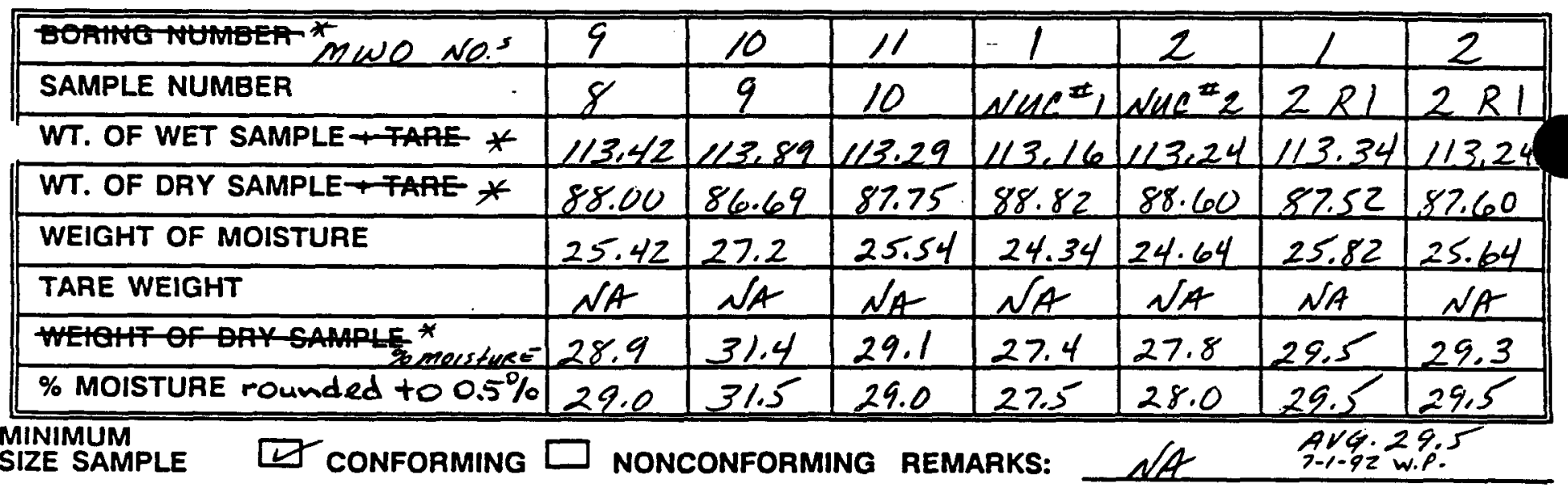

SIZE SAMPLE $\square$ CONFORMING $\square$ NONCONFORMING REMARKS: NA

MORE THAN ONE SOIL TYPE: NO

METHOD OF DRYING: $\square 230+/-9$ DEGREES F $\square$ OTHER:

MATERIAL (SIZE/AMOUNT) EXCLUDED FROM TEST: \}

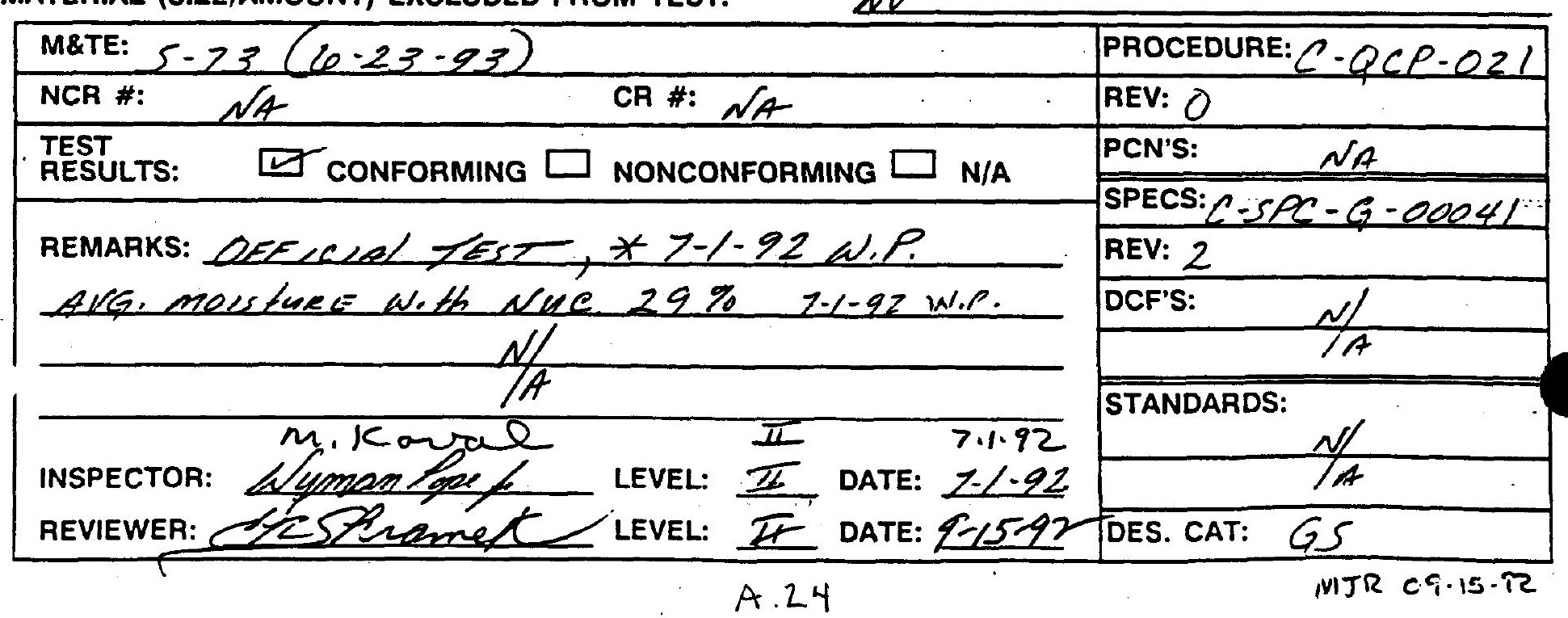


YUK INFORMATION ONLY

ASR 18-178 (3/92)

FILE $10 \$ 80143$
EBASCO SERVICES INCORPORATED

DETERMINATION OF WATER CONTENT

ATM D-2216 ( )
PAGE 3 OF 5

ASTM D-4643 (87)

PROJ/AMO: 4794

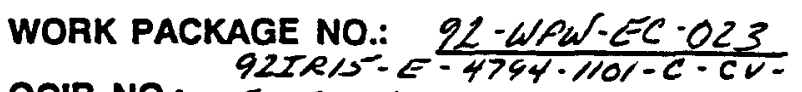

DA: $\mathrm{COOL}$ TWO: $9660 \mathrm{O}$ AC: NA

CIR NO.: 9 -0006-000Z

LAB \#: $\$ 97-715$ DATE TESTED: $1-1-92$ ACPT. CRITERIA:

MATERIAL DESCRIPTION: KAOLN ClAY C.LIFT

LOCATION: BuRIal GRound soils aNatomic compaction

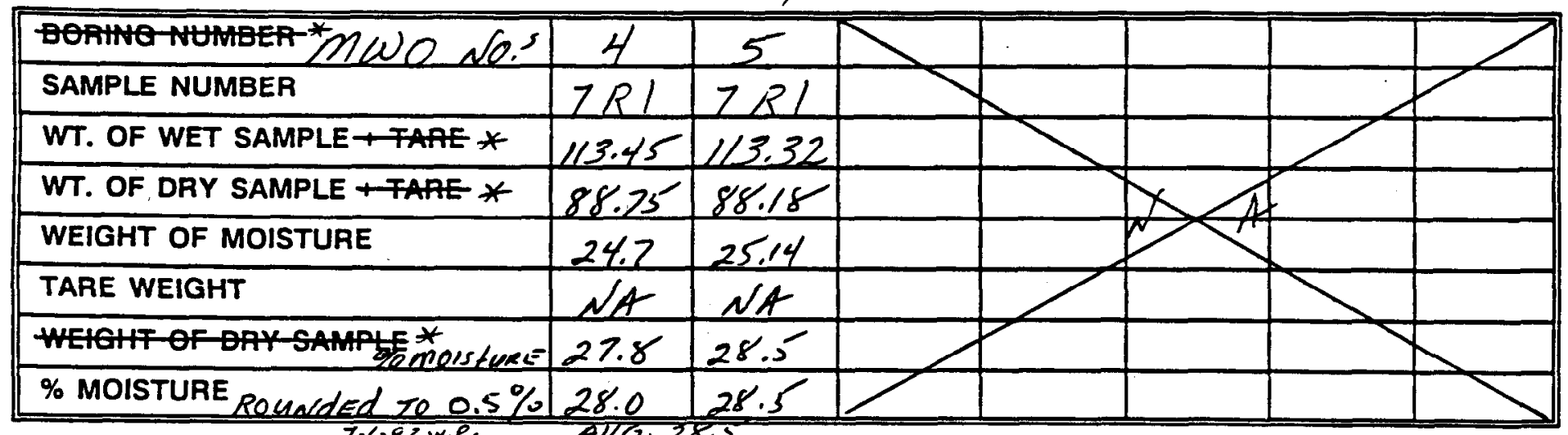

\begin{tabular}{|l|l|l|l|l|l|l|l|}
\hline \hline BORING NUMBER & & & & & & & \\
\hline SAMPLE NUMBER & & & & & & & \\
\hline WT. OF WET SAMPLE + TARE & & & & & & & \\
\hline T. OF DRY SAMPLE + TARE & & & & & & & \\
\hline WEIGHT OF MOISTURE & & & & & & & \\
\hline TARE WEIGHT & & & & & & & \\
\hline WEIGHT OF DRY SAMPLE & & & & & & & \\
\hline$\%$ MOISTURE & & & & & & & \\
\hline
\end{tabular}

MINIMUM

SIZE SAMPLE $\square$ CONFORMING $\square$ NONCONFORMING REMARKS: $\triangle$

MORE THAN ONE SOIL TYPE: NO

METHOD OF DRYING: $\square 230+/-9$ DEGREes F $\square$ OTHER: IWO

MATERIAL (SIZE/AMOUNT) EXCLUDED FROM TEST: NO

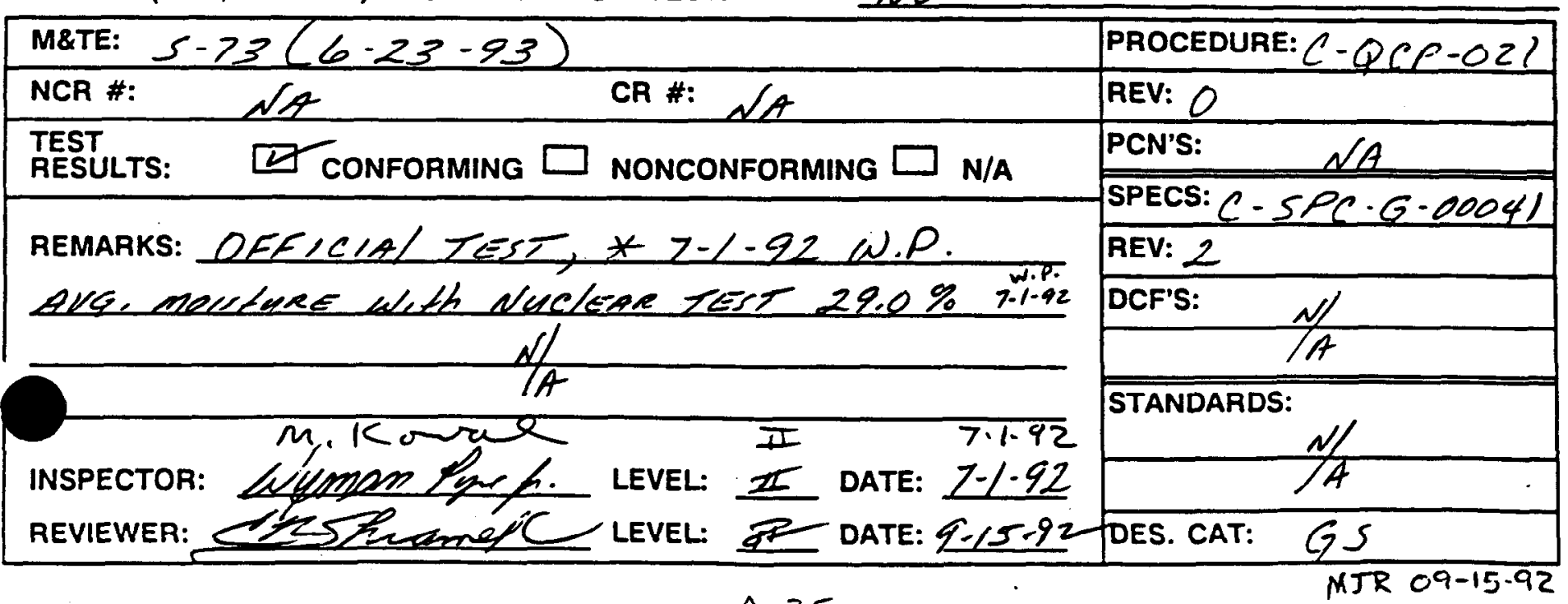

A 25

MJR 09-15.92 
FOR INFORMATION ONLY

ASP $18-178(3 / 92)$

EBASCO SERVICES INCORPORATED

DETERMINATION OF WATER CONTENT

ASTI D-2216 ( )

ASTM D-4643 (87)

PAGE $\frac{4}{1}$ OF 5

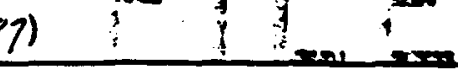

REPT \#: 4125 PROJ/AMO: $4>94$

DA: 1001 WC: 9660 AC: _ NA

WORK PACKAGE NO.: $\frac{q 2 \cdot W P W-E C \cdot 023}{92 I R I S-E=-4794-1101-C-C V_{-}}$

LAB \#: S92-7/4 DATE TESTED: $1-/-92$ ACPT. CRITERIA:

MATERIAL DESCRIPTION: HAOLN ClaY

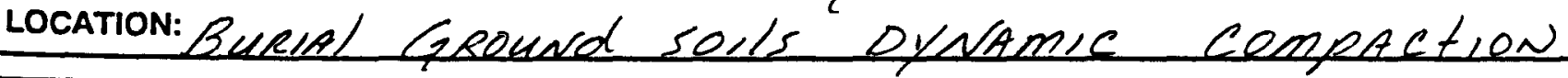

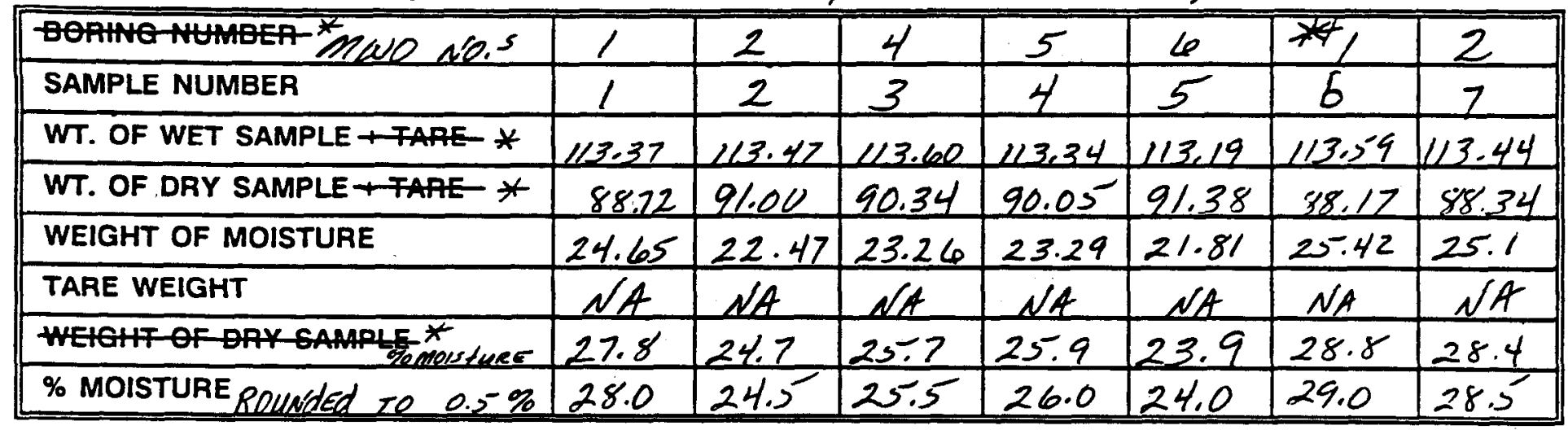

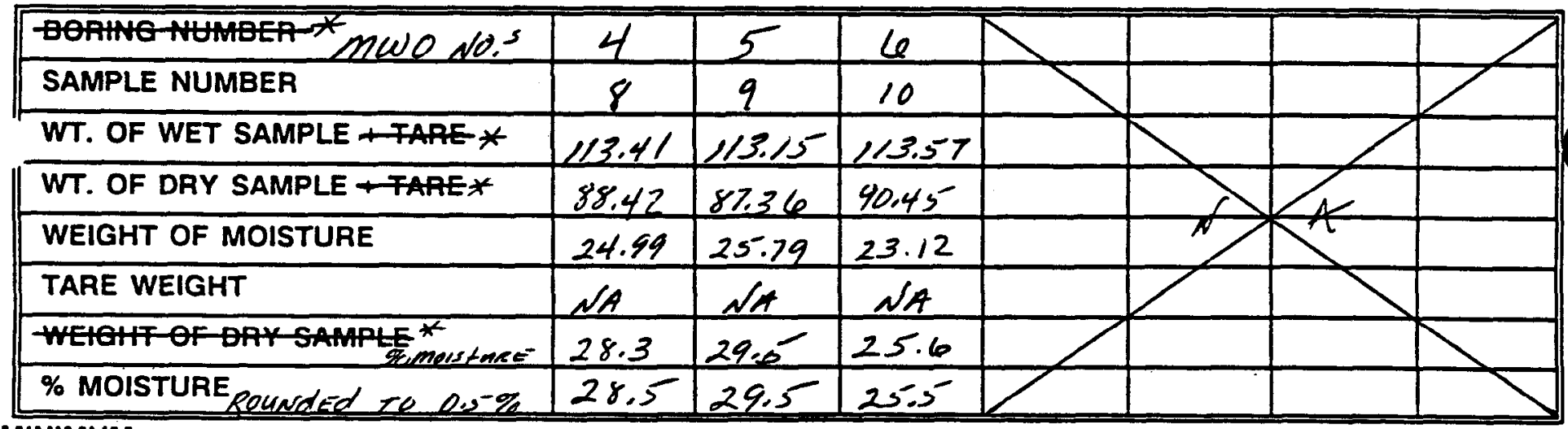

MINIMUM SAMPLE $\square$ CONFORMING $\square$ NONCONFORMING REMARKS: $\Lambda / A$

MORE THAN ONE SOIL TYPE: $\quad N O$

METHOD OF DRYING: $\square 230+/-9$ DEGREES F $\square$ OTHER: $\mathscr{M}$

MATERIAL (SIZE/AMOUNT) EXCLUDED FROM TEST:

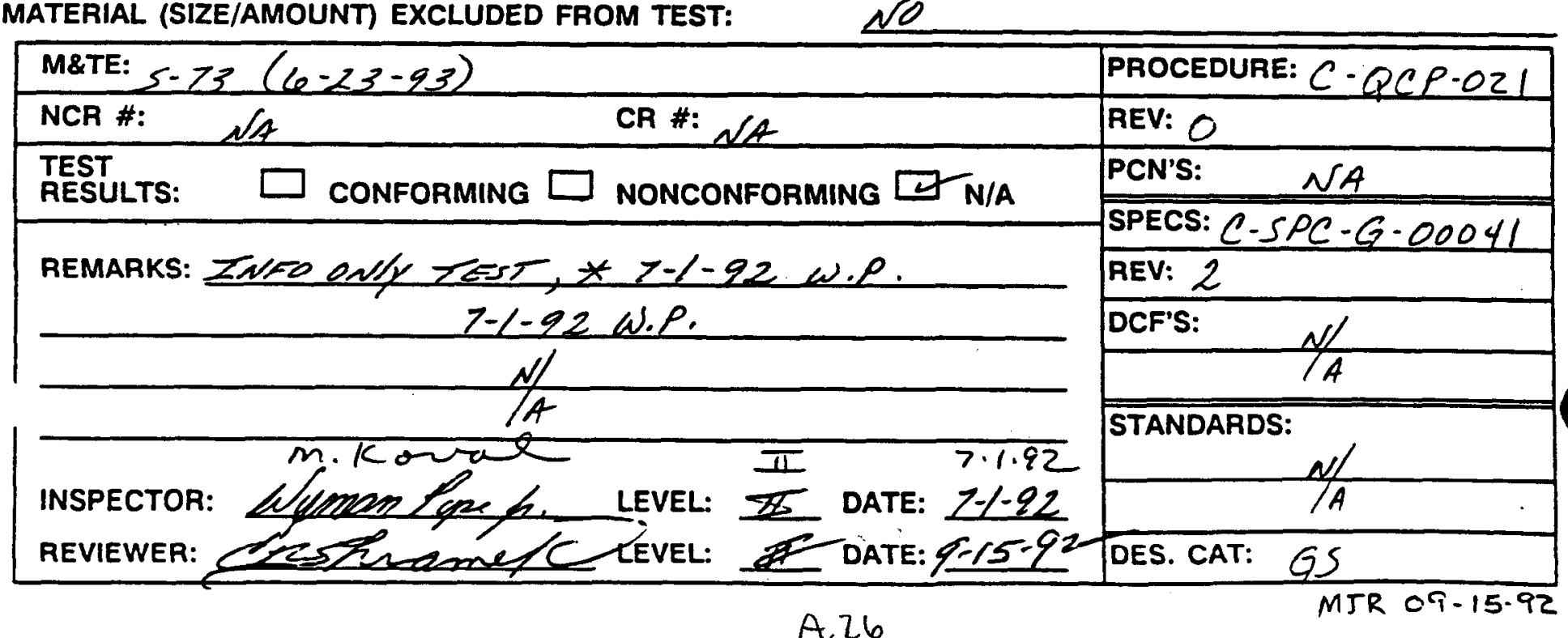


REPT \# 4125 AXC: N/A

PROJI

AMO:

DA: $\leq 001$ TWC: 9660

WORK PACKAGE NO. 92 wew $-\angle 023$ QCIR NO.' $0006-5-6-4>94-1101-C-C V-E-$

MATERIAL DESCRIPTION:

LAB \#: $592-7 / 6$ DATE TESTED: $7-7-92$ METHOD: A

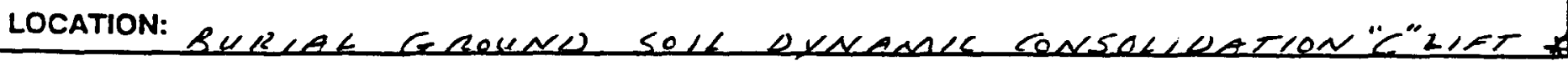

12

3

4

5

\begin{tabular}{|c|c|c|c|c|c|}
\hline A. WEIGHT MOLD + WET SOIL & 5972 & $=$ & 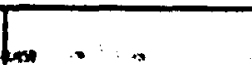 & & 7 \\
\hline B. WEIGHT MOLD & 4213 & 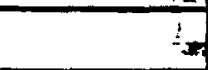 & $\frac{1}{4}$ & 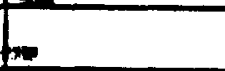 & 7 \\
\hline C. WEIGHT WET SOIL (A-B) G./LBS. & $\frac{758}{3.878}$ & 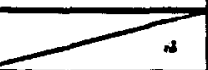 & $\sum_{3+\infty}^{i+\infty}$ & & 2 \\
\hline D. VOLUME OF MOLD & 30.30 & & & 7 & \\
\hline E. WET DENSITY, LBS./CU. FT. & 1175 & & & & \\
\hline F. MOISTURE CAN NUMBER & $0 / 5$ & & $\Lambda$ & $\angle$ & \\
\hline G. WEIGHT WET SAMPLE + TARE & 1774.7 & & & A & \\
\hline H. WEIGHT DRY SAMPLE + TARE & 1442.9 & & & & \\
\hline I. WEIGHT MOISTURE (G-H) & 331.8 & & & & \\
\hline J. WEIGHT TARE & 82.6 & & & & \\
\hline K. WEIGHT DAY SAMPLE (H-J) & 1360.3 & & & & \\
\hline$\%$ MOISTURE $(1 / \mathrm{K} \times 100)$ & $2 \% \cdot 4$ & & & & $\cdots$ \\
\hline M. DRY DENSITY, LBS./CU. FT. & 944 & 7 & & & \\
\hline
\end{tabular}

NOTE: DRY DENSITY (LINE M) $=($ LINE E X 100)/(100 + LNE L)

PREPARATION METHOD: $\square$ DRY $\square$ WET

RAMMER: $\square$ MANUAL $\square$ MECHANICAL

OPTIMUM MOISTURE:

$N / A$

MAXIMUM DENSITY:

N/A

ACCEPTANCE CRITERIA: N NIA

DESIGN CATE GORY "GS"A.r 7-8-40

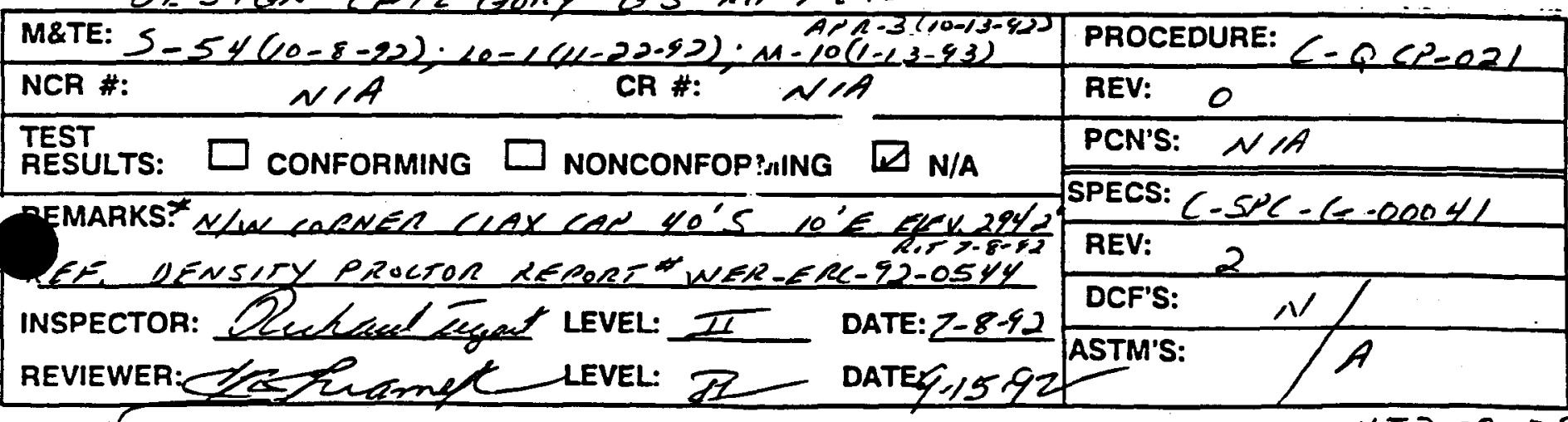


3EPT : $\quad 4126$ $\mid \begin{aligned} & \text { DA:COOL TWC: } \frac{9660}{\text { antractor: Bechtel }} \\ & \text { Material description: KaOlin Clay }\end{aligned}$ PROJAMO: 4794 WORK PACKAGE NO: $92-\omega P \omega-E C-O 23$ $42 I R 15-E-4784-1101-C-C V-G-$ ACCEPTANCE CRITERIA: $95 \%$ compaction $90-94$ PCF

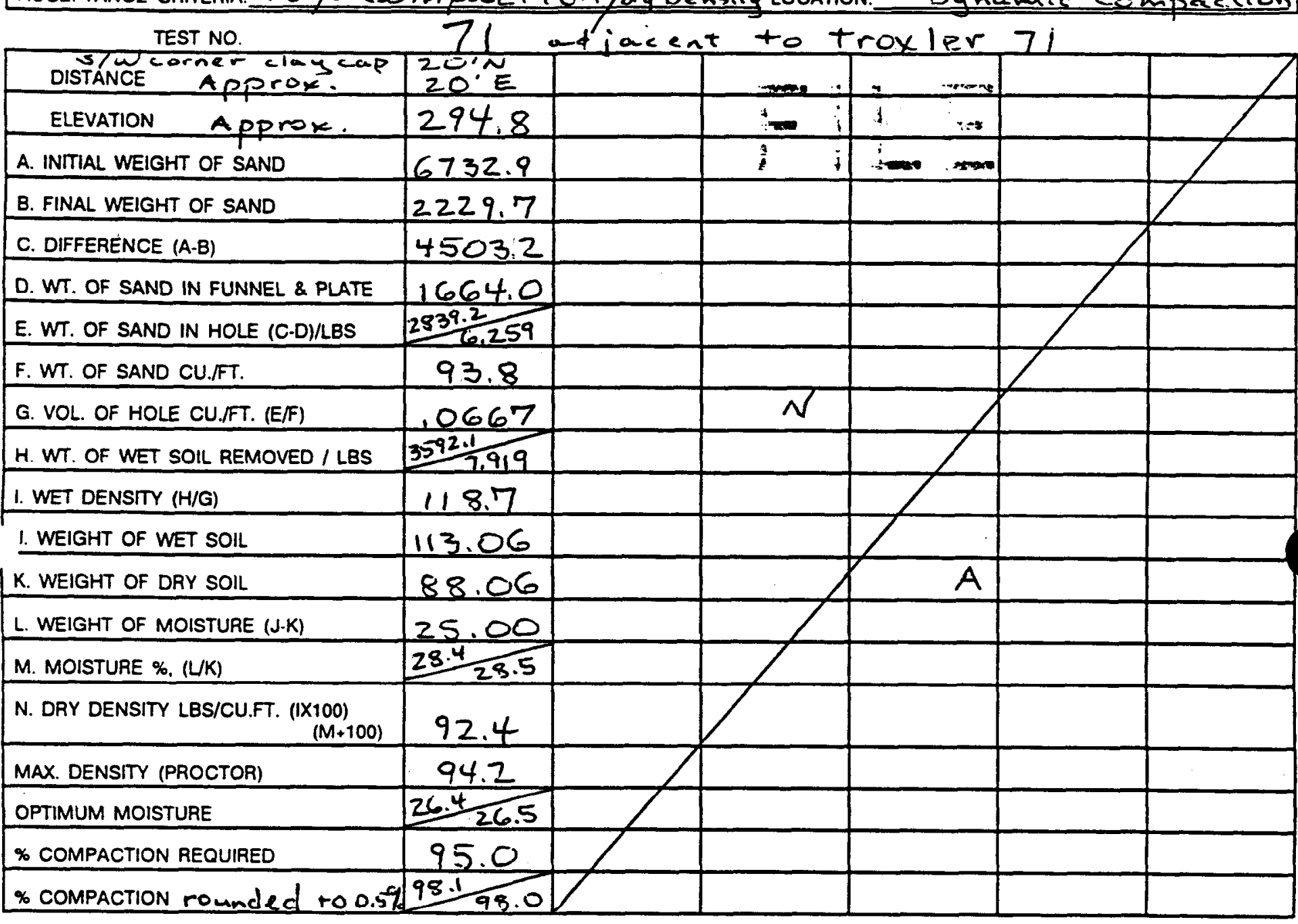
DENSITY PROCTOR REPORT : WER-ERC-92-0544.

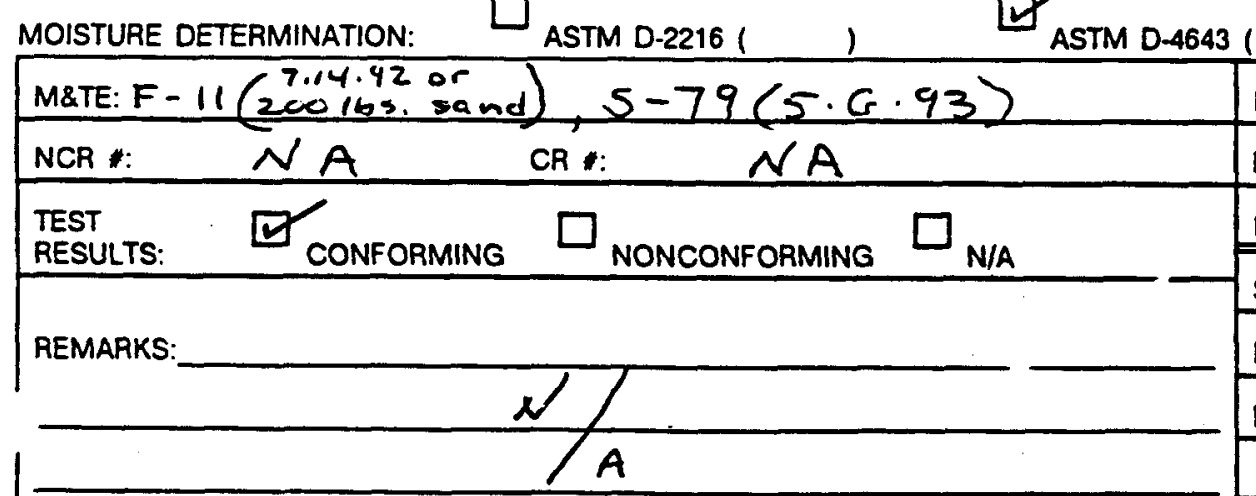

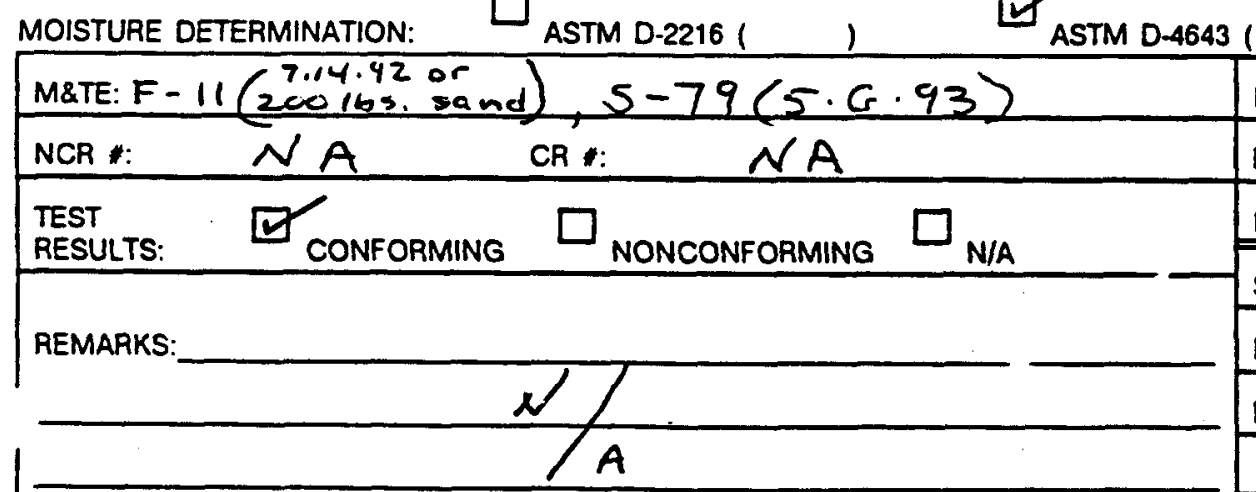
DESIGN CATEGORY: GS INSPECTOR: $7 \cdot$ G. Dalim LEVEL:II DATE: $\frac{7.4-92}{\text { REVIEWER }}$ A. 28 
FOR INFORMATION ONLY

ASP $18.180(3 / 92)$

EBASCO SERVICES INCORPORATED

PAGE 2 OF $z$

MOISTURE \& DENSITY TESTS USING SURFACE PROBES

ATM D-2922 $(812 / 8)$

REPT \#: $\frac{4126}{26}$ PROJ/AMO: 4794

DA: $\subseteq 001$ TWO: 9660 AXE: $N A$

CONTRACTOR: Bechtel

MATERIAL DEscRiption: Kaolin Clay

acceptance Criteria: $95 \%$ compaction, $90-94$ PCF Dry Density DRAWINGS) \& REV(S): $\quad C-C V-G-0006 R / 1$ LOCATION: Burial Ground Soils Dynamic Compaction-DLift

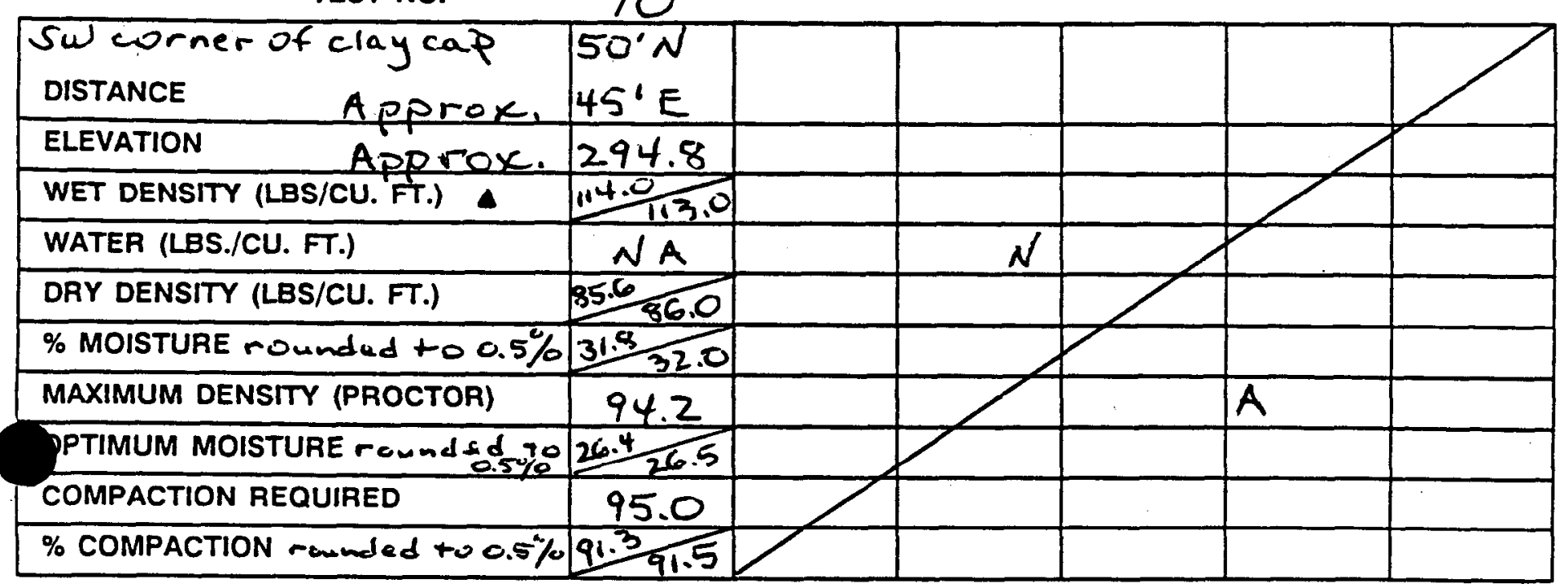

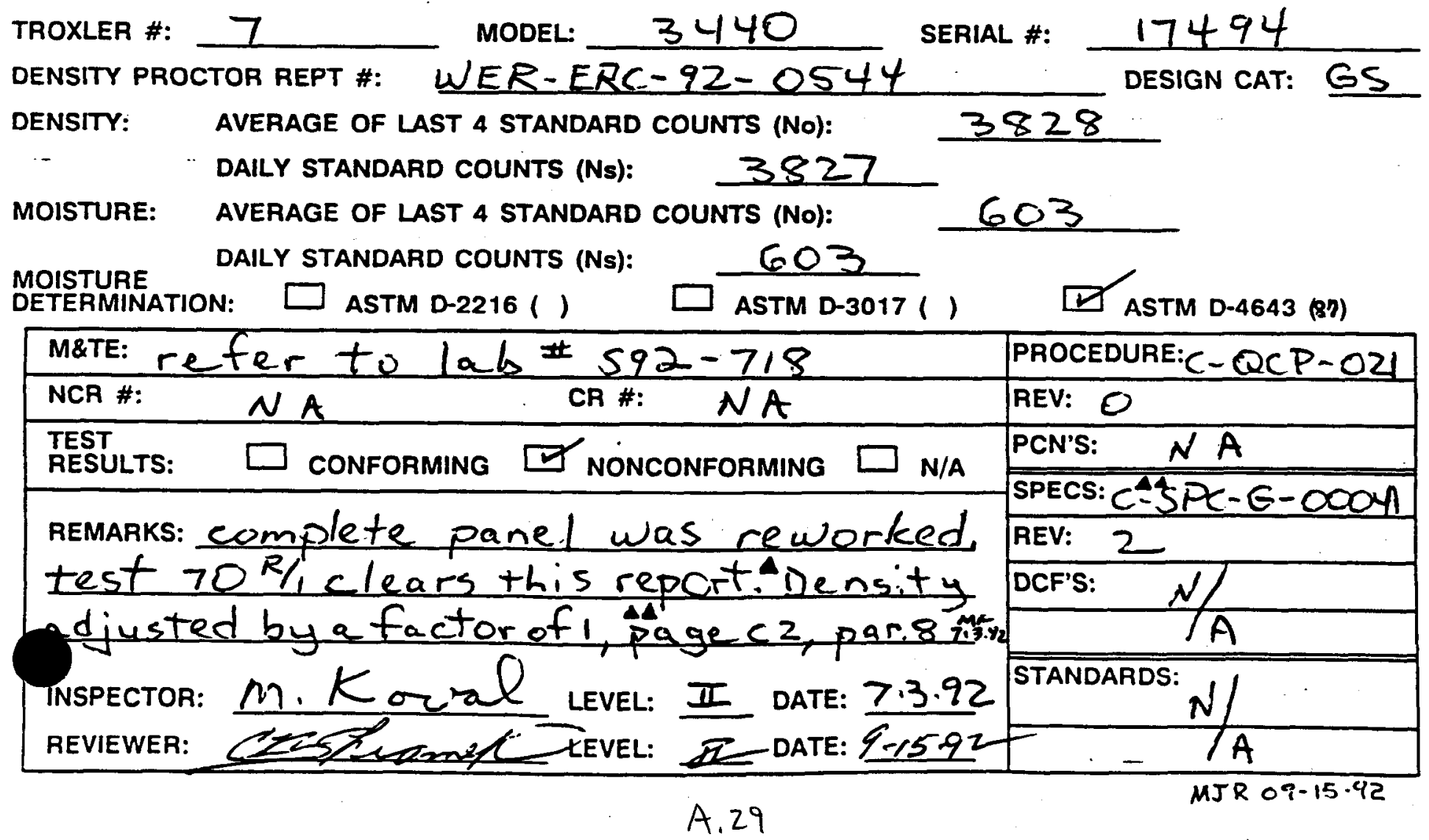


FOR INFORMATION ONLY

ASP $18-180(3 / 92)$

EBASCO SERVICES INCORPORATED

PAGE

3 of 1

MOISTURE \& DENSITY TESTS USING SURFACE PROBES

ASTI D-2922 ( $517 / 20)$

REPT \#: $\quad 4126$ PROJ/AMO: 4794

DA: $C 0 O 1$ TWO: 9660 AC: NA CONTRACTOR: Bechtel
WORK PACKAGE NO.: 92 - WPW.EC-O23

QCIR NO.: $\begin{aligned} & 92 I R I 5-\bar{E}-4794-1101-C- \\ & \text { CV- } 6-0006-0002\end{aligned}$

MATERIAL DESCRIPTION: KaOlin Clay

acceptance criteria: $95 \%$ compaction; $90-94$ Pc Dry Density DRAWINGS) \& REVS): $C-C V-G-0006 \mathrm{R} / \mathrm{C}$

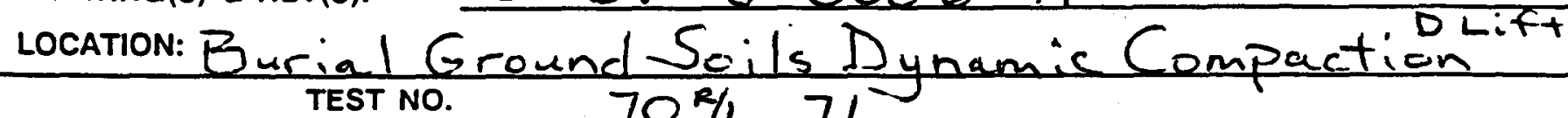

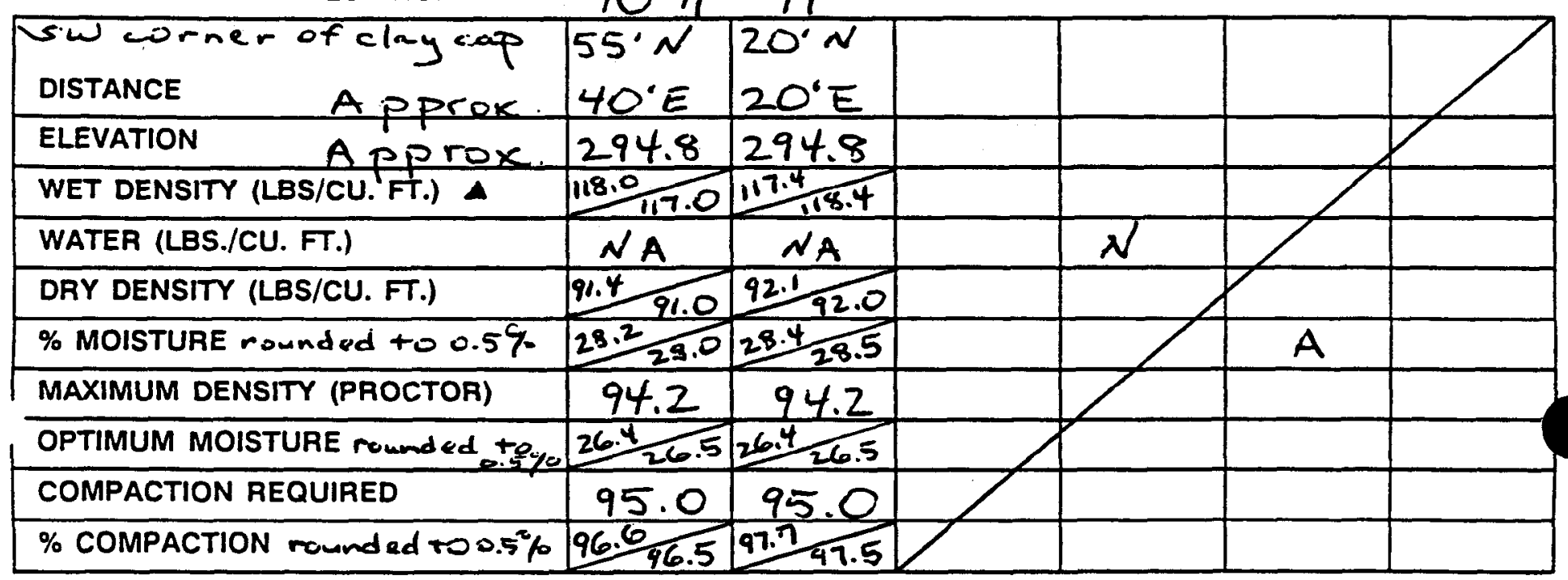

TROXLER \#: $\frac{7}{\text { DENSITY PROCTOR REPT \#: }}$ SER $\quad \frac{3440}{\text { SERE RIAL \#: }}$ - $\frac{17494}{\text { DESIGN CAT: GS }}$ DENSITY: $\quad$ AVERAGE OF LAST 4 STANDARD COUNTS (No): 3829

DAILY STANDARD COUNTS (NS): $\quad 3819$

MOISTURE: AVERAGE OF LAST 4 STANDARD COUNTS (No): 602

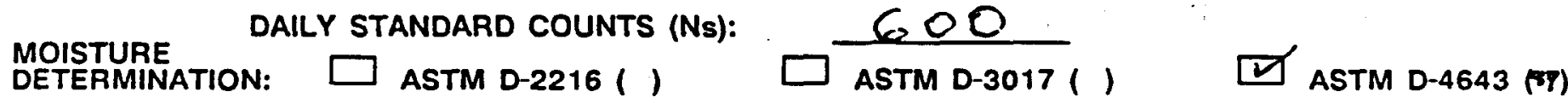

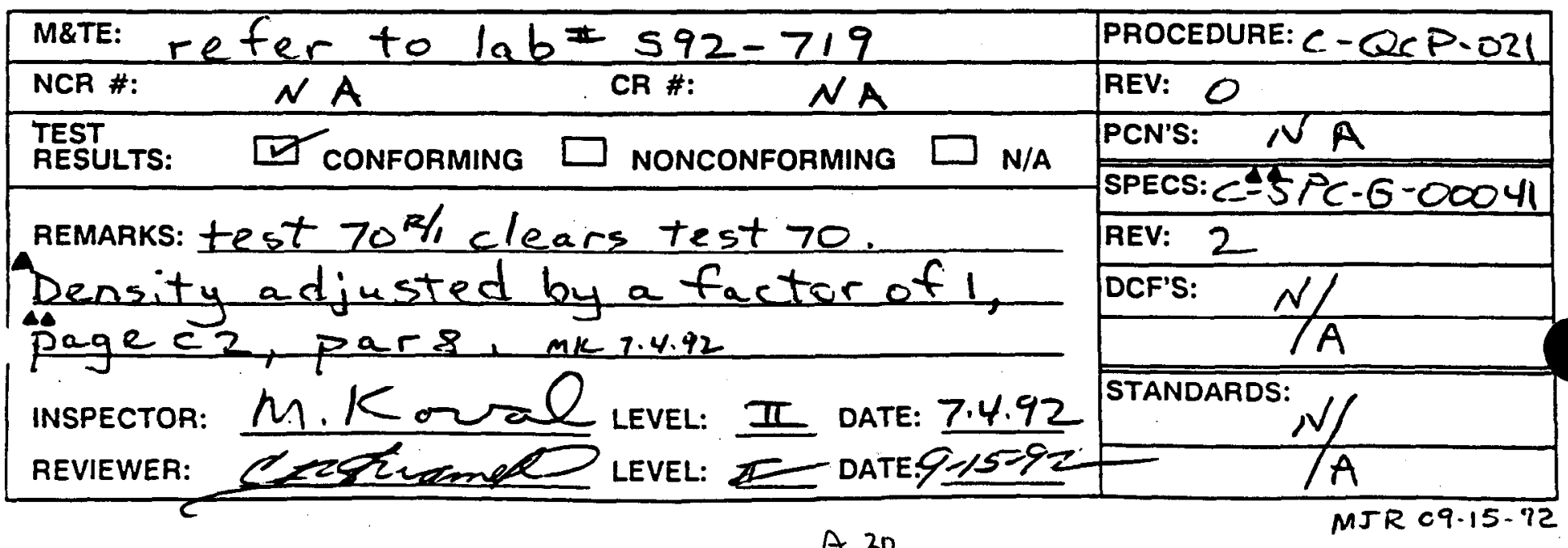

A. 30 
FOR INFORMATION ONLY

ASP $18-178(3 / 92)$

EBASCO SERVICES INCORPORATED

DETERMINATION OF WATER CONTENT

ATM D-2216 ( )

AS TM D-4643 (87)

REPT \#: 4126 PROJ/AMO: 4794 WORK PACKAGE NO.: 92-WPU-EC-O23 DA: COOL TWA: 9660 AXe: $N A$ CIR NO.: $\quad 92 I R 15-E-4794=1101-C-C V-$ LAB \#: $592-7,7$ DATE TESTED: 7.3 .92 ACPT. CRITERIA: MATERIAL DESCRIPTION: Kaolin Clay

Location: Burial Ground Soils Dynamic Compaction,olift

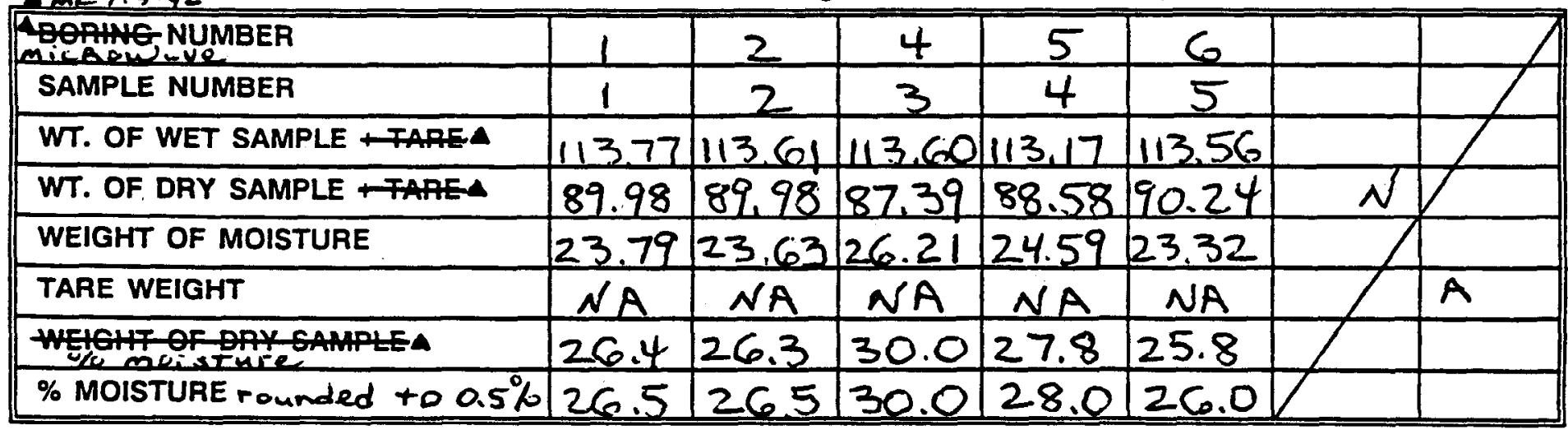

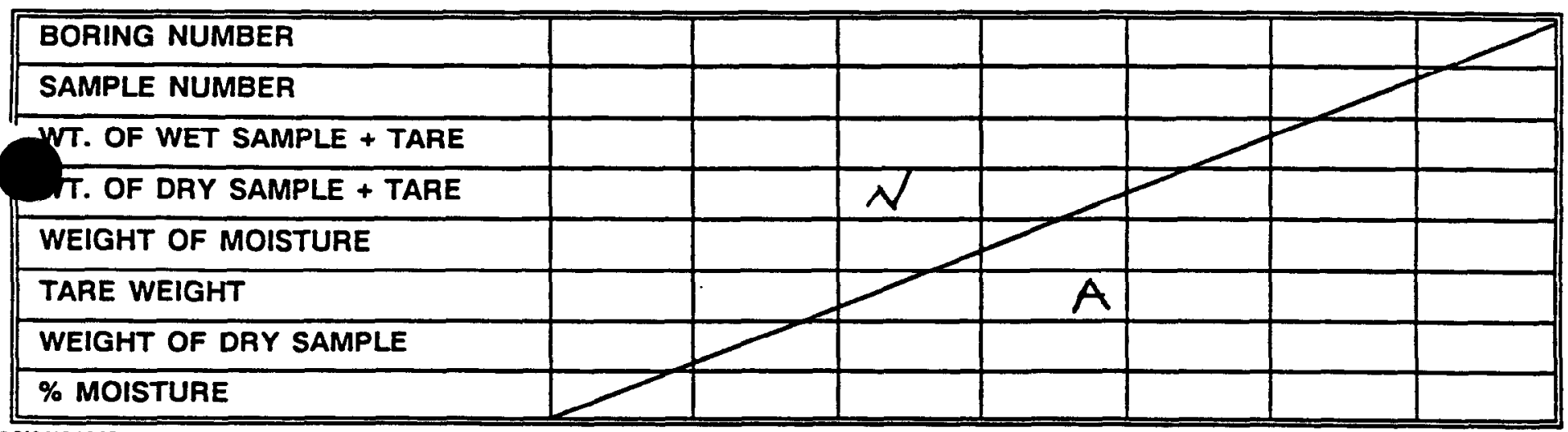

MINIMUM SAMPLE $\square$ CONFORMING $\square$ NONCONFORMING REMARKS: $N A$ MORE THAN ONE SOIL TYPE: $\quad N O$

METHOD OF DRYING: $\square$ 230 +/-9 DEGREES F $\square$ OTHER: microwave. MATERIAL (SIZE/AMOUNT) EXCLUDED FROM TEST: $N A$

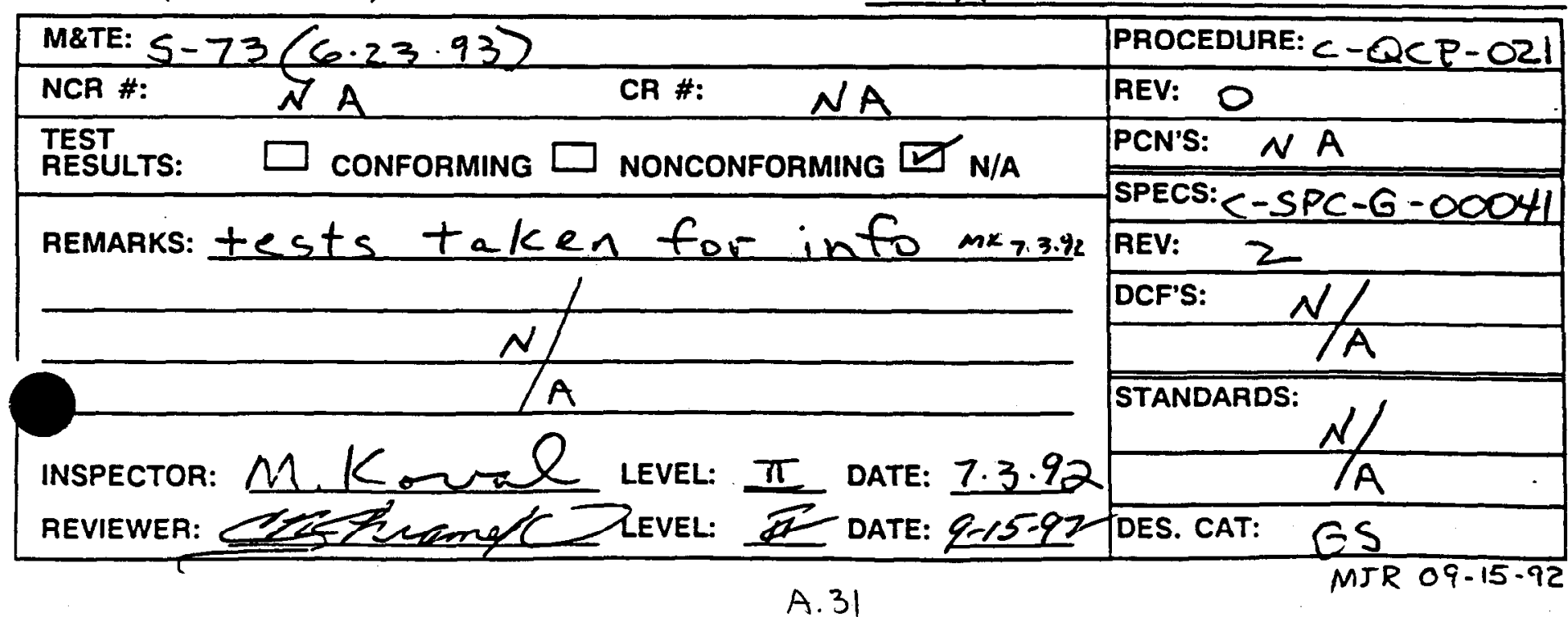


FOR INFORMATION ONLY

ASA $18.178(3 / 92)$
FILE ID $\$ 80143$
EBASCO SERVICES INCORPORATED

DETERMINATION OF WATER CONTENT

ATM D-2216 ( )

$\square$ ASTM D-4643 (87)

PAGE

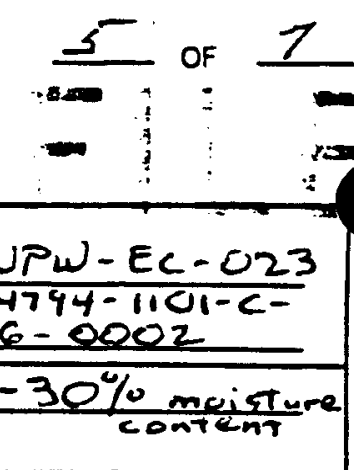

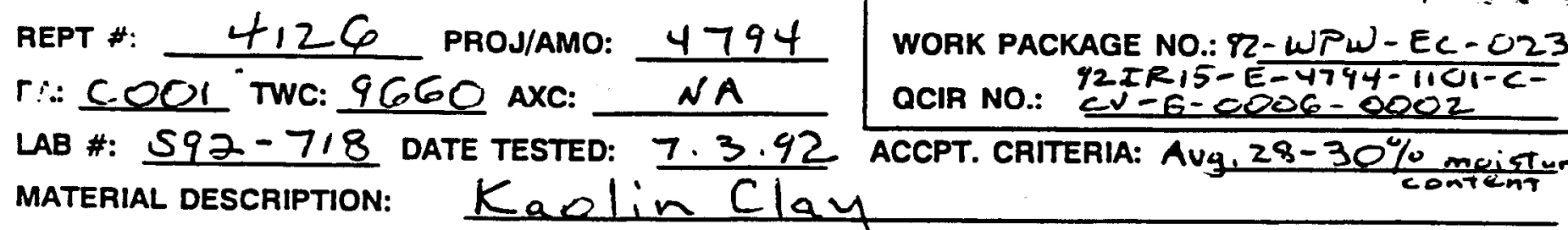
MATERIAL DESCRIPTION: Kaolin Clay

LOCATION: Burial Ground Soils Dynamic Compaction-DLitft

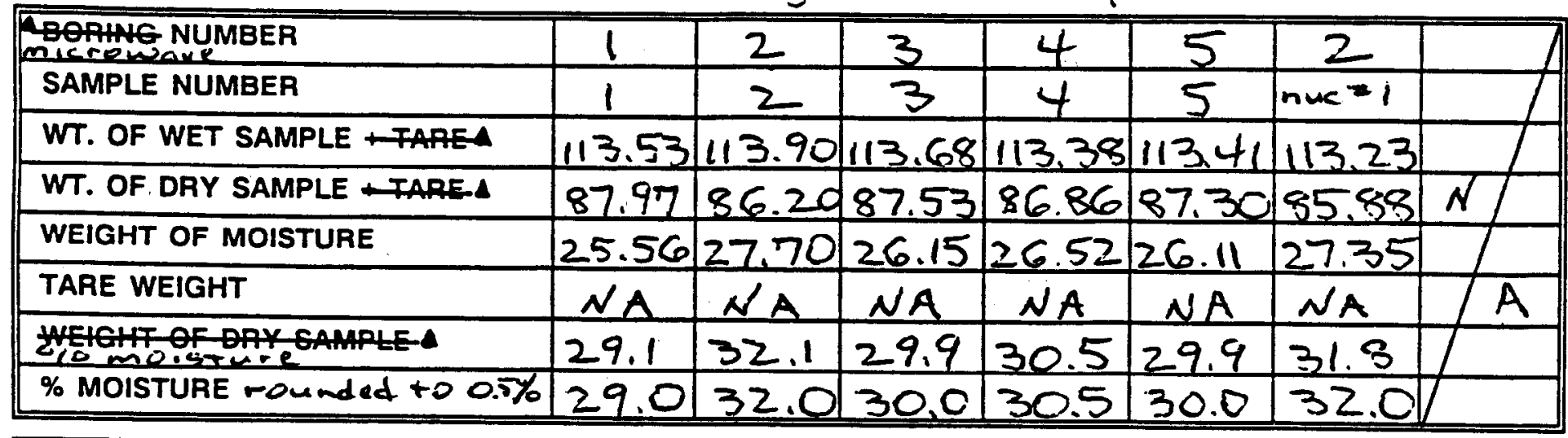

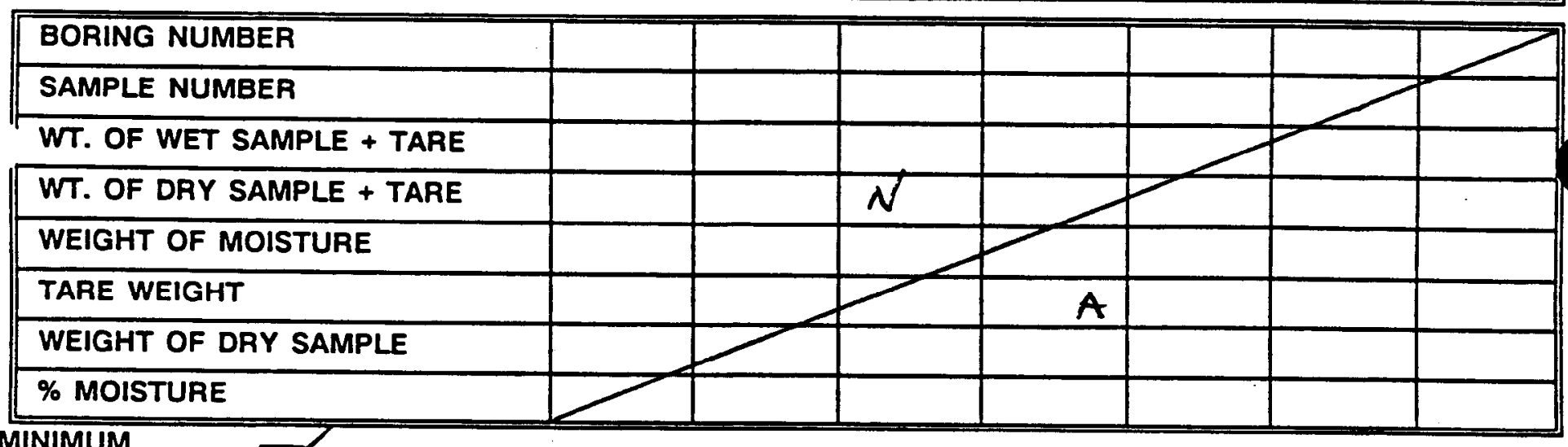

MINIMUM SAMPLE $\square$ CONFORMING $\square$ NONCONFORMING REMARKS: $\leadsto$ A MORE THAN ONE SOIL TYPE: $\quad N O$

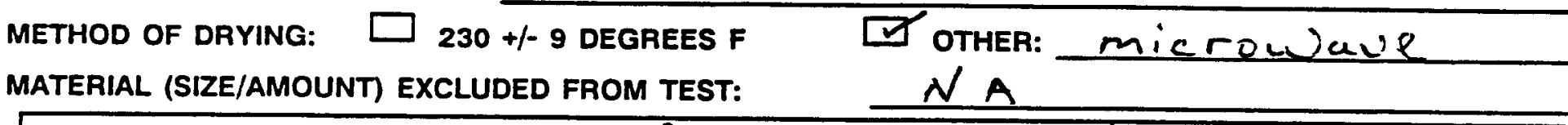

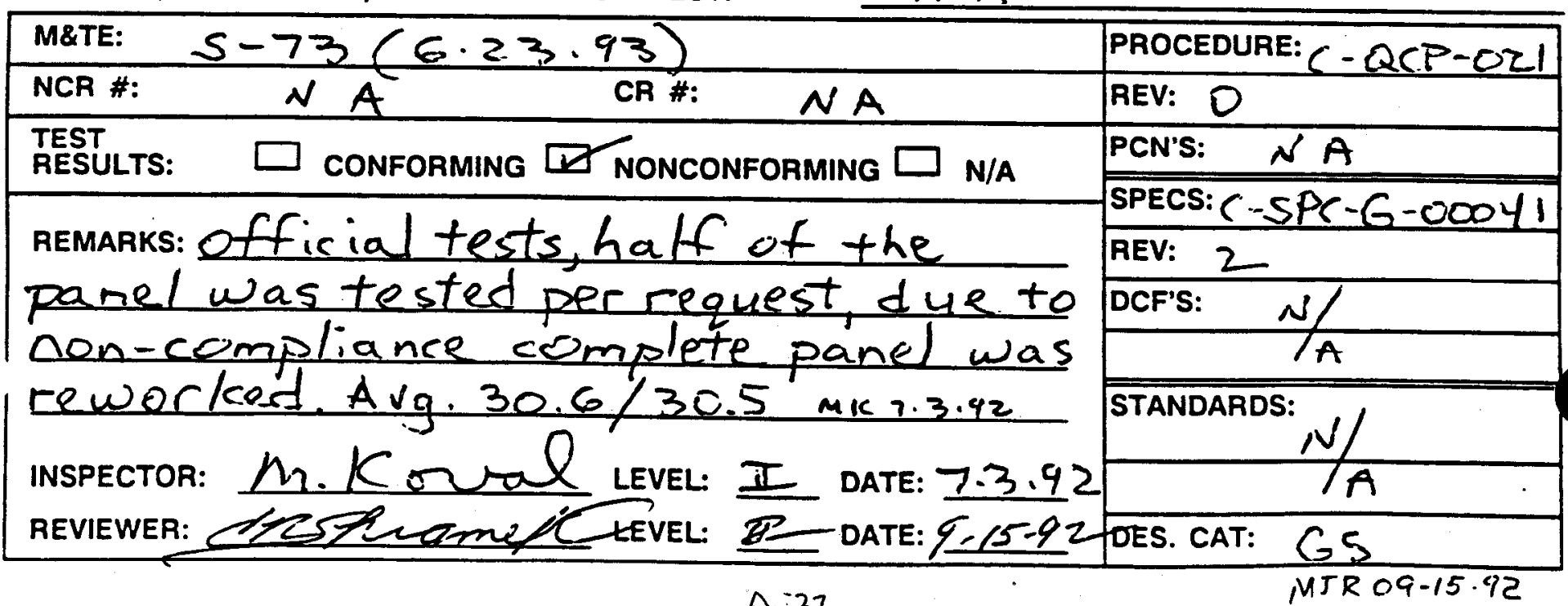


FOR INFORMATION ONLY

ASR 18-178 (3/92)

FILE ID $\$ 80143$
EBASCO SERVICES INCORPORATED

DETERMINATION OF WATER CONTENT

ASTI D-2216 ( )
ASTM D-4643 (87)

PAGE

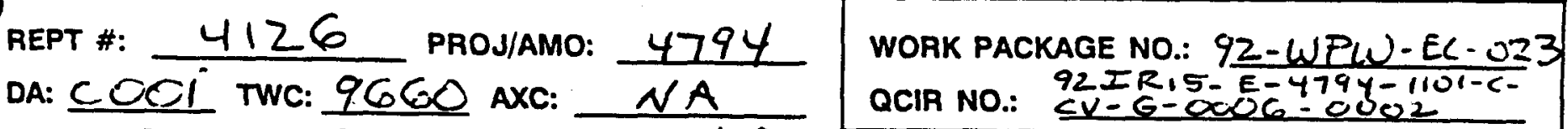

LAB \#: $592-719$ DATE TESTED: 2.4 .92 ACPT. CRITERIA: $\frac{\text { Avg. } 28-30 \%}{\text { meiszdire content }}$

MATERIAL Description: Kaolin Clay

LOCATION: Burial Ground Soils Dynamic Compaction. D Lift

\begin{tabular}{||l|c|c|c|c|c|c|c|}
\hline SAMPLE NUMBER & 1 & 2 & 4 & 5 & 6 & 7 & 8 \\
\hline WT. OF WET SAMPLE & 1 & 2 & 3 & 4 & 5 & 6 & 7 \\
\hline WT. OF DRY SAMPLE & 113.99 & 113.37 & 113.71 & 113.85 & 113.15 & 113.68 & 113.46 \\
\hline WEIGHT OF MOISTURE & 86.93 & 85.33 & 87.40 & 87.03 & 86.93 & 85.60 & 87.02 \\
\hline TARE WEIGHT & 27.06 & 28.04 & 26.31 & 26.82 & 26.22 & 28.08 & 26.44 \\
\hline NA & NA & NA & NA & NA & NA & NA \\
\hline$\%$ MOISTURE rounded to $0.5 \%$ & 31.1 & 32.9 & 30.1 & 30.8 & 30.2 & 32.8 & 30.4 \\
\hline
\end{tabular}

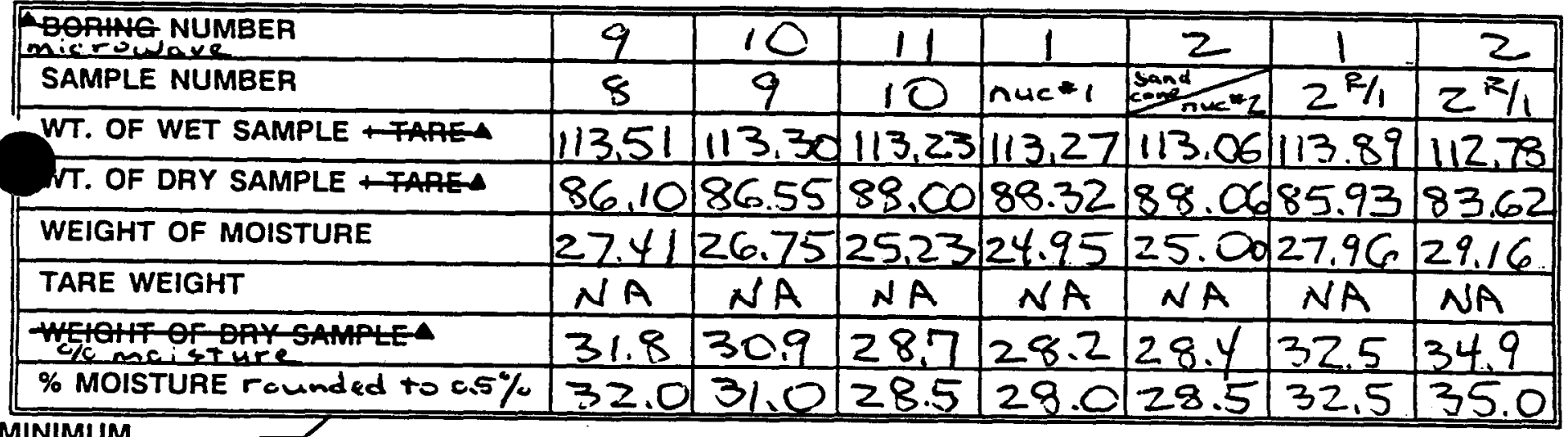

MIZE SAMPLE $\square$ CONFORMING $\square$ NONCONFORMING REMARKS: NA

MORE THAN ONE SOIL TYPE: $\quad N^{\prime} O$

METHOD OF DRYING: $\square 230+/-9$ DEGREES F

MATERIAL (SIZE/AMOUNT) EXCLUDED FROM TEST:

IT OTHER: microwave

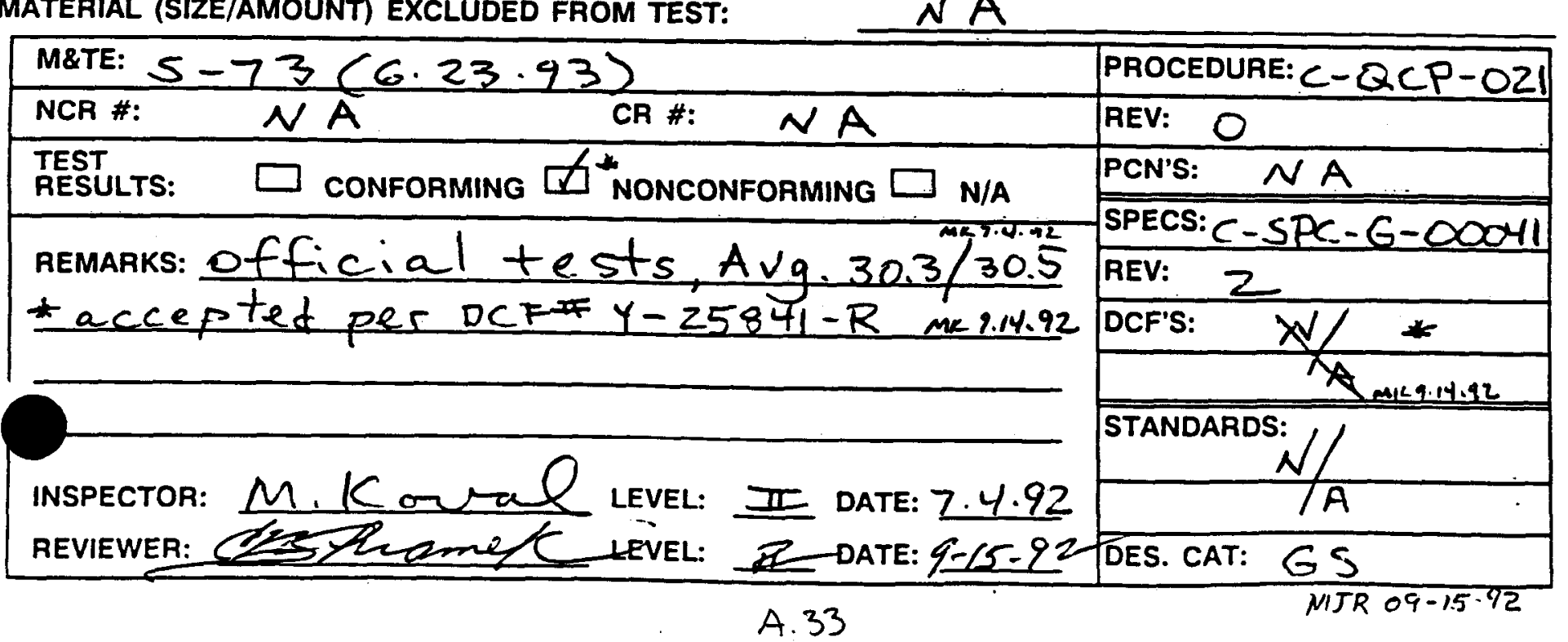


FUR INFUKMMAIIUN ONLY

ASP $18-178(3 / 92)$

EBASCO SERVICES INCORPORATED

DETERMINATION OF WATER CONTENT

ATM D-2216 ()

ASTM D-4643 (87)

PAGE 7 OF 7

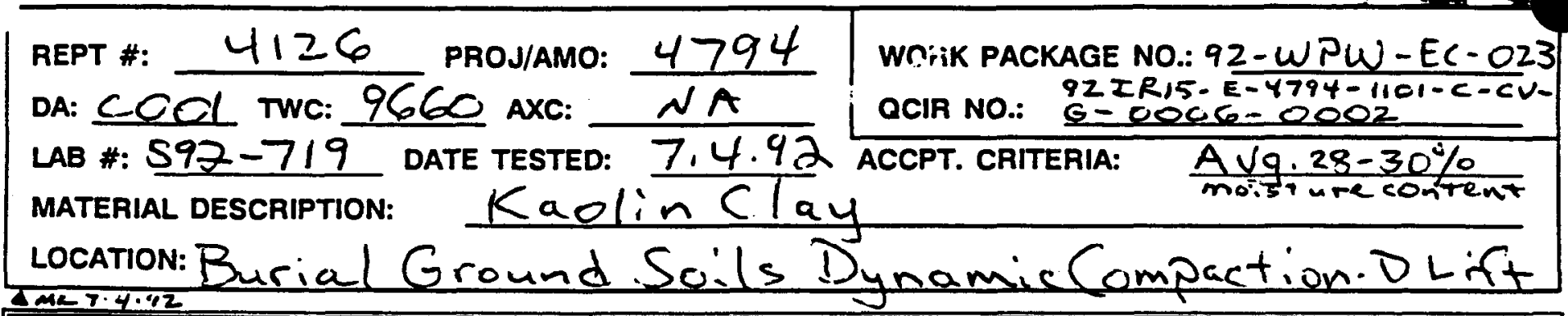

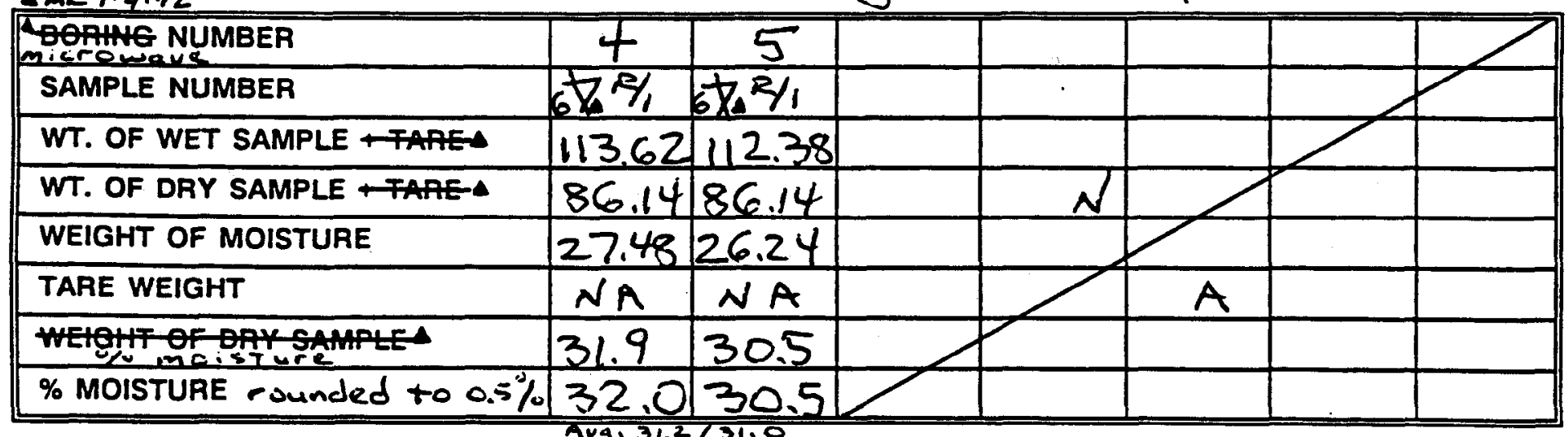

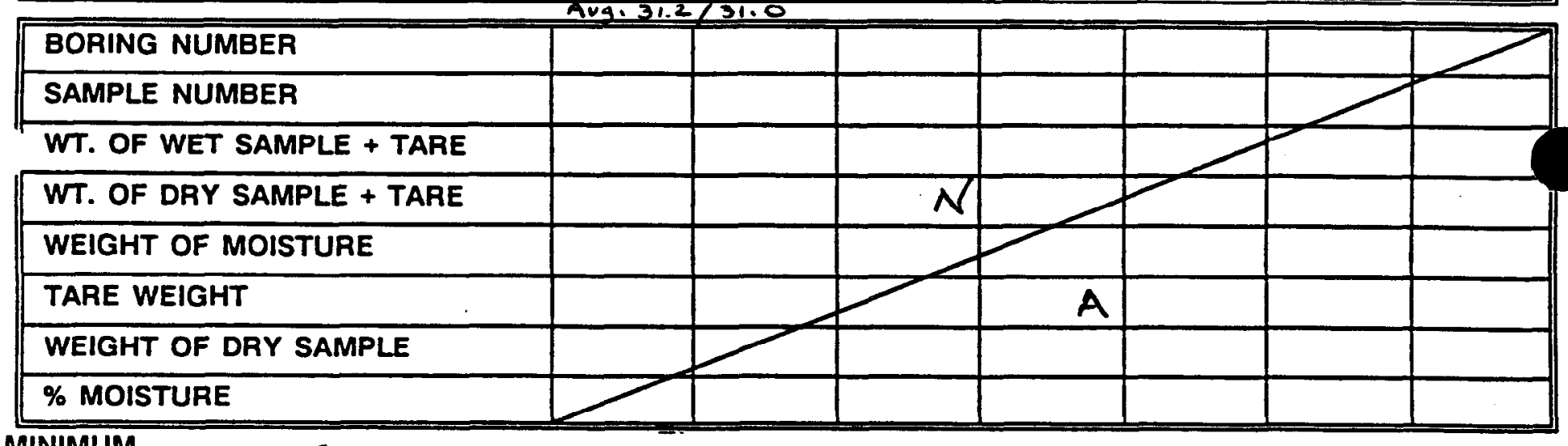

MINIMUM SAMPLE $\square$ CONFORMING $\square$ NONCONFORMING REMARKS: $N$ A MORE THAN ONE SOIL TYPE: $\quad$ NO

METHOD OF DRYING: $\square 230$ +/-9 DEGREES F $\square$ OTHER: microwave MATERIAL (SIZE/AMOUNT) EXCLUDED FROM TEST: $\quad N A$

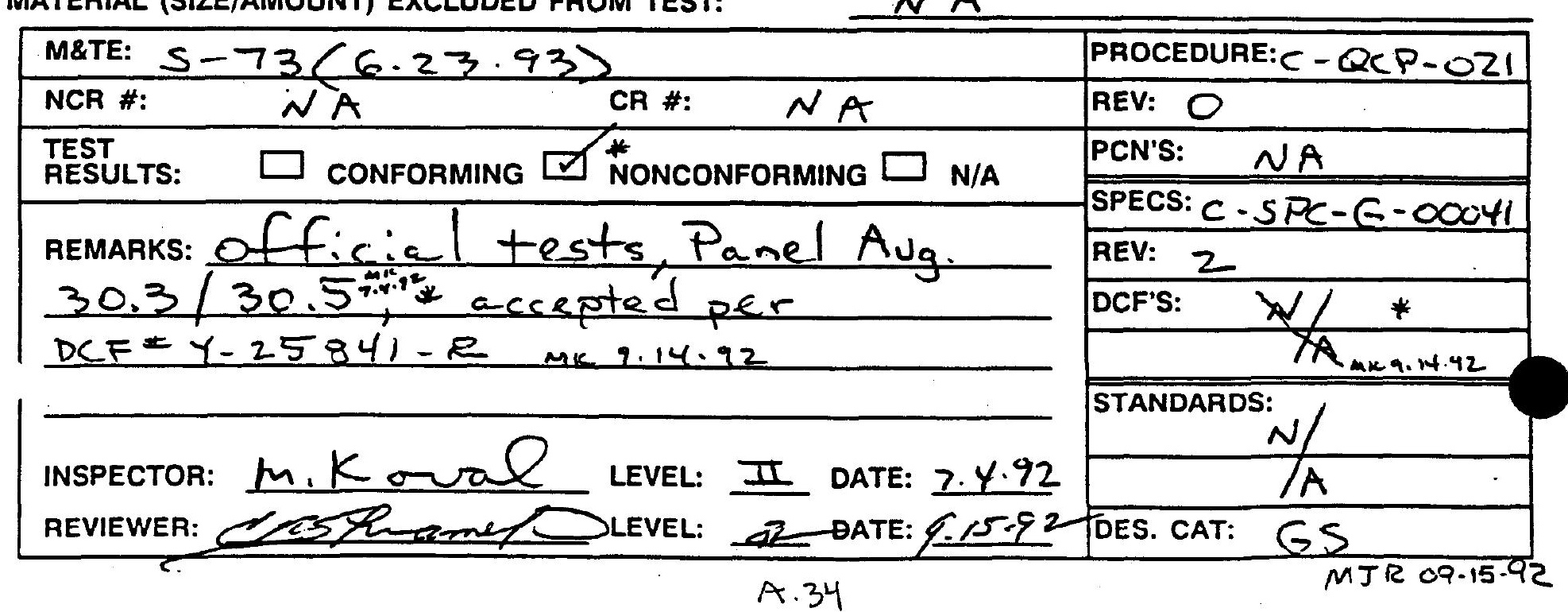


ASR 18-180 (3/92)

FOR INFORMATION ONLVIL

EBASCO SERVICES INCORPORATED

PAGE

MOISTURE \& DENSITY TESTS USING SURFACE PROBES

ATM D-2922 $\left(81 Z_{2}\right)$

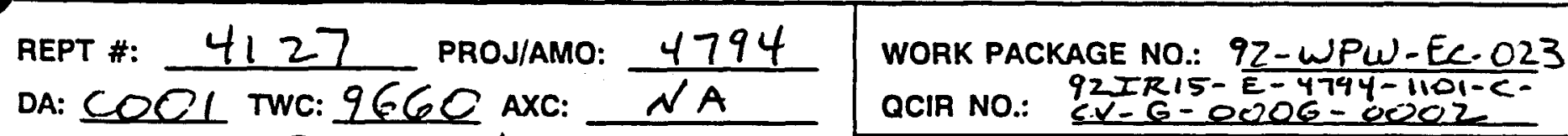

CONTRACTOR: Bechtel

MATERIAL Description: ladin $\mathrm{Clay}_{\text {a }}$

ACCEPTANCE CRITERIA: $95 \%$ compaction; $90-94$ PCF Dry density DRAWINGS) \& REV(S): $c-c V-6-0006 R / 1$ LOCATION: Burial Ground Soils Dynamic Compaction - E Lift

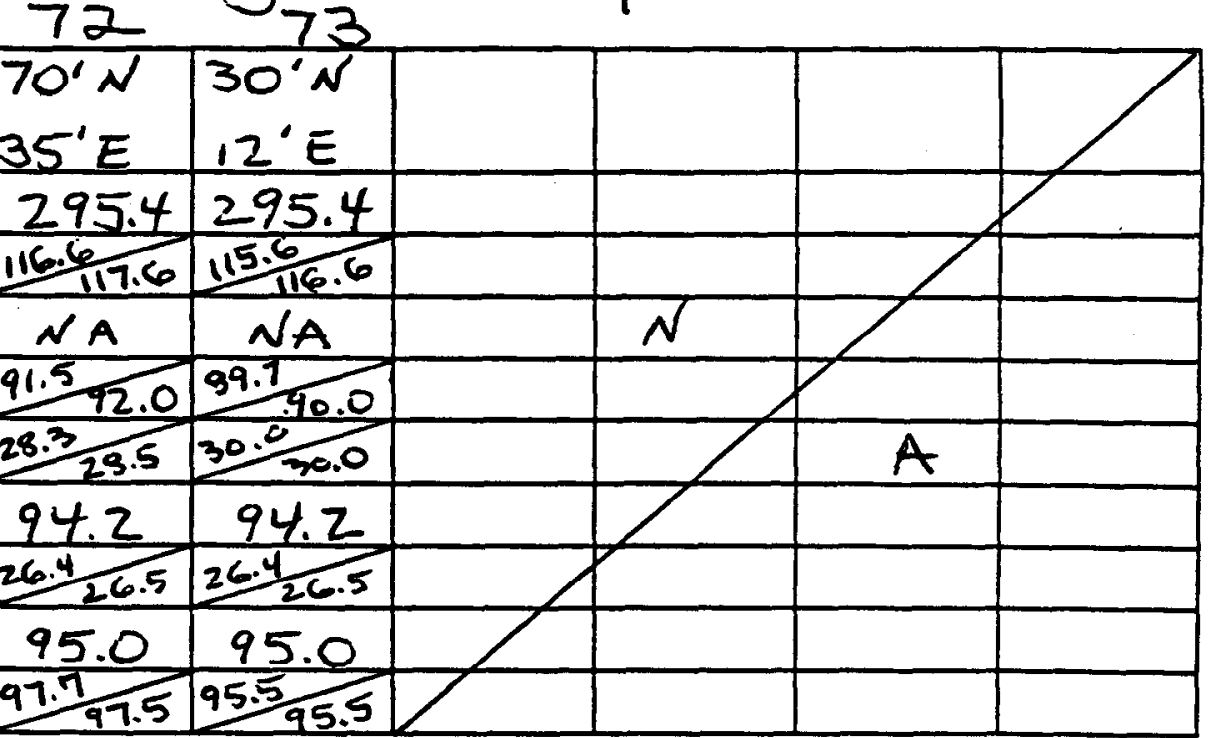

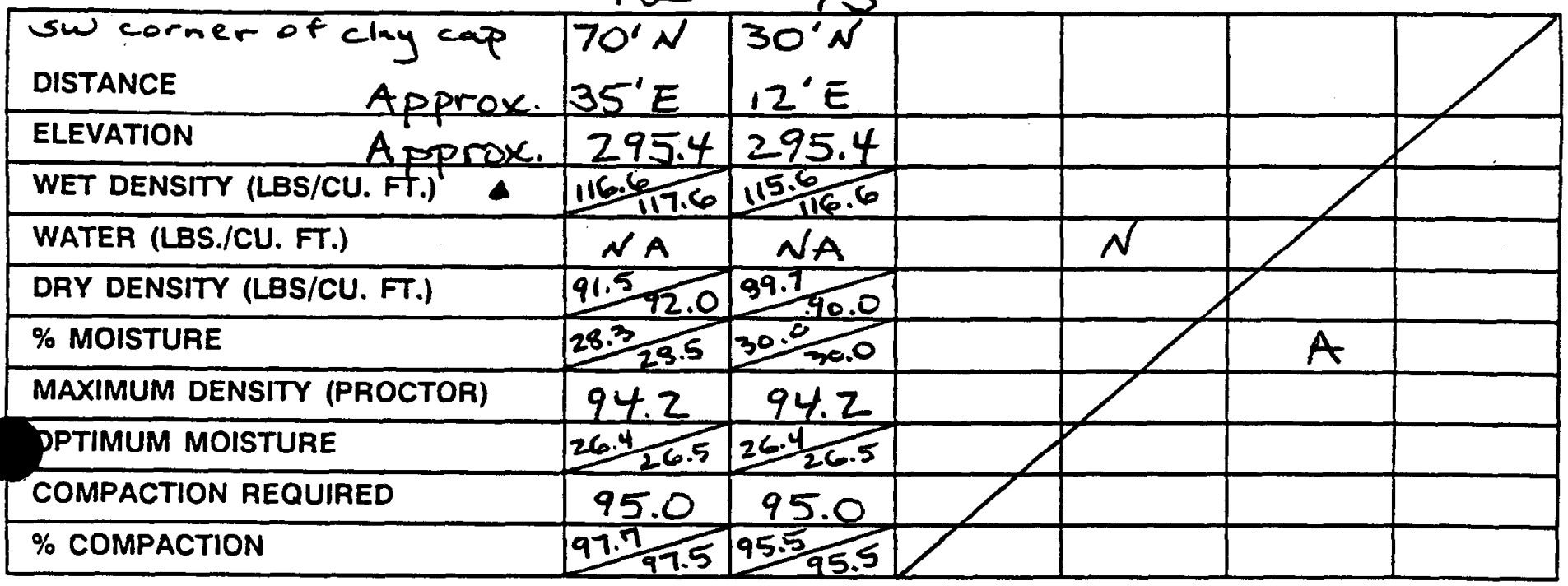

TROXLER \#: 7 MODEL: 3440 SERIAL \#: 17494

DENSITY PROCTOR REPT \#: WER-ERC-92-0544 DESIGN CAT: GS DENSITY: AVERAGE OF LAST 4 STANDARD COUNTS (No): 3822

DALLY STANDARD COUNTS (Ns): $\quad 3846$

MOISTURE: AVERAGE OF LAST 4 STANDARD COUNTS (No): 602

MOISTURE DALY STANDARD COUNTS (Ns): $\frac{597}{\square \text { ASTI D-3017 ( ) }} \square_{\text {ASTM D-4643 (87) }}$

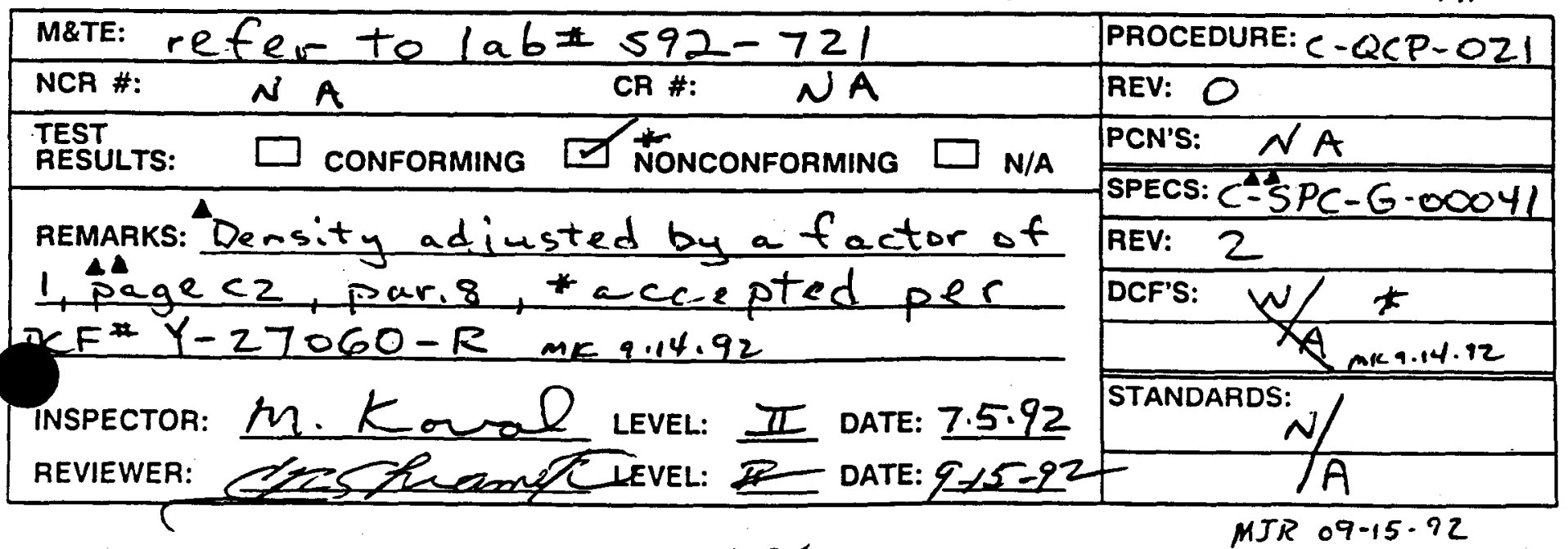

A. 35

MIR $09-15 \cdot 92$ 
FUR INFURIVIATION ONLY

APR $18.178(3 / 92)$

EBASCO SERVICES INCORPORATED

DETERMINATION OF WATER CONTENT

ATM D-2216 ( )

ASTI $0-4643$ (\$)

PAGE

PROJ/AMO: $\quad 4794$

REPT \#: 4127

60 Axe: $\frac{479}{N A}$

WORK PACKAGE NO.: $92-\omega P \omega-E C-C Z 3$

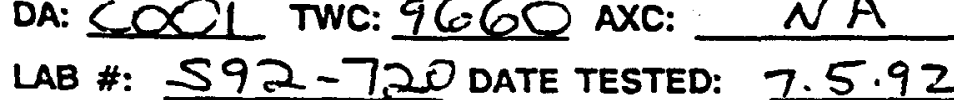

ACPT. CRITERIA: NA

MATERIAL DESCRIPTION: Karin $\mathrm{Kay}$

LOCATION: Burial Ground Soils Dynamic Compaction - E Lift

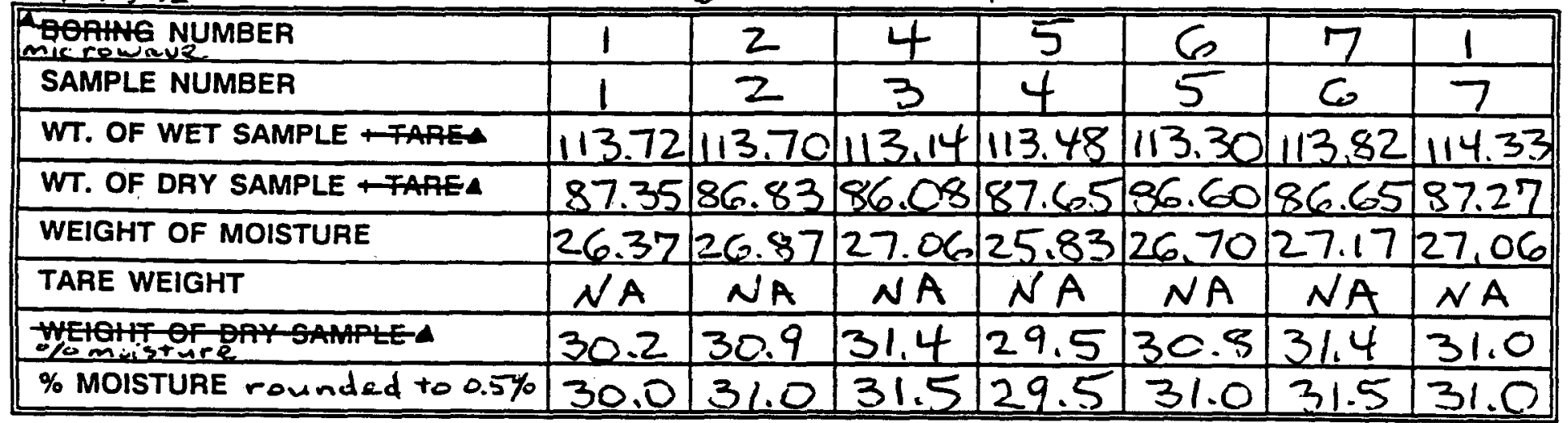

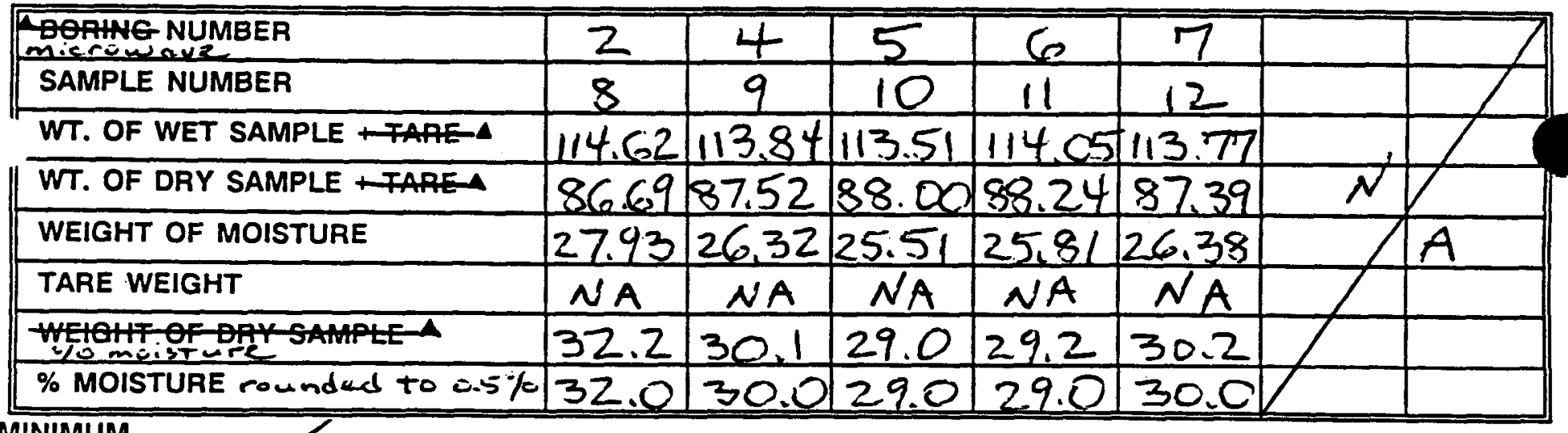

MINIMUM SAMPLE $\square$ CONFORMING $\square$ NONCONFORMING REMARKS: $N A$

MORE THAN ONE SOIL TYPE:

METHOD OF DRYING: $\square 230+1-9$ DEGREES F $\square$ OTHER: microu2ave

MATERIAL (SIZE/AMOUNT) EXCLUDED FROM TEST: $N A$

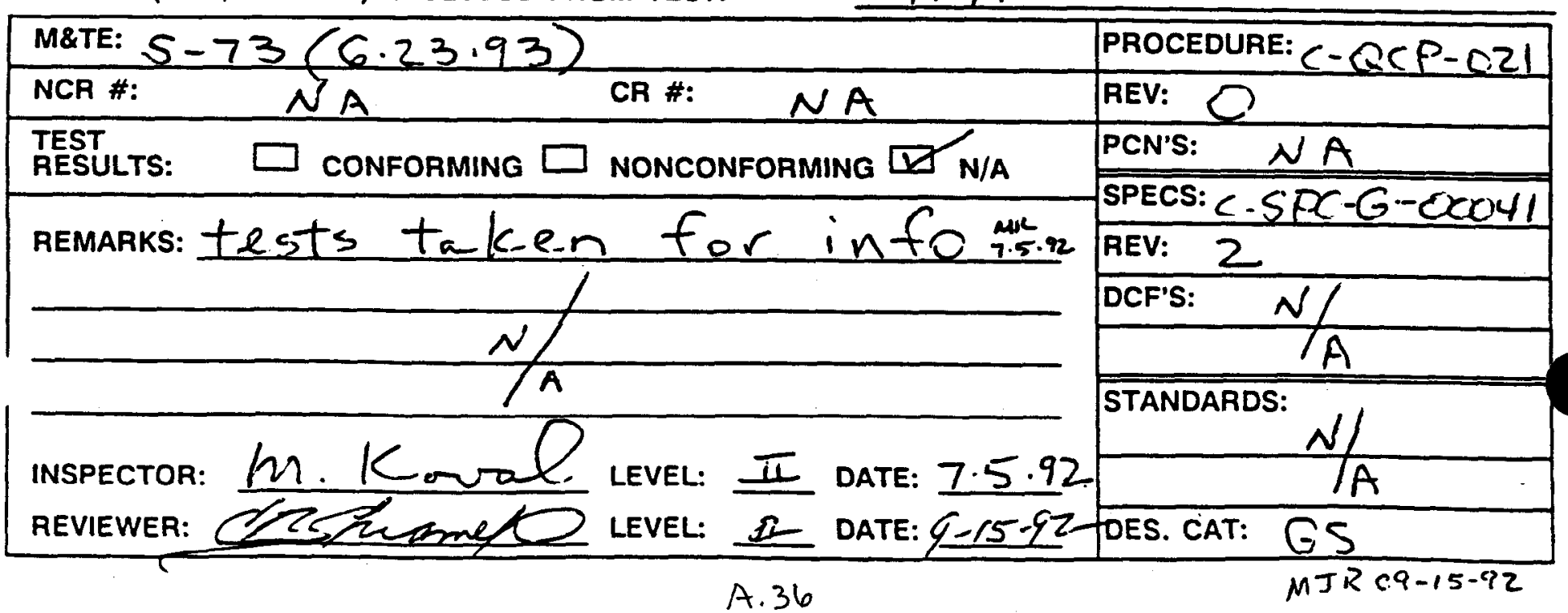


FOR INFORMATION ONLY

EBASCO SERVICES INCORPORATED

ASP $18.178(3 / 92)$

DETERMINATION OF WATER CONTENT

ASTI D-2216 ( )

PAGE

$\square$ ASTM D-4643 (87)

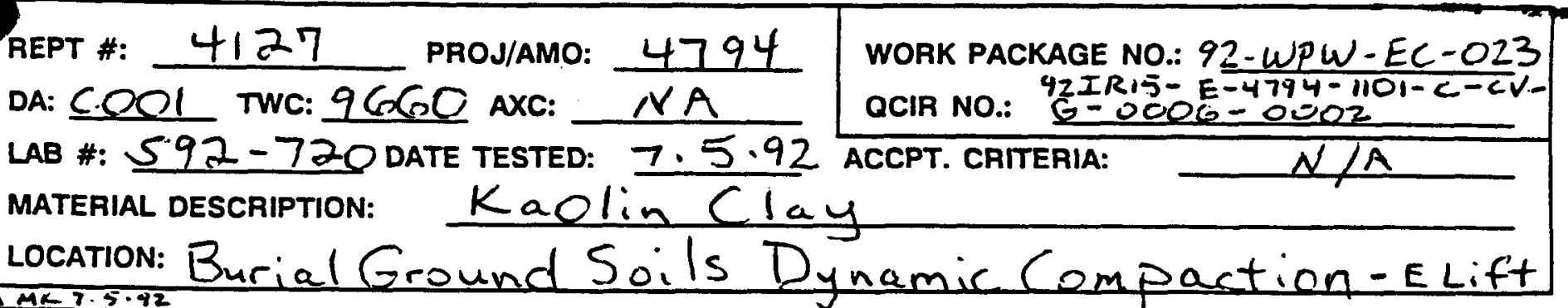

\begin{tabular}{||l|c|c|c|c|c|c|c||}
\hline SAMPLE NUMBER & 1 & 2 & 4 & 5 & 6 & 7 & 8 \\
\hline WT. OF WET SAMPLE - & 1 & 2 & 3 & 4 & 5 & 6 & 7 \\
\hline WT. OF, DRY SAMPLE & 113.30 & 11484 & 14.22 & 113.21 & 113.44 & 113.84 & 113.82 \\
\hline WEIGHT OF MOISTURE & 89.59 & 91.19 & 89.72 & 89.40 & 87.65 & 89.76 & 89.60 \\
\hline TARE WEIGHT & NA & NA & NA & NA & NA & NA & NA \\
\hline \% & 23.65 & 24.50 & 23.81 & 25.79 & 24.08 & 24.22 \\
\hline MOISTURE rounded to $0.5 \%$ & 28.0 & 26.0 & 27.5 & 26.5 & 29.5 & 27.0 & 27.0 \\
\hline
\end{tabular}

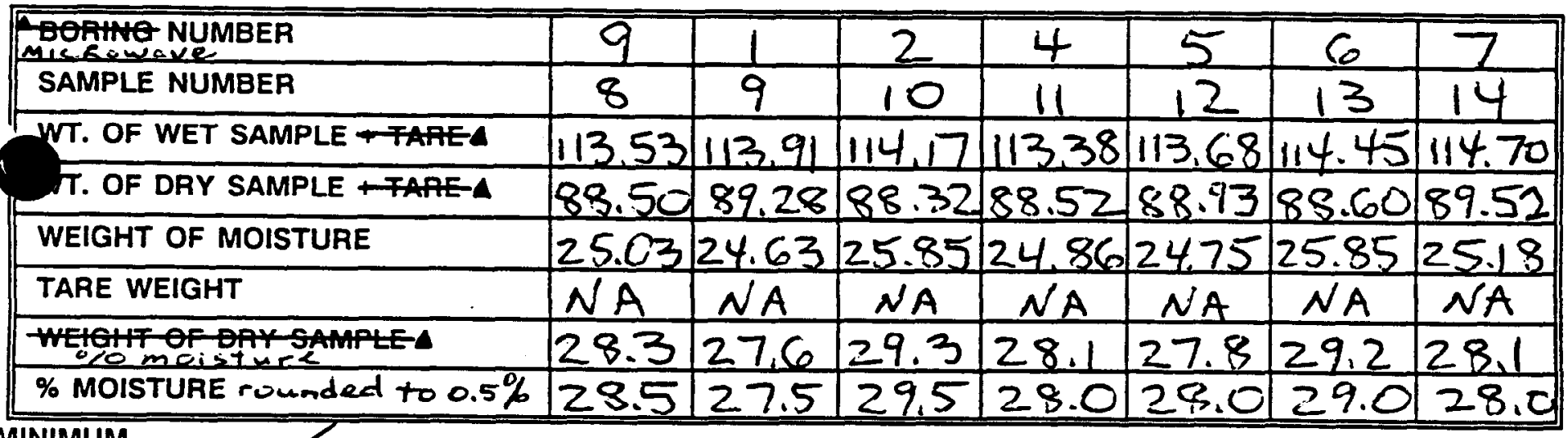

MIZE SAMPLE $\square$ CONFORMING $\square$ NONCONFORMING REMARKS: $N A$ MORE THAN ONE SOIL TYPE: $\quad \Delta ! O$

METHOD OF DRYING: $\square 230$ +/- 9 DEGREES F P OTHER: Microwave MATERIAL (SIZE/AMOUNT) EXCLUDED FROM TEST: $\quad$

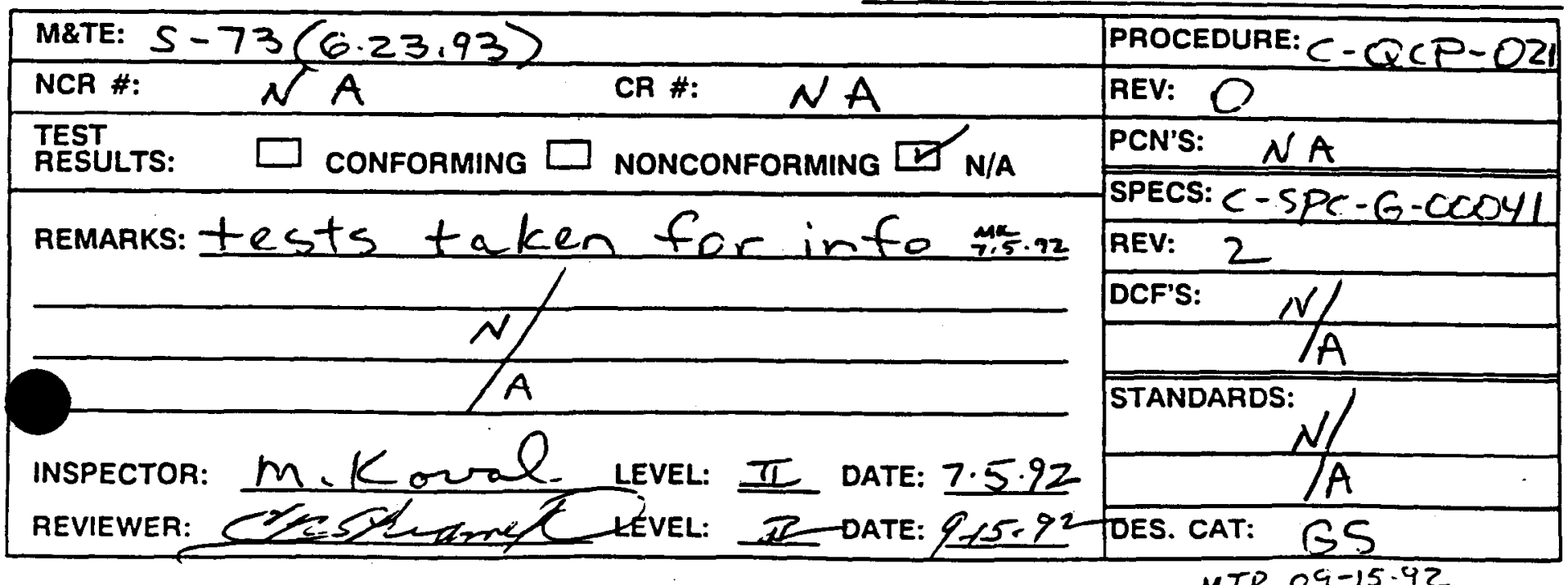

A. 37

MIR O9-15.92 
FOR INFORMATION ONLY

ASR 18-178 (3/92)

EBASCO SERVICES INCORPORATED

DETERMINATION OF WATER, CONTENT

ASTI D-2216 ( )

ASTI D-4643 (BT)

REPT \#: 4127 PROJ/AMO: 4794

DA: $5 O C L^{-}$THC: ICaO Axe: NA

WORK PACKAGE NO.: 92-WPW-EC-O23

CIR NO.: $\quad \begin{aligned} & 42 I R I 5-E-4794-1101-C \\ & \text { CV }\end{aligned}$

LAB \#: $592-721$ DATE TESTED: 7.5 .92 ACCPT. CAITERIA: Avq.28-3C\%

MATERIAL DESCRIPTION: Kaolin clay

LOCATION: Burial Ground Soils Dynamic Conpaction-ELift

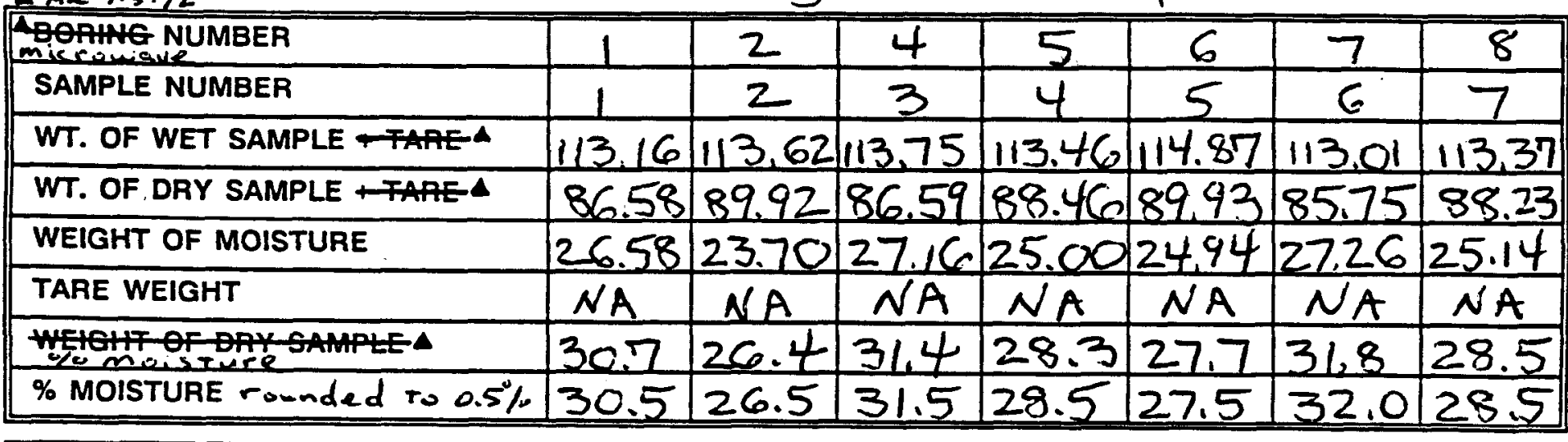

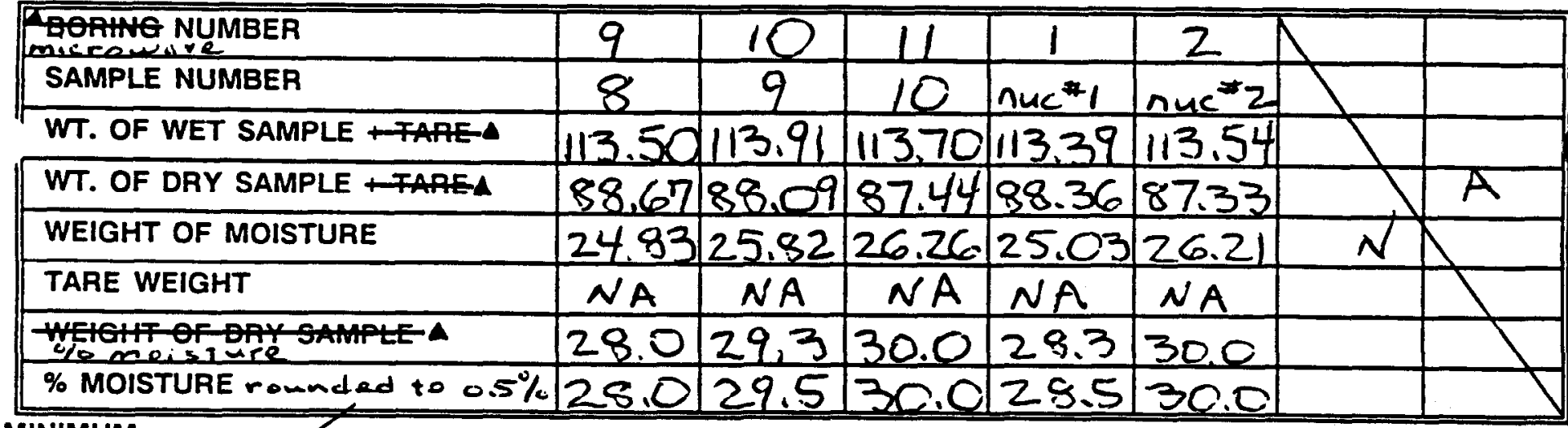

MINIMUM SAMPLE $\square$ CONFORMING $\square$ NONCONFORMING REMARKS: $N A$ MORE THAN ONE SOIL TYPE: NO

METHOD OF DRYING: $\square 230$ +/-9 DEGREES F $\square$ OTHER: Microwave MATERIAL (SIZE/AMOUNT) EXCLUDED FROM TEST: $\quad N A$

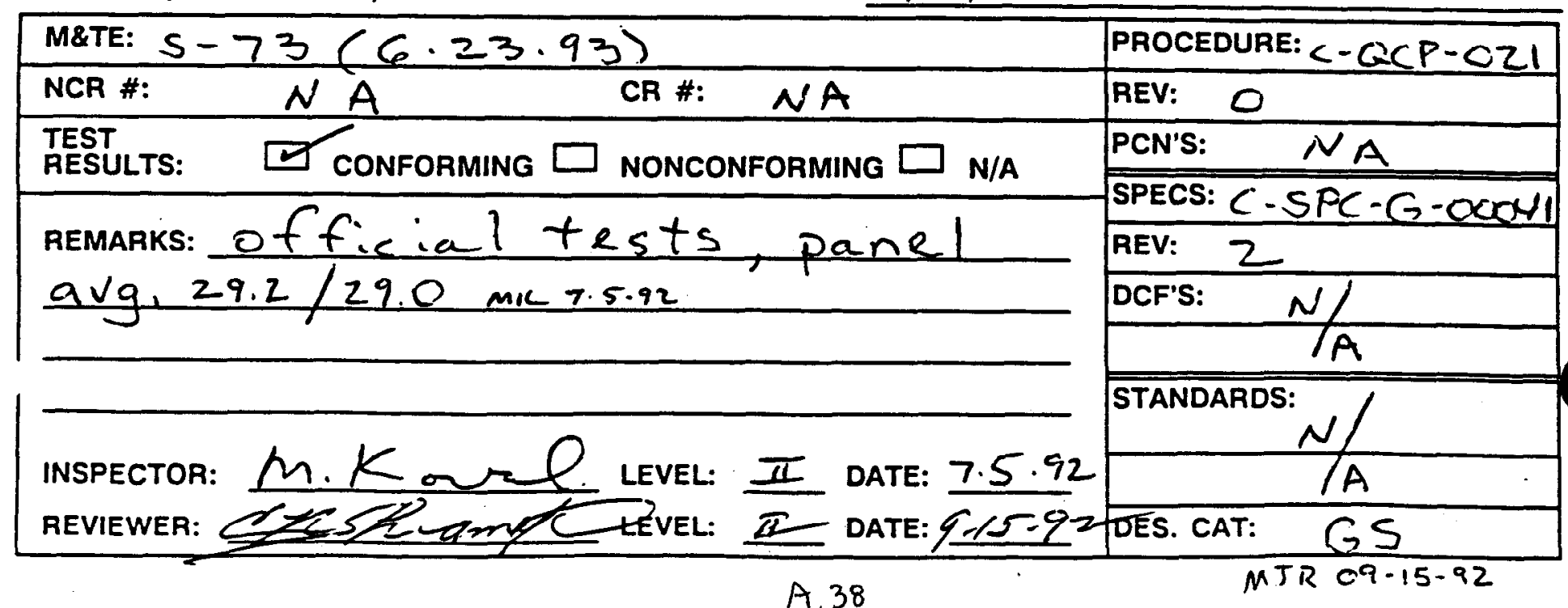


PEPT \# 4127 AXC: NIA

PROJ/

AMO:

DA: 1001 TWC: 9660

WORK PACKAGE NO. 42 WP $-\angle \mathrm{C}-023$ OCIR NO. 2 TRI $5-F-4749-1101-C-C V-C$

MATERIAL DESCRIPTION:

LAB \# KAOWN CKAY

$5 \varepsilon 2-2 \alpha 2$ DATE TESTED: LOCATION: BuRCAL GROUNC SOLL QYACAMIC CON SOLLATTION E LET 1

2

3

4

5

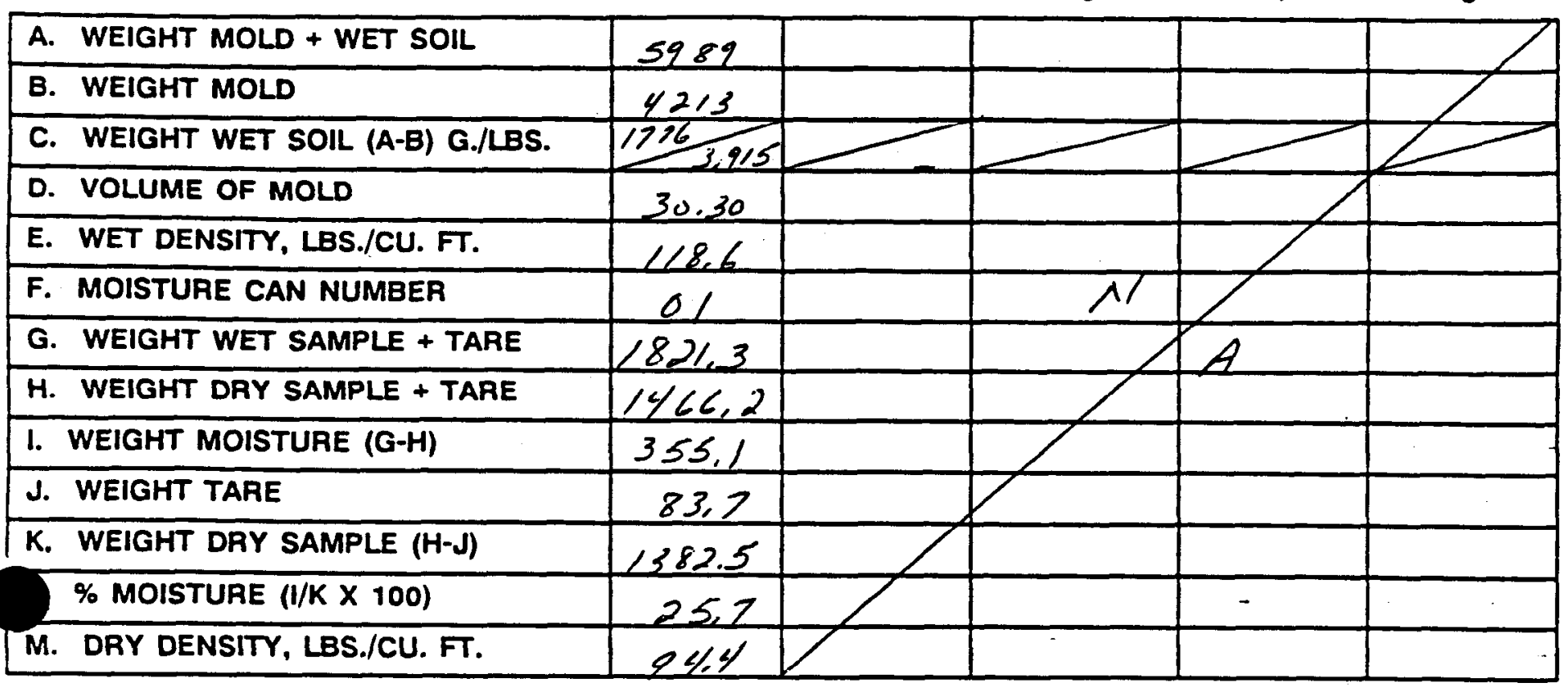

NOTE: DRY DENSITY (LINE M) $=($ LINE E X 100)/(100 + LINE L)

PREPARATION METHOD: $\square$ DRY $\square$ WET

RAMMER: $\square$ MANUAL $\square$ MECHANICAL

OPTIMUM MOISTURE: N NAA

MAXIMUM DENSITY:

NIA

ACCEPTANCE CRITERIA:

$\triangle / A$

DESIGAR CATEGOAY: "GS" RIT $7-842$

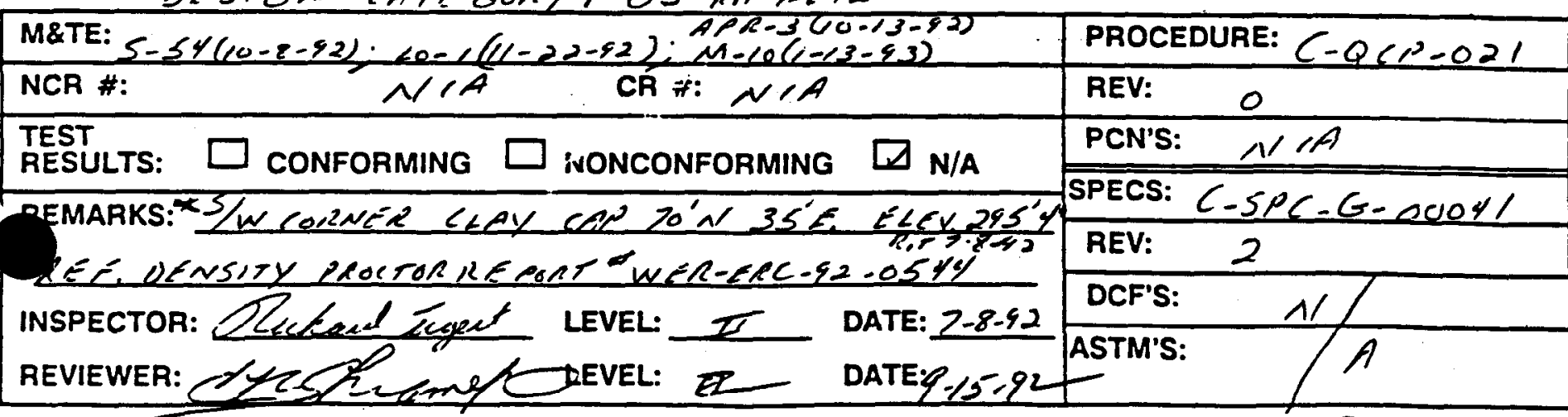

REVIEWER: 


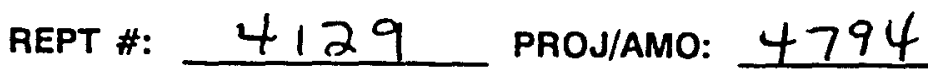
DA:C.OCI TWC: 9660 AXC: $\mathrm{NA}$ LAB \#: $592-723$ DATE TESTED: 7.6 .97 MATERIAL DESCRIPTION: Kaclin Clay

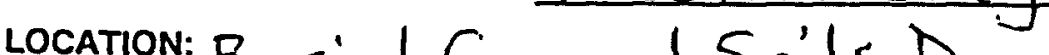

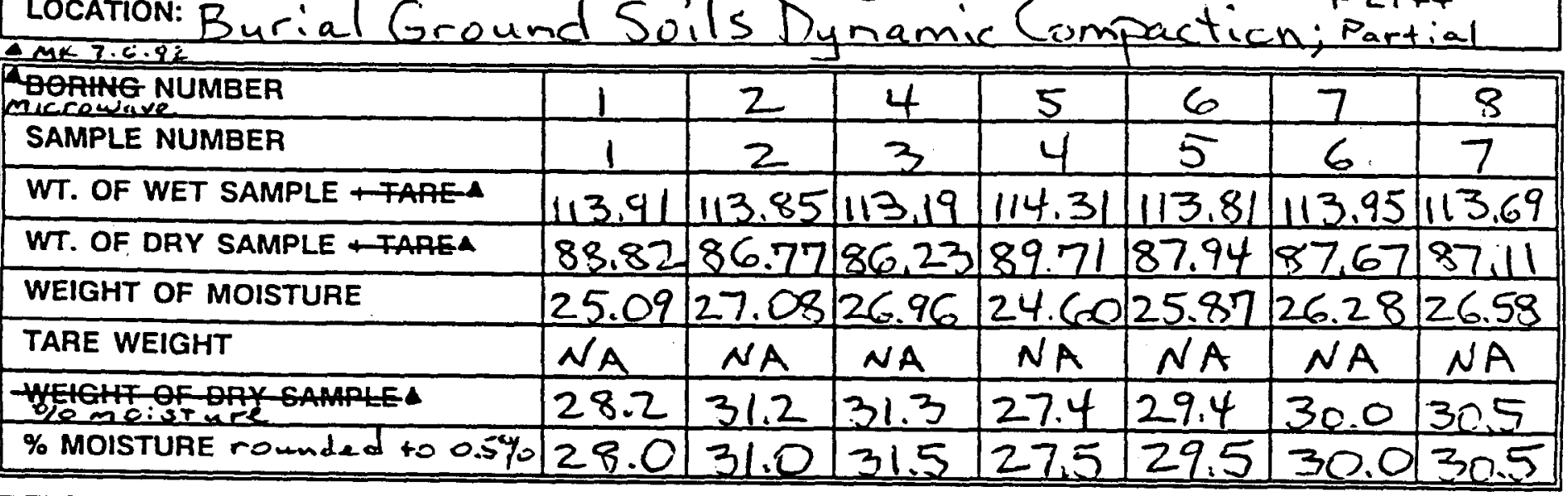

\begin{tabular}{|c|c|c|c|c|c|c|c|}
\hline DOAINGNUMBER & 9 & 10 & 11 & 1 & 2 & & \\
\hline SAMPLE NUMBER & 8 & 9 & 10 & AHC $* 1$ & nuckses sione & & \\
\hline WT. OF WET SAMPLE - TAAE & 113.65 & 113.72 & 114.11 & 113.84 & 113.61 & & A \\
\hline T. OF DRY SAMPLE TAREA & 86.46 & $\$ 7.82$ & 87.67 & 89.16 & 88.94 & & \\
\hline WEIGHT OF MOISTURE & 27.19 & 25.90 & 26.44 & 24.68 & 24.67 & $N$ & \\
\hline TARE WEIGHT & NA & NA & NA & NA & NA & & \\
\hline 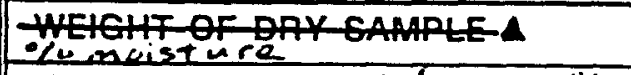 & 31,4 & 29.5 & 30.2 & 27.7 & 27.7 & & \\
\hline$\%$ MOISTURE rounded to $0.5 \%$ & 31.5 & 29.5 & 300 & 27.5 & 27.5 & & \\
\hline
\end{tabular}
MORE THAN ONE SOIL TYPE: NO METHOD OF DRYING: $\square 230+/$ - 9 DEGREES F MATERIAL (SIZE/AMOUNT) EXCLUDED FROM TEST:

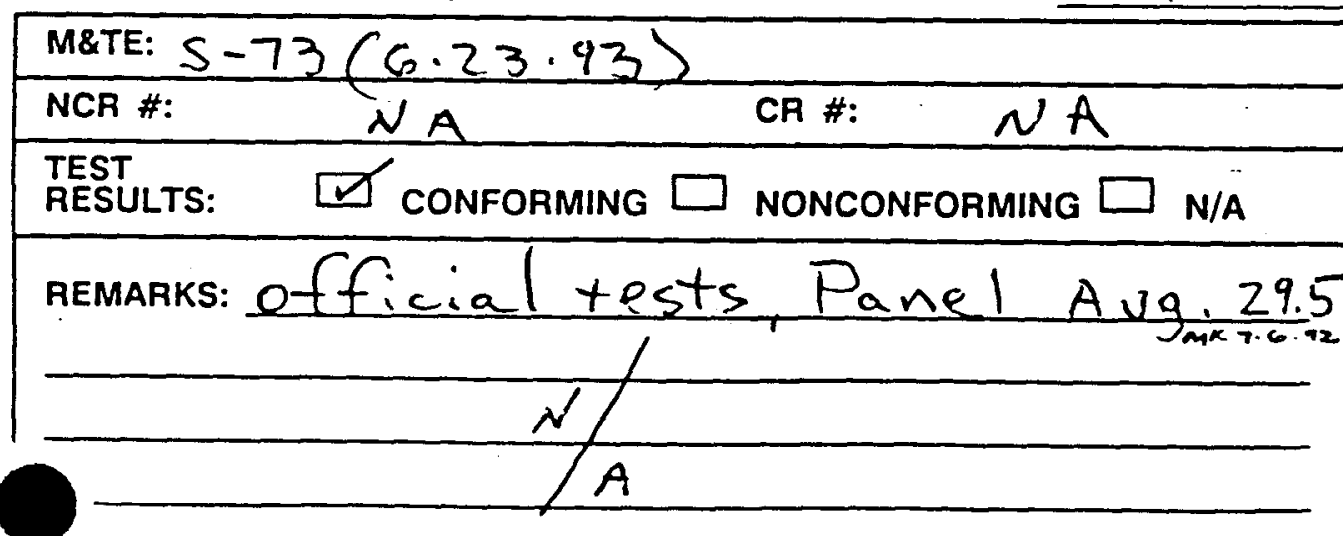

WORK PACKAGE NO.: $92-W P W-E C-0 Z 3$ QTIR IR15-E-477Y-1101-C-CV QCIR NO.: G-0006-00\%2 ACCPT. CRITERIA: Avg. $28-30 \%$ meistune

$$
\text { ACCPT. }
$$$$
\text { 然 }
$$ 
Appendix B consists of the preliminary, supporting data. This data was primarily used to calibrate the Dynamic Compaction Facility model with the actual Mixed Waste Management Facility. In addition, this work assessed the equipment and instrumentation performance criteria for actual testing. The following is a listing of the different sections within appendix B:

- Appendix B.1 presents the supportive data from the Spectral Analysis of Shear Waves (SASW) technique, which analyzed the similarities between the Dynamic Compaction Facility kaolin clay cap and the Mixed Waste Management Facility kaolin clay cap.

- Appendix B.2 presents the supportive data from the low-strain refraction surveys. Though this method was not particularly successful, it did provide a validation of the determination of the shear wave velocity.

- Appendix B.3 presents the supportive data from the impact velocity calibration. This work quantified the efficiency of the production crane in preparation to configure the actual dynamic compaction test.

The impact of a dynamic compaction weight induces cyclic vibrations into the soil structure, similar to that from an earthquake. The dynamic displacement exerted on a structure is the mechanism for damage. To correctly assess the risk to the MWMF kaolin closure system, the seismic characteristics of the soils and structures, combined with strong motion monitoring during testing allow a quantification of damage thresholds.

Shear wave analysis was done on both the MWMF and the DCF kaolin clay closure systems. The Spectral Analysis of Shear Waves method of analysis allowed examination of the near surface soil layers. From this analysis, the MWMF kaolin clay was found to be more "stiff" than the DCF kaolin clay. This stiffness is attributed to desiocation and aging of the MWMF clay.

The data included herein is a synopsis from the EBASCO report [4]. If a more complete data set is required, the information can be obtained from this reference. 
Experimental and Theoretical Dispersions

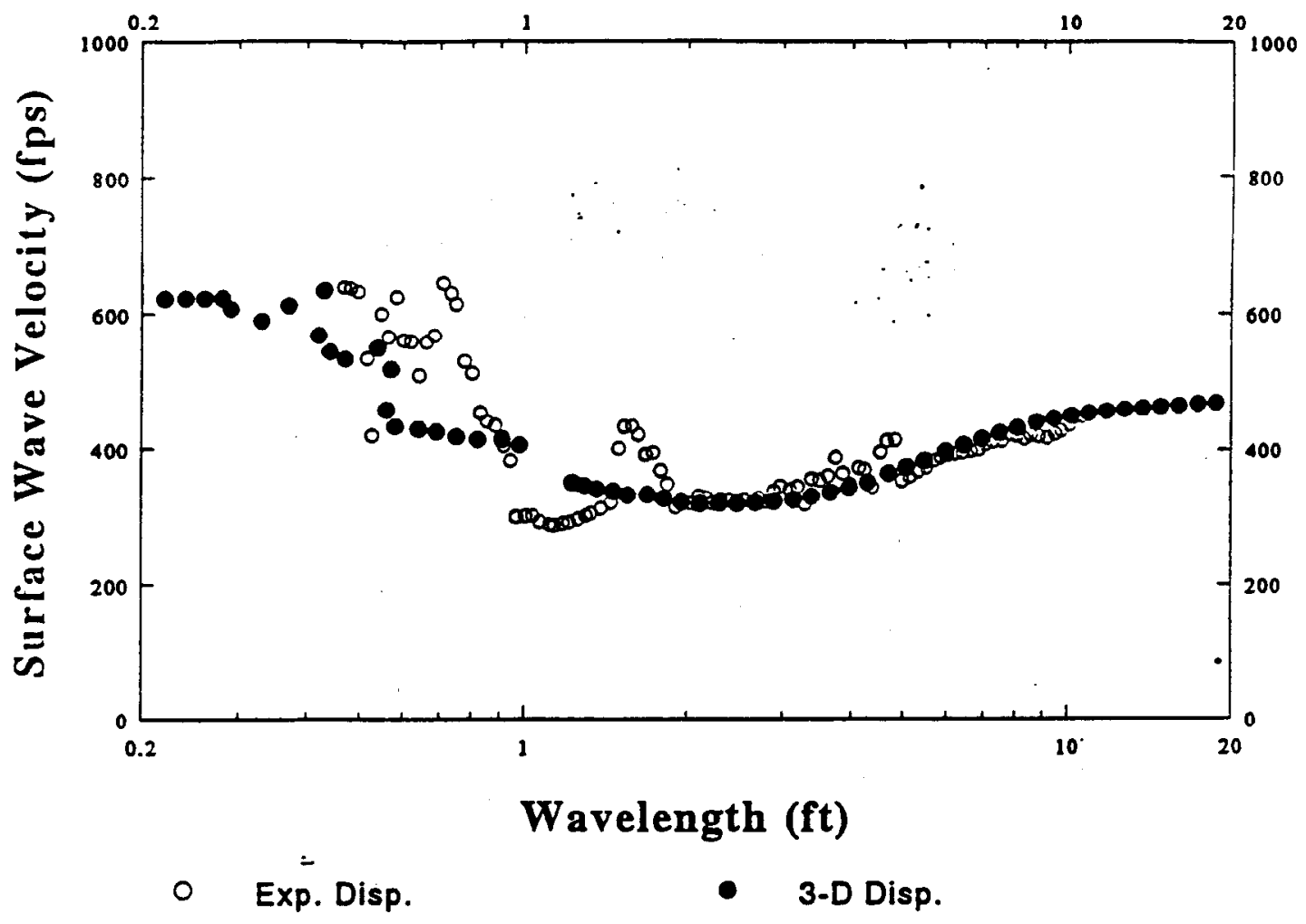

Shear Wave Velocity Profile

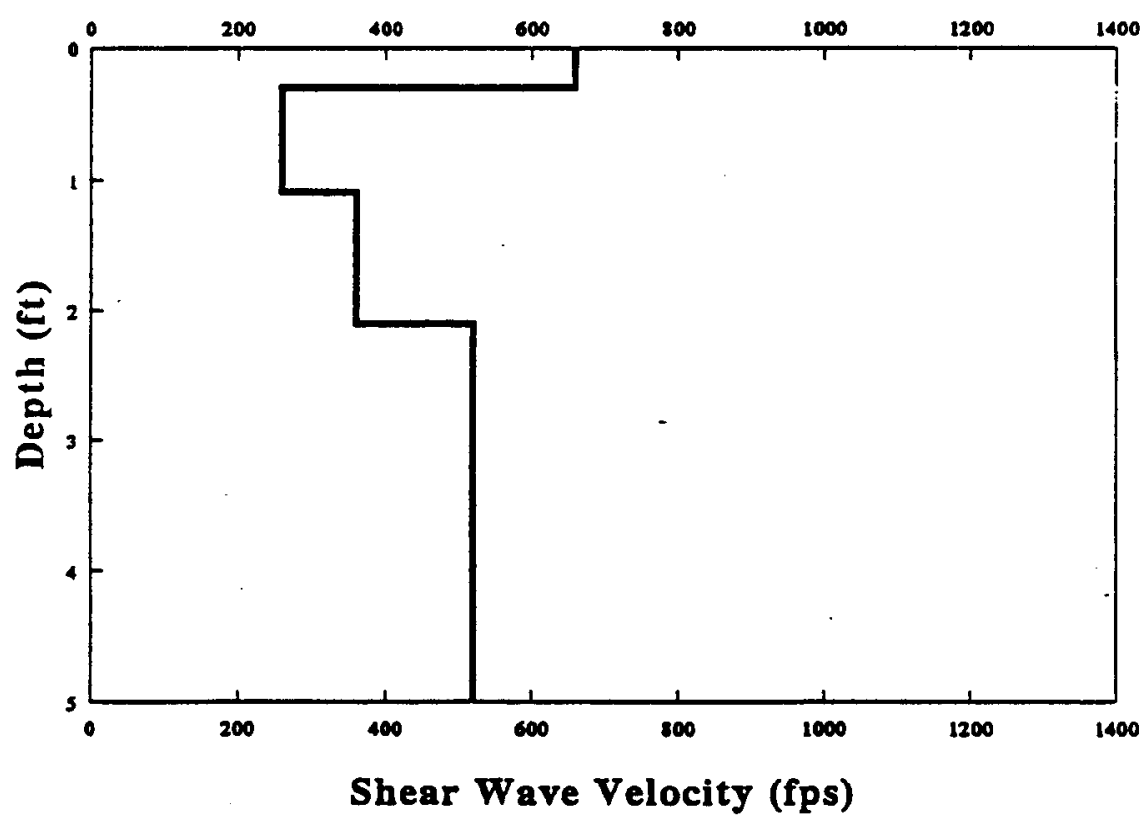

Job 205

$$
\text { Dynamic Test Facility - Site } 2 \text { (North - South) }
$$

Fig. A-2 
Experimental and Theoretical Dispersions

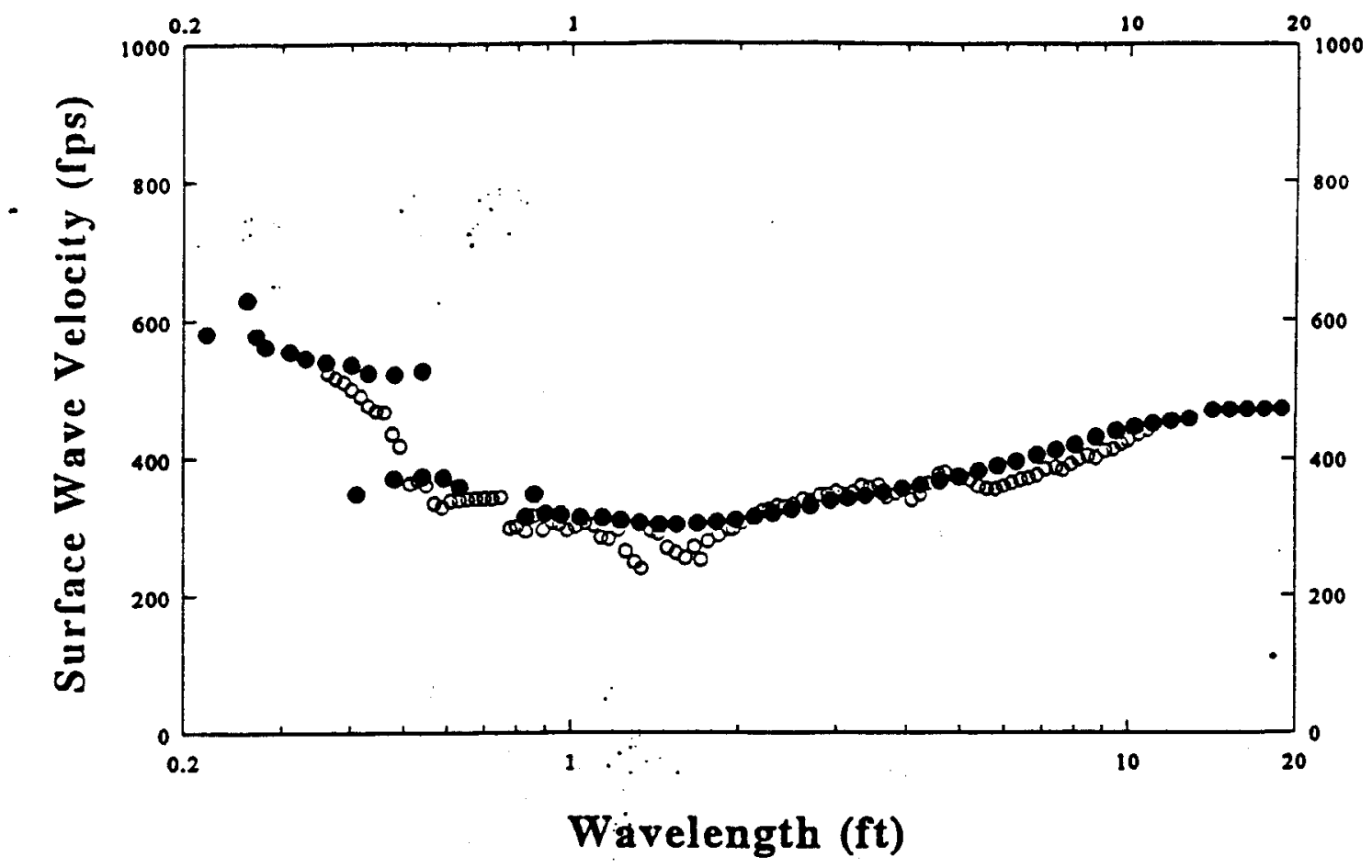

- Exp. Disp.

- 3-D Disp.

Shear Wave Velocity Profile

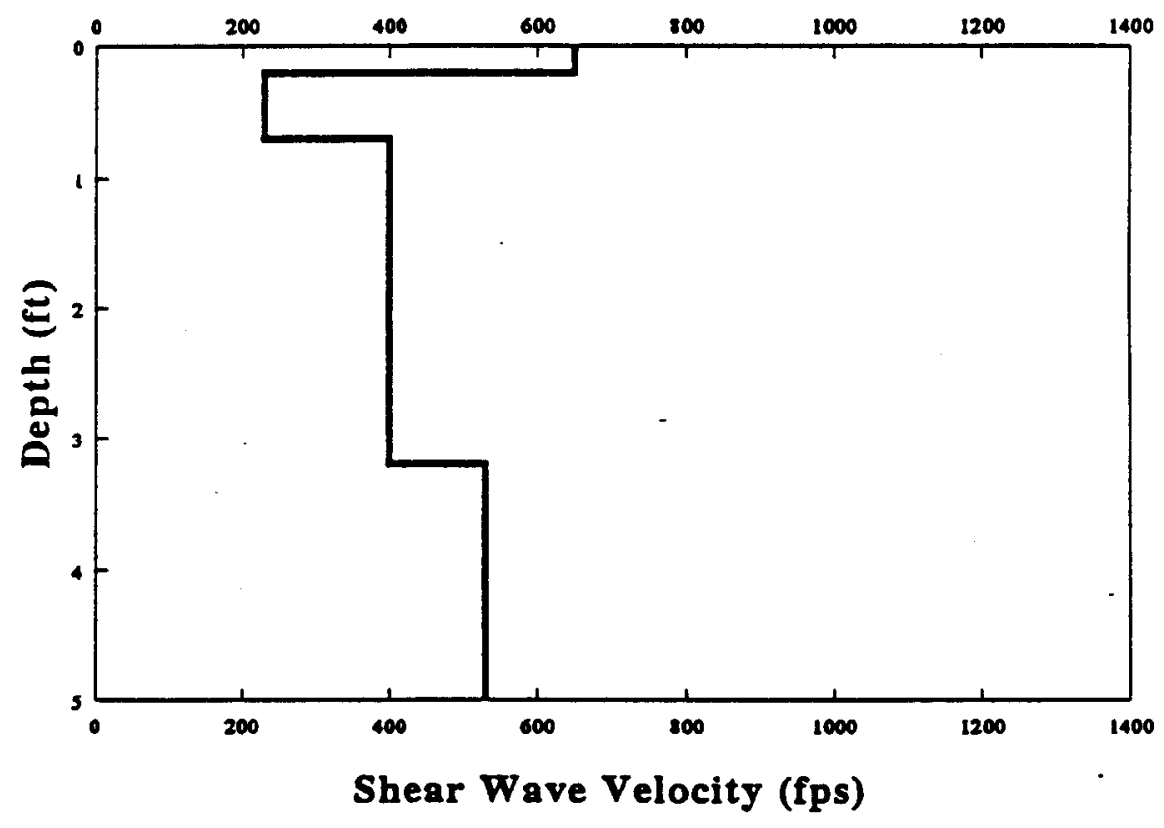

Job 205

Dynamic Test Facility - Site 3 (East-West)

Fig. A-3 


\section{Experimental and Theoretical Dispersions}

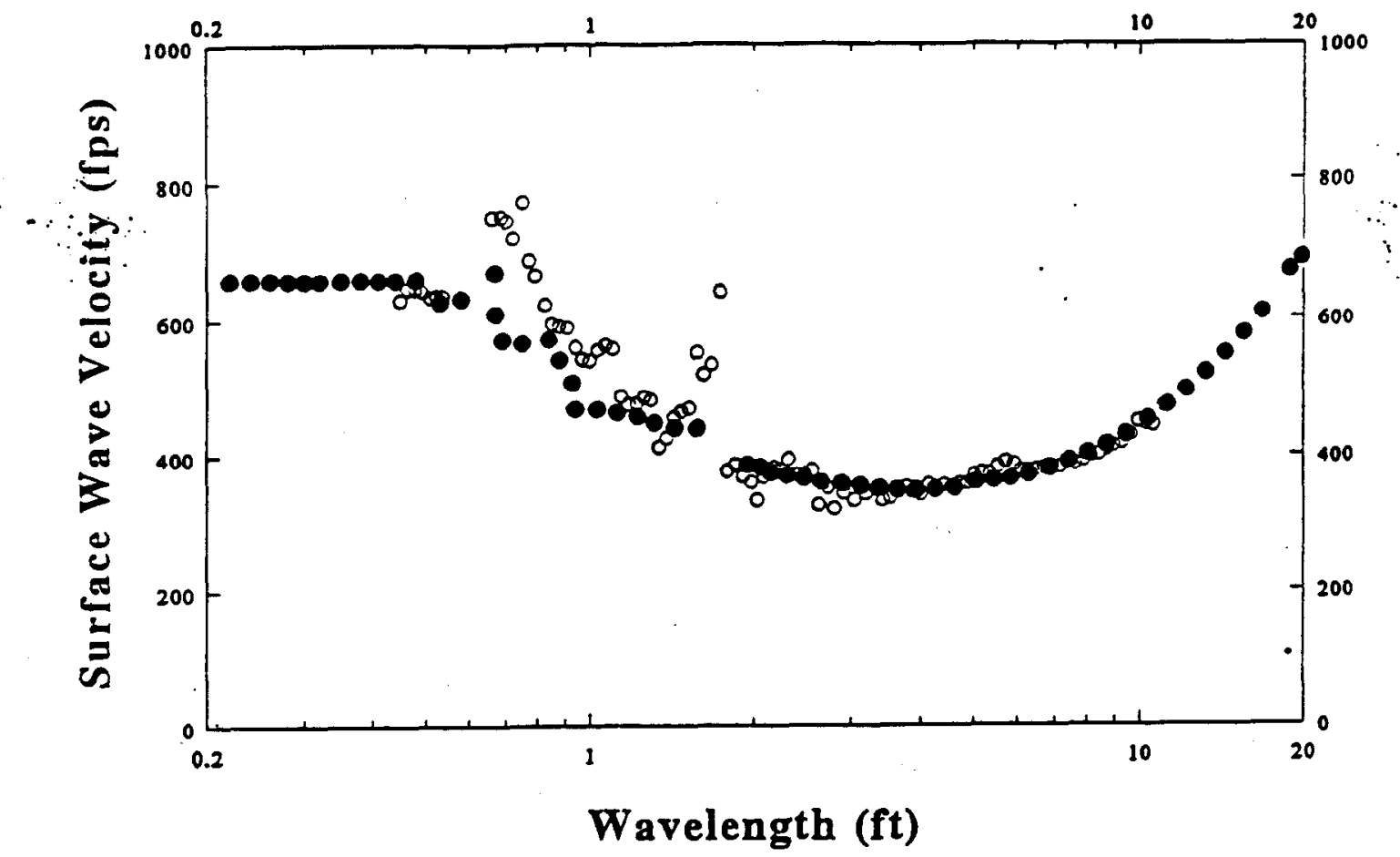

- Exp. Disp.

- 3-D Disp.

Shear Wave Velocity Profile

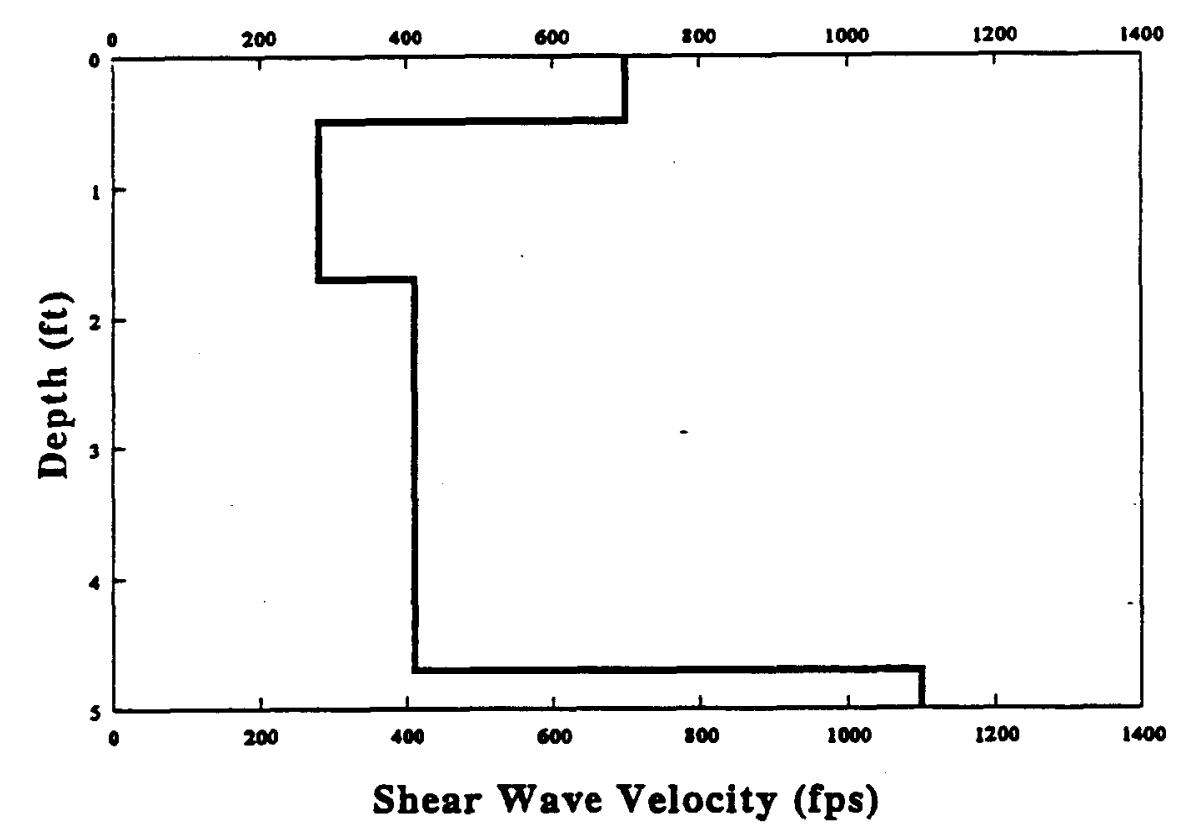

Dynamic Test Facility - Site 4 (East-West)

Fig. A-4 
Experimental and Theoretical Dispersions

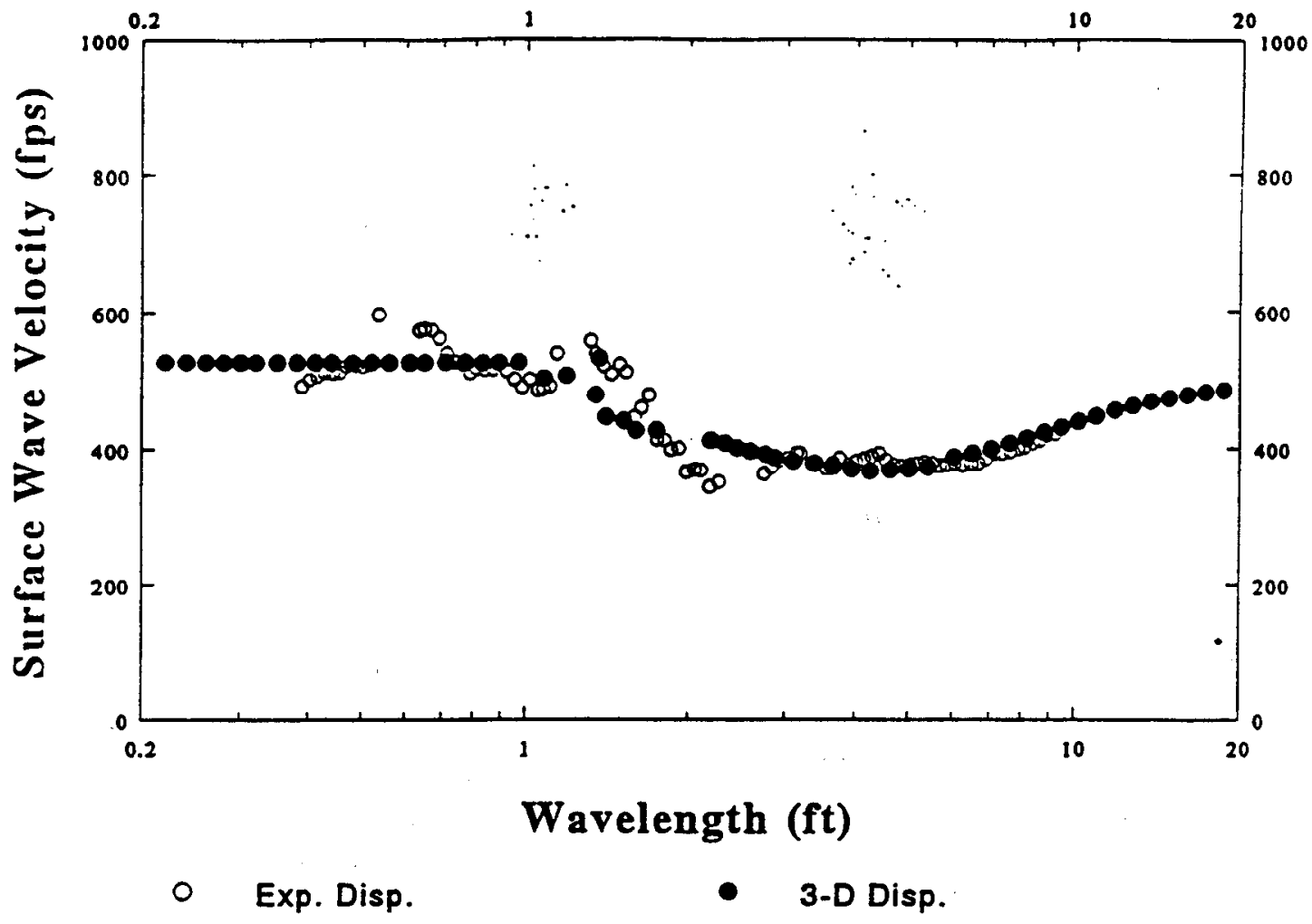

Shear Wave Velocity Profile

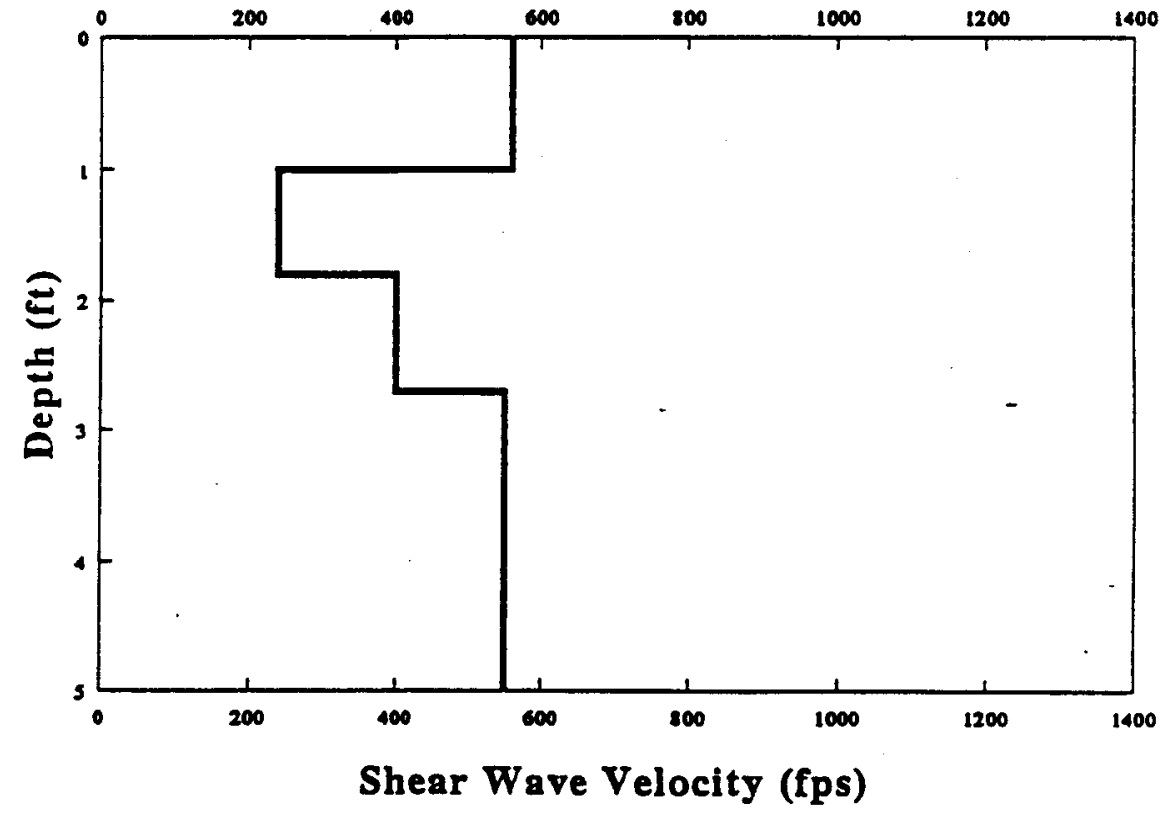

Job 205

Dynamic Test Facility - Site 5 (East-West)

Fig. A-5 
Experimental and Theoretical Dispersions

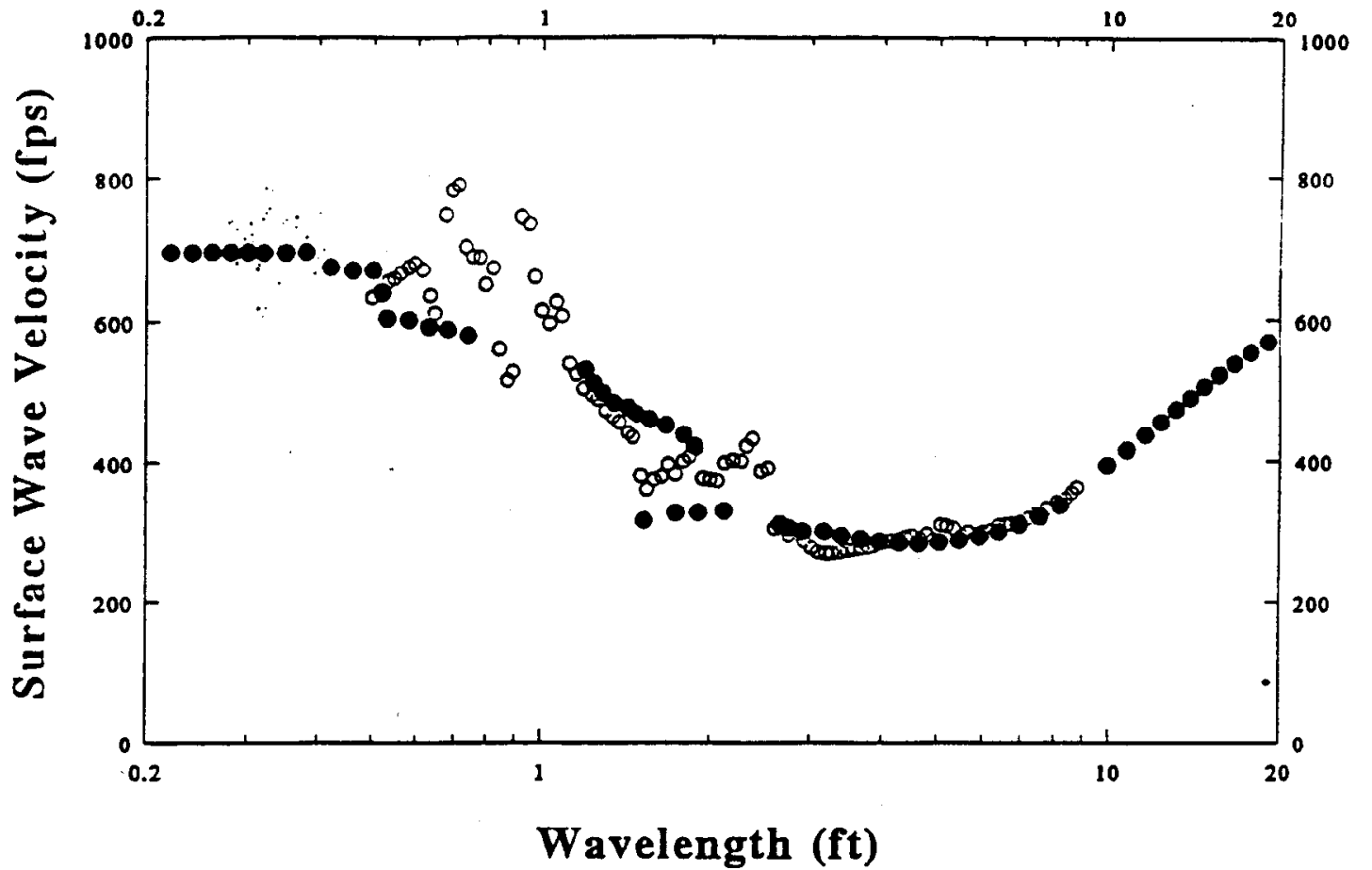

- Exp. Disp. $\quad$ 3-D Disp.

Shear Wave Velocity Profile

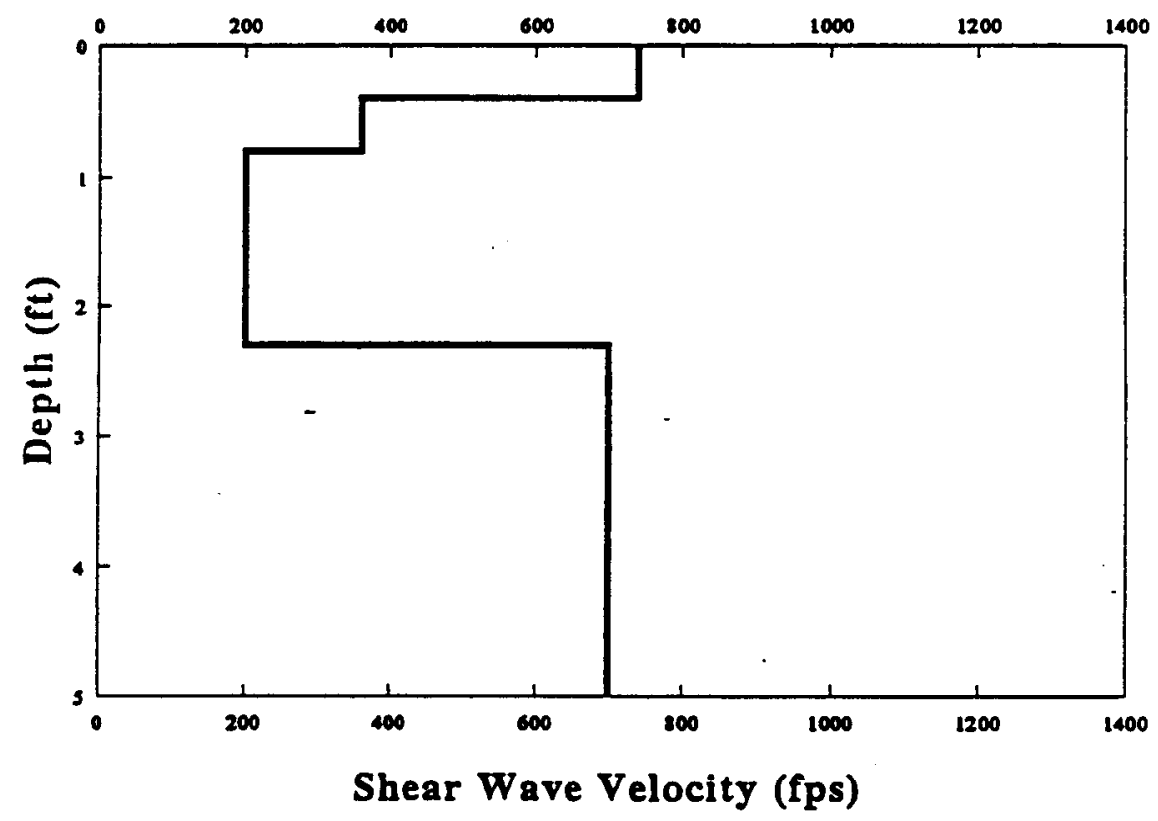

Job 205

Dynamic Test Facility - Site 6 (North - South)

Fig. A-6 
Experimental and Theoretical Dispersions

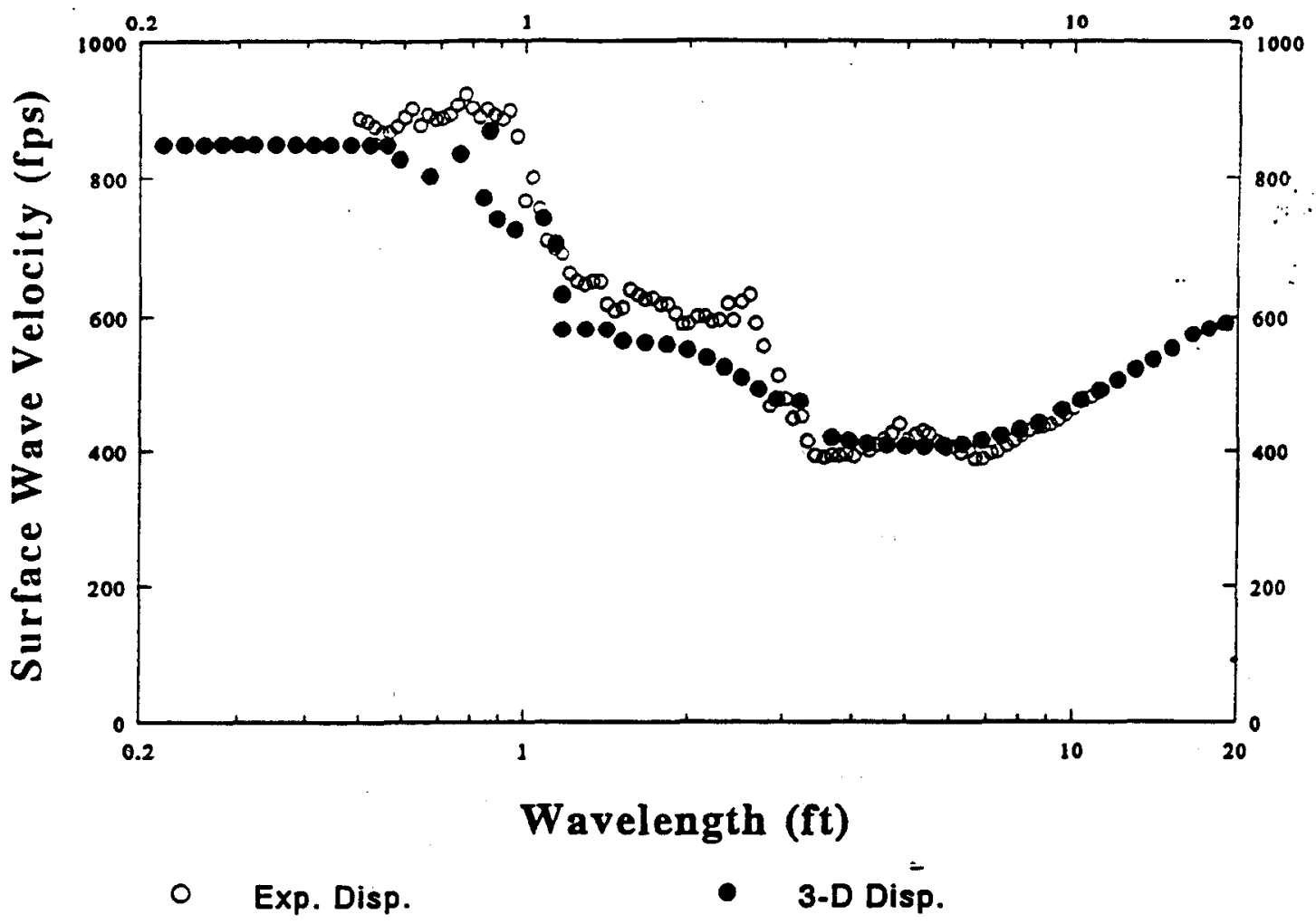

Shear Wave Velocity Profile

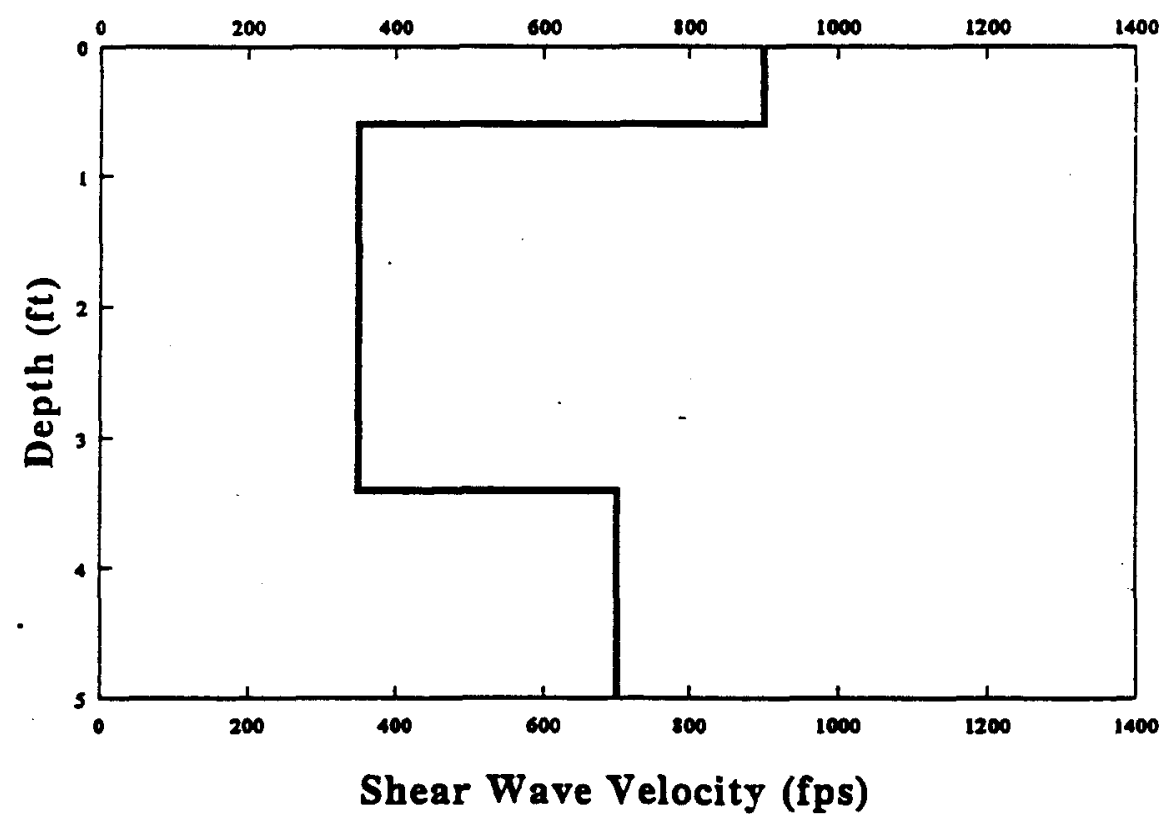

Job 205

Dynamic Test Facility - Site 7 (East-West)

Fig. A-7 
Experimental and Theoretical Dispersions

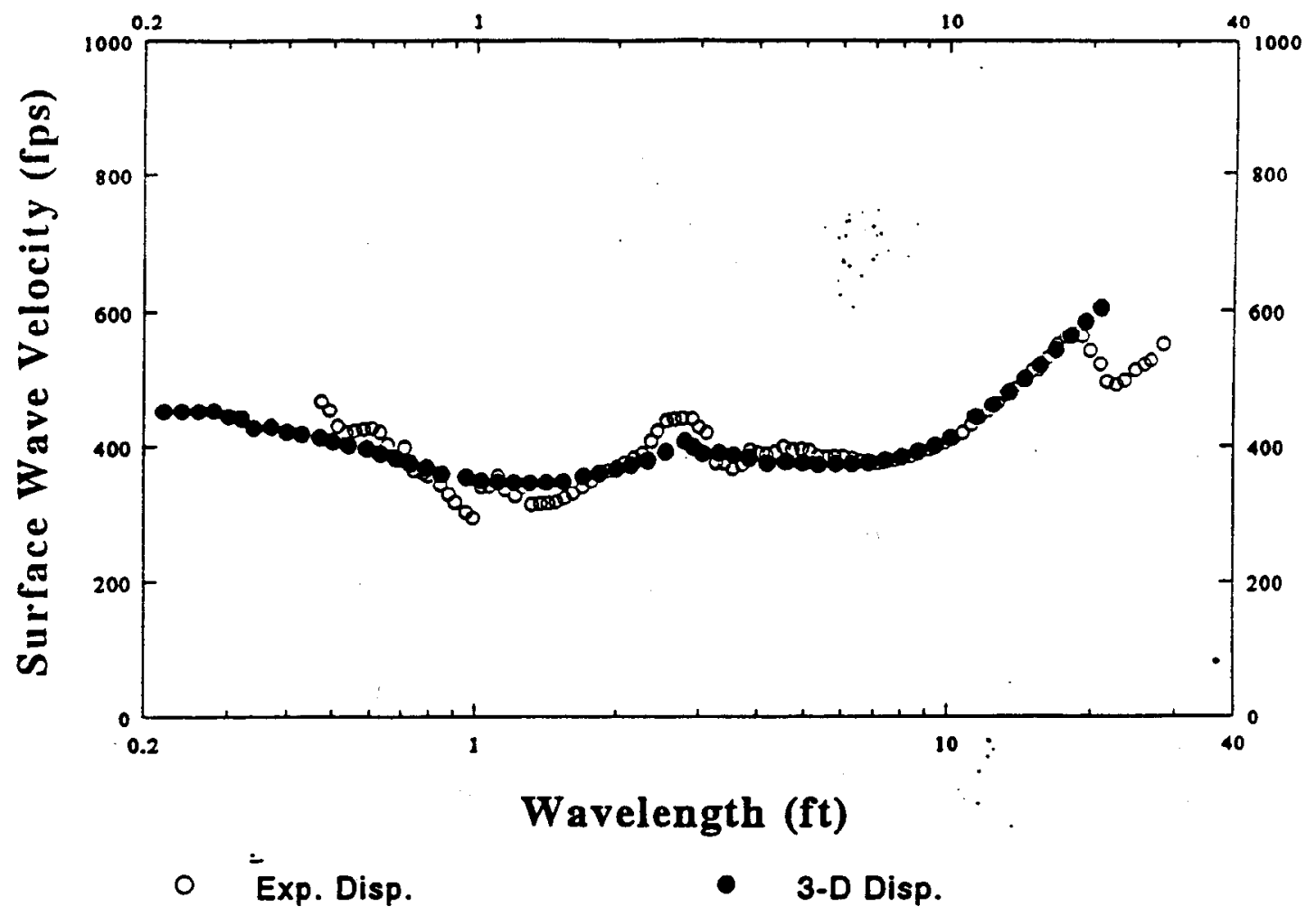

Shear Wave Velocity Profile

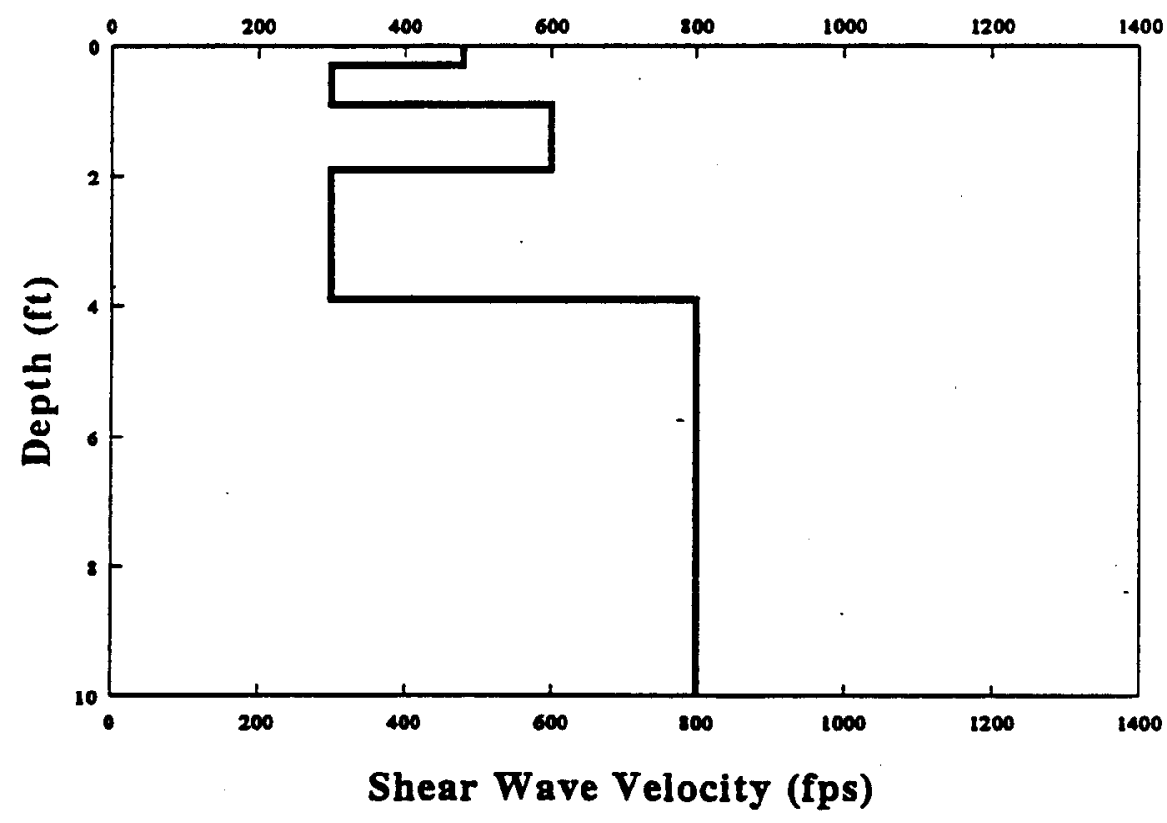

Job 205

Dynamic Test Facility - Site 8 (North - South) Profile Depth $<10 \mathrm{ft}$

Fig. A-8 


\section{Experimental and Theoretical Dispersions}

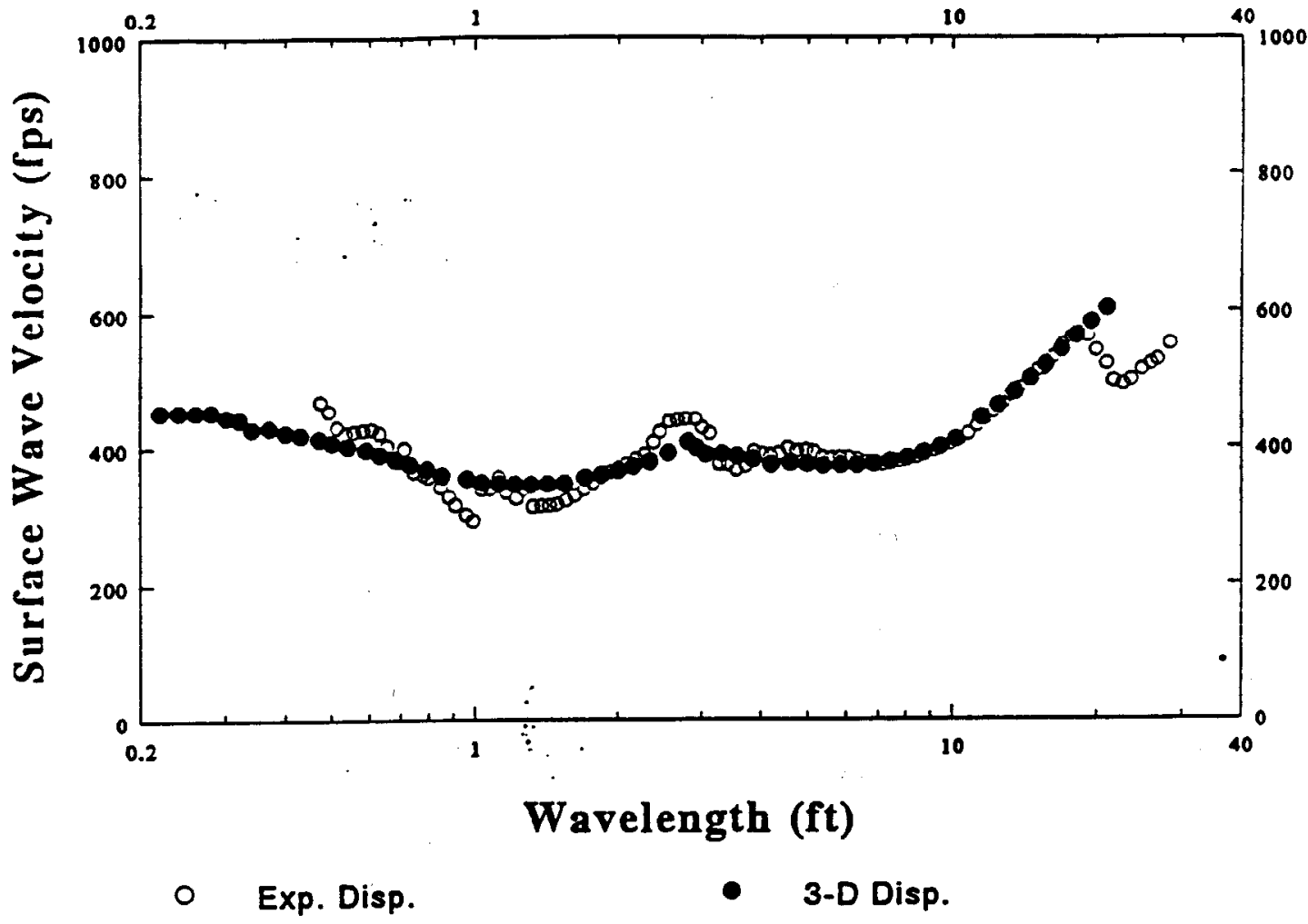

Shear Wave Velocity Profile

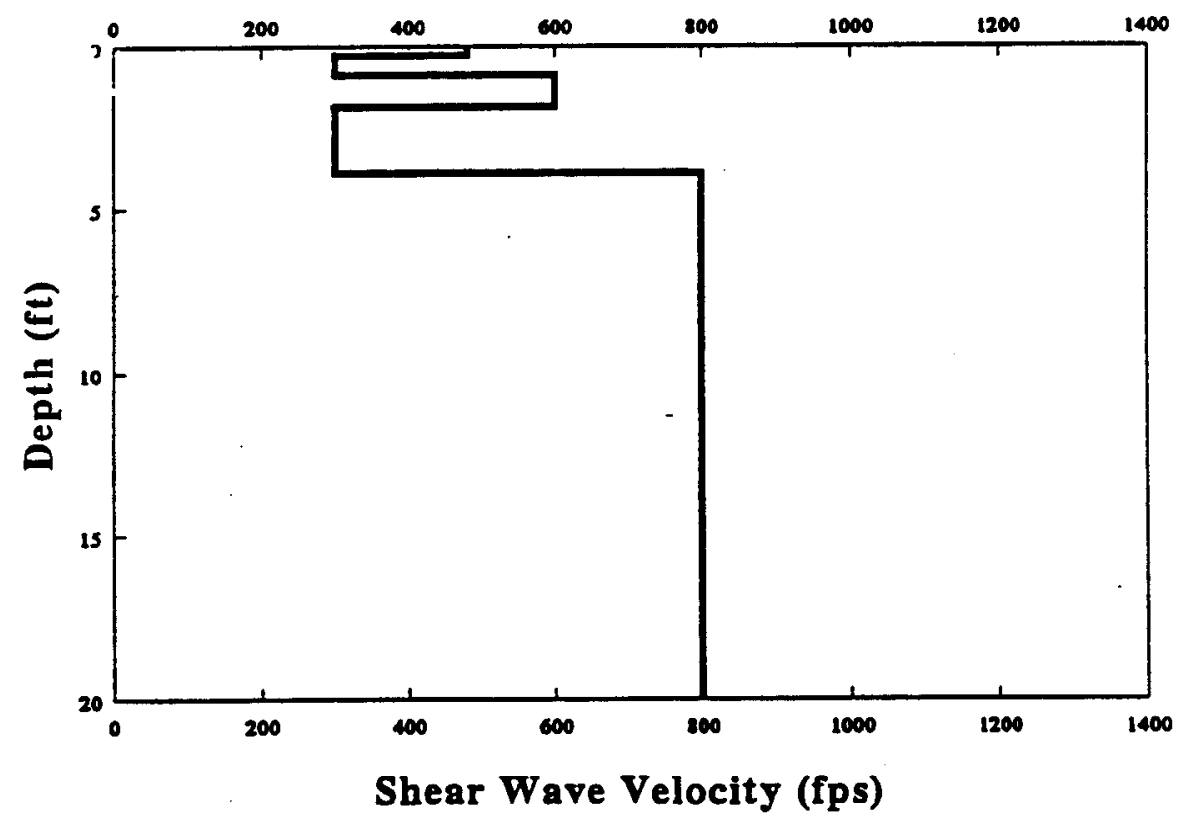

Job 205

Dynamic Test Facility - Site 8 (North - South) Profile Depth $<20 \mathrm{ft}$

Fig. A-9 
Experimental and Theoretical Dispersions
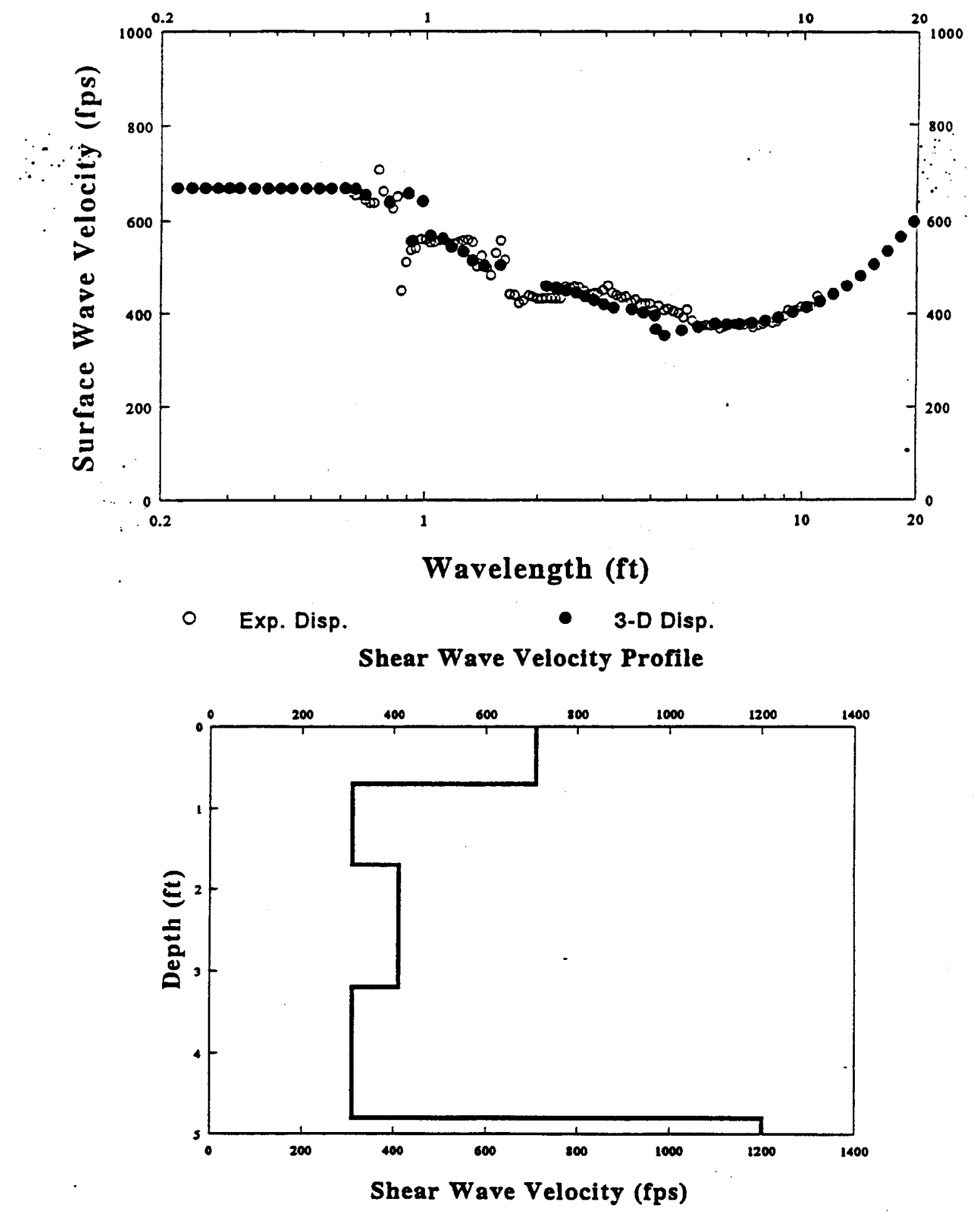

Job 205

Dynamic Test Facility - Site 9 (East - West)

Fig. $A-10$ 
Experimental and Theoretical Dispersions

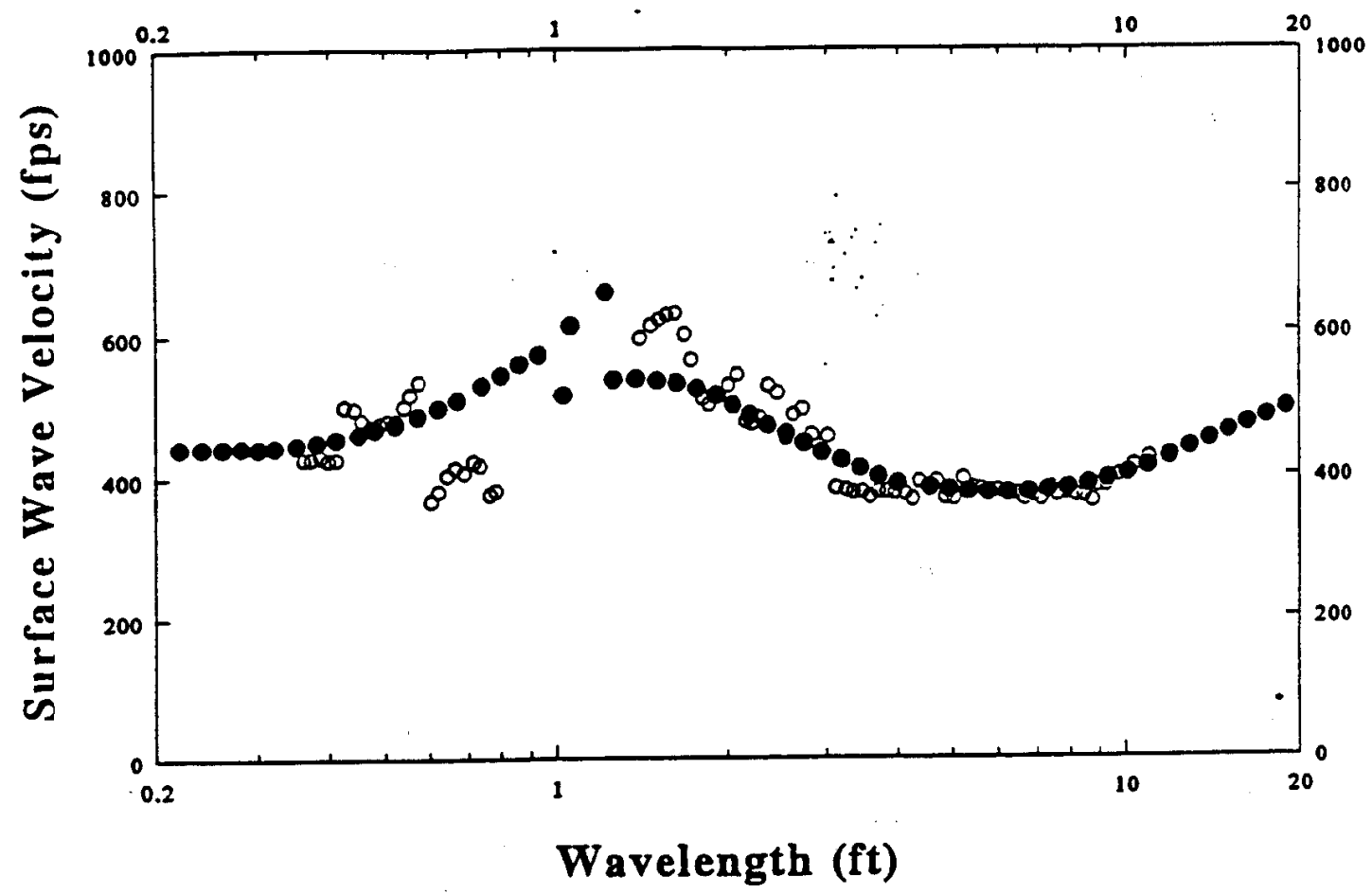

- Exp. Disp.

- 3-D Disp.

Shear Wave Velocity Profile

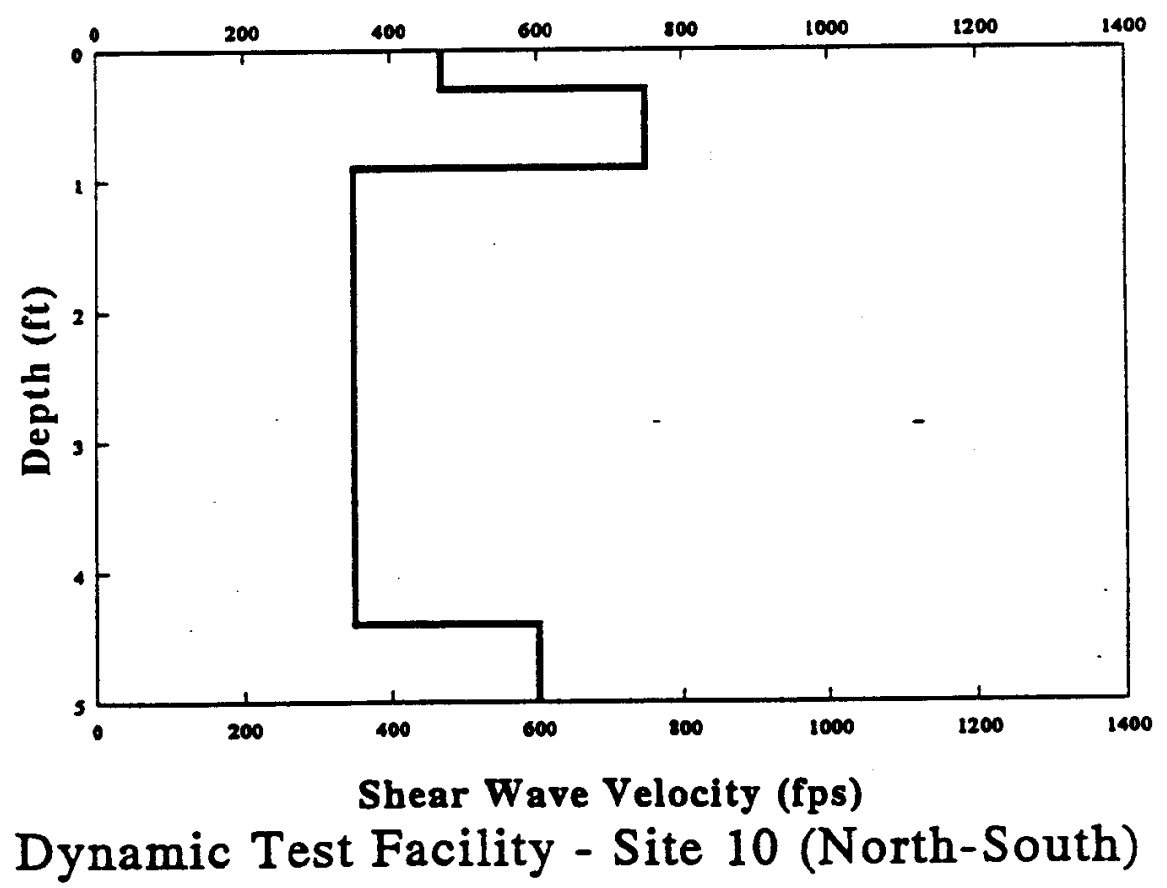

Job 205

Fig. A-11 
Experimental and Theoretical Dispersions

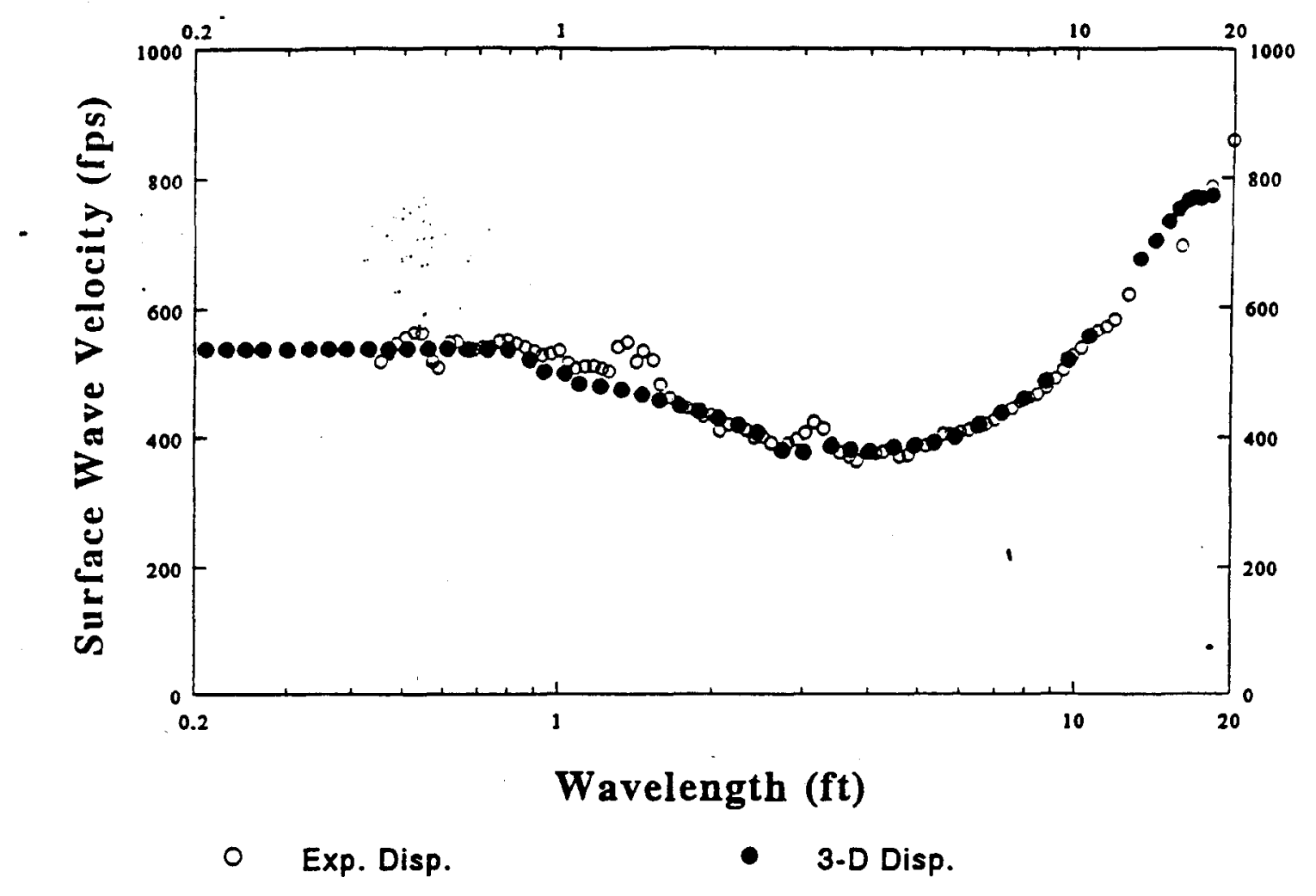

Shear Wave Velocity Profile

Job 205

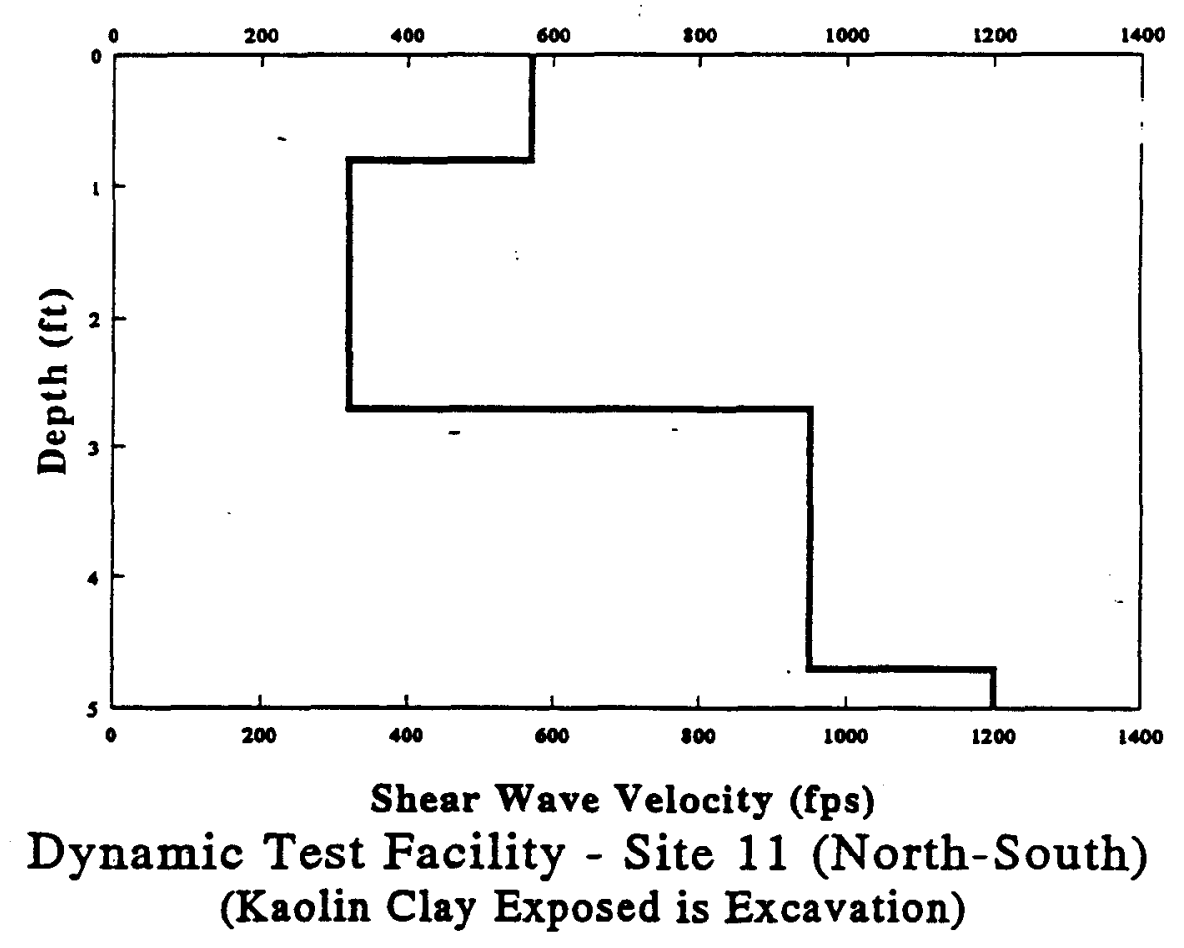

Fig. A-12 


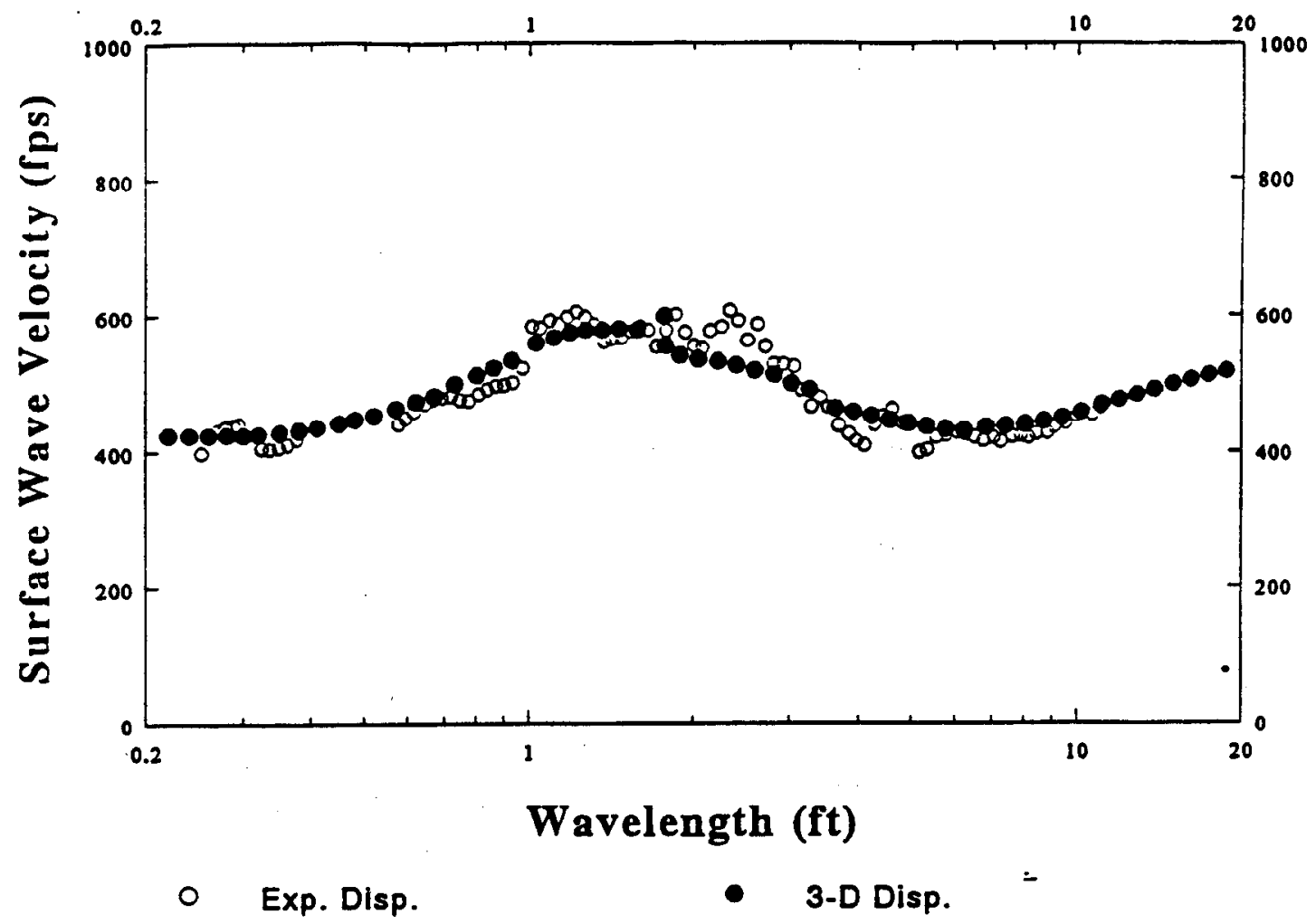

Shear Wave Velocity Profile

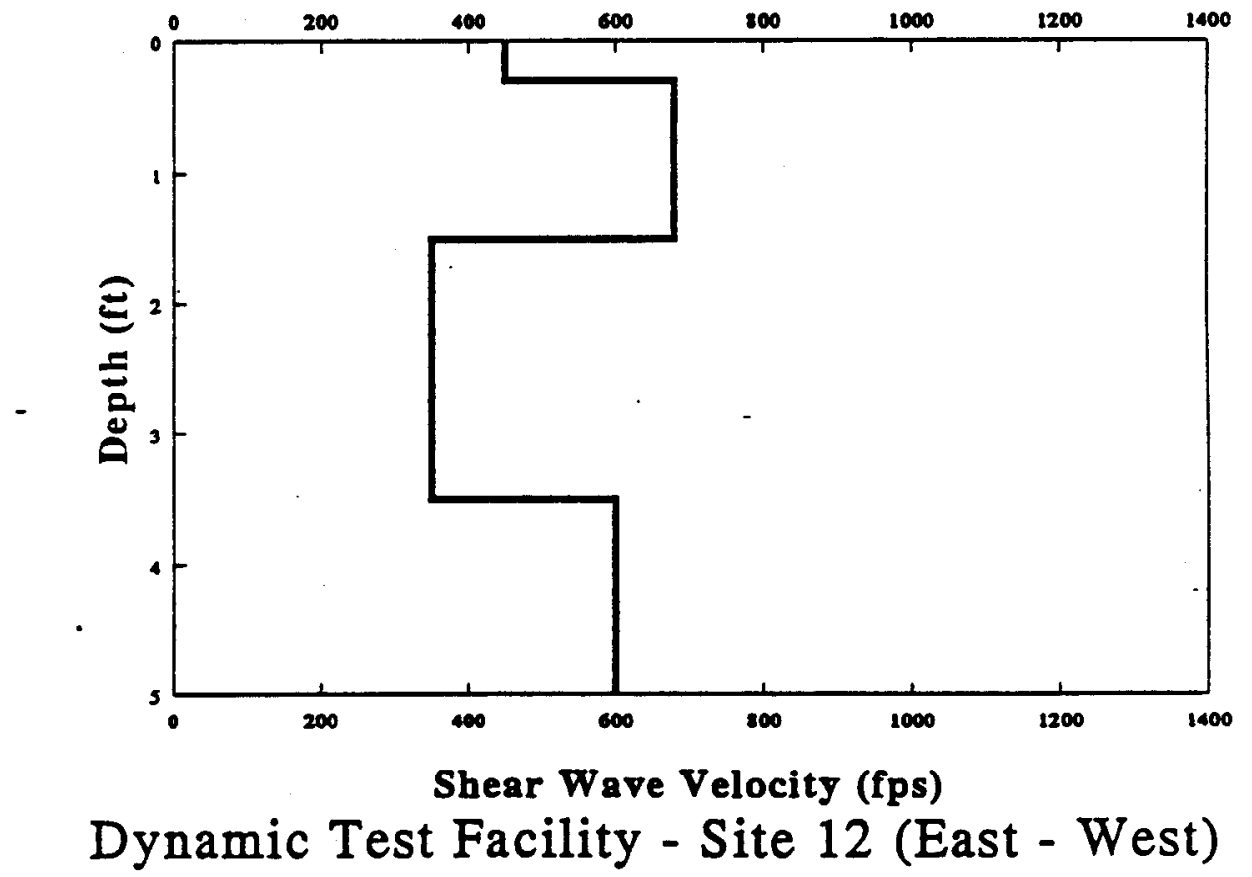

Job 205

Fig. $A-13$ 
Experimental and Theoretical Dispersions

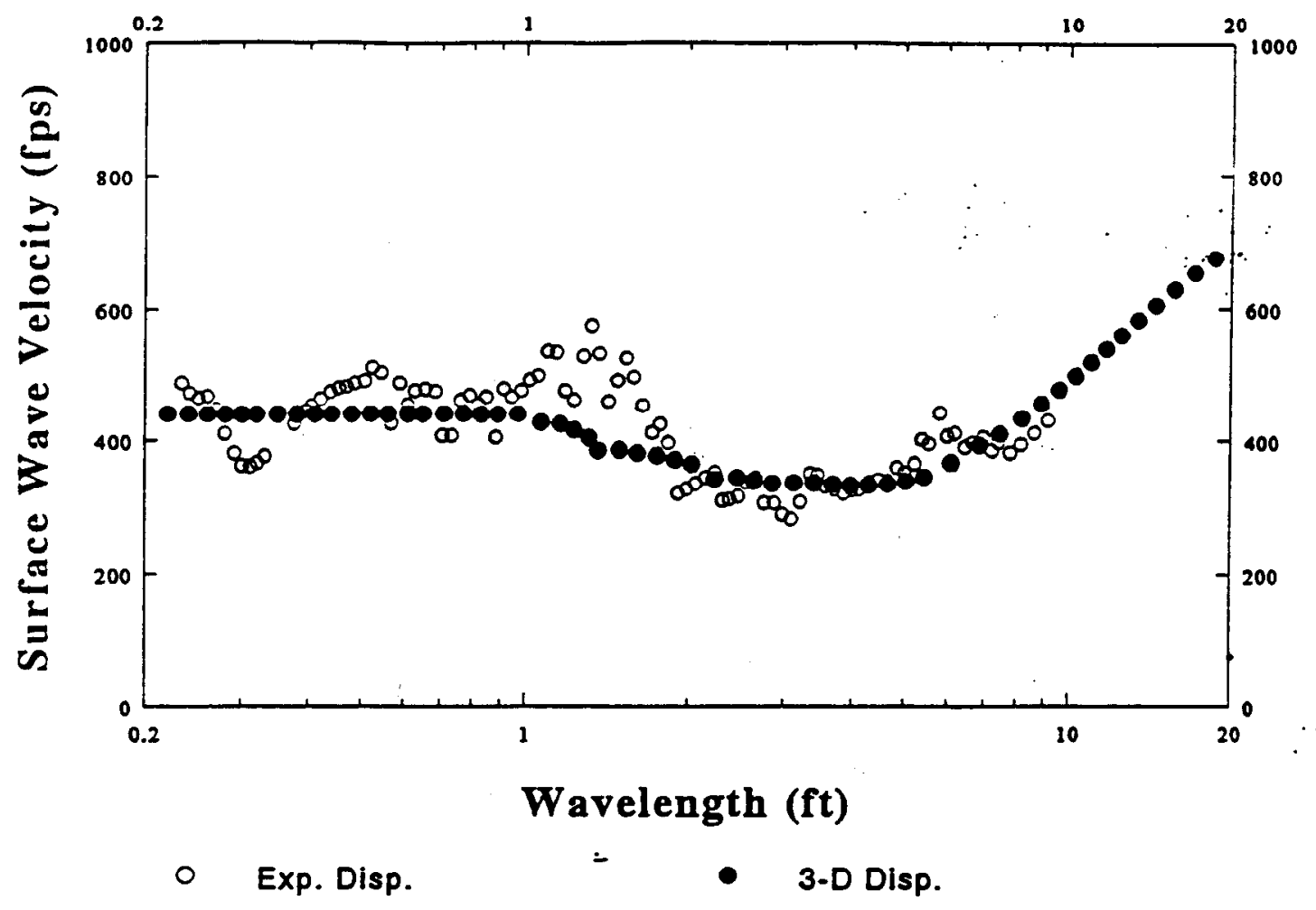

Shear Wave Velocity Profile

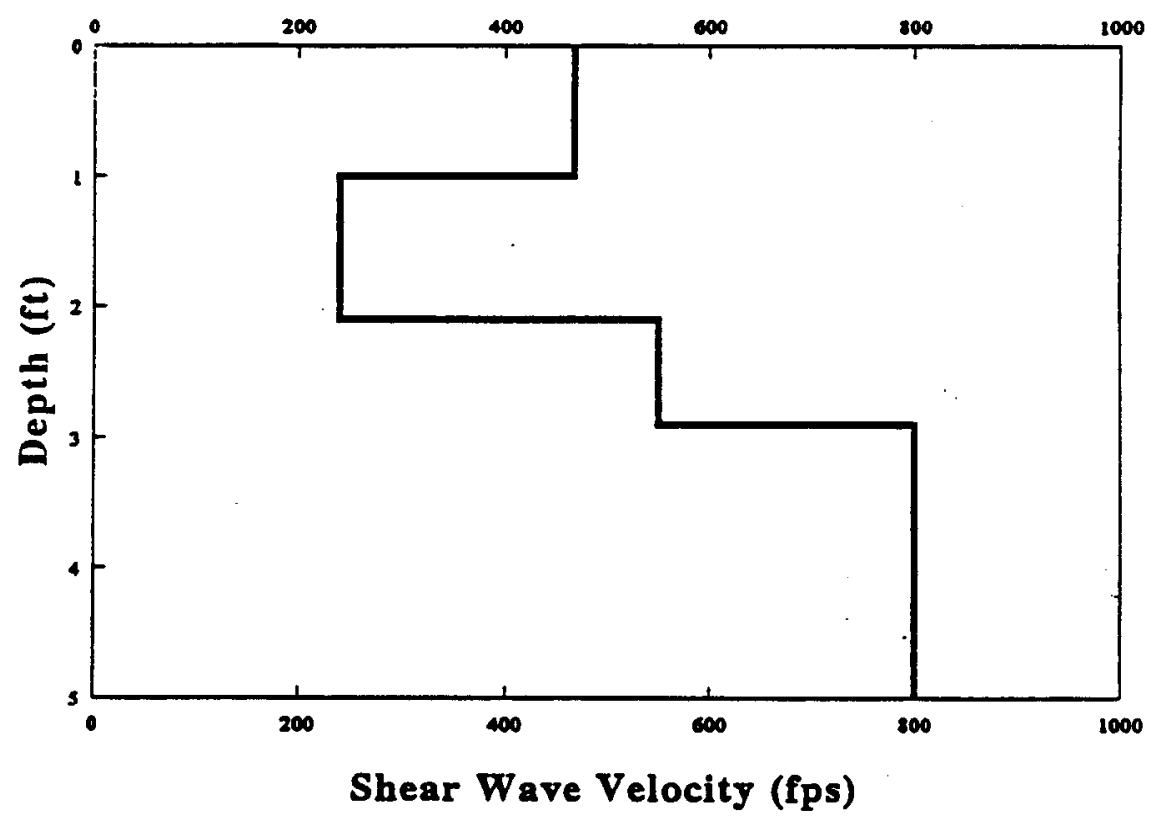

Job 205

Dynamic Test Facility - Site 13 (North-South)

Fig. A-14 
Experimental and Theoretical Dispersions

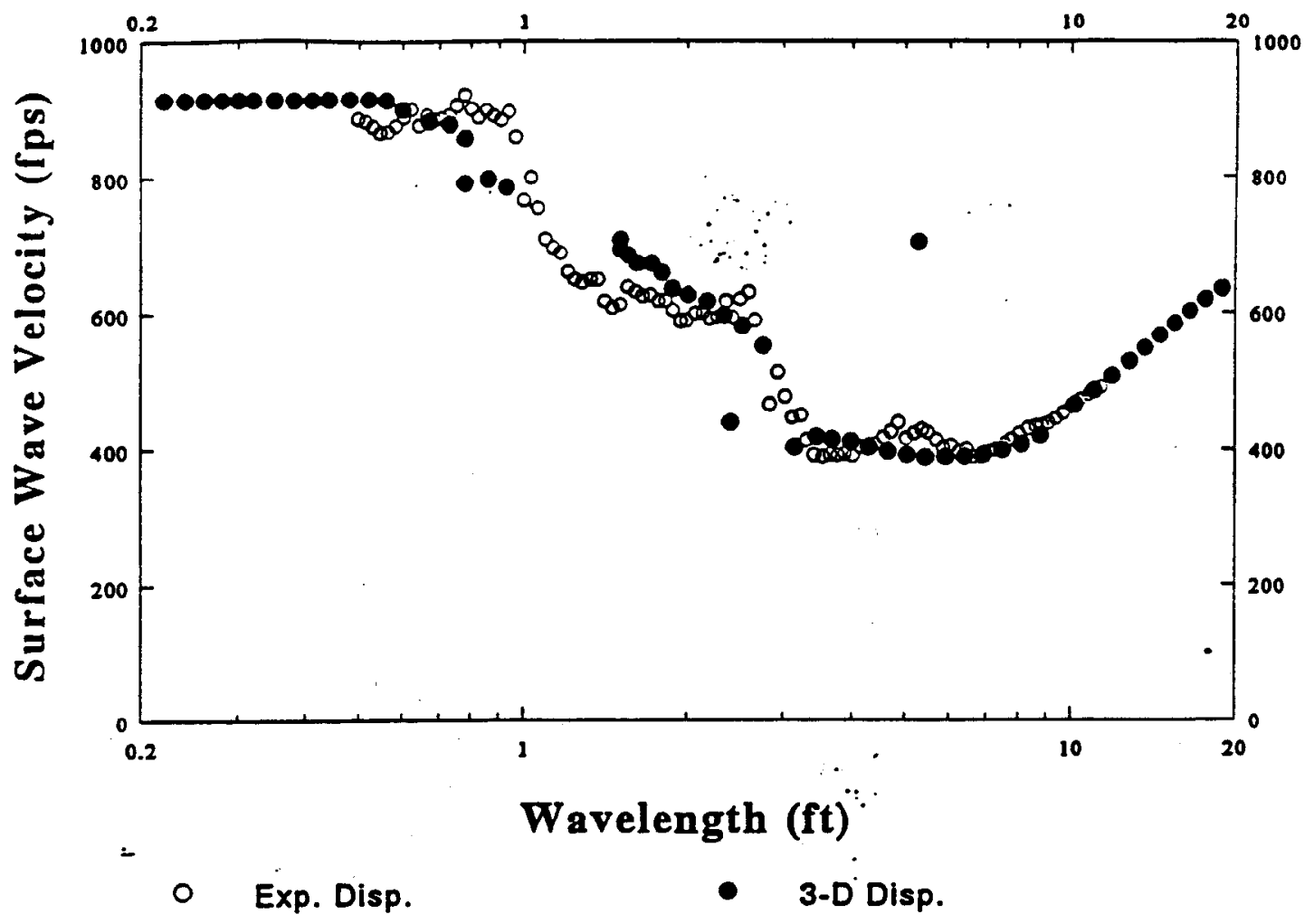

Shear Wave Velocity Profile

Job 205

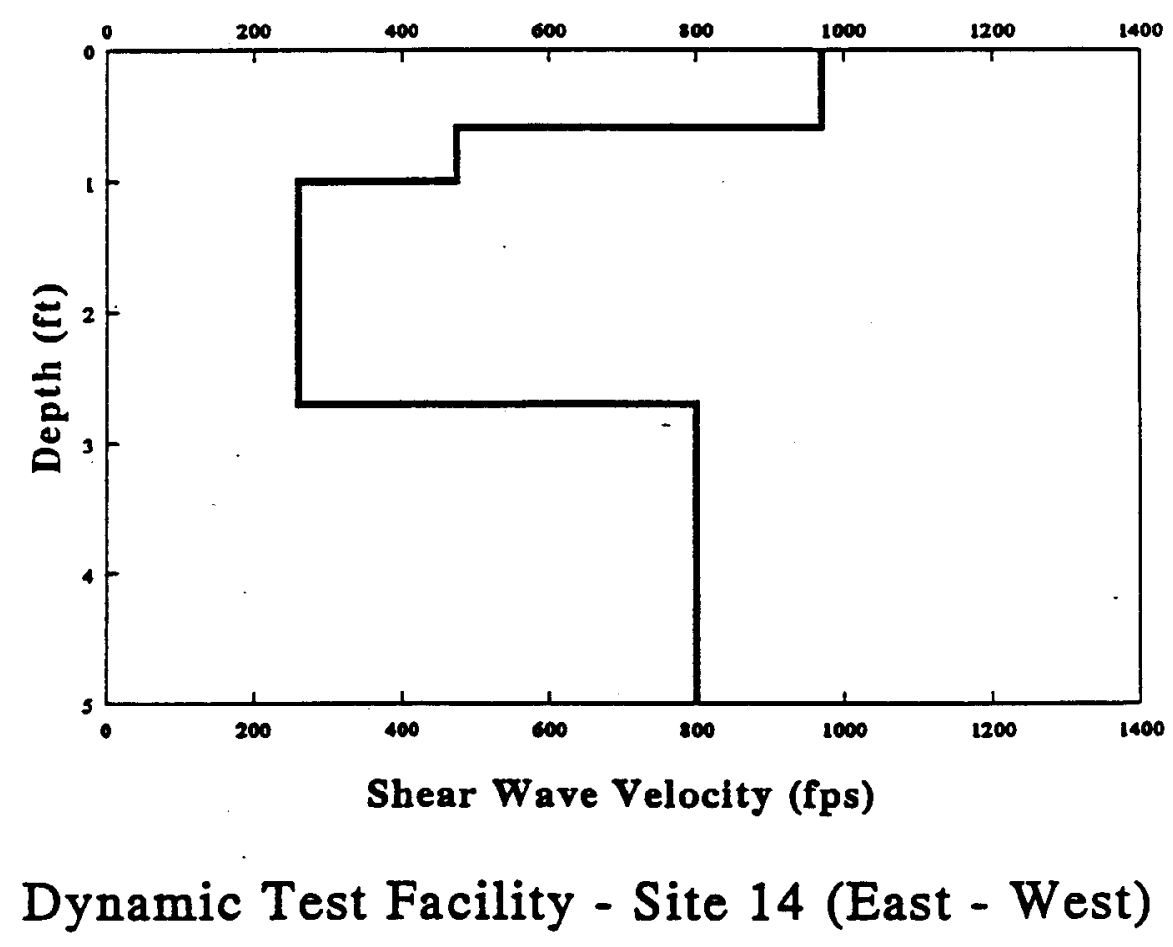

Fig. A-15 
Experimental and Theoretical Dispersions

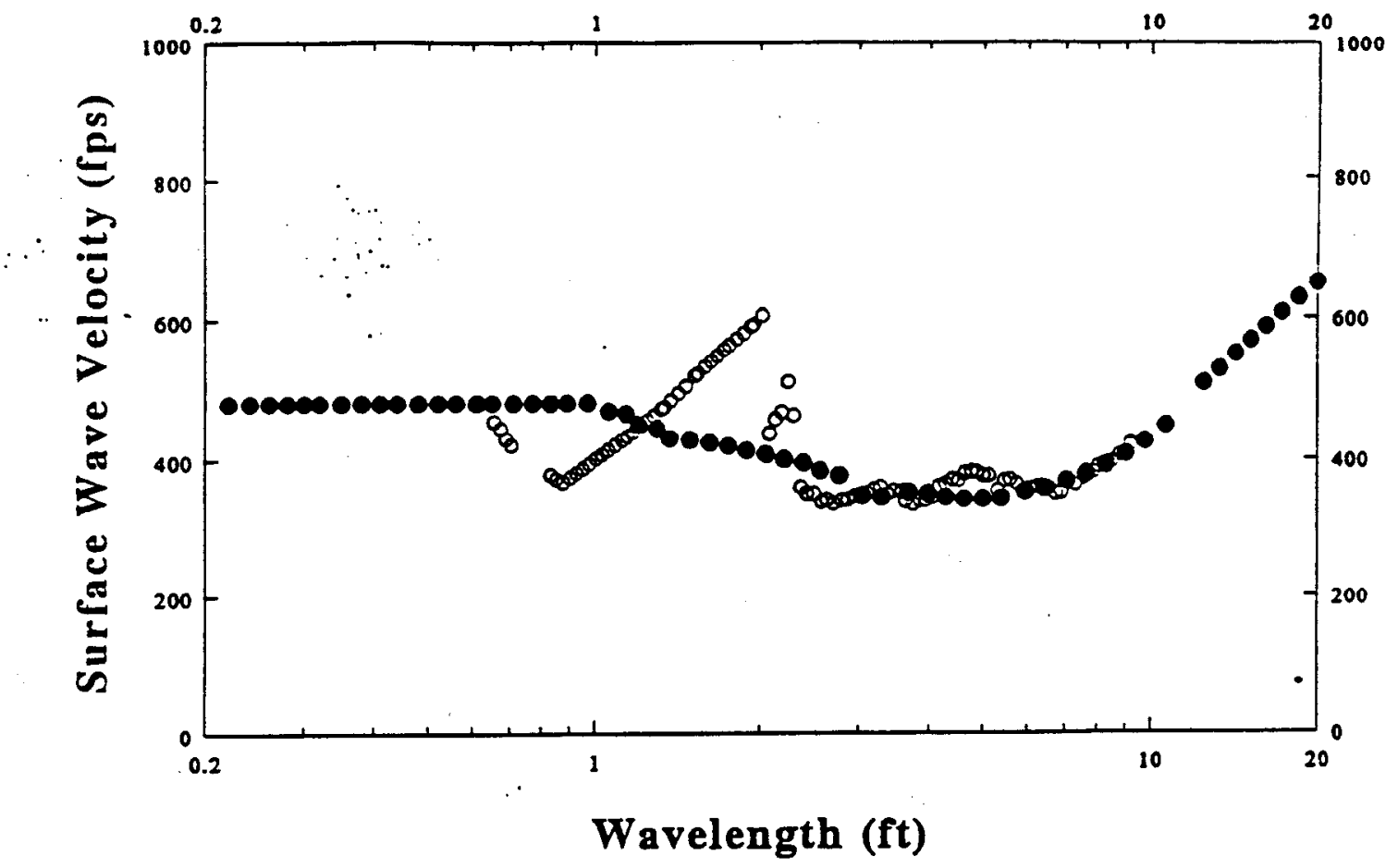

- Exp. Disp.

- 3-D Disp.

Shear Wave Velocity Profile

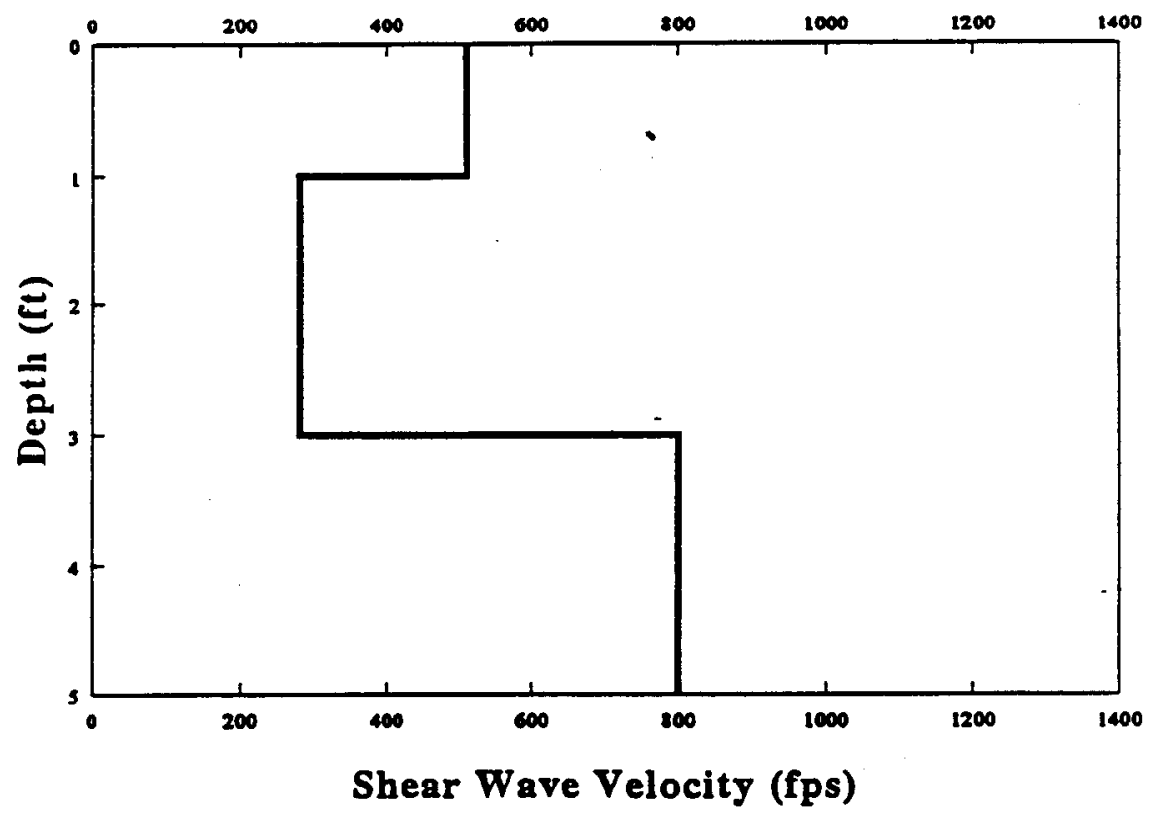

Job 205

Dynamic Test Facility - Site 15 (North - South)

Fig. A-16 


\section{Experimental and Theoretical Dispersions}

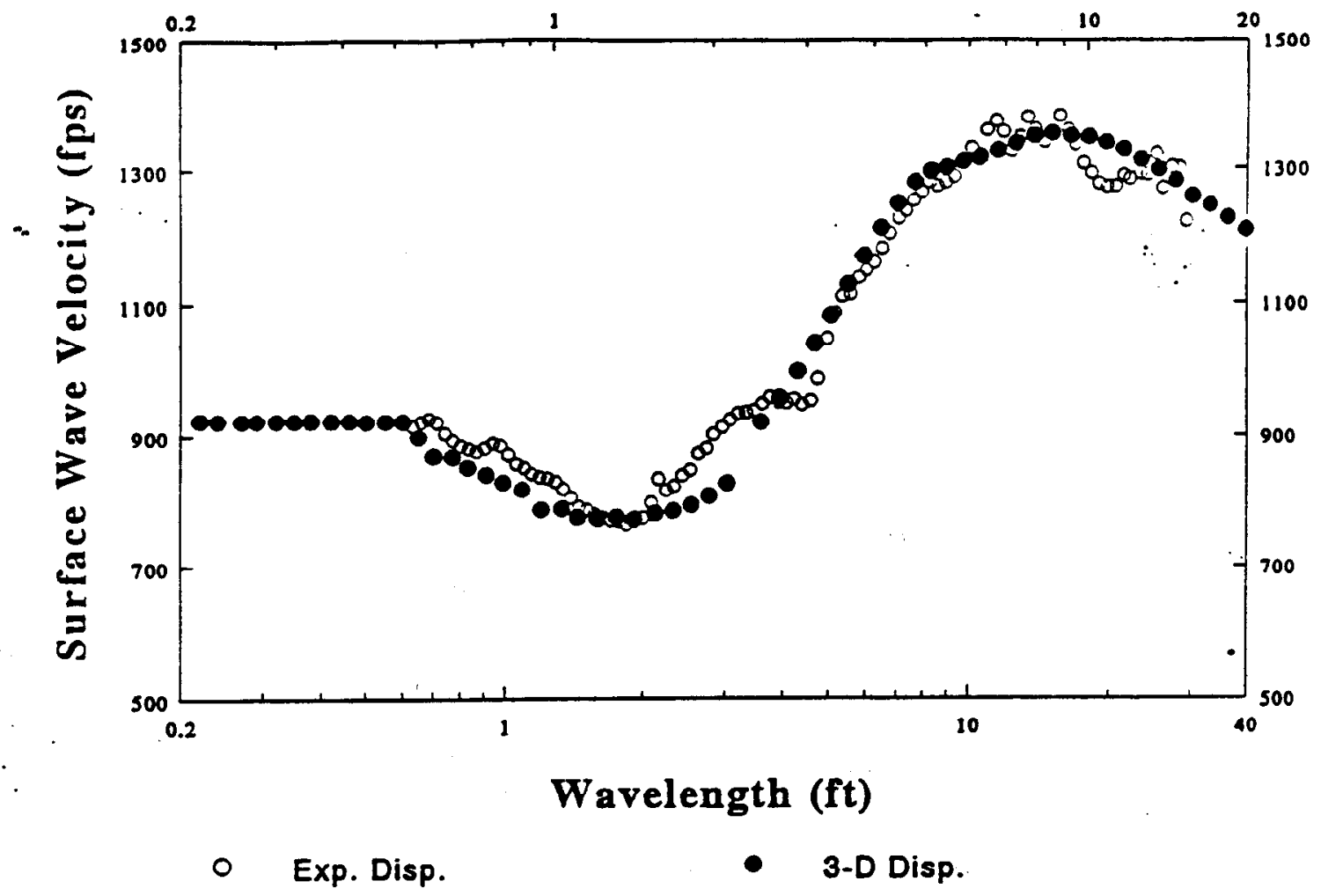

Shear Wave Velocity Profile

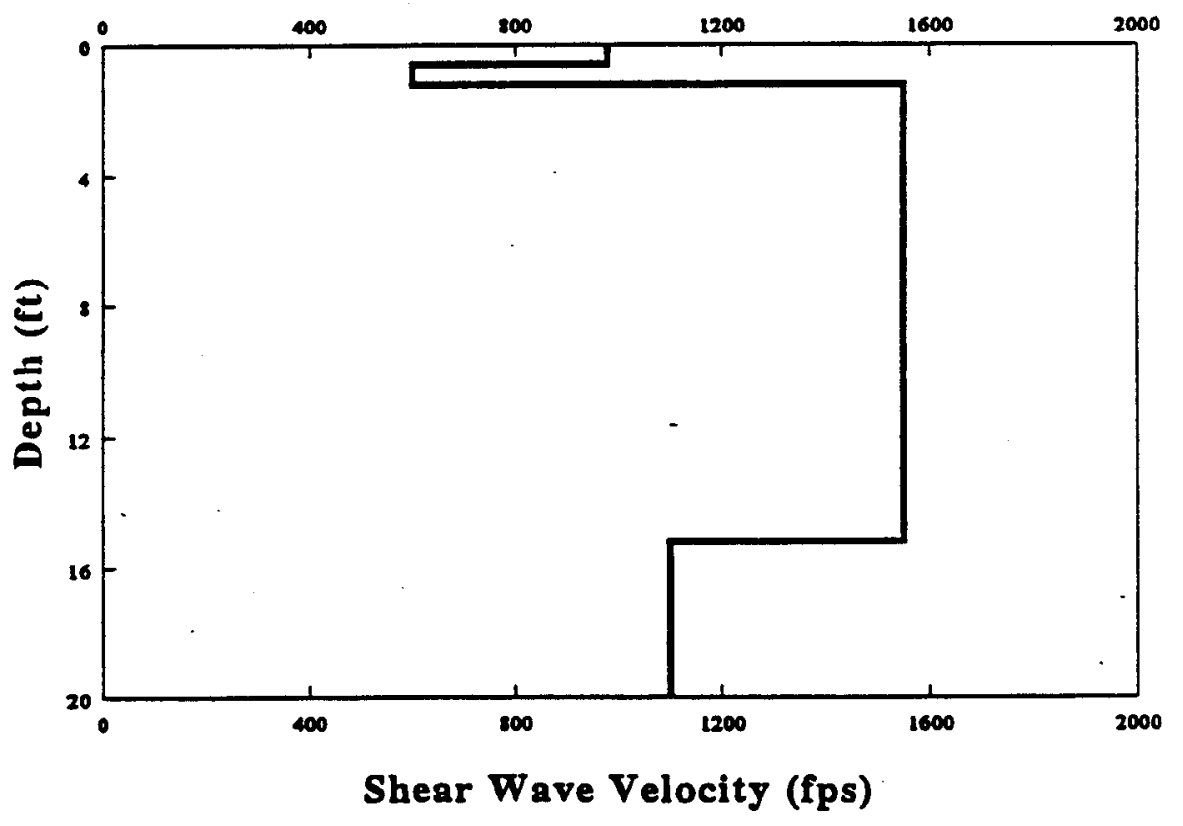

Dynamic Test Facility - Natural Ground Station 8 (East - West)

Fig. A-17 
Experimental and Theoretical Dispersions

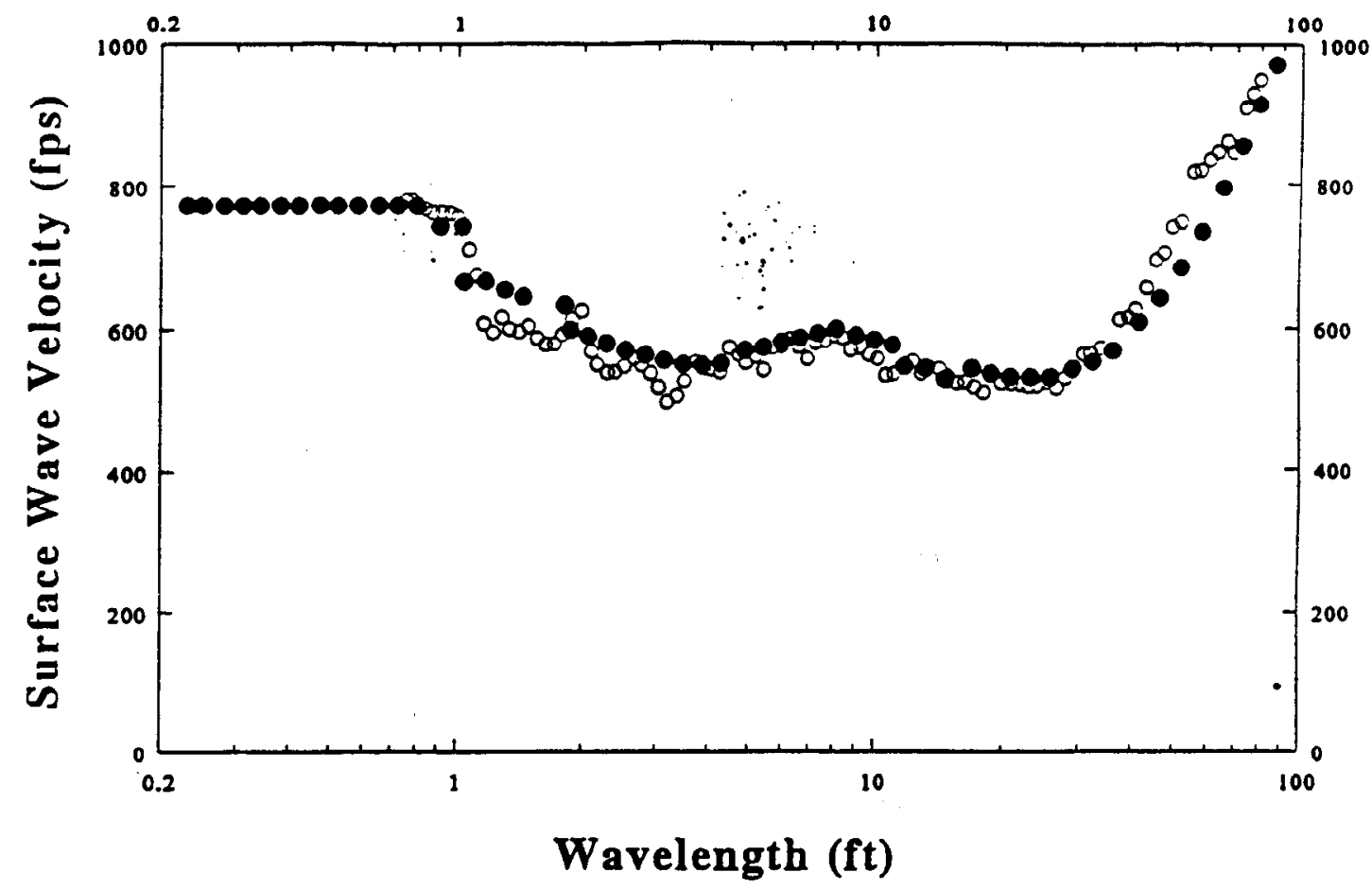

- Exp. Disp.

- 3-D Disp.

Shear Wave Velocity Profile

Job 205

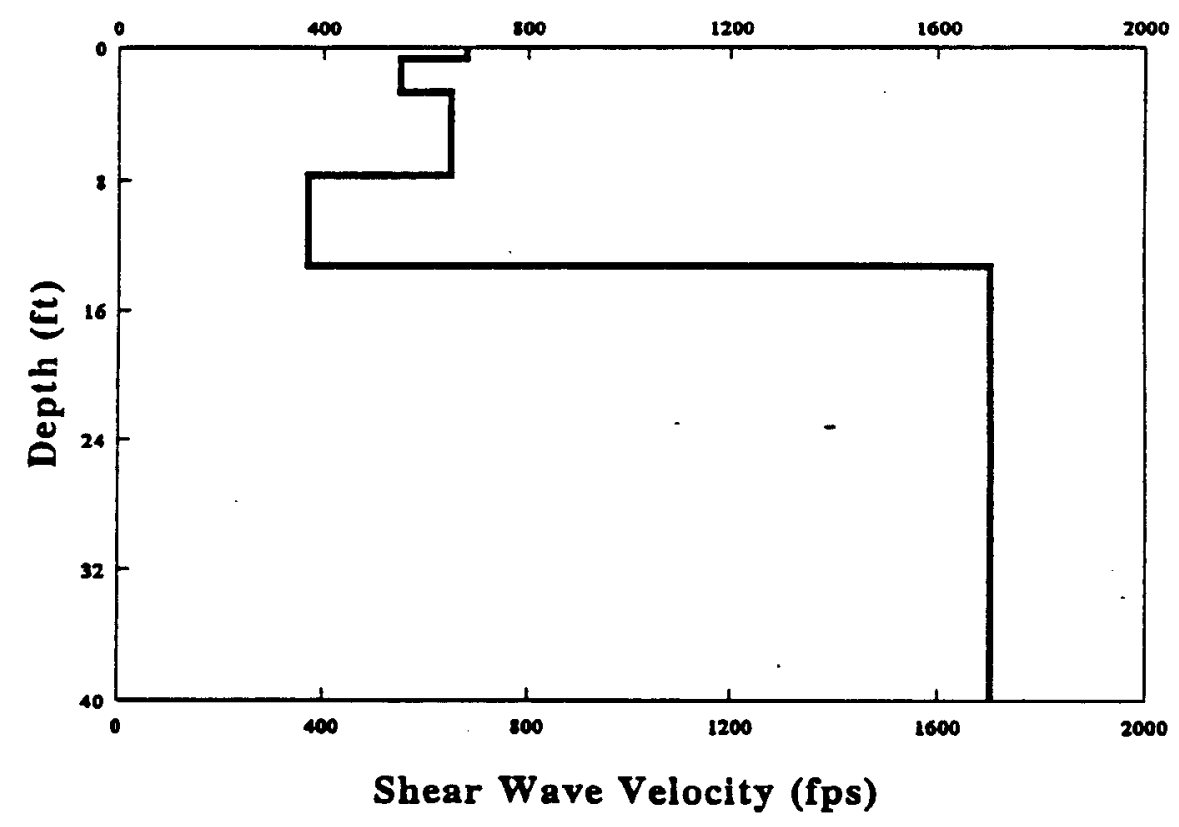

Boxes: Center (North-South)

Fig. A-18 


\section{Experimental and Theoretical Dispersions}

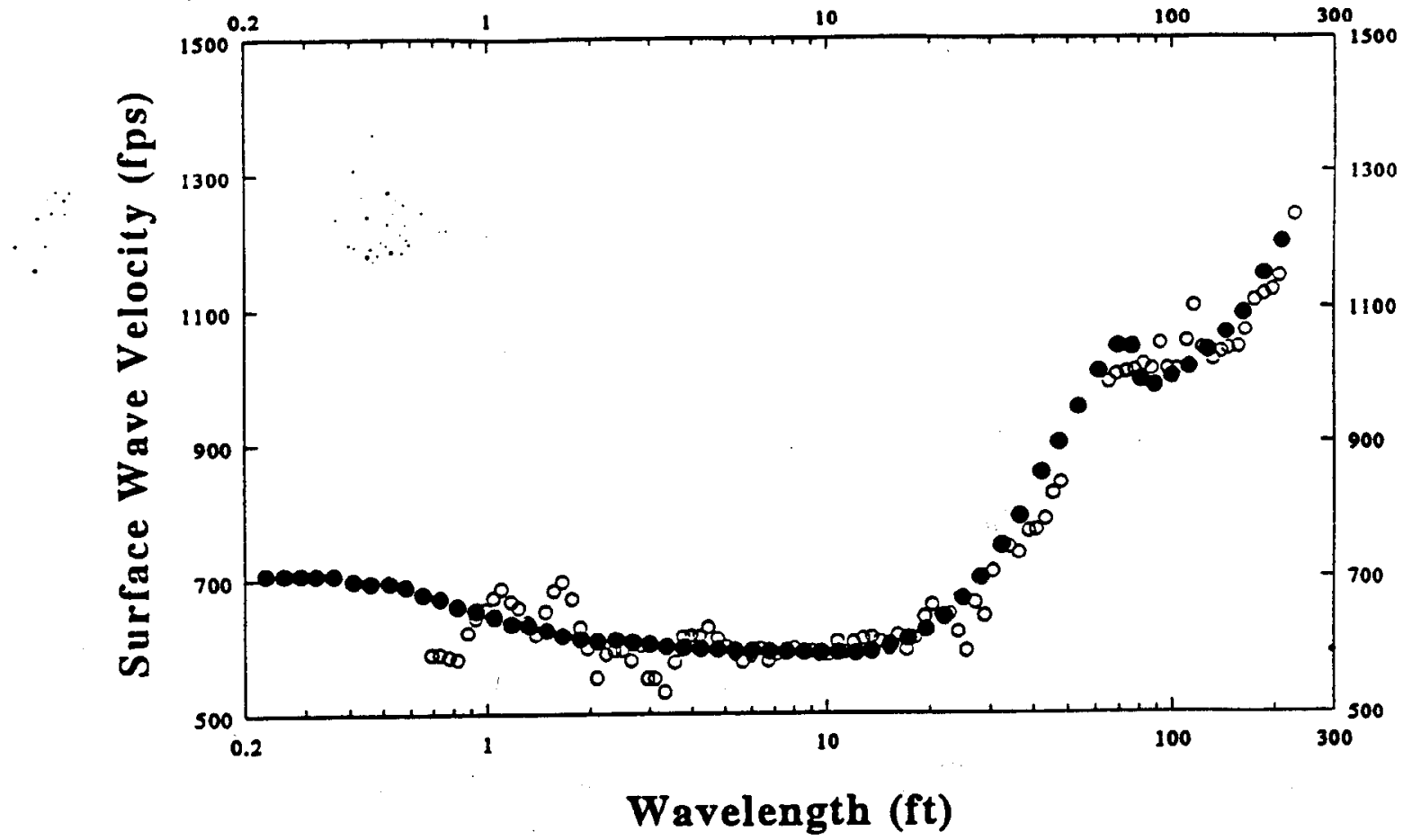

$\circ$ Exp. Disp. $\quad$ 3-D Disp.

Shear Wave Velocity Profile

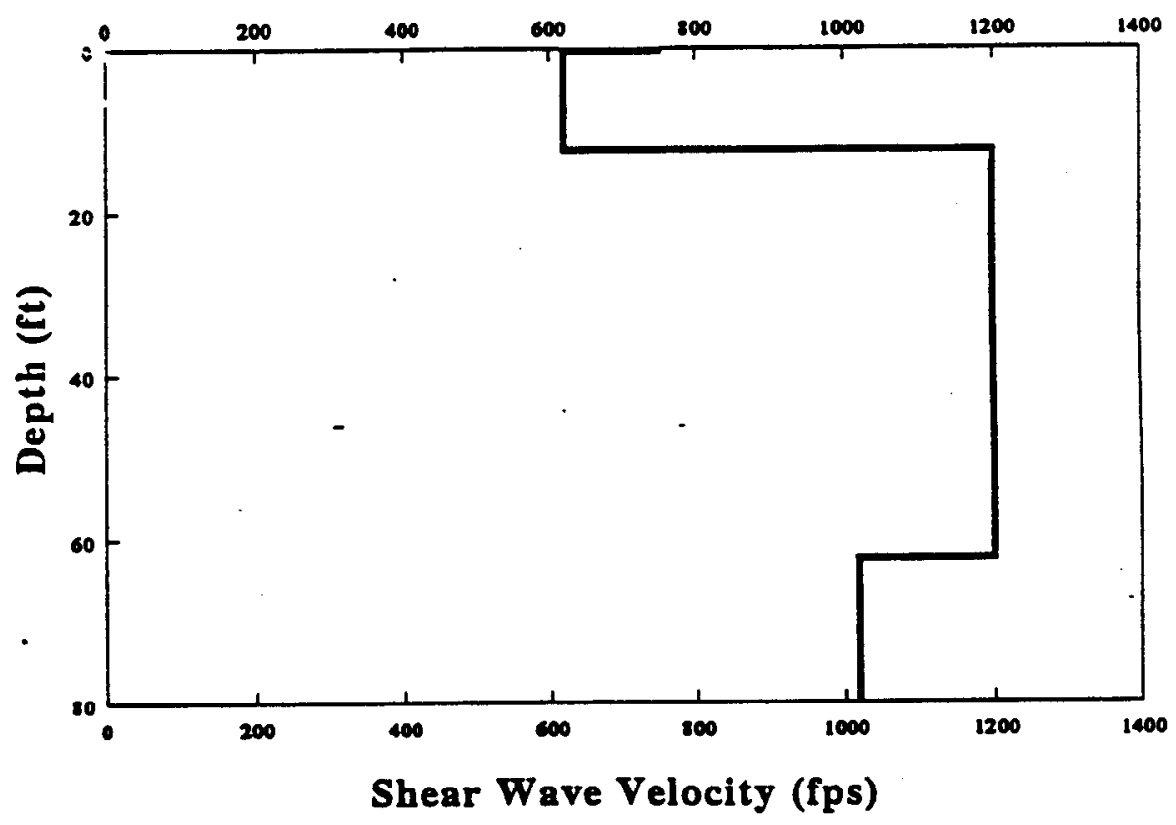

Job 205

Boxes: South Side (North-South)

Fig. A-19 
APPENDIX B

MIXED WASTE MANAGEMENT FACIITYY

SASW DISPERSIONS

AND SHEAR WAVE

VEIOCITY PROFILES

Job No. 205 
Experimental and Theoretical Dispersions
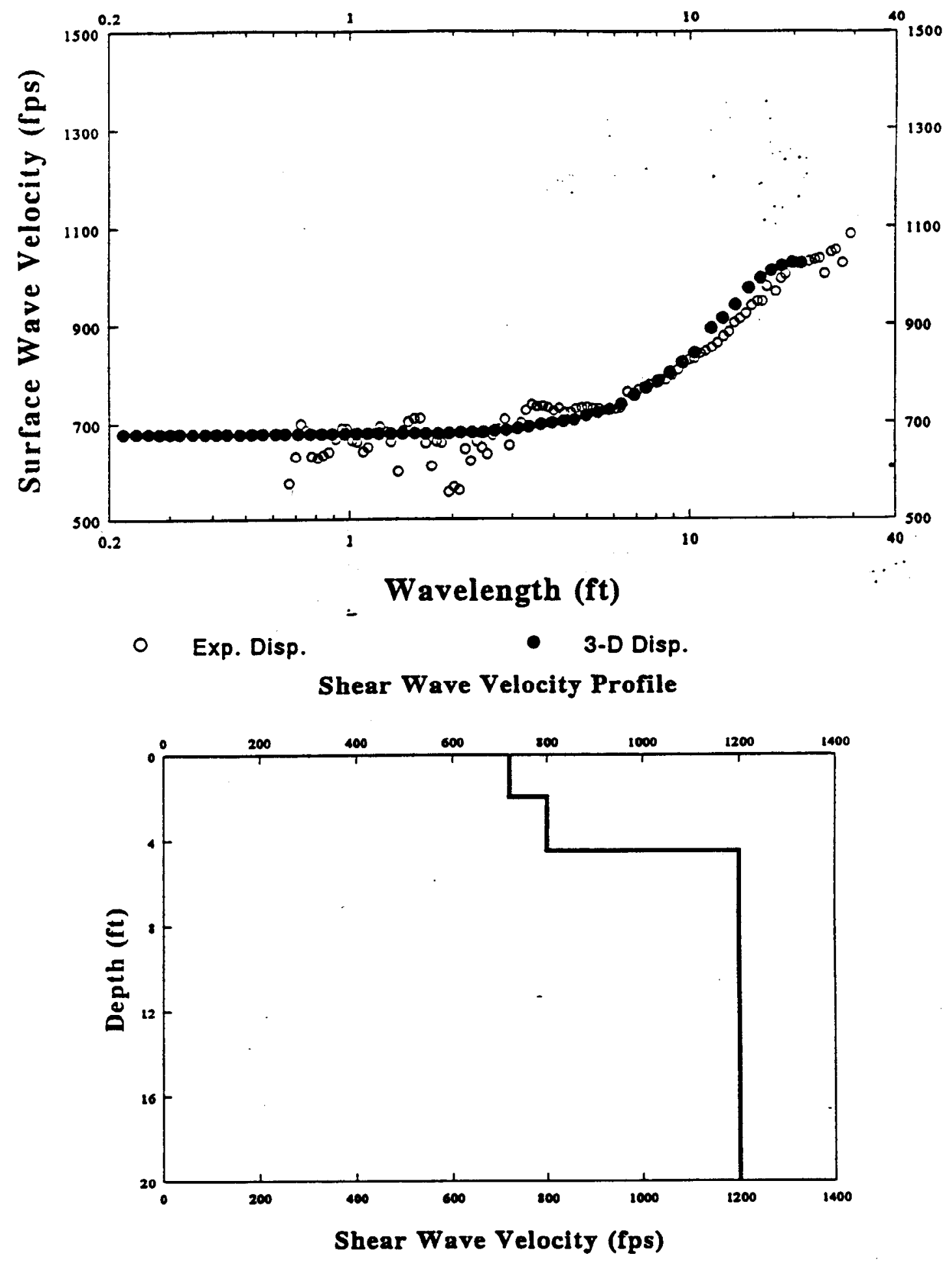

Job 205 Horseshoe, Station 1 Natural Ground (North-South) 
Experimental and Theoretical Dispersions

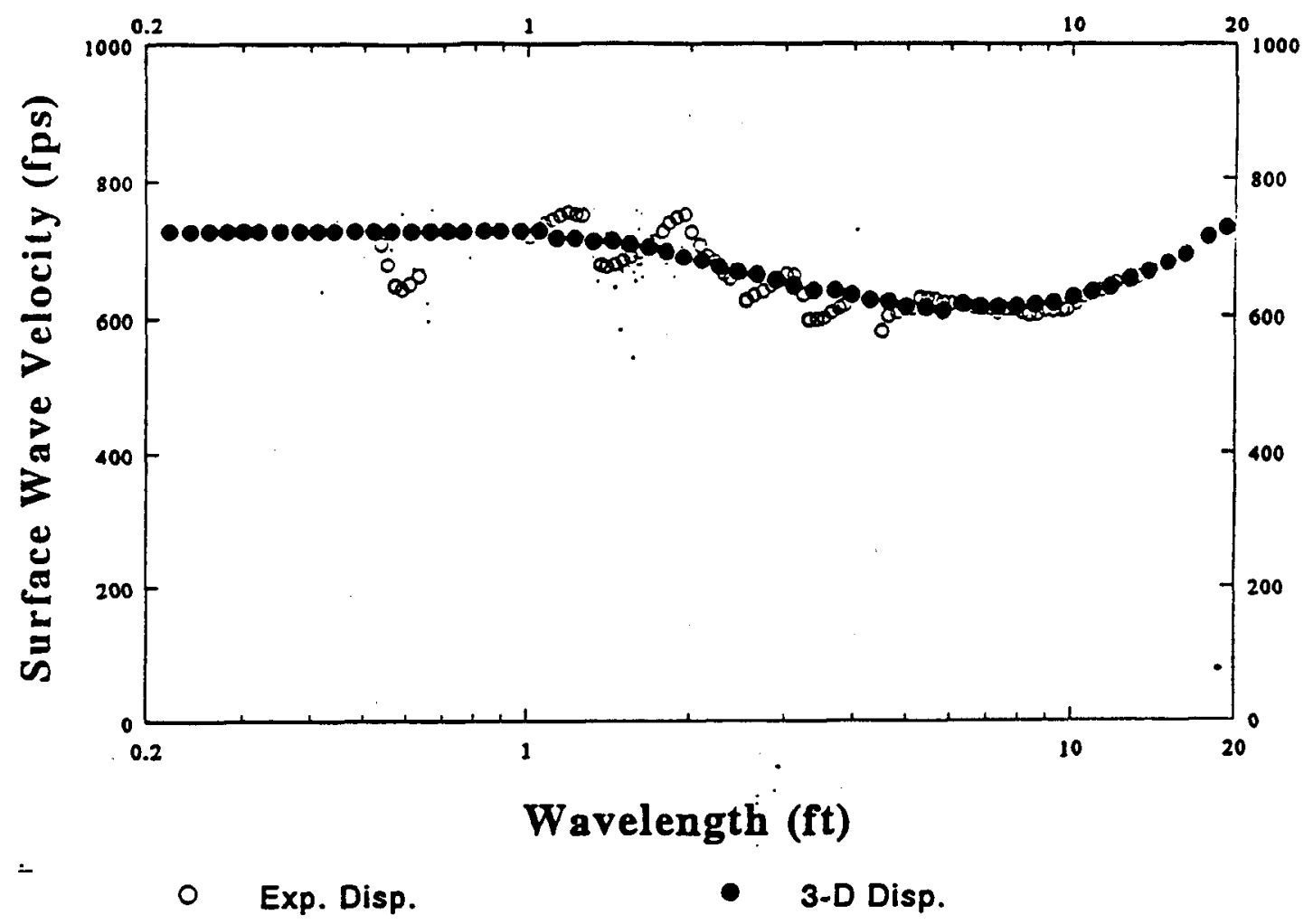

Shear Wave Velocity Profile

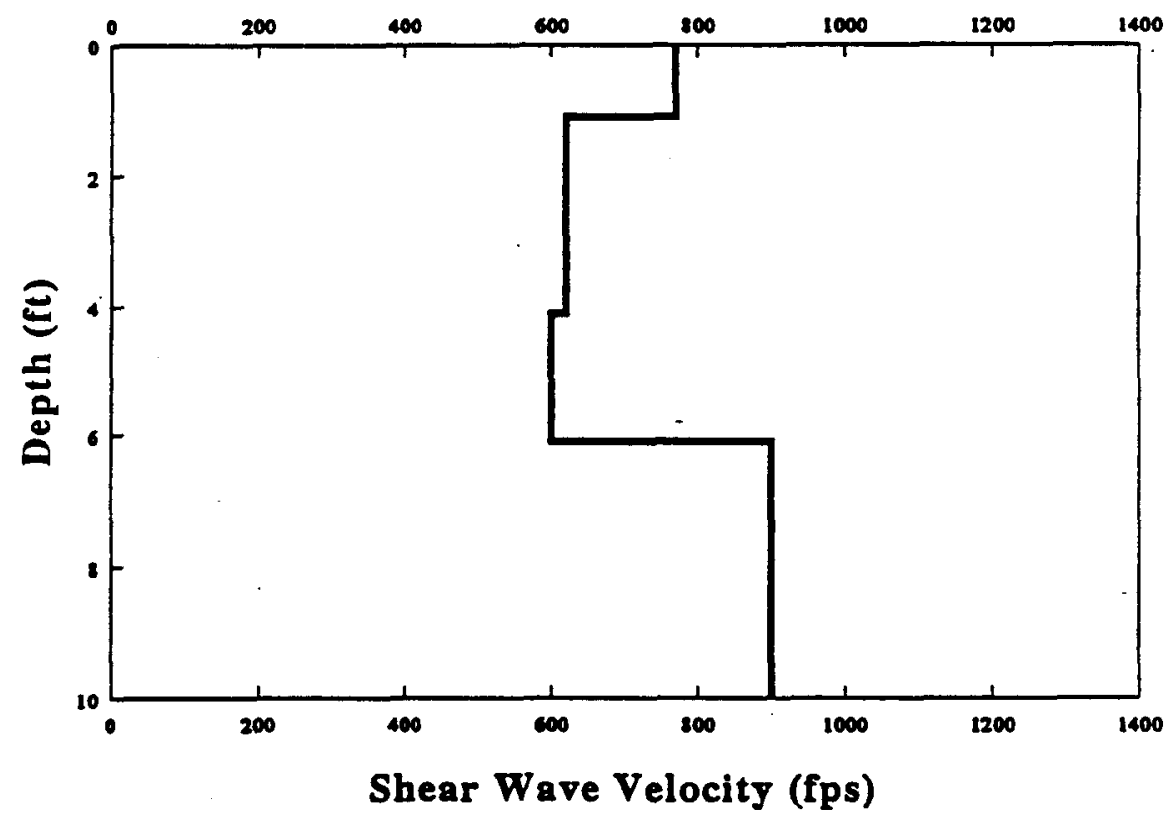

Job 205

Horseshoe - Station 2 (North - South)

Fig. B-2 
Experimental and Theoretical Dispersions

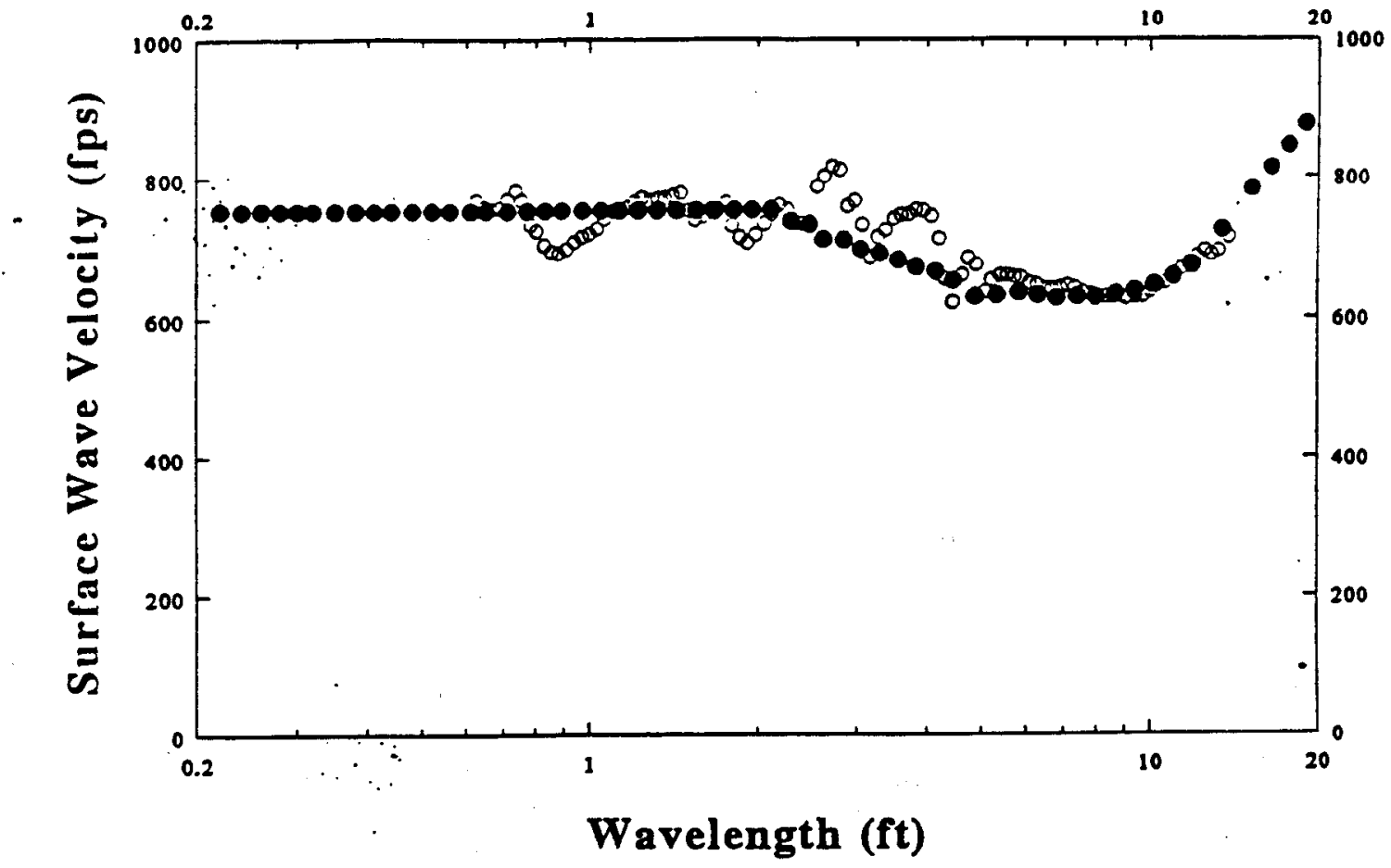

- Exp. Disp. $\quad$ 3-D Disp.

Shear Wave Velocity Profile

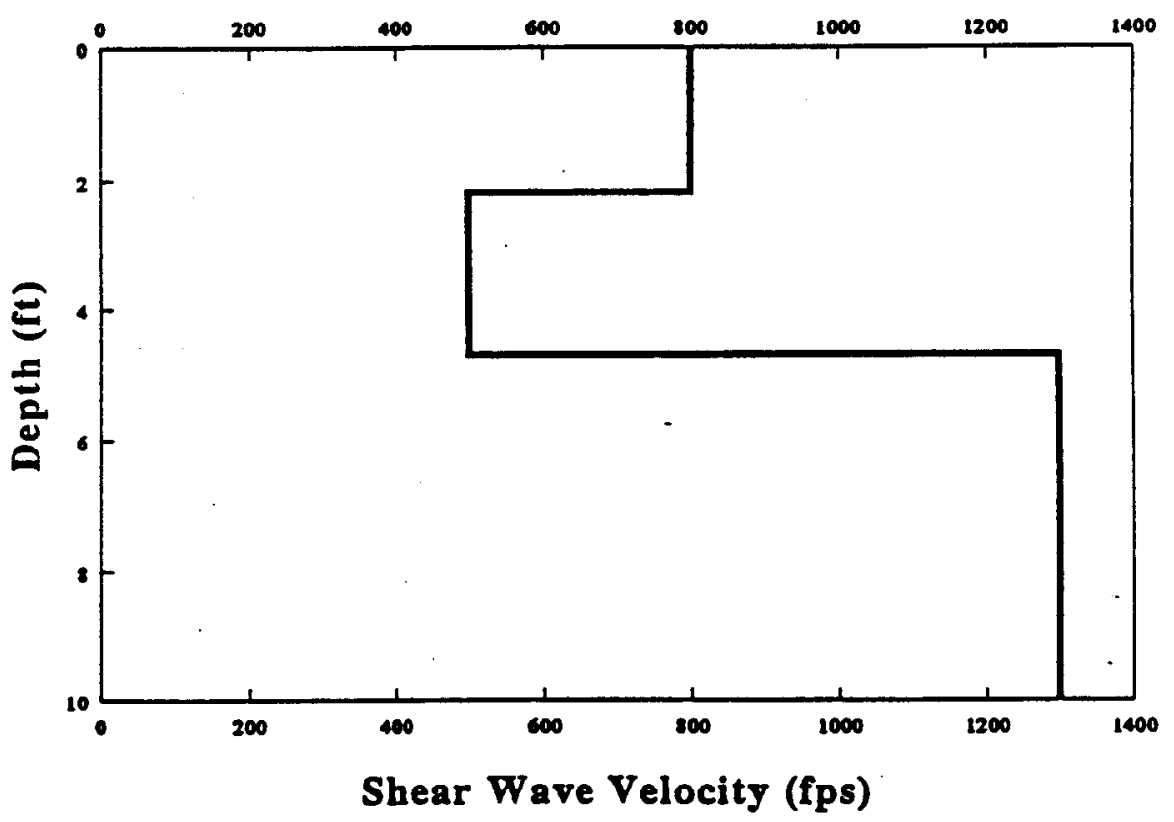

Job 205

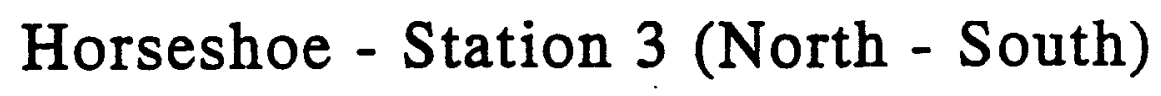

Fig. B-3 
Experimental and Theoretical Dispersions

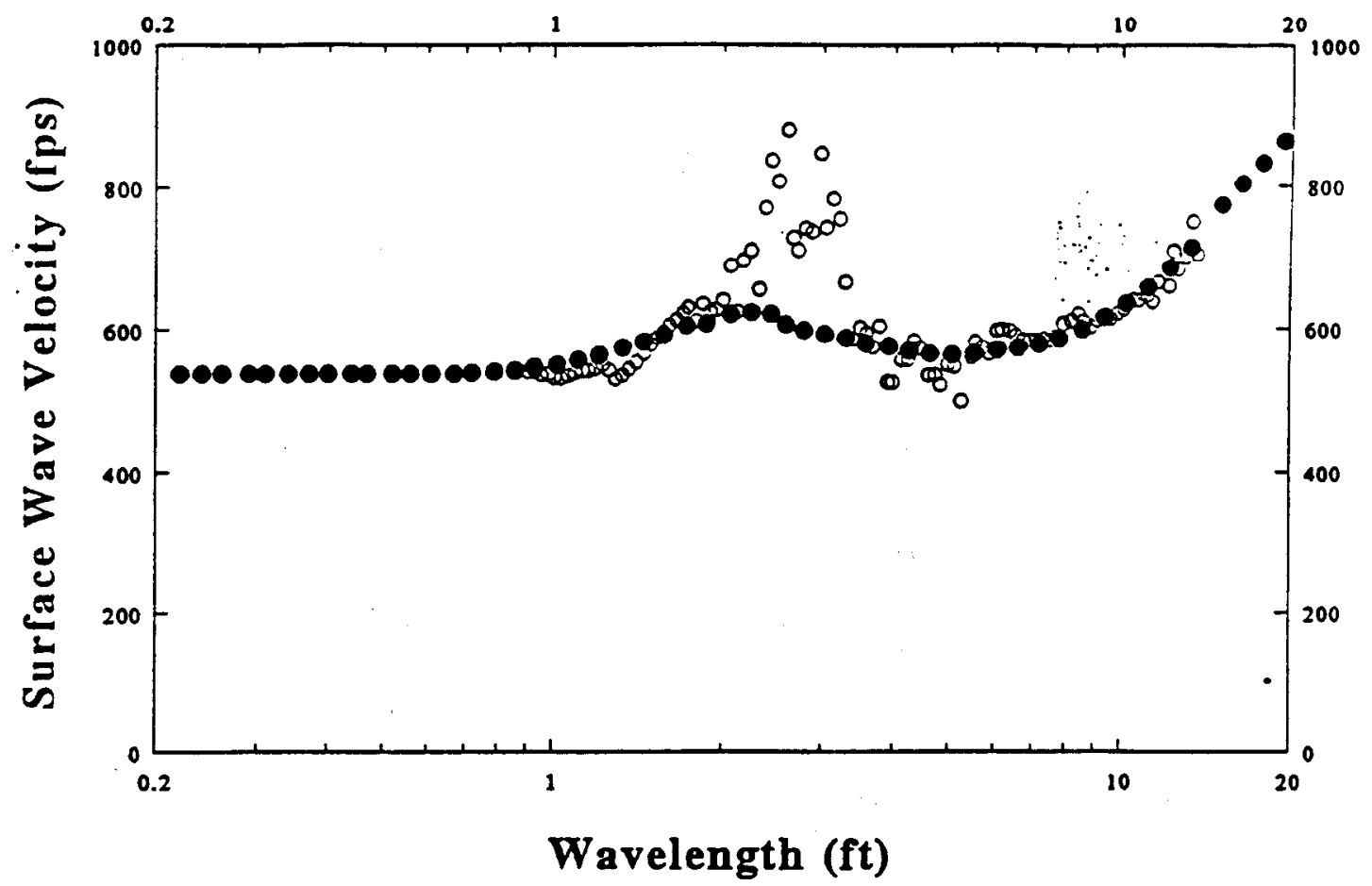

- Exp. Disp. - 3-D Disp.

Shear Wave Velocity Profile

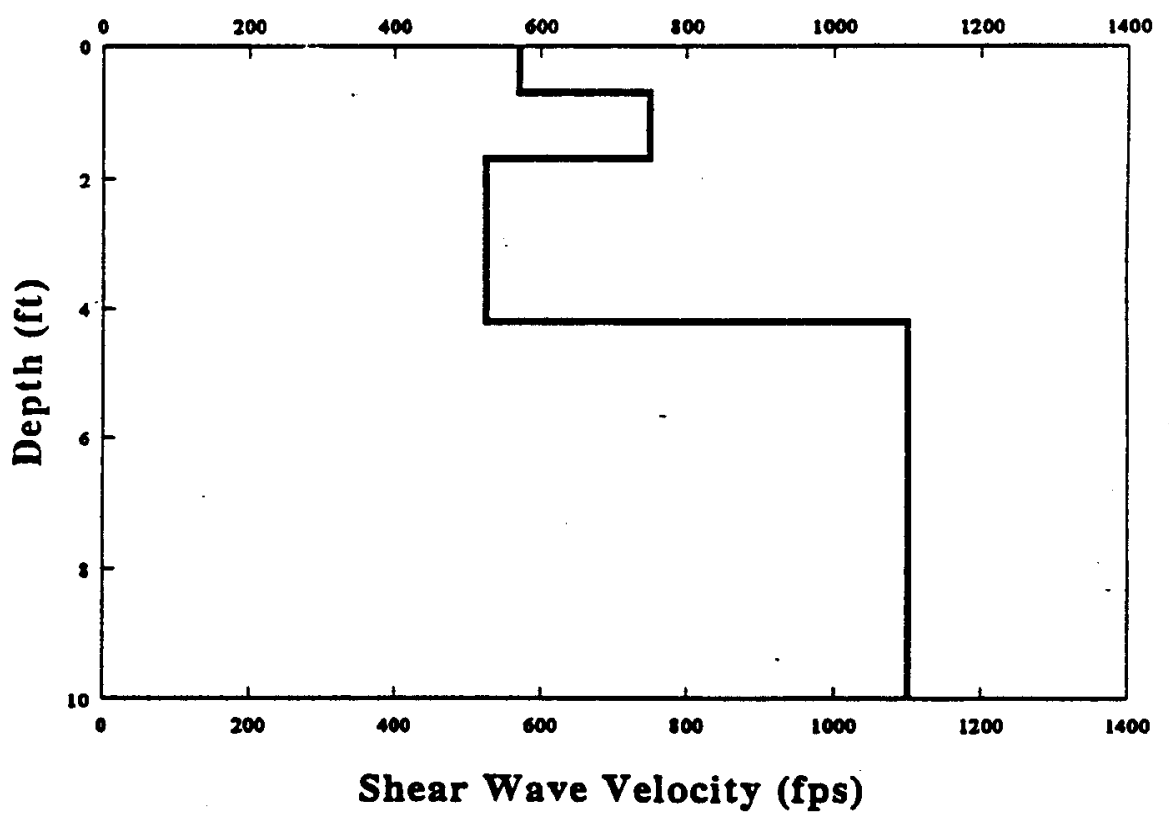

Job 205

\section{Horseshoe - Station 4 (East West)}

Fig. B-4 
Experimental and Theoretical Dispersions

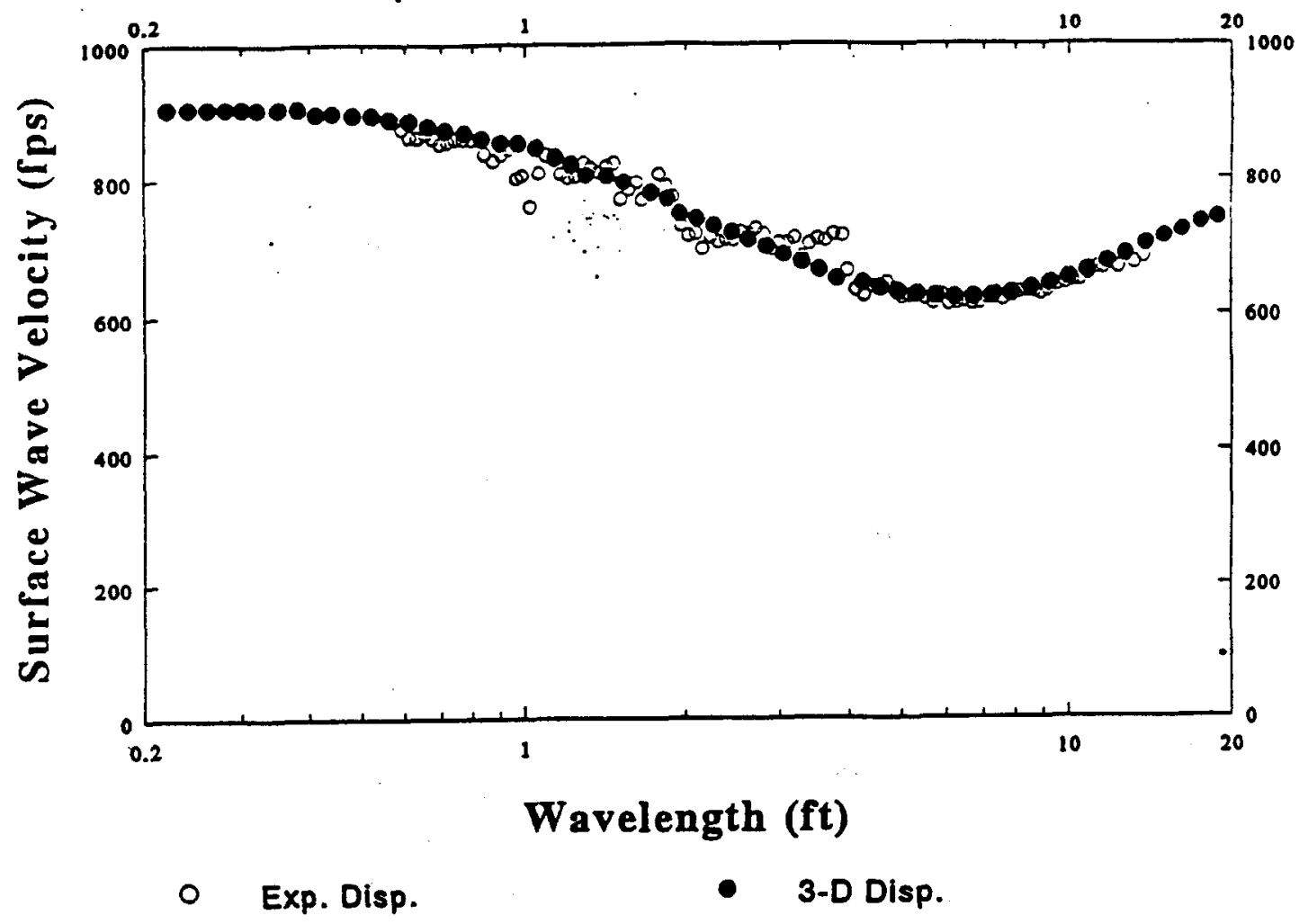

Shear Wave Velocity Profile

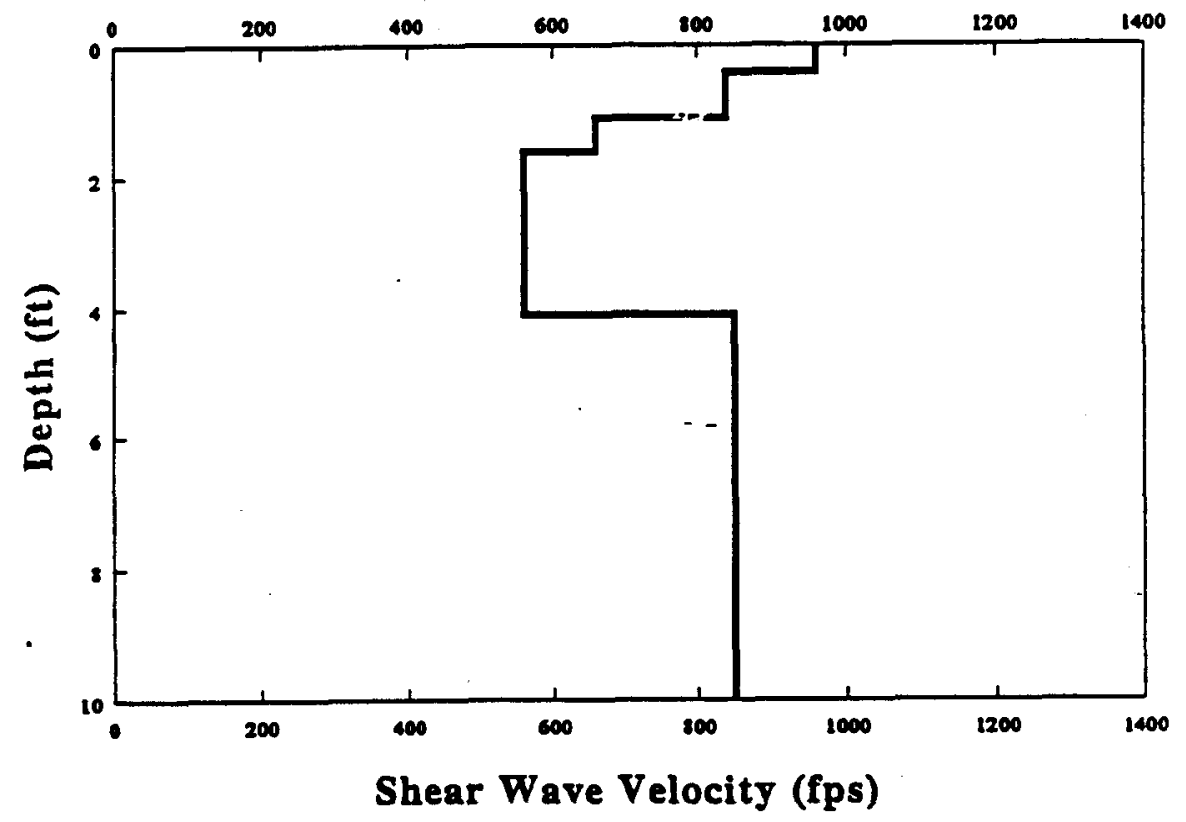

Job 205

Horseshoe - Station 5 (North - South)

Fig. B-5 
Experimental and Theoretical Dispersions

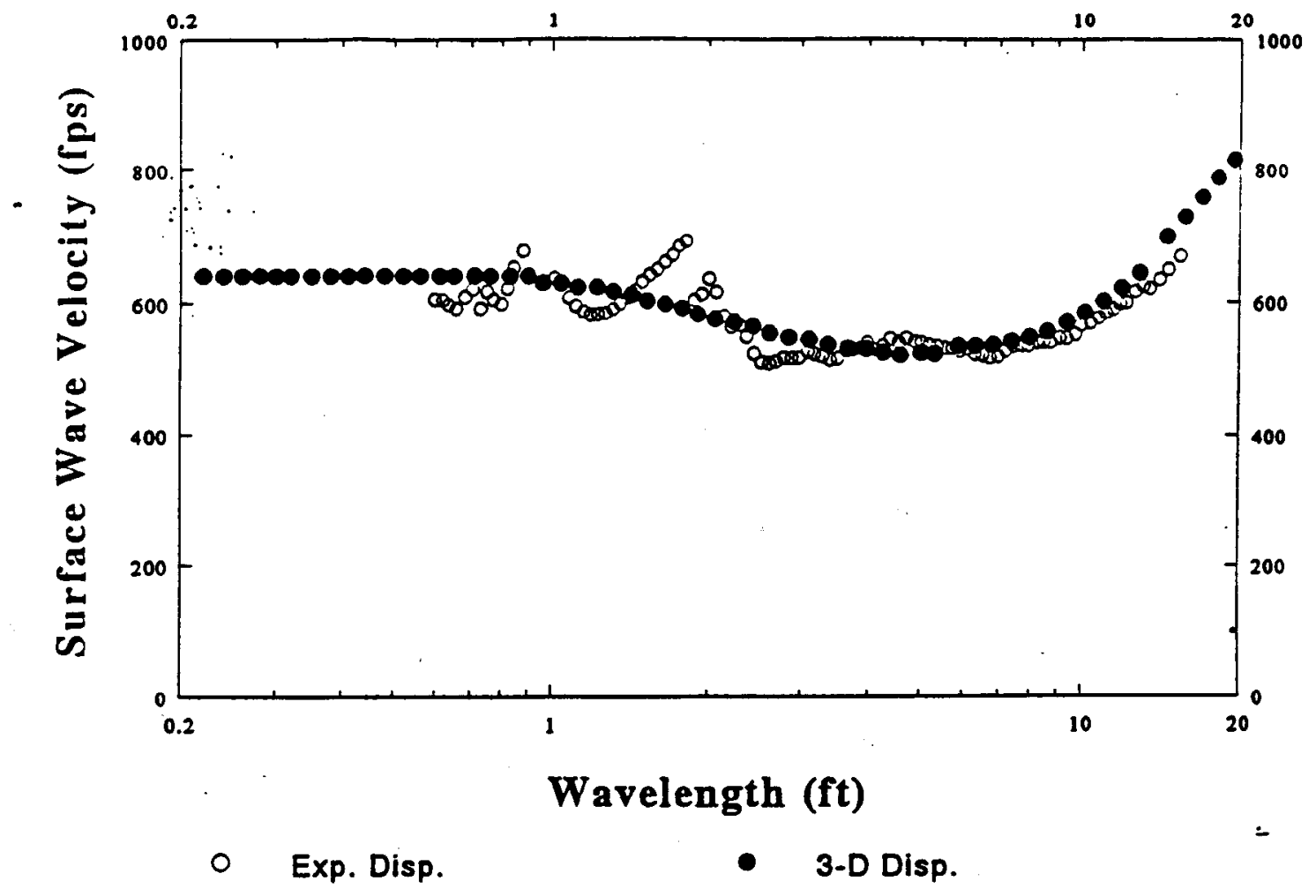

Shear Wave Velocity Profile

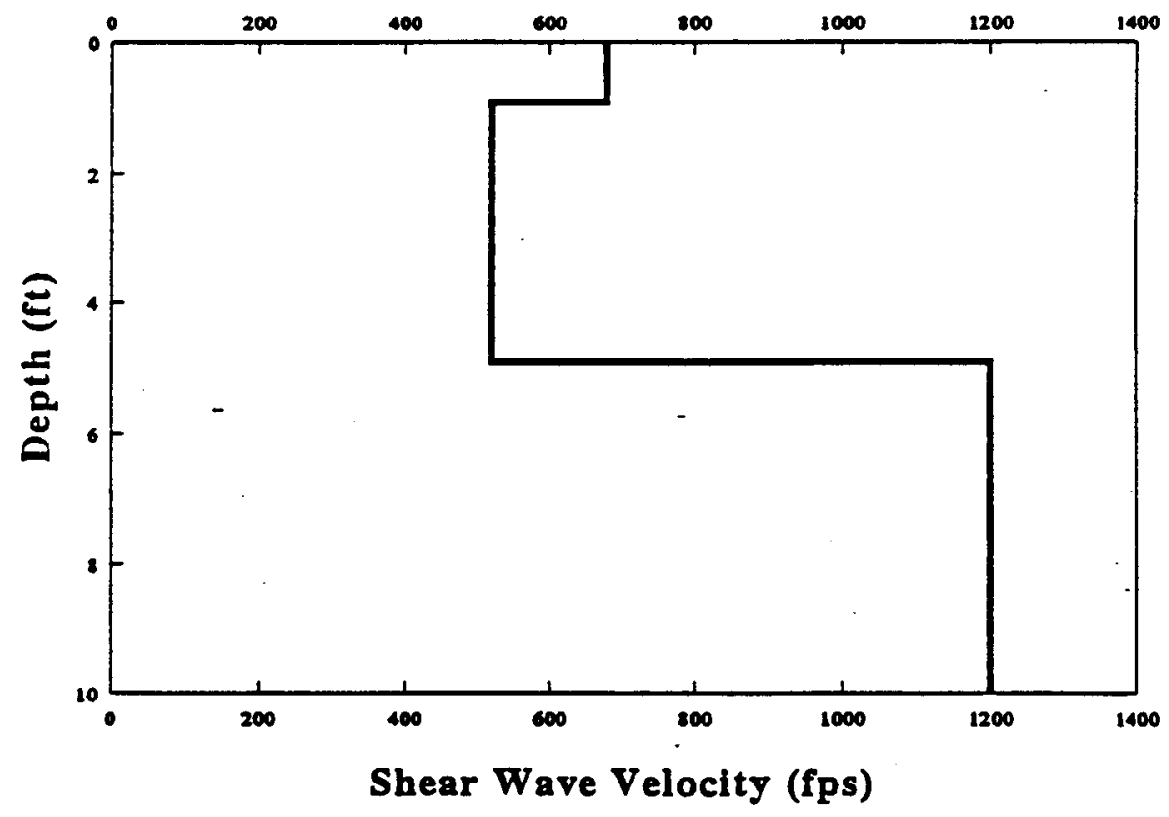

Job 205

Horseshoe - Station 6 (North - South)

Fig. B-6 
Experimental and Theoretical Dispersions

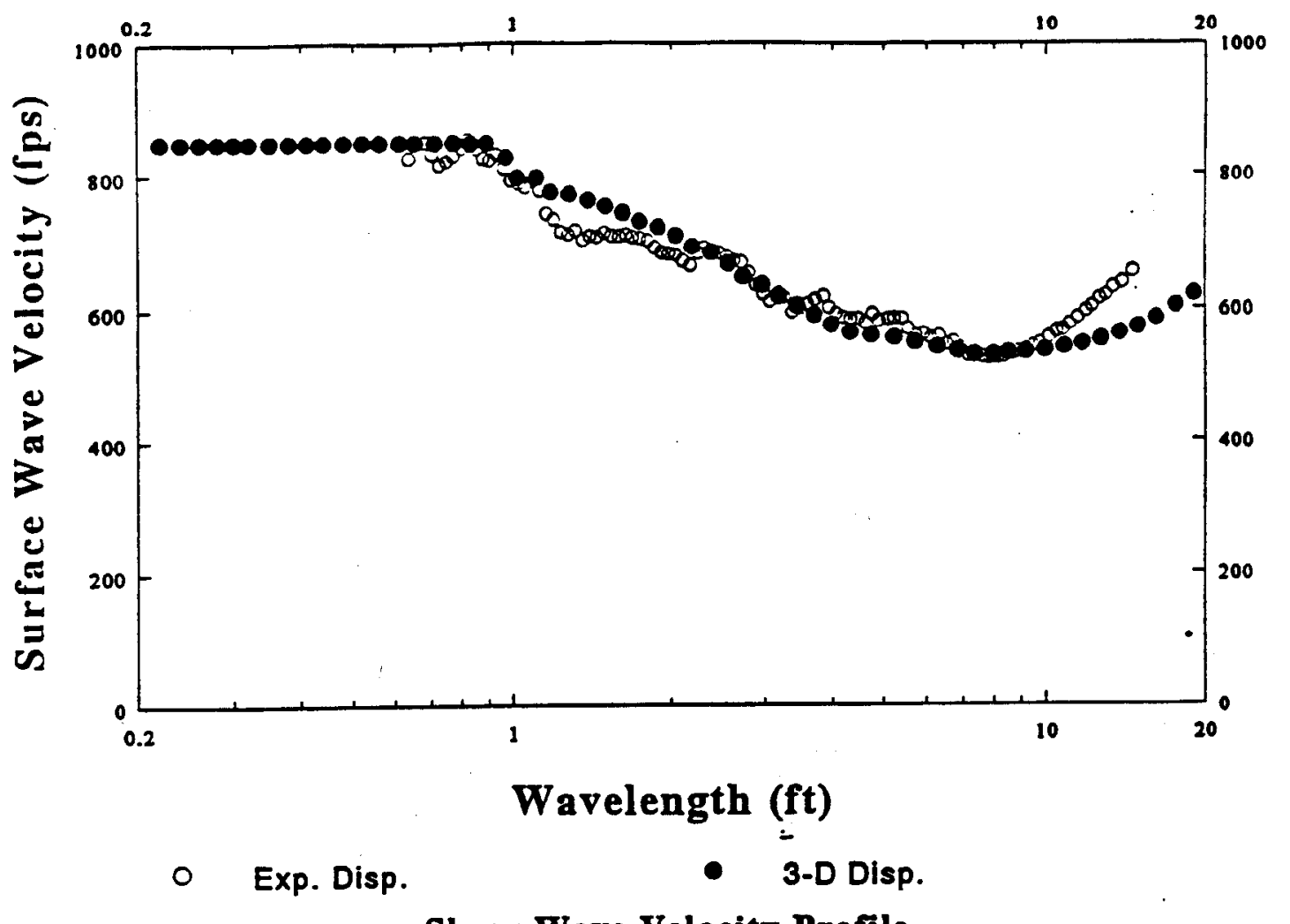

Shear Wave Velocity Profile

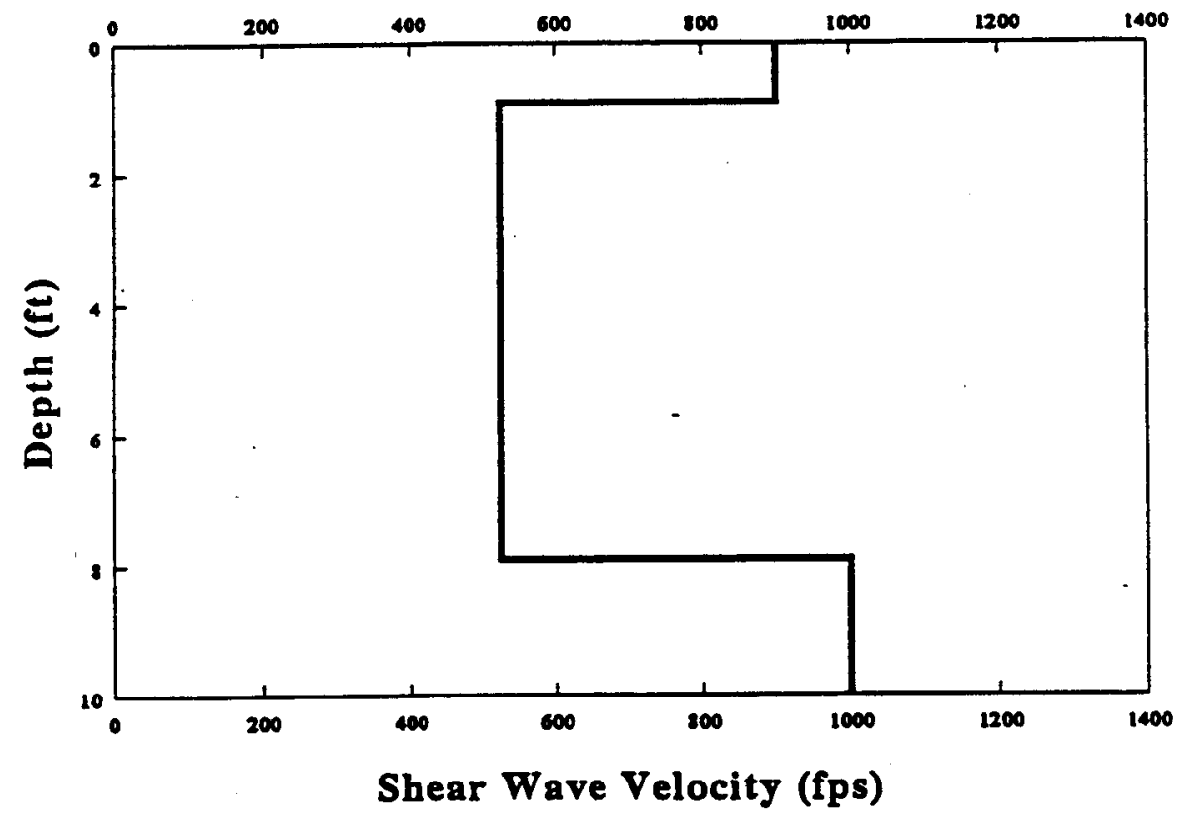

Job 205

Horseshoe - Station 7 (North - South)

Fig. B-7 
Experimental and Theoretical Dispersions

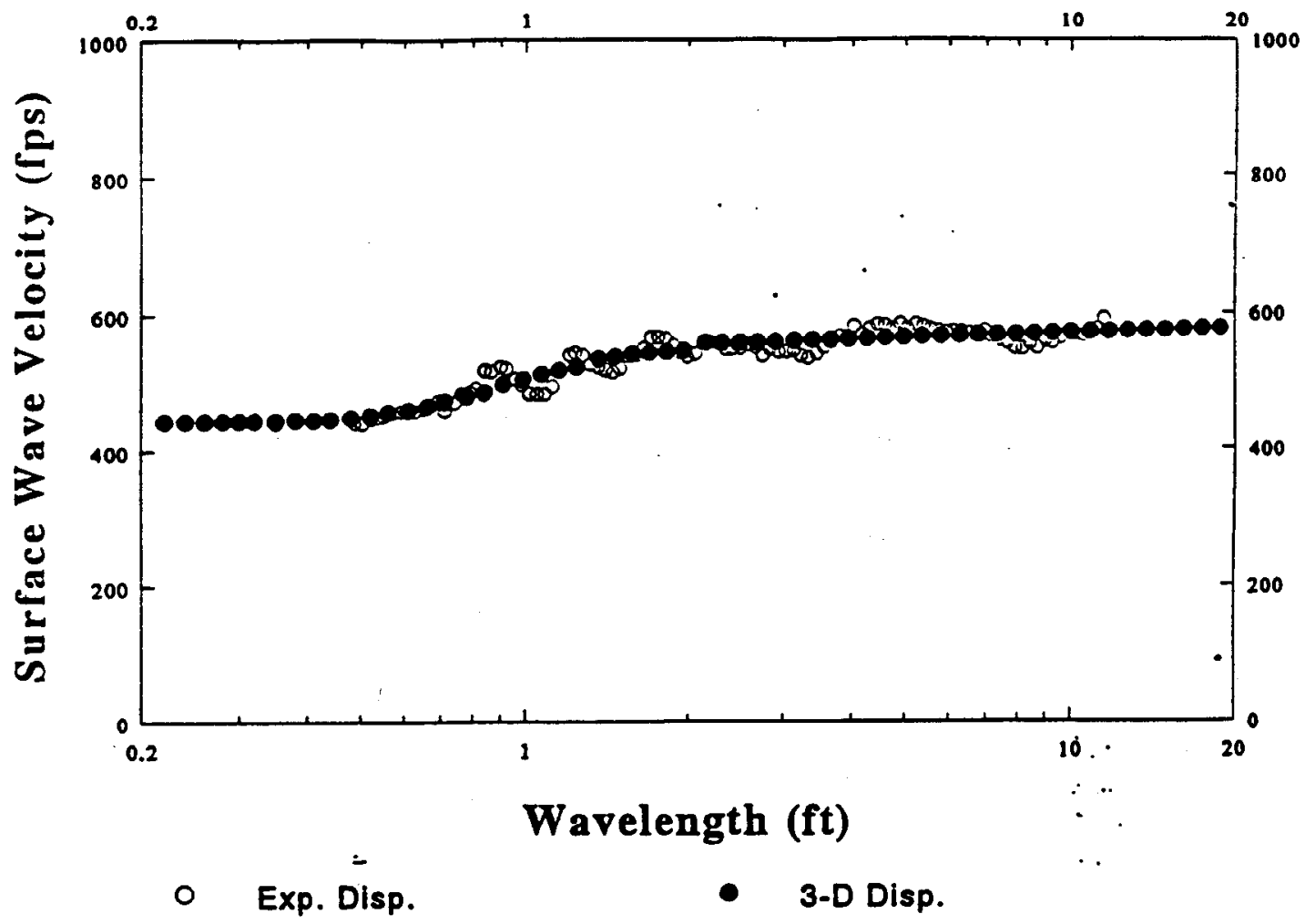

Shear Wave Velocity Profile

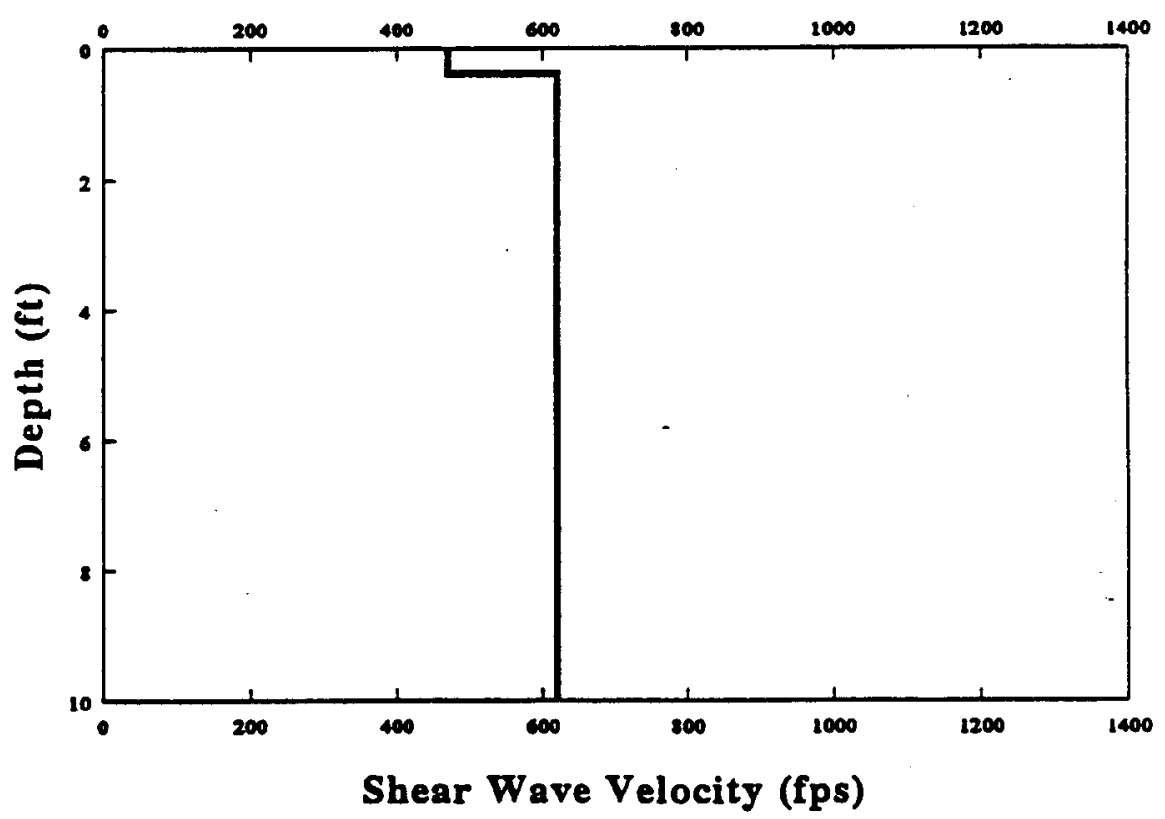

Job 205

Horseshoe - Station 8 (East - West)

Fig. B-8 
Experimental and Theoretical Dispersions

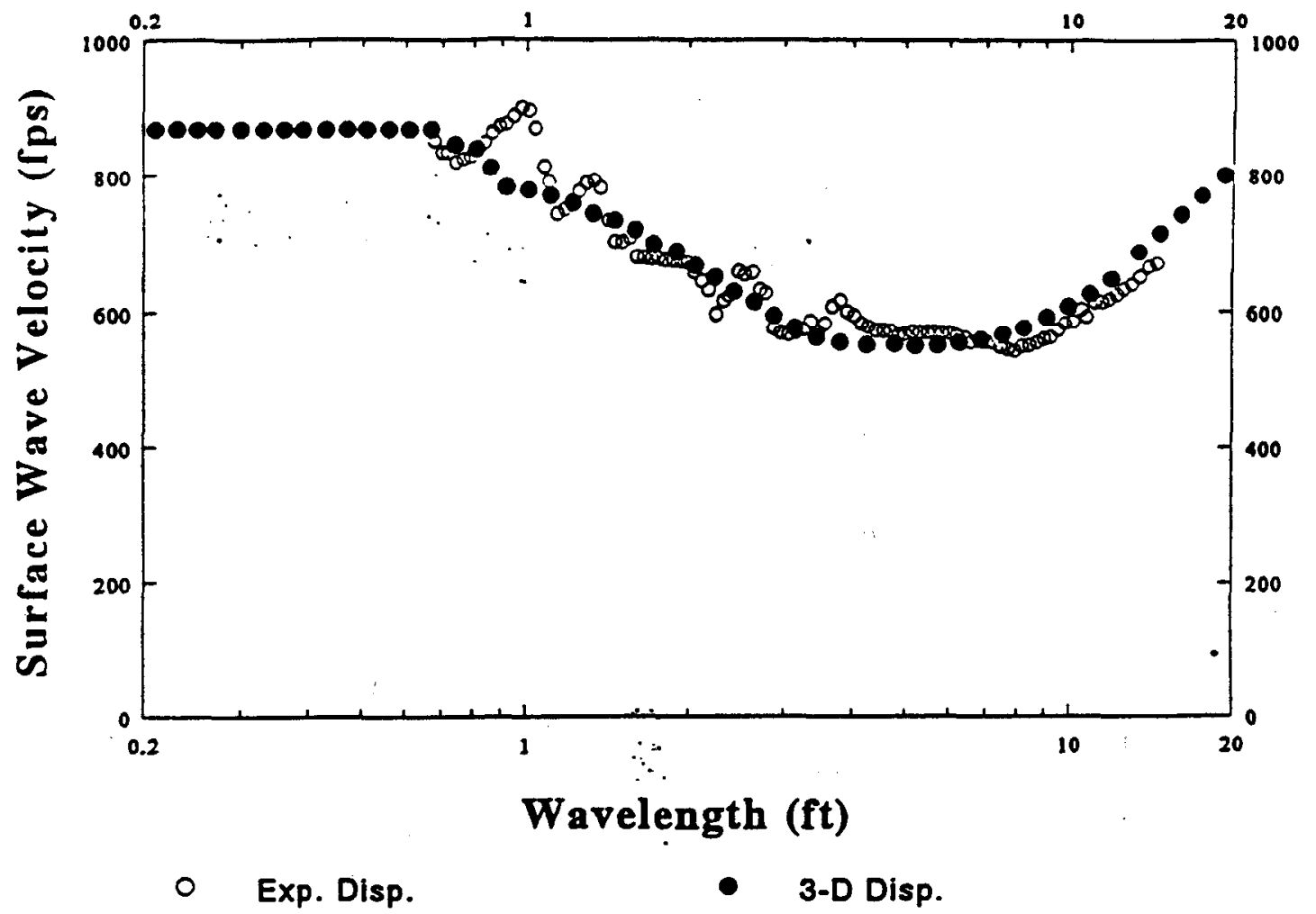

Shear Wave Velocity Profile

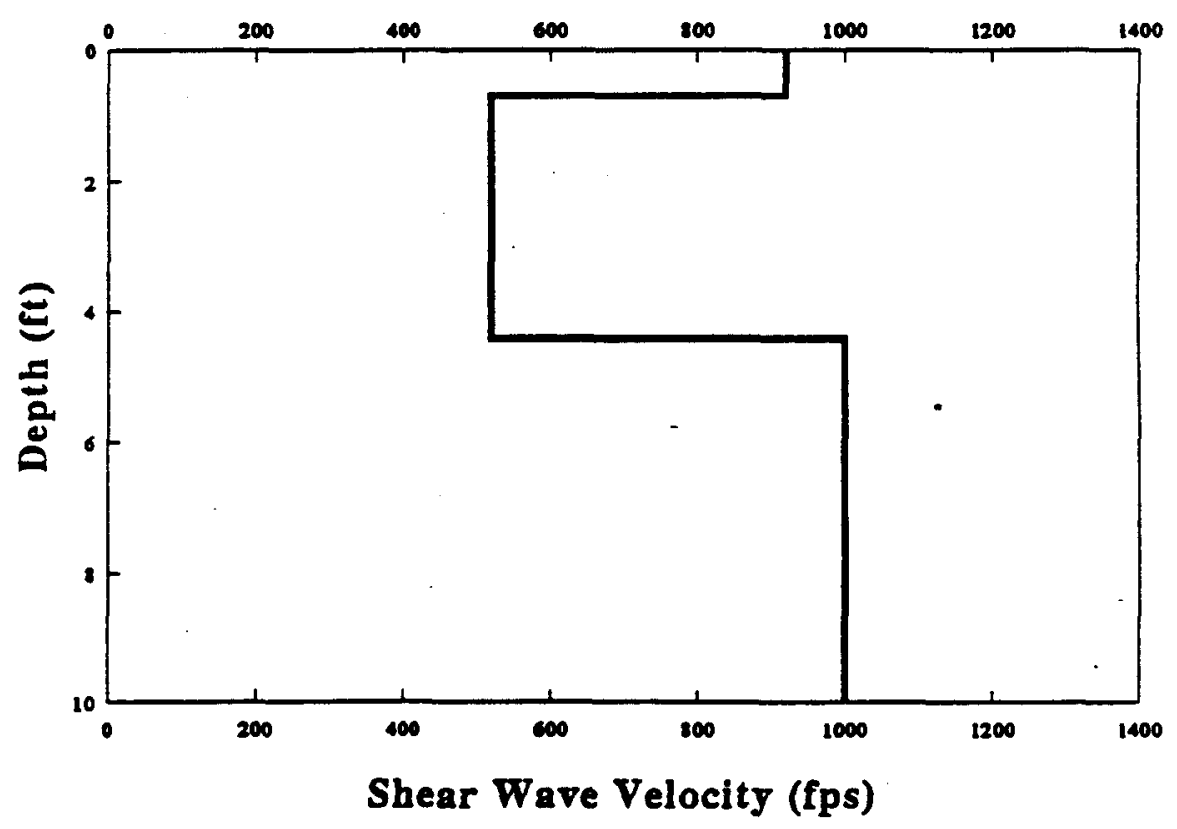

Job 205

Horseshoe - Station 9 (East - West)

Fig. B-9 
Experimental and Theoretical Dispersions
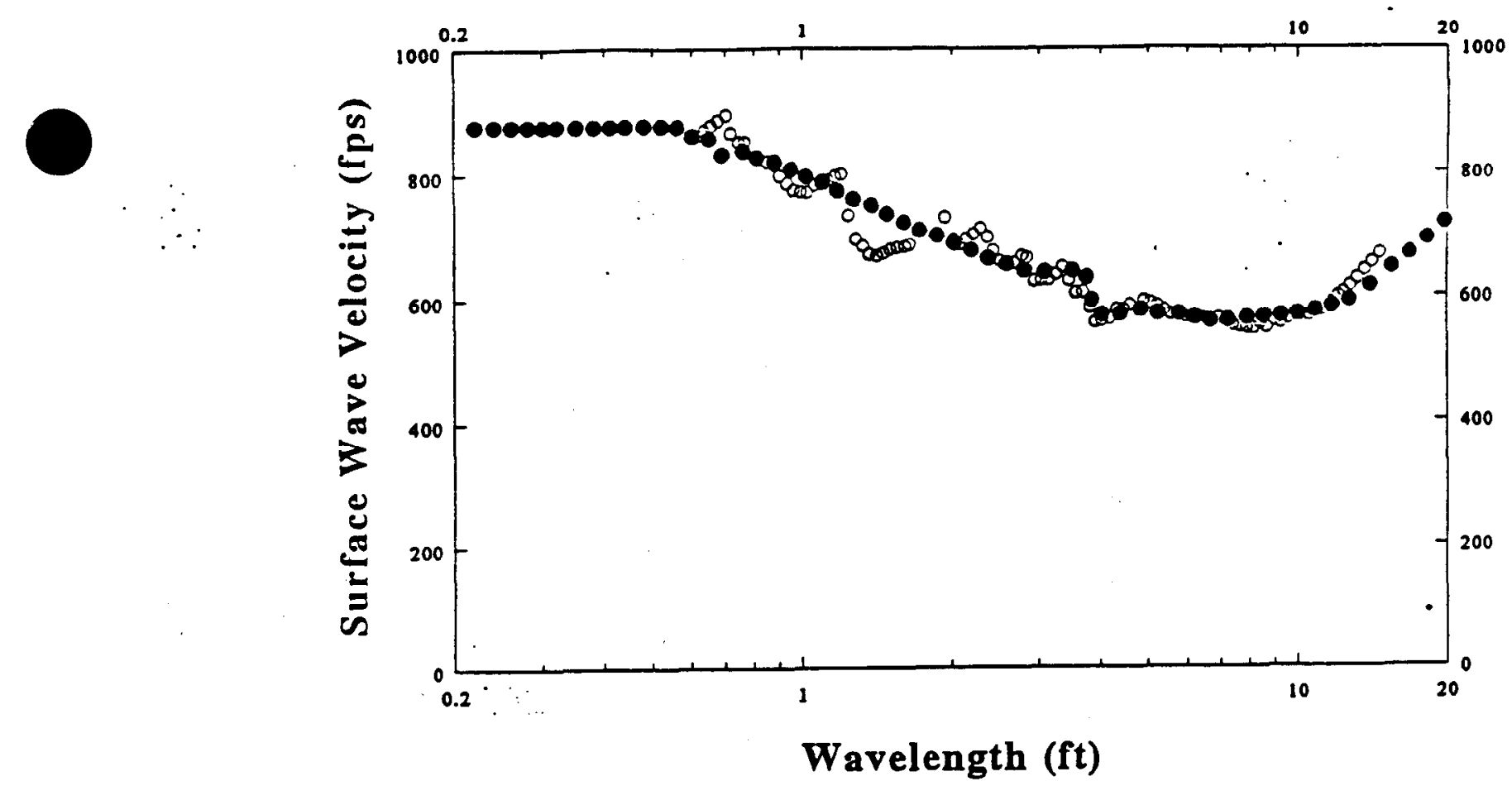

$\circ \quad$ Exp. Disp.

- 3-D Disp.

Shear Wave Velocity Profile

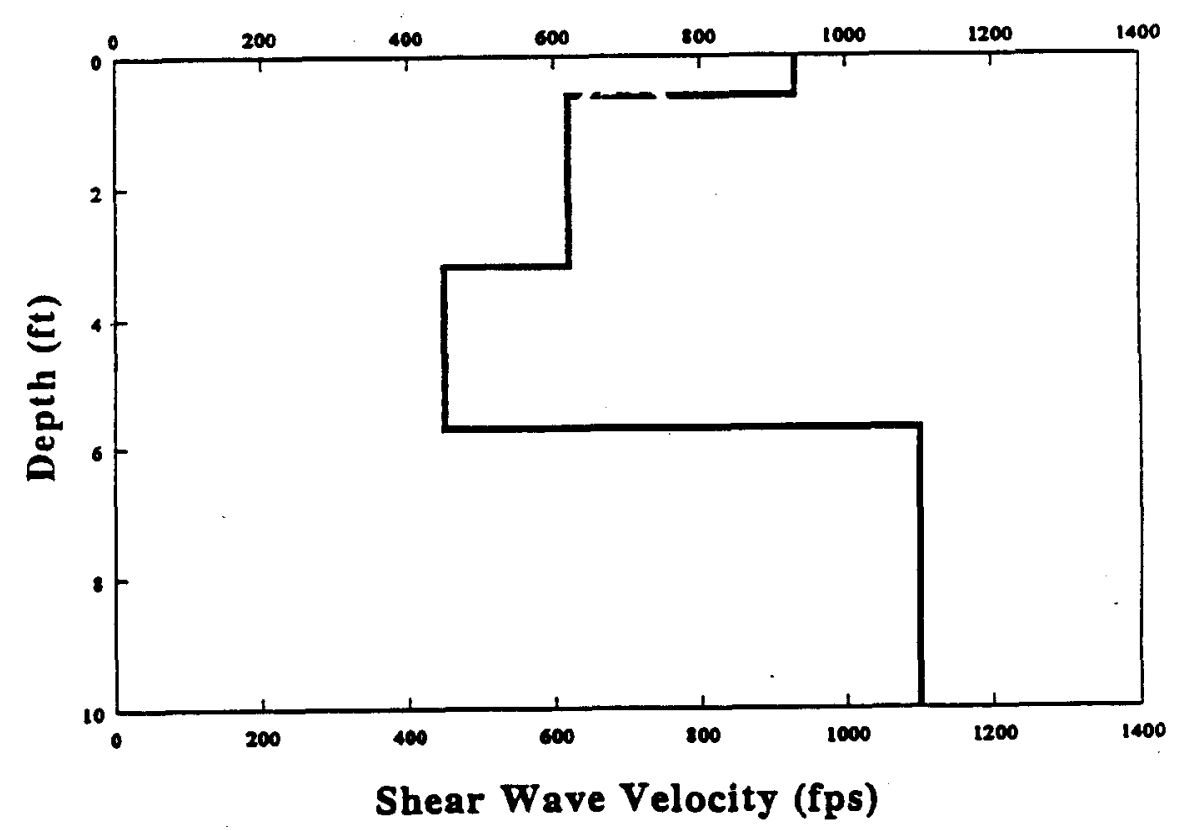

Job 205

Horseshoe - Station 10 (East - West)

Fig. B-10 


\section{Experimental and Theoretical Dispersions}

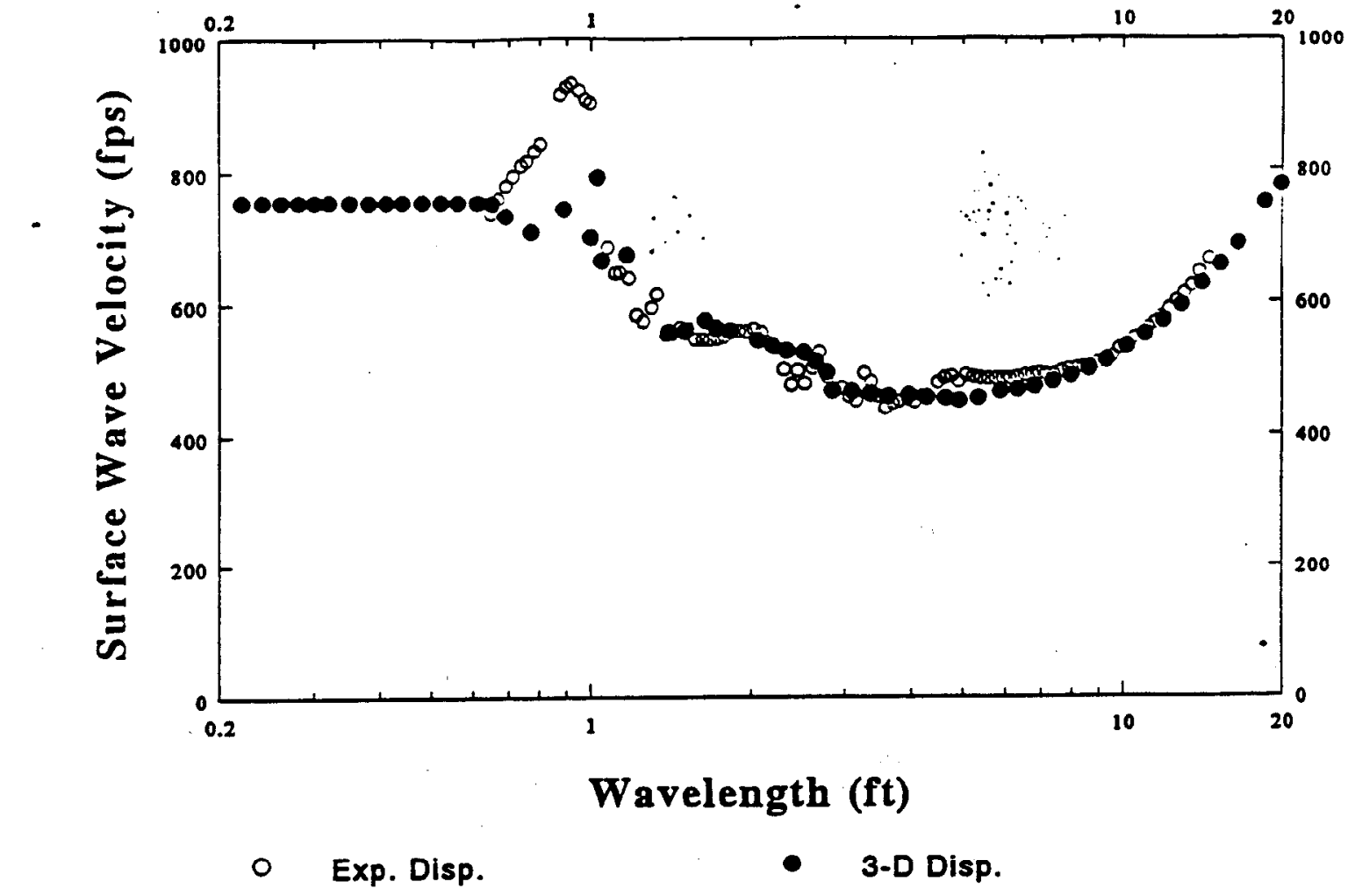

Shear Wave Velocity Profile

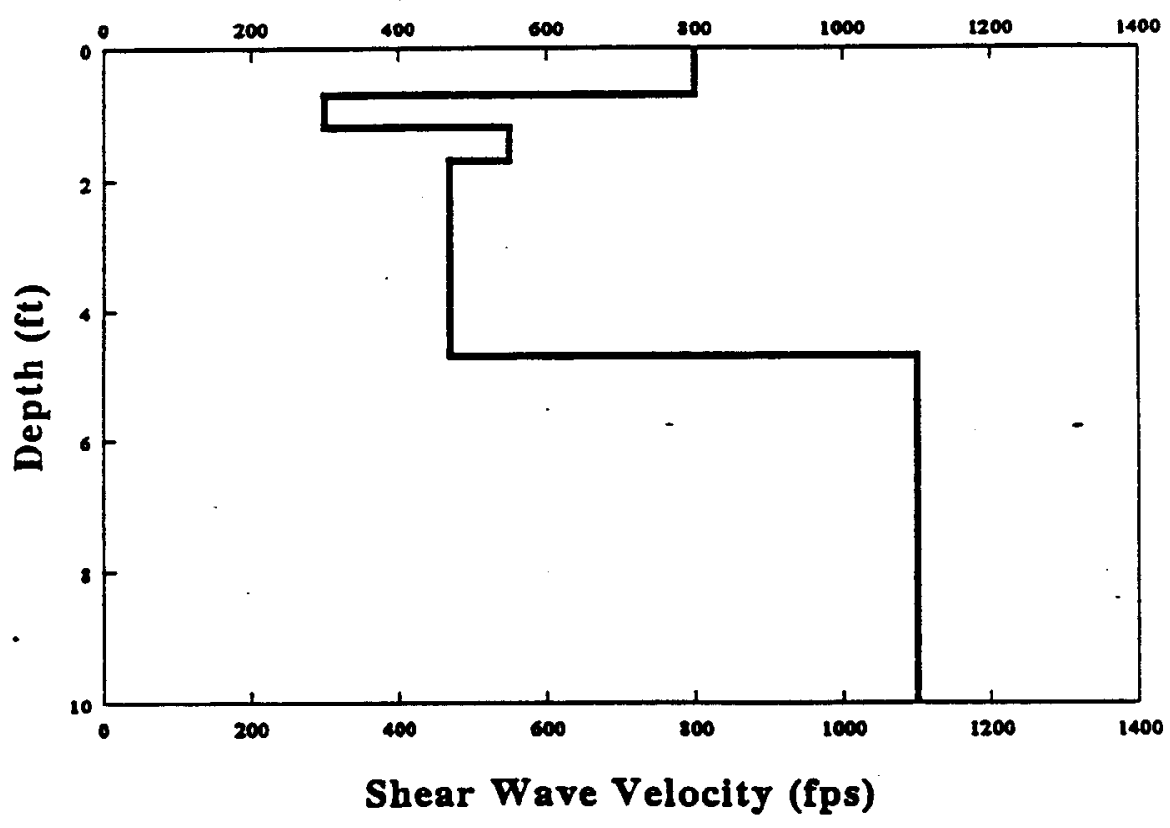

Job 205

Horseshoe - Station 11 (East - West)

Fig. B-11 


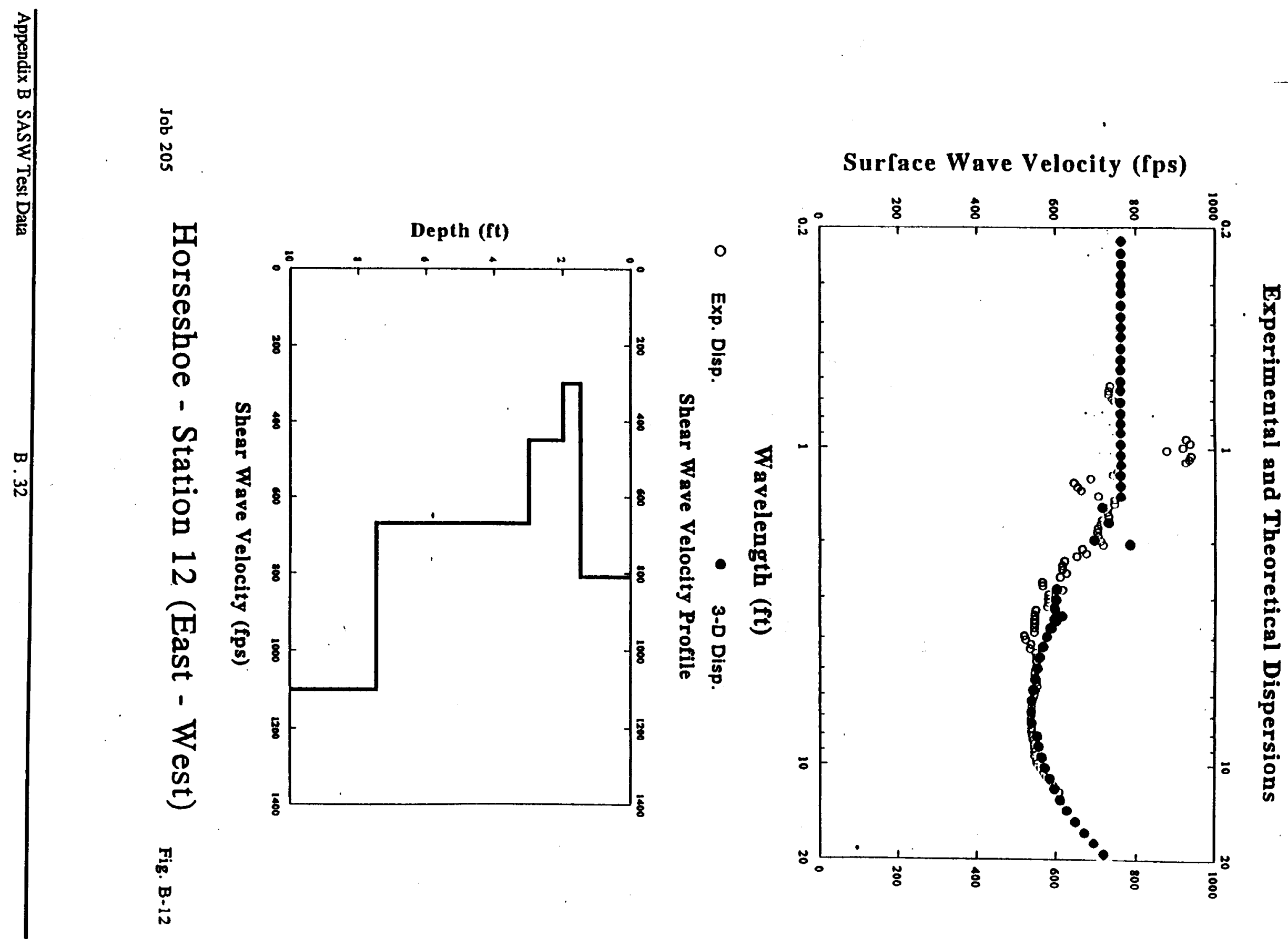


Experimental and Theoretical Dispersions

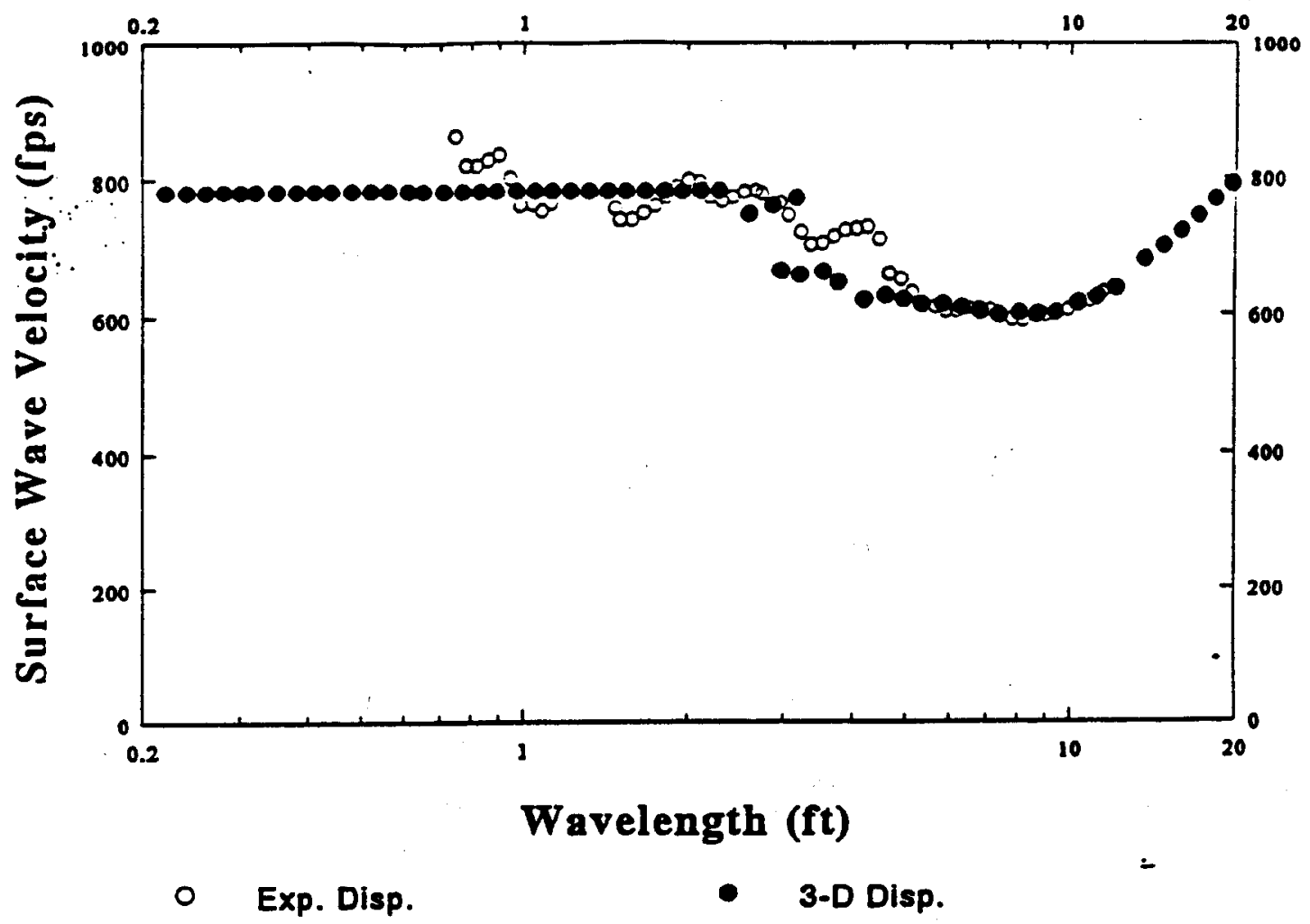

Shear Wave Velocity Profile

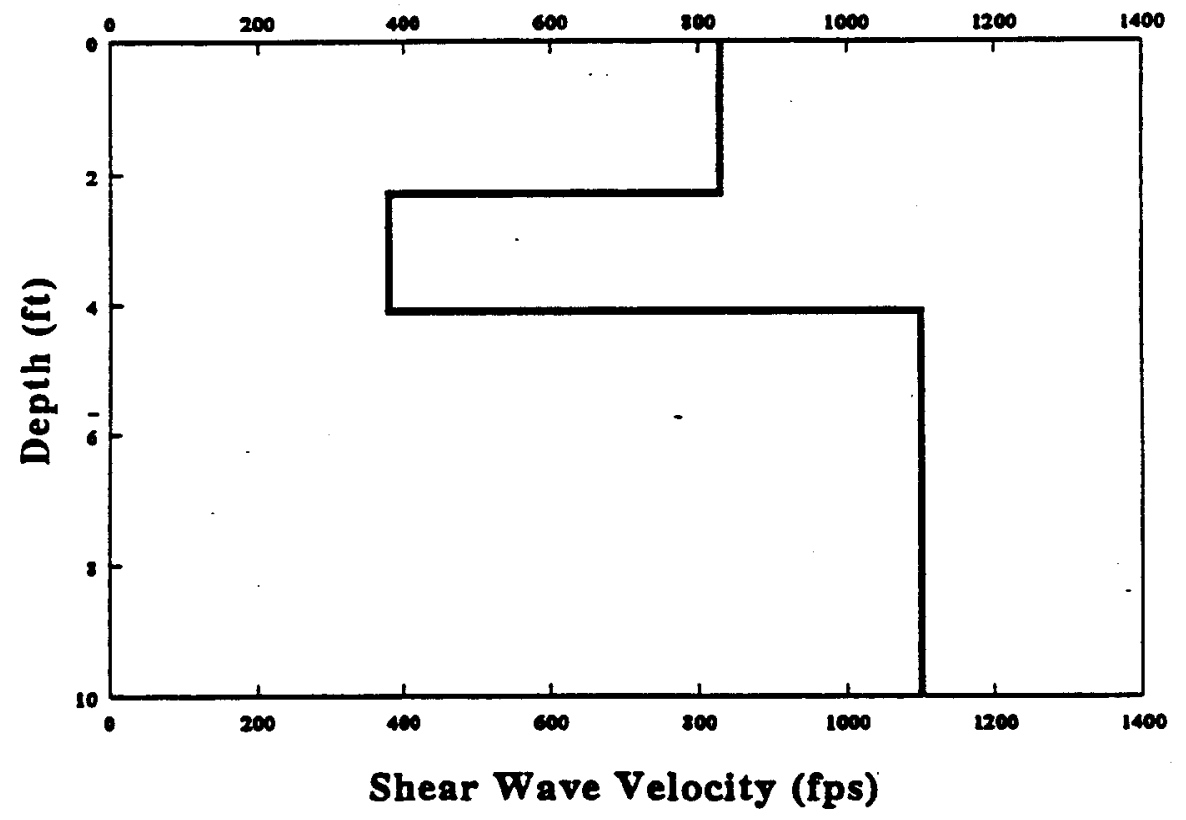

Job 205

Horseshoe - Station 13 (East - West)

Fig. B-13 
Experimental and Theoretical Dispersions
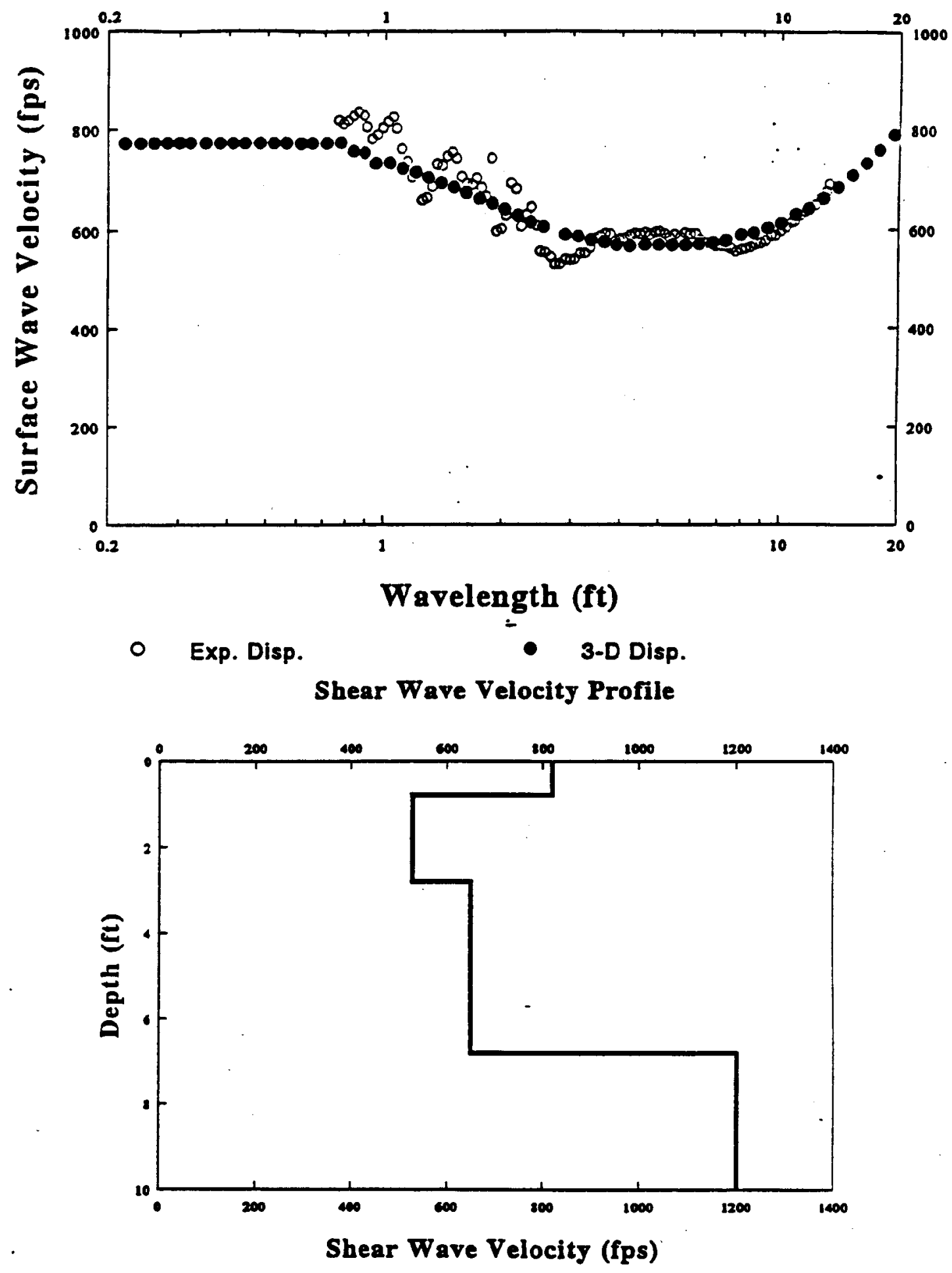

Job 205

Horseshoe - Station 14 (East - West)

Fig. B-14 


\section{Experimental and Theoretical Dispersions}

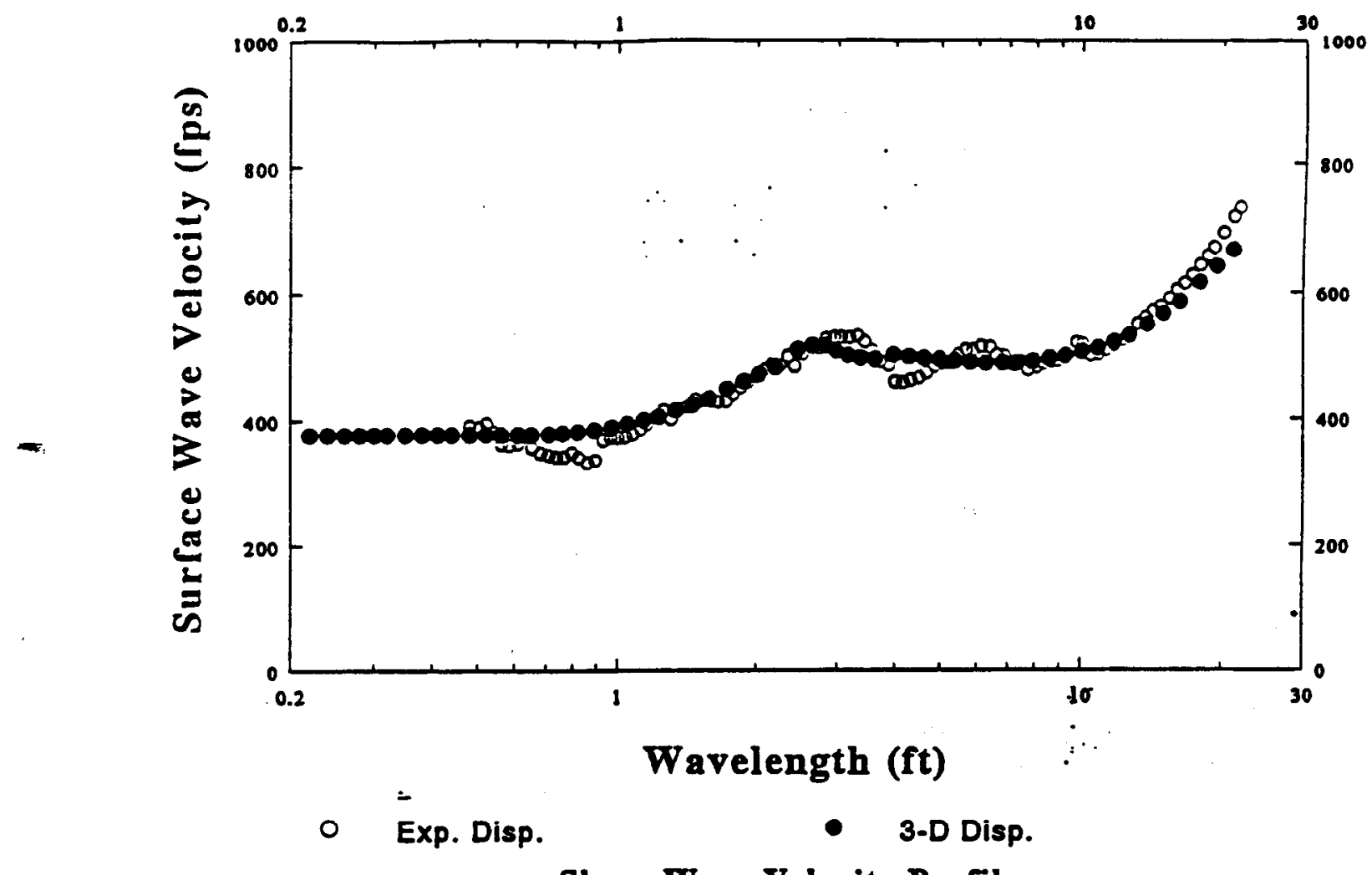

Shear Wave Velocity Profile

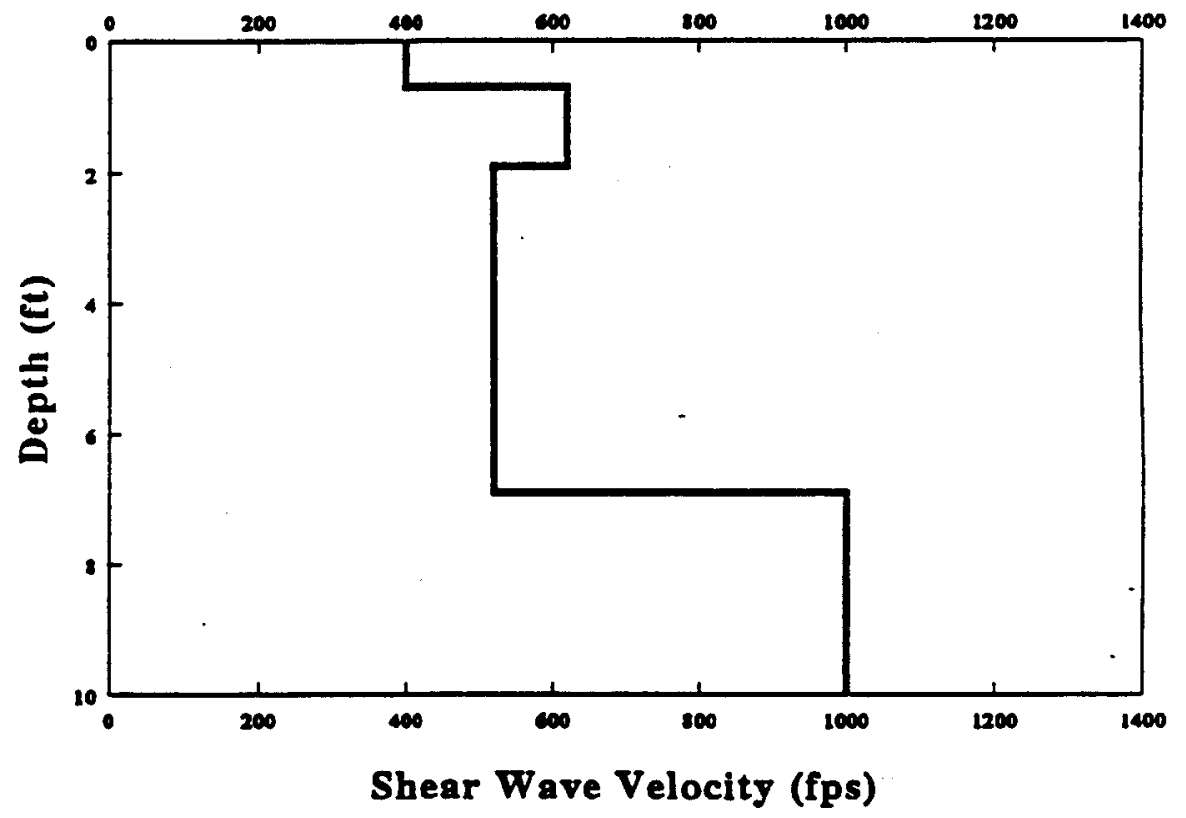

Mixed Waste Facility Line A (100 ft -- East - West)

Fig. B-15 
Experimental and Theoretical Dispersions

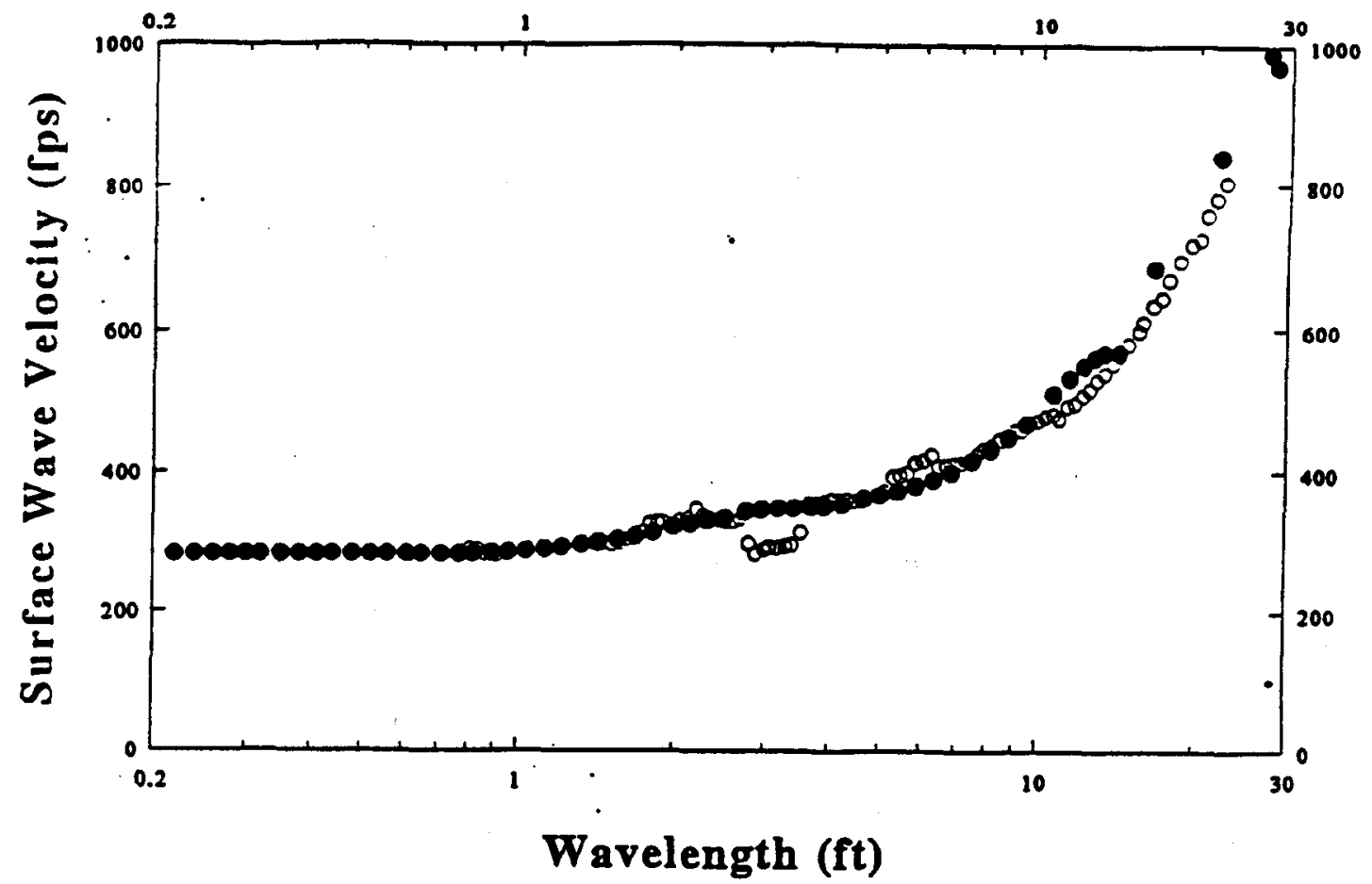

- Exp. Disp.

- 3.D Disp.

Shear Wave Velocity Profile

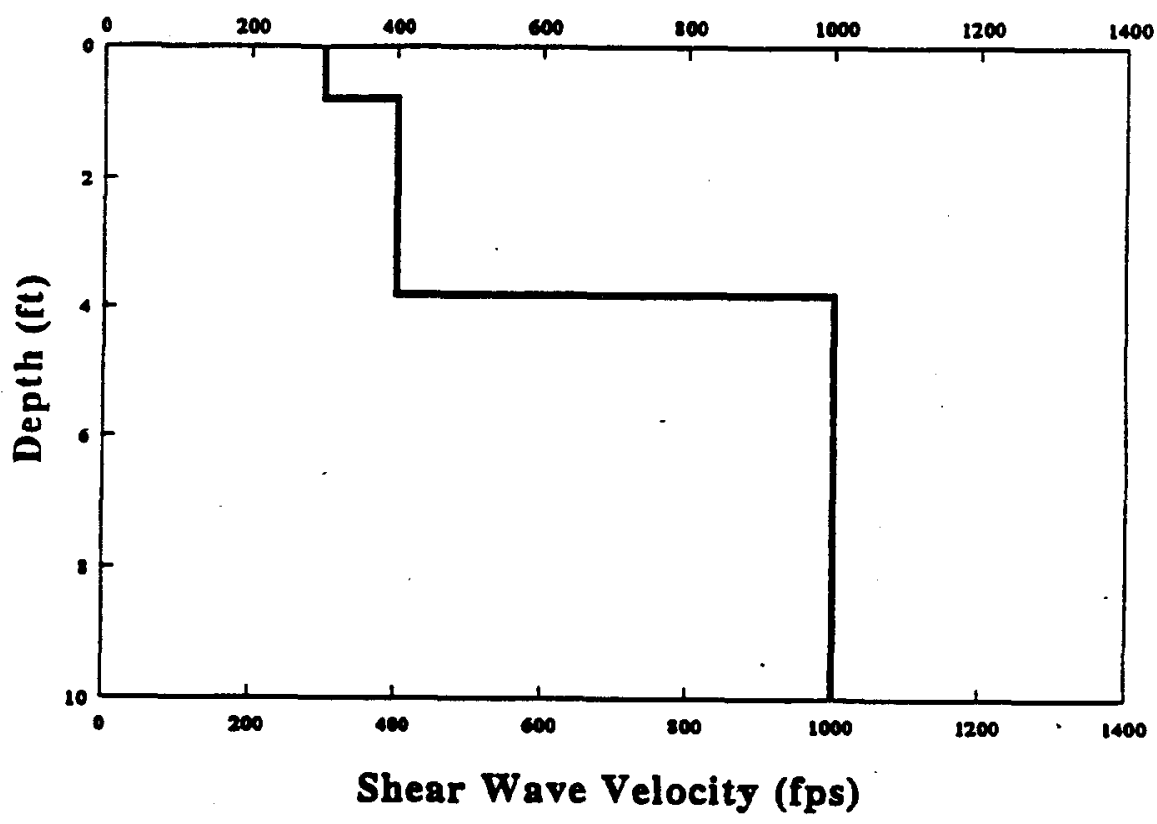

Job 205

Mixed Waste Facility Line A (400 ft -- East - West)

Fig. B-16 
Experimental and Theoretical Dispersions

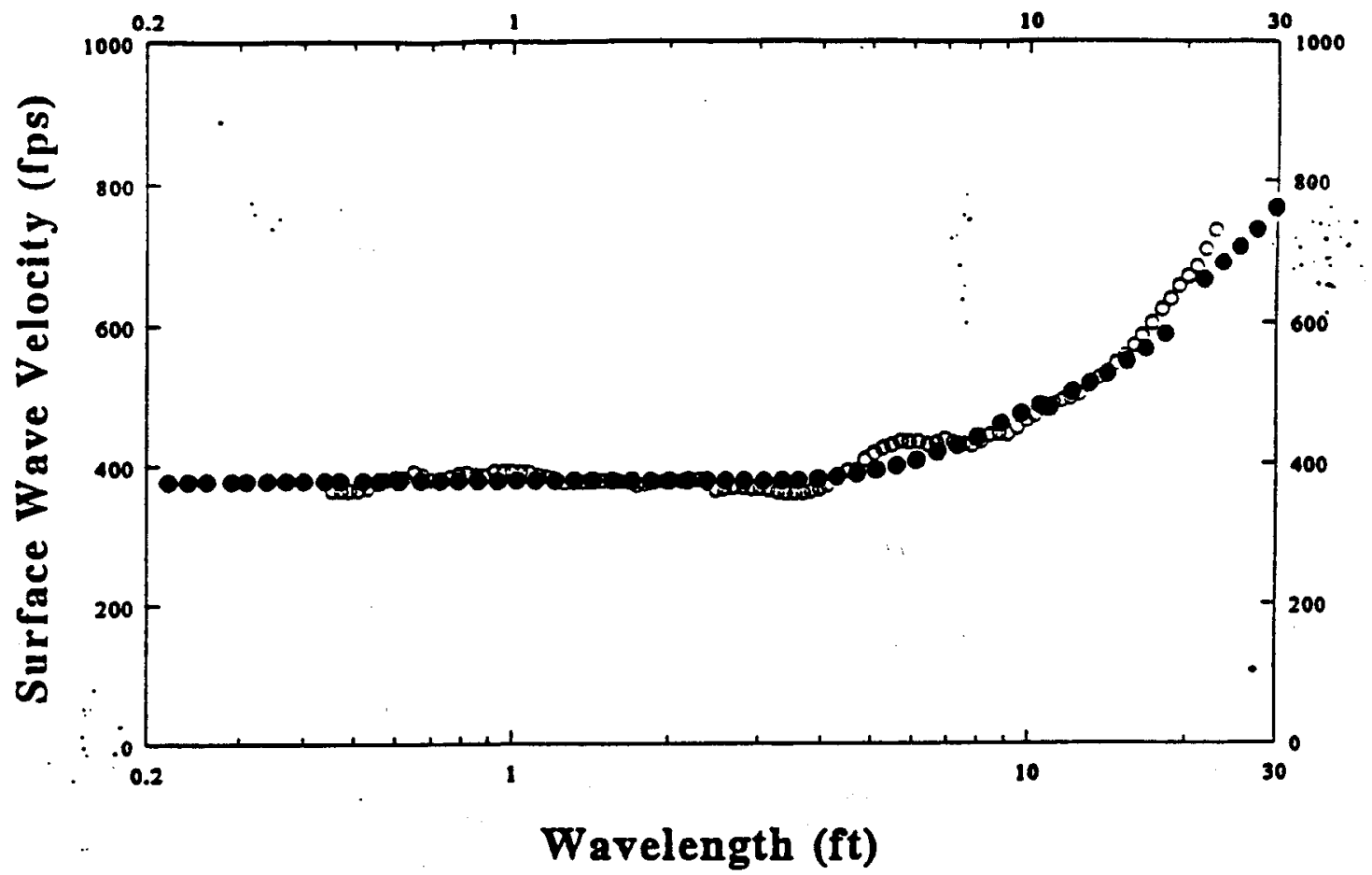

- Exp. Disp.

- 3-D Disp.

Shear Wave Velocity Profile

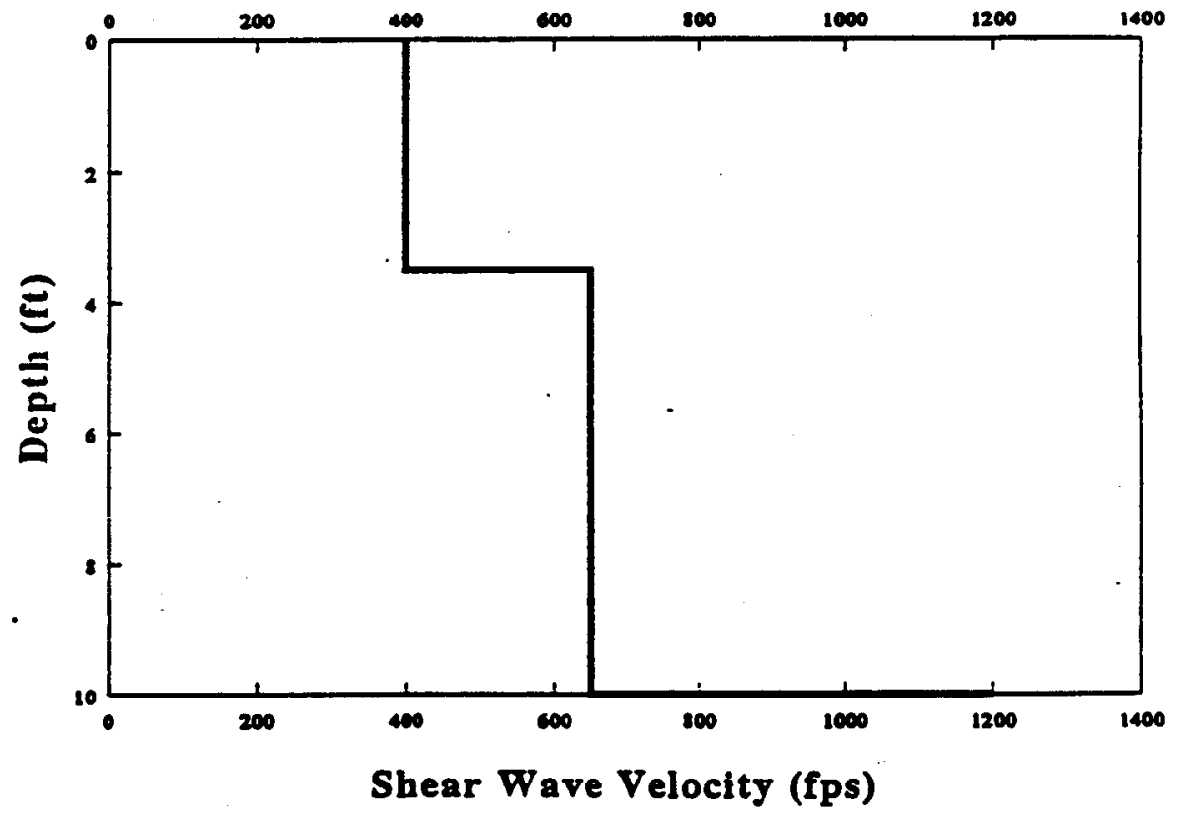

Job 205

Mixed Waste Facility Line A (700 ft -- East - West)

Fig. B-17 


\section{Experimental and Theoretical Dispersions}

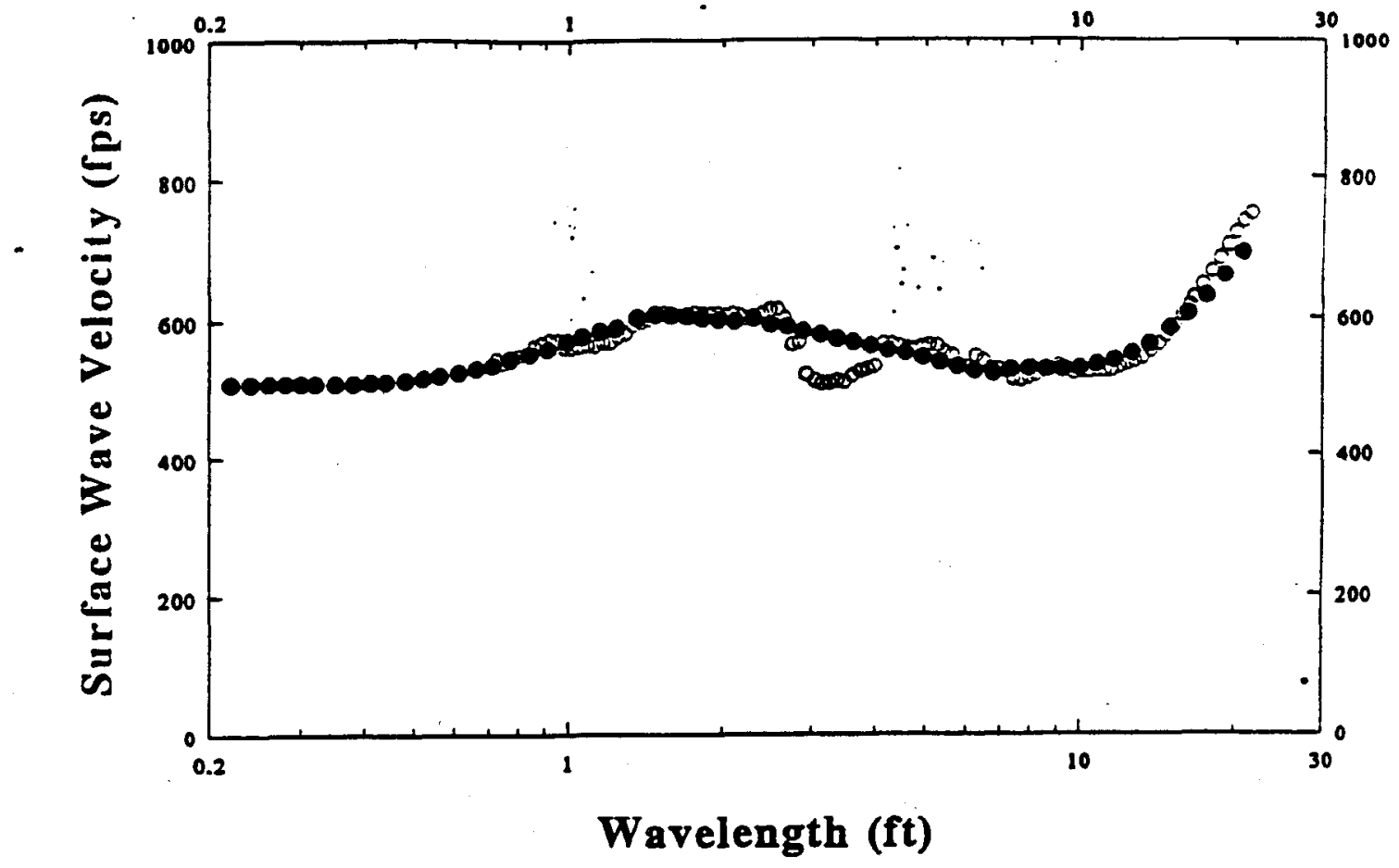

- Exp. Disp.

- 3-D Disp.

Shear Wave Velocity Profile

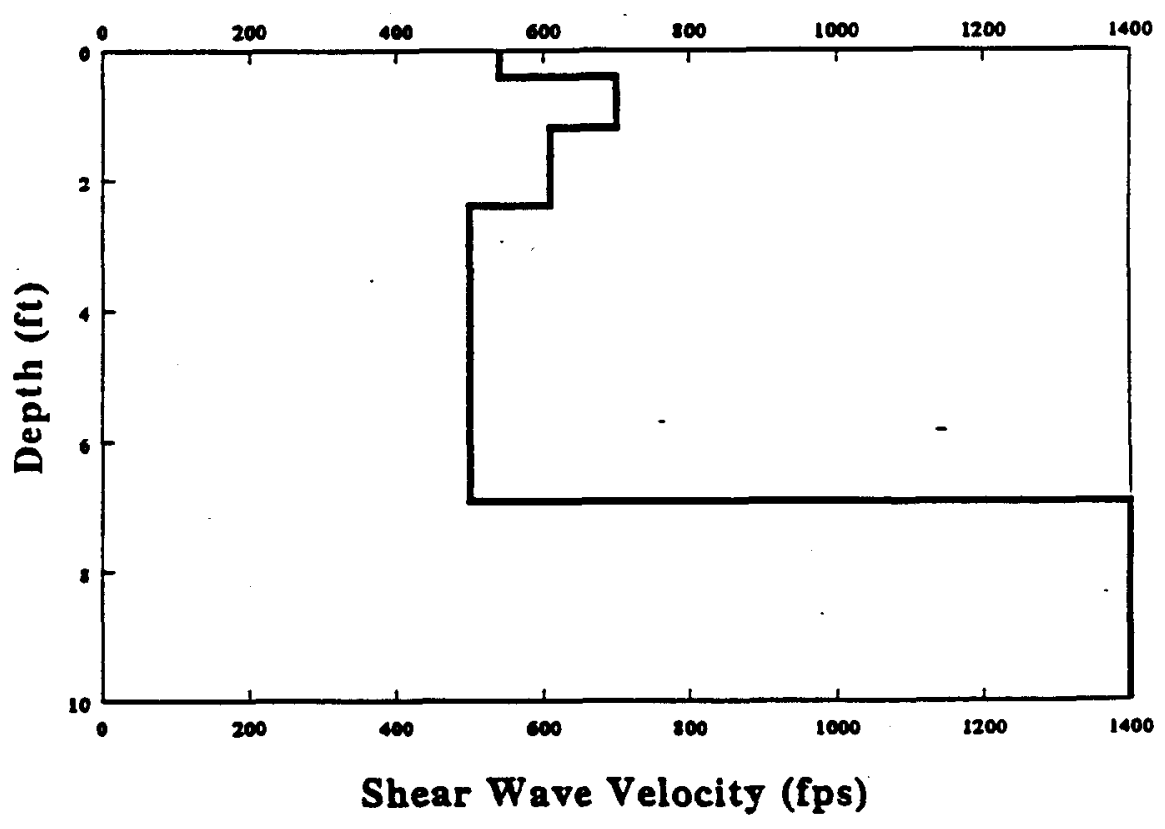

Job 205

Mixed Waste Facility Line A (1000 ft -- East - West)

Fig. B-18 


\section{Experimental and Theoretical Dispersions}

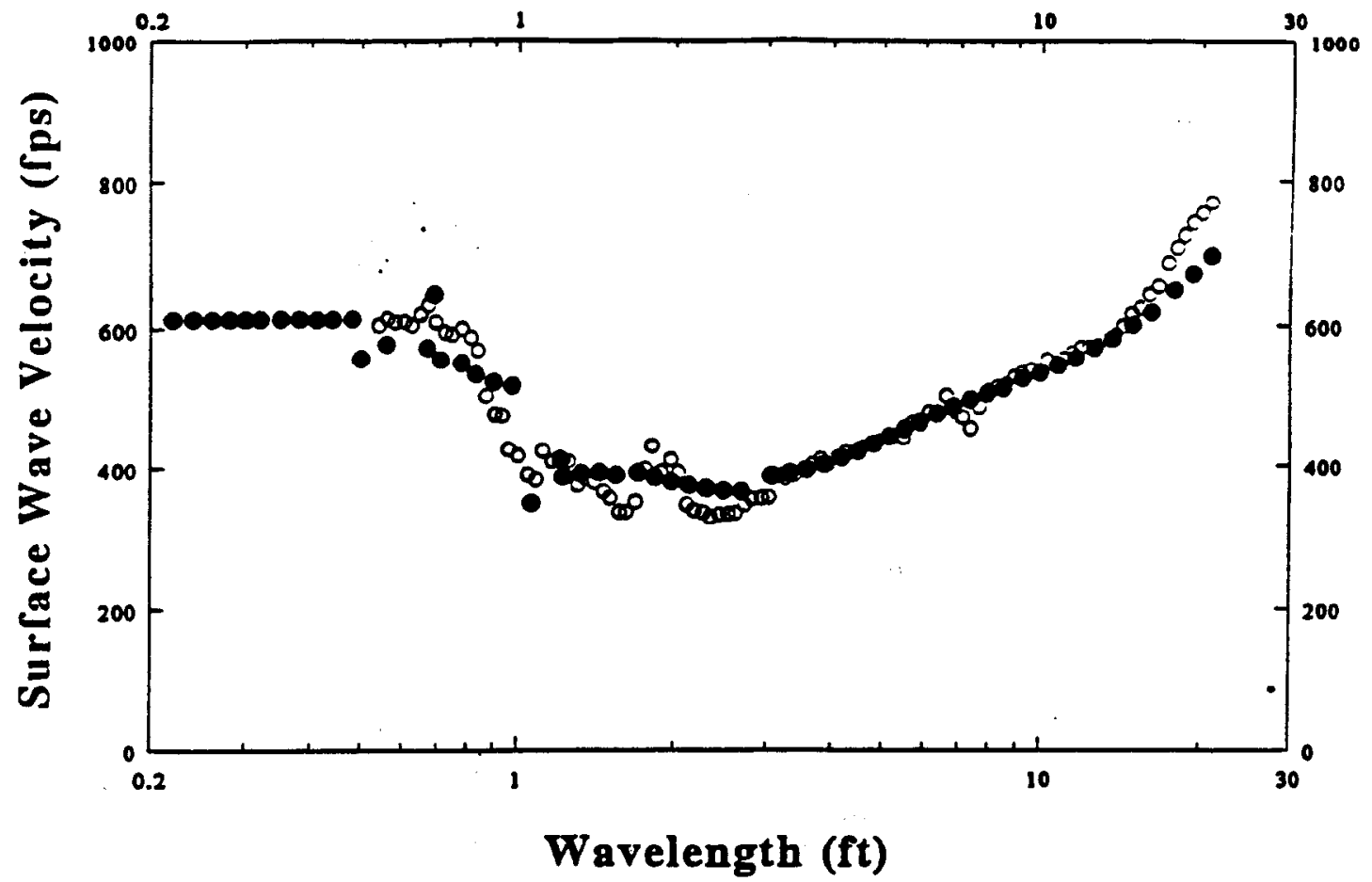

- Exp. Disp.

- 3-D Disp.

Shear Wave Velocity Profile

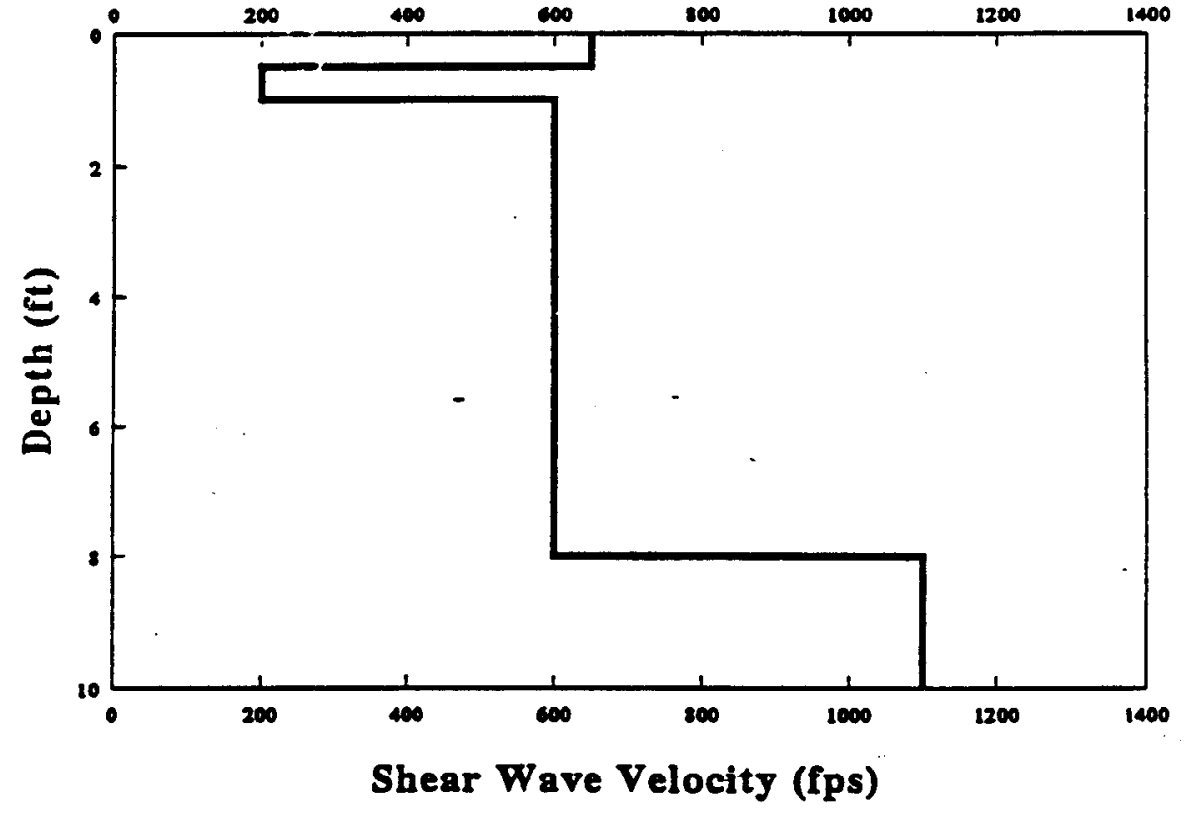

Job 205

Mixed Waste Facility Line A (1300 ft, East-West)

Fig. B-19 
Experimental and Theoretical Dispersions

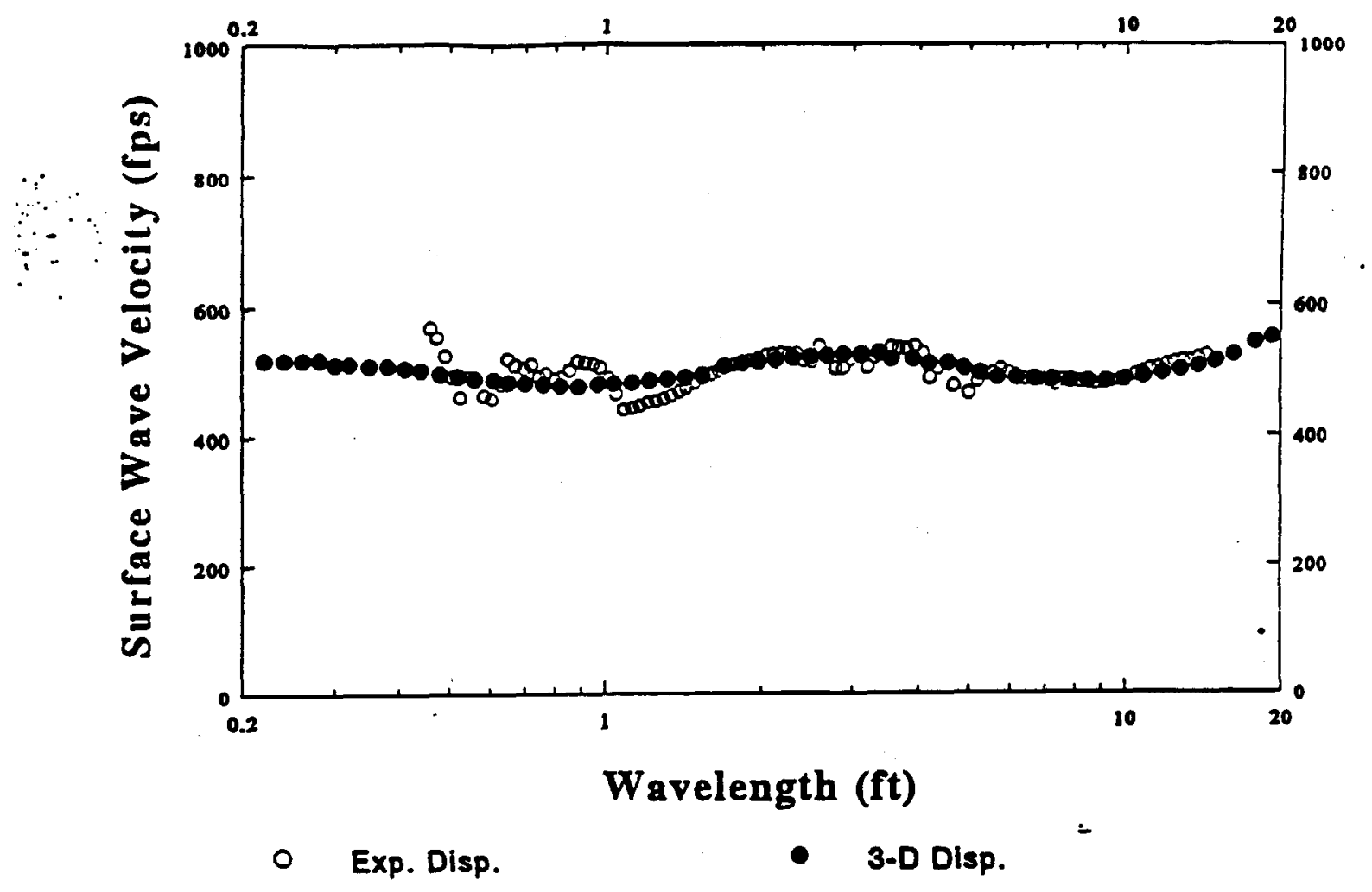

Shear Wave Vélocity Profile

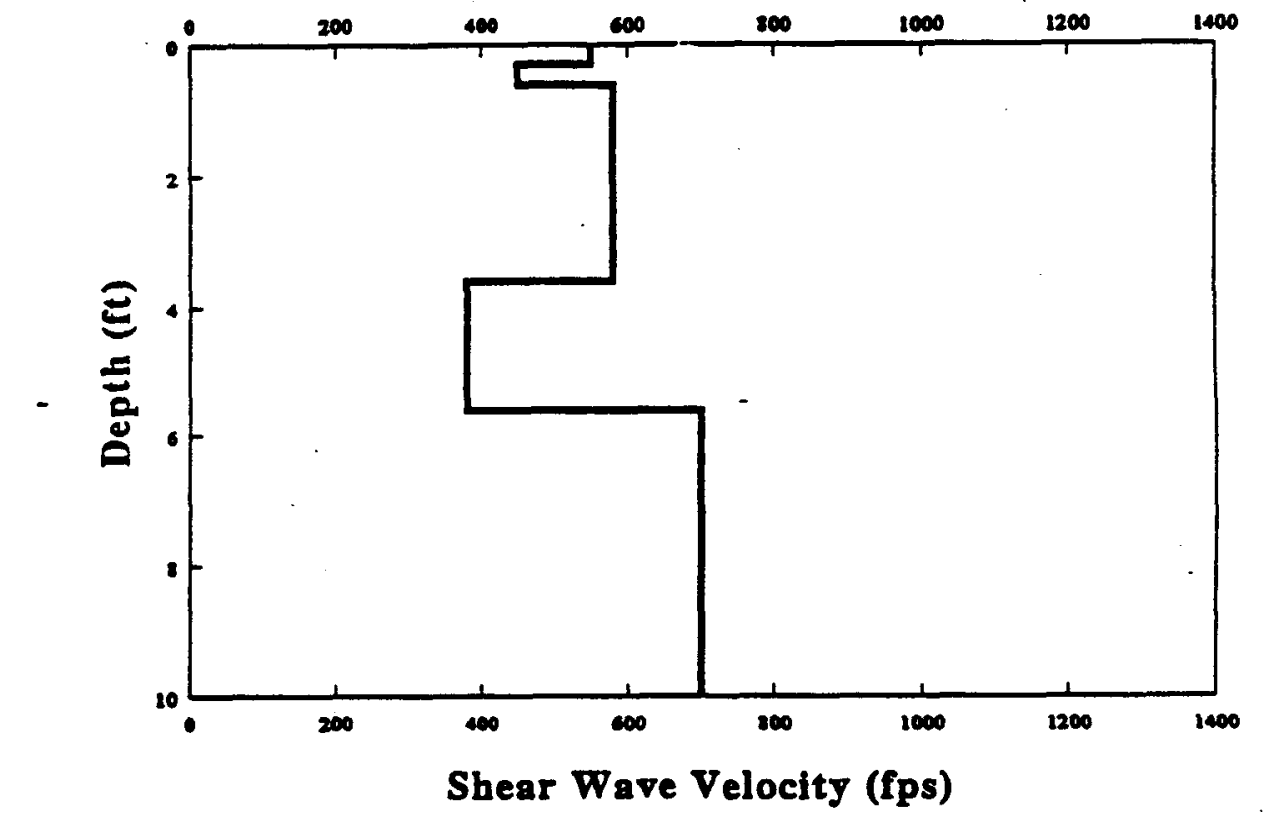

Job 205

Mixed Waste Facility Line B (600 ft, East-West)

Fig. B-20 
Experimental and Theoretical Dispersions

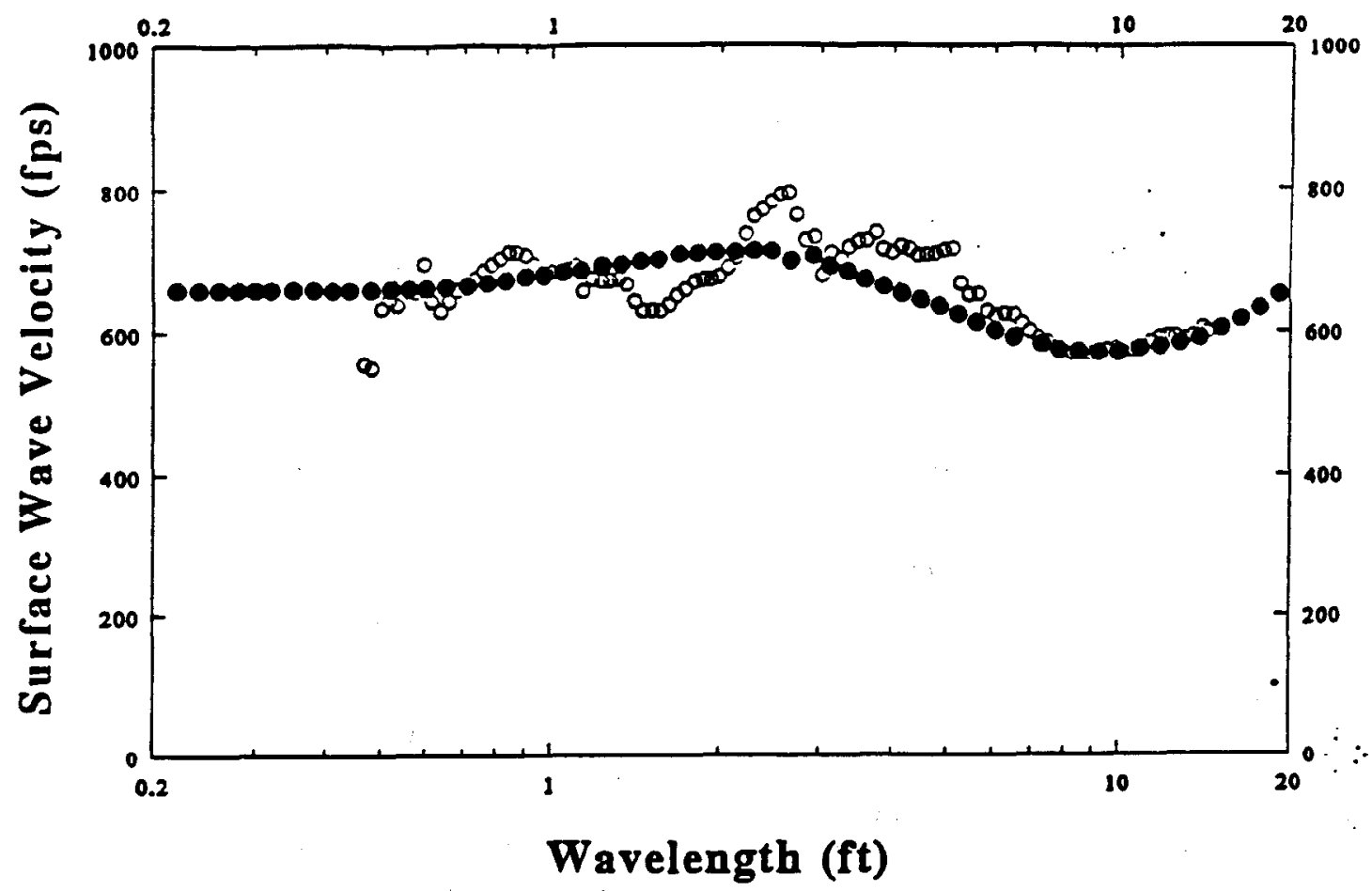

- Exp. Disp.

- 3-D Disp.

Shear Wave Velocity Profile

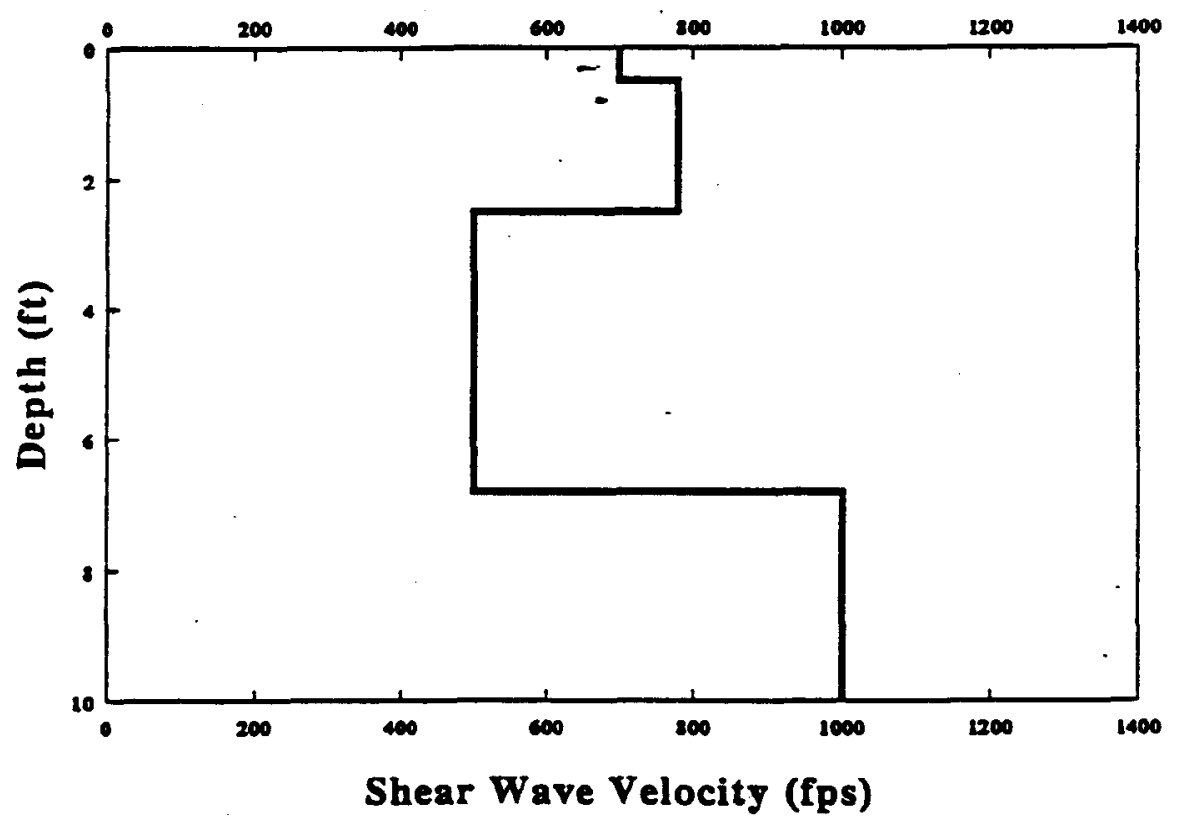

Job 205

Mixed Waste Facility - Line B (800 ft -- East - West)

Fig. B-21 
Rev. 1

\section{Appendix B.2 Low-Strain Test Data}

As a companion to the Spectral Analysis of Shear Wave (SASW) program, a low-strain testing program was conducted. The energy for this program was generated by dropping a 2,000 lb weight from $10 \mathrm{ft}$. Though the low-strain, refraction program was inhibited by the soil structure configuration, it did successfully measure the shear wave velocity. This determination provided a redundant support to the SASW program.

The data included herein is a summary of the more complete discussion included in the EBASCO report [4]. If a more complete data set is required, the information can be obtained from this reference. 
TABLE III

Seismic Refraction Data

for the Dynamic Test Facility (DTF) and the Mixed Waste Management Facility (MWMF)

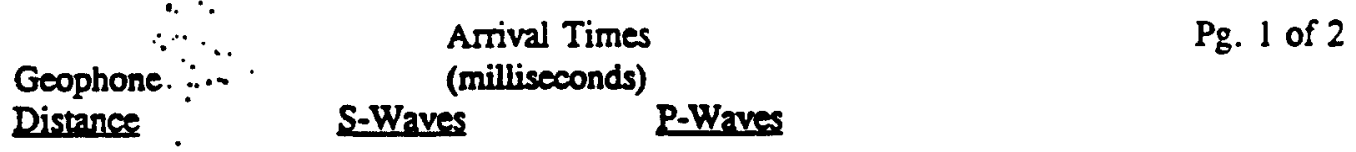

DTF Site SR1 (See Fig. 1 for locations - data plotted in Fig. 9)

$\begin{array}{lll}2 & 2.52 & 1.55 \\ 4 & 4.16 & 2.45 \\ 6 & 5.92 & 3.47 \\ 8 & 7.36 & 4.58 \\ 10 & 9.12 & 5.64 \\ 12 & 11.1 & 6.84 \\ 14 & 14.2 & 8.32 \\ 16 & 15.65 & 9.36 \\ 18 & 18.68 & 11.84 \\ 20 & 20.18 & 12.8 \\ 22 & 22.56 & 14 \\ 24 & 23.68 & 14.72\end{array}$

MWMF (Horseshoe Area) Site SR2 (See Fig. 2 for Locations - data plotted in Fig. 10)

$\begin{array}{lll}2 & 3.58 & 1.57 \\ 4 & 5.41 & 2.6 \\ 6 & 9.3 & 3.63 \\ 8 & 11.3 & 4.91 \\ 10 & 14.7 & 6.56 \\ 12 & 16.8 & 7.76 \\ 14 & 19.2 & 9.4 \\ 16 & 22.3 & 10.6 \\ 18 & 24.2 & 12.84 \\ 20 & 25.9 & 14.12 \\ 22 & 34.7 & 16.12 \\ 24 & 37.4 & 17.16\end{array}$

Job No. 205 


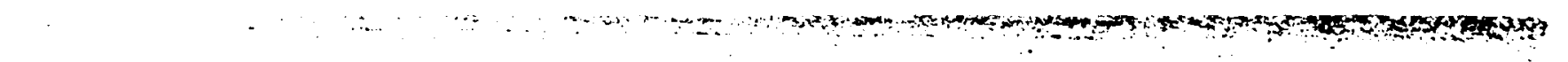

TABLE III (Cont.)

Seismic Refraction Data

for the Mixed Waste Management Facility

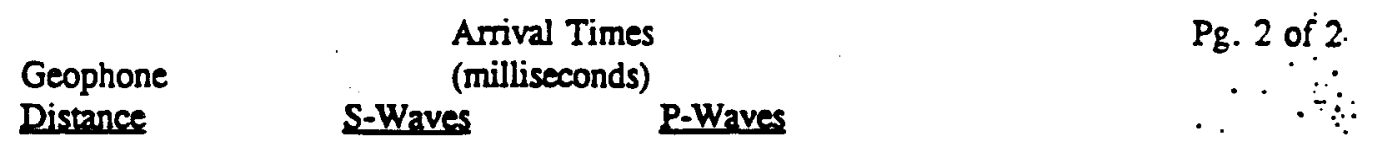

MWMF (Concrete Ditch Area) Site SR3 (See Fig. 3 for locations - data plotted in Fig. 11)

$\begin{array}{lll}2 & 2.46 & 1.34 \\ 4 & 4.16 & 2.11 \\ 6 & 5.31 & 2.85 \\ 8 & 6.8 & 3.55 \\ 10 & 8.56 & 4.9 \\ 12 & 10.2 & 6.27 \\ 14 & 11.8 & 6.98 \\ 16 & 13.9 & 8.13 \\ 18 & 17.7 & 9.15 \\ 20 & 20.3 & 10.18 \\ 22 & 21.4 & 14.21 \\ 24 & 24.5 & 15.36\end{array}$

Job No. 205 


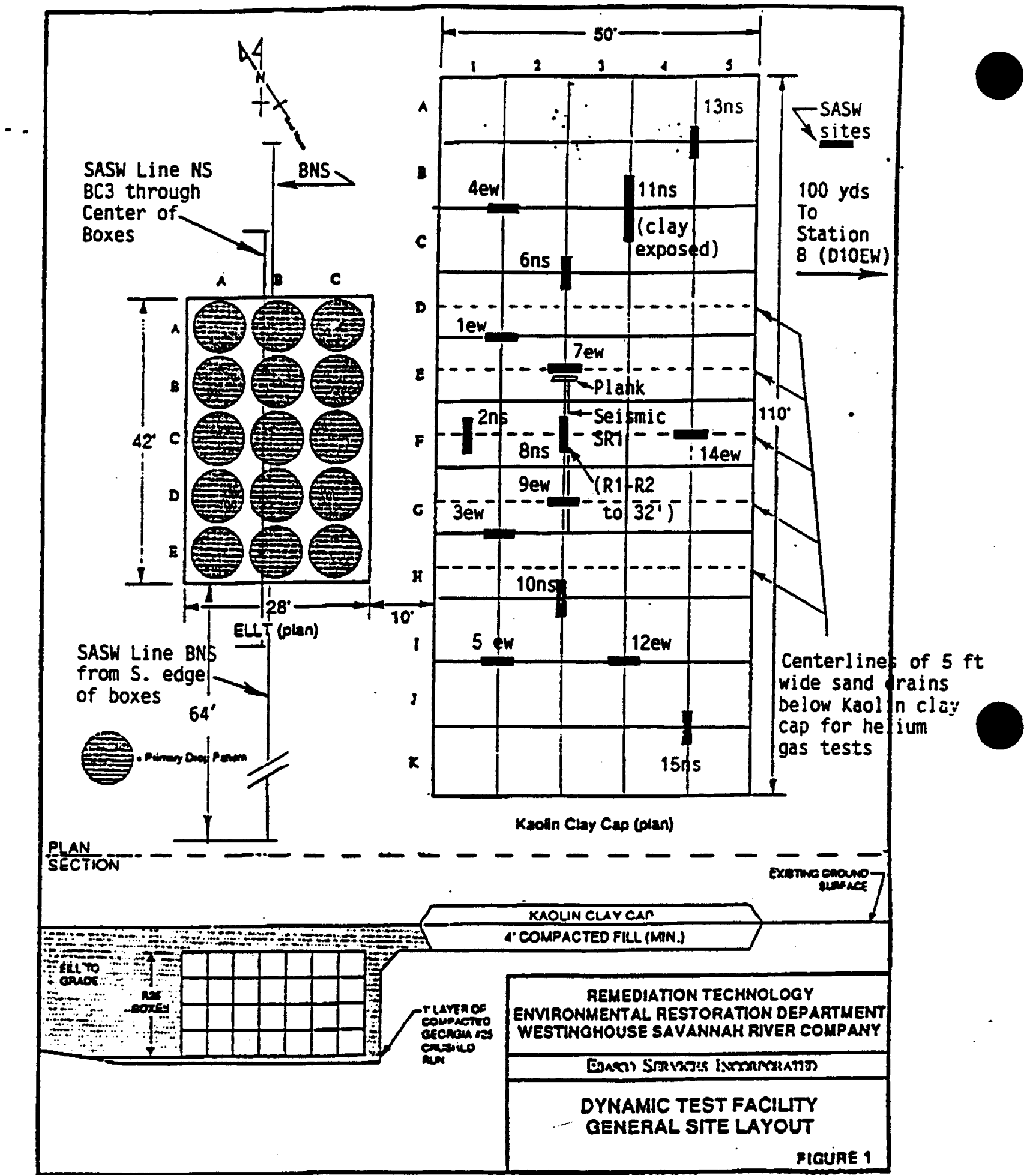

Job No. 205

DTF SASW SITES

Fig. 1 


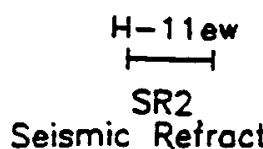

$\mathrm{N}$

. H-14ew

H-10ew

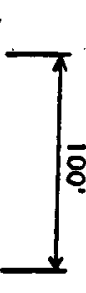

T-9ew

$\stackrel{H-8 e w}{\longmapsto}$

Seismic Refroction

Centerlines of SASW Survey Lines

marked with a labeled " $H-9^{n}$ green

painted short stake.
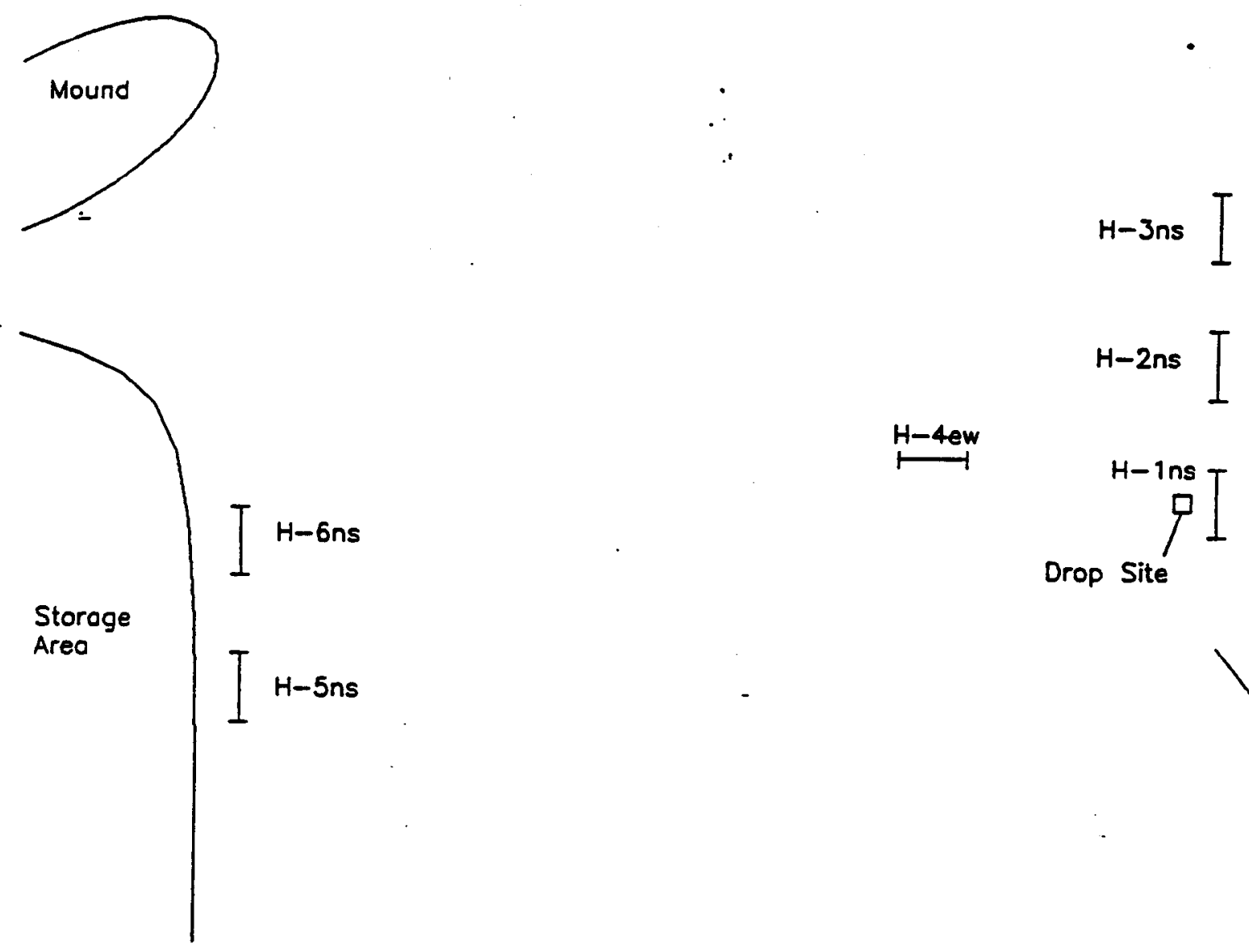

H-2ns $I$

H-4ew

Drop Site

MWMF Horseshoe SASW Sites

Job No. 205

Fig. 2 
P- and S- Wave Seis c Refraction Survey DTF Site SR 1 across SASW Sites 7, 8 \& 9

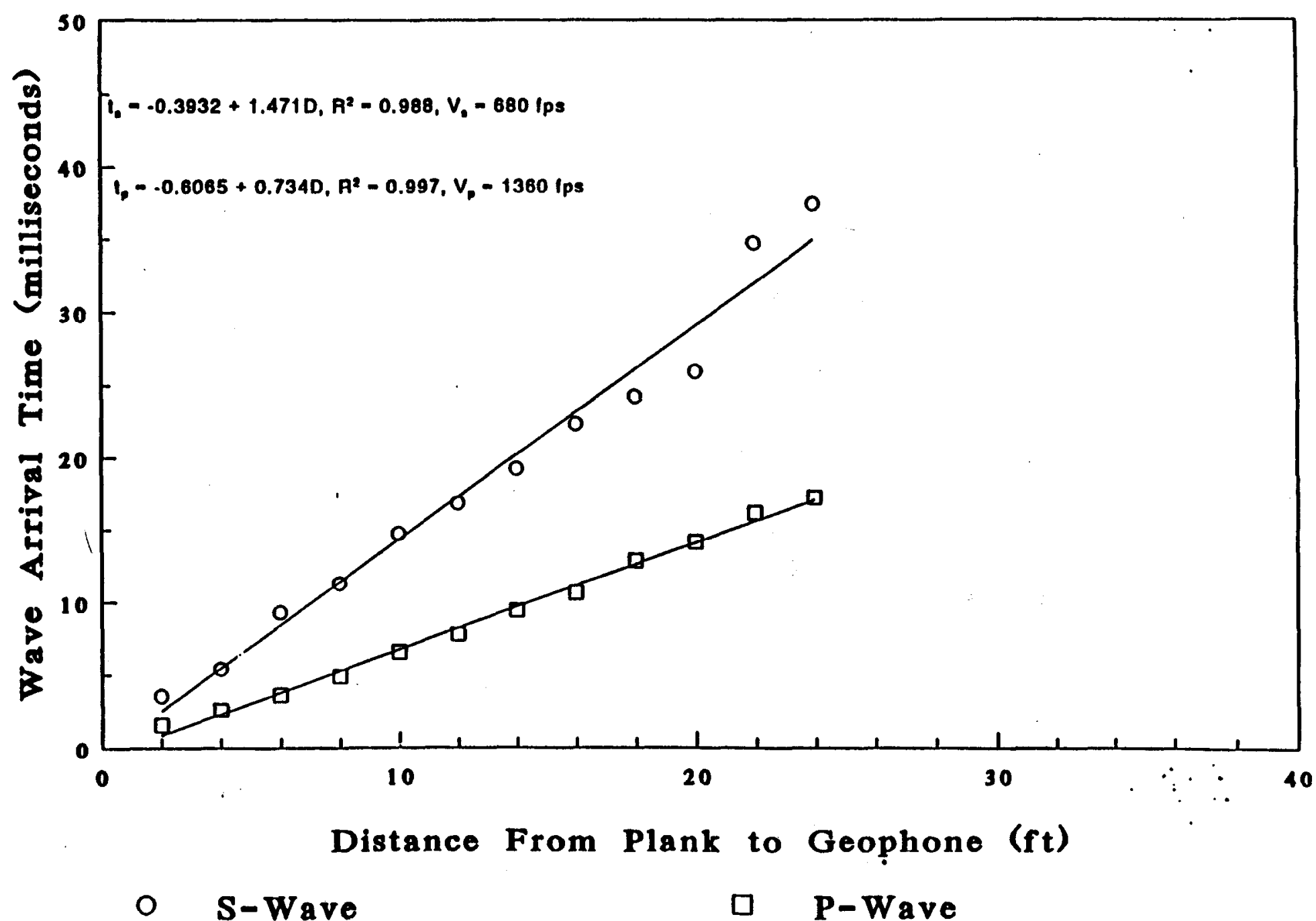

Job No. 205

Fig. 9 
P- and S- Wave Si mic Refraction Survey MWMF Horseshoe Site H1 $1 \mathrm{ew}$ Site SR 2

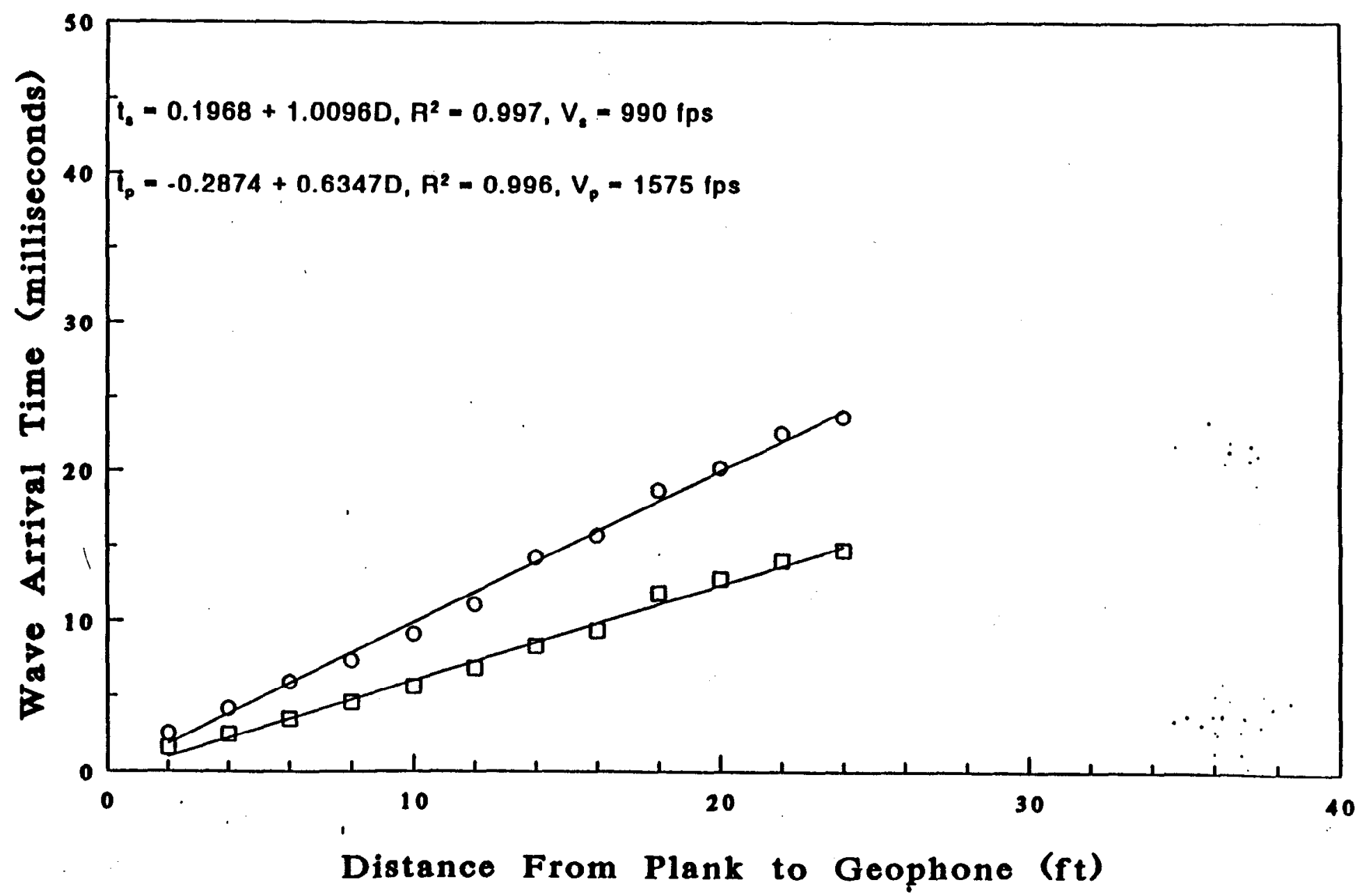

O S-Wave

ㅁ P-Wave

Job No. 205 
P- and S- Wave Se mic Refraction Surrey MWMF Concrete Ditch Site A700ew SR3

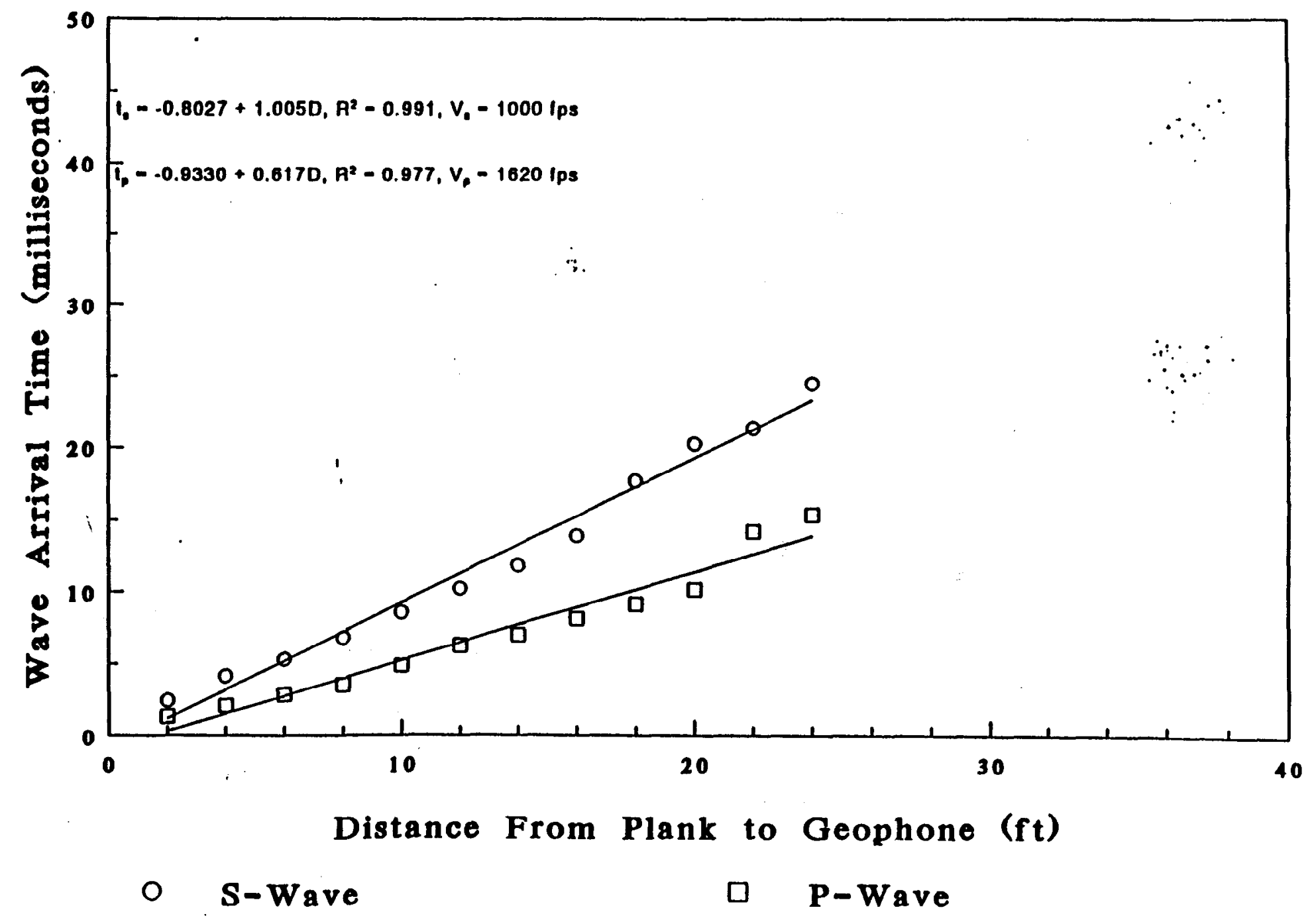

Job NO. 205 
Rev. 1

\section{Appendix B.3}

\section{Impact Velocity Calibration Data}

\section{Appendix Summary}

Each crane used to hoist and drop a dynamic compaction weight has different configurations and resulting coefficients of friction. To optimize the energy imparted to buried wastes, it is important to monitor and control the crane efficiency. Also, the DCF test model required the correlation of the energy at impact between the test and actual production. To accomplish this end, the impact velocity calibration test phase was created and conducted.

The impact velocity calibration test phase was conducted by building two vertical towers between which the dynamic compaction weight would pass. A series of electronic sensors was placed along the towers. As the weight passes through the sensor beams, the velocity is computed. Knowing the instantaneous velocity, the impact energy can be calculated and compared to the frictionless model described by physics.

The data included herein is a summary of the more complete discussion included in the EBASCO report [4]. If a more complete data set is required, the information can be obtained from this reference. In addition, a discussion and outline of the mathematics is included.

\section{Impact Velocity Testing Overview}

The following discussion provides a more in depth explanation of the methods and calculations involved in the impact velocity calibration date. The kinetic energy delivered to the Dynamic Compaction Facility (DCF) test waste matrix by each drop can be determined using basic physics. In simplest terms the kinetic energy delivered is equal to one half the mass of the weight multiplied by the impact velocity squared. Because the efficiency of the crane that will be sued at the DCF is not known, the impact velocity of the weight cannot be easily calculated. Further, if a full-scale follow-up dynamic compaction program is implemented, a different type of crane might be used.

The technology chosen to determine weight impact velocity is a series of laser diode photoelectric cells mounted vertically on two poses at predetermined heights. As the tamper falls downward it sequentially breaks a series of photocell beams at several predetermined heights above the ground surface. The interval between each successive break was recorded. Since the beams are located a known distance apart, the interval velocity and interval crane efficiency can be calculated. Determination of instantaneous impact velocity is then a simple matter of extrapolation using the quantities measured in the photocell gates.

\section{Calculations Involving Tamper Velocity/Crane Efficiency}

For an object in free fall, the impact velocity ( $v$ ) can be calculated as:

$$
v=(2 \mathrm{gh})^{1 / 2}
$$

where $g$ is the acceleration of gravity $\left(32.15 \mathrm{ft} / \mathrm{s}^{2}\right)$ and $\mathrm{h}$ is the drop height. Note that for free fall calculations, impact velocity is independent of tamper weight. However, each crane unavoidable has inertia and fiction associated with the rotation of the cable drum and cable draw through the block/pulley system, etc. Therefore, the actual impact velocity is always less than the free fall value. As suggested by Lukas (1986), this can be accounted for by introducing an efficiency factor " $e$ " such that the equation to calculate impact velocity becomes: 


$$
v=\left(2 g_{\text {ave }}\right)^{1 / 2}
$$

This efficiency factor " $e$ " varies greatly depending on the type of equipment used. From this basic concept of crane efficiency the various quantities associated motion can be related through the following four general equations:

$$
\begin{gathered}
v=v_{0}+g e_{a v g} t \\
h=v_{0} t+\frac{1}{2} g e_{a v g} t^{2} \\
v^{2}=v_{0}^{2}+2 g e_{a v g} h \\
v_{a v g}=\frac{\left(v+v_{0}\right)}{2}
\end{gathered}
$$

where:

$$
\begin{aligned}
& h=\text { height (ft) } \\
& v=\text { instantaneous velocity (ft/s) } \\
& v_{0}=\text { initial velocity }(\mathrm{ft} / \mathrm{s}) \\
& v_{\mathrm{avg}}=\text { average velocity }(\mathrm{f} / \mathrm{s}) \\
& t \quad=\text { time (seconds) } \\
& \mathrm{g}=\text { acceleration ( } 32.15 \mathrm{ft} / \mathrm{s}) \\
& \mathrm{e}_{\mathrm{avg}}=\text { average crane efficiency (equals } 1.0 \text { for free-fall) }
\end{aligned}
$$

As demonstrated by these equations, the time it takes for an object to fall can provide a measure of impact velocity. For example, from a height of $\mathbf{4 2}$ feet, a free fall drop time of 1.62 seconds is predicted from equation 2. As previously mentioned, crane efficiencies always lower the effective velocity of a falling object (relative to free fall). For example, crane efficiencies of $80 \%$ and $60 \%$ increase drop times from 42 feet to 1.81 and 2.09 seconds, respectively. The technology that we have implemented for velocity measurements yields the time that it takes for the tamper to travel over two measured distances (interval 1 and interval 2). The measure quantities required by this technique are shown in Figure B.3.1. 
Rev. 1

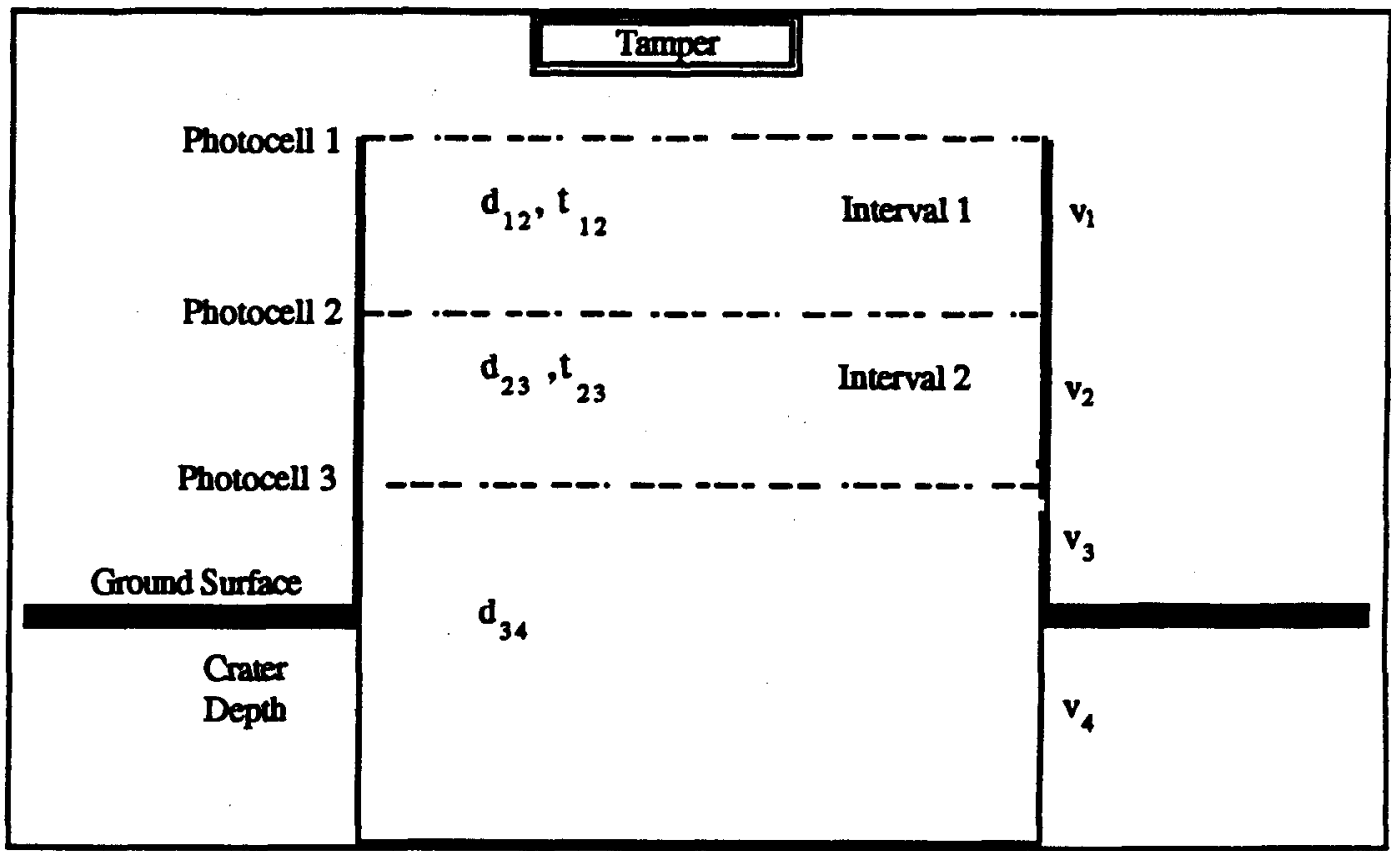

Figure B.3.1 Ilustration of the measured quantities and configuration for the impact velocity measurements.

where:

$d_{12}=$ distance between photocell 1 and photocell 2

$d_{23}=$ distance between photocell 2 and photocell 3

$d_{34}=$ distance between photocell 3 and crater bottom

$t_{12}=$ time tamper takes to travel from photocell 1 to photocell 2

$t_{23}=$ time tamper takes to travel from photocell 2 to photocell 3

$v_{0}=$ instantaneous velocity at time of tamper release $(=0)$

the desired calculated quantities are:

$v_{1}=$ instantaneous velocity at photocell 1

$v_{2}=$ instantaneous velocity at photocell 2

$v_{3}=$ instantaneous velocity at photocell 3

$v_{4}=$ instantaneous velocity at impact (terminal velocity)

$e_{12}=$ interval crane efficiency based on intervals 1,2

$e_{a v g}=$ average crane efficiency for entire drop 
In order to effectively use the measured interval data in conjunction with equations (1), (2), (3), and (4) several algebraic manipulations must be undertaken to produce the desired results of terminal velocity and crane efficiency. The derivation of these equations is outlined as follows.

General Equations (1), (2), (3), and (4) become more specific to the interval velocity measurements, and are:

$$
\begin{gathered}
v=v_{0}+g e_{12} t \\
h=v_{0} t+\frac{1}{2} g e_{12} t^{2} \\
v^{2}=v_{0}^{2}+2 g e_{12} h \\
v_{a v E}=\frac{\left(v+v_{0}\right)}{2}
\end{gathered}
$$

where:

$$
\begin{aligned}
& \text { h }=\text { height }(\mathrm{ft}) \\
& \mathrm{v}=\text { instantaneous velocity }(\mathrm{ft} / \mathrm{s}) \\
& v_{0}=\text { initial velocity }(\mathrm{ft} / \mathrm{s}) \\
& v_{\mathrm{avg}}=\text { average velocity }(\mathrm{ft} / \mathrm{s}) \\
& t \quad=\text { time (seconds) } \\
& g \quad=\text { acceleration }\left(32.15 \mathrm{ft} / \mathrm{s}^{2}\right) \\
& \mathrm{e}_{12}=\text { interval } 1.2 \mathrm{crane} \text { efficiency }
\end{aligned}
$$

\section{Calculation of Interyal Crane Efficiency $\left(e_{12}\right)$}

From equation (5), instantaneous velocity at photocell 2 is:

$$
v_{2}=v_{1}+e_{12} g t_{12}
$$

From equation (6), instantaneous velocity at photocell 3 is:

$$
v_{3}=v_{2}+e_{12} g t_{23}
$$

Adding equations (9) and (10):

$$
v_{2}+v_{3}=v_{1}+v_{2}+e_{12} g\left(t_{12+t_{23}}\right)
$$

Dividing (11) by 2 to get average interval velocity:

$$
\frac{\left(v_{2}+v_{3}\right)}{2}=\frac{\left(v_{1}+v_{2}\right)}{2}+\frac{\left[e_{12} g\left(t_{12}+t_{23}\right)\right]}{2}
$$

Average velocity for interval 2 can be expressed two ways:

$$
\frac{\left(v_{1}+v_{2}\right)}{2}=\frac{d_{12}}{t_{12}}
$$


Average velocity for interval 2 can be expreseed two ways:

$$
\frac{\left(v_{2}+v_{3}\right)}{2}=\frac{d_{23}}{t_{23}}
$$

Substituting average velocity based on distance and time (equations (13) and (14)) into equation (12):

$$
\frac{d_{23}}{t_{23}}=\frac{d_{12}}{t_{12}}+\frac{\left[e_{12} g\left(t_{12}+t_{23}\right)\right]}{2}
$$

Solving equation (15) for interval crane efficiency $\left(e_{12}\right)$ :

$$
e_{12}=\frac{2\left(\frac{d_{23}}{t_{23}}-\frac{d_{12}}{t_{12}}\right)}{g\left(t_{12}+t_{23}\right)}
$$

Calculation of Instantaneous Velocity at Point of Impact $\left(v_{4}\right)$

Solving equation (14) for $v_{2}$ :

$$
v_{2}=2\left(\frac{d_{23}}{d_{23}}\right)-v_{3}
$$

Substituting $v_{2}$ from equation (17) into equation (10):

$$
v_{3}=\left[2\left(\frac{d_{23}}{t_{23}}\right)-v_{3}\right]+e_{12} g t_{23}
$$

Simplifying equation (18):

$$
v_{3}=\frac{d_{23}}{t_{23}}+\frac{\left(e_{12} g t_{23}\right)}{2}
$$

Solving equation (13) for $v_{1}$ :

$$
v_{1}=2\left(\frac{d_{12}}{t_{12}}\right)-v_{2}
$$

Substituting $v_{1}$ from equation (20) into equation (9):

$$
v_{2}=\left[2\left(\frac{d_{12}}{d_{12}}\right)-v_{2}\right]+e_{12} g t_{12}
$$

Simplifying equation (21):

$$
v_{2}=\frac{d_{12}}{t_{12}}+\frac{\left(e_{12} g t_{12}\right)}{2}
$$


Solving equation (5) for $v_{1}$ :

$$
v_{1}=v_{2}=e_{12} g t_{12}
$$

Substituting $v_{2}$ from equation (22) into equation (23):

$$
v_{1}=\left[\frac{d_{12}}{t_{12}}+\frac{\left(e_{12} g t_{12}\right)}{2}\right]-e_{12} g t_{12}
$$

Substituting $v_{3}$ from equation (19) into equation (7):

$$
v_{4}=\left[\left(\frac{d_{23}}{t_{23}}+\frac{\left(e_{12} g t_{23}\right)}{2}\right)^{2}+2 g e_{12} d_{34}\right]^{1 / 2}
$$

Calculation of Average Crane Efficiency for Entire Drop $\left(e_{\text {avg }}\right)$

From equation (3) $v_{4}^{2}=v_{0}^{2}+2 g e_{a v} h$. Substituting the initial tamper velocity of zero $\left(v_{0}=0\right)$ and $v_{4}$ from equation (25) into equation (26), and solving for $e_{\text {avg: }}$ :

$$
\begin{aligned}
& e_{\text {avg }}=\frac{v_{4}^{2}}{2 g h} \\
& =\frac{\left\{\left[\left(\frac{d_{23}}{t_{23}}+\frac{\left(e_{12} g t_{23}\right)}{2}\right)^{2}+2 g e_{12} d_{34}\right]^{0.5}\right\}^{2}}{2 g h} \\
& =\frac{\left\{\left[\frac{d_{23}}{t_{23}}+\frac{\left(e_{12} g t_{23}\right)}{2}\right]^{2}+2 g e_{12} d_{34}\right\}}{2 g h} \\
& =\frac{d_{12}}{t_{12}}-\frac{e_{12} g t_{12}}{2}
\end{aligned}
$$

\section{Calculation of Kinetic Energy Eor Weight Impact}

The approximate energy delivered to the DCF test waste matrix by each drop can be determined using basic physics. In simplest terms, the kinetic energy delivered to the DCF waste matrix can be expressed by:

$$
\text { k.e. }=\frac{1}{2} \mathbf{m v ^ { 2 }}
$$

where:

$$
\begin{aligned}
& \text { k.e. }=\text { kinetic energy in f /lbs } \\
& m \quad=\text { mass in slugs }=(\text { weight/gravity) } \\
& v \quad=\text { terminal velocity }
\end{aligned}
$$

\section{B. 55}


Rev. 1

Substituting the velocity value obtained from equation (25) and conversion of the $42,000 \mathrm{lb}$ weight to mass (slugs), then kinetic energy delivered to the DCF matrix is:

$$
\text { k.e. }=\frac{1}{2}\left[(42,000 \mathrm{lbs}) /\left(32.15 \mathrm{ft} / \mathrm{s}^{2}\right)\right] \mathrm{v}_{4}^{2}
$$

These formulae were incorporated into a spreadsheet so that real time calculations of weight terminal velocity and average crane efficiency could be determined.

A description of the field setup of the measuring equipment at the DCF and a summary of the observation results is included herein. 
WSRC-TR-94-0159

Rev. 1

March 21, 1994

Dynamic Compaction Report

(Pages 57 through 58 Left Intentionally Blank) 


\subsection{FIELD SETUP OF MEASURING EQUIPMIENT AT THE DTF}

The field setup for photocell tower arrays and associated electronies is presented diagrammatically on Figure 1.6-1. The first step in setting up the photocell towers was to pre-drill pilot holes (3/4" diameter, 1' deep) at each of the tower locations (see Figure 1.6-1 inset). The pilot holes were then fitted with 3/4" diameter steel pipe (pounded flush with theground surface). The 9" stainless steel spike at the end of each tower was then inserted into the 3/4" pipe, allowing the tower to free-stand vertically. At this point the towers were shimmed with wood blocks to horizontality (or near horizontality), and 4" $\times 4^{\text {" fence post }}$ bubble levels were utilized to achieve a vertical tower orientation. The towers were then tied into position with guy-wires, with 6' to 7 ' long $1^{\prime \prime}$ diameter rebar stabilizers added at 90 degrees to one another and lashed to the tower. These stabilizers helped to provide additional resistance to swaying motions due to wind loading, and most importantly provided torsional (twisting) resistance. Electrical connections were then made, including $12 \mathrm{~V}$ power to each photocell, line hookups to the signal conditioning box, and fitting the trigger and signal cables to the timing circuitry (EG\&G ES-1225 exploration seismograph). At this point the photocell arrays were ready to be aligned. This process was accomplished by use of a 30" long stainless steel sighting tube and Sisteco hand leveling tool (accurate to 0.1 degree). The photocell signal conditioning box was outfitted with a loud piezoelectric buzzer that sounded as the photocell transmitter and receiver came into alignment. Alignment was accomplished by a combination of sighting and leveling of the sensor bracket/photocell assembly. The photocell bracket was thru-bolted (bolts not tightened) to the aluminum angle stock which allowed for up-and-down rotation of the photocells. Side-to-side sensor motion was accomplished by rotating the photocell assembly. Once the buzzer signaled aligament the photocell was tightened into position by use of a c-clamp (photccell assembly to aluminum angle stock) and wing-nut (photocell bracket to photocell assembly). Further alignment refinements were necessary at this point. Very small vertical and horizontal adjustments were made to assure that each photocell receiver was centered within the transmitter beam. The distance from photocell transmitter to receiver was set to 82 feet, which is more than the recommended maximum range of 65 feet. In practice this made the photocells extremely susceptible to small rotational movements (misalignment), thus requiring very precise initial photocell alignment. In order to complete the towar setup a measurement of the distance from the breakpoint in photocell beam number 3 to the ground surface (impact ara) was made. 


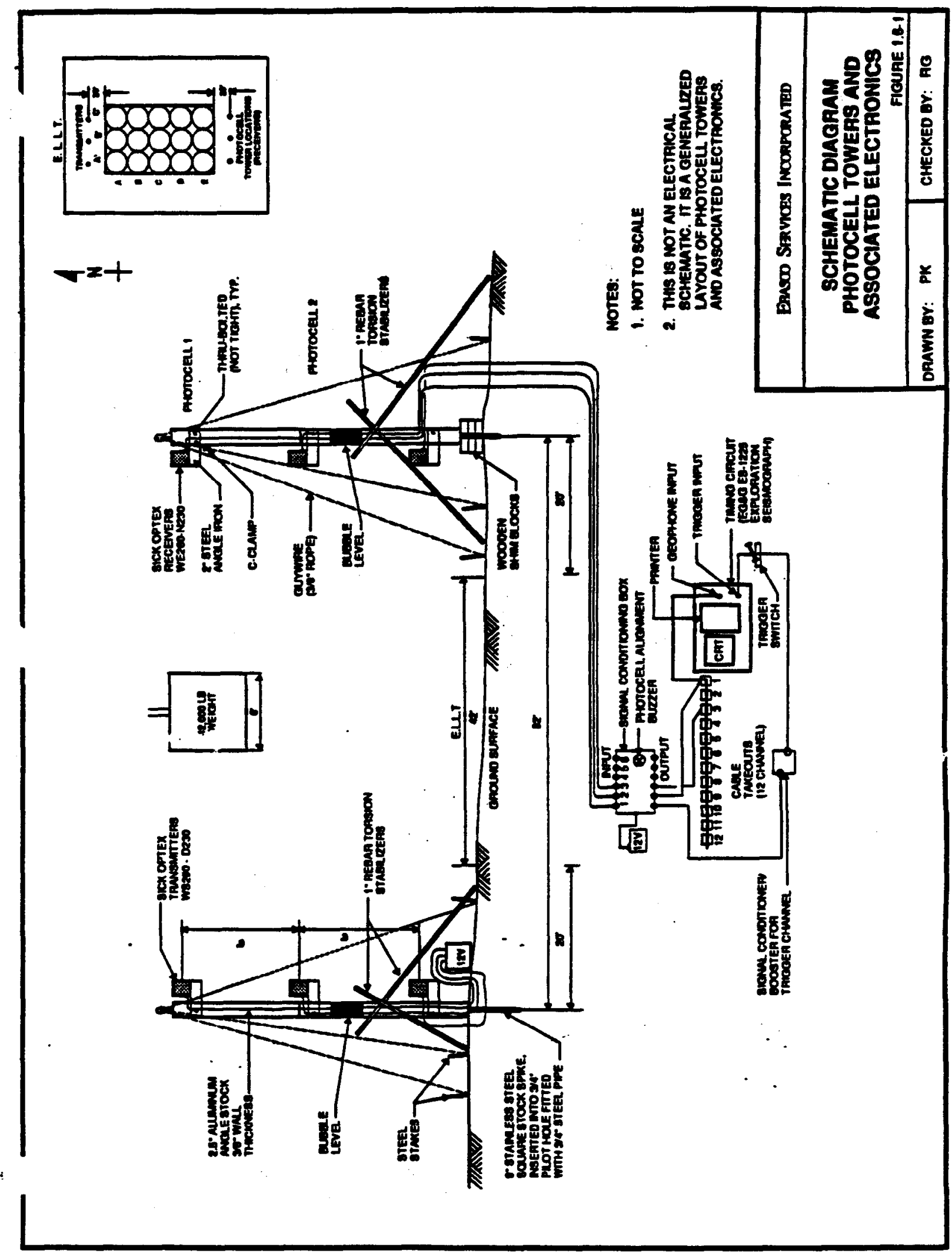


Once the photocell tower setup was completed the drop testing commenced. As the 42,000 pound weight descended it broke the 1st photocell beam, which triggered the seismograph to begin the timing circuit. The timing circuit window was typically set to record for 1.0 seconds (1000 milliseconds), which allowed dat sampling (photocell 2 and 3 interrogation) to oecur every 0.5 milliseconds. The seismograph was operated in "preview mode" which disallowed subsequent triggers (i.e. cable/block/choke assembly moving in front of the photocells) from stacking and corrupting the firat trigfer dat. As soon as the compaction weight impacted the trigger channel was electrically disconnected from the seismograph by means of a toggle switch. This disconnection provided additional security against aocideneal triggers. At this point the seismograph operator used the built-in cursor cappabilities of the seismograph to read off the event triggers for photocells 2 and 3, and made a hard copy printout of the record.

The 2 pieces of dam gathered from the seismograph represents the time it took for the 42,000 pound weight to pass from photocell 1 to photocell 2, and from photocell 1 to photocell 3. To determine the instantaneous velocity at impact and other desired parameters (1.e. crane efficiency) these data were entered into a Lotus 1-2-3 spreadsheat ruming on a portable computer. This setup allowed for real time determination of tamper velocity and crane efficiency. The mathematics and layout of the calculation spreadsheet were discussed in Section 1.3.

Calibration drops with the 42,000 pound tamper were conducted 7/13/92 in a cleared field 380 feet east of the DTF, at calibration drop location $D+10$. Calibration rests were performed from several different droc heights $(15,20,25,35,42$, and $50 \mathrm{ft}$ ), with ordering of drop height from lowest to highest. Table 1.6-1 summarizes the average crane efficiencies realized from each of the different drop heights. The complete velocity/kinetic energy/efficiency spreadsheet used for the calibration drops is presented as Table 1.6-2. As shown on Table $1.6-1$, the terminal (impact velocity, $v_{4}$ ) at the initially proposed production drop height of $42 \mathrm{ft}$ was approximately $39.8 \mathrm{ft} / \mathrm{s}$. This value was lower than the anticipated velocity of approximately $46 \mathrm{ft} / \mathrm{s}$ (for a $42 \mathrm{ft}$ drop height and crane with 80-90\% efficiency). This is due to the fact that the Manitowoc crane that was used could not lift the 42,000 pound weight with a single cable, and relied upon a blockspulley arrangement that reduced average crane efficiency to approximately $54 \%$ (see Table 1.6-1, which shows remarkably uniform average crane efficiencies given the large range of drop heights). Based on this lower crane efficiency and impact velocity it was determined that a higher drop height (50 $\mathrm{A}$ ) would be implemented for the production drops. Hard-copy paper records of the 13 DTF 


\begin{tabular}{|c|c|c|c|}
\hline $\begin{array}{l}\text { Drep } \\
\text { Nenoter }\end{array}$ & $\begin{array}{l}\text { Dopp flotht } \\
\text { Feat }\end{array}$ & 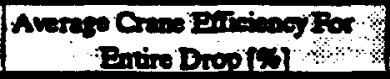 & Ba \\
\hline$C-1$ & 150 & 0.5S4 & \\
\hline $\mathbf{C}-\mathbf{2}$ & 25.0 & ass4 & \\
\hline $\mathbf{C}-3$ & 15.0 & 0567 & \\
\hline$c-4$ & 200 & 0516 & \\
\hline$C-5$ & 20.0 & Q512 & \\
\hline$C-6$ & no & oses & \\
\hline $\mathrm{C}-7$ & 250 & QSOS & \\
\hline $\mathrm{C}-8$ & 25.0 & 0.501 & \\
\hline $\mathrm{C}-9$ & 35.0 & assi & \\
\hline$c-10$ & 35.0 & osas & \\
\hline C-11 & 420 & Q574 & \\
\hline$c-12$ & 420 & 0057 & Bed Trierer From Nenarement Rope \\
\hline$c-13$ & sa.0 & assi & \\
\hline
\end{tabular}

12000 Round Truper Calitration Drops Adiecent to (E)st On The DTF Averese Crase Eriviency

Average 0536

Nore: Teat 12 Excluded (Bad Trieger)

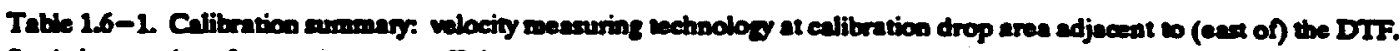
Stativios are given for averige ure effriency. 


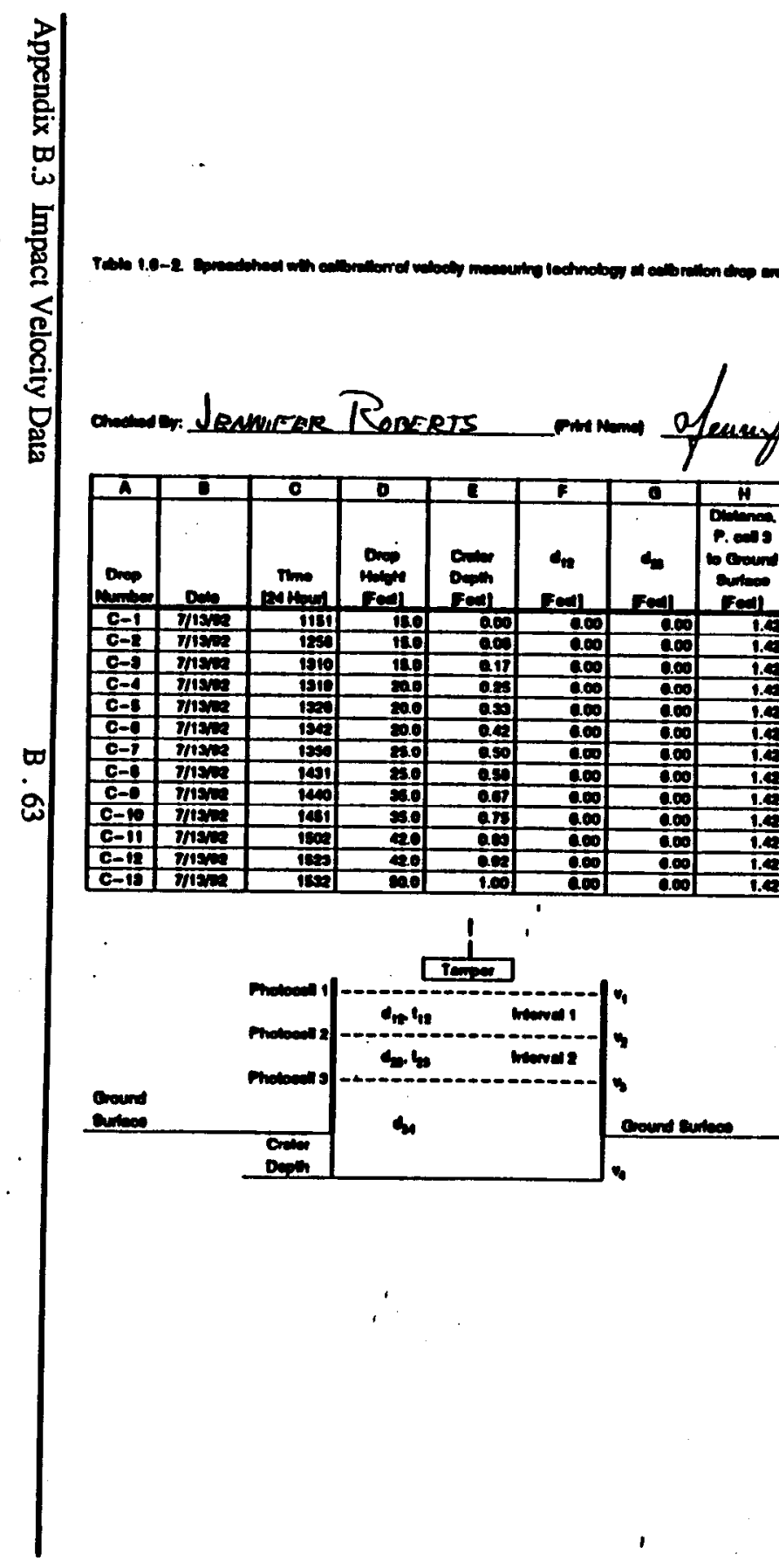


Calibration drops are included as Appendix B.

\subsection{PRODUCTION DROP DATA}

Production dropping was conducted from 7/15/92 to 7/21/92, at a total of 19 drop points. Hard-copy paper records of all DTF production drops are included as Appendix C. Figure 1.7-1 shows the location of each drop point, drop location type (primary, secondary, or tertiary), and sequence in which each drop was completed. Table 1.7-1 includes all of the primary and secondary drop point spreadsheet calculations/dan that were collected using the interval photocell measuring equipment. This includes determination of terminal velocity, binetic energy, and average crane efficiency for each drop. For the purposes of examining reproducibility of the crane drops and photocell measurements, Table 1.7-2 summarizes the instantaneous velocity at photocell $3\left(V_{3}\right)$ and average crane efficiency (the terminal velocity, $v_{4}$, was not chosen for comparative purposes because crater depth/terminal velocity changes with each drop). As shown on Table 1.7-2 the instantaneous velocity at photocell 3 averages $41.43 \mathrm{ft} / \mathrm{s}$ with a standard deviation of $0.44 \mathrm{ft} / \mathrm{s}$. The average crane efficiency for all the production drops is 0.555 (55.5\%) with a standard deviation of $0.015(1.5 \%)$. These results indicate a high degree of reproducibility for both the crane and the interval photocell measurement equipment.

Due to this high degree of reproducibility (a fact that was available real time) it was determined that the interval photocell measurements were not necessary for the final four drop locations (tertiary drop points T-1, T-2, T-3, and T-4). By using the average crane efficiency obtained from measurements at the primary and secondary drop locations is: is possible to calculate both tamper impact velocity and linetic energy for each of the tertiary drops. Table 1.7-3 presents these data. 


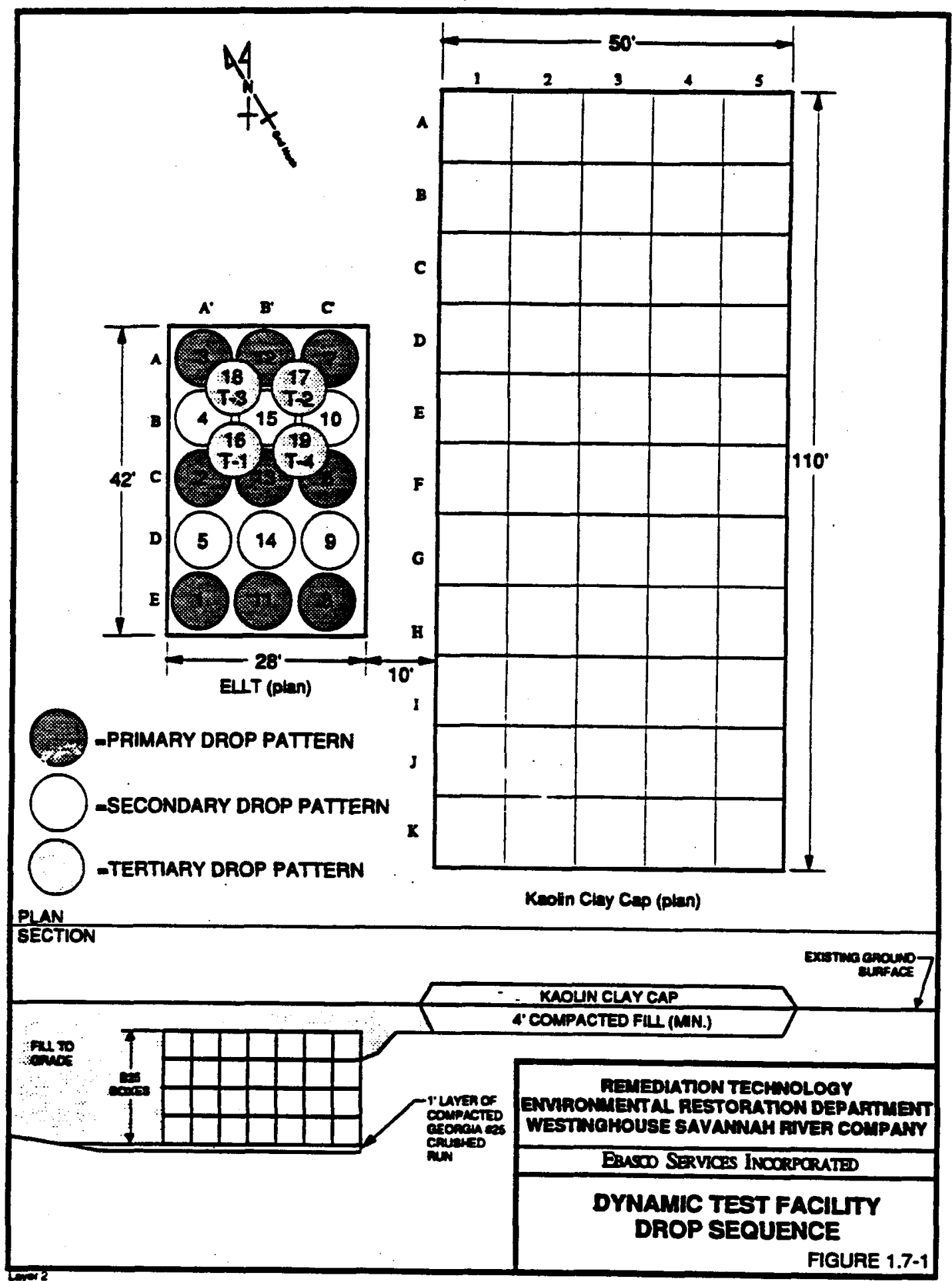




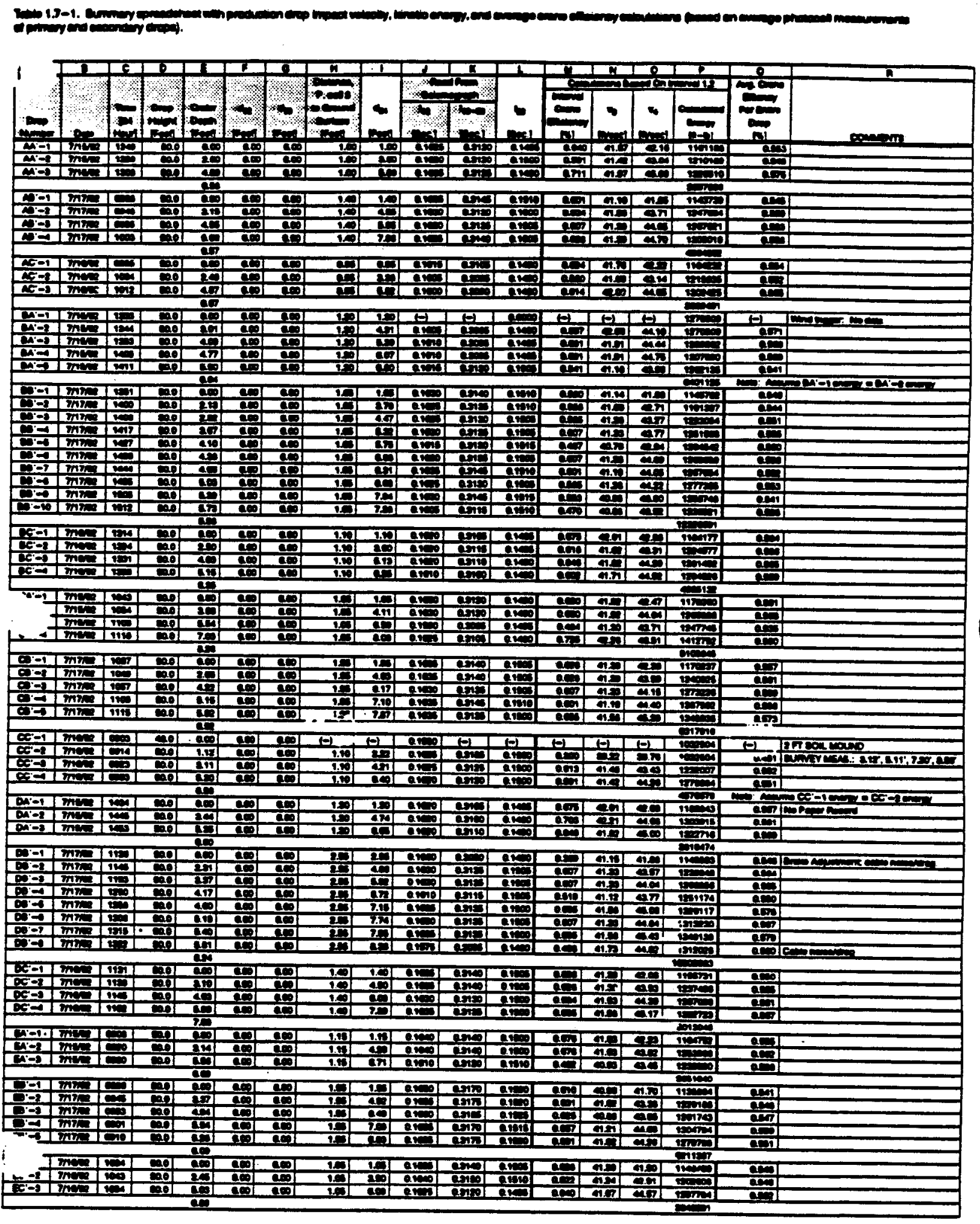




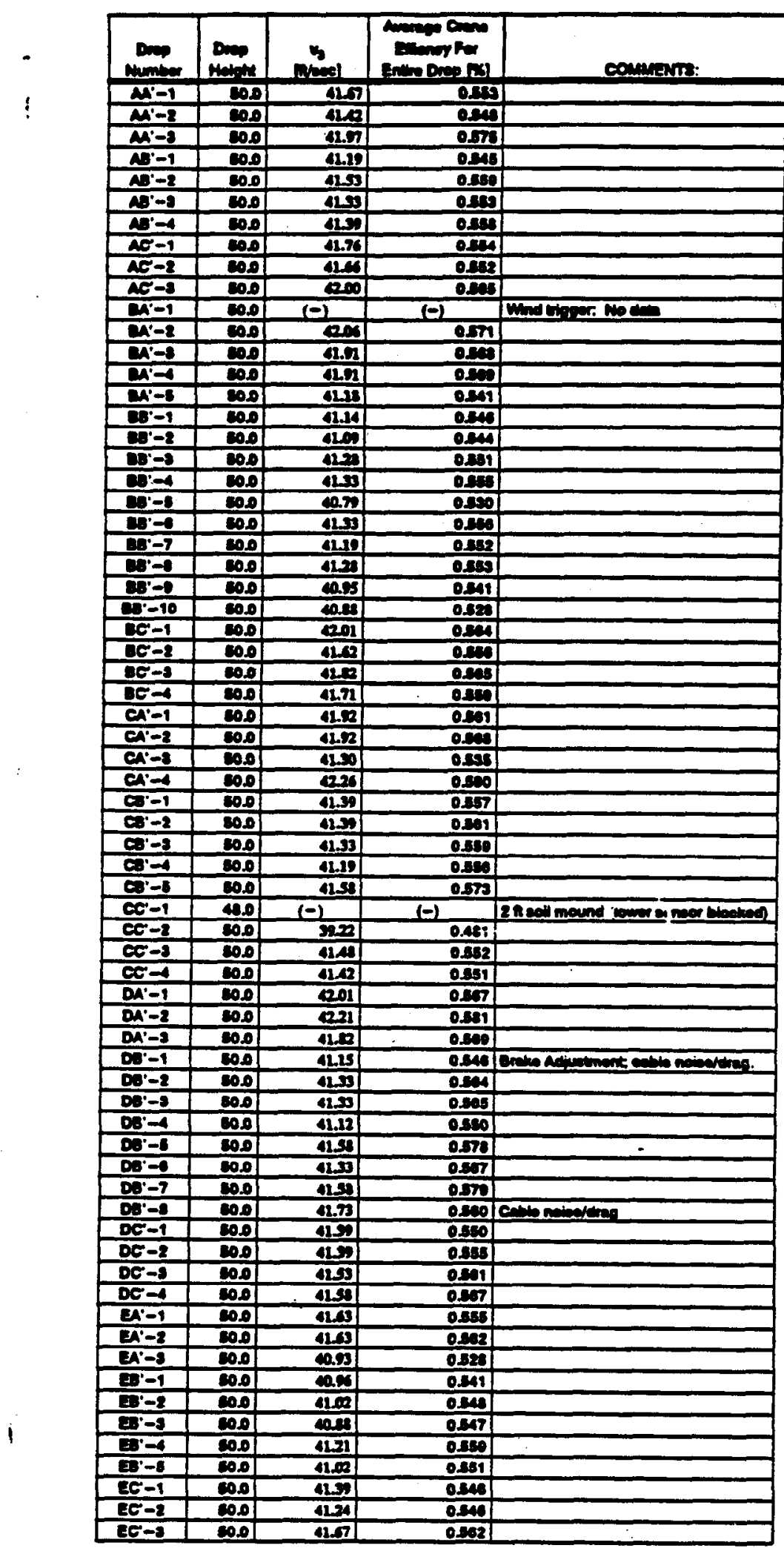

Tabl 1.7-2. sondaies of prodmetion trops

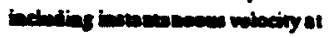
phaned 3 (

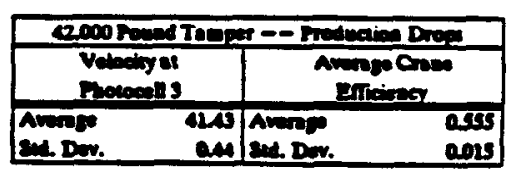

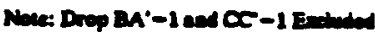




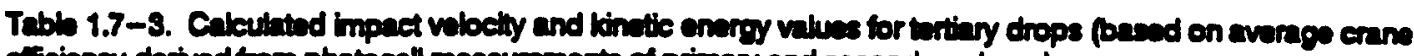
eficiency darived trom photocell measurements of primay and secondary drops).

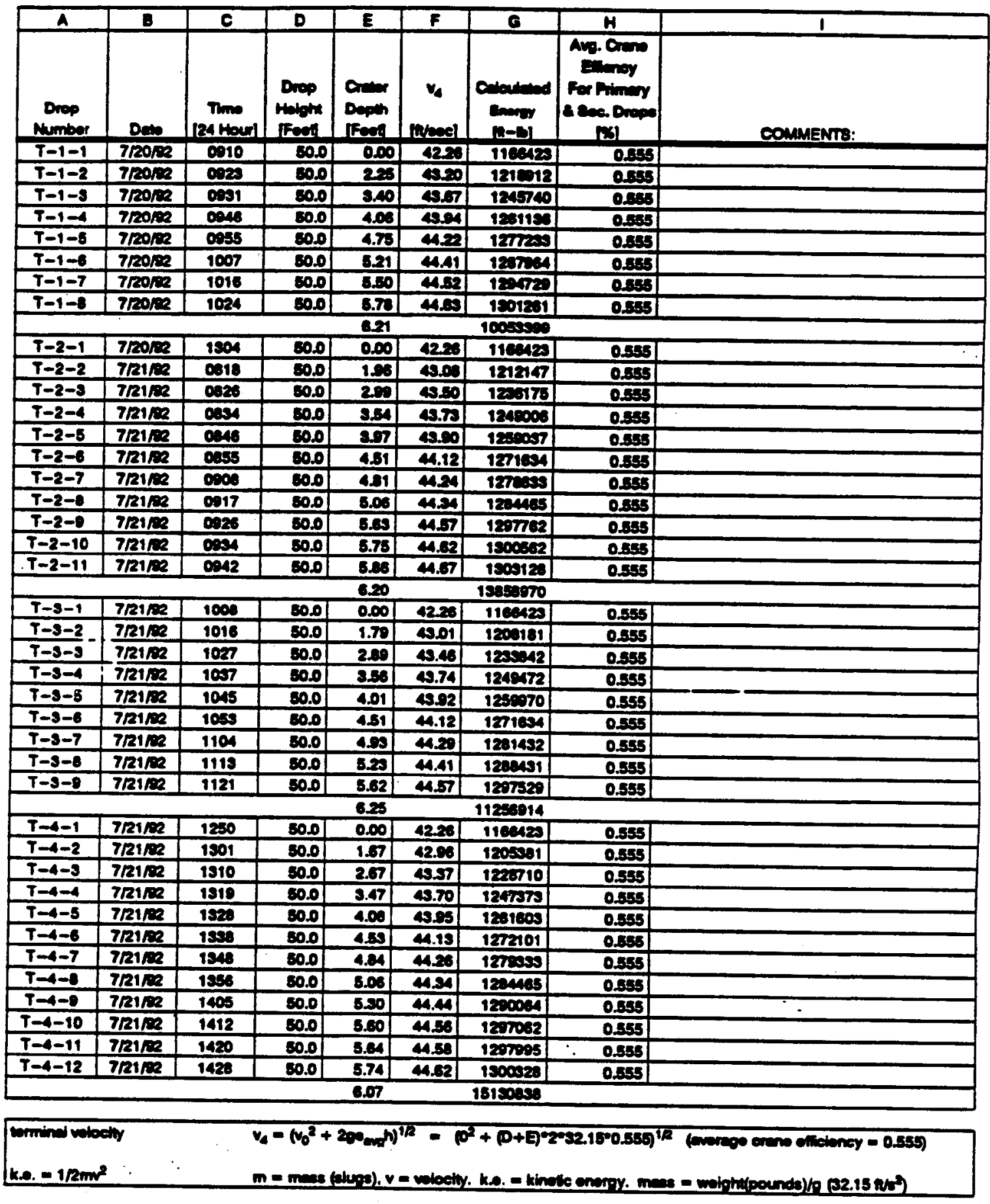




\subsection{OBSERVATIONS}

All 19 production drop locations met the refusal criteria of a $6 \mathrm{ft}$ deep crater prior to 20 drops. Primary drop locations (AA', CA', E', $\mathrm{AB}^{\prime}, \mathrm{CB}^{\prime}, \mathrm{EB}^{\prime}, \mathrm{AC}^{\prime}, \mathrm{CC}^{\prime}$, and $\mathrm{EC}^{\prime}$ ) required the fewest number of blows to reach refusal (typically 3 to 5 drops). Secondary drop locations (BA', DA', BB', DB', BC', and $\mathrm{DC}^{\prime}$ ) required more drops to reach $6 \mathrm{ft}$ crater depth (3 to 10), and tertiary drop locations (T-1, T-2, T-3, and T-4) the most (8 to 12). The number of drops at each location is shown graphically on Figure 1.8-1. Not surprisingly the increase in number of drops from primary, to secondary, to tertiary locations reflects the fact that each successive location had an increase in neighboring sites that had been previously compacted.

The number of drops at each location is plotted against crater depth on Figure 1.8-2 [primary drops (Figure 1.8-2a), secondary drops (Figure 1.8-2b), and tertiary drops (Figure 1.8-2c)]. On these figures measured crater depth (y-axis) is plotted against corresponding drop number at each location. A nearly vertical line (i.e. the primary drops on Figure 1.8-2a) indicates a low number of drops required to reach the $6 \mathrm{ft}$ crater depth refusal criteria, and a relatively large compaction (increase in crater depth) experienced per drop. A line that is arcuate describes a drop location that required a larger number of blows to reach the refusal criteria (i.e. the tertiary drops on Figure 1.8-2c), and experienced relatively little compaction per drop. If compaction was carried out to $\geq 20$ drops the arcunte line would become horizontal to subhorizontal and indicate the ultimate refusal depth. Figure 1.8-2b (secondary drops, locations $\mathrm{BA}^{\prime}, \mathrm{DA}^{\prime}, \mathrm{DC}^{\prime}$, and $\mathrm{BC}^{\prime}$ transitioning to $\mathrm{DB}^{\prime}$ and $\mathrm{BB}^{\prime}$ ) shows an interesting change from a primary drop iuse signature (Figure 1.8-2a) to the more arcuate line signatures of the tertiary drops (Figure 1.8-2C). This change is a function of the sequencing of the drops, as later drops had neighboring waste materials/craters that had already been dymamically compacted and filled with soil (with infilled soil compacted to moderate density by gentle tamping with the $42,000 \mathrm{lb}$ weight). The inflection point located near the top of the tertiary drops plots (Figure 1.8-2c) indicates a slight increase in compaction per drop for each of the last few drops. This might be the result of a temporary soil/waste "bridge" that gave way after repeated compaction drops, causing minor failure of lower B-25 box(es).

Figure 1.8-3 plots compaction per drop (feet) on the y-axis against drop number on the $x$ axis for: (a) all drops, (b) primary drops, (c) secondary drops, and (d) tertiary drops. The " $T$ "- shaped plotting symbol shows the average (mean) compaction value for each drop number (the shor horizontal bar) and the standard deviation about the mean (the vertical 


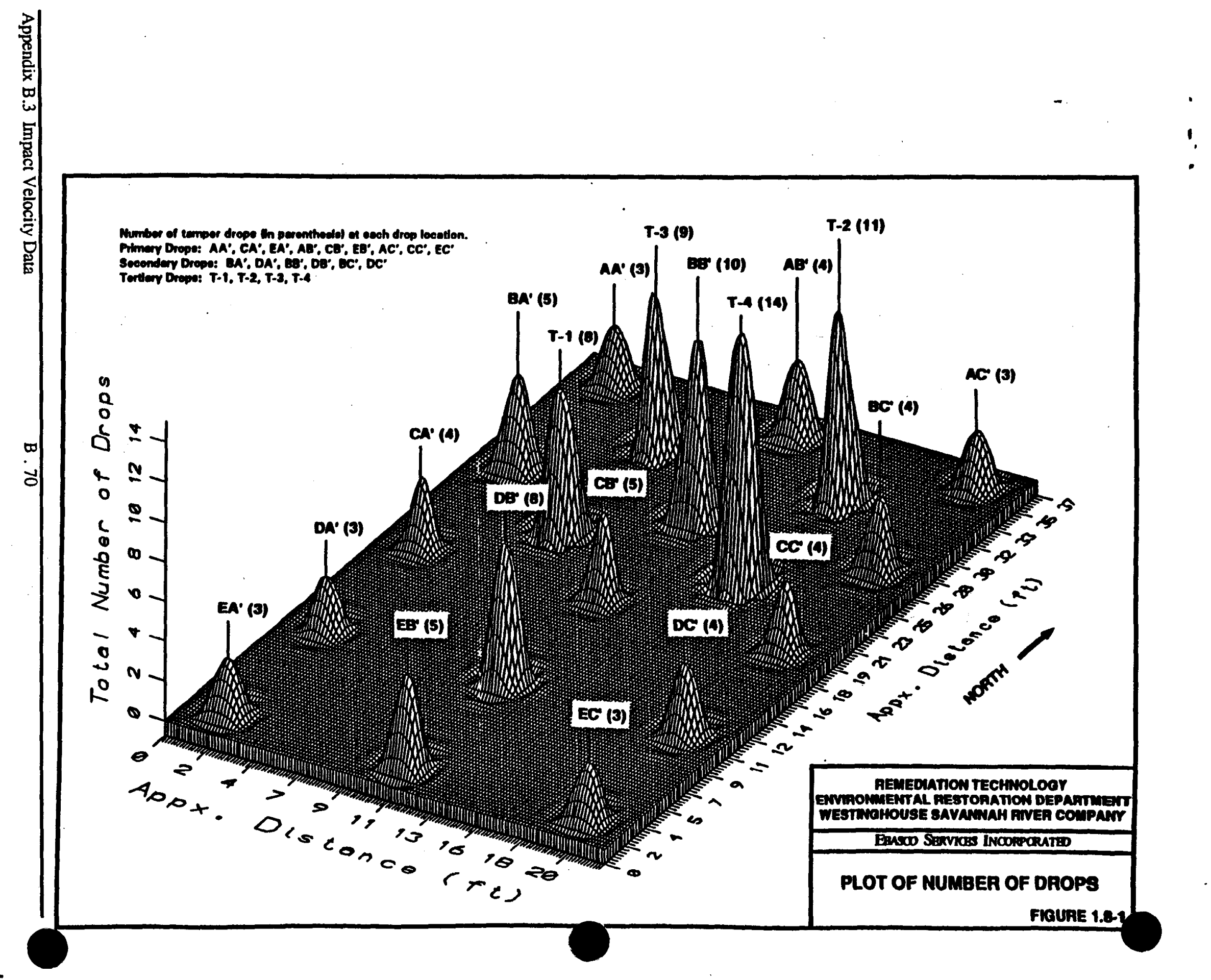




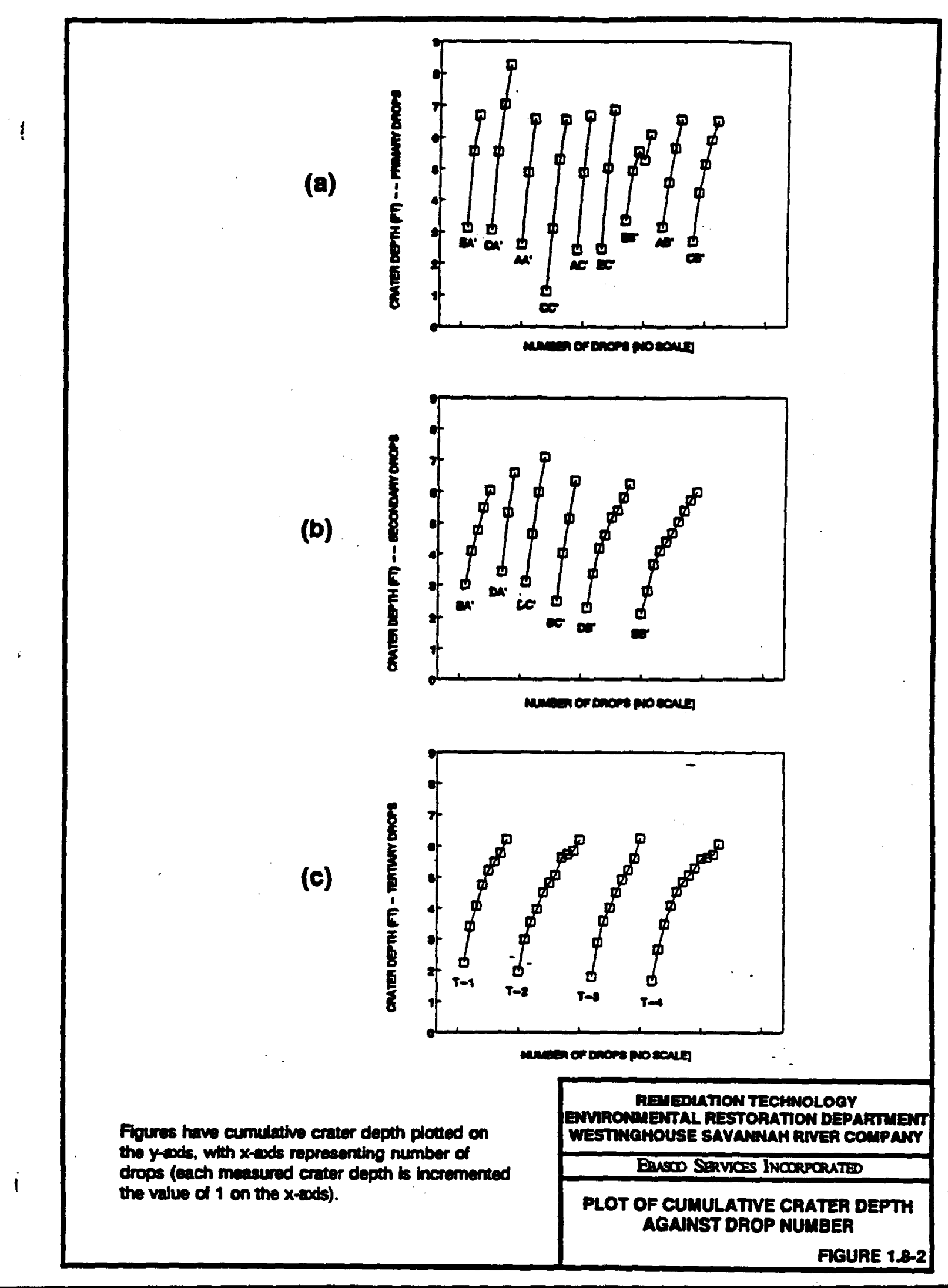




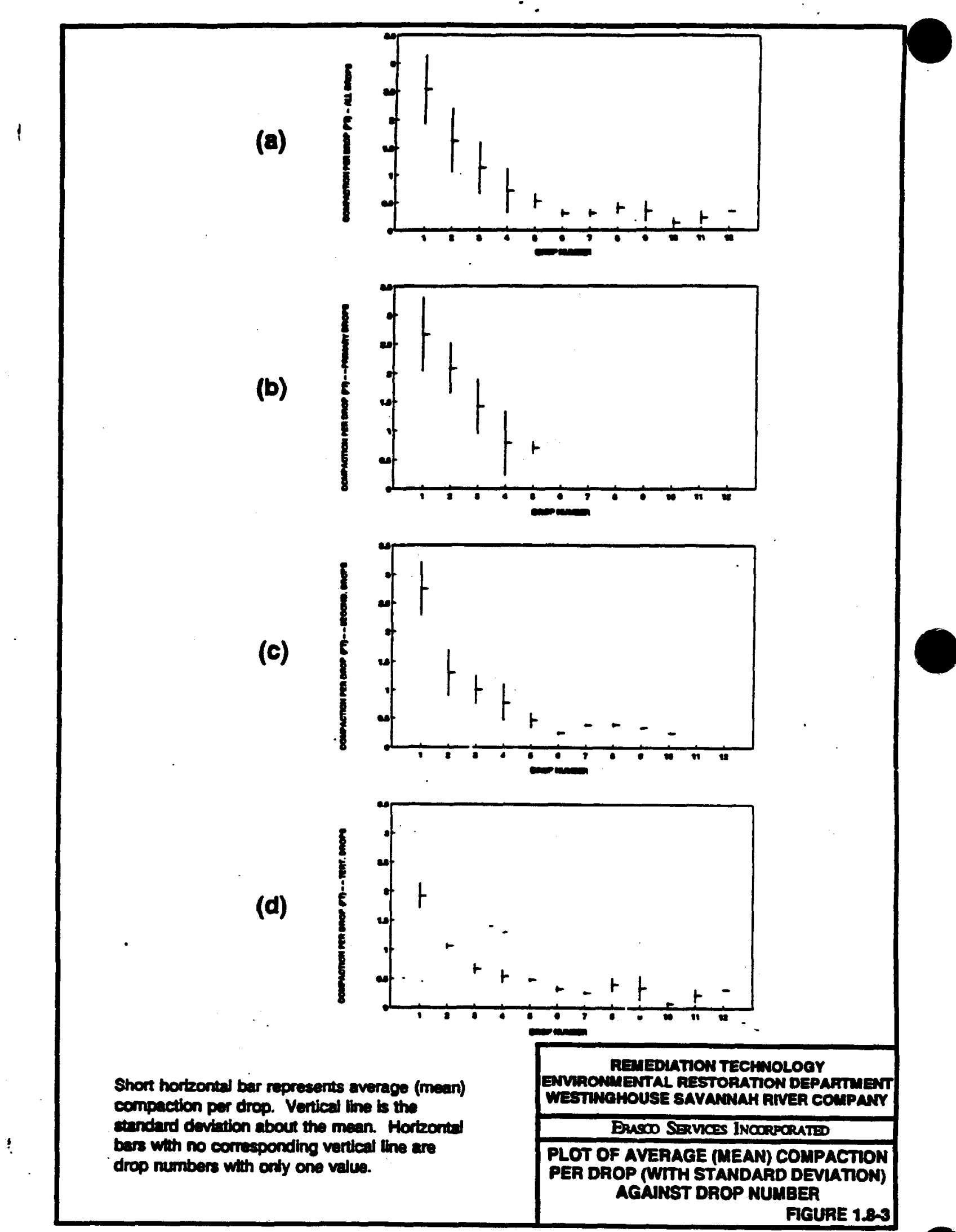

Short hortzontal bar represents average (mear) compaction per drop. Vertical line is the condard devitation about the mean. Horkontol bars wth no comesponding vertical the are drop numbers with only one value.

FICURE 183 
line). As shown on Figure 1.8-3 the primary and secondary drops have the largest initial compaction for first-drops (appz. 2.7 to 2.8 feet). Tertiary first-drops realized significantly less compaction (appx. 1.9 feet). Other trends observed on Figure 1.8-3 include: (1) amaller standard deviations for secondary and tertiary drops relative to primary drops, and (2) a more rapid decrease in compaction-per-drop for subsequent secondary and rertiary drops relative to primary drops. The slight increase in compaction-per-drop observed in the secondary and tertiary drop plots for drop numbers 7, 8, and 9 may be related to a bridging effect giving way to failure of B-25 box(es) in the lower portion of the ELLT.

Figure 1.8-4 plots cumulative linetic energy (k.e.) in footpounds delivered to the waste matrix at each drop point (the larger the peak the larger the energy input). Primary drop locations ( $A^{\prime} A^{\prime}, C A^{\prime}, E A^{\prime}, A^{\prime}, C B^{\prime} E B^{\prime}, A^{\prime}, C^{\prime}$, and $E C^{\prime}$ ) typically received a uniform amount of kinetic energy (peak heights are fairly equivalent). Secondary drop locations BA', DA', BC', and DC' tend to have slightly larger to moderately larger k.e. values relative to primary drop points. Secondary drop locations BB' and DB' were surrounded by previously compacted drop locations, and therefore required more drops to meet the $6 \mathrm{f}$ criter refusal criteria (resulting in larger k.e. inputs). The tertiary locations (T-1, T-2, T-3, and T-4) underwent the largest number of tamper drops and received the largest energy inputs; approximately 3 to 4 times as great as the primary drop points. Energy calculations for each primary and secondary drop point are given on Table 1.7-1, and tertiary drop points on Table 1.7-3. 


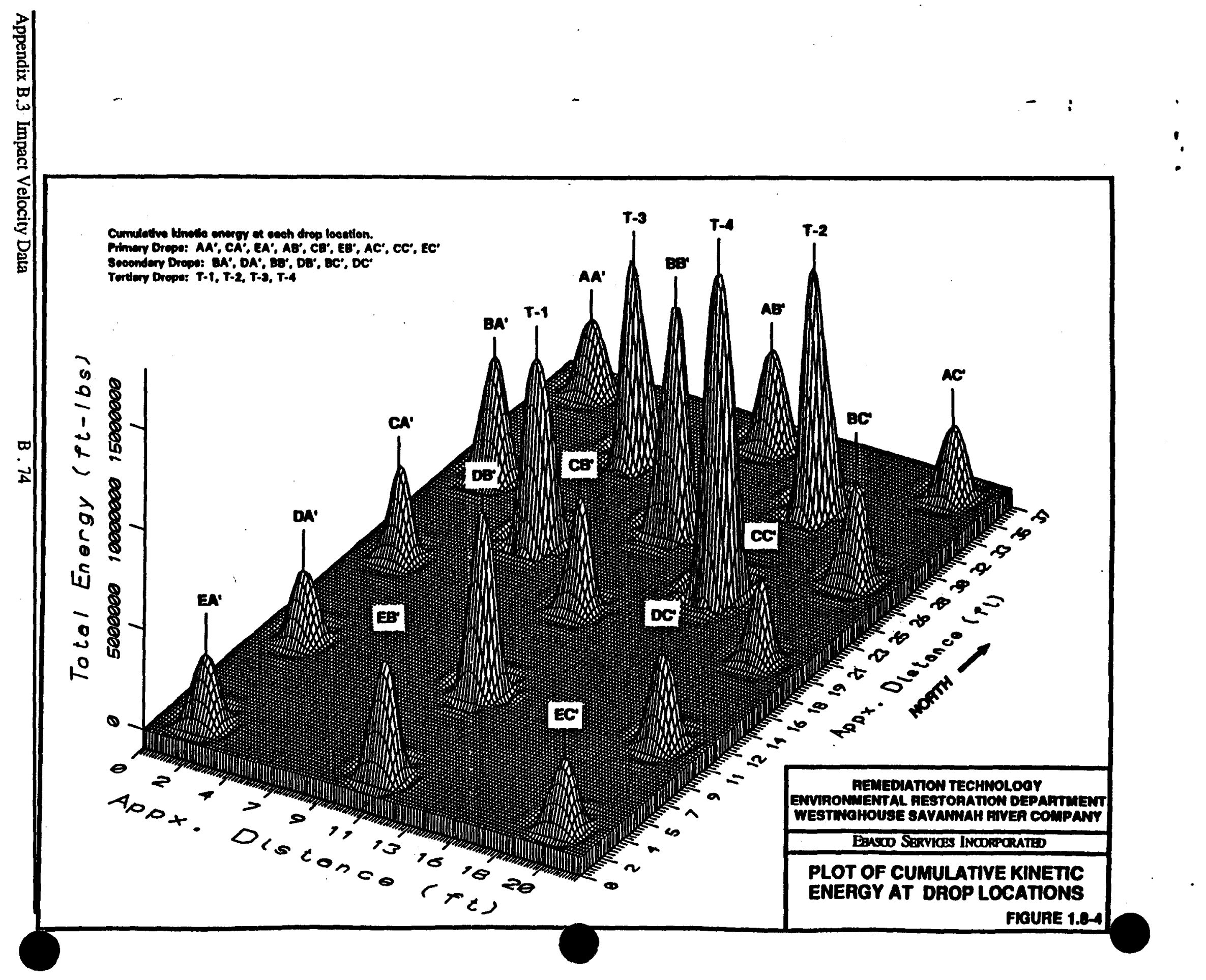




\subsection{REFERENCES}

Lukes, R.G., "Dynamic Compaction for Highway Construction," Vol. 1, Derign and Construction Guidelines, Federnl Fighway Administration, Office of Revearch and Development, U.S.D.O.T., Washington, D.C., Report No. FHWARD-86/133 (July 1986).

Westinghouse Savannah River Company Project Engineering Services Contrnet, Instrumentation Plan: Dynamic Test Facility Task 048 (Draft Report), May 8, 1992. Prepared by: Ebasco Services Incorporated, 2528 Center West Parkway, Augusta, Georgia, 30909.

Ebasco Services Incorporated Project Engineering Services Contract, Task Order Proposal Cost Estimate for Task 048. Imolementation of Dynamic Text Eacility Instrumentation Plan, Prepared for Westinghouse Savannah River Company, June 9, 1992. 
WSRC-TR-94-0159

Rev. 1

March 21, 1994

Dynamic Compaction Report

Appendix B.4

Strong-Motion Sensor Baseline Data

The dynamic compaction weight was dropped on natural undisturbed soils to establish an attenuation baseline to configure the actual test. Instrumentation was spread in a symmetrical array, radiating outward from the point of impact. This operation successfully defined an attenuation baseline for both the peak particle velocity and the vertical displacement decay.

The data included herein is a summary of the more complete discussion included in the EBASCO report ${ }^{4}$. If a more complete data set is required, the information can be obtained from this reference. 
Rev. 1

A key testing elements is the vibratory or strong motion monitoring during dynamic compaction. Dynamic compaction induces vibrations within the soil matrix similar to those produced during an earthquake. The key difference is the shape and location of the energy source. An earthquake is a rupture in the earth's structure and is normally deep and linear in shape and form. Dynamic compaction affects the surface and is considered a point source. These differences cause changes in the primary manifestation of the vibratory energy and wave forms. The predominate wave form is the Rayleigh wave, which is a retrograde elliptical motion in the vertical plane. Strong motion detectors can monitor many different, but related parameters. These parameters include frequencies, accelerations, velocities, and displacements. All these parameters are useful to some extent, dependent upon the analysis. For looking at damage to structures, the peak particle velocity (or instantaneous velocity at a point on the ground) is the best indicator of damage potential and annoyance levels. The displacement in the vertical direction also is a primary source of damage and can be used as an indicator to filter out the Rayleigh type wave forms.

The data herein provides an overview of the peak particle velocity observations versus distance and scaled energy. This data is a synopsis from the EBASCO report [4]. If a comprehensive data set is required, the information can be obtained from this reference. 


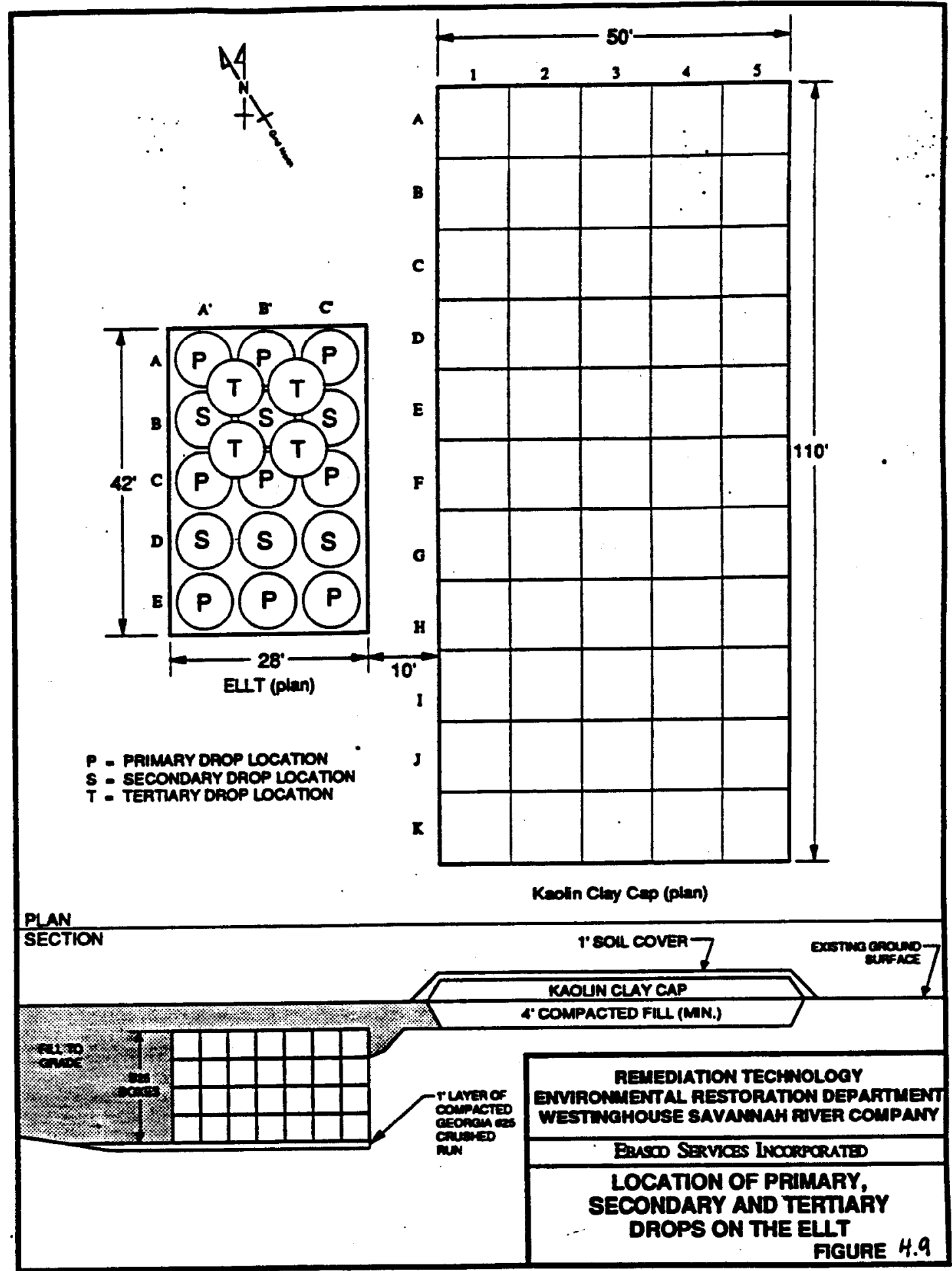

Appendix C Seismic and Vibratory Data

C. 2 


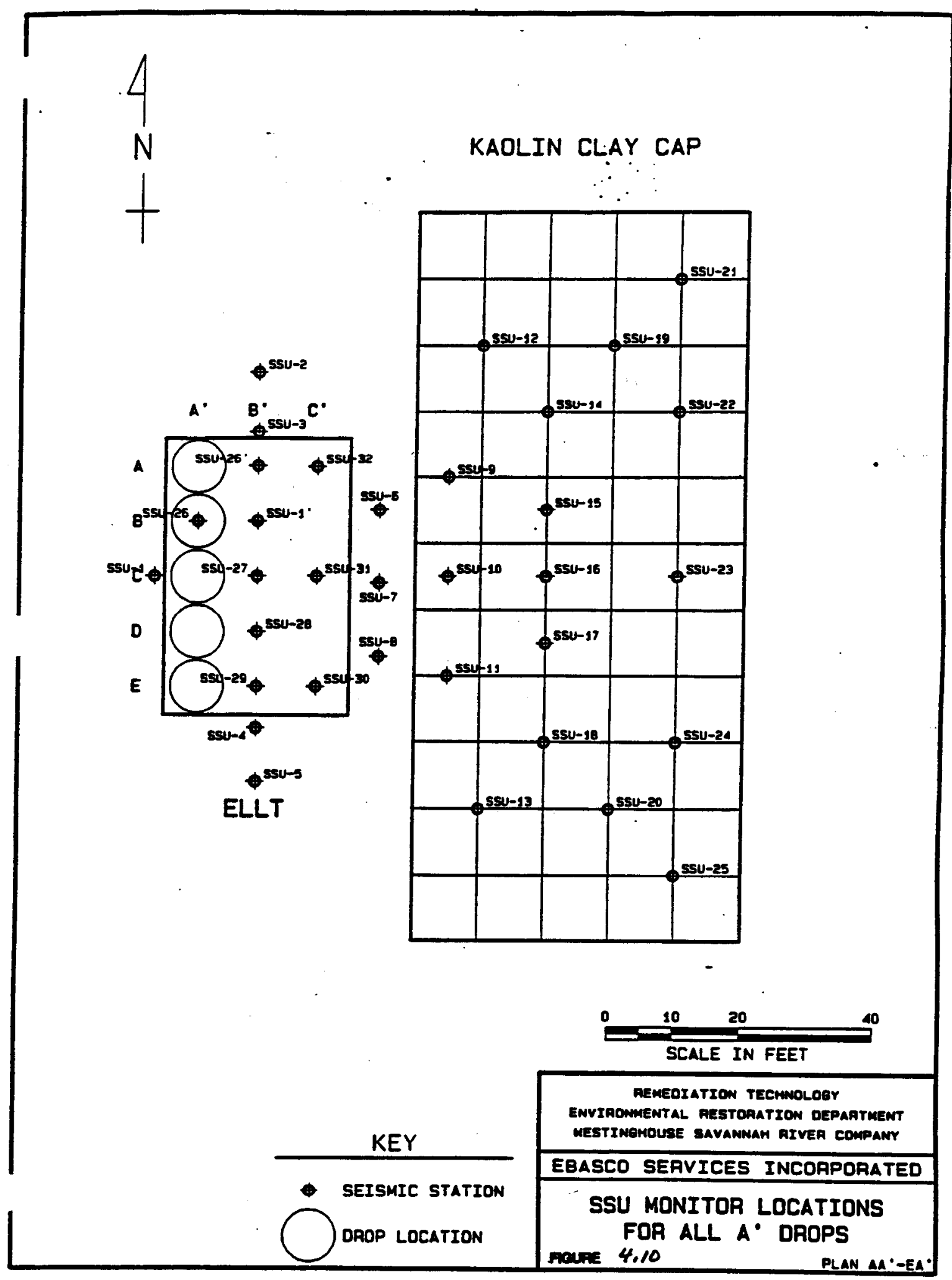




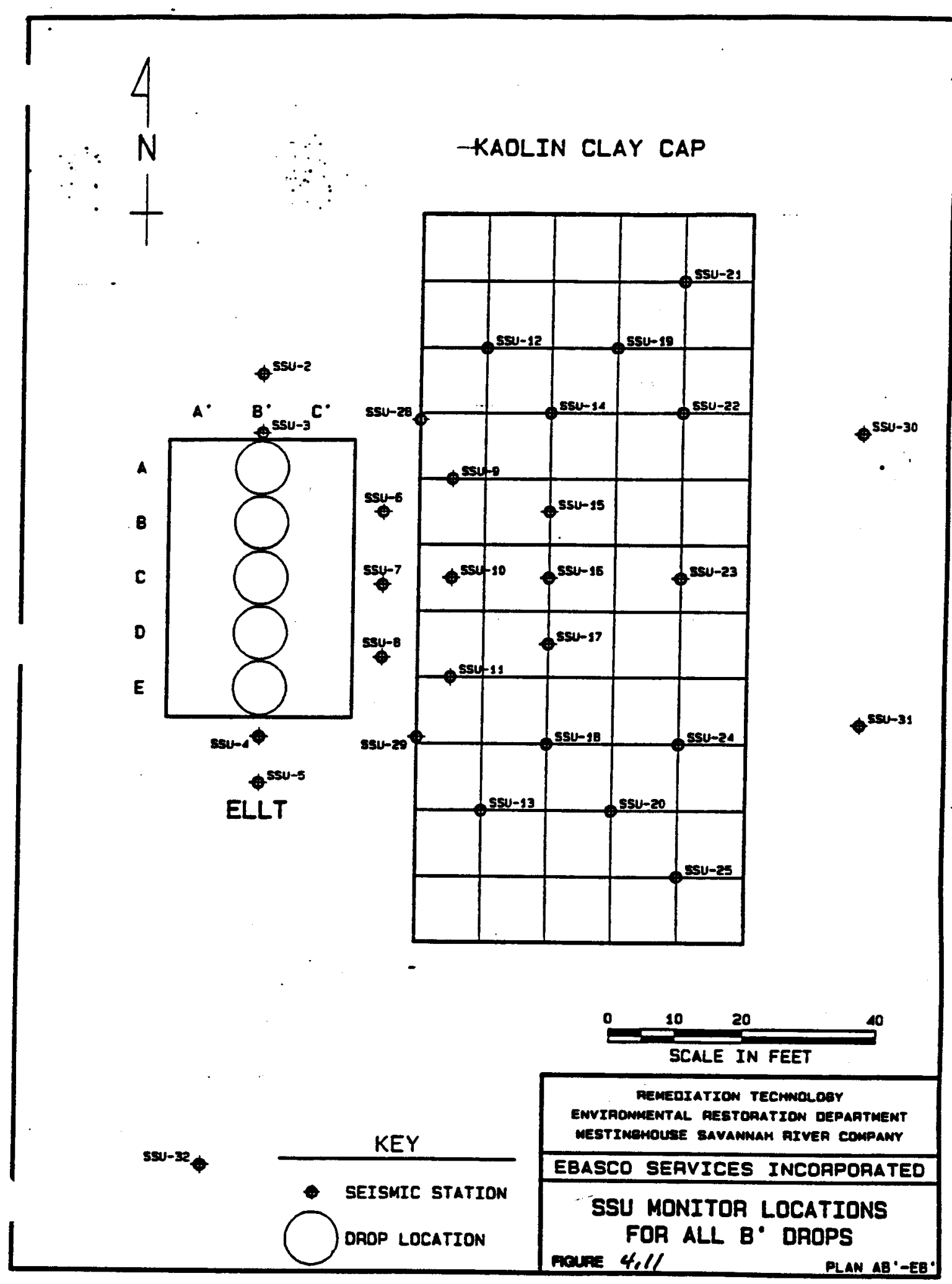




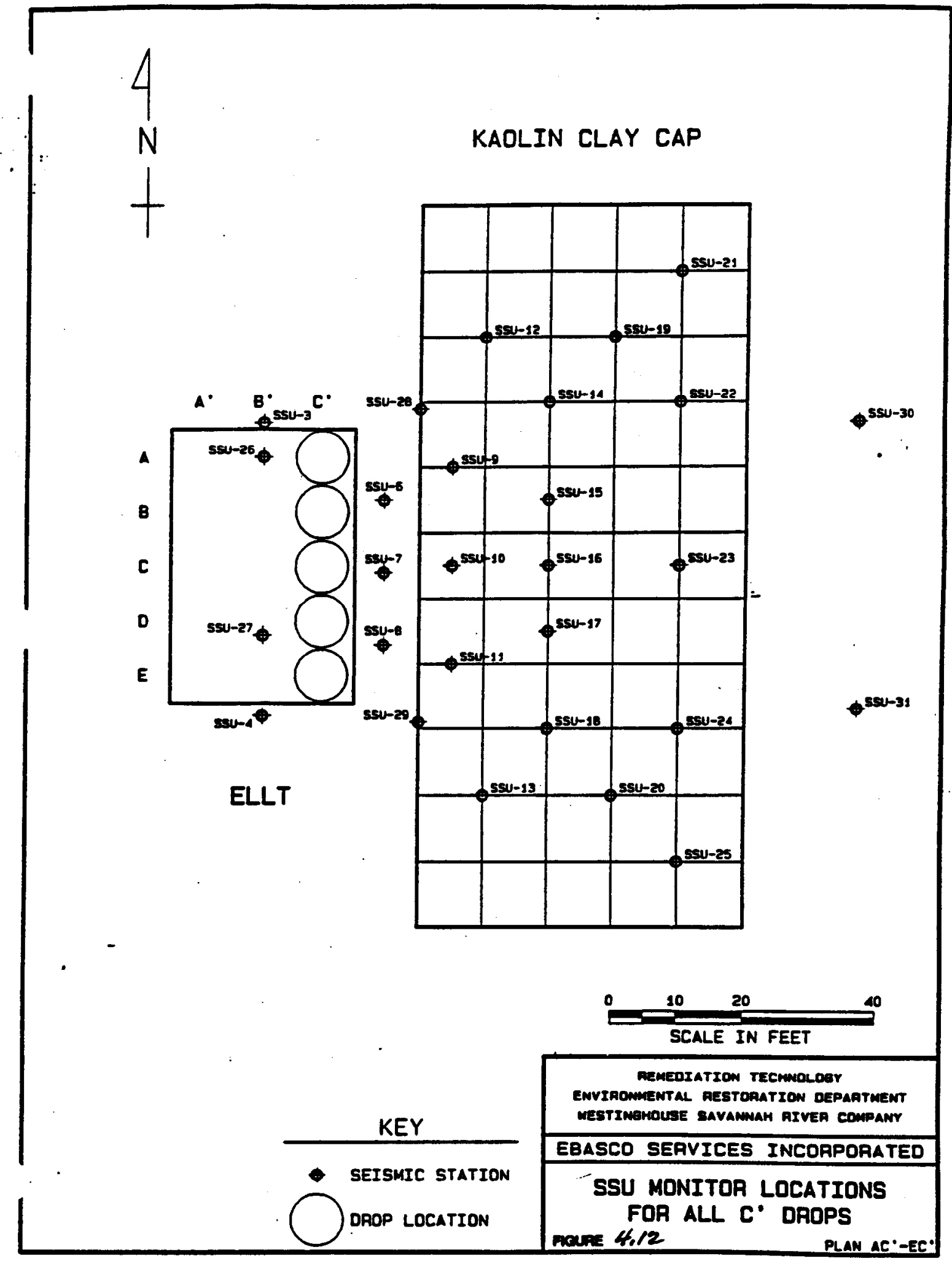




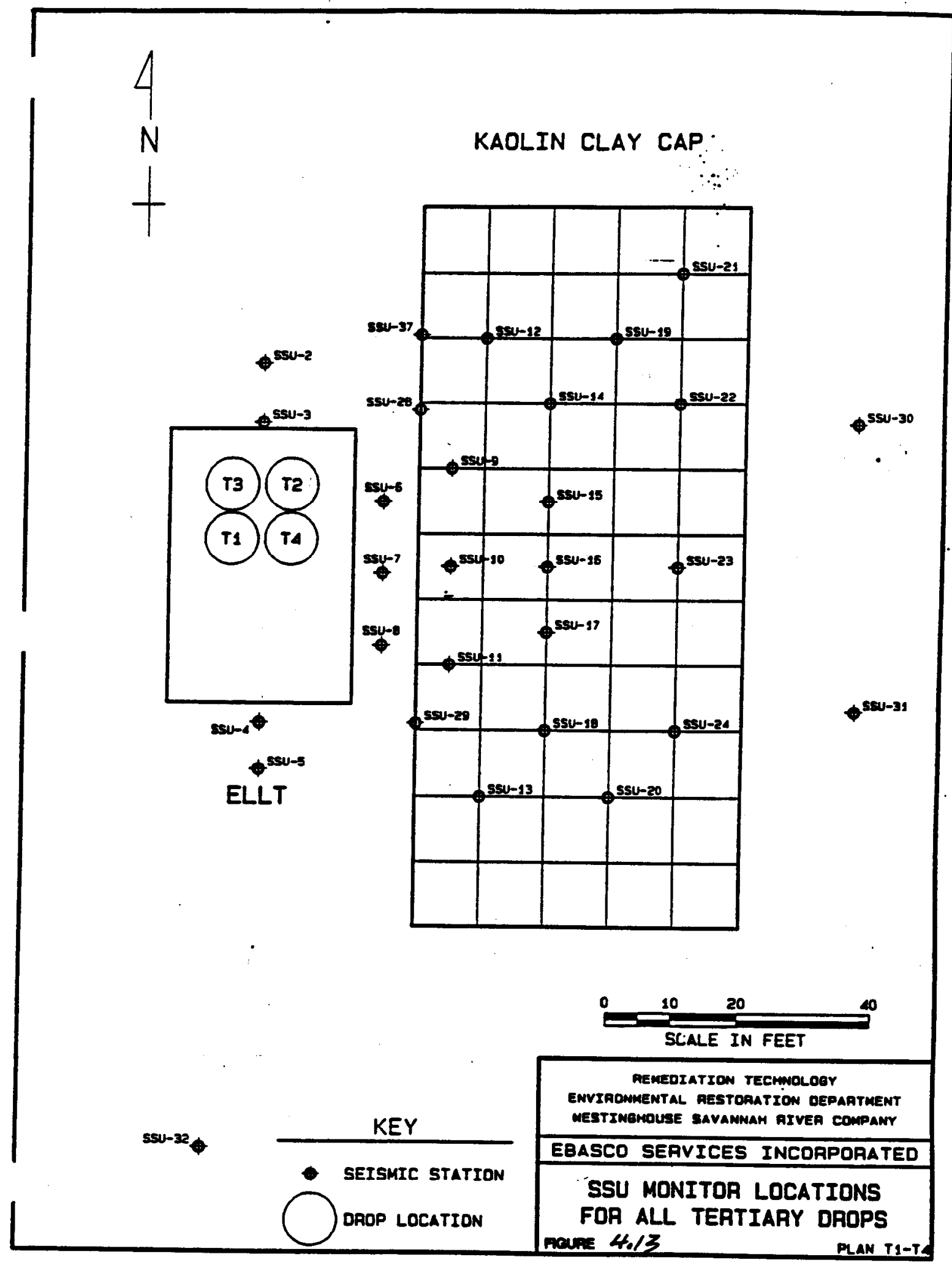

Appendix C Seismic and Vibratory Data

C. 6 


\section{PPV VERSUS SCALED ENERGY FACTOR}
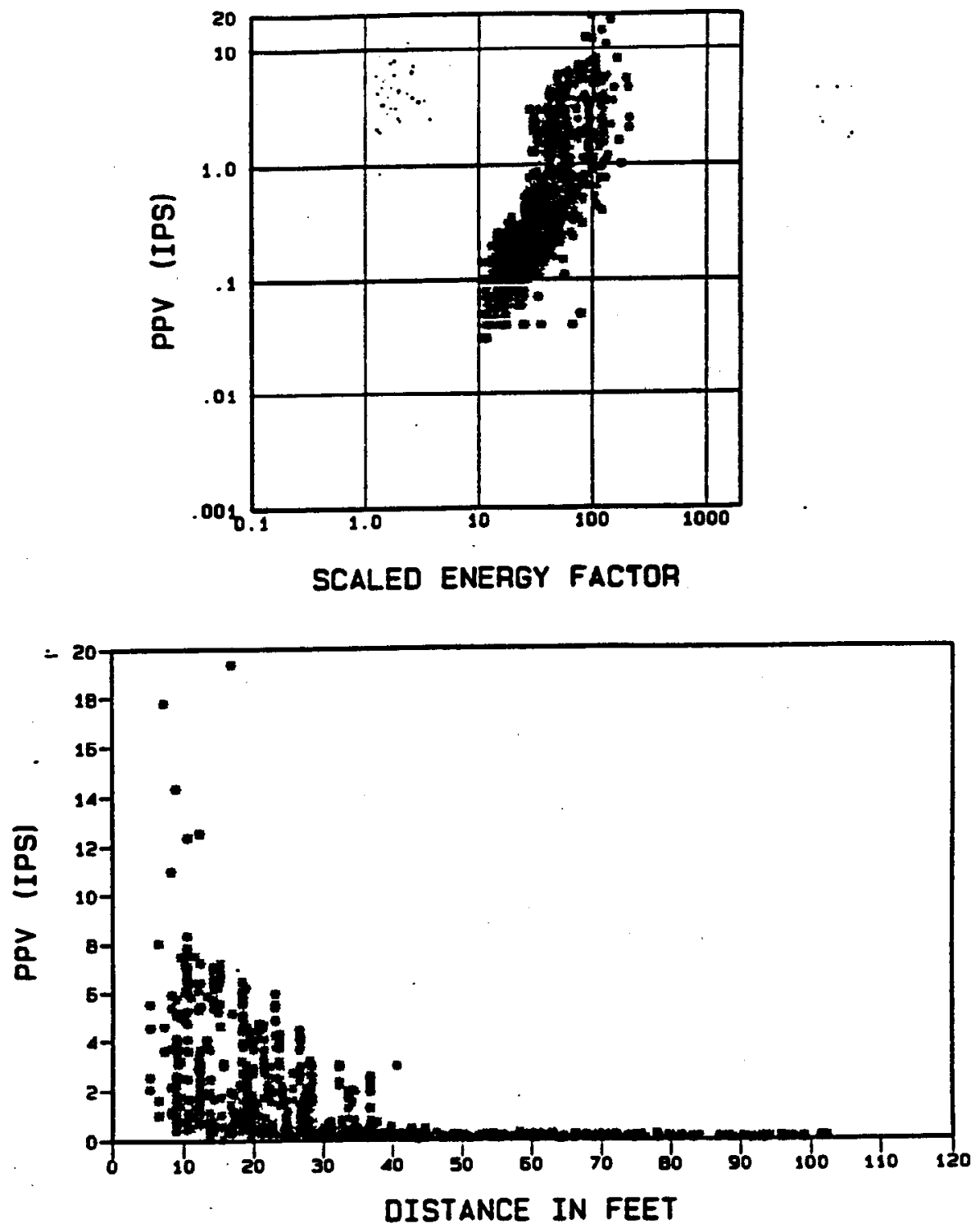
4

$N$
$T$

KAOLIN CLAY CAP

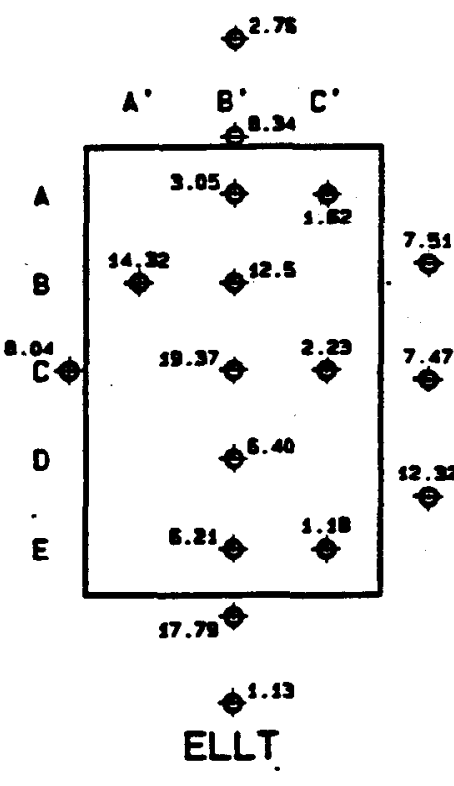

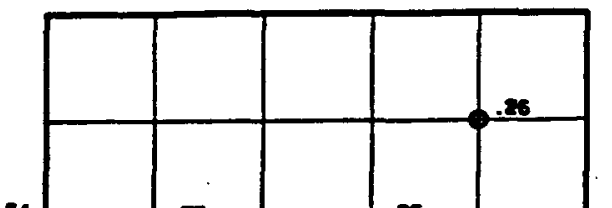

$\varphi^{-17}$

.

$\phi^{\cdot 20}$

。

$10 \quad 20$

$\infty$

SCALE IN FEET

AEMEDzatION TECMMOLOST EMVIAOMMENTAL AESTOAATION DEPAATMENT mestrmenouse savanuay aIVER compant

NOTE: values represent the axinu observed PPy (IPS) experienced at eaen seisaic station. The total number of orops experienced at each station varied.

EBASCO SEAVICES INCOAPOAATED

MAXIMUM OBSERVED PPV

FOR ALL DROPS

Pan maxt

Figure 4.15 


\section{PPV VERSUS SCALED ENERGY FACTOR}
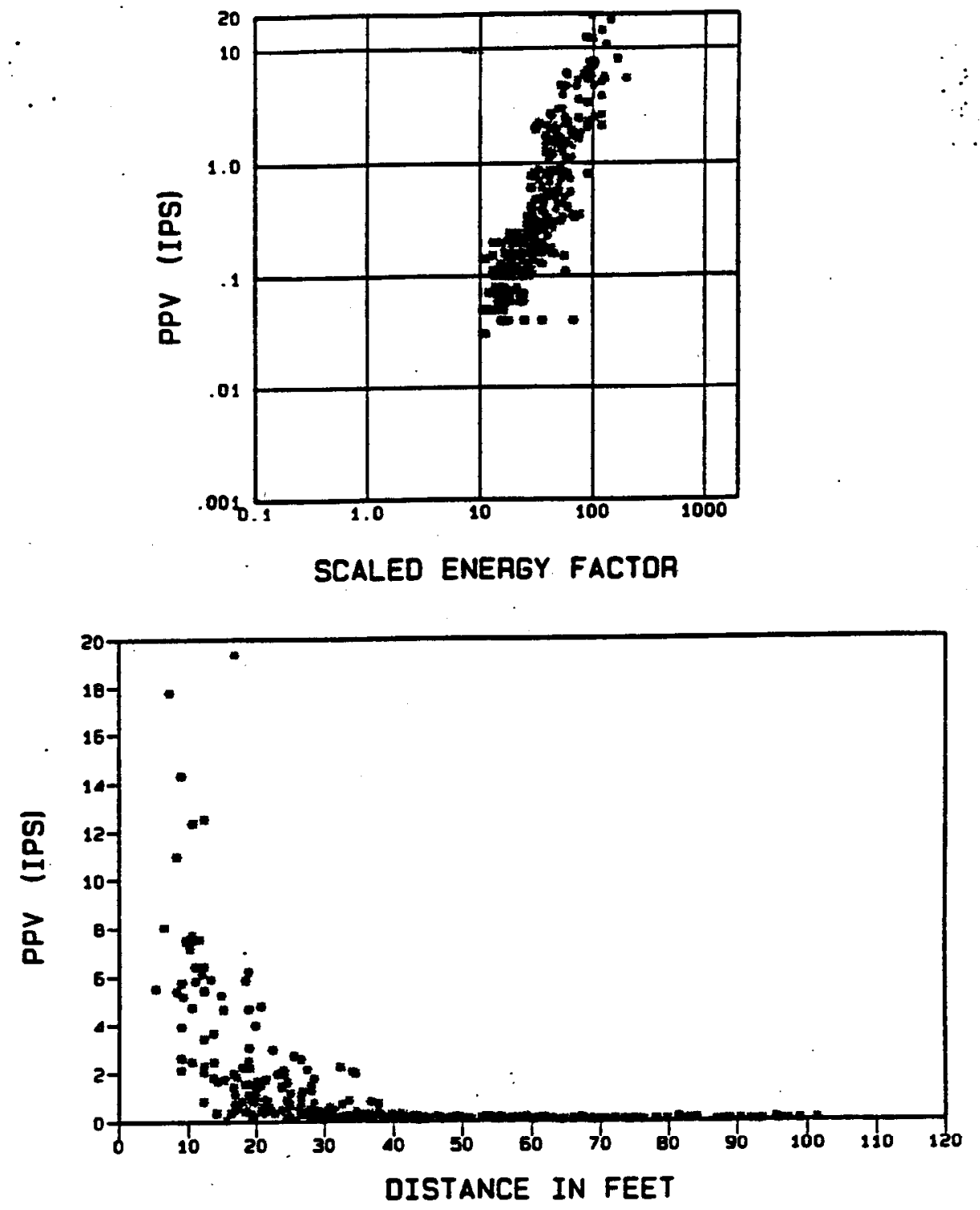

AEMEOTATIOM TECMMLOOY ENVIROMMENTAL AESTCAATION OEPARTMEMT mestrmenouse savanmah fIVEA compawr EBASCO SEAVICES INCOAPOAATED PPV VEASUS SCALED ENERGY FACTOR FOR ALL FIRST DAOPS AT DTF

Freune SEF.oOE

Figure 4.16 


\section{PPV VERSUS SCALED ENERGY FACTOR}
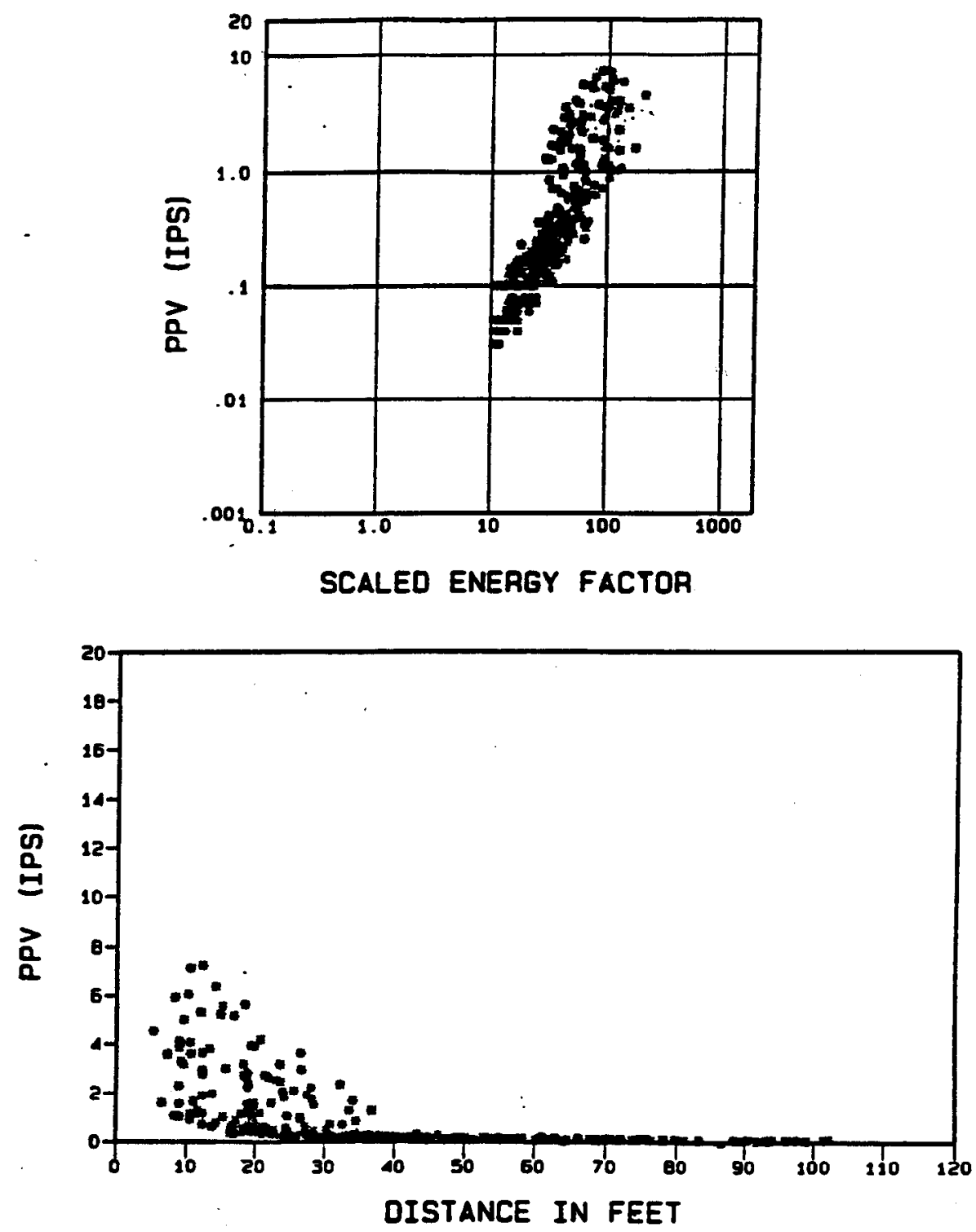

MENERIATION TECMMOLOBY ENVIAOMmENTAL AESTOAATION DEPAATUENT

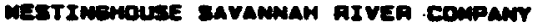

EBASCO SFAVICES INCDAPOAATED

PPY VERSUS SCALEO ENERGY

FACTOR FOR ALL SECOND DAOPS AT DTF

FIGLARE SEF.00E

Figure 4.17 


\section{PPV VERSUS SCALED ENERGY FACTOR}
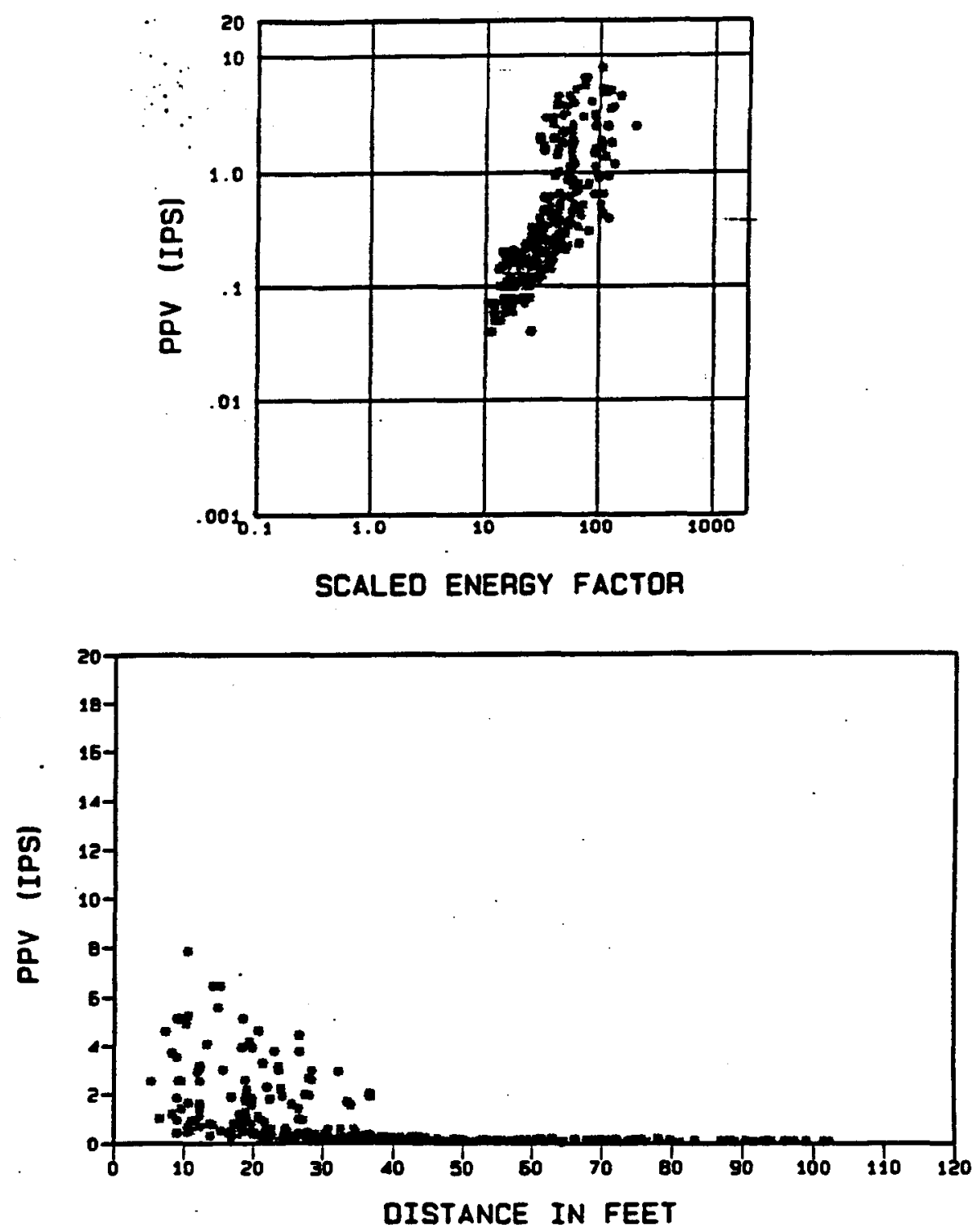

PEMEOLATION TECmwQLogY EOUINONUENTAL AESTORATION DEPAATMENT westrachouse savanuar RIVEA company

EBASCD SEAVICES INCOAPOAATED

PPV VERSUS SCALED ENERGY FACTOA FOA ALL THIAD DAOPS AT DTF

FIEUAE SEF.007

Figure 4.18 


\section{PPV VERSUS SCALED ENERGY FACTOR}
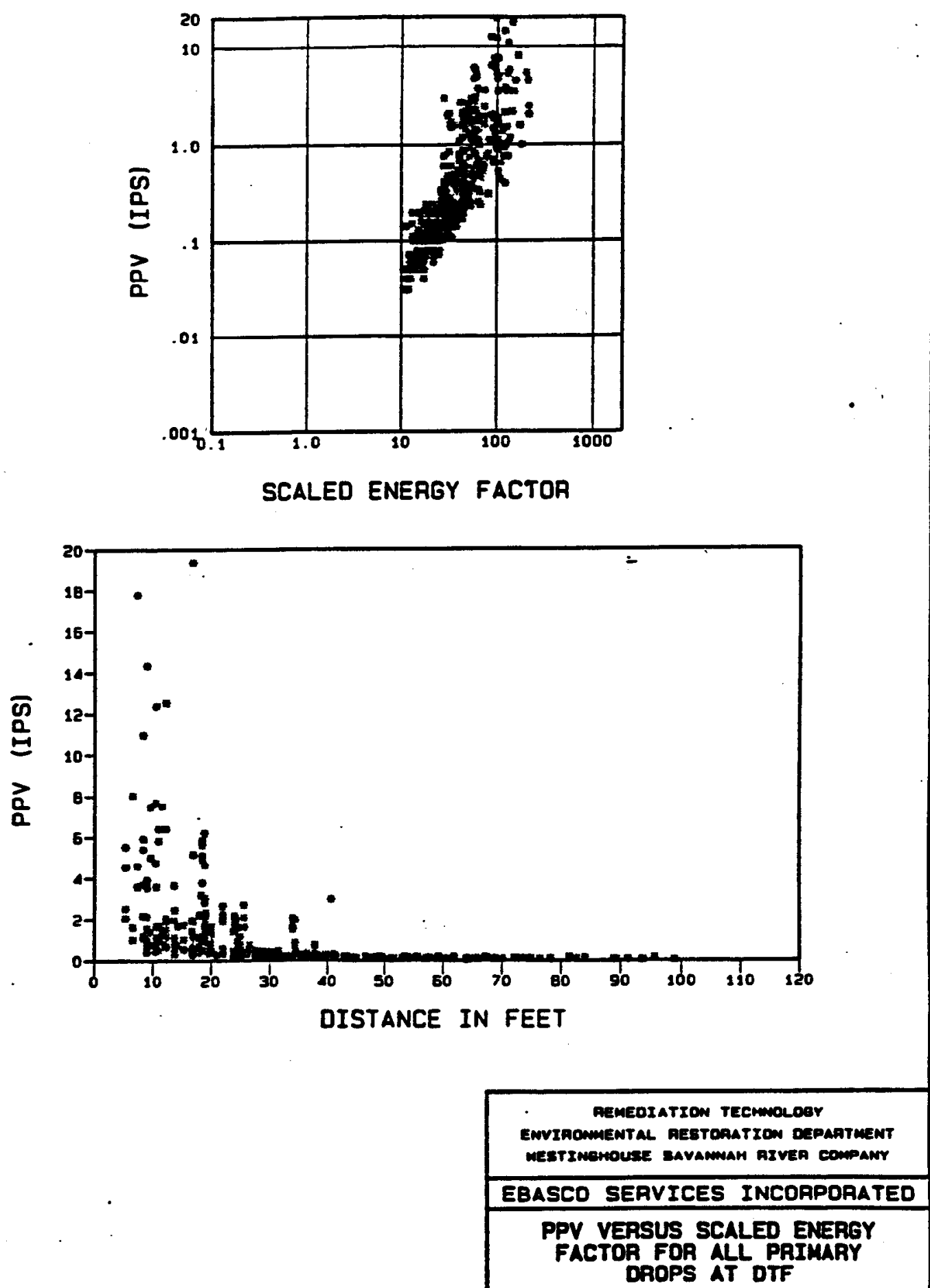

FIEUAE SEF.oog

Figure 4,19 


\section{PPV VERSUS SCALED ENERGY FACTOR}
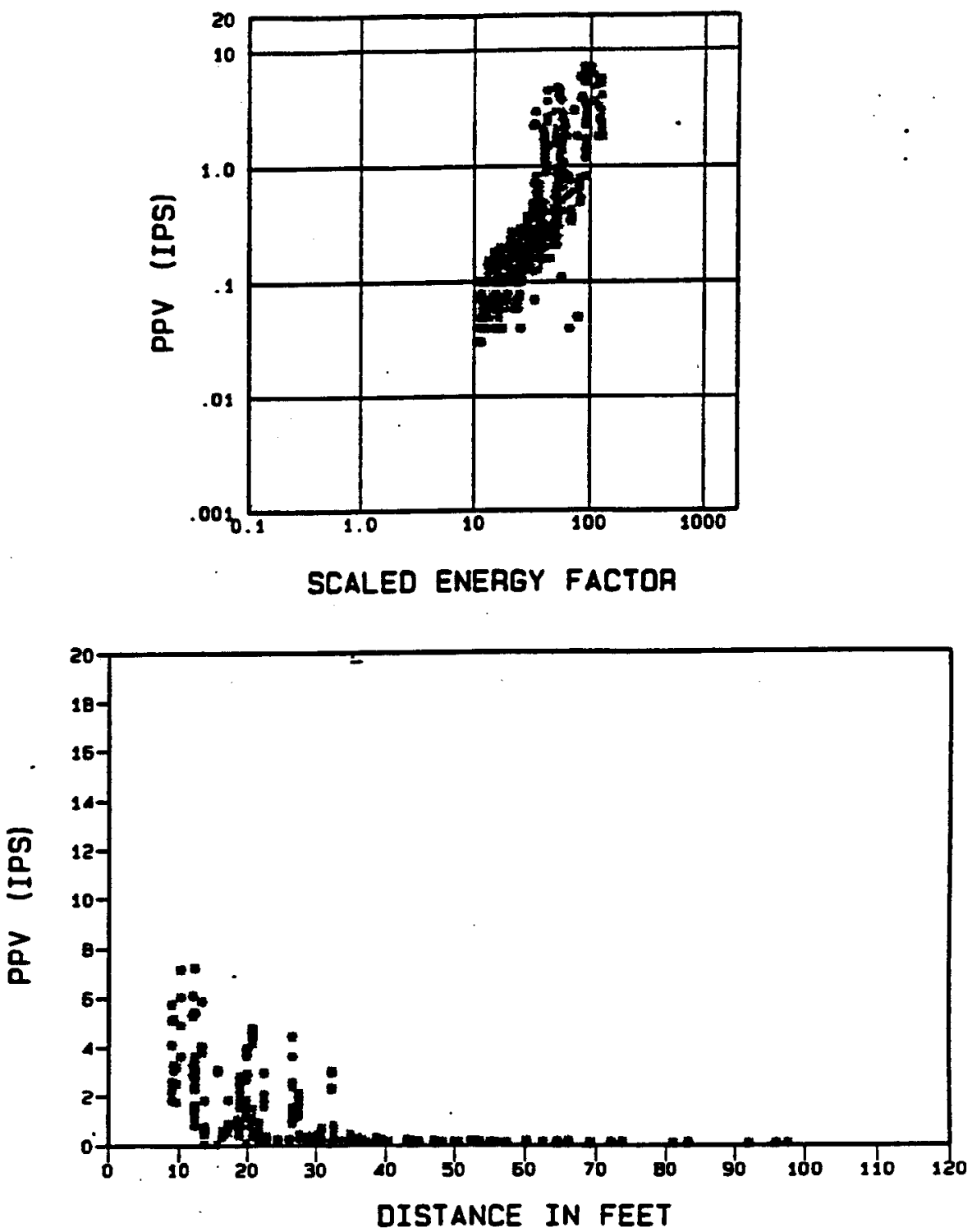

AEMEOTATION TECMMOLOCY EArIAOMmENTAL AESTOAATION DEPAATMENT MEstimanouse savammam aIvea compamy

EQASCO SEAVICES INCOAPOAATED

PPY VERSUS SCALED ENERGY

FACTOR FOA ALL SECONDARY DADPS AT DTF

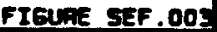

Figure. 4.20 


\section{PPV VERSUS SCALED ENERGY FACTOR}

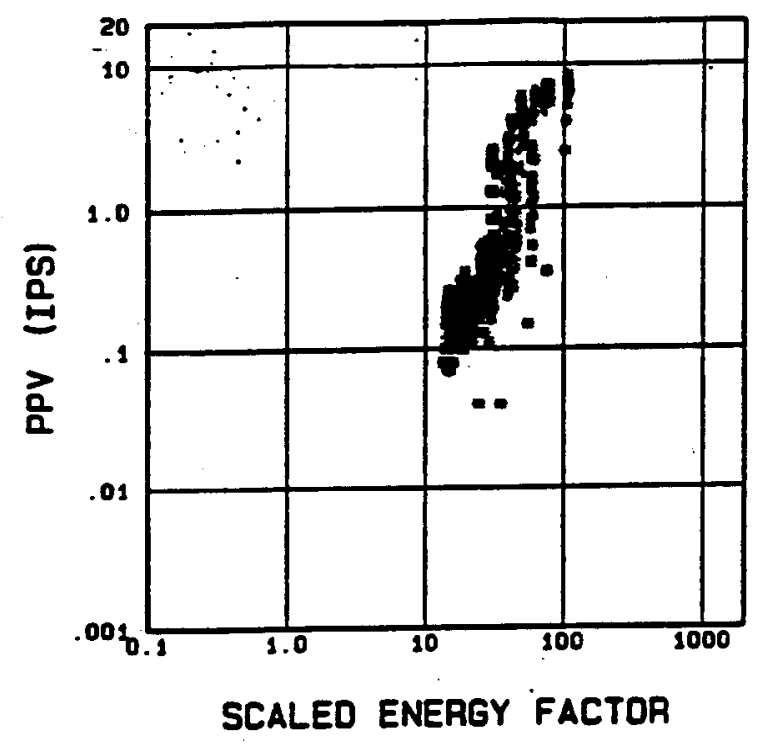

$-$

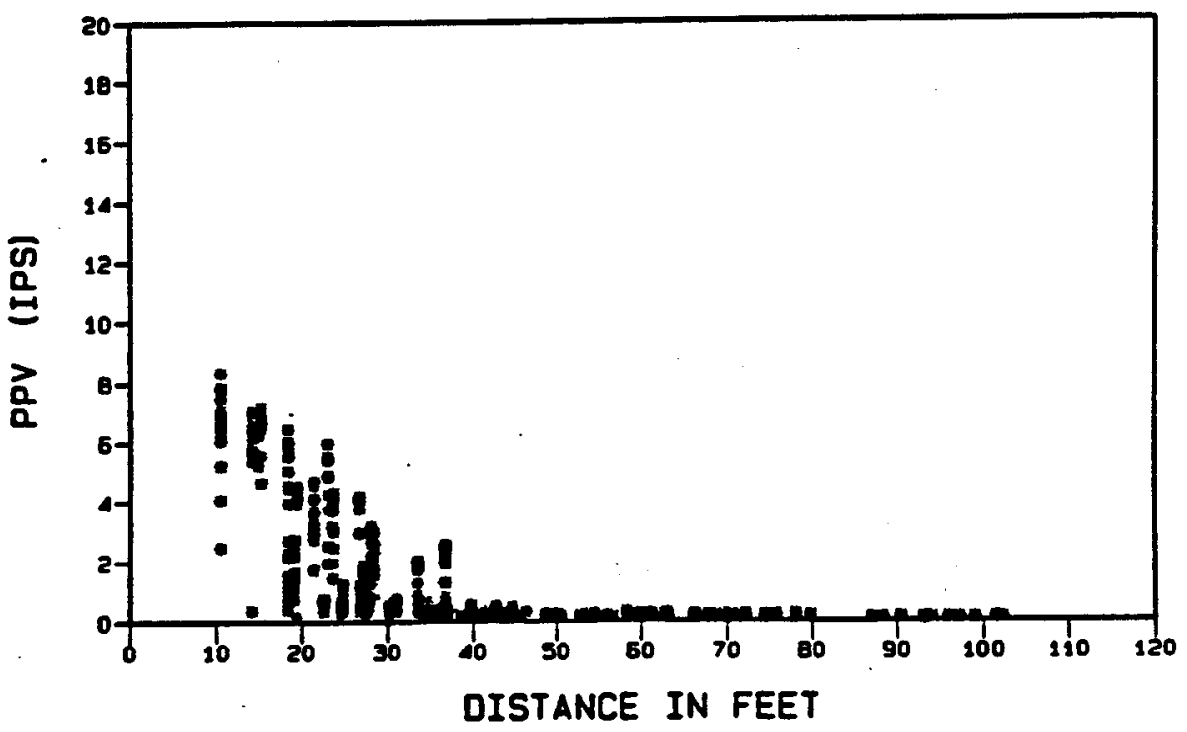

nEMEOJATION TECMNOLDeT ENVIAONMENTAL RESTOAATION DEPAATMENT mestzmenouse savamman Az VER company

EBASCO SEAVICES INCDAPOAATEO

PPV VERSUS SCALED ENERGY

FACTOR FOR ALL TERTIARY

DAOPS AT DTF

FIGUAE SEF .OOC

Figure 4.4 


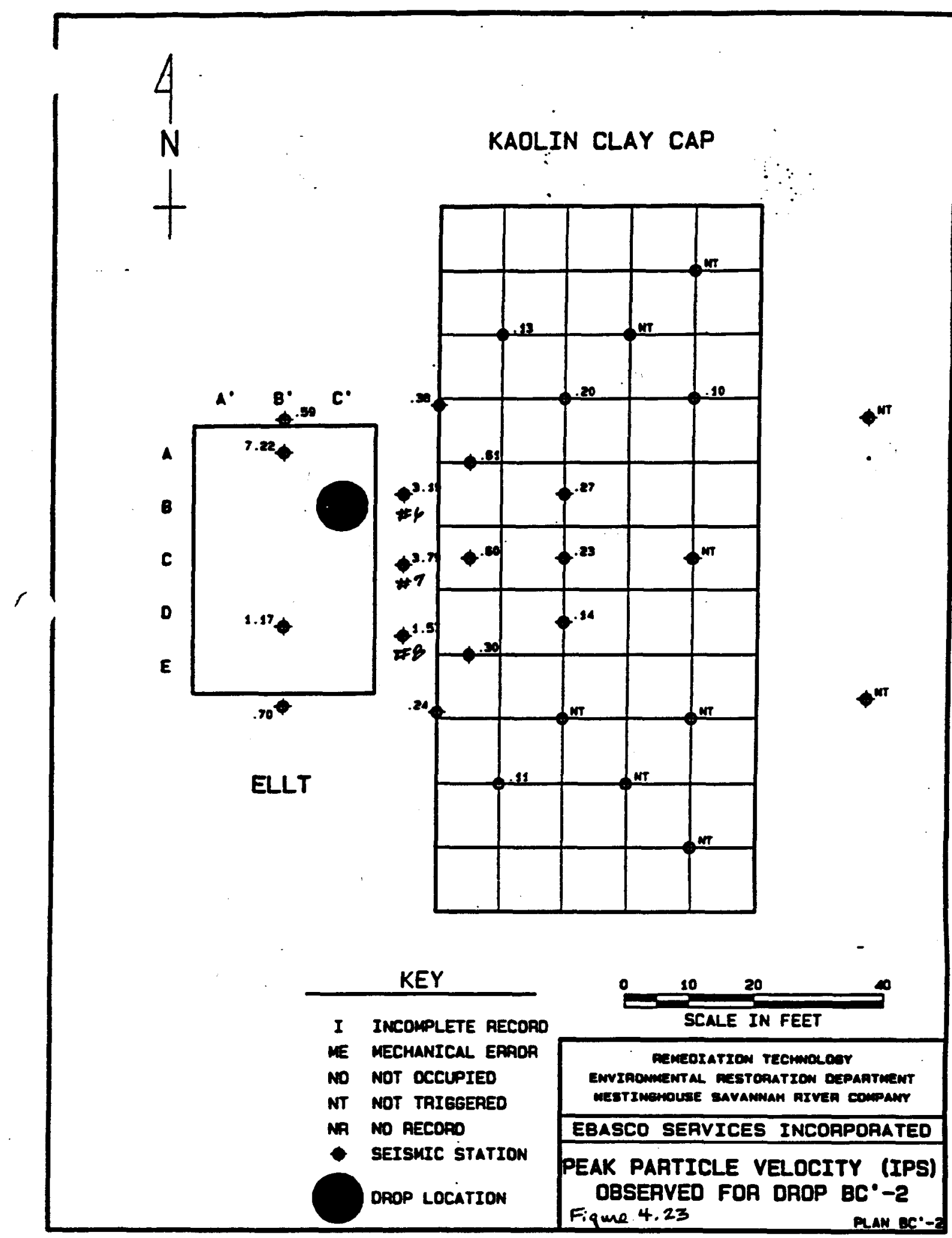


4

$\mathrm{N}$

KAOLIN CLAY CAP

1

$\because$

$A^{*}$

$8^{\circ} c^{\circ}$

A

2.82

B

C

D

1.00

E

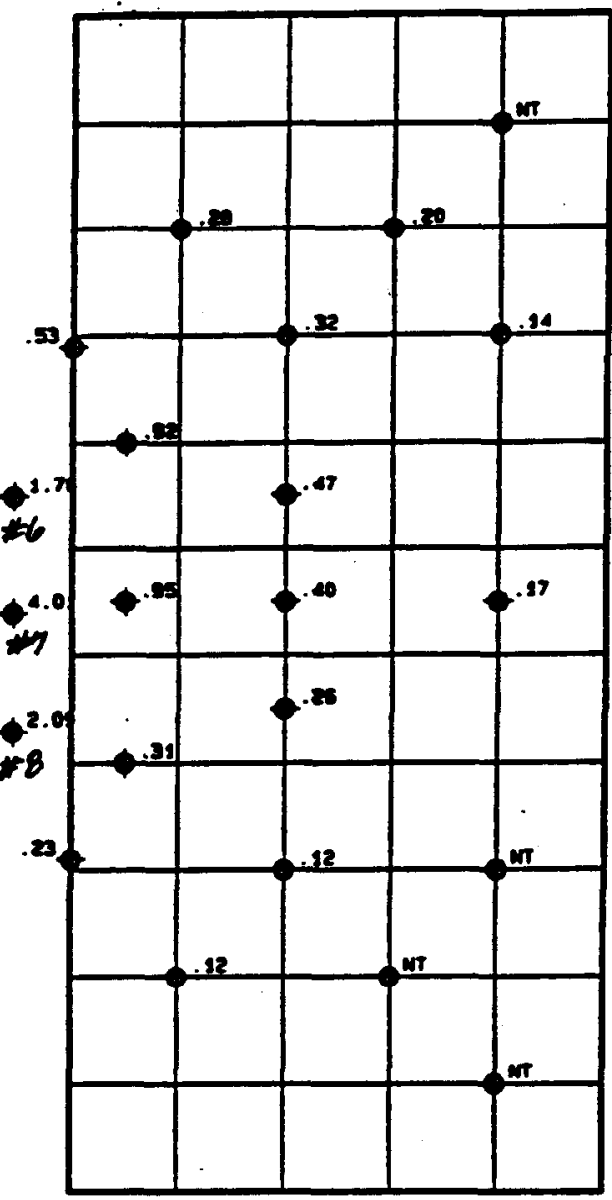

ELLT

KEY

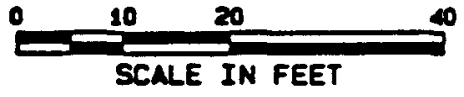

I IMCOMPLETE RECORO

SCALE IN FEET

ME MECHANICAL EAROR

NO NOT OCCUPIED

nindozatzon tecmoloor

NT NOT TRIGGERED

MP NO RECORO

- SEISHIC STATION

DPOP LOCATION

EMVIAOMmENTAL MESTOAATION DEPARTMENT Mestzmenolese savanman aIven compam

EBASCO SEAVICES INCOAPORATED

PEAK PAATICLE VELOCITY (IPS) OBSERVED FOA DROP BC -4

finure 4.24

PAN ac:- 


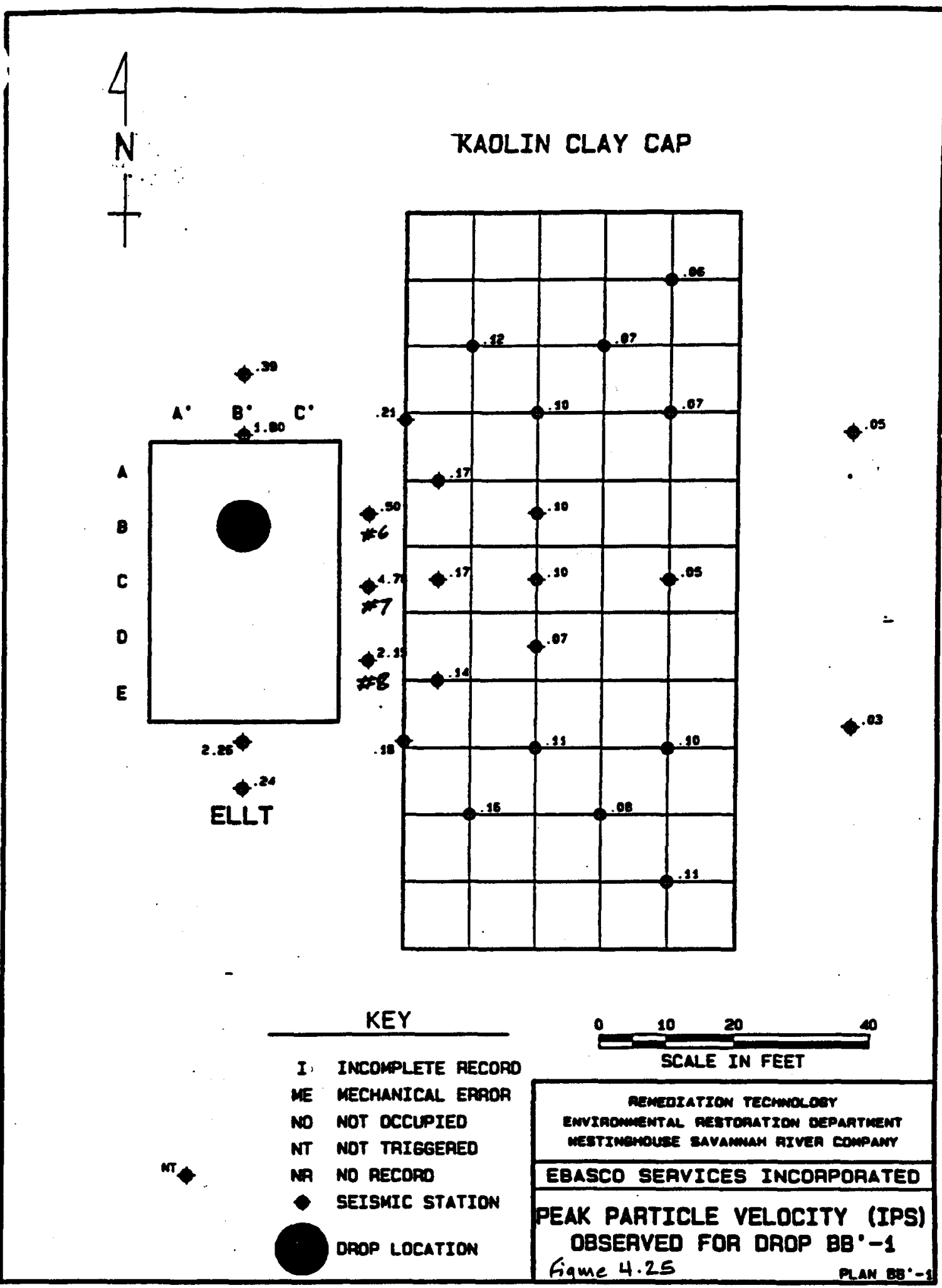


Rev. 1

\section{Post Test Data}

The post dynamic compaction phase of testing included the measurement of the hydraulic conductivity of the kalin clay and the evaluation of the compaction of the buried B-25 boxes. The hydraulic conductivity was measured insitu using six Sealed Double-Ringed Infiltrometers. The data obtained is presented herein.

The data included herein is a synopsis from the EBASCO report [4]. If a more complete data set is required, the information can be obtained from this reference. 
SEALED DOUBLE-RINGED INFILTROMETER DATA, DCF TEST

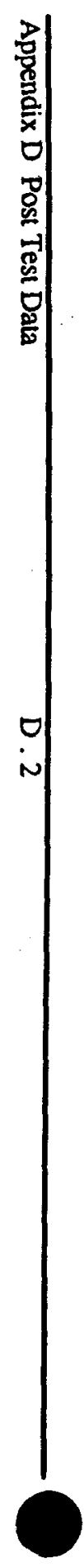

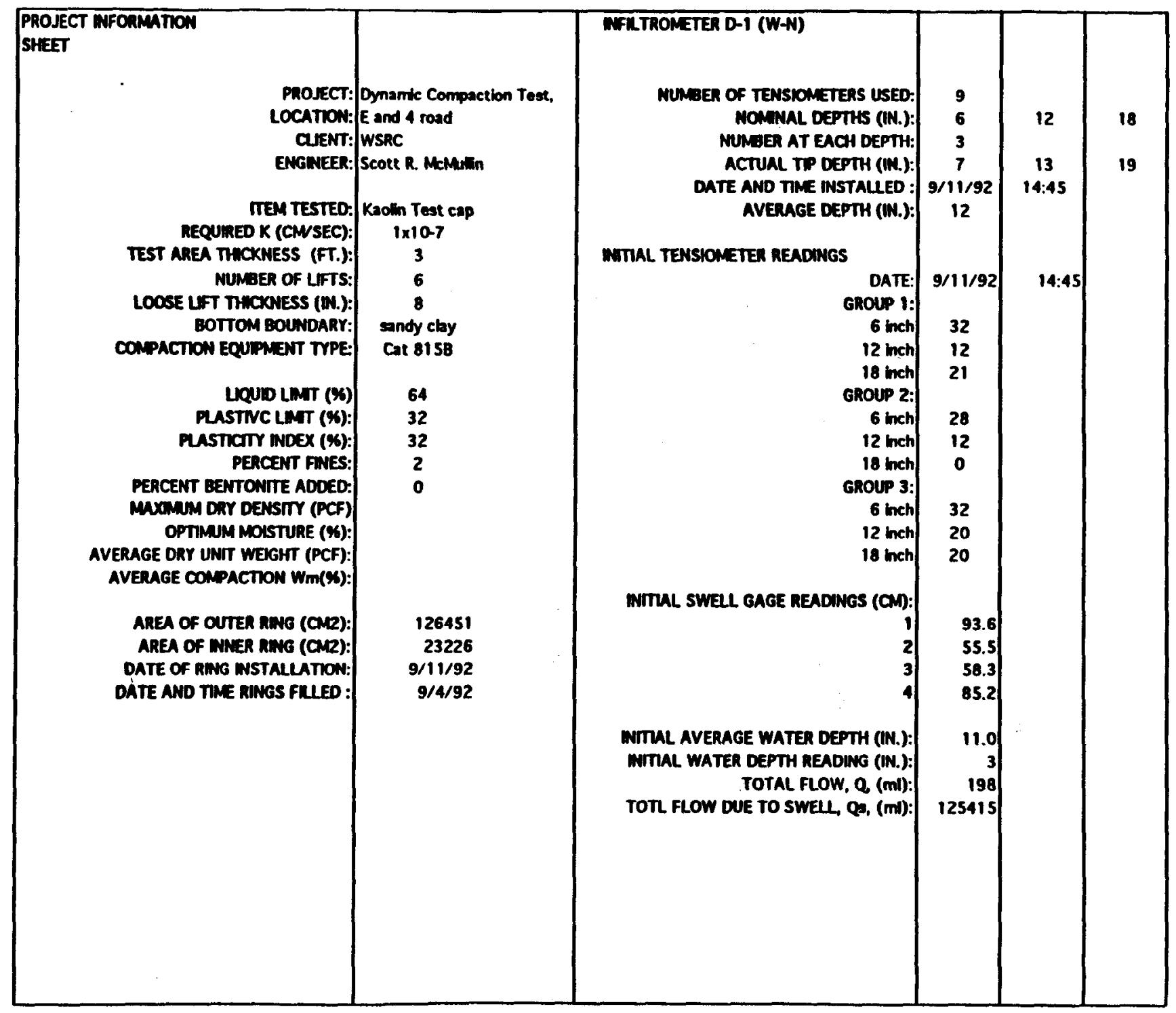




\begin{tabular}{|c|c|c|c|c|c|c|c|c|c|}
\hline \multicolumn{10}{|c|}{$\begin{array}{l}\text { DATA SHEET FOR WATER BAGS } \\
\text { WFRTRONETER D-1 }(W-N) \\
\end{array}$} \\
\hline \multirow{2}{*}{\multicolumn{4}{|c|}{ BAG CONNECTION AND DISCONNECTION }} & \multirow{3}{*}{$\begin{array}{c}\text { t } \\
\text { NTERVAL } \\
\text { TMEE }\end{array}$} & \multicolumn{2}{|c|}{ BAG I } & \multicolumn{2}{|c|}{ BAG 2} & \multirow{3}{*}{$\begin{array}{c}\text { MET } \\
\text { CHANGE } \\
(0)\end{array}$} \\
\hline & & & & & \multirow{2}{*}{$\begin{array}{c}\text { IMITAL } \\
\text { WEGHT } \\
\text { (f) }\end{array}$} & \multirow{2}{*}{$\begin{array}{l}\text { FWNAL } \\
\text { WENHT } \\
\text { (v) }\end{array}$} & \multirow{2}{*}{$\begin{array}{c}\text { MITAL } \\
\text { WESHT } \\
\text { (n) }\end{array}$} & \multirow{2}{*}{$\begin{array}{c}\text { FWAL } \\
\text { WEGHT } \\
(0)\end{array}$} & \\
\hline DATE ON & DATE OFF & nME ON & The OFF & & & & & & \\
\hline 11-Sep & 14-Sep & $14: 45$ & 15:10 & 260700 & 3735.7 & 3551.4 & 3817.8 & 3559.8 & 442.3 \\
\hline 14-Sep & - & 15:53 & - & $\cdot$ & 3551.4 & - & 3559.8 & $\cdot$ & NA \\
\hline- & 16-Sep & $\cdot$ & 14:00 & 166020 & $\cdot$ & 3272.9 & - & 3023.6 & 814.7 \\
\hline 16-Sep & 17-Sep & $15: 43$ & $13: 55$ & 79920 & 3272.9 & 3159.1 & 3023.6 & 2839.7 & 297.7 \\
\hline 17-Sep & - & $14: 48$ & - & - & 3159.1 & $\cdot$ & 2839.7 & $\cdot$ & NA \\
\hline - & 19-Sep & $\cdot$ & $10: 29$ & 157260 & $\cdot$ & 2387.3 & - & 3046.5 & 565.0 \\
\hline 19-Sep & 21-Sep & $11: 44$ & $11: 55$ & 173460 & 2387.3 & 1567.9 & 3046.5 & 3198.8 & 667.1 \\
\hline $21-$ Sep & 22-Sep & 13:50 & 13:28 & 85080 & 3508.4 & 3190.3 & 3146.9 & 3133.1 & 331.9 \\
\hline 22-Sep & 23-Sep & 14:05 & $11: 20$ & 76500 & 3190.3 & 3144.8 & 3146.9 & 2914.9 & 277.5 \\
\hline 23-Sep & 24-Sep & $12: 04$ & $11: 00$ & 82560 & 3144.8 & 2929.7 & 2914.9 & 3089.4 & 40.6 \\
\hline 24-Sep & 25-Sep & $12: 00$ & 13:35 & 92100 & 2929.7 & 3150.1 & 3089.4 & 2571.3 & 297.7 \\
\hline 25-Sep & 26-Sep & $14: 22$ & 11:05 & 74580 & 3150.1 & 2966.9 & 2571.3 & 2490.3 & 264.2 \\
\hline 26-Sep & 29-Sep & $11: 30$ & 13:55 & 267900 & 2966.9 & 2916.6 & 2490.3 & 1591.5 & 949.1 \\
\hline 29-Sep & 30-Sep & $14: 45$ & $14: 47$ & 86520 & 2916.6 & 2791.2 & 2736.4 & 2382.8 & 479.0 \\
\hline 30-Sep & $1-0<t$ & $15: 15$ & $13: 31$ & 80160 & 2791.2 & 2842.6 & 2382.8 & 2172.2 & 159.2 \\
\hline $1-0 c t$ & $2-0 c t$ & $14: 00$ & $13: 35$ & 84900 & 2842.6 & 2644.9 & 2172.2 & 2201.4 & 168.5 \\
\hline 2-Oct & $6-0 \mathrm{ct}$ & $14: 10$ & $8: 46$ & 326160 & 2644.9 & 2029.3 & 2201.4 & 2074.0 & 743.0 \\
\hline $6-0<t$ & 9-oct & $9: 20$ & $12: 45$ & 271500 & 2714.2 & 2383.6 & 2138.4 & 1538.7 & 930.3 \\
\hline 9-0ct & 13-0ct & $13: 21$ & 10.28 & 335220 & 2383.6 & 2176.3 & 2611.3 & 2550.9 & 297.7 \\
\hline $13-0 \mathrm{ct}$ & $16-0 \mathrm{et}$ & $11: 00$ & 10:05 & 255900 & 2176.3 & 2014.9 & 2550.9 & 2212.4 & 499.9 \\
\hline $16-0 \mathrm{ct}$ & $20-0 \mathrm{ct}$ & 10.35 & $10: 35$ & 345600 & 2014.9 & 2070.8 & 2212.4 & 1983.5 & 173.0 \\
\hline $20-0 \mathrm{ct}$ & 23-0et & $10: 35$ & $12: 45$ & 267000 & 2070.8 & 2170.9 & 2731.6 & 2054.4 & 577.1 \\
\hline $23-d c t$ & $27-0 c t$ & $13: 30$ & $8: 35$ & 327900 & 2170.9 & 2171.8 & 2054.4 & 1756.3 & 297.2 \\
\hline 27-Oct & $30-0 c t$ & 9:53 & $12: 55$ & 270120 & 2171.8 & 2236.5 & 2901.0 & 2471.7 & 364.6 \\
\hline $30-0 \mathrm{ct}$ & 3-Nov & 13:25 & $8: 50$ & 329100 & 2236.5 & 2206.6 & 2471.7 & 2109.3 & 392.3 \\
\hline 3-Nov & 6-Nov & $9: 25$ & 11:12 & 265620 & 2206.6 & 2306.4 & 2109.3 & 1911.6 & 97.9 \\
\hline 6-Nov & 10-Nov & $12: 05$ & $11: 00$ & 341700 & 2306.4 & 2353.5 & 2735.8 & 2307.3 & 381.4 \\
\hline 10-Nov & 13-Hov & $11: 55$ & $10: 15$ & 253200 & 2353.5 & 2051.5 & 2307.3 & 2112.7 & 496.6 \\
\hline 13-Hov & 17- Nov & 10.50 & $10: 33$ & 344580 & 2051.5 & 2113.8 & 2112.7 & 2149.3 & -98.9 \\
\hline 17 Hov & 20-thov & $11: 08$ & $10: 30$ & 256920 & 2113.8 & 1819 & 2149.3 & 1968.7 & 475.4 \\
\hline 20-Nov & 25Nov & 11:10 & $10: 20$ & 429000 & 2556.7 & 2053.4 & 2796.3 & 2702.2 & 597.4 \\
\hline 25-Nov & 4-Dec & 11:05 & 10:12 & 774420 & 2053.4 & 1992.9 & 2702.2 & 2438.6 & 324.1 \\
\hline 4-Dec & 18-Dec & 10.50 & 13:46 & 1220160 & 1992.9 & 1700.2 & 2438.6 & 1421.2 & 1310.1 \\
\hline 18-Dec & 23-Dec & $14: 16$ & $10: 35$ & 418740 & 3094.5 & 3092.6 & 3059.5 & 2762.2 & 299.2 \\
\hline 23-Dec & 31-Dec & $11: 05$ & $10: 46$ & 690060 & 3092.6 & 2682.1 & 2762.2 & 2667.3 & 505.4 \\
\hline 31-Dec & 8-bn & $11: 20$ & $13: 25$ & 698700 & 2682.1 & 2103.7 & 2667.3 & 2601.4 & 644.3 \\
\hline
\end{tabular}


SEALED DOUBLE-RINGED INFILTROMETER DATA, DCF TEST

\begin{tabular}{|c|c|c|c|c|c|c|c|c|c|}
\hline \multicolumn{10}{|c|}{$\begin{array}{l}\text { DATA SHEET FOR WATER DEPTH AND TEMPERATURE } \\
\text { WFRTROMETER D-1 }(W-N)\end{array}$} \\
\hline DATE & $\begin{array}{c}\text { START } \\
\text { WAT. DEPTH } \\
\text { READINO } \\
\text { (ln) } \\
\end{array}$ & $\begin{array}{c}\text { START } \\
\text { WATER } \\
\text { DEPTH } \\
\text { (la. } \\
\end{array}$ & $\begin{array}{c}\text { END } \\
\text { WAT. DEPTH } \\
\text { READNG } \\
\text { (h.) }\end{array}$ & $\begin{array}{c}\text { END } \\
\text { WATER } \\
\text { DEPTH } \\
\text { (l) }\end{array}$ & $\begin{array}{c}\text { AVG. } \\
\text { WATER } \\
\text { DEPTH } \\
\text { (ln) }\end{array}$ & $\begin{array}{l}\text { START } \\
\text { WATER } \\
\text { TEMP } \\
\text { (of) } \\
\end{array}$ & $\begin{array}{l}\text { END } \\
\text { WATER } \\
\text { TENP } \\
\text { (of) } \\
\end{array}$ & $\begin{array}{c}\text { AVG. } \\
\text { WATER } \\
\text { TENP } \\
\text { of }\end{array}$ & $\begin{array}{c}\text { TEMP. } \\
\text { CHANGE } \\
\text { (OF) }\end{array}$ \\
\hline 14-Sep & 3.00 & 11.00 & 3.00 & 11.00 & 11.00 & 82 & 73 & 78 & -9 \\
\hline 15-Sep & 3.00 & 11.00 & 2.75 & 10.75 & 10.88 & 73 & 72 & 73 & -1 \\
\hline 16-Sep & 2.75 & 10.75 & 2.75 & 10.75 & 10.75 & 72 & 74 & 73 & 2 \\
\hline 17-Sep & 2.75 & 10.75 & 2.75 & 10.75 & 10.75 & 74 & 74 & 74 & 0 \\
\hline 18-Sep & 2.75 & 10.75 & 2.75 & 10.75 & 10.75 & 74 & 74 & 74 & 0 \\
\hline 19-Sep & 2.75 & 10.75 & 2.75 & 10.75 & 10.75 & 74 & 74 & 74 & 0 \\
\hline 21-Sep & 2.75 & 10.75 & 2.50 & 10.50 & 10.63 & 74 & 75 & 75 & 1 \\
\hline 22-Sep & 2.50 & 10.50 & 2.50 & 10.50 & 10.50 & 75 & 77 & 76 & 2 \\
\hline 23-Sep & 2.50 & 10.50 & 2.50 & 10.50 & 10.50 & 77 & 76 & 77 & -1 \\
\hline 24-Sep & 2.50 & 10.50 & 3.00 & 11.00 & 10.75 & 76 & 67 & 72 & -9 \\
\hline 25-Sep & 3.00 & 11.00 & 2.75 & 10.75 & 10.88 & 67 & 65 & 66 & -2 \\
\hline 26-Sep & 2.75 & 10.75 & 3.00 & 11.00 & 10.88 & 65 & 65 & 65 & 0 \\
\hline 29-Sep & 3.00 & 11.00 & 3.00 & 11.00 & 11.00 & 65 & 70 & 68 & 5 \\
\hline 30-Sep & 3.00 & 11.00 & 2.75 & 10.75 & 10.88 & 70 & 64 & 67 & -6 \\
\hline 1.0ct & $\begin{array}{l}2.75 \\
2.50\end{array}$ & $\begin{array}{l}10.75 \\
10.50\end{array}$ & $\begin{array}{l}2.50 \\
2.50\end{array}$ & 10.50 & 10.63 & 64 & 62 & 63 & -2 \\
\hline 2-Oct & 2.50 & 10.50 & 2.50 & 10.50 & 10.50 & 62 & 61 & 62 & -1 \\
\hline 6-0ct & 2.50 & 10.50 & 3.75 & 11.75 & 11.13 & 61 & 58 & 60 & -3 \\
\hline goct & 3.75 & 11.75 & 4.75 & 12.75 & 12.25 & 58 & 66 & 62 & 8 \\
\hline $13-0 \mathrm{ct}$ & 4.75 & 12.75 & 3.00 & 11.00 & 11.88 & 66 & $\$ 2$ & 59 & .14 \\
\hline $16-0 \mathrm{ct}$ & 3.00 & 11.00 & 3.00 & 11.00 & 11.00 & S2 & 63 & 58 & 11 \\
\hline $20-0 \mathrm{ct}$ & 3.00 & 11.00 & 3.00 & 11.00 & 11.00 & 63 & 53 & 58 & -10 \\
\hline 23-Oct & 3.00 & 11.00 & 2.75 & 10.75 & 10.88 & 53 & 57 & S5 & 4 \\
\hline $27-0 c t$ & 2.75 & 10.75 & 2.75 & 10.75 & 10.75 & 57 & 59 & 58 & 2 \\
\hline $30-0 \mathrm{ct}$ & 2.75 & 10.75 & 2.50 & 10.50 & 10.63 & 59 & 59 & 59 & 0 \\
\hline 3+tov & 2.50 & 10.50 & 2.75 & 10.75 & 10.63 & 59 & 64 & 62 & 5 \\
\hline 6-Hov & 2.75 & 10.75 & 3.50 & 11.50 & 11.13 & 64 & 57 & 61 & -7 \\
\hline 10-Hov & 3.50 & 11.50 & 3.25 & 11.25 & 11.38 & 57 & so & 54 & -7 \\
\hline 13-Nov & 3.25 & 11.25 & 3.50 & 11.50 & 11.38 & 50 & 58 & 54 & 8 \\
\hline 17-Nov & 3.50 & 11.30 & 3.50 & 11.50 & 11.50 & 58 & 45 & 52 & .13 \\
\hline 20.Hov & 3.50 & 11.50 & 3.50 & 11.50 & 11.50 & 45 & so & 48 & 5 \\
\hline 25-Nov & 3.50 & 11.50 & 3.25 & 11.25 & 11.38 & 50 & 59 & 55 & 9 \\
\hline 4-Dec & 3.25 & 11.25 & 3.50 & 11.50 & 11.38 & 59 & 46 & 53 & -13 \\
\hline 18-Dec & 3.50 & 11.50 & 3.50 & 11.50 & 11.50 & 46 & 46 & 46 & 0 \\
\hline 23-Dec & 3.50 & 11.50 & 3.50 & 11.50 & 11.50 & 46 & 46 & 46 & 0 \\
\hline 31-Dec & 3.50 & 11.50 & 3.50 & 11.50 & 11.50 & 46 & 46 & 46 & 0 \\
\hline 8- $\operatorname{lan}$ & 3.50 & 11.50 & 4.00 & 12.00 & 11.75 & 46 & 58 & 52 & 12 \\
\hline
\end{tabular}




\begin{tabular}{|c|c|c|c|c|c|c|c|c|c|c|c|c|c|}
\hline \multirow[b]{2}{*}{ DATE } & \multirow[b]{2}{*}{ DAY } & \multicolumn{3}{|c|}{ GROUP NUNBER I } & \multicolumn{3}{|c|}{ GROUP NUMBER 2} & \multicolumn{3}{|c|}{ GROUP NUMBER 3} & \multicolumn{3}{|c|}{$\begin{array}{c}\text { AVERAGE } \\
\text { TENSIOMETER READNGS }\end{array}$} \\
\hline & & $\begin{array}{l}6 \text { WOH } \\
\text { (cb) }\end{array}$ & $\begin{array}{l}12 \text { WCH } \\
\text { (cb) }\end{array}$ & $\begin{array}{c}18 \mathrm{WCH} \\
\text { (cb) }\end{array}$ & $\begin{array}{l}6 \mathrm{WCH} \\
\text { (cb) }\end{array}$ & $\begin{array}{c}12 \mathrm{WCH} \\
\text { (eb) }\end{array}$ & $\begin{array}{c}18 \mathrm{NCH} \\
(\mathrm{Cb})\end{array}$ & $\begin{array}{l}6 \text { math } \\
\text { (cb) }\end{array}$ & $\begin{array}{l}12 \mathrm{WCH} \\
\text { (cb) }\end{array}$ & $\begin{array}{c}18 \mathrm{mCH} \\
(\mathrm{cb})\end{array}$ & $\begin{array}{l}6 \mathrm{WCH} \\
\text { (cb) }\end{array}$ & $\begin{array}{l}12 \mathrm{WCH} \\
\text { (cb) }\end{array}$ & $\begin{array}{c}18 \text { NMCH } \\
(\mathrm{eb})\end{array}$ \\
\hline & 1 & 0 & 0 & 0 & 0 & 0 & 0 & 0 & 0 & 0 & 0 & 0 & 0 \\
\hline 14-Sep & 3 & 32 & 12 & 21 & 28 & 12 & 0 & 32 & 20 & 20 & 31 & 15 & 14 \\
\hline 15-Sep & 4 & 12 & 24 & 26 & 6 & 15 & 16 & 8 & 22 & 29 & 9 & 20 & 24 \\
\hline 16-Sep & 5 & 11 & 22 & 25 & o & 15 & 16 & 0 & 22 & 28 & 4 & 20 & 23 \\
\hline 17.5ep & 6 & 8 & 14 & 23 & $\mathbf{0}$ & 12 & 16 & 2 & 18 & 27 & 3 & 15 & 22 \\
\hline 18-Sep & 7 & 3 & 12 & 22 & 2 & 16 & 14 & 0 & 17 & 22 & 2 & 15 & 19 \\
\hline 19-Sep & - & 4 & 10 & 19 & 0 & 12 & 13 & 2 & 15 & 23 & 2 & 12 & 18 \\
\hline 21-Sep & 10 & 4 & 9 & 18 & $\mathbf{0}$ & 10 & 12 & 2 & 12 & 20 & 2 & 10 & 17 \\
\hline 22-Sep & 11 & 4 & 8 & 18 & $\mathbf{0}$ & 10 & 12 & 2 & 11 & 18 & 2 & 10 & 16 \\
\hline 23-Sep & 12 & 2 & 8 & 16 & o & 10 & 10 & 2 & 10 & 18 & 1 & 9 & 15 \\
\hline 24-Sep & 13 & 2 & 2 & 14 & o & B & 9 & $\mathbf{0}$ & 10 & 15 & 1 & 7 & 13 \\
\hline 25-Sep & 14 & 2 & 4 & 16 & o & 10 & 10 & 0 & 12 & 20 & 1 & 9 & 15 \\
\hline 26-Sep & 15 & 6 & 5 & 16 & 0 & 8 & 10 & 0 & 12 & 22 & 2 & 8 & 16 \\
\hline 29-Sep & 18 & 0 & 2 & is & 0 & 5 & 9 & 0 & 9 & 18 & 0 & 5 & 14 \\
\hline 30-Sep & 19 & 0 & 2 & 14 & o & 6 & 8 & 0 & 10 & 16 & 0 & 6 & 13 \\
\hline $1-0 c t$ & 20 & 0 & 2 & 15 & 0 & 7 & 9 & 0 & 10 & 20 & 0 & 6 & 15 \\
\hline $2-0 c t$ & 21 & 0 & 2 & 16 & 0 & 8 & 10 & 0 & 12 & 21 & 0 & 7 & 16 \\
\hline $6-0<t$ & 25 & 0 & 0 & 12 & 0 & 2 & 8 & 0 & 8 & 17 & 0 & 3 & 12 \\
\hline $9-0<t$ & 28 & 0 & 0 & 12 & 0 & 2 & 7 & 0 & 8 & 18 & 0 & 3 & 12 \\
\hline 13-0ct & 32 & 0 & 0 & 10 & 0 & 0 & 2 & 0 & 4 & 14 & 0 & 1 & 9 \\
\hline 16-0et & 35 & 0 & 0 & 8 & 0 & 0 & 0 & 0 & 4 & 14 & 0 & 1 & 7 \\
\hline $20-0 c t$ & 39 & 0 & 0 & 8 & 0 & 0 & 2 & 0 & 7 & 16 & 0 & 2 & 9 \\
\hline $23-0 \mathrm{ct}$ & 42 & 0 & 0 & o & 0 & o & 5 & o & 7 & 17 & 0 & 2 & 7 \\
\hline $27-0 \mathrm{ct}$ & 46 & 0 & 0 & 8 & 0 & 0 & 0 & o & 7 & 15 & 0 & 2 & 8 \\
\hline 30-0ct & 49 & o & 0 & 8 & 0 & 0 & 2 & 0 & 7 & 12 & 0 & 2 & 7 \\
\hline 3- Hov & 53 & 0 & 0 & 4 & 0 & 0 & 1 & 0 & 4 & 12 & 0 & 1 & 6 \\
\hline 6-Nov & 56 & 0 & 0 & 2 & 0 & 0 & 0 & 0 & 4 & 10 & 0 & $i$ & 4 \\
\hline 10-Nov & 60 & 0 & o & 4 & 0 & o & 0 & 0 & 4 & 16 & 0 & 1 & 7 \\
\hline 13 Hov & 63 & D & D & 6 & 0 & 0 & 0 & 0 & 4 & 13 & 0 & 1 & 6 \\
\hline 17 Hov & 67 & 0 & 0 & 2 & o & 0 & 0 & 0 & 6 & 14 & 0 & 2 & 5 \\
\hline 20-Nov & 70 & 0 & 0 & 2 & 0 & 0 & 0 & 0 & 4 & 14 & 0 & 1 & 5 \\
\hline 25-Nov & 75 & o & 0 & 0 & o & 0 & 0 & 0 & 2 & 10 & o & 1 & 3 \\
\hline 4-Dex & 84 & 0 & 0 & 0 & 0 & 0 & 0 & 0 & 4 & 13 & o & 1 & 4 \\
\hline 18-Dec & 97 & 0 & 0 & 0 & 0 & 0 & 0 & 0 & 4 & 12 & 0 & 1 & 4 \\
\hline 23-Dec & 102 & 0 & 0 & o & o & 0 & 0 & 0 & 0 & 0 & 0 & 0 & 0 \\
\hline 31-Dec & 110 & o & 0 & 0 & 0 & 0 & 0 & 0 & 0 & 10 & o & 0 & 3 \\
\hline 8-fan & 118 & 0 & 0 & 0 & 0 & 0 & 0 & 0 & 0 & 0 & 0 & 0 & 0 \\
\hline
\end{tabular}


SEALED DOUBLE-RINGED INFILTROMETER DATA, DCF TEST

\begin{tabular}{|c|c|c|c|c|c|c|c|c|c|c|c|c|c|c|}
\hline \multicolumn{9}{|c|}{$\begin{array}{l}\text { DATA SHEET FOR SWELL DATA } \\
\text { INFMTROMETER D-1 (W-N) } \\
\end{array}$} & \multicolumn{6}{|c|}{$\begin{array}{l}\text { CALCULATION SHEET FOR FLOW-RATE AND ADNUSTMENT VALUES } \\
\text { WFUTROMETER D-I (W-W) }\end{array}$} \\
\hline \multirow{2}{*}{$\begin{array}{l}\text { READWNG } \\
\text { DATE }\end{array}$} & \multirow{2}{*}{$\begin{array}{l}\text { READING } \\
\text { TME }\end{array}$} & \multirow{2}{*}{$\begin{array}{c}\text { DAY } \\
\text { MUMBER } \\
\end{array}$} & \multicolumn{4}{|c|}{ SWELL NFORMATION } & \multirow{2}{*}{$\begin{array}{l}\text { DAY } \\
\text { NO. }\end{array}$} & \multirow{2}{*}{$\begin{array}{l}(\operatorname{mm}) \\
\text { AVG. } \\
\text { SWEL }\end{array}$} & \multirow{2}{*}{$\underset{(m)}{Q}$} & \multirow{2}{*}{$\begin{array}{c}\text { AvG } \\
\text { DaY No. }\end{array}$} & \multirow{2}{*}{$\begin{array}{c}1 \\
(\mathrm{~cm} / \mathrm{eos})\end{array}$} & \multirow{2}{*}{$\begin{array}{c}\text { EST. FLOW } \\
\text { DUE TO } \\
\text { TEMP. CHG. } \\
\text { (m) }\end{array}$} & \multirow{2}{*}{$\begin{array}{l}\text { \%OF } \\
\text { TOTAL } \\
\text { FLOW } \\
\text { (mi) }\end{array}$} & \multirow{2}{*}{$\begin{array}{c}\text { Q } \\
\text { WHEN BAe } \\
\text { WAS OFF } \\
\text { (m) }\end{array}$} \\
\hline & & & si & $\mathbf{S 2}$ & 53 & S4 & & & & & & & & \\
\hline 14-Sep & $16: 49$ & 3 & 91.6 & 52.4 & 55.5 & 80.8 & 3 & 3.08 & 142.3 & 2 & $7.30 E-08$ & -150.0 & 33.9 & 9 \\
\hline 15-Sep & $15: 45$ & 4 & 91.3 & 52.8 & 54.3 & 81.1 & 4 & 3.28 & • & - & - & -16.7 & $\cdot$ & - \\
\hline 16-Sep & $14: 10$ & 5 & 91.8 & 52.6 & 47.8 & 81.8 & $\mathbf{5}$ & 4.65 & 814.7 & 4 & $2.11 E-07$ & 33.3 & 4.1 & 27 \\
\hline 17-Sep & $14: 10$ & 6 & 92.0 & 52.8 & 54.8 & 80.8 & 6 & 3.05 & 297.7 & 6 & $1.60 E-07$ & 0.0 & 0.0 & 12 \\
\hline 18-Sep & 15:34 & 7 & 91.2 & 51.2 & 54.6 & 81.3 & 7 & 3.58 & - & - & - & 0.0 & - & - \\
\hline 19-Sep & $10: 51$ & 8 & 90.4 & 52.7 & 54.4 & 80.7 & 8 & 3.60 & 565.0 & 7 & $1.55 E-07$ & 0.0 & 0.0 & 17 \\
\hline 21-Sep & 12:56 & 10 & 91.0 & 52.7 & 54.4 & 81.8 & 10 & 3.18 & 667.1 & 9 & $1.66 E-07$ & 16.7 & 2.5 & 26 \\
\hline 22-Sep & $14: 25$ & 11 & 91.2 & 52.5 & 54.3 & 61.7 & 11 & 3.23 & 331.9 & 10 & 1.68E-07 & 33.3 & 10.0 & 5 \\
\hline 23-Sep & $9: 28$ & 12 & 91.2 & $\$ 3.1$ & 54.7 & 81.9 & 12 & 2.93 & 277.5 & 11 & $1.56 E-07$ & -16.7 & 6.0 & 9 \\
\hline 26-Sep & $10: 27$ & 15 & 98.6 & 54.1 & 54.6 & 88.3 & 15 & -0.75 & 264.2 & 14 & $1.53 E-07$ & 0.0 & 0.0 & 7 \\
\hline 29-Sep & 13:03 & 18 & 118.7 & 55.7 & 55.6 & 105.2 & 18 & -10.65 & 949d & 16 & $1.53 E-07$ & 83.3 & 8.8 & 8 \\
\hline 30-Sep & $10: 48$ & 19 & 108.4 & 55.1 & 55.6 & 94.4 & 19 & -5.23 & 479.0 & 19 & $2.38 E-07$ & -100.0 & 20.9 & 6 \\
\hline 1-oct & $14: 20$ & 20 & 101.1 & 54.9 & 55.2 & 89.3 & 20 & -1.98 & 159.2 & 19 & 8.5SE-08 & -33.3 & 20.9 & 4 \\
\hline $2-0 e t$ & $12: 52$ & 21 & 98.6 & 54.6 & 55.0 & 88.3 & 21 & -0.98 & 168.5 & 20 & 8.55E-08 & -16.7 & 9.9 & 6 \\
\hline $6-0<t$ & 9.35 & 25 & 107.7 & 56.5 & 56.1 & 96.3 & 25 & -6.00 & 743.0 & 23 & 9.81E-08 & .50 .0 & 6.7 & 3 \\
\hline $9-0<t$ & $12: 04$ & 28 & 120.5 & 107.1 & 62.6 & 63.3 & 28 & -15.23 & 930.3 & 26 & $1.48 E-07$ & 133.3 & 14.3 & 6 \\
\hline 13-0ct & $9: 40$ & 32 & 121.5 & 63.6 & 63.7 & 109.2 & 32 & -16.35 & 297.7 & 30 & $3.82 E-08$ & -233.3 & 78.4 & 1 \\
\hline $16-0 c t$ & $8: 04$ & 35 & 103.7 & 63.4 & 64.4 & 97.5 & 35 & -9.10 & 499.9 & 33 & 8.41E-08 & 183.3 & 36.7 & 4 \\
\hline $20-0 c t$ & $10: 43$ & 39 & 103.9 & 63.4 & 64.4 & 97.0 & 39 & -9.03 & 173.0 & 37 & $2.16 E-08$ & -166.7 & 96.3 & 0 \\
\hline 23-0ct & $13: 41$ & 42 & 103.1 & 63.5 & 63.8 & 97.6 & 42 & -8.85 & 577.1 & 40. & $9.31 E-08$ & 66.7 & 11.6 & 5 \\
\hline 27 -oct & 9.47 & 46 & 99.5 & 62.5 & 63.8 & 94.0 & 46 & -6.80 & 297.2 & 44 & $3.90 E-08$ & 33.3 & 11.2 & 5 \\
\hline $30-0 \mathrm{ct}$ & $11: 16$ & 49 & 99.5 & 61.9 & 62.5 & 92.4 & 49 & -5.93 & 364.6 & 47 & S.81E-08 & 0.0 & 0.0 & 2 \\
\hline 3-Now & $8: 22$ & $\mathbf{5 3}$ & 107.0 & 61.5 & 63.4 & 98.8 & 53 & -9.53 & 392.3 & 51 & 5.13E-08 & 83.3 & 21.2 & 2 \\
\hline 6+Nov & $10: 33$ & 56 & 117.1 & 62.9 & 53.3 & 110.1 & 56 & -12.70 & 97.9 & 54 & $1.59 E-08$ & -116.7 & 119.2 & 4 \\
\hline 10-Nov & 10.05 & 60 & 123.1 & 62.8 & 63.7 & 127.5 & 60 & -21.13 & 381.4 & 58 & 4.81E-08 & -116.7 & 30.6 & i \\
\hline 13-Nov & $9: 38$ & 63 & 132.0 & 64.0 & 65.4 & 138.5 & 63 & -26.83 & 496.6 & 61 & 8.44E-08 & 133.3 & 26.8 & 4 \\
\hline 17-Nov & 9:38 & 67 & 99.4 & 63.4 & 64.1 & 102.0 & 67 & -9.08 & .98 .9 & 65 & $-1.24 E-08$ & -216.7 & 219.1 & 1 \\
\hline 20-Nov & 9.38 & 70 & 109.3 & 63.6 & 63 & 98.7 & 70 & -10.50 & 475.4 & 68 & 7.97E-08 & 83.3 & 17.5 & 3 \\
\hline 18-Dec & & 97 & & & & & & & 1310.1 & 91 & 4.62E-08 & 0.0 & 0.0 & 2 \\
\hline 23-Dec & & 102 & & & & & & & 299.2 & 100 & 3.08E-08 & 0.0 & 0.0 & 1 \\
\hline 31-Dec & & 110 & & & & & & & 505.4 & 107 & $3.15 E-08$ & 0.0 & 0.0 & 1 \\
\hline 8-tan & & 118 & & & & & & & 644.3 & 115 & $3.97 E-08$ & 200.0 & 31.0 & \\
\hline
\end{tabular}




\begin{tabular}{|c|c|c|c|c|c|c|c|c|}
\hline $\begin{array}{l}\text { LCVATA } \\
\text { IITROME }\end{array}$ & $\begin{array}{l}\text { HEET FOR } \\
\text { D-1 (W-N) }\end{array}$ & RAULC & NDUCTIVTY & & & & & \\
\hline DAY MO. & $\begin{array}{c}\times 10-7 \\
1 \\
(\mathrm{~cm} / \mathrm{sec})\end{array}$ & $\begin{array}{l}\text { WATER } \\
\text { DEPTH } \\
\text { (b) }\end{array}$ & $\begin{array}{c}\text { W. FRONT } \\
\text { DEPTH } \\
\text { (ID) }\end{array}$ & GRADEENT & DAY MO. & hrophus & $\begin{array}{c}x 10-7 \\
\text { SWELL } \\
1 \\
(\mathrm{~cm} / \mathrm{sec})\end{array}$ & 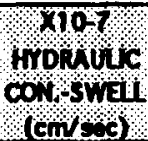 \\
\hline & & & & & 1 & $176 \%$ & & \\
\hline 3 & 0.7 & 11.00 & 1.23 & 9.91 & 3 & 04 & 0.73 & 0,07 \\
\hline 4 & - & 10.88 & 1.60 & 7.80 & 4 & 0.6 & & $\%$ \\
\hline 5 & 2.1 & 10.75 & 1.99 & 6.40 & 5 & 0.3 & 2.11 & 0.33 \\
\hline 6 & 1.6 & 10.75 & 2.39 & 5.50 & 6 & 0.3 & 1.60 & $0: 29$ \\
\hline 7 & - & 10.75 & 2.81 & 4.82 & 7 & 0.6 & - & 3 \\
\hline 8 & 1.5 & 10.75 & 3.14 & 4.43 & 8 & 0.3 & 1.55 & 0.35 \\
\hline 10 & 1.7 & 10.63 & 3.97 & 3.68 & 10 & 0.5 & 1.66 & 0.45 \\
\hline 11 & 1.7 & 10.50 & 4.39 & 3.39 & 11 & 0.5 & 1.68 & 0.50 \\
\hline 12 & 1.6 & 10.50 & 4.71 & 3.23 & 12 & 0.5 & 1.56 & 0.48 \\
\hline 13 & 0.2 & 10.75 & 5.14 & 3.09 & 13 & 0.1 & 0.21 & 0.07 \\
\hline 14 & 1.4 & 10.88 & 5.59 & 2.95 & 14 & 0.5 & 1.39 & 0.47 \\
\hline 15 & 1.5 & 10.88 & 5.93 & 2.83 & 15 & 0.3 & 1.53 & 0.54 \\
\hline 18 & 1.5 & 11.00 & 4.48 & 3.45 & 18 & 0.4 & 1.53 & 0.44 \\
\hline 19 & 2.4 & 10.88 & 4.71 & 3.31 & 19 & 0.7 & 2.38 & 072 \\
\hline 20 & 0.9 & 10.63 & 5.00 & 3.13 & 20 & 0.3 & 0.86 & 0.27 \\
\hline 21 & 0.9 & 10.50 & 5.23 & 3.01 & 21 & 0.3 & 0.85 & 0.28 \\
\hline 25 & 1.0 & 11.13 & 6.20 & 2.80 & 25 & 0.4 & 0.98 & 0.35 \\
\hline 28 & 1.5 & 12.25 & 6.97 & 2.76 & 28 & 0.5 & 1.48 & 0.54 \\
\hline 32 & 0.4 & 11.88 & 7.95 & 2.49 & 32 & 02 & 0.38 & 0.15 \\
\hline 35 & 0.8 & 11.00 & 8.68 & 2.27 & 35 & 6.) & 0.84 & 0.37 \\
\hline 39 & 0.2 & 11.00 & 9.71 & 2.13 & 39 & $0.1 \%$ & 0.22 & 0.10 \\
\hline 42 & 0.9 & 10.88 & 8.12 & 2.34 & 42 & 04 & & 0,00 \\
\hline 46 & 0.4 & 10.75 & 8.86 & 2.21 & 46 & 0.2 & 0.39 & 0,16 \\
\hline 49 & 0.6 & 10.63 & 9.46 & 2.12 & 49 & 0.3 & 0.58 & 0.27 \\
\hline 53 & 0.5 & 10.63 & 10.21 & 2.04 & 53 & 03 & 0.51 & 0.25 \\
\hline 56 & 0.2 & 11.13 & 10.80 & 2.03 & 56 & 01 & 0.16 & 0.08 \\
\hline 60 & 0.5 & 11.38 & 11.58 & 1.98 & 60 & 0.2 & 0.48 & 0.24 \\
\hline 63 & 0.8 & 11.38 & 12.15 & 1.94 & 63 & 0.1 & 0.84 & 0.44 \\
\hline 67 & -0.1 & 11.50 & 12.93 & 1.89 & 67 & $0.1 \%$ & -0.12 & -0.07 \\
\hline 70 & 0.8 & 11.50 & 13.51 & 1.85 & 70 & 0.4 & 0.80 & $0: 43$ \\
\hline 75 & 0.6 & 11.38 & 14.96 & 1.76 & 75 & 0.3 & 0.60 & 0.34 \\
\hline 84 & 0.2 & 11.38 & 16.76 & 1.68 & 84 & 0.1 & 0.18 & 0.11 \\
\hline 97 & 0.5 & 11.50 & 19.48 & 1.59 & 97 & 0.3 & 0.46 & 0.29 \\
\hline 102 & 0.3 & 11.50 & 20.48 & 1.56 & 102 & 0.2 & 0.31 & 0.20 \\
\hline 110 & 0.3 & 11.50 & 22.08 & 1.52 & 110 & 02 & 0.32 & 0.21 \\
\hline 118 & 0.4 & 11.75 & 23.68 & 1.50 & 118 & 0.3 & 0.40 & 0.21 \\
\hline
\end{tabular}


SEALED DOUBLE-RINGED INFILTROMETER DATA, DCF TEST

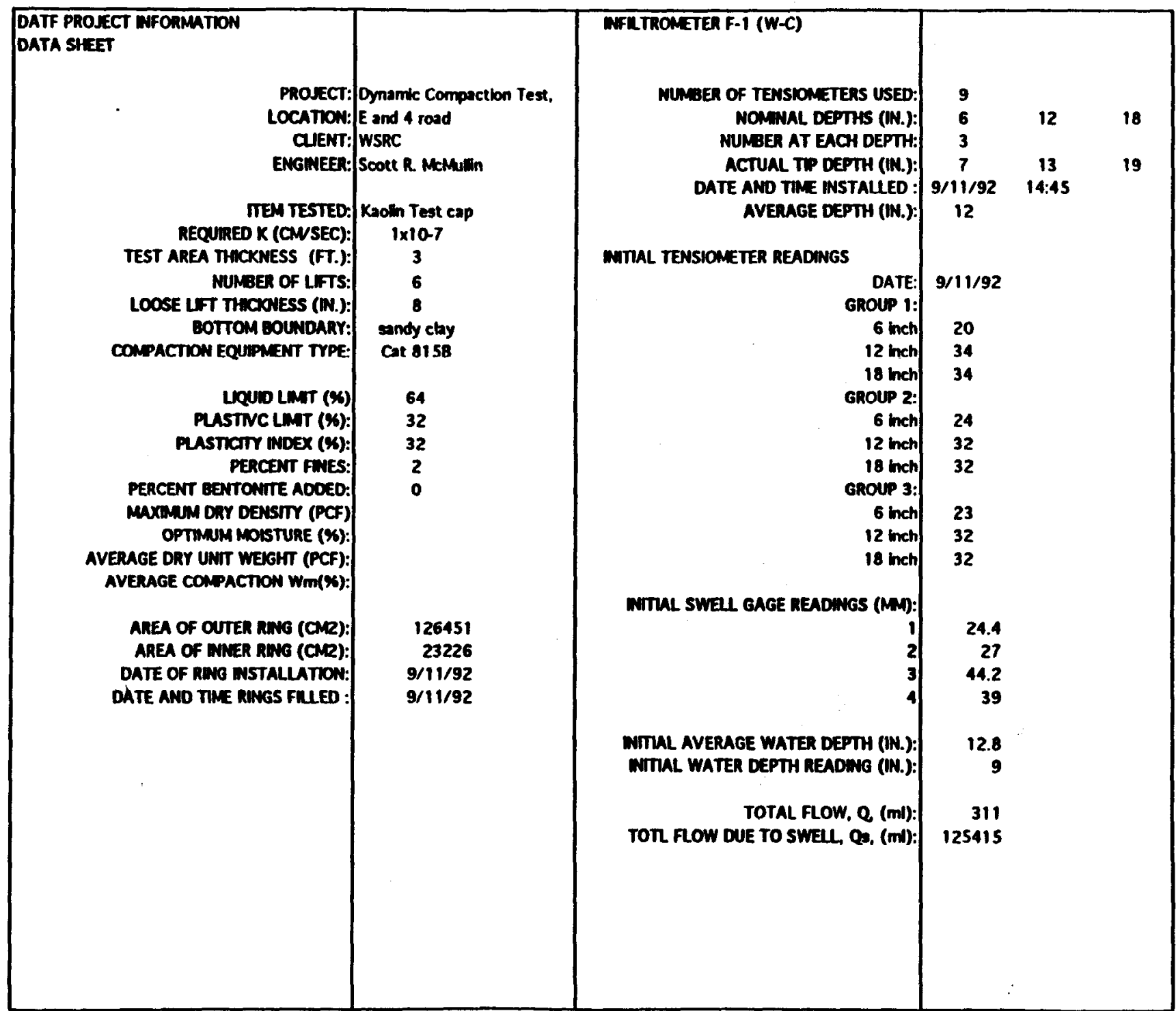




\begin{tabular}{|c|c|c|c|c|c|c|c|c|c|}
\hline \multicolumn{10}{|c|}{$\begin{array}{l}\text { DATA SHEET FOR WATER BAGS } \\
\text { WFU TROMETER F-1 (W-C) }\end{array}$} \\
\hline \multirow{2}{*}{\multicolumn{4}{|c|}{ BAG CONNECTION AND DISCONNECTION }} & \multirow{3}{*}{$\begin{array}{l}\text { t } \\
\text { ATERVAL } \\
\text { TIME }\end{array}$} & \multicolumn{2}{|c|}{$8 A 61$} & \multicolumn{2}{|c|}{ BAG 2 } & \multirow{3}{*}{$\begin{array}{c}\text { NET } \\
\text { CHANGE } \\
\text { (1) }\end{array}$} \\
\hline & & & & & \multirow{2}{*}{$\begin{array}{c}\text { MTIMAL } \\
\text { WEGKT } \\
(0) \\
\end{array}$} & \multirow{2}{*}{$\begin{array}{c}\text { FNAL } \\
\text { WEIGHT } \\
(0)\end{array}$} & \multirow{2}{*}{$\begin{array}{c}\text { MITAL } \\
\text { WEAGH } \\
\text { (a) }\end{array}$} & \multirow{2}{*}{$\begin{array}{c}\text { FWAL } \\
\text { WEIGHT } \\
(1)\end{array}$} & \\
\hline DATE ON & DATE OFF & TIME ON & THE OFF & & & & & & \\
\hline 11-Sep & 14-Sep & $14: 45$ & 15:08 & 260580 & 3926.5 & 3197.6 & 3866.9 & 3310.9 & 1284.9 \\
\hline 14-Sep & $\cdot$ & $15: 53$ & - & $\cdot$ & 3197.6 & - & 3310.9 & - & - \\
\hline 16-Sep & $\begin{array}{l}\text { 16-Sep } \\
\text { 17-Sep }\end{array}$ & $15: 43$ & $\begin{array}{l}14: 00 \\
13: 57\end{array}$ & $\begin{array}{c}166020 \\
80040\end{array}$ & 2595.7 & $\begin{array}{l}2595.9 \\
2681.3\end{array}$ & & $\begin{array}{l}3272.7 \\
2967.8\end{array}$ & 639.9 \\
\hline 17-Sep & - & $14: 46$ & - & - & 2681.3 & $\begin{array}{c}2681.3 \\
.\end{array}$ & $\begin{array}{l}3272.7 \\
2967.8\end{array}$ & $\begin{array}{c}2967.8 \\
.\end{array}$ & $\begin{array}{c}219.3 \\
.\end{array}$ \\
\hline- & 19-Sep & - & 10.30 & 157440 & 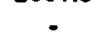 & 2477.5 & 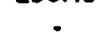 & 2659.8 & 511.8 \\
\hline 19-Sep & 21-Sep & $11: 43$ & $11: 56$ & 173580 & 2477.5 & 2097.1 & 2659.8 & 2484.4 & 555.8 \\
\hline 21-Sep & 22-Sep & 13:49 & 13:45 & 86160 & 2097.1 & 1645.3 & 2484.4 & 2693.4 & 242.8 \\
\hline 22-Sep & 23-Sep & $14: 07$ & 11:22 & 76500 & 1645.3 & 1519.8 & 2693.4 & 2610.7 & 208.2 \\
\hline 23-Sep & 24-Sep & $12: 02$. & $11: 02$ & 82800 & 1519.8 & 1652.9 & 2610.7 & 2340.1 & 137.5 \\
\hline 24-sep & 25-Sep & $12: 02$ & $13: 37$ & 92100 & 3331.4 & 3223.5 & 3396.8 & 3209.1 & 295.6 \\
\hline 25-Sep & 26-Sep & $14: 24$ & 11:05 & 74460 & 3223.5 & 3156.5 & 3209.1 & 3038.3 & 237.8 \\
\hline 26-Sep & 29-Sep & $11: 30$ & $13: 55$ & 267900 & 3156.5 & 2658.9 & 3038.3 & 2725.1 & 810.8 \\
\hline 29-Sep & 30-Sep & $14: 45$ & $14: 49$ & 86640 & 2658.9 & 2719.2 & 2725.1 & 2074.7 & 590.1 \\
\hline 30-Sep & 1 -oct & $15: 16$ & 13:32 & 80160 & 2719.2 & 2620.6 & 2074.7 & 2034.6 & 138.7 \\
\hline $1-0 \mathrm{ct}$ & $2-0 \mathrm{ct}$ & $14: 02$ & $13: 36$ & 84840 & 2620.6 & 2369.0 & 2034.6 & 2122.8 & 163.4 \\
\hline $2-0 c t$ & 6-0ct & $14: 12$ & $8: 47$ & 326100 & 2369.0 & 1643.0 & 2122.8 & 2285.5 & 563.3 \\
\hline 6-0ct & $9-0 \mathrm{ct}$ & $9: 22$ & $12: 48$ & 271560 & 1643.0 & 1605.4 & 2285.5 & 1647.1 & 676.0 \\
\hline 9-0ct & 13-0et & $13: 15$ & $10: 29$ & 335640 & 2620.8 & 2851.6 & 2603.4 & 2126.2 & 246.4 \\
\hline 13-Oet & $16-0 \mathrm{ct}$ & 11:02 & 10:06 & 255840 & 2851.6 & 2766.8 & 2126.2 & 1743.4 & 467.6 \\
\hline $16-0 \mathrm{ct}$ & $20-0 \mathrm{ct}$ & $10: 37$ & 10.36 & 345540 & 2766.8 & 2596.6 & 2613.4 & 2481.5 & 302.1 \\
\hline $20-0 \mathrm{ct}$ & $23-0 c t$ & $11: 11$ & $12: 47$ & 264960 & 2596.6 & 2777.9 & 2481.5 & 1815.0 & 485.2 \\
\hline 23-0ct & $27-0 c t$ & $13: 32$ & $8: 40$ & 328080 & 2777.9 & 2642.0 & 2786.3 & 2602.6 & 319.6 \\
\hline 27-0ct & $30-0 c t$ & $10: 00$ & $12: 57$ & 269820 & 2642.0 & 2355.0 & 2602.6 & 2489.8 & 399.8 \\
\hline $30-0 c t$ & 3-Nov & 13:37 & $8: 53$ & 328560 & 2355.0 & 2228.3 & 2489.8 & 2296.1 & 320.4 \\
\hline 3-Nov & 6-Nov & $9: 26$ & $11: 13$ & 265620 & 2228.3 & 2341.4 & 2296.1 & 2002.4 & 180.6 \\
\hline 6-Hov & 10-Nov & 12:07 & 11:02 & 341700 & 2341.4 & 2049.0 & 2002.4 & 1877.9 & 416.9 \\
\hline 10-Nov & 13 Hov & $12: 00$ & $10: 16$ & 252960 & 2990.2 & 2982.5 & 3044.4 & 2466.3 & 585.8 \\
\hline 13 Hov & 17 - Nov & $10: 51$ & 10.34 & 344580 & 2982.5 & 2734.5 & 2466.3 & 2627 & 87.3 \\
\hline 17-Nov & 20-Nov & $11: 09$ & 10.32 & 256980 & 2734.5 & 2656.1 & 2627 & 2251.5 & 453.9 \\
\hline 20-Nov & 25 Alov & $11: 12$ & $10: 22$ & 429000 & 2656.1 & 2230.3 & 2251.5 & 2157.8 & 519.5 \\
\hline 25-Nov & 4-Dec & $11: 08$ & $10: 14$ & 774360 & 2230.3 & 1958.1 & 2157.8 & 1925.6 & 504.4 \\
\hline 4-Dec & 18-Dec & $10: 55$ & 13:47 & 1219920 & 3352.7 & 2027.4 & 3246.5 & 2178.8 & 2393.0 \\
\hline 18-Dec & 23-Dec & $14: 18$ & $10: 36$ & 418680 & 3072.4 & 2908.4 & 3215.7 & 3058.3 & 321.4 \\
\hline 23-Dec & 31-Doc & 11:07 & $10: 48$ & 690060 & 2908.4 & 2504.5 & 3058.3 & 2886.7 & 575.5 \\
\hline 31-Dec & 8-tan & $11: 22$ & $13: 27$ & 698700 & 2504.5 & 2650.3 & $28 B 6.7$ & 2130.3 & 610.6 \\
\hline
\end{tabular}


SEALED DOUBLE-RINGED INFILTROMETER DATA, DCF TEST

\begin{tabular}{|c|c|c|c|c|c|c|c|c|c|}
\hline \multicolumn{10}{|c|}{$\begin{array}{l}\text { DATA SHEET FON WATER DEPTH ANO TERPERATURE } \\
\text { WFLTROMETER F-1 }(W-C)\end{array}$} \\
\hline DATE & $\begin{array}{c}\text { STANT } \\
\text { WAT. DEPTH } \\
\text { READNNG } \\
\text { (lo) }\end{array}$ & $\begin{array}{c}\text { STAKT } \\
\text { WATER } \\
\text { DEPTH } \\
\text { (h.) }\end{array}$ & $\begin{array}{c}\text { END } \\
\text { WAT. DEPTH } \\
\text { READWG } \\
\text { (lh) }\end{array}$ & $\begin{array}{l}\text { END } \\
\text { WATER } \\
\text { DEPTH } \\
\text { (h) }\end{array}$ & $\begin{array}{l}\text { AVG. } \\
\text { WATER } \\
\text { DEPTH } \\
\text { (In) }\end{array}$ & $\begin{array}{l}\text { STANT } \\
\text { WATER } \\
\text { TENP } \\
\text { (OF) } \\
\end{array}$ & $\begin{array}{l}\text { END } \\
\text { WATER } \\
\text { TENP } \\
\text { (OF) } \\
\end{array}$ & $\begin{array}{c}\text { AVG. } \\
\text { WATER } \\
\text { TENP } \\
\text { of } \\
\end{array}$ & $\begin{array}{l}\text { TEMP. } \\
\text { CHANGE } \\
\text { (of) }\end{array}$ \\
\hline 14-Sep & 9.00 & 12.75 & 9.00 & 12.75 & 12.75 & 84 & 74 & 79 & -10 \\
\hline • & 9.00 & 1275 & 2.75 & 6.50 & 9.63 & 74 & 72 & 73 & -2 \\
\hline 16-Sep & 2.75 & 6.50 & 9 & 12.75 & 9.63 & 72 & 73 & 73 & 1 \\
\hline 17-Sep & 9.00 & 12.75 & 9.00 & 12.75 & 12.75 & 73 & 72 & 73 & -1 \\
\hline 18-Sep & 9.00 & 12.75 & 9.00 & 12.75 & 12.75 & 72 & 74 & 73 & 2 \\
\hline 19-Sep & 9.00 & 12.75 & 9.00 & 12.75 & 12.75 & 74 & 75 & 75 & $i$ \\
\hline 21-Sep & 9.00 & 12.75 & 8.75 & 12.50 & 12.63 & 75 & 75 & 75 & 0 \\
\hline 22-Sep & 8.75 & 12.50 & 8.75 & 12.50 & 16.25 & 75 & 77 & 76 & 2 \\
\hline 23-Sep & 8.75 & 12.50 & 8.75 & 12.50 & 16.25 & 77 & 75 & 76 & -2 \\
\hline 24-Sep & 8.75 & 12.50 & 9.00 & 12.75 & 16.50 & 75 & 67 & 71 & -8 \\
\hline 25-Sep & 9.00 & 12.75 & 9.25 & 13.00 & 16.75 & 67 & 63 & 65 & -4 \\
\hline 26-Sep & 9.25 & 13.00 & 9.25 & 13.00 & 16.75 & 63 & 63 & 63 & 0 \\
\hline 29-Sep & 9.25 & 13.00 & 9.00 & 12.75 & 16.50 & 63 & 69 & 66 & 6 \\
\hline 30-sop & 9.00 & 12.75 & 9.00 & 12.75 & 16.50 & 69 & 64 & 67 & -5 \\
\hline 1-Oct & 9.00 & 12.75 & 9.00 & 12.75 & 16.50 & 64 & 62 & 63 & -2 \\
\hline 2-0ct & 9.00 & 12.75 & 9.00 & 12.75 & 16.50 & 62 & 60 & 61 & -2 \\
\hline 6-Oct & 9.00 & 12.75 & 10.00 & 13.75 & 17.50 & 60 & 56 & 58 & -4 \\
\hline 9-Oct & 10.00 & 13.75 & 11.25 & 15.00 & 18.75 & 56 & 65 & 61 & 9 \\
\hline $13-0 \mathrm{ct}$ & 11.25 & 15.00 & 9.25 & 13.00 & 16.75 & 65 & 59 & 62 & -6 \\
\hline 16-0ct & 9.25 & 13.00 & 9.00 & 12.75 & 16.50 & 59 & 63 & 61 & 4 \\
\hline $20-0 \mathrm{ct}$ & 9.00 & 12.75 & 9.00 & 12.75 & 16.50 & 63 & 54 & 59 & -9 \\
\hline $23-0 \mathrm{ct}$ & 9.00 & 12.75 & 9.00 & 12.75 & 16.50 & 54 & 57 & 56 & 3 \\
\hline $27-0 c t$ & 9.00 & 12.75 & 8.75 & 12.50 & 16.25 & 57 & 58 & 58 & 1 \\
\hline $30-0 \mathrm{ct}$ & 8.75 & 12.50 & 8.75 & 12.50 & 16.25 & 58 & 63 & 61 & 5 \\
\hline 3- $\mathrm{Nov}$ & 8.75 & 12.50 & 9.00 & 12.75 & 16.50 & 63 & 64 & 64 & 1 \\
\hline 6-Nov & 9.00 & 12.75 & 9.50 & 13.25 & 17.00 & 64 & 58 & 61 & 6 \\
\hline 10-Nov & 9.50 & 13.25 & 9.00 & 12.75 & 16.50 & 58 & 49 & 54 & -9 \\
\hline 13-Hov & 9.00 & 12.75 & 9.75 & 13.50 & 17.25 & 49 & 58 & 54 & 9 \\
\hline 17- Nov & 9.75 & 13.50 & 9.25 & 13.00 & 16.75 & 58 & 46 & 52 & .12 \\
\hline 20-Nov & 9.25 & 13.00 & 9.25 & 13.00 & 16.75 & 46 & 47 & 47 & 1 \\
\hline 25-Nov & 9.25 & 13.00 & 9.50 & 13.25 & 17.00 & 47 & 58 & 53 & 11 \\
\hline 4-Dec & 9.50 & 13.25 & 9.00 & 12.75 & 16.50 & 58 & 45 & 52 & -13 \\
\hline 18-Dec & 9.00 & 12.75 & 9.25 & 13.00 & 16.75 & 45 & 45 & 45 & 0 \\
\hline 23-Dec & 9.25 & 13.00 & 9.25 & 13.00 & 16.75 & 45 & 45 & 45 & 0 \\
\hline 31-Dec & 9.25 & 13.00 & 9.25 & 13.00 & 16.75 & 45 & 45 & 45 & 0 \\
\hline 8-tan & 9.25 & 13.00 & 10.00 & 13.75 & 17.50 & 45 & 57 & 51 & 12 \\
\hline
\end{tabular}




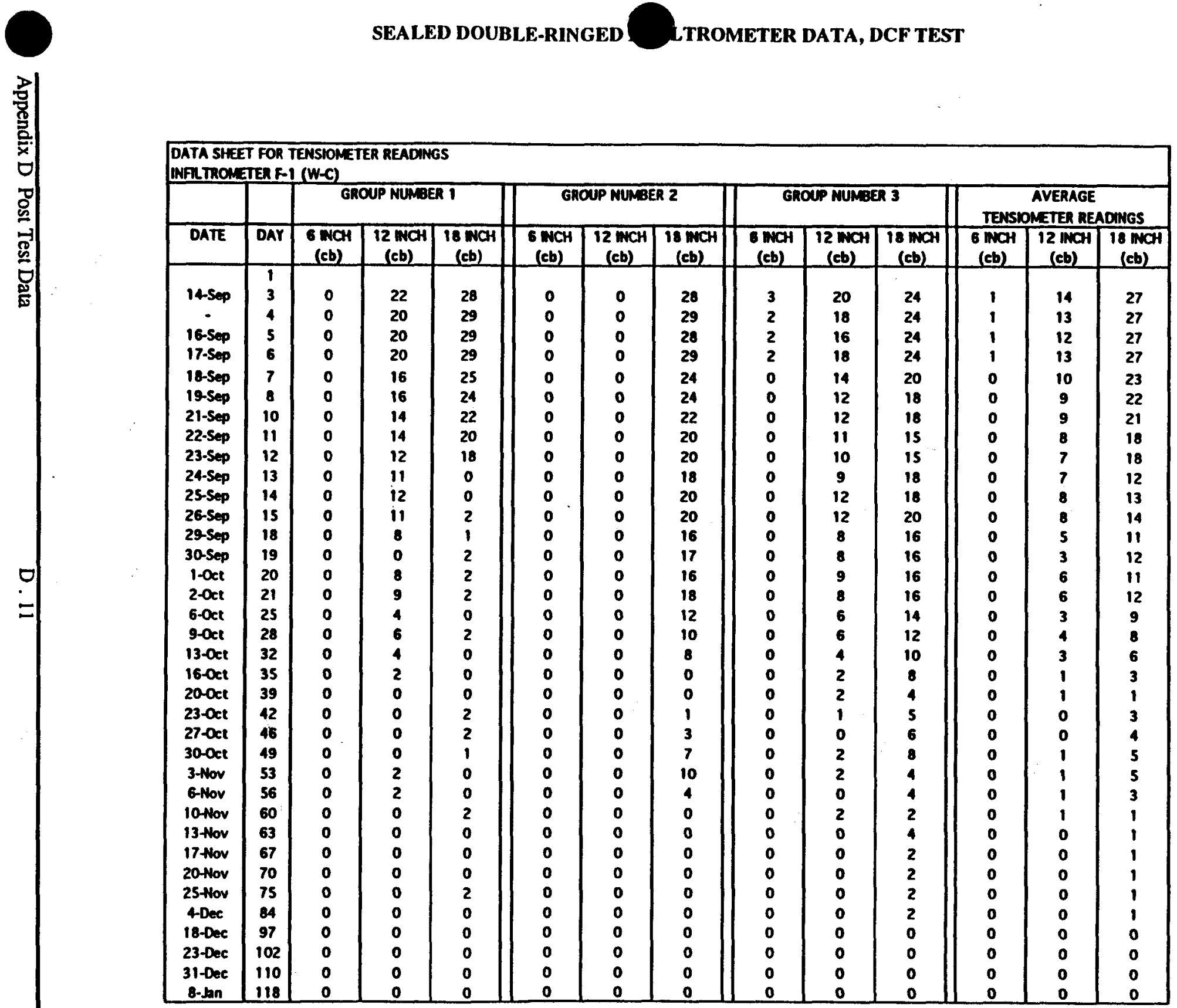


SEALED DOUBLE-RINGED INFTLTROMETER DATA, DCF TEST

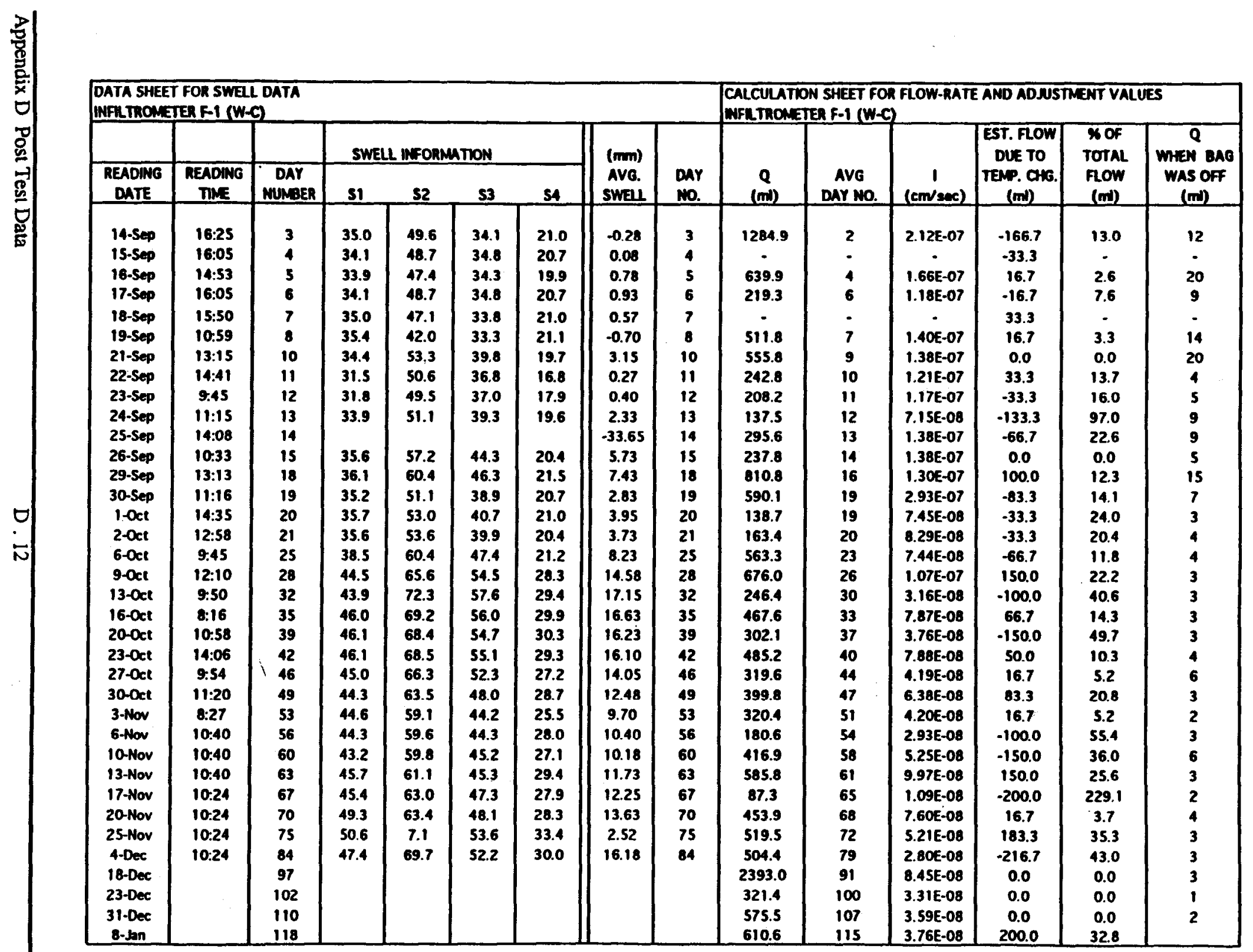




\begin{tabular}{|c|c|c|c|c|c|c|c|c|}
\hline \multicolumn{9}{|c|}{$\begin{array}{l}\text { CALCULATION SHEET FOR HYDRAULIC CONDUCTIVITY } \\
\text { WFULTROMETER D-I (W-C) }\end{array}$} \\
\hline DAY NO. & $\begin{array}{c}\times 10-7 \\
1 \\
(\mathrm{~cm} / \mathrm{sec})\end{array}$ & $\begin{array}{c}\text { WATER } \\
\text { DEPTH } \\
\text { (m) }\end{array}$ & $\begin{array}{c}\text { W. FRONT } \\
\text { DEPTH } \\
\text { (h) }\end{array}$ & GRADIENT & DAY MO. & $\begin{array}{l}\text { xiot } \\
\text { ronoto } \\
\text { cont }\end{array}$ & $\begin{array}{c}\text { X10-7 } \\
\text { SWELL } \\
1 \\
\text { (cm/sec) }\end{array}$ & 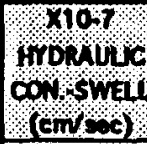 \\
\hline 2 & 2.1 & 12.75 & 1.51 & 9.45 & $\begin{array}{l}1 \\
3\end{array}$ & 02 & 2.12 & 022 \\
\hline - & - & 9.63 & - & - & 4 & 03 & - & భै? \\
\hline 4 & 1.7 & 9.63 & 4.01 & 3.40 & 5 & 0.5 & 1.66 & 089 \\
\hline 6 & 1.2 & 12.75 & 5.50 & 3.32 & 6 & 00 & 1.18 & 006 \\
\hline - & - & 12.75 & - & - & 7 & 03 & • & \% \\
\hline 7 & 1.4 & 12.75 & 0.77 & 17.60 & 8 & 00 & 1.40 & 0.08 \\
\hline 9 & 1.4 & 12.63 & 0.99 & 13.80 & 10 & 01 & 1.38 & 0.10 \\
\hline 10 & 1.2 & 16.25 & 1.16 & 14.98 & 11 & 01 & 1.21 & 0.08 \\
\hline 11 & 1.2 & 16.25 & 1.27 & 13.81 & 12 & 01 & 1.17 & 0.08 \\
\hline 12 & 0.7 & 16.50 & 1.37 & 13.01 & 13 & 01 & 0.71 & 0.05 \\
\hline 13 & 1.4 & 16.75 & 1.49 & 12.23 & 14 & 01 & 1.38 & 011 \\
\hline 14 & 1.4 & 16.75 & 1.60 & 11.46 & 15 & 001 & 1.38 & 012 \\
\hline 16 & 1.3 & 16.50 & 1.82 & 10.05 & 18 & 01 & 1.30 & 0113 \\
\hline 19 & 2.9 & 16.50 & 2.06 & 9.03 & 19 & 0.3 & 2.93 & 0.32 \\
\hline 19 & 0.7 & 16.50 & 2.17 & 8.62 & 20 & 0.1 & 0.74 & 0.09 \\
\hline 20 & 0.8 & 16.50 & 2.27 & 8.26 & 21 & 01 & 0.83 & 0.10 \\
\hline 23 & 0.7 & 17.50 & 2.54 & 7.89 & 25 & 0.1 & 0.74 & 0.09 \\
\hline 26 & 1.1 & 18.75 & 2.93 & 7.40 & 28 & 0.1 & 1.07 & 0.14 \\
\hline 30 & 0.3 & 16.75 & 3.32 & 6.05 & 32 & 01 & 0.32 & 0.05 \\
\hline 33 & 0.8 & 16.50 & 3.70 & 5.46 & 35 & 01 & 0.79 & 0.13 \\
\hline 37 & 0.4 & 16.50 & 4.09 & 5.03 & 39 & 01 & 0.38 & 007 \\
\hline 40 & 0.8 & 16.50 & 4.49 & 4.68 & 42 & $0: 2$ & 0.79 & 0.17 \\
\hline 44 & 0.4 & 16.25 & 4.87 & 4.34 & 16 & 01 & 0.42 & 010 \\
\hline 47 & 0.6 & 16.25 & 5.26 & 4.09 & 49 & 02 & 0.64 & 016 \\
\hline 51 & 0.4 & 16.50 & 5.65 & 3.92 & 53 & 0,1 & 0.42 & 011 \\
\hline 54 & 0.3 & 17.00 & 6.04 & 3.82 & 56 & 01 & 0.29 & 008 \\
\hline 58 & 0.5 & 16.50 & 6.43 & 3.57 & 60 & 01 & 0.53 & 015 \\
\hline 61 & 1.0 & 17.25 & 15.34 & 2.12 & 63 & 0,5 & 1.00 & 047 \\
\hline 65 & 0.1 & 16.75 & 16.21 & 2.03 & 67 & 0.1 & 0.11 & 005 \\
\hline 68 & 0.8 & 16.75 & 17.08 & 1.98 & 70 & 0.4 & 0.76 & 0.38 \\
\hline 72 & 0.5 & 17.00 & 18.08 & 1.94 & 75 & 0.3 & 0.52 & 0.27 \\
\hline 79 & 0.3 & 16.50 & 19.83 & 1.83 & 84 & 0.2 & $0.2 B$ & 015 \\
\hline 91 & 0.8 & 16.75 & 22.73 & 1.74 & 97 & 03 & 0.84 & 0,49 \\
\hline 100 & 0.3 & 16.75 & 25.10 & 1.67 & 102 & 02 & 0.33 & 020 \\
\hline 107 & 0.4 & 16.75 & 26.71 & 1.63 & 110 & 02 & 0.36 & 0.22 \\
\hline 115 & 0.4 & 17.50 & 28.73 & 1.61 & 118 & 0.2 & 0.38 & 0.23 \\
\hline
\end{tabular}


SEALED DOUBLE-RINGED INFILTROMETER DATA, DCF TEST

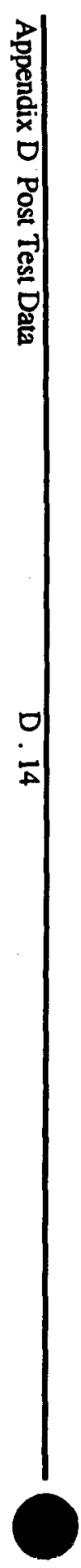

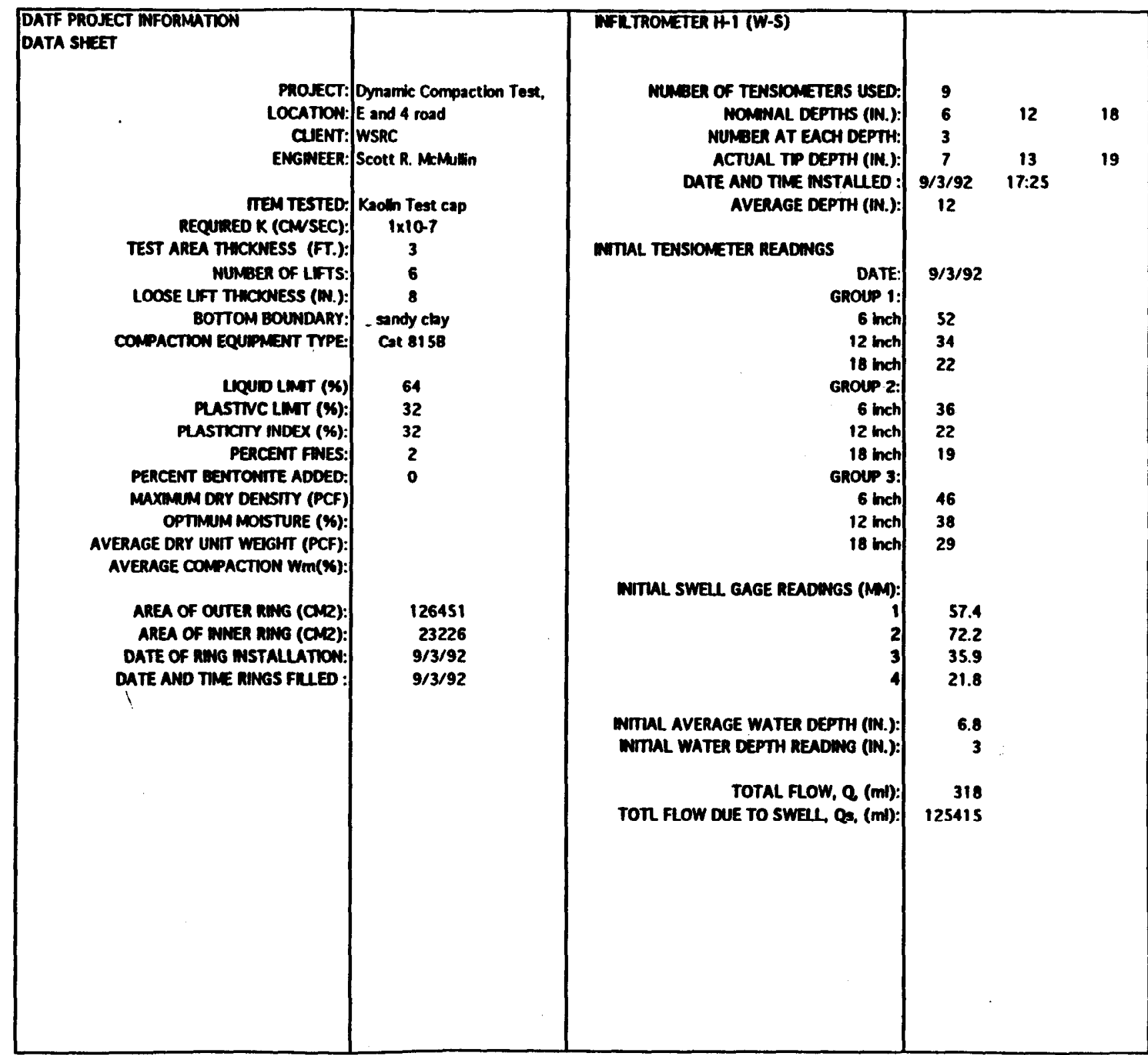




\begin{tabular}{|c|c|c|c|c|c|c|c|c|c|}
\hline $\begin{array}{l}\text { DATA SHEE } \\
\text { MFUTROM }\end{array}$ & $\begin{array}{l}\text { FOR WATE } \\
\text { IEA H1 } \mathrm{W} \text {. }\end{array}$ & & & & & & & & \\
\hline & & & & & & & & & \\
\hline RAE CONM & DATE OFF & nNE ON & TIME OFF & $\begin{array}{c}\text { E } \\
\text { WTERVAL } \\
\text { TMEE }\end{array}$ & $\begin{array}{c}\text { WITIL } \\
\text { WEGHT } \\
\text { (R) }\end{array}$ & $\begin{array}{l}\text { FMAL } \\
\text { WEIGHT } \\
\text { (I) }\end{array}$ & $\begin{array}{l}\text { WITMLL } \\
\text { WEIGHT } \\
\text { (0) }\end{array}$ & $\begin{array}{l}\text { FWAL } \\
\text { WEGHT } \\
\text { (l) }\end{array}$ & $\begin{array}{c}\text { NET } \\
\text { CHANGE } \\
\text { (q) }\end{array}$ \\
\hline 3-Sep & 4-Sep & 17:25 & - & - & 3871.0 & - & 3658.0 & - & - \\
\hline 4-Sep & S.Sen & • & - & • & - & - & - & - & - \\
\hline S-Sep & 10-sep & • & $12: 15$ & 586200 & • & 3118.6 & - & 3155.7 & 1254.7 \\
\hline 10-Sep & 14-Sep & $12: 45$ & $15: 05$ & 354000 & 3387.3 & 1474.2 & 3155.7 & 2848.1 & 2220.7 \\
\hline 14-Sep & 15-sep & $15: 47$ & • & • & 3738.8 & - & 2848.1 & - & • \\
\hline 15-Sep & 16-Sep & - & $14: 02$ & 166500 & • & 3208.1 & • & 2462.3 & 916.5 \\
\hline $16-5 e p$ & 17-Sep & $15: 40$ & $13: 58$ & 80280 & 3208.1 & 3042.1 & 2462.3 & 2192.6 & 435.7 \\
\hline 17-Sep & • & $14: 41$ & - & - & 3042.1 & - & 2192.6 & - & • \\
\hline$\bullet$ & 19-Sep & $\cdot$ & 10.31 & 157800 & • & 2478.1 & - & 1999.0 & 757.6 \\
\hline 19-Sep & 21-Sep & $11: 42$ & $11: 57$ & 173700 & 2478.1 & 1899.9 & 1999.0 & 1746.5 & 830.7 \\
\hline 21-Sep & 22-Sep & $13: 45$ & $13: 50$ & 86700 & 3444.4 & 3303.3 & 3290.0 & 3061.5 & 369.6 \\
\hline 22-Sep & 23-Sep & $14: 09$ & $11: 24$ & 76500 & 3303.3 & 3222.7 & 3061.5 & 2762.2 & 379.9 \\
\hline 23-Sep & 24-Sep & $12: 00$ & $11: 04$ & 83040 & 3222.7 & 3095.1 & 2762.2 & 1563.2 & 1326.6 \\
\hline 24-Sep & 25-5ep & 12:02 & 13:38 & 92160 & 3095.1 & 3185.8 & 3194.7 & 2799.4 & 304.6 \\
\hline 25-Sep & 26-Sep & $14: 26$ & $11: 06$ & 74400 & 3185.5 & 3190.6 & 2799.4 & 2508.9 & 285.4 \\
\hline 26-Sep & 29-Sep & $11: 31$ & $13: 56$ & 267900 & 3190.6 & 2601.1 & 2508.9 & 2115.7 & 982.7 \\
\hline 29-Sep & 30-Sep & $14: 46$ & $14: 50$ & 86640 & 2601.1 & 2297.5 & 2115.7 & 1850.6 & 568.7 \\
\hline 30-Sep & $1-0<t$ & 15:17 & 13:33 & 80160 & 2297.5 & 2196.5 & 1850.6 & 1641.1 & 310.5 \\
\hline $1-0<1$ & $2-0 \mathrm{ct}$ & $14: 04$ & $13: 37$ & 84780 & 2196.5 & 1931.3 & 1641.1 & 1647.5 & 258.8 \\
\hline $2-0 \mathrm{ct}$ & $6-0 \mathrm{ct}$ & 14:14 & $8: 48$ & 326040 & 3190.8 & 2464.3 & 3049.1 & 2993.3 & 782.3 \\
\hline 6-0et & 9-0ct & $9: 24$ & $12: 51$ & 271620 & 2464.3 & 1753.4 & 2993.3 & 2924.6 & 779.6 \\
\hline 9-0et & 13-Oct & 13:20 & $10: 30$ & 335400 & 3056.8 & 2739.4 & 2924.6 & 2870.2 & 371.8 \\
\hline 13-0ct & $16-0 \mathrm{ct}$ & 11:04 & 10.07 & 255780 & 2739.4 & 2552.0 & 2870.2 & 2503.0 & 554.6 \\
\hline $16-0 c t$ & $20-0 \mathrm{ct}$ & $10: 39$ & $10: 37$ & 345480 & 2552.0 & 2440.9 & 2503.0 & 2229.7 & 384.4 \\
\hline $20-0 \mathrm{ct}$ & $23-0<t$ & $11: 13$ & $12: 48$ & 264900 & 2440.9 & 1582.5 & 2229.7 & 2552.0 & 536.1 \\
\hline $23-0 \mathrm{ct}$ & $27-0 c t$ & 13:35 & $8: 43$ & 328080 & 2658.8 & 2503.7 & 2552.0 & 2291.0 & 416.1 \\
\hline $27-0 c t$ & $30-0<t$ & $10: 12$ & $12: 59$ & 269220 & 2503.7 & 2414.0 & 2291.0 & 1981.7 & 399.0 \\
\hline $30-0 \mathrm{ct}$ & 3-Nov & $13: 39$ & $8: 56$ & 328620 & 2414.0 & 2288.4 & 2982.8 & 2667.6 & 440.8 \\
\hline 3+Hov & 6-Nov & $9: 27$ & $11: 14$ & 265620 & 2288.4 & 2241.3 & 2667.6 & 2435.2 & 279.5 \\
\hline 6-Nov & 10-Nov & $12: 09$ & $11: 04$ & 341700 & 2241.3 & 2206.2 & 2435.2 & 2568.9 & -98.6 \\
\hline 10-Hov & 13-Hov & 12:02 & $10: 17$ & 252900 & 2206.2 & 1731.0 & 2568.9 & 1968.1 & 1076.0 \\
\hline 13-Nov & 17 Hov & 10.52 & $10: 35$ & 344580 & 2957.4 & 2739.3 & 3004.8 & 2890.0 & 332.9 \\
\hline 17 Hov & 20-Nov & $11: 10$ & 10.33 & 256980 & 2739.3 & 2285.2 & 2890.0 & 2879.2 & 464.9 \\
\hline 20-Nov & 25- Hov & $11: 14$ & $10: 25$ & 429060 & 2285.2 & 2278.4 & 2879.2 & 2251.4 & 634.6 \\
\hline 25- Nov & 4-Dec & $11: 11$ & $10: 16$ & 774300 & 2278.4 & 2053.9 & 2251.4 & 1802.3 & 673.6 \\
\hline 4Dec & 18-Dec & $11: 16$ & $13: 49$ & 1218780 & 2053.9 & 1753.4 & 1802.3 & 1724.4 & 378.4 \\
\hline 18-Dec & 23-Dec & $14: 20$ & $10: 37$ & 418620 & 3169.6 & 3092.3 & 3106.1 & 2797.8 & 385.6 \\
\hline 23-Dec & 31-Dec & $11: 09$ & $10: 50$ & 690060. & 3092.3 & 2664.8 & 2797.8 & 2605.8 & 619.5 \\
\hline 31-Dec & 8-tan & 11:24 & $13: 29$ & 698700 & 2664.8 & 2758 & 2605.8 & 1807.7 & 704.9 \\
\hline
\end{tabular}


SEALED DOUBLE-RINGED INFILTROMETER DATA, DCF TEST

\begin{tabular}{|c|c|c|c|c|c|c|c|c|c|}
\hline \multicolumn{10}{|c|}{$\begin{array}{l}\text { DATA SHEET FOR WATER DEPTH AND TEMPERATURE } \\
\text { WFRTROMETER H-1 (W-S) }\end{array}$} \\
\hline DATE & $\begin{array}{c}\text { START } \\
\text { WAT. DEPTH } \\
\text { MEADANG } \\
\text { (b) } \\
\end{array}$ & $\begin{array}{c}\text { START } \\
\text { WATER } \\
\text { DEPTH } \\
(h) \\
\end{array}$ & $\begin{array}{c}\text { ENO } \\
\text { WAT. DEPTH } \\
\text { READWG } \\
\text { (h.) }\end{array}$ & $\begin{array}{l}\text { END } \\
\text { WATER } \\
\text { DEPTH } \\
((1)\end{array}$ & $\begin{array}{c}\text { AVG. } \\
\text { WATER } \\
\text { DEPTH } \\
\text { (h) }\end{array}$ & $\begin{array}{l}\text { START } \\
\text { WATER } \\
\text { TEMP } \\
\text { (of) } \\
\end{array}$ & $\begin{array}{l}\text { END } \\
\text { WATER } \\
\text { TEMP } \\
\text { (Of) }\end{array}$ & $\begin{array}{c}\text { AVQ. } \\
\text { WATER } \\
\text { TENP } \\
\text { of }\end{array}$ & $\begin{array}{c}\text { TEMP. } \\
\text { CHANGE } \\
\text { (of) }\end{array}$ \\
\hline 4-Sep & 3.00 & 6.75 & 3.00 & 6.75 & 6.75 & 82 & 81 & 82 & -1 \\
\hline S-Sep & 3.00 & 6.75 & 3.00 & 6.75 & 6.75 & 81 & 79 & 80 & -2 \\
\hline $10-5 e p$ & 3.00 & 6.75 & 4 & 7.75 & 7.25 & 79 & 78 & 79 & -1 \\
\hline 14-Sep & 3.75 & 7.50 & 4.00 & 7.75 & 7.63 & 78 & 75 & 77 & -3 \\
\hline 15-Sep & 4.00 & 7.75 & 4.00 & 7.75 & 7.75 & 75 & 73 & 74 & -2 \\
\hline 16-Sep & 4.00 & 7.75 & 3.75 & 7.50 & 7.63 & 73 & 74 & 74 & 1 \\
\hline $17-5 e p$ & 3.75 & 7.50 & 3.75 & 7.50 & 7.50 & 74 & 75 & 75 & 1 \\
\hline 18-Sep & 3.75 & 7.50 & 3.75 & 7.50 & 7.50 & 75 & 76 & 76 & 1 \\
\hline 19-Sep & 3.75 & 7.50 & 3.75 & 7.50 & 7.50 & 76 & 76 & 76 & 0 \\
\hline 21-Sep & 3.75 & 7.50 & 3.75 & 7.50 & 7.50 & 76 & 77 & 77 & 1 \\
\hline 22-Sep & 3.75 & 7.50 & 3.75 & 7.50 & 7.50 & 77 & 78 & 78 & 1 \\
\hline 23-Sep & 3.75 & 7.50 & 3.75 & 7.50 & 7.50 & 78 & 77 & 78 & -1 \\
\hline 24-Sep & 3.75 & 7.50 & 4.00 & 7.75 & 7.63 & 77 & 71 & 74 & .6 \\
\hline 25-Sep & 4.00 & 7.75 & 4.25 & 8.00 & 7.88 & 71 & 68 & 70 & -3 \\
\hline 26-Sep & 4.25 & 8.00 & 4.00 & 7.75 & 7.88 & 68 & 67 & 68 & .1 \\
\hline 29-Sep & 4.00 & 7.75 & 4.00 & 7.75 & 7.75 & 67 & 71 & 69 & 4 \\
\hline 30-sep & 4.00 & 7.75 & 4.00 & 7.75 & 7.75 & 71 & 67 & 69 & 4 \\
\hline $1-0 \mathrm{ct}$ & 4.00 & 7.75 & 4.00 & 7.75 & 7.75 & 67 & 66 & 67 & -1 \\
\hline $2-0 c t$ & 4.00 & 7.75 & 4.00 & 7.75 & 7.75 & 66 & 64 & 65 & -2 \\
\hline 6-0ct & 4.00 & 7.75 & 5.00 & 8.75 & 8.25 & 64 & 63 & 64 & -1 \\
\hline 90ct & 5.00 & 8.75 & 5.00 & 8.75 & 8.75 & 63 & 67 & 65 & 4 \\
\hline 13-0ct & 5.00 & 8.75 & 3.50 & 7.25 & 8.00 & 67 & 63 & 65 & -4 \\
\hline $16-0 \mathrm{ct}$ & 3.50 & 7.25 & 3.25 & 7.00 & 7.13 & 63 & 65 & 64 & 2 \\
\hline $20-0 \mathrm{ct}$ & 3.25 & 7.00 & 3.25 & 7.00 & 7.00 & 65 & 58 & 62 & .7 \\
\hline $23-0 \mathrm{ct}$ & 3.25 & 7.00 & 3.00 & 6.75 & 6.88 & 58 & 61 & 60 & 3 \\
\hline 27-0et & 3.00 & 6.75 & 3.00 & 6.75 & 6.75 & 61 & 60 & 61 & -1 \\
\hline $30-0 \mathrm{ct}$ & 3.00 & 6.75 & 3.00 & 6.75 & 6.75 & 60 & 65 & 63 & 5 \\
\hline 3-Non & 3.00 & 6.75 & 3.75 & 7.50 & 7.13 & 65 & 64 & 65 & -1 \\
\hline 6-Now & 3.75 & 7.50 & 3.50 & 7.25 & 7.38 & 64 & 63 & 64 & -1 \\
\hline 10-Nov & 3.50 & 7.25 & 3.25 & 7.00 & 7.13 & 63 & 54 & 59 & .9 \\
\hline 13- Hov & 3.25 & 7.00 & 3.5 & 7.25 & 7.13 & 54 & 60 & 57 & 6 \\
\hline 17-Nov & 3.50 & 7.25 & 3.5 & 7.25 & 7.25 & 60 & 50 & 55 & -10 \\
\hline 20-Nov & 3.50 & 7.25 & 3.25 & 7.00 & 7.13 & 50 & s5 & 53 & 5 \\
\hline 25-Nov & 3.25 & 7.00 & 3.5 & 7.25 & 7.13 & 55 & 60 & 58 & 5 \\
\hline 4-Dec & 3.50 & 7.25 & 3.25 & 7.00 & 7.13 & 60 & 49 & 55 & -11 \\
\hline $18-D e c$ & 3.25 & 7.00 & 3.5 & 7.25 & 7.13 & 49 & 49 & 49 & 0 \\
\hline 23-Dec & 3.50 & 7.25 & 3.25 & 7.00 & 7.13 & 49 & 49 & 49 & 0 \\
\hline 31-Dee & 3.25 & 7.00 & 3.5 & 7.25 & 7.13 & 49 & 49 & 49 & 0 \\
\hline 8.tan & 3.50 & 7.25 & 4 & 7.75 & 7.50 & 49 & 58 & 54 & 9 \\
\hline
\end{tabular}




\begin{tabular}{|c|c|c|c|c|c|c|c|c|c|c|c|c|c|}
\hline \multicolumn{14}{|c|}{$\begin{array}{l}\text { DATA SHEET FOR TENSIOMETER READINGS } \\
\text { WFLT THOMETER H-1 (W-S) }\end{array}$} \\
\hline \multirow[b]{2}{*}{ DATE } & \multirow[b]{2}{*}{ DAY } & \multicolumn{3}{|c|}{ GROUP NUMBER I } & \multicolumn{3}{|c|}{ GROUP MUMBER 2} & \multicolumn{3}{|c|}{ GROUP NUMBER 3} & \multicolumn{3}{|c|}{$\begin{array}{c}\text { AVERAGE } \\
\text { TENSIONETEA READNGS }\end{array}$} \\
\hline & & $\begin{array}{l}6 \text { NOH } \\
\text { (cb) }\end{array}$ & $\begin{array}{c}12 \text { WCH } \\
\text { (cb) }\end{array}$ & $\begin{array}{c}18 \mathrm{NCH} \\
(\mathrm{cb})\end{array}$ & $\begin{array}{l}6 \text { WCH } \\
\text { (cb) }\end{array}$ & $\begin{array}{c}12 \mathrm{WCH} \\
(\mathrm{cb})\end{array}$ & $\begin{array}{c}18 \text { WCH } \\
(\mathrm{cb}) \\
\end{array}$ & $\begin{array}{c}6 \text { Mach } \\
(c b)\end{array}$ & $\begin{array}{c}12 \mathrm{maCH} \\
(\mathrm{Cb})\end{array}$ & $\begin{array}{c}18 \mathrm{WCH} \\
(\mathrm{Cb})\end{array}$ & $\begin{array}{c}6 \text { WMCH } \\
(\mathrm{cb})\end{array}$ & $\begin{array}{c}12 \mathrm{MCH} \\
(\mathrm{Cb})\end{array}$ & $\begin{array}{c}18 \mathrm{mat} \\
(\mathrm{cb})\end{array}$ \\
\hline 4-Sep & 1 & 42 & 40 & 32 & 32 & 31 & 26 & 40 & 16 & 38 & 38 & 39 & 32 \\
\hline 5-Sep & 2 & 30 & 34 & 32 & 22 & 28 & 28 & 26 & 42 & 38 & 26 & 35 & 33 \\
\hline 10-sep & 7 & 6 & 16 & 22 & 0 & 10 & 18 & 6 & 20 & 28 & 4 & 15 & 23 \\
\hline 14-Sep & 11 & 0 & 12 & 18 & 0 & 2 & 14 & 2 & 16 & 20 & 1 & 10 & 17 \\
\hline 15-Sep & 12 & 0 & 12 & 18 & 0 & 0 & 13 & 0 & 14 & 22 & 0 & 9 & 18 \\
\hline 16-Sep & 13 & 0 & 12 & 18 & 0 & 0 & 13 & 0 & 13 & 22 & 0 & 8 & 18 \\
\hline 17 -Sep & 14 & 0 & 10 & 17 & 0 & 0 & 13 & 2 & 13 & 20 & 1 & 8 & 17 \\
\hline 18-Sep & 15 & 0 & 10 & 16 & 0 & 0 & 12 & 0 & 12 & 18 & 0 & 7 & 15 \\
\hline 19-Sep & 16 & 0 & 10 & 16 & 0 & 0 & 12 & 0 & 12 & 18 & 0 & 7 & 15 \\
\hline 21-Sep & 18 & 0 & 18 & 15 & 0 & 0 & 10 & 0 & 10 & 16 & o & 9 & 14 \\
\hline 22-Sep & 19 & 0 & 9 & 15 & 0 & 0 & 10 & 0 & 10 & 16 & 0 & 6 & 14 \\
\hline 23-Sep & 20 & 0 & 8 & 14 & o & 0 & 10 & 0 & 10 & 16 & 0 & 6 & 13 \\
\hline 24-Sep & 21 & 0 & 8 & 12 & 0 & 0 & 4 & 0 & 8 & 16 & 0 & 5 & 11 \\
\hline 23-Sep & 22 & 0 & 8 & 14 & 0 & 0 & 8 & 0 & 10 & 18 & 0 & 6 & 13 \\
\hline 26-Sep & 23 & 0 & 8 & 15 & 0 & 0 & 10 & 0 & 10 & 18 & 0 & 6 & 14 \\
\hline 29-Sep & 26 & 0 & 7 & 14 & o & o & 10 & 0 & 8 & 15 & 0 & 5 & 13 \\
\hline 30-sep & 27 & 0 & 8 & 12 & o & 0 & 10 & 0 & 10 & 14 & 0 & 6 & 12 \\
\hline $1-0 c t$ & 28 & 0 & 7 & 14 & 0 & 0 & 8 & 0 & 9 & 16 & 0 & 5 & 13 \\
\hline $2-0 c t$ & 29 & 0 & 8 & 14 & 0 & 0 & 10 & 0 & 9 & 16 & 0 & 6 & 13 \\
\hline 6-Oct & 33 & 0 & 4 & 12 & 0 & 0 & 8 & 0 & 7 & 14 & 0 & 4 & 11 \\
\hline 9-0et & 36 & 0 & 6 & 13 & 0 & 0 & 9 & 0 & 9 & 16 & 0 & 5 & 13 \\
\hline 13-0et & 40 & 0 & 4 & 10 & 0 & 0 & 4 & 0 & 4 & 14 & D & 3 & 9 \\
\hline $16-0 \mathrm{ct}$ & 43 & 0 & 2 & 11 & 0 & 0 & 5 & 0 & 4 & 13 & 0 & 2 & 10 \\
\hline $20-0 \mathrm{ct}$ & 47 & 0 & 2 & 12 & 0 & 0 & 4 & 0 & 4 & 14 & D & 2 & 10 \\
\hline $23-0<t$ & so & 0 & 3 & 12 & 0 & 0 & 10 & 0 & 4 & is & o & 2 & 12 \\
\hline $27-0 \mathrm{xt}$ & 54 & 0 & 2 & 11 & 0 & 0 & 8 & 0 & 3 & 12 & o & 2 & 10 \\
\hline $30-0 \mathrm{ct}$ & 57 & 0 & 4 & 12 & 0 & 0 & 9 & o & 4 & 12 & 0 & 3 & 11 \\
\hline 3-Nov & 61 & 0 & 2 & 10 & o & 0 & 8 & 0 & 2 & 10 & 0 & 1 & 9 \\
\hline 6-Nov & 64 & 0 & 0 & 8 & 0 & 0 & 6 & 0 & 2 & 10 & 0 & 1 & 8 \\
\hline 10+tov & 68 & 0 & 2 & 11 & 0 & 0 & 8 & 0 & 6 & 14 & 0 & 3 & 11 \\
\hline 13+tov & $n$ & 0 & 0 & 10 & 0 & 0 & 9 & 0 & 2 & 12 & 0 & 1 & 10 \\
\hline 17 Hov & 75 & 0 & 2 & 10 & 0 & 0 & 8 & 0 & 2 & 14 & 0 & 1 & 11 \\
\hline 20-Nov & 78 & 0 & 0 & 10 & 0 & 0 & 10 & 0 & 3 & 12 & 0 & 1 & 11 \\
\hline $25 \mathrm{Hov}$ & 83 & 0 & 0 & 8 & 0 & 0 & 6 & 0 & 0 & 9 & 0 & 0 & 8 \\
\hline 4-Dec & 92 & 0 & 2 & 10 & 0 & 0 & 8 & o & 4 & 12 & 0 & 2 & 10 \\
\hline 18-Dec & 106 & 0 & o & 8 & 0 & 0 & 8 & 0 & 2 & 12 & 0 & 1 & 9 \\
\hline 23-Dec & 111 & 0 & 0 & 8 & 0 & 0 & 8 & 0 & 0 & 10 & 0 & 0 & 9 \\
\hline 31-Dec & 119 & 0 & 0 & 8 & 0 & 0 & 8 & 0 & 0 & 10 & 0 & 0 & 9 \\
\hline $8-\ln n$ & 127 & 0 & 0 & B & 0 & 0 & 6 & 0 & 0 & 8 & 0 & 0 & 7 \\
\hline
\end{tabular}


SEALED DOUBLE-RINGED INFILTROMETER DATA, DCF TEST

\begin{tabular}{|c|c|c|c|c|c|c|c|c|c|c|c|c|c|c|}
\hline \multicolumn{9}{|c|}{$\begin{array}{l}\text { DATA SHEET FOR SWELL DATA } \\
\text { WFLTROMETER H-1 (W-S) } \\
\end{array}$} & \multicolumn{6}{|c|}{$\begin{array}{l}\text { CALCULATION SHEET FOR FLOW-RATE AMD ADJUSTMENT VALUES } \\
\text { WFITRONETER H })(\text { (W-S) }\end{array}$} \\
\hline & & & \multicolumn{4}{|c|}{ SWELL IMFORMMTION } & \multirow{2}{*}{$\begin{array}{l}\text { (mm) } \\
\text { AVG. } \\
\text { SWEEL }\end{array}$} & \multirow[b]{2}{*}{$\begin{array}{l}\text { DAY } \\
\text { NO. }\end{array}$} & \multirow[b]{2}{*}{$\underset{(m)}{Q}$} & \multirow[b]{2}{*}{$\begin{array}{l}\text { AVG } \\
\text { DaY Mo. }\end{array}$} & \multirow[b]{2}{*}{$\begin{array}{c}1 \\
(\mathrm{~cm} / \mathrm{eec})\end{array}$} & \multirow{2}{*}{$\begin{array}{c}\text { EST. FLOW } \\
\text { DUE TO } \\
\text { TEMP. CAK. } \\
\text { (mi) }\end{array}$} & \multirow{2}{*}{$\begin{array}{l}\text { xof } \\
\text { TOTAL } \\
\text { FLOW } \\
\text { (m) }\end{array}$} & \multirow{2}{*}{$\begin{array}{c}\text { Q } \\
\text { WHas BAo } \\
\text { WAS OFF } \\
\text { (mi) } \\
\end{array}$} \\
\hline $\begin{array}{l}\text { READWG } \\
\text { DATE }\end{array}$ & $\begin{array}{l}\text { READNG } \\
\text { TINE }\end{array}$ & $\begin{array}{c}\text { DAY } \\
\text { MUMBER }\end{array}$ & si & 52 & 53 & s4 & & & & & & & & \\
\hline 4-Sep & 15:15 & 1 & $\mathbf{5 5 . 5}$ & 72.2 & 35.9 & 21.8 & -0.48 & $\mathbf{1}$ & - & 1 & - & - & - & - \\
\hline S-Sep & $8: 55$ & 2 & 56.3 & 66.9 & 32.2 & 15.3 & -4.15 & 2 & - & 2 & - & - & - & - \\
\hline 10-sep & 12:30 & 7 & 70.5 & 81.3 & 38.3 & 23.2 & 6.50 & 7 & 1254.7 & 3 & $9.22 E-08$ & -16.7 & 1.3 & 8 \\
\hline 14-Sep & $16: 15$ & 11 & 98.0 & 30.4 & 45.5 & 106.5 & 23.28 & 11 & 2220.7 & 9 & 2.70E-07 & -50.0 & 2.3 & 15 \\
\hline 15-Sep & $16: 30$ & 12 & 97.0 & 29.8 & 44.8 & 102.5 & 21.70 & 12 & 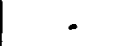 & 11 & - & - & - & - \\
\hline 16-Sep & $15: 06$ & 13 & 96.7 & 29.7 & 45.0 & 105.0 & 22.28 & 13 & 916.5 & 12 & 2.37E-07 & 16.7 & 1.8 & 32 \\
\hline 17-Sep & $14: 32$ & 14 & 96.2 & 34.6 & 49.8 & 104.3 & 24.40 & 14 & 435.7 & 13 & 2.34E-07 & 16.7 & 3.8 & 13 \\
\hline 18-Sep & 14:07 & 15 & 101.2 & 32.0 & 46.6 & 108.4 & 25.23 & 15 & - & 14 & - & 16.7 & - & - \\
\hline 19-Sep & $11: 07$ & 16 & 96.1 & 29.3 & 45.6 & 104.1 & 21.95 & 16 & 757.6 & 15 & 2.07E-07 & 0.0 & 0.0 & 20 \\
\hline 21-Sep & $12: 10$ & 18 & 85.5 & 27.0 & 42.9 & 96.4 & 16.13 & 18 & 830.7 & 17 & 2.06E-07 & 16.7 & 2.0 & 29 \\
\hline 22-Sep & $14: 54$ & 19 & 84.6 & 26.5 & 42.7 & 93.8 & 15.08 & 19 & 369.6 & 18 & $1.84 E-07$ & 16.7 & 4.5 & 5 \\
\hline 23-Sep & $10: 03$ & 20 & 76.7 & 24.6 & 39.7 & 86.8 & 10.13 & 20 & 379.9 & 19 & $2.14 E-07$ & -16.7 & 4.4 & 23 \\
\hline 24-Sep & $11: 24$ & 21 & 90.7 & 26.2 & 42.6 & 100.0 & 18.05 & 21 & 1326.6 & 20 & $6.88 E-07$ & -100.0 & 7.5 & 34 \\
\hline 25-Sep & $14: 25$ & 22 & 101.4 & 30.3 & 45.2 & 110.0 & 24.90 & 22 & 304.6 & 21 & $1.42 E-07$ & -50.0 & 16.4 & 10 \\
\hline 26-Sep & 10.35 & 23 & 104.1 & 31.0 & 46.2 & 112.4 & 26.60 & 23 & 285.4 & 22 & $1.65 E-07$ & -16.7 & 5.8 & 6 \\
\hline 29-5ep & $13: 23$ & 26 & 116.0 & 35.9 & 51.6 & 123.5 & 34.93 & 26 & 982.7 & 24 & $1.58 E-07$ & 66.7 & 6.8 & 15 \\
\hline 30-Sep & $11: 29$ & 27 & 111.2 & 31.8 & 48.0 & 117.4 & 30.28 & 27 & 568.7 & 26 & $2.83 E-07$ & -66.7 & 11.7 & 8 \\
\hline 1-Oet & $14: 30$ & 28 & 110.3 & 31.2 & 47.4 & 117.0 & 29.65 & 28 & 310.5 & 27 & 1.67E-07 & -16.7 & 5.4 & 6 \\
\hline $2-0 \mathrm{ct}$ & 13:03 & 29 & 108.6 & 31.1 & 46.6 & 115.6 & 28.65 & 29 & 258.8 & 28 & $1.31 E-07$ & -33.3 & 12.9 & 6 \\
\hline $6.0 \mathrm{ct}$ & 9.55 & 33 & 122.0 & 36.8 & 53.8 & 25.4 & 12.68 & 33 & 782.3 & 31 & $1.03 E-07$ & -16.7 & 2.1 & 6 \\
\hline $9-0<t$ & $12: 14$ & 36 & 133.6 & 57.8 & 72.7 & 137.5 & 53.58 & 36 & 779.6 & 34 & $1.24 E-07$ & 66.7 & 8.6 & 3 \\
\hline $13-0 \mathrm{ct}$ & 10.59 & 40 & 136.5 & 61.0 & 74.2 & 136.7 & 55.28 & 40 & 371.8 & 38 & $4.77 E-08$ & -66.7 & 17.9 & 3 \\
\hline $16-0 c t$ & $8: 21$ & 43 & 66.2 & 32.1 & 50.3 & 78.5 & 9.95 & 43 & 554.6 & 41 & $9.34 E-08$ & 33.3 & 6.0 & 3 \\
\hline $20-0 c t$ & 11:06 & 47 & 67.6 & 32.0 & 50.8 & 79.8 & 10.73 & 47 & 384.4 & 45 & 4.79E-08 & -116.7 & 30.4 & 3 \\
\hline $23-0<t$ & 13:37 & so & 67.7 & 30.8 & 48.9 & 80.0 & 10.03 & so & 536.1 & 48 & $8.71 E-08$ & 50.0 & 9.3 & 5 \\
\hline 27 -0ct & 10.05 & 54 & 64.4 & 28.9 & 46.8 & 77.4 & 7.55 & 54 & 416.1 & 52 & $5.46 E-08$ & -16.7 & 4.0 & 7 \\
\hline $30-0 c t$ & 11:26 & 57 & 62.6 & 27.1 & 44.9 & 75.3 & 5.65 & 57 & 399.0 & 55 & 6.38E-08 & 83.3 & 20.9 & 3 \\
\hline 3-Hov & $8: 32$ & 61 & 61.6 & 25.7 & 43.8 & 74.5 & 4.58 & 61 & 440.8 & 59 & $5.78 E-08$ & -16.7 & 3.8 & 2 \\
\hline 6-Nov & $10: 46$ & 64 & 66.1 & 29.0 & 45.9 & 78.8 & 8.13 & 64 & 279.5 & 62 & 4.53E-08 & -16.7 & 6.0 & 1 \\
\hline 10-Nov & $10: 25$ & 68 & 65.6 & 29.3 & 46.4 & 79.8 & 8.45 & 68 & -98.6 & 66 & $-1.24 E-08$ & -150.0 & 152.1 & 7 \\
\hline 13-Nov & $9: 51$ & 71 & 78.5 & 34.6 & 53.1 & 88.9 & 16.95 & 71 & 1076.0 & 69 & $1.83 E-07$ & 100.0 & 9.3 & 5 \\
\hline 17-Nov & $10: 39$ & 75 & - & • & • & - & - & 75 & 332.9 & 73 & $4.16 E-08$ & -166.7 & 50.1 & 3 \\
\hline 20-Nov & $10: 15$ & 78 & 76.1 & 34.5 & 51.6 & B6.4 & 15.33 & 78 & 464.9 & 76 & 7.79E-08 & 83.3 & 17.9 & 4 \\
\hline 25-Nov & 10.03 & 83 & 97.4 & 48.2 & 68.4 & 105.1 & 32.95 & 83 & 634.6 & 80 & 6.37E-08 & 83.3 & 13.1 & 3 \\
\hline 4-Dec & $10: 03$ & 92 & 87.4 & 42 & 61.2 & 94.7 & 24.50 & 92 & 673.6 & 87 & $3.75 E-08$ & -183.3 & 27.2 & 2 \\
\hline 18-Dec & 10.03 & 106 & 87.4 & 42 & 61.2 & 94.7 & 24.50 & 106 & 378.4 & 99 & $1.34 E-08$ & 0.0 & 0.0 & 1 \\
\hline 23-Dec & $10: 03$ & 111 & 87.4 & 42 & 61.2 & 94.7 & 24.50 & 111 & 385.6 & 108 & 3.97E-08 & 0.0 & 0.0 & 2 \\
\hline 31-Dec & 10.03 & 119 & 87.4 & 42 & 61.2 & 94.7 & 24.50 & 119 & 619.5 & 115 & $3.87 E-08$ & 0.0 & 0.0 & 2 \\
\hline 8-Jan & 10.03 & 127 & 87.4 & 42 & 61.2 & 94.7 & 24.50 & 127 & 704.9 & 123 & $4.34 E-08$ & 150.0 & 21.3 & \\
\hline
\end{tabular}


SEALED DOUBLE-RINGED

\begin{tabular}{|c|c|c|c|c|c|c|c|c|}
\hline \multicolumn{9}{|c|}{$\begin{array}{l}\text { CALCULATION SHEET FOR HYDRAULIC CONDUCTIVITY } \\
\text { INFRTROMETER D-1 (W-S) }\end{array}$} \\
\hline DAY NO. & $\begin{array}{c}\times 10.7 \\
1 \\
(\mathrm{~cm} / \mathrm{sec})\end{array}$ & $\begin{array}{l}\text { WATER } \\
\text { DEPTH } \\
\text { (m) }\end{array}$ & $\begin{array}{c}\text { W. FRONT } \\
\text { DEPTH } \\
((n) \\
\end{array}$ & GRADENT & DAY $M O$. & Holom & $\begin{array}{c}x 10-7 \\
\text { SWELL } \\
1 \\
(\mathrm{~cm} / \mathrm{sec})\end{array}$ & $\begin{array}{l}\text { riost } \\
\text { rophus } \\
\text { con swail }\end{array}$ \\
\hline 1 & - & 6.75 & - & - & 1 & 1 & - & $?$ \\
\hline 2 & - & 6.75 & - & • & 2 & ? & - & ?ै \\
\hline 3 & 0.9 & 7.25 & 3.39 & 3.14 & 7 & 0,9 & 0.92 & 029 \\
\hline 9 & 2.7 & 7.63 & 2.80 & 3.73 & 11 & 07 & 2.70 & 012 \\
\hline 11 & - & 7.75 & • & • & 12 & \% & - & ४ै \\
\hline 12 & 2.4 & 7.63 & 3.76 & 3.03 & 13 & 0. & 2.37 & 0.78 \\
\hline 13 & 2.3 & 7.50 & 4.23 & 2.77 & 14 & 0.8 & 2.34 & 084 \\
\hline 14 & - & 7.50 & - & - & is & ४ै & - & ४ै \\
\hline 15 & 2.1 & 7.50 & 4.67 & 2.60 & 16 & 0.8 & 2.07 & 079 \\
\hline 17 & 2.1 & 7.50 & 5.29 & 2.42 & 18 & 09 & 2.06 & 0.65 \\
\hline 18 & 1.8 & 7.50 & 5.79 & 2.29 & 19 & 0.8 & 1.84 & 080 \\
\hline 19 & 2.1 & 7.50 & 3.31 & 3.27 & 20 & 07 & 2.14 & 0,65 \\
\hline 20 & 6.9 & 7.63 & 3.47 & 3.20 & 21 & 2,2 & 6.88 & 215 \\
\hline 21 & 1.4 & $T .88$ & 3.65 & 3.16 & 22 & 00 & 1.42 & 0.45 \\
\hline 22 & 1.7 & 7.88 & 3.82 & 3.06 & 23 & 0.5 & 1.65 & 0.54 \\
\hline 24 & 1.6 & 7.75 & 4.17 & 2.86 & 26 & 0.6 & 1.58 & 0.55 \\
\hline 26 & 2.8 & 7.75 & 4.52 & 2.71 & . 27 & 10 & 2.83 & 104 \\
\hline 27 & 1.7 & 7.75 & 4.69 & 2.65 & 28 & 0.6 & 1.67 & 0,63 \\
\hline 28 & 1.3 & 7.75 & 4.86 & 2.59 & 29 & 0.5 & 1.31 & 0.51 \\
\hline 31 & 1.0 & 8.25 & 5.27 & 2.56 & 33 & 01 & 1.03 & 040 \\
\hline 34 & 1.2 & 8.75 & 5.87 & 2.49 & 36 & 0.5 & 1.24 & 050 \\
\hline 38 & 0.5 & 8.00 & 6.48 & 2.24 & 40 & 02 & 0.48 & 0.21 \\
\hline 41 & 0.9 & 7.13 & 7.07 & 2.01 & 43 & 00 & 0.93 & 016 \\
\hline 45 & 0.5 & 7.00 & 7.67 & 1.91 & 47 & 0,3 & 0.48 & 0.25 \\
\hline 48 & 0.9 & 6.88 & 8.28 & 1.83 & so & 0,5 & 0.87 & 048 \\
\hline 52 & 0.5 & 6.75 & 8.87 & 1.76 & 54 & 0,3 & 0.55 & 031 \\
\hline 55 & 0.6 & 6.75 & 9.47 & 1.71 & 57 & 04 & 0.64 & 0,37 \\
\hline 59 & 0.6 & 7.13 & 10.07 & 1.71 & 61 & 03 & 0.58 & 034 \\
\hline 62 & 0.5 & 7.38 & 10.66 & 1.69 & 64 & 01 & 0.45 & 027 \\
\hline 66 & -0.1 & 7.13 & 11.27 & 1.63 & 68 & 01 & -0.12 & 0.08 \\
\hline 69 & 1.8 & 7.13 & 11.87 & 1.60 & 71 & 11 & 1.83 & 114 \\
\hline 73 & 0.4 & 7.25 & 12.47 & 1.58 & 75 & 0.3 & 0.42 & 0,26 \\
\hline 76 & 0.8 & 7.13 & 13.07 & 1.55 & 78 & 0.5 & 0.78 & 0.50 \\
\hline 80 & 0.6 & 7.13 & 13.75 & 1.52 & 83 & 0.4 & 0.64 & 0,12 \\
\hline 87 & 0.4 & 7.13 & 14.95 & 1.48 & 92 & 0.3 & 0.37 & 0.25 \\
\hline 99 & 0.1 & 7.13 & 16.94 & 1.42 & 106 & 018 & 0.13 & 0.09 \\
\hline 108 & 0.4 & 7.13 & 18.56 & 1.38 & 111 & 0,3 & 0.40 & 0.29 \\
\hline 115 & 0.4 & 7.13 & 19.67 & 1.36 & 119 & 0.3 & 0.39 & 0.28 \\
\hline 123 & 0.4 & 7.50 & 21.05 & 1.36 & 127 & $0,3 \%$ & 0.43 & 0.32 \\
\hline
\end{tabular}




\begin{tabular}{|c|c|c|c|c|c|}
\hline 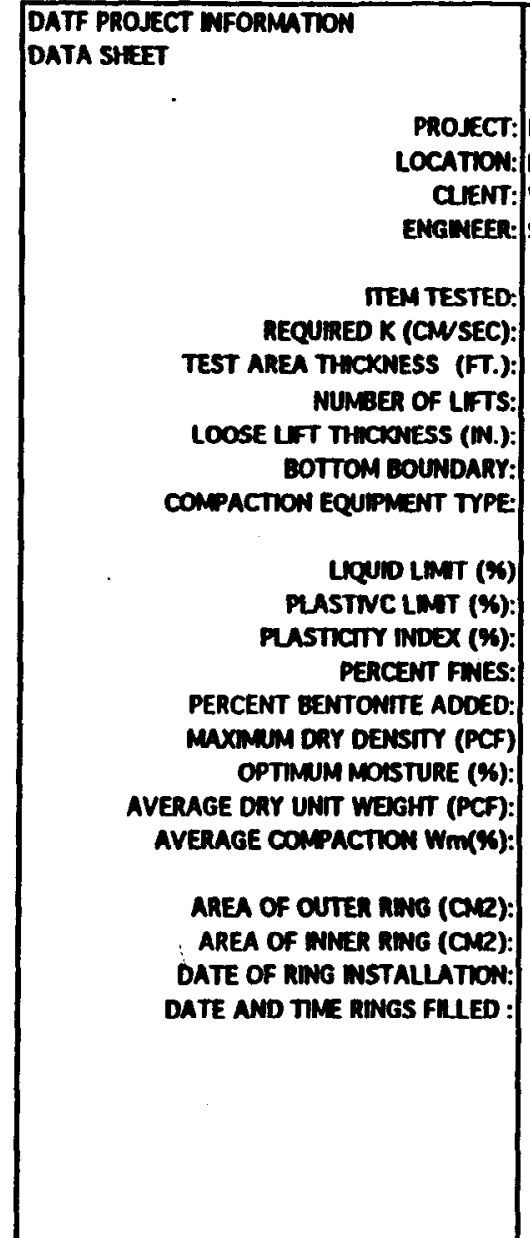 & $\begin{array}{l}\text { Dymamic Compaction Test, } \\
\text { E and } 4 \text { road } \\
\text { WSRC } \\
\text { Scott R. Memulin } \\
\text { Kaolin Tost cap } \\
1 \times 10-7 \\
3 \\
6 \\
8 \\
\text { sandy chy } \\
\text { Cat } 8158 \\
64 \\
61 \\
32 \\
2 \\
0\end{array}$ & 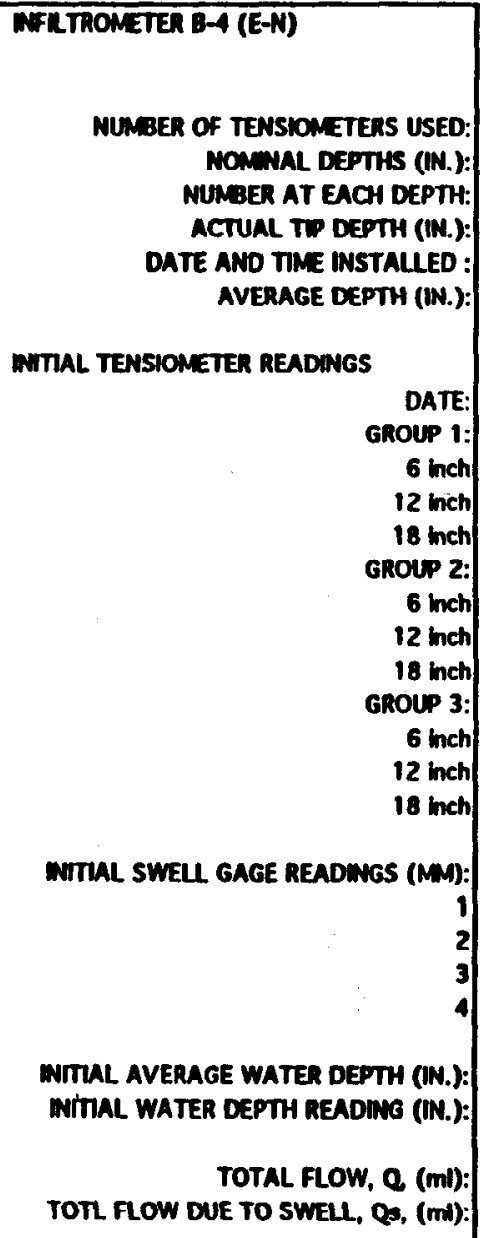 & $\begin{array}{c}9 \\
6 \\
3 \\
7 \\
9 / 11 / 92 \\
12 \\
\\
9 / 11 / 92 \\
0 \\
24 \\
26 \\
10 \\
23 \\
30 \\
0 \\
8 \\
21 \\
\\
64.5 \\
52.5 \\
54.4 \\
80.7 \\
12.3 \\
9 \\
330 \\
125415\end{array}$ & $\begin{array}{c}12 \\
13 \\
14: 30\end{array}$ & $\begin{array}{l}18 \\
19\end{array}$ \\
\hline
\end{tabular}




\begin{tabular}{|c|c|c|c|c|c|c|c|c|c|}
\hline \multicolumn{10}{|c|}{$\begin{array}{l}\text { DATA SHEET FOR WATER BAGS } \\
\text { WFATROMETER B-4 (E-N) }\end{array}$} \\
\hline \multirow{2}{*}{\multicolumn{4}{|c|}{ BAG CONNECTION AND DISCONMECTION }} & \multirow[b]{2}{*}{$\begin{array}{c}\text { E' } \\
\text { WTERVAL } \\
\text { TWEE }\end{array}$} & \multicolumn{2}{|c|}{ BAG 1 } & \multicolumn{2}{|c|}{ BAG 2 } & \multirow[b]{2}{*}{$\begin{array}{l}\text { NET } \\
\text { CHAWGE } \\
\text { (g) }\end{array}$} \\
\hline & & & & & $\begin{array}{l}\text { INMALAL } \\
\text { WEIGHT } \\
\text { (0) }\end{array}$ & $\begin{array}{l}\text { FWAL } \\
\text { WEGHT } \\
\text { (g) }\end{array}$ & $\begin{array}{l}\text { WITAL } \\
\text { WEGGHT } \\
\text { (g) }\end{array}$ & $\begin{array}{c}\text { FWAL } \\
\text { WEIGHT } \\
\text { (g) }\end{array}$ & \\
\hline 11-Sep & 14-Sep & 14:30 & 15:11 & 261660 & 3871.0 & 3339.4 & 3658.0 & 3329.4 & 860.2 \\
\hline 14-Sep & 15-Sep & 15:37 & - & - & 3329.4 & - & 3329.4 & - & - \\
\hline$\therefore$ & 16-Sep & $\therefore$ & 15:15 & 171480 & • & 1269.9 & - & 3210.3 & 2178.6 \\
\hline 16-Sep & 17-Sep & $15: 44$ & 14:01 & 80220 & 3303.7 & 3307.7 & 3210.3 & 3202.0 & 4.3 \\
\hline 17-Sep & • & $14: 47$ & • & • & 3307.7 & - & 3202.0 & - & - \\
\hline$\cdot$ & 19-Sep & $\cdot$ & $10: 34$ & 157620 & - & 2634.8 & - & 2976.3 & 898.6 \\
\hline 19-Sep & 21-Sep & 11:36 & 12:00 & 174240 & 2634.8 & 2549.7 & 2976.3 & 2390.0 & 671.4 \\
\hline 21-Sep & 22-Sep & 13:46 & 13:47 & 86460 & 2549.7 & 2441.1 & 2390.0 & 2175.3 & 323.3 \\
\hline 22-Sep & 23-Sep & 14:15 & 11:32 & 76620 & 2441.1 & 2256.8 & 2175.3 & 2073.5 & 286.1 \\
\hline 23-Sop & 24-Sop & $12: 06$ & 11:10 & 83040 & 2256.8 & 2150.7 & 2073.5 & 1788.4 & 391.2 \\
\hline 24-Sep & 25-Sep & $12: 10$ & 13:42 & 91920 & 2150.7 & 2162.3 & 3221.0 & 2905.7 & 303.7 \\
\hline 25-Sep & 26-Sep & 14:31 & 11:07 & 74160 & 2162.3 & 2131.0 & 2905.7 & 2635.2 & 301.8 \\
\hline 26-Sep & 29-Sep & 11:32 & 13:58 & 267960 & 2131.0 & 1782.7 & 2635.2 & 1958.6 & 1024.9 \\
\hline 29-Sep & 30-Sep & 14:47 & 14:51 & $\mathbf{8 6 6 4 0}$ & 2497.0 & 1920.8 & 2719.7 & 2776.7 & 519.2 \\
\hline 30-Sep & 1-0ct & 15:18 & 13:36 & 80280 & 1920.8 & 1809.1 & 2776.7 & 2639.3 & 249.1 \\
\hline $1.0 z t$ & $2-0 c t$ & 14:10 & 13:40 & 84600 & 1809.1 & 1718.7 & 2639.3 & 2493.4 & 236.3 \\
\hline $2-0 e t$ & 6-0et & 14:20 & $8: 51$ & 325860 & 3210.5 & 2482.0 & 2493.4 & 2418.5 & B03.4 \\
\hline $6-0 \mathrm{ct}$ & 9-0ct & 9:27 & $12: 57$ & 271800 & 2418.5 & 1852.3 & 2418.5 & 2372.5 & 612.2 \\
\hline 9-0ct & 13-0xt & 13:22 & $10: 33$ & 335460 & 2566.1 & 2404.5 & 2372.5 & 2109.0 & 425.1 \\
\hline 13-0ut & $16-0 \mathrm{t}$ & 11:10 & 10:10 & 255600 & 2404.5 & 1948.2 & 2109.0 & 2109.0 & 456.3 \\
\hline 16-0ct & $20-0 z t$ & $10: 45$ & $10: 40$ & 345300 & 1948.2 & 1775.7 & 2109 & 1819.9 & 461.6 \\
\hline $20-0 \mathrm{ct}$ & 23-0ct & 11:19 & $12: 54$ & 264900 & 2821.5 & 2748.3 & 2768.5 & 2353.9 & 487.8 \\
\hline 23-0ct & $27-0 x t$ & 13:43 & $8: 55$ & 328320 & 2748.3 & 2975.6 & 2353.9 & 1812.3 & 314.3 \\
\hline 27-0ct & 30-0ct & 10:31 & 13:05 & 268440 & 2975.6 & 2776.3 & 2856.3 & 2969.2 & 86.4 \\
\hline $300 \mathrm{ct}$ & 3-Nov & 13:45 & 9.05 & 328800 & 2776.3 & 2504.7 & 2969.2 & 2549.1 & 691.7 \\
\hline 3-Hov & G-Nov & 9:30 & $11: 17$ & 265620 & 2504.7 & 2919.0 & 2549.1 & 1822.4 & 312.4 \\
\hline 6-Nov & 10-Hov & 12:15 & 11:10 & 341700 & 2919.0 & 2630.9 & 2829.6 & 2052.2 & 1065.5 \\
\hline 10-Nov & $17 \mathrm{Hov}$ & 12:08 & 10:38 & 599400 & 2630.9 & 2339.7 & 3103.0 & 2844.1 & 550.1 \\
\hline $17+$ Hov & 20-Nov & 11:13 & 10:38 & 257100 & 2339.7 & 2216.7 & 2844.1 & 2594.0 & 373.1 \\
\hline 20-Nov & 25 Hov & 11:22 & 10:32 & 429000 & 2216.7 & 2175.6 & 2594.0 & 1860.1 & 775.0 \\
\hline 25-Nov & 4-Dec & 11:18 & $10: 22$ & 774240 & 2175.6 & 1793.3 & 2830.0 & 2401.0 & 811.3 \\
\hline 4-Dee & 18-Dec & 11:15 & 13:53 & 1219080 & 3319.9 & 957.8 & 2401.0 & 1964.5 & 2798.6 \\
\hline 18-Doc & 23-Doce & 14:24 & $10: 40$ & 418560 & 2965.1 & 1877.5 & 2826.0 & 1971.3 & 1942.3 \\
\hline 23-Dec & 31-Dec & 11:13 & 10:50 & 689820 & 3101.0 & 2583.2 & 2995.3 & 2788.3 & 724.8 \\
\hline 31.Dec & 8-kn & $11: 24$ & 13:25 & 698460 & 2583.2 & 1838.7 & 2788.3 & 2831.9 & 700.9 \\
\hline
\end{tabular}


SEALED DOUBLE-RINGED INFLTROMETER DATA, DCF TEST

\begin{tabular}{|c|c|c|c|c|c|c|c|c|c|}
\hline \multicolumn{10}{|c|}{$\begin{array}{l}\text { DATA SHEET FOA WATER DEPTH AND TEMPERATURE } \\
\text { WFLTROMETER B-A (E-N) }\end{array}$} \\
\hline DATE & $\begin{array}{c}\text { START } \\
\text { WAT. DEPTH } \\
\text { READNG } \\
\text { (ll) } \\
\end{array}$ & $\begin{array}{c}\text { STAKT } \\
\text { WATER } \\
\text { DEPTH } \\
\text { (h.) }\end{array}$ & $\begin{array}{c}\text { END } \\
\text { WAT. DEPTH } \\
\text { READWG } \\
\text { (h.) } \\
\end{array}$ & $\begin{array}{l}\text { END } \\
\text { WATER } \\
\text { DEPTH } \\
\text { (b) }\end{array}$ & $\begin{array}{l}\text { AVE. } \\
\text { WATER } \\
\text { DEPTH } \\
\text { (in) }\end{array}$ & $\begin{array}{l}\text { START } \\
\text { WATER } \\
\text { TEMP } \\
\text { (OF) } \\
\end{array}$ & $\begin{array}{l}\text { END } \\
\text { WATER } \\
\text { TEMP } \\
\text { (OF) }\end{array}$ & $\begin{array}{l}\text { AVG. } \\
\text { WATER } \\
\text { TENP } \\
\text { of } \\
\end{array}$ & $\begin{array}{l}\text { TEMP. } \\
\text { CHANGE } \\
\text { (of) }\end{array}$ \\
\hline 14-Sep & 9.00 & 12.25 & 9.00 & 12.25 & 12.25 & 82 & 81 & 82 & -1 \\
\hline 15-Sep & 9.00 & 12.25 & 9.00 & 12.25 & 12.25 & 81 & 74 & 78 & -7 \\
\hline 16-Sep & 9.00 & 12.25 & 8.75 & 12.00 & 12.13 & 74 & 74 & 74 & 0 \\
\hline 17-Sep & 8.75 & 12.00 & 8.75 & 12.00 & 12.00 & 74 & 75 & 75 & 1 \\
\hline 18-Sep & 8.75 & 12.00 & 8.75 & 12.00 & 12.00 & 75 & 76 & 76 & 1 \\
\hline 19-Sep & 8.75 & 12.00 & 8.75 & 12.00 & 12.00 & 76 & 75 & 76 & -1 \\
\hline 21-Sep & 8.75 & 12.00 & 8.75 & 12.00 & 12.00 & 75 & 77 & 76 & 2 \\
\hline 22-Sep & 8.75 & 12.00 & 8.75 & 12.00 & 12.00 & 77 & 77 & 77 & 0 \\
\hline 23-Sep & 8.75 & 12.00 & 8.75 & 12.00 & 12.00 & 77 & 77 & 77 & 0 \\
\hline 24-Sep & 8.75 & 12.00 & 9.00 & 12.25 & 12.13 & 77 & 66 & 72 & -11 \\
\hline 25-Sep & 9.00 & 12.25 & 9.00 & 12.25 & 12.25 & 66 & 63 & 65 & -3 \\
\hline 26-Sep & 9.00 & 12.25 & 9.00 & 12.25 & 12.25 & 63 & 64 & 64 & 1 \\
\hline 29-Sep & 9.00 & 12.25 & 9.00 & 12.25 & 12.25 & 64 & 71 & 68 & 7 \\
\hline 30-Sep & 9.00 & 12.25 & 9.00 & 12.25 & 12.25 & 71 & 65 & 68 & -6 \\
\hline $1-0 \mathrm{ct}$ & 9.00 & 12.25 & 8.75 & 12.00 & 12.13 & 65 & 63 & 64 & -2 \\
\hline $2-0<t$ & 8.75 & 12.00 & 8.75 & 12.00 & 12.00 & 63 & 62 & 63 & -1 \\
\hline $6-0 \mathrm{ct}$ & 6.75 & 12.00 & 9.50 & 12.75 & 12.38 & 62 & 59 & 61 & -3 \\
\hline 9-oct & 9.50 & 12.75 & 11.75 & 15.00 & 13.08 & 59 & 67 & 63 & 8 \\
\hline 13-0ct & 11.75 & 15.00 & 9.25 & 12.50 & 13.75 & 67 & 60 & 64 & -7 \\
\hline $16-0 c t$ & 9.25 & 12.50 & 9.25 & 12.50 & 12.50 & 60 & 64 & 62 & 4 \\
\hline $20-0 c t$ & 9.25 & 12.50 & 9.00 & 12.25 & 12.38 & 64 & 54 & 59 & -10 \\
\hline $23-0 \mathrm{t}$ & 9.00 & 12.25 & 9.00 & 12.25 & 12.25 & 54 & 58 & 56 & 4 \\
\hline 27 -0ct & 9.00 & 12.25 & 8.75 & 12.00 & 12.13 & 58 & 59 & 59 & 1 \\
\hline $30-0 c t$ & 8.75 & 8.75 & 8.75 & 12.00 & 10.38 & 59 & 64 & 62 & 5 \\
\hline 3-Nov & 8.75 & 8.75 & 8.75 & 12.00 & 10.38 & 64 & 65 & 65 & 1 \\
\hline 6-Hov & 8.75 & 9.25 & 8.75 & 12.00 & 10.63 & 65 & 59 & 62 & 6 \\
\hline 10-Nov & 8.75 & 9.25 & 8.75 & 12.00 & 10.63 & 59 & so & 55 & -9 \\
\hline 17-Nov & 8.75 & 9.50 & 8.75 & 12.00 & 10.75 & 30 & 58 & 54 & 8 \\
\hline 20-Nov & 8.75 & 9.25 & 8.75 & 12.00 & 10.63 & 58 & 48 & 53 & -10 \\
\hline 25- Nov & 8.75 & 9.00 & 8.75 & 12.00 & 10.50 & 48 & 52 & 50 & 4 \\
\hline 4-Dec & 8.75 & 9.00 & 9.25 & 12.50 & 10.75 & 52 & 60 & 56 & 8 \\
\hline 18-Dec & 9.25 & 9.00 & 9.25 & 12.50 & 10.75 & 60 & 46 & 53 & -14 \\
\hline 23-Dec & 9.25 & 9.00 & 9.25 & 12.50 & 10.75 & 46 & 46 & 46 & 0 \\
\hline 31-Dec & 9.25 & 9.00 & 9.25 & 12.50 & 10.75 & 46 & 46 & 46 & 0 \\
\hline 8-bn & 9.25 & 9.00 & 10.00 & 13.25 & 11.13 & 46 & 58 & 52 & 12 \\
\hline
\end{tabular}




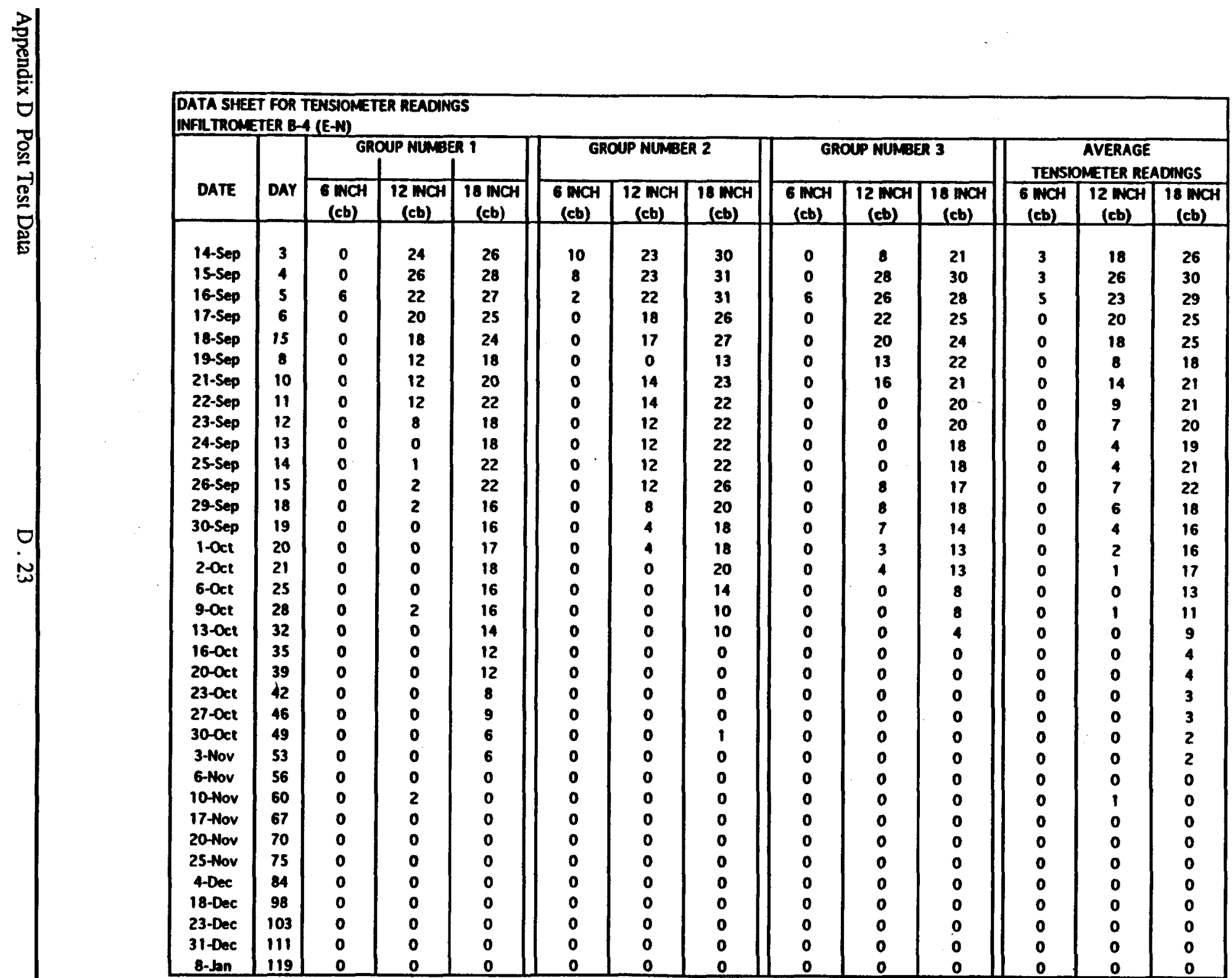


SEALED DOUBLE-RINGED INFILTROMETER DATA, DCF TEST

\begin{tabular}{|c|c|c|c|c|c|c|c|c|c|c|c|c|c|c|}
\hline \multicolumn{8}{|c|}{$\begin{array}{l}\text { DATA SHEET FON SWELL DATA } \\
\text { WFHTROMETER B-4 (E+N) } \\
\end{array}$} & \multicolumn{7}{|c|}{$\begin{array}{l}\text { CALCULATION SHEET FON FLOW-RATE AND ADJUSTMENT VALUES } \\
\text { MFRTROMETER B-4 (E-N) }\end{array}$} \\
\hline \multirow[b]{2}{*}{$\begin{array}{l}\text { READNV } \\
\text { DATE }\end{array}$} & \multirow[b]{2}{*}{$\begin{array}{l}\text { READWH } \\
\text { TIME }\end{array}$} & \multirow[b]{2}{*}{$\begin{array}{c}\text { DAY } \\
\text { MUMBER }\end{array}$} & \multicolumn{4}{|c|}{ SWELL NFFORMATION } & \multirow{2}{*}{$\begin{array}{l}\text { (mon) } \\
\text { AVO. } \\
\text { SWEL }\end{array}$} & \multirow[b]{2}{*}{$\begin{array}{l}\text { DAY } \\
\text { No. }\end{array}$} & \multirow[b]{2}{*}{$\begin{array}{c}Q \\
(m)\end{array}$} & \multirow[b]{2}{*}{$\begin{array}{c}\text { AVO } \\
\text { DAY MO. }\end{array}$} & \multirow[b]{2}{*}{$\begin{array}{c}1 \\
(\mathrm{con} / \mathrm{sec})\end{array}$} & \multirow{2}{*}{$\begin{array}{l}\text { EST. FLOW } \\
\text { DUE TO } \\
\text { TEMP. ONG. } \\
\text { (m) }\end{array}$} & \multirow{2}{*}{$\begin{array}{l}\text { X OF } \\
\text { TOTAL } \\
\text { FLOW } \\
(\mathrm{ml})\end{array}$} & \multirow{2}{*}{$\begin{array}{c}\text { Q } \\
\text { Wrin BAd } \\
\text { WAS OFF } \\
\text { (min) }\end{array}$} \\
\hline & & & 51 & 52 & 53 & SA & & & & & & & & \\
\hline 14-Sep & 15:15 & $\mathbf{3}$ & 64.5 & 52.5 & 54.4 & 80.7 & 0.00 & 3 & 860.2 & 2 & $1.42 E-07$ & -16.7 & 1.9 & -2097 \\
\hline 15-Sep & $8: 55$ & 4 & 59.6 & 49.7 & 52.1 & 75.3 & -3.85 & 4 & . & . & - & . & . & - \\
\hline 16-5ep & $12: 30$ & 5 & 59.8 & 49.6 & 52.8 & 75.5 & -3.60 & s & 2178.6 & 4 & $5.47 E-07$ & 0.0 & 0.0 & 11 \\
\hline 17-Sep & $15: 00$ & 6 & 60.3 & 49.4 & 52.8 & 76.1 & -3.38 & 6 & 4.3 & 6 & $2.31 E-09$ & 16.7 & 387.6 & \\
\hline • & $17: 00$ & - & 60.0 & 49.8 & 52.5 & 75.6 & -3.55 & & - & - & • & 16.7 & - & \\
\hline 19-Sep & $11: 32$ & 8 & 60.5 & 49.9 & 52.4 & 76.4 & -3.23 & 8 & 898.6 & 9 & 2.45E-07 & -16.7 & 1.9 & 18 \\
\hline 21.Sep & 13:35 & 10 & 60.4 & 49.0 & 51.1 & 76.5 & -3.78 & 10 & 671.4 & 9 & $1.66 E-07$ & 33.3 & 5.0 & 24 \\
\hline 22-Sep & 15:33 & 11 & 60.8 & 50.0 & 51.9 & 77.0 & -3.10 & 11 & 323.3 & 10 & $1.61 E-07$ & 0.0 & 0.0 & 6 \\
\hline 23-Sep & $11: 13$ & 12 & 60.7 & 49.5 & 51.5 & 76.8 & -3.40 & 12 & 286.1 & 11 & 1.61E-07 & 0.0 & 0.0 & 9 \\
\hline 24-Sep & $11: 55$ & 13 & 60.6 & 50.0 & 52.4 & 77.1 & -3.00 & 13 & 391.2 & 12 & 2.03E-07 & -183.3 & 46.9 & 14 \\
\hline 25-Sep & 15:01 & 14 & 62.2 & 51.5 & 54.8 & 77.7 & -1.48 & 14 & 303.7 & 13 & 1.42E-07 & -50.0 & 16.5 & 11 \\
\hline 26-Sep & $11: 00$ & 15 & 62.2 & 52.0 & 55.0 & 77.5 & -1.35 & 15 & 301.8 & 14 & 1.75E-07 & 16.7 & 5.5 & 6 \\
\hline 29-Sep & 13:52 & 18 & 64.5 & 55.2 & 58.2 & 81.3 & 1.78 & 18 & 1024.9 & 16 & $1.65 E-07$ & 116.7 & 11.4 & 14 \\
\hline 30-Sep & $14: 28$ & 19 & 64.8 & 58.2 & 60.5 & 80.6 & 3.00 & 19 & 519.2 & 19 & $2.58 E-07$ & -100.0 & 19.3 & 7 \\
\hline $1-0 c t$ & 15:24 & 20 & 64.6 & 57.5 & 61.2 & 81.1 & 3.08 & 20 & 249.1 & 19 & $1.34 E-07$ & -33.3 & 13.4 & 6 \\
\hline $2-0 c t$ & 13:30 & 21 & 63.8 & 56.8 & 59.6 & 79.9 & 2.00 & 21 & 236.3 & 20 & 1.20E-07 & -16.7 & 7.1 & 6 \\
\hline $6-0 \mathrm{ct}$ & $10: 22$ & 25 & 67.8 & 56.0 & 59.7 & 81.9 & 3.33 & 25 & 803.4 & 23 & $1.06 \mathrm{E}-07$ & -50.0 & 6.2 & 5 \\
\hline $9-0<t$ & $12: 31$ & 28 & 77.3 & 65.3 & 70.0 & 93.9 & 13.60 & 28 & 612.2 & 26 & 9.70E-08 & 133.3 & 21.8 & 3 \\
\hline $13-0 \mathrm{ct}$ & 10.24 & 32 & 80.7 & 66.5 & 71.0 & 97.0 & 15.78 & 32 & 425.1 & 30 & S.46E-08 & -116.7 & 27.4 & 3 \\
\hline $16-0 c t$ & $8: 42$ & 35 & 71.2 & 62.8 & 64.5 & 87.9 & 8.58 & 35 & 456.3 & 33 & 7.69E-08 & 66.7 & 14.6 & 3 \\
\hline $20-0 \mathrm{ct}$ & $11: 27$ & 39 & 72.9 & 63.5 & 65.3 & 89.2 & 9.70 & 39 & 461.6 & 37 & S.76E-08 & -166.7 & 36.1 & 4 \\
\hline 23-0ct & $13: 57$ & 42 & 74.0 & 89.6 & 65.8 & 64.5 & 10.45 & 42 & 487.8 & 40 & 7.93E-08 & 66.7 & 13.7 & 4 \\
\hline $27-0 c t$ & 10.32 & 46 & 73.3 & 63.8 & 64.9 & 91.0 & 10.23 & 46 & 314.3 & 44 & $4.12 E-08$ & 16.7 & 5.3 & 4 \\
\hline $30-0 c t$ & $11: 40$ & 49 & 77.4 & 61.0 & 61.9 & 93.4 & 10.40 & 49 & 86.4 & 47 & $1.39 E-08$ & 83.3 & 96.5 & 3 \\
\hline 3-Now & $8: 47$ & 53 & 71.5 & 57.8 & 60.7 & 87.4 & 6.33 & 53 & 691.7 & 51 & $9.06 E-08$ & 16.7 & 2.4 & 2 \\
\hline 6-NON & $11: 07$ & .56 & 67.1 & 58.4 & 61.6 & 86.5 & 5.38 & 56 & 312.4 & 54 & $5.06 E-08$ & -100.0 & 32.0 & 7 \\
\hline 10-Nov & 10.55 & 60 & 73.3 & 60.1 & 62.1 & 89.4 & 8.20 & 60 & 1065.5 & 58 & $1.34 E-07$ & -150.0 & 14.1 & 7 \\
\hline 17-Nov & 10.11 & 67 & 65.9 & 61 & 55.4 & 83.9 & 3.53 & 67 & 550.1 & 63 & 3.95E-08 & 133.3 & 24.2 & 2 \\
\hline 20-Nov & $11: 14$ & 70 & 77.3 & 63.5 & 60 & 90.6 & 9.83 & 70 & 373.1 & 68 & $6.25 E-08$ & -166.7 & 44.7 & 4 \\
\hline 25-Nov & $10: 17$ & 75 & 80.2 & 70.5 & 69.8 & 93.9 & 15.58 & 75 & 775.0 & 72 & 7.78E-08 & 66.7 & 8.6 & 4 \\
\hline 4-Dec & $10: 10$ & 84 & 73.3 & 71.8 & 73.1 & 88.5 & 13.65 & 84 & 811.3 & 79 & 4.51E-08 & 133.3 & 16.4 & 5 \\
\hline 18-Dec & $10: 10$ & 98 & 73.3 & 71.8 & 73.1 & 88.5 & 13.65 & 98 & 2798.6 & 91 & $9.88 E-08$ & -233.3 & 8.3 & 6 \\
\hline 23-Dec & $10: 10$ & 103 & 73.3 & 71.8 & 73.1 & 88.5 & 13.65 & 103 & 1942.3 & 100 & $2.00 E-07$ & 0.0 & 0.0 & 6 \\
\hline 31-Dec & 10.10 & 111 & 73.3 & 71.8 & 73.1 & 88.5 & 13.65 & 111 & 724.8 & 107 & 4.52E-08 & 0.0 & 0.0 & 2 \\
\hline 8-bn & 10.10 & 119 & 73.3 & 71.8 & 73.1 & 88.5 & 13.65 & 119 & 700.9 & 115 & 4.32E-08 & 200.0 & 28.5 & WALUEI \\
\hline
\end{tabular}




\begin{tabular}{|c|c|c|c|c|c|c|c|c|}
\hline \multicolumn{9}{|c|}{$\begin{array}{l}\text { CALCILATION SHEET FOR HTDRAULIC CONDUCTIVITY } \\
\text { INFILTROMETER D-1 (E-N) }\end{array}$} \\
\hline DAY NO. & $\begin{array}{c}\times 10-7 \\
1 \\
(\mathrm{~cm} / \mathrm{sec}) \\
\end{array}$ & $\begin{array}{c}\text { WATER } \\
\text { DEPTH } \\
\text { (in) }\end{array}$ & $\begin{array}{c}\text { W. FRONT } \\
\text { DEPTH } \\
\text { (in) }\end{array}$ & GRADIENT & DAY No. & 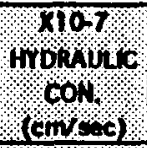 & $\begin{array}{c}10-7 \\
\text { SWELL } \\
1 \\
(\mathrm{~cm} / \mathrm{sec}) \\
\end{array}$ & 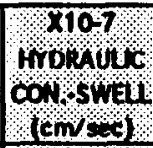 \\
\hline 3 & 1.4 & 12.25 & 3.64 & 4.37 & $\begin{array}{l}1 \\
3\end{array}$ & 0.3 & 1.42 & 032 \\
\hline$\dot{0}$ & - & 12.25 & & & $\cdot$ & $\$$ & - & ?ै \\
\hline 5 & 5.5 & 12.13 & 5.90 & 3.06 & 5 & $1 \%$ & 5.47 & 179 \\
\hline 6 & 0.0 & 12.00 & 2.13 & 6.65 & 6 & 00 & 0.02 & 000 \\
\hline 7 & 1 & 12.00 & 2.47 & & 7 & ? & 0.50 & భै \\
\hline 8 & 2.5 & 12.00 & 2.78 & 5.32 & 8 & 085 & 2.45 & 046 \\
\hline 10 & 1.7 & 12.00 & 3.52 & 4.41 & 10 & 04 & 1.66 & 038 \\
\hline 11 & 1.6 & 12.00 & 3.90 & 4.08 & 11 & 01 & 1.61 & 039 \\
\hline 12 & 1.6 & 12.00 & 4.19 & 3.67 & 12 & 04 & 1.61 & 042 \\
\hline 13 & 2.0 & 12.13 & 4.55 & 3.66 & 13 & 00 & 2.03 & 0,55 \\
\hline 14 & 1.4 & 12.25 & 4.95 & 3.48 & 14 & 04 & 1.42 & 041 \\
\hline 15 & 1.8 & 12.25 & 5.24 & 3.34 & 15 & 0,5 & 1.75 & 0.53 \\
\hline 18 & 1.6 & 12.25 & 6.34 & 2.93 & 18 & 0.6 & 1.65 & 0,56 \\
\hline 19 & 2.6 & 12.25 & 6.71 & 2.83 & 19 & 0.9 & 2.58 & 0.91 \\
\hline 20 & 1.3 & 12.13 & 7.07 & 2.71 & 20 & 0.5 & 1.34 & 0.49 \\
\hline 21 & 1.2 & 12.00 & 7.40 & 2.62 & 21 & 0.5 & 1.20 & 0.46 \\
\hline 25 & 1.1 & 12.38 & 8.76 & 2.41 & 25 & 0.4 & 1.06 & 0.44 \\
\hline 28 & 1.0 & 13.88 & 9.85 & 2.41 & 28 & 0.1 & 0.97 & 0.40 \\
\hline 32 & 0.5 & 13.75 & 11.23 & 2.22 & 32 & 02 & 0.55 & 025 \\
\hline 35 & 0.8 & 12.50 & 12.27 & 2.02 & 35 & 0,1 & 0.77 & 038 \\
\hline 39 & 0.6 & 12.38 & 13.72 & 1.90 & 39 & 0.3 & 0.58 & 030 \\
\hline 42 & 0.8 & 12.25 & 14.82 & 1.83 & 42 & 0.4 & 0.79 & 043 \\
\hline 46 & 0.4 & 12.13 & 16.18 & 1.75 & 46 & 02 & 0.41 & 0224 \\
\hline 49 & 0.1 & 10.38 & 17.25 & 1.60 & 49 & 01 & 0.14 & 0,09 \\
\hline 53 & 0.9 & 10.38 & 18.62 & 1.56 & 53 & 0.6 & 0.91 & 0.58 \\
\hline 56 & 0.5 & 10.63 & 19.71 & 1.54 & 56 & 03 & 0.51 & 0,33 \\
\hline 60 & 1.3 & 10.63 & 21.12 & 1.50 & 60 & 09 & 1.34 & 0,89 \\
\hline 67 & 0.4 & 10.75 & 23.58 & 1.46 & 67 & 03 & 0.40 & 0,27 \\
\hline 70 & 0.6 & 10.63 & 24.66 & 1.43 & 70 & 0. & 0.62 & 044 \\
\hline 75 & 0.8 & 10.50 & 26.41 & 1.40 & 75 & 0.6 & 0.78 & 0.56 \\
\hline 84 & 0.5 & 10.75 & 29.58 & 1.36 & 84 & 03 & 0.45 & 033 \\
\hline 98 & 1.0 & 10.75 & 34.52 & 1.31 & 98 & 0.8 & 0.99 & 0.75 \\
\hline 103 & 2.0 & 10.75 & 36.29 & 1.30 & 103 & 15 & 2.00 & 1,54 \\
\hline 111 & 0.5 & 10.75 & 39.11 & 1.27 & 111 & 0.4 & 0.45 & $0: 35$ \\
\hline 119 & 0.4 & 11.13 & 41.94 & 1.27 & 119 & 0,3 & 0.43 & $0: 34$ \\
\hline
\end{tabular}


SEALED DOUBLE-RINGED INFILTROMETER DATA, DCF TEST

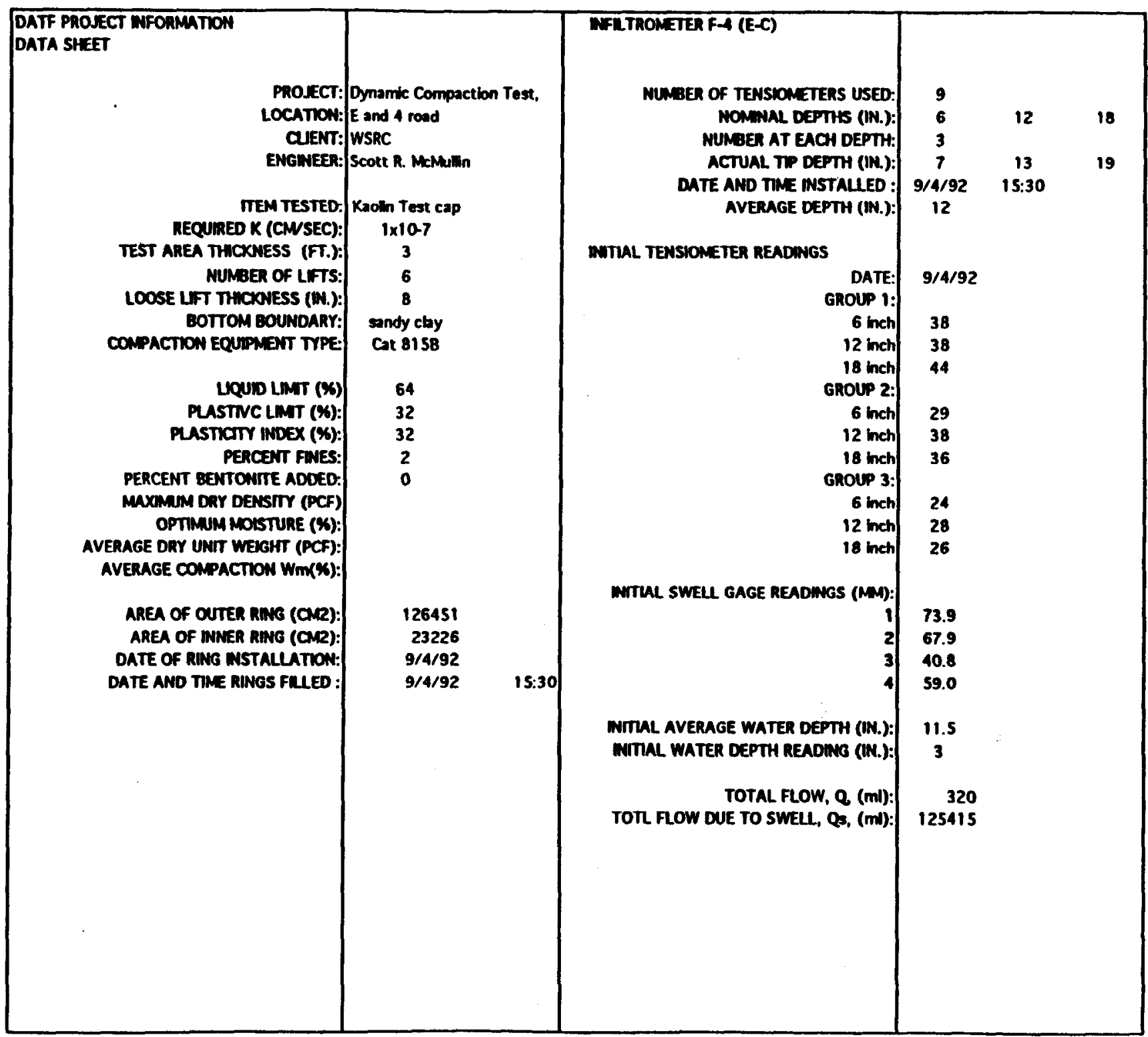




\begin{tabular}{|c|c|c|c|c|c|c|c|c|c|}
\hline \multirow{3}{*}{\multicolumn{4}{|c|}{$\begin{array}{l}\text { DATA SHEET FOR WATER BAGS } \\
\text { WHFUTROMETER F-4 (E-C) } \\
\text { |BAG CONNECTION AND DISCONNECTION }\end{array}$}} & \multirow{4}{*}{$\begin{array}{l}\text { PTERVAL } \\
\text { TWE }\end{array}$} & \multirow{2}{*}{\multicolumn{2}{|c|}{ BAG 1}} & \multirow{2}{*}{\multicolumn{2}{|c|}{ BAG 2 }} & \multirow{4}{*}{$\begin{array}{c}\text { MET } \\
\text { CHANGE } \\
\text { (I) }\end{array}$} \\
\hline & & & & & & & & & \\
\hline & & & & & \multirow{2}{*}{$\begin{array}{l}\text { WITAL } \\
\text { WESHT } \\
\text { (q) }\end{array}$} & \multirow{2}{*}{$\begin{array}{l}\text { FWAL } \\
\text { WEAHT } \\
\text { (q) }\end{array}$} & \multirow{2}{*}{$\begin{array}{l}\text { WITLAL } \\
\text { WERGHT } \\
\text { (n) }\end{array}$} & \multirow{2}{*}{$\begin{array}{l}\text { FWAL } \\
\text { WEKGHT } \\
\text { (q) }\end{array}$} & \\
\hline DATE ON & DATE OFF & TINE ON & TME OFF & & & & & & \\
\hline 4-Sep & • & $14: 15$ & - & • & 3411.3 & - & 3595.4 & - & . \\
\hline • & 10-Sep & - & 12:15 & 511200 & - & 2909.2 & - & 3206.3 & 891.2 \\
\hline 10-Sep & 14.Sep & $12: 45$ & $15: 15$ & 354600 & 2909.2 & 1537.1 & 3206.3 & 2057.8 & 2520.6 \\
\hline 14-Sep & • & 15:38 & • & • & 3417.1 & - & 3539.9 & - & - \\
\hline - & 16-Sep & $\cdot$ & 13:59 & 166860 & - & 2618.2 & - & 3150.2 & 1188.6 \\
\hline 16-Sep & 17-Sep & 15:36 & $14: 00$ & 80640 & 2618.2 & 2182.2 & 3150.2 & 3004.5 & 581.7 \\
\hline 17-Sep & - & $14: 45$ & • & - & 2182.2 & 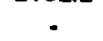 & 3004.5 & - & - \\
\hline- & 19-Sep & - & 10:33 & 157680 & - & 1998.9 & . & 2151.1 & 1036.7 \\
\hline 19-Sep & 21-Sep & $11: 38$ & $11: 59$ & 174060 & 1998.9 & 1249.0 & 2151.1 & 1799.4 & 1101.6 \\
\hline 21-Sep & 22-Sep & 13:46. & $13: 51$ & 86700 & 3329.7 & 2948.2 & 3404.4 & 3195.5 & 590.4 \\
\hline 22-5ep & 23-Sep & $14: 13$ & $11: 28$ & 76500 & 2948.2 & 2852.5 & 3195.5 & 2835.8 & 455.4 \\
\hline 23-Sep & 24-Sep & $11: 56$ & $11: 08$ & 83520 & 2852.5 & 2717.6 & 2835.8 & 2717.6 & 253.1 \\
\hline 24-Sep & 25-Sep & $12: 08$ & $13: 40$ & 91920 & 2566.9 & 2404.1 & 2566.9 & 2465.0 & 264.7 \\
\hline 25-Sep & 26-Sep & $14: 30$ & $11: 07$ & 74220 & 2404.1 & 1832.6 & 2465.0 & 2582.0 & 454.5 \\
\hline 26-Sep & 29-Sep & $11: 32$ & 13:57 & 267900 & 1832.6 & 1215.9 & 2582.0 & 1678.8 & 1519.9 \\
\hline 29-5ep & 30-sep & $14: 47$ & $14: 52$ & 86700 & 2500.3 & 2410.1 & 2653.4 & 2372.9 & 370.7 \\
\hline 30-Sep & $1-0<t$ & 15:19 & $13: 35$ & 80160 & 2410.1 & 2303.3 & 2372.9 & 2060.7 & 419.0 \\
\hline $1-0 \mathrm{ct}$ & $2-0 c t$ & $14: 08$ & 13:39 & 84660 & 2303.3 & 2129.6 & 2060.7 & 1901.4 & 333.0 \\
\hline $2-0 c t$ & $6-0<t$ & $14: 18$ & $8: 50$ & 325920 & 3231.5 & 2479.2 & 3185.4 & 2684.4 & 1253.3 \\
\hline 6-oct & 9-0ct & $9: 26$ & 12:55 & 271740 & 2479.2 & 2064.3 & 2684.4 & 2007.4 & 1091.9 \\
\hline 9-0ct & $13-0 \mathrm{ct}$ & $13: 20$ & $10: 32$ & 335520 & 2064.3 & 1096.3 & 2007.4 & 2287.1 & 688.3 \\
\hline 13-0ct & 16-0ct & $11: 08$ & $10: 09$ & 255660 & 2692.8 & 2845.9 & 2287.1 & 1688.3 & 445.7 \\
\hline 16-Oct & $20-0 \mathrm{ct}$ & $10: 43$ & 10:39 & 345360 & 2845.9 & 2383.3 & 2606.5 & 2539.5 & 529.6 \\
\hline $20-0 \mathrm{ct}$ & $23-0 \mathrm{ct}$ & $11: 17$ & 12:53 & 264960 & 2383.3 & 1375.6 & 2539.5 & 2264.8 & 1282.4 \\
\hline $23-0 \mathrm{ct}$ & $27-0 \mathrm{ct}$ & $13: 41$ & $8: 50$ & 328140 & 2682.5 & 1981.2 & 2264.8 & 2379.5 & 586.6 \\
\hline $27-0 c t$ & $30-0 \mathrm{ct}$ & $10: 30$ & 13:03 & 268380 & 2923.1 & 2609.6 & 2379.5 & 2172.6 & 520.4 \\
\hline $300 \mathrm{ct}$ & 3-Hov & $13: 43$ & $9: 01$ & 328680 & 2609.6 & 2419.2 & 2172.6 & 1750.6 & 612.4 \\
\hline 3-Hov & 6-Nov & $9: 29$ & 11:16 & 265620 & 2419.2 & 2214.0 & 1750.6 & 1556.8 & 399.0 \\
\hline 6-Nov & 10-Nov & $12: 13$ & 11:08 & 341700 & 2214.0 & 1841.2 & 2890.1 & 2675.7 & 587.2 \\
\hline 10-Alov & 13Hov & $12: 06$ & $10: 19$ & 252780 & 2751.8 & 2207.3 & 2675.7 & 2581.4 & 638.8 \\
\hline 13-Alov & 17- Hov & $10: 54$ & $10: 37$ & 344580 & 2207.3 & 2065.9 & 2581.4 & 2591.6 & 131.2 . \\
\hline 17-Nov & 20-Nov & $11: 12$ & 10:36 & 257040 & 2065.9 & 1313.3 & 2591.6 & 2682.1 & 662.1 \\
\hline 20-Nov & 25-Hov & $11: 19$ & $10: 30$ & 429060 & 2809.4 & 2233.0 & 2682.1 & 2521.3 & 737.2 \\
\hline 25-Nov & 4-Dec & $11: 16$ & $10: 20$ & 774240 & 2233.0 & 1583.6 & 2841.3 & 2736.9 & 753.8 \\
\hline 4-Dec & 18-Dec & $11: 10$ & $13: 52$ & 1219320 & 3229.8 & 2086.7 & 2736.7 & 2107.9 & 1771.9 \\
\hline 18-Dec & 23-Dec & $14: 23$ & $10: 39$ & 418560 & 2086.7 & 1736.6 & 2107.9 & 2179.4 & 278.6 \\
\hline 23-Dec & 31-Dec & $11: 11$ & $10: 48$ & 689820 & 3093.4 & 2866.2 & 2927.2 & 2400.6 & 753.8 \\
\hline 31-Dec & 8-jan & $11: 22$ & $13: 27$ & 698700 & 2866.2 & 2345.7 & 2400.6 & 2316.4 & 604.7 \\
\hline
\end{tabular}


SEALED DOUBLE-RINGED INFILTROMETER DATA, DCF TEST

\begin{tabular}{|c|c|c|c|c|c|c|c|c|c|}
\hline \multicolumn{10}{|c|}{$\begin{array}{l}\text { DATA SHEET FOR WATER DEPTH AND TEMPERATURE } \\
\text { WFU TROMETER F-4 (E-C) }\end{array}$} \\
\hline DATE & $\begin{array}{c}\text { START } \\
\text { WAT. DEPTH } \\
\text { READING } \\
\text { (W) } \\
\end{array}$ & $\begin{array}{l}\text { START } \\
\text { WATER } \\
\text { DEPTH } \\
\text { (ln.) }\end{array}$ & $\begin{array}{c}\text { END } \\
\text { WAT. DEPTH } \\
\text { READWG } \\
\text { (hn) }\end{array}$ & $\begin{array}{c}\text { END } \\
\text { WATER } \\
\text { DEPTH } \\
\text { (h) }\end{array}$ & $\begin{array}{c}\text { AVG. } \\
\text { WATER } \\
\text { DEPTH } \\
\text { (In) } \\
\end{array}$ & $\begin{array}{l}\text { START } \\
\text { WATER } \\
\text { TEMP } \\
\text { (OF) }\end{array}$ & $\begin{array}{l}\text { END } \\
\text { WATER } \\
\text { TEMP } \\
\text { (OF) } \\
\end{array}$ & $\begin{array}{c}\text { AVG. } \\
\text { WATER } \\
\text { TEMP } \\
\text { of } \\
\end{array}$ & $\begin{array}{c}\text { TEMP. } \\
\text { CHANGE } \\
\text { (OF) }\end{array}$ \\
\hline 5-Sep & 3.0 & 11.5 & 3.0 & 11.5 & 11.5 & 83 & 81 & 82 & -2 \\
\hline 10-Sep & 3.0 & 11.5 & 4.4 & 12.9 & 12.2 & 81 & 77 & 79 & -5 \\
\hline 14-Sep & 4.4 & 12.9 & 4.5 & 13.0 & 12.9 & 77 & 74 & 75 & -3 \\
\hline 15-Sep & 4.5 & 13.0 & 4.0 & 12.5 & 12.8 & 74 & 74 & 74 & 0 \\
\hline 16-Sep & 4.0 & 12.5 & 4.3 & 12.8 & 12.6 & 74 & 73 & 74 & -1 \\
\hline 17-Sep & 4.3 & 12.8 & 4.3 & 12.8 & 12.8 & 73 & 74 & 74 & 1 \\
\hline 18-Sep & 4.3 & 12.8 & 4.3 & 12.8 & 12.8 & 74 & 76 & 75 & 2 \\
\hline 19-Sep & 4.3 & 12.8 & 4.3 & 128 & 12.8 & 76 & 75 & 76 & -1 \\
\hline 21-Sep & 4.3 & 12.8 & 4.3 & 12.8 & 12.8 & 75 & 75 & 75 & 0 \\
\hline 22.Sep & 4.3 & 12.8 & 4.3 & 12.8 & 12.8 & 75 & 76 & 76 & 1 \\
\hline 23-Sep & 4.3 & 12.8 & 4.0 & 12.5 & 12.6 & 76 & 76 & 76 & 0 \\
\hline 24-Sep & 4.0 & 12.5 & 4.5 & 13.0 & 12.8 & 76 & 68 & 72 & -8 \\
\hline 25-Sep & 4.5 & 13.0 & 4.5 & 13.0 & 13.0 & 68 & 65 & 67 & -3 \\
\hline 26-Sep & 4.5 & 13.0 & 4.5 & 13.0 & 13.0 & 65 & 65 & 65 & 0 \\
\hline 29-Sep & 4.5 & 13.0 & 4.5 & 13.0 & 13.0 & 65 & 70 & 68 & 5 \\
\hline 30-5ep & 4.5 & 13.0 & 4.0 & 12.5 & 12.8 & 70 & 65 & 68 & -5 \\
\hline 1-oct & 4.0 & 12.5 & 3.5 & 12.0 & 12.3 & 65 & 63 & 64 & -2 \\
\hline $2-0 \mathrm{ce}$ & 3.5 & 12.0 & 3.5 & 12.0 & 12.0 & 63 & 61 & 62 & $\cdot-2$ \\
\hline 6-0ct & 3.5 & 12.0 & 4.3 & 12.8 & 12.4 & 61 & 60 & 61 & -1 \\
\hline 9-oct & 3.5 & 12.0 & 5.8 & 14.3 & 13.1 & 60 & 67 & 64 & 7 \\
\hline 13-Oet & 5.8 & 14.3 & 3.8 & 12.3 & 13.3 & 67 & 60 & 64 & -7 \\
\hline 16-0ct & 3.8 & 12.3 & 3.5 & 12.0 & 12.1 & 60 & 63 & 62 & 3 \\
\hline 20-0ct & 3.5 & 12.0 & 3.5 & 12.0 & 12.0 & 63 & 55 & 59 & -8 \\
\hline 23-Oct & 3.5 & 12.0 & 3.3 & 11.8 & 11.9 & 35 & 58 & 57 & 3 \\
\hline $27-0 c t$ & 3.3 & 11.8 & 3.3 & 11.8 & 11.8 & 58 & 58 & 58 & 0 \\
\hline $30-0 c t$ & 3.3 & 11.8 & 3.2 & 11.7 & 11.7 & 58 & 66 & 62 & 8 \\
\hline 3 Hov & 3.2 & 11.7 & 3.5 & 12.0 & 11.9 & 66 & 65 & 66 & -1 \\
\hline 6-Nov & 3.5 & 12.0 & 3.8 & 12.3 & 12.1 & 65 & 60 & 63 & -5 \\
\hline 10-Nov & 3.8 & 12.3 & 3.5 & 12.0 & 12.1 & 60 & 49 & 55 & -11 \\
\hline 13-Nov & 3.5 & 12.0 & 3.8 & 12.3 & 12.1 & 49 & 58 & 54 & 9 \\
\hline 17-Nov & 3.8 & 12.3 & 3.5 & 12.0 & 12.1 & 58 & 47 & 53 & -11 \\
\hline 20-Nov & 3.5 & 12.0 & 3.5 & 12.0 & 12.0 & 47 & 51 & 49 & 4 \\
\hline 25-Nov & 3.5 & 12.0 & 4.0 & 12.5 & 12.3 & 51 & 59 & 55 & 8 \\
\hline 4-Dec & 4.0 & 12.5 & 3.3 & 11.8 & 12.1 & 59 & 46 & 53 & -13 \\
\hline 18-Doc & 3.3 & 11.8 & 3.8 & 12.3 & 12.0 & 46 & 46 & 46 & 0 \\
\hline 23-Dec & 3.8 & 12.3 & 3.5 & 12.0 & 12.1 & 46 & 46 & 46 & 0 \\
\hline 31-Dec & 3.5 & 12.0 & 3.5 & 12.0 & 12.0 & 46 & 46 & 46 & 0 \\
\hline 8-bn & 3.5 & 12.0 & 4.0 & 12.5 & 12.3 & 46 & 58 & 52 & 12 \\
\hline
\end{tabular}




\begin{tabular}{|c|c|c|c|c|c|c|c|c|c|c|c|c|c|}
\hline \multicolumn{14}{|c|}{ DATA SHEET FOR TENSIOMETER READINGS } \\
\hline \multirow[b]{2}{*}{ DATE } & \multirow[b]{2}{*}{ DAY } & \multicolumn{3}{|c|}{ (ILC) GROUP NUMBER I } & \multicolumn{3}{|c|}{ GROUP MUMMER 2} & \multicolumn{3}{|c|}{ GROUP MUMBER 3} & \multicolumn{3}{|c|}{$\begin{array}{c}\text { AVERAGE } \\
\text { TENSWOMETER READHGS }\end{array}$} \\
\hline & & $\begin{array}{l}\text { 6MCH } \\
\text { (eb) }\end{array}$ & $\begin{array}{l}12 \text { NC } \\
\text { (cb) }\end{array}$ & $\begin{array}{l}18 \text { WCH } \\
\text { (cb) }\end{array}$ & $\begin{array}{l}6 \text { WCH } \\
\text { (cb) }\end{array}$ & $\begin{array}{c}12 \mathrm{WCH} \\
\text { (cb) }\end{array}$ & $\begin{array}{c}18 \text { WCH } \\
\text { (cb) }\end{array}$ & $\begin{array}{l}6 \text { WOH } \\
\text { (cb) }\end{array}$ & $\begin{array}{l}12 \text { mat } \\
\text { (cb) }\end{array}$ & $\begin{array}{c}18 \text { WCH } \\
\text { (cb) }\end{array}$ & $\begin{array}{l}6 \text { WCH } \\
\text { (cb) }\end{array}$ & $\begin{array}{c}12 \text { WCH } \\
\text { (cb) }\end{array}$ & $\begin{array}{c}18 \text { WCA } \\
\text { (cb) }\end{array}$ \\
\hline S-Sep & 1 & 28 & 26 & 24 & 28 & 39 & 32 & 34 & 39 & 32 & 30 & 35 & 29 \\
\hline 10-Sep & 6 & 6 & 16 & 18 & 2 & 17 & 23 & 6 & 18 & 21 & 5 & 17 & 21 \\
\hline 14-Sep & 10 & 0 & 10 & 14 & 0 & 10 & 14 & 0 & 11 & 14 & 0 & 10 & 14 \\
\hline 15-sep & 11 & 0 & 10 & 14 & 0 & 8 & 16 & 0 & 10 & 14 & 0 & 9 & is \\
\hline 16-Sep & 12 & 0 & 9 & 14 & 0 & 8 & 16 & 0 & 8 & 13 & 0 & 8 & 14 \\
\hline 17-Sep & 13 & 0 & 8 & 12 & 0 & 6 & 15 & 0 & 8 & 10 & 0 & 7 & 12 \\
\hline 18-sep & 14 & $\mathbf{0}$ & 8 & 12 & 0 & 4 & 14 & 0 & 7 & 8 & 0 & 6 & 11 \\
\hline 19-5ep & 15 & 0 & 5 & 10 & 0 & 2 & 13 & 0 & 4 & 8 & 0 & 4 & 10 \\
\hline 21-Sep & 17 & o & 4 & 10 & 0 & 0 & 12 & 0 & 2 & 4 & 0 & 2 & 9 \\
\hline 22-Sep & 18 & 0 & 4 & 11 & o & 0 & 13 & o & 2 & 4 & 0 & 2 & 9 \\
\hline 23-Sep & 19 & $\mathbf{0}$ & 4 & 9 & 0 & 0 & 10 & o & $i$ & 0 & 0 & 2 & 6 \\
\hline 24-Sep & 20 & 0 & 2 & 8 & 0 & 0 & 8 & 0 & 0 & 0 & 0 & 1 & 5 \\
\hline 25-Sep & 21 & 0 & 0 & 10 & 0 & 0 & 10 & 0 & 0 & 0 & 0 & 0 & 7 \\
\hline 26-Sep & 22 & 0 & 0 & 10 & 0 & 0 & 10 & 0 & 0 & 0 & 0 & 0 & 7 \\
\hline 29-Sep & 25 & 0 & o & 8 & 0 & 0 & 8 & 0 & 0 & 0 & 0 & 0 & 5 \\
\hline 30-sep & 26 & 0 & 0 & 8 & 0 & 0 & 8 & 0 & 0 & 0 & 0 & 0 & 5 \\
\hline 1-0ct & 27 & 0 & 0 & 8 & 0 & 0 & 8 & o & o & 0 & 0 & 0 & 5 \\
\hline $2-0 \mathrm{ct}$ & 28 & 0 & 2 & 10 & 0 & o & 10 & 0 & 0 & 0 & 0 & 1 & 7 \\
\hline 6-0at & 32 & o & o & 7 & 0 & 0 & 4 & 0 & 0 & 0 & o & 0 & 4 \\
\hline $9-0 \mathrm{t} t$ & 35 & o & 2 & - & 0 & o & 8 & 0 & 0 & 0 & 0 & 1 & 5 \\
\hline 13-Oct & 39 & 0 & 0 & 4 & 0 & 0 & 4 & 0 & 0 & 0 & 0 & 0 & 3 \\
\hline $16-\infty \mathrm{ct}$ & 42 & 0 & 0 & 3 & 0 & 0 & 2 & 0 & 0 & 0 & 0 & 0 & 2 \\
\hline $20-0 \mathrm{et}$ & 46 & 0 & 0 & 4 & 0 & 0 & 4 & 0 & 1 & 0 & 0 & 0 & 3 \\
\hline 23-Oct & 49 & D & 0 & 8 & 0 & 0 & 8 & 0 & 0 & 0 & 0 & 0 & 5 \\
\hline $27-0 \mathrm{ct}$ & 53 & 0 & 0 & 4 & 0 & 0 & 4 & 0 & 0 & 0 & 0 & 0 & 3 \\
\hline $30-0<t$ & 56 & 0 & 2 & 4 & o & o & 5 & 0 & 0 & 0 & 0 & 1 & 3 \\
\hline 3-Mor & 60 & 0 & 0 & 2 & 0 & 0 & 2 & 0 & 0 & 2 & 0 & 0 & 2 \\
\hline 6-Nov & 63 & 0 & 0 & 2 & 0 & 0 & 2 & 0 & 0 & 0 & 0 & 0 & $i$ \\
\hline 10+Nov & 67 & 0 & 0 & 7 & o & o & 7 & 0 & 0 & 0 & o & 0 & 5 \\
\hline 13+Hov & 70 & 0 & 0 & 4 & o & 0 & 2 & 0 & 0 & 0 & 0 & 0 & 2 \\
\hline 17 Hov & 74 & 0 & 0 & 4 & o & 0 & 3 & 0 & 0 & 0 & 0 & 0 & 2 \\
\hline 20-Nov & 77 & 0 & 0 & 6 & 0 & 0 & 4 & 0 & 0 & 0 & 0 & 0 & 3 \\
\hline 25 -Hov & 82 & 0 & 0 & 2 & 0 & 0 & 0 & 0 & 0 & 0 & 0 & 0 & 1 \\
\hline 4-Dec & 91 & 0 & 0 & 6 & 0 & 0 & 6 & 0 & 0 & 0 & 0 & 0 & 4 \\
\hline 18-Dec & 105 & 0 & o & 2 & 0 & 0 & 4 & 0 & 0 & 0 & 0 & 0 & 2 \\
\hline 23-Dec & 110 & 0 & 0 & 2 & 0 & 0 & 2 & 0 & 0 & 0 & D & 0 & 1 \\
\hline 31-Dec & 118 & 0 & 0 & 0 & 0 & 0 & 0 & 0 & 0 & 0 & 0 & 0 & 0 \\
\hline 8.tan & 126 & 0 & 0 & 0 & 0 & 0 & 0 & 0 & 0 & 0 & 0 & 0 & 0 \\
\hline
\end{tabular}


SEALED DOUBLE-RINGED INFILTROMETER DATA, DCF TEST

\begin{tabular}{|c|c|c|c|c|c|c|c|c|c|c|c|c|c|c|}
\hline \multicolumn{8}{|c|}{$\begin{array}{l}\text { DATA SHEET FOR SWELL DATA } \\
\text { INFL TROMETER F-A (E-C) }\end{array}$} & \multicolumn{7}{|c|}{$\begin{array}{l}\text { CALCULATON SHEET FOR FLOW-AATE AND ADUUSTMETT VALUES } \\
\text { WFRTROWETER F-A (E-C) }\end{array}$} \\
\hline \multirow{2}{*}{$\begin{array}{l}\text { READWG } \\
\text { DATE }\end{array}$} & \multirow[b]{2}{*}{$\begin{array}{l}\text { READWN } \\
\text { TME }\end{array}$} & \multirow[b]{2}{*}{$\begin{array}{l}\text { - DAY } \\
\text { MUMBER } \\
\end{array}$} & \multicolumn{4}{|c|}{ SWELL MEORMMTION } & \multirow{2}{*}{$\begin{array}{l}\text { (mm) } \\
\text { AVG. } \\
\text { SWEL }\end{array}$} & \multirow[b]{2}{*}{$\begin{array}{l}\text { DAY } \\
\text { NO. }\end{array}$} & \multirow[b]{2}{*}{$\underset{(m)}{Q}$} & \multirow[b]{2}{*}{$\begin{array}{l}\text { AVG } \\
\text { DAY wo. }\end{array}$} & \multirow[b]{2}{*}{$\begin{array}{c}1 \\
(\mathrm{~cm} / 20 \mathrm{ec})\end{array}$} & \multirow{2}{*}{\begin{tabular}{|c|} 
EST. FLOW \\
DUE TO \\
TEMP. CH6. \\
(m)
\end{tabular}} & \multirow{2}{*}{$\begin{array}{l}\text { Fof } \\
\text { TOTAL } \\
\text { Fow } \\
\text { (mi) }\end{array}$} & \multirow{2}{*}{$\begin{array}{c}\text { Q } \\
\text { WHEN BAG } \\
\text { WAS OFF } \\
\text { (m) }\end{array}$} \\
\hline & & & si & 52 & s3 & s4 & & & & & & & & \\
\hline S-Sep & $9: 10$ & 1 & 74.0 & 67.8 & 40.8 & 59.0 & 0.00 & 1 & - & . & - & -33.3 & . & - \\
\hline 10-Sepp & 11:15 & 6 & 75.0 & 78.4 & 73.9 & 90.1 & 18.95 & 6 & 691.2 & 3 & $7.51 E-08$ & -75.0 & 8.4 & 8 \\
\hline 14-Sep & $12: 30$ & 10 & 59.8 & 49.6 & 52.8 & 75.5 & -0.98 & 10 & 2520.6 & 8 & $3.06 E-07$ & -41.7 & 1.7 & 10 \\
\hline 15-Sop & 16:15 & 11 & 69.4 & 55.6 & 32.5 & 73.7 & 2.40 & 11 & - & . & 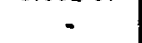 & 0.0 & $\cdot$ & 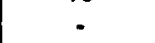 \\
\hline 16-Sep & 16:50 & 12 & 88.7 & 56.2 & 33.0 & 74.4 & 2.68 & 12 & 1188.6 & 11 & $3.07 E-07$ & -16.7 & 1.4 & 42 \\
\hline 17-Sep & 14:54 & 13 & 88.7 & 56.7 & 32.8 & 75.4 & 3.00 & 13 & 581.7 & 12 & 3.11E-07 & 16.7 & 2.9 & 10 \\
\hline 18-Sep & $16: 54$ & 14 & 89.5 & 61.1 & 37.3 & 75.0 & 5.33 & 14 & $\cdot$ & & & 33.3 & $\cdot$ & - \\
\hline 19-Sep & $11: 21$ & 15 & 90.1 & 60.2 & 36.6 & 75.6 & 5.23 & 15 & 1036.7 & 14 & $2.83 E-07$ & -16.7 & 1.6 & 25 \\
\hline 21-Sep & 12:34 & 17 & 90.0 & 59.9 & 36.4 & 74.7 & 4.85 & 17 & 1101.6 & 16 & $2.72 E-07$ & 0.0 & 0.0 & 42 \\
\hline 22-Sep & 15:20 & 18 & 90.8 & 60.3 & 36.9 & 75.2 & 5.40 & 18 & 590.4 & 17 & $2.93 E-07$ & 16.7 & 2.8 & 8 \\
\hline 23-Sep & 10:56 & 19 & 90.2 & 59.9 & 36.9 & 75.0 & 5.10 & 19 & 455.4 & 18 & $2.56 \mathrm{E}-07$ & 0.0 & 0.0 & 8 \\
\hline 24-5ep & $11: 45$ & 20 & 90.5 & 59.8 & 37.4 & 75.5 & 5.40 & 20 & 253.1 & 19 & 1.30E-07 & -133.3 & 52.7 & 11 \\
\hline 25-Sep & 14:58 & 21 & 91,0 & 61.1 & 38.4 & 76.2 & 6.28 & 21 & 264.7 & 20 & $1.24 E-07$ & -50.0 & 18.9 & 14 \\
\hline 26-5ep & $10: 47$ & 22 & 92.0 & 61.4 & 38.4 & 76.7 & 6.73 & 22 & 454.5 & 21 & 2.64E-07 & 0.0 & 0.0 & 9 \\
\hline 29-Sep & 13:42 & 25 & 92.9 & 63.4 & 40.0 & 77.1 & 7.95 & 25 & 1519.9 & 23 & 2.44E-07 & 83.3 & 5.5 & 15 \\
\hline 30-Sep & $14: 00$ & 26 & 92.7 & 62.3 & 39.1 & 77.4 & 7.48 & 26 & 370.7 & 25 & $1.84 E-07$ & -83.3 & 22.5 & 8 \\
\hline $1-0 z t$ & 15:14 & 27 & 92.8 & 62.3 & 39.2 & 77.3 & 7.50 & 27 & 419.0 & 26 & 2.25E-07 & -33.3 & 8.0 & 9 \\
\hline $2-0 c t$ & 13:19 & 28 & 92.6 & 62.1 & 38.9 & 77.4 & 7.35 & 28 & 333.0 & 27 & $1.69 E-07$ & -33.3 & 10.0 & 9 \\
\hline $6-0 \mathrm{ct}$ & 10:13 & 32 & 96.1 & 68.7 & 44.6 & 80.6 & 12.10 & 32 & 1253.3 & 30 & $1.66 E-07$ & -16.7 & 1.3 & 8 \\
\hline 9-0et & $12: 25$ & 35 & 96.6 & 66.6 & 43.6 & 82.4 & 11.90 & 35 & 1091.9 & 33 & $1.73 E-07$ & 116.7 & 10.7 & 5 \\
\hline 13-0et & $10: 15$ & 39 & 97.8 & 67.6 & 43.4 & 84.2 & 12.85 & 39 & 688.3 & 37 & 8.83E-08 & -116.7 & 16.9 & 4 \\
\hline $16-0 \mathrm{ct}$ & $8: 35$ & 42 & 92.8 & 63.0 & 44.7 & 81.8 & 10.18 & 42 & 445.7 & 40 & 7.51E-08 & 50.0 & 11.2 & 3 \\
\hline $200 \mathrm{ct}$ & 11:21 & 16 & 93.0 & 62.7 & 44.5 & 82.4 & 10.25 & 46 & 529.6 & 44 & 6.60E-08 & -133.3 & 25.2 & 7 \\
\hline $23.0 \mathrm{ct}$ & 13:30 & 49 & 93.4 & 62.8 & 43.3 & 81.6 & 9.88 & 49 & 1282.4 & 47 & $2.08 E-07$ & 50.0 & 3.9 & 10 \\
\hline $27-0 \mathrm{ct}$ & $10: 25$ & 53 & 92.6 & 61.4 & 12.8 & 80.3 & 8.93 & 53 & 586.6 & 51 & 7.70E-08 & 0.0 & 0.0 & 11 \\
\hline $30-0 \mathrm{ct}$ & 11:36 & 56 & 92.7 & 60.9 & 41.9 & 80.3 & 8.55 & 56 & 520.4 & 54 & $8.35 E-08$ & 133.3 & 25.6 & 5 \\
\hline 3-Hov & $8: 42$ & 60 & 93.5 & 61.2 & 42.3 & 79.9 & 8.83 & 60 & 612.4 & 58 & 8.02E-08 & -16.7 & 2.7 & 3 \\
\hline 6-Nov & 11:00 & 63 & 93.6 & 63.4 & 43.2 & 81.5 & 10.03 & 63 & 399.0 & 61 & $6.47 E-08$ & $-83,3$ & 20.9 & 6 \\
\hline 10-Nov & 10.45 & 67 & 93.4 & 62.3 & 42.9 & 81.0 & 9.50 & 67 & 587.2 & 65 & 7.40E-08 & -183.3 & 31.2 & 7 \\
\hline 13-Nov & 10:04 & 70 & 96.5 & 68.3 & 50.2 & 85.3 & 14.68 & 70 & 638.8 & 68 & $1.09 E-07$ & 150.0 & 23.5 & 3 \\
\hline 17-Nov & $10: 59$ & 74 & 90.5 & 65.5 & 45.7 & 84.2 & 11.08 & 74 & 131.2 & 72 & $1.64 E-08$ & -183.3 & 139.7 & 3 \\
\hline 20-Nov & $10: 20$ & $n$ & 93.0 & 64.5 & 47.5 & 79.4 & 10.70 & 77 & 662.1 & 75 & I.11E-07 & 66.7 & 10.1 & 6 \\
\hline 25-Nov & $10: 12$ & 82 & 104.2 & 75.5 & 60.0 & 95.6 & 23.43 & 82 & 737.2 & 79 & 7.40E-08 & 133.3 & 18.1 & 4 \\
\hline 4-Dec & 10:05 & 91 & 97.8 & 68.2 & 50.4 & 86.0 & 15.20 & 91 & 753.8 & 86 & 4.19E-08 & -216.7 & 28.7 & 4 \\
\hline 18-Dec & 10.05 & 105 & 97.8 & 68.2 & 50.4 & 86.0 & 15.20 & 105 & 1771.9 & 98 & $6.26 \mathrm{E}-08$ & 0.0 & 0.0 & 2 \\
\hline 23-000 & 10.05 & 110 & 97.8 & 68.2 & 50.4 & 86.0 & 15.20 & 110 & 278.6 & 107 & 2.87E-08 & 0.0 & 0.0 & 2 \\
\hline 31-Dec & $10: 05$ & 118 & 97.8 & 68.2 & 50.4 & 86.0 & 15.20 & 118 & 753.8 & 114 & $4.70 E-08$ & 0.0 & 0.0 & 2 \\
\hline 8- - bn & 10.05 & 126 & 97.8 & 68.2 & 50.4 & 86.0 & 15.20 & 126 & 604.7 & 122 & $3.73 E-08$ & 200.0 & 33.1 & \\
\hline
\end{tabular}




\begin{tabular}{|c|c|c|c|c|c|c|c|c|}
\hline \multicolumn{9}{|c|}{$\begin{array}{l}\text { CALCULATION SHEET FOR HYORAULC CONDUCTVIVIT } \\
\text { WFR TROMEIER D-1 (E-C) }\end{array}$} \\
\hline DAY NO. & $\begin{array}{c}\times 10.7 \\
1 \\
(\mathrm{~cm} / 200)\end{array}$ & $\begin{array}{l}\text { WATER } \\
\text { DEPTH } \\
\text { (b) }\end{array}$ & $\begin{array}{c}\text { W. FRONT } \\
\text { DEPTH } \\
(\text { (I) }\end{array}$ & GRADIENT & DAY MO. & 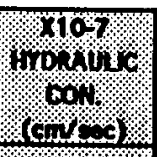 & $\begin{array}{c}x 10.7 \\
\text { SWELl } \\
1 \\
(\mathrm{~cm} / \mathrm{sec}) \\
\end{array}$ & $\begin{array}{l}6107 \\
6010\end{array}$ \\
\hline - & - & 11.50 & . & . & . & 8. & . & .. \\
\hline 6 & 0.8 & 12.18 & 4.37 & 3.79 & 6 & 0.2 & 0.75 & 8.20 \\
\hline 10 & 3.1 & 12.93 & 7.41 & 2.75 & 10 & 6 & 3.06 & W. \\
\hline - & - & 12.75 & • & - & - & & $\cdot$ & \\
\hline 12 & 3.1 & 12.63 & 10.33 & 2.22 & 12 & 189 & 3.07 & 81.6 \\
\hline 13 & 3.1 & 12.75 & 3.11 & 5.09 & 13 & 0.6 & 3.11 & $0.6 \%$ \\
\hline - & $\cdot$ & 12.75 & • & • & - & 19. & . & \\
\hline 15 & 2.8 & 12.78 & 3.56 & 4.59 & 15 & $0.6 \%$ & 2.83 & 8.62. \\
\hline 17 & 2.7 & 12.78 & 4.05 & 4.15 & 17 & $0 \%$ & 2.72 & 066. \\
\hline 18 & 2.9 & 12.75 & 10.80 & 2.18 & 18 & 13. & 2.93 & 831. \\
\hline 19 & 2.6 & 12.63 & 11.29 & 2.12 & 19 & 112 & 2.56 & \% 1 . \\
\hline 20 & 1.3 & 12.75 & 11.91 & 2.07 & 20 & 8.6 & 1.30 & 603. \\
\hline 21 & 1.2 & 13.00 & 12.59 & 2.03 & 21 & 8.6 & 1.24 & 061 . \\
\hline 22 & 2.6 & 13.00 & 13.08 & 1.99 & 22 & 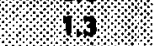 & 2.64 & 1332 \\
\hline 25 & 2.4 & 13.00 & 14.96 & 1.87 & 25 & 113 & 2.44 & 301. \\
\hline 26 & 1.8 & 12.75 & 15.56 & 1.82 & 26 & 810 & 1.84 & 101. \\
\hline 27 & 2.3 & 12.25 & 16.19 & 1.76 & 27 & 113. & 2.25 & 128 \\
\hline 28 & 1.7 & 12.00 & 16.75 & 1.72 & 28 & 10. & 1.69 & 8.9. \\
\hline 32 & 1.7 & 12.38 & 19.07 & 1.65 & 32 & 10 & 1.66 & 800. \\
\hline 35 & 1.7 & 13.13 & 20.92 & 1.63 & 35 & 61\%. & 1.73 & 106 \\
\hline 39 & 0.9 & 13.25 & 23.27 & 1.57 & 39 & $00 \%$ & 0.88 & 0.36. \\
\hline 42 & 0.8 & 12.13 & 25.03 & 1.48 & 12 & 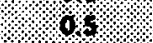 & 0.75 & $0.51 \%$ \\
\hline 46 & 0.7 & 12.00 & 27.50 & 1.44 & 46 & $0.9 \%$ & 0.66 & 6.10. \\
\hline 49 & 2.1 & 11.88 & 29.35 & 1.40 & 49 & 16 & 2.08 & \% \\
\hline 53 & 0.8 & 11.75 & 31.67 & 1.37 & 53 & 6.6 & 0.77 & 856 \\
\hline 56 & 0.8 & 11.74 & 33.50 & 1.35 & 56 & 0.6. & 0.83 & 802 \\
\hline 60 & 0.8 & 11.87 & 35.83 & 1.33 & 60 & 0.6 & 0.80 & 060 \\
\hline 63 & 0.6 & 12.13 & 37.69 & 1.32 & 63 & 0.3. & 0.65 & 0.9. \\
\hline 67 & 0.7 & 12.13 & 40.08 & 1.30 & 67 & 8.8. & 0.74 & $85 \%$ \\
\hline 70 & 1.1 & 12.13 & 41.86 & 1.29 & 70 & (6.). & 1.09 & 0.01 \\
\hline 74 & 0.2 & 12.13 & 44.29 & 1.27 & 74 & $0 \%$ & 0.16 & 0.13 \\
\hline 77 & 1.1 & 12.00 & 46.07 & 1.26 & 77 & 0.9 & 1.11 & 0.80 \\
\hline 82 & 0.7 & 12.25 & 49.07 & 1.25 & 82 & 0.6 & 0.74 & 0.59 \\
\hline 91 & 0.4 & 12.13 & 54.46 & 1.22 & 91 & 0.3. & 0.42 & 0314 \\
\hline 105 & 0.6 & 12.00 & 62.86 & 1.19 & 105 & 0.5 & 0.63 & 0.53 \\
\hline 110 & 0.3 & 12.13 & 65.86 & 1.18 & 110 & 0.2 & 0.29 & 821 \\
\hline 118 & 0.5 & 12.00 & 70.66 & 1.17 & 118 & $0 . \%$ & 0.47 & 0.10 \\
\hline 126 & 0.4 & 12.25 & 75.46 & 1.16 & 126 & 0.3 & 0.37 & \\
\hline
\end{tabular}




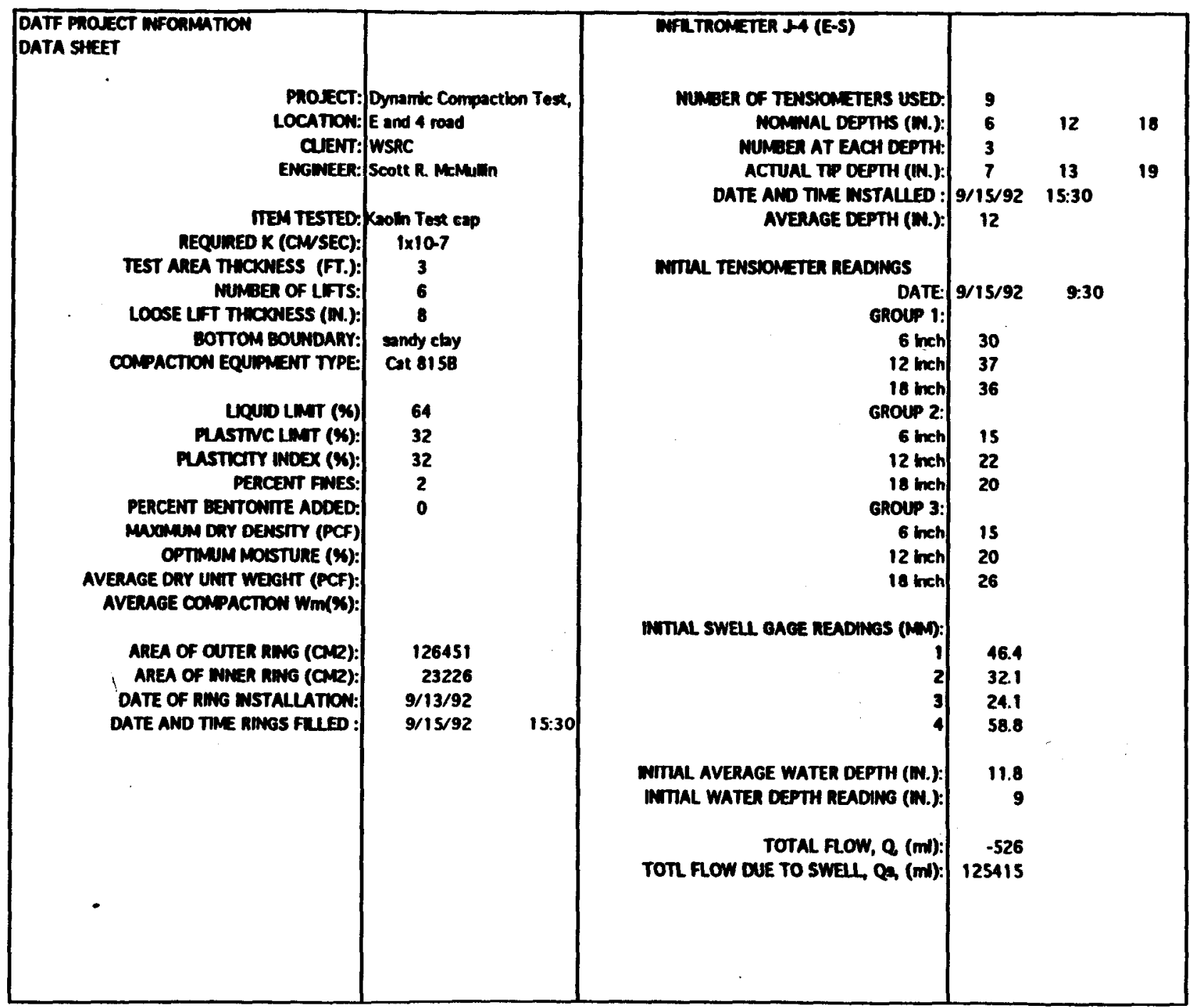




\begin{tabular}{|c|c|c|c|c|c|c|c|c|c|}
\hline \multicolumn{10}{|c|}{$\begin{array}{l}\text { DATA SHEFT FON WATEN BAGS } \\
\text { WFUTROMETER H } \\
\end{array}$} \\
\hline \multirow{2}{*}{\multicolumn{4}{|c|}{ BAG CONMECTION ANO DESCONNECTION }} & \multirow{3}{*}{$\begin{array}{c}\text { t } \\
\text { WTERNAL } \\
\text { TIME }\end{array}$} & \multicolumn{2}{|c|}{ BAG I } & \multicolumn{2}{|c|}{ BAG 2} & \multirow{3}{*}{$\begin{array}{c}\text { MET } \\
\text { CHANGE } \\
(9)\end{array}$} \\
\hline & & & & & \multirow{2}{*}{$\begin{array}{l}\text { Minhal } \\
\text { Weat } \\
\text { (0) }\end{array}$} & \multirow{2}{*}{$\begin{array}{c}\text { FNAL } \\
\text { WEIGHT } \\
(0)\end{array}$} & \multirow{2}{*}{$\begin{array}{c}\text { MNIIAL } \\
\text { WEGMT } \\
(())\end{array}$} & \multirow{2}{*}{$\begin{array}{l}\text { FNAL } \\
\text { WEXGHT } \\
\text { (q) }\end{array}$} & \\
\hline DATE ON & DATE OFF & IME ON & TIE O.FF & & & & & & \\
\hline - & - & - & - & - & - & . & - & - & - \\
\hline 16-Sop & 17-5ep & 15:34 & 13:59 & 80700 & 3104.5 & 2641.2 & 2987.2 & 2997.0 & 453.5 \\
\hline 17.Sep & - & $14: 43$ & $\cdot$ & $\cdot$ & 2641.2 & - & 2997.0 & $\cdot$ & - \\
\hline- & 19-Sep & $\cdot$ & 10.32 & 157740 & $\cdot$ & 2266.4 & $\cdot$ & 2533.7 & $\mathbf{8 3 8 . 1}$ \\
\hline 19Sep & 21-Sep & $11: 40$ & $11: 58$ & 173880 & 2266.4 & 1757.3 & 2533.7 & 2152.1 & 890.7 \\
\hline 21-Sep & 22-Sep & 13:44 & 13:54 & 87000 & 2900.0 & 2556.7 & 2152.1 & 2026.3 & 469.1 \\
\hline 22-Sep & 23-Sep & $14: 11$ & 11:26 & 76500 & 2556.7 & 1941.9 & $\begin{array}{l}2026.3 \\
21111\end{array}$ & 2111.1 & 530.0 \\
\hline $\begin{array}{l}\text { 23-Sep } \\
24-\text { Sep }\end{array}$ & $\begin{array}{l}\text { 24-Sep } \\
25-\text { Sep }\end{array}$ & $\begin{array}{l}11: 58 \\
12: 06\end{array}$ & 11:06 & 83280 & 1941.9 & $\begin{array}{l}1665.6 \\
2436.7\end{array}$ & $\begin{array}{l}2111.1 \\
2089.4\end{array}$ & $\begin{array}{l}2089.4 \\
2172.3\end{array}$ & 298.0 \\
\hline $\begin{array}{l}\text { 24-Sep } \\
\text { 25-Sep }\end{array}$ & $\begin{array}{l}\text { 25-Sep } \\
26-5 e p\end{array}$ & $\begin{array}{l}12: 06 \\
13: 28\end{array}$ & $\begin{array}{l}13: 39 \\
11: 06\end{array}$ & 91980 & 3094.4 & $\begin{array}{l}2436.7 \\
2435.5\end{array}$ & 2172.3 & $\begin{array}{l}2172.3 \\
1760.0\end{array}$ & $\begin{array}{r}574.8 \\
413.5\end{array}$ \\
\hline 26-Sep & 29-Sep & $11: 31$ & $13: 57$ & 267960 & 2435.5 & 2217.4 & 1760.0 & 751.1 & 1227.0 \\
\hline 29-Sep & 30-Sep & $14: 46$ & $14: 53$ & 86820 & 2217.4 & 2126.3 & 2475.6 & 2136.6 & 430.1 \\
\hline 30-sep & 1-0ct & 15:20 & $13: 34$ & 80040 & 2126.3 & 2120.4 & 2136.6 & 1817.3 & 325.2 \\
\hline $1-0 c t$ & $2-0 \mathrm{ct}$ & 14:06 & 13:38 & 84720 & 2120.4 & 1800.4 & 1817.3 & 1826.7 & 310.6 \\
\hline $2-0 \mathrm{ct}$ & 6-Oct & 14:16 & $6: 49$ & 325980 & 2752.7 & 2308.3 & 2788.6 & 2208.2 & 1024.8 \\
\hline $6-0<t$ & 9-0ct & 9:25 & $12: 53$ & 271680 & 2308.3 & 1675.2 & 2208.2 & 1891.8 & 949.5 \\
\hline 9-0<t & 13-Oct & 13:18 & 10.31 & 335580 & 2360.0 & 2203.8 & 2404.0 & 2049.6 & 510.6 \\
\hline 13-0et & 16-0ct & 11:06 & 10.08 & 255720 & 2203.8 & 1854.2 & 2049.6 & 1789.0 & 610.2 \\
\hline 16-Oet & 20-0et & $10: 41$ & 10.38 & 345420 & 2382.4 & 2370.5 & 2499.4 & 2123.4 & 387.9 \\
\hline 20-Oct & 23-Oct & $11: 15$ & $12: 51$ & 264960 & 2370.5 & 2225.9 & 2123.4 & 1568.7 & 699.3 \\
\hline 23-Oet & 27-Oet & $13: 38$ & $8: 45$ & 328020 & 2225.9 & 1837.3 & 2502.0 & 2221.0 & 669.6 \\
\hline 27 Oet & $30-0 \mathrm{ct}$ & 10.20 & $13: 01$ & 268860 & 2456.8 & 1945.5 & 2221.0 & 2166.0 & 566.3 \\
\hline $30-0 \mathrm{et}$ & 3-Hov & $13: 41$ & $8: 58$ & 328620 & 2366.0 & 2147.9 & 2166.0 & 2181.4 & 202.7 \\
\hline 3-Nov & 6-tlov & $9: 28$ & 11:15 & 265620 & 2147.9 & 2088.9 & 2181.4 & 2074.6 & 165.8 \\
\hline GNor & 10-ttov & $12: 11$ & 11:06 & 341700 & 2008.9 & 1908.0 & 2074.6 & 1708.2 & 547.3 \\
\hline 10-N100 & 13-Nov & $12: 04$ & 10.18 & 252840 & 2659.4 & 2005.6 & 2497.2 & 2267.1 & 883.9 \\
\hline 13-Nov & 17- Nov & 10.53 & 10.36 & 344580 & 2005.6 & 1985.5 & 2267.1 & 2021.2 & 266.0 \\
\hline 17-Nov & 20-Nov & $11: 11$ & 10.35 & 257040 & 1985.5 & 1756.2 & 2021.2 & 1710.6 & 539.9 \\
\hline 20-10v & 25-Nov & $11: 17$ & 10.27 & 429000 & 2787.8 & 2001.1 & 2446.4 & 1985.0 & 1248.1 \\
\hline 25-Hov & 4-Dec & $11: 13$ & 10.18 & 774300 & 2625.4 & 2244.0 & 2822.2 & 2435.3 & 768.3 \\
\hline 4-Dec & 18-Dec & 11:05 & 13:51 & 1219560 & 2244.0 & 2190.5 & 2435.3 & 2043.2 & 445.6 \\
\hline 18-Dec & 23-Dec & $14: 21$ & 10.38 & 418620 & 2190.5 & 2081.6 & 2043.2 & 2820.1 & -668.0 \\
\hline 23-Dec & 31-Dec & $11: 10$ & $10: 46$ & 689760 & 2081.6 & 1988.9 & 2820.1 & 2451.3 & 461.5 \\
\hline 31-Dec & 8-tan & $11: 20$ & $13: 29$ & 698940 & 1988.9 & 1387.9 & 2451.3 & 2451.5 & 600.8 \\
\hline
\end{tabular}


SEALED DOUBLE-RINGED INFILTROMETER DATA, DCF TEST

\begin{tabular}{|c|c|c|c|c|c|c|c|c|c|}
\hline \multicolumn{10}{|c|}{$\begin{array}{l}\text { DATA SHEET FOR WATER DEPTH AND TEMPERATURE } \\
\text { WFLTROMETER H- (E-S) }\end{array}$} \\
\hline DATE & $\begin{array}{c}\text { START } \\
\text { WAT. DEPTH } \\
\text { REAONV } \\
\text { (b) } \\
\end{array}$ & $\begin{array}{l}\text { START } \\
\text { WATER } \\
\text { DEPTH } \\
\text { (h.) } \\
\end{array}$ & $\begin{array}{c}\text { END } \\
\text { WAT. DEPTH } \\
\text { READWN } \\
\text { (in.) } \\
\end{array}$ & $\begin{array}{l}\text { END } \\
\text { WATER } \\
\text { DEPTH } \\
\text { (b) }\end{array}$ & $\begin{array}{l}\text { AVG. } \\
\text { WATER } \\
\text { DEPTH } \\
\text { (li) }\end{array}$ & $\begin{array}{l}\text { START } \\
\text { WATER } \\
\text { TENP } \\
\text { (Of) }\end{array}$ & $\begin{array}{c}\text { END } \\
\text { WATER } \\
\text { TEMP } \\
\text { (of) }\end{array}$ & $\begin{array}{c}\text { AVE. } \\
\text { WATER } \\
\text { TEMP } \\
\text { of }\end{array}$ & $\begin{array}{l}\text { TEMP. } \\
\text { CHANGE } \\
\text { (OF) }\end{array}$ \\
\hline 16-5ep & 9.0 & 11.8 & 9.00 & 11.8 & 11.8 & 74 & 74 & 74 & 0 \\
\hline 17-Sep & 9.0 & 11.8 & 9.00 & 11.8 & 11.8 & 74 & 76 & 75 & 2 \\
\hline 18-Sep & 9.0 & 11.8 & 9.00 & 11.8 & 11.8 & 76 & 76 & 76 & 0 \\
\hline 19-5ep & 9.0 & 11.8 & 8.75 & 11.5 & 11.6 & 76 & 75 & 76 & -1 \\
\hline 21-Sep & 8.8 & 11.5 & 8.75 & 11.5 & 11.5 & 75 & 77 & 76 & 2 \\
\hline 22-Sep & 8.8 & 11.5 & 8.75 & 11.5 & 11.5 & 77 & .78 & 78 & 1 \\
\hline 23-Sep & 8.8 & 11.5 & 8.75 & 11.5 & 11.5 & 78 & 76 & 77 & -2 \\
\hline 24-Sep & 8.8 & 11.5 & 9.00 & 11.8 & 11.6 & 76 & 67 & 72 & -9 \\
\hline 2S-Sep & 9.0 & 11.8 & 9.00 & 11.8 & 11.8 & 67 & 65 & 66 & -2 \\
\hline 26-Sep & 9.0 & 11.8 & 9.25 & 12.0 & 11.9 & 65 & 65 & 65 & 0 \\
\hline 29-Sep & 9.3 & 12.0 & 9.25 & 12.0 & 12.0 & 65 & 71 & 68 & 6 \\
\hline $30-5 e p$ & 9.3 & 12.0 & 9.00 & 11.8 & 11.9 & 71 & 64 & 68 & -7 \\
\hline 1-0ct & 9.0 & 11.8 & 9.00 & 11.8 & 11.8 & 64 & 63 & 64 & -1 \\
\hline $2-0 \mathrm{ct}$ & 9.0 & 11.8 & 9.00 & 11.8 & 11.8 & 63 & 61 & 62 & -2 \\
\hline 6-0ct & 9.0 & 11.8 & 10.25 & 13.0 & 12.4 & 61 & 60 & 61 & -1 \\
\hline g-oct & 9.5 & 12.3 & 11.25 & 14.0 & 13.1 & 60 & 66 & 63 & 6 \\
\hline $13-\infty c t$ & 11.3 & 14.0 & 9.75 & 12.5 & 13.3 & 66 & 60 & 63 & -6 \\
\hline 16-0ct & 9.8 & 12.5 & 9.25 & 12.0 & 12.3 & 60 & 64 & 62 & 4 \\
\hline $20-0 \mathrm{ct}$ & 9.3 & 12.0 & 9.00 & 11.8 & 11.9 & 64 & 55 & 60 & -9 \\
\hline 23-Oct & 9.0 & 11.8 & 9.00 & 11.8 & 11.8 & 55 & so & 57 & 3 \\
\hline 27-Ocet & 9.0 & 11.8 & 8.70 & 11.5 & 11.6 & 58 & 59 & 59 & 1 \\
\hline 30-0ct & 8.7 & 11.5 & 8.75 & 11.5 & 11.5 & 59 & 62 & 61 & 3 \\
\hline 3-Hor & 8.8 & 11.5 & 9.00 & 11.8 & 11.6 & 62 & 65 & 64 & 3 \\
\hline 6-Nov & 9.0 & 11.8 & 9.25 & 12.0 & 11.9 & 65 & 59 & 62 & -6 \\
\hline 10-Ator & 9.3 & 12.0 & 9.00 & 11.8 & 11.9 & 59 & 49 & 54 & -10 \\
\hline 13 Hov & 9.0 & 11.8 & 9.50 & 12.3 & 12.0 & 49 & 59 & 54 & 10 \\
\hline $17-\mathrm{HOV}$ & 9.5 & 12.3 & 9.00 & 11.8 & 12.0 & 59 & 46 & 53 & -13 \\
\hline 20-Nov & 9.0 & 11.8 & 9.25 & 12.0 & 11.9 & 46 & 49 & 48 & 3 \\
\hline 23-Hov & 9.3 & 12.0 & 9.25 & 12.0 & 12.0 & 49 & 60 & 55 & 11 \\
\hline 4-Dec & 9.3 & 12.0 & 9.00 & 11.8 & 11.9 & 60 & 45 & 53 & .15 \\
\hline 18-Dec & 9.0 & 11.8 & 9.25 & 12.0 & 11.9 & 45 & 45 & 45 & 0 \\
\hline 23-Dec & 9.3 & 12.0 & 9.25 & 12.0 & 12.0 & 45 & 45 & 45 & 0 \\
\hline 31-Dec & 9.3 & 12.0 & 9.25 & 12.0 & 12.0 & 45 & 45 & 45 & 0 \\
\hline 8-tan & 9.3 & 12.0 & 10.00 & 12.8 & 12.4 & 45 & 59 & 52 & 14 \\
\hline
\end{tabular}




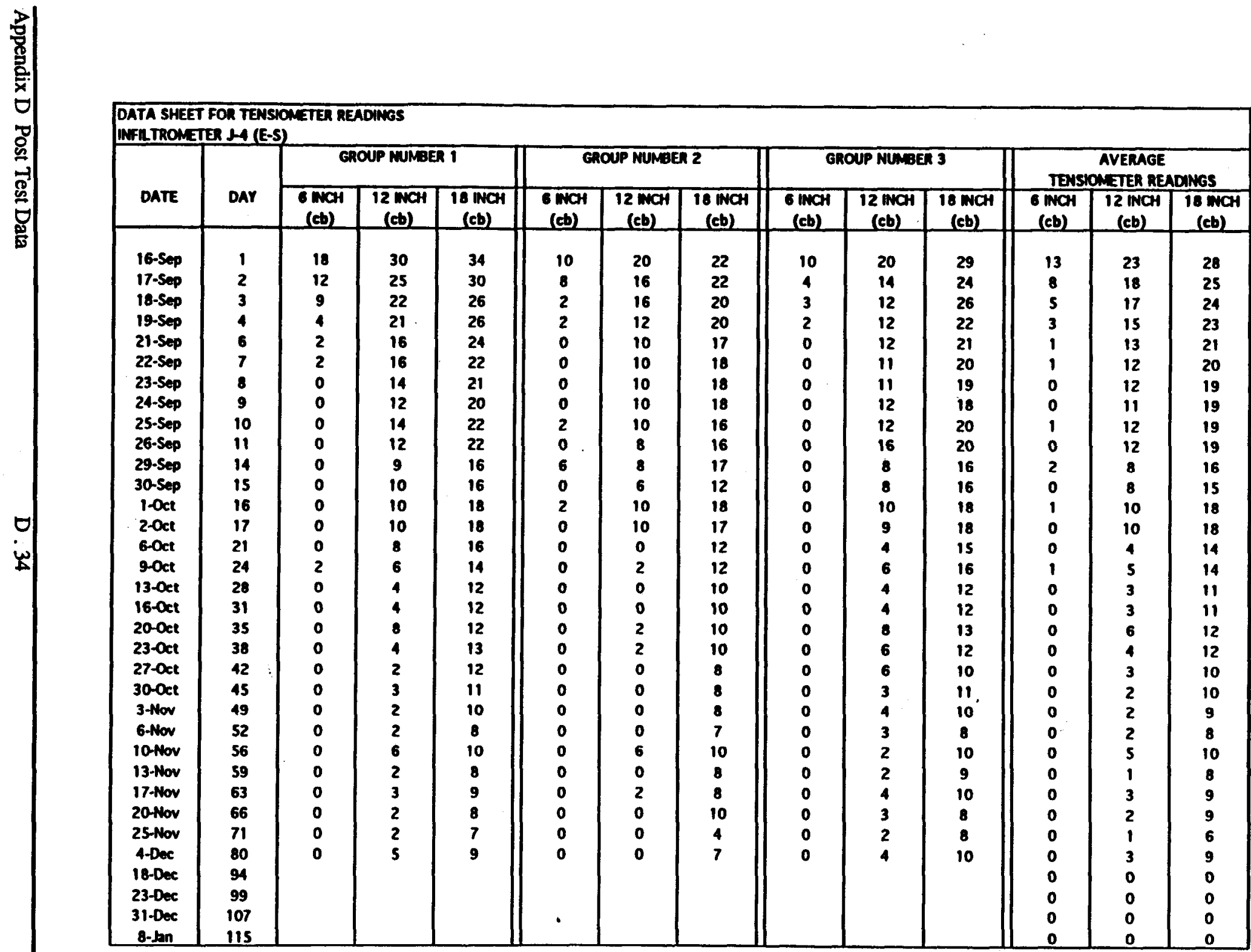




\begin{tabular}{|c|c|c|c|c|c|c|c|c|c|c|c|c|c|c|}
\hline \multicolumn{8}{|c|}{$\begin{array}{l}\text { DATA SHEET FON SWEL OATA } \\
\text { WFA TROMETER HA (E-S) }\end{array}$} & & \multicolumn{6}{|c|}{$\begin{array}{l}\text { CALCULATION SHEET FON FLOW-ATE AMD ADJUSTMENT VRLUES } \\
\text { WFLTROMETER J-A (E-S) }\end{array}$} \\
\hline \multirow[b]{2}{*}{$\begin{array}{l}\text { READING } \\
\text { DATE }\end{array}$} & \multirow[b]{2}{*}{$\begin{array}{c}\text { READANO } \\
\text { TMEE } \\
\end{array}$} & \multirow[b]{2}{*}{$\begin{array}{ll}\text { Dar } \\
\text { momege }\end{array}$} & \multicolumn{4}{|c|}{ SWELl MFORMATION } & \multirow{2}{*}{$\begin{array}{l}\text { AVG. } \\
\text { SWELI } \\
(\mathrm{mm})\end{array}$} & \multirow[b]{2}{*}{$\begin{array}{l}\text { Dar } \\
\text { NO. }\end{array}$} & \multirow[b]{2}{*}{$\underset{\text { (m) }}{Q}$} & \multirow[b]{2}{*}{$\begin{array}{l}\text { AVG } \\
\text { Dar wo. }\end{array}$} & \multirow[b]{2}{*}{$\begin{array}{c}1 \\
(\mathrm{em} / \mathrm{enc}) \\
\end{array}$} & \multirow{2}{*}{$\begin{array}{c}\text { EST. FLOW } \\
\text { DUE TO } \\
\text { TEM. CHS. } \\
\text { (w) }\end{array}$} & \multirow{2}{*}{$\begin{array}{l}\text { \%OF } \\
\text { TOTAL } \\
\text { FLOW } \\
\text { (mi) }\end{array}$} & \multirow{2}{*}{$\begin{array}{c}\text { Q } \\
\text { MHEN DAO } \\
\text { WAS OFF } \\
\text { (ad) }\end{array}$} \\
\hline & & & s1 & $\mathbf{s 2}$ & $\mathbf{s 3}$ & s4 & & & & & & & & \\
\hline 15-Sep & \begin{tabular}{|l|}
$17: 05$ \\
\end{tabular} & 0 & 42.3 & 27.8 & 20.2 & 56.2 & 3.73 & 0 & & & & & & \\
\hline 16-Sep & 9.10 & 1 & 41.0 & 28.6 & 20.8 & 55.6 & 3.85 & 1 & • & - & • & 0.0 & - & • \\
\hline 17-Sep & $14: 46$ & 2 & 11.4 & 28.0 & 21.4 & 56.0 & 3.65 & 2 & 453.5 & $\mathbf{1}$ & 2.42E-07 & 33.3 & 7.4 & -454 \\
\hline 10-Sep & 16:22 & 3 & 40.4 & 27.9 & 21.1 & 55.4 & 4.15 & 3 & - & - & $\cdot$ & 0.0 & & 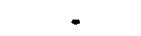 \\
\hline 19-Sep & 11:15 & 4 & 41.2 & 28.3 & 21.7 & 54.9 & 3.83 & 4 & 838.1 & 3 & $2.29 E-07$ & -16.7 & 2.0 & -862 \\
\hline 21-Sep & 13:35 & 6 & 41.6 & 29.1 & 22.2 & 36.8 & 2.93 & 6 & 890.7 & 5 & 2.21E-07 & 33.3 & 3.7 & 33 \\
\hline 22-Sep & 15:03 & 7 & 42.3 & 30.0 & 22.4 & 57.1 & 240 & 7 & 469.1 & 6 & $2.32 E-07$ & 16.7 & 3.6 & 6 \\
\hline 23-Sep & 10:37 & 8 & 41.9 & 29.4 & 22.3 & 56.8 & 2.75 & 8 & 530.0 & 7 & 2.98E-07 & -33.3 & 6.3 & 10 \\
\hline 24-Sep & 11:38 & 9 & 42.0 & 29.5 & 22.9 & 57.2 & 2.45 & 9 & 298.0 & 8 & 1.5AE-07 & .150 .0 & 50.3 & 18 \\
\hline 25-Sep & 14:10 & 10 & 56.7 & 31.3 & 34.2 & 71.1 & -7.98 & 10 & 574.8 & 9 & $2.69 E-07$ & -33.3 & 5.8 & -4 \\
\hline 26-Sep & $10: 43$ & 11 & 62.0 & 32.8 & 24.5 & 74.1 & -8.00 & 11 & 413.5 & 10 & 2.29E-07 & 0.0 & 0.0 & 7 \\
\hline 29-Sep & 13:31 & 14 & 78.9 & 34.5 & 27.5 & 92.6 & -18.03 & 14 & 1227.0 & 12 & $1.97 E-07$ & 100.0 & 8.1 & 14 \\
\hline 30-Sep & 13:25 & 15 & 75.5 & 34.3 & 27.9 & 86.6 & -15.73 & 15 & 430.1 & 14 & 2.13E-D7 & .116.7 & 27.1 & 7 \\
\hline $1-0 c t$ & 15:03 & 16 & 76.1 & 35.0 & 28.0 & 86.4 & -16.03 & 16 & 325.2 & 15 & $1.75 E-07$ & -16.7 & 5.1 & 7 \\
\hline $2-0 \mathrm{ct}$ & 13:09 & 17 & 75.5 & 33.9 & 27.8 & 86.6 & -15.60 & 17 & 310.6 & 16 & $1.58 E-07$ & -33.3 & 10.7 & 8 \\
\hline 6-0ct & $10: 02$ & 21 & 95.5 & 36.6 & 29.9 & 106.0 & -26.65 & 21 & 1024.8 & 19 & 1.35E-07 & -16.7 & 1.6 & 7 \\
\hline $9-0<t$ & $12: 20$ & 24 & 126.7 & 50.6 & 45.5 & 138.5 & -49.98 & 24 & 949.5 & 22 & $1.50 E-07$ & 100.0 & 10.5 & 4 \\
\hline 13-0et & 10:07 & 28 & 129.9 & 78.4 & 68.7 & 141.0 & -64.15 & 28 & 510.6 & 26 & 6.55E-08 & -100.0 & 19.6 & 4 \\
\hline 16-att & 8:27 & 31 & 60.5 & 44.7 & 38.7 & 72.6 & -13.78 & 31 & 610.2 & 29 & 1.03E-07 & 66.7 & 10.9 & 3 \\
\hline $20-0 \mathrm{ct}$ & 11:13 & 35 & 64.4 & 45.8 & 39.4 & 76.4 & -16.15 & 35 & 387.9 & 33 & 4.84E-08 & -150.0 & 38.7 & 4 \\
\hline $23-0 \mathrm{ct}$ & 13:50 & 38 & 65.8 & 41.2 & 47.4 & 77.3 & -17.58 & 36 & 699.3 & 36 & 1.14E-07 & 50.0 & 7.2 & 7 \\
\hline $27-0 \mathrm{ct}$ & 10:15 & 12 & 63.3 & 47.5 & 40.8 & 75.8 & -16.50 & 42 & 669.6 & 40 & 8.79E-08 & 16.7 & 2.5 & 12 \\
\hline 30-0et & 11:32 & 45 & 61.5 & 42.4 & 37.5 & 74.4 & -13.60 & 45 & 566.3 & 43 & $9.07 E-08$ & 50.0 & 8.8 & 3 \\
\hline 3-Hov & $8: 37$ & 49 & 35.6 & 39.5 & 34.3 & 66.3 & -8.58 & 49 & 202.7 & 47 & 2.66E-08 & 50.0 & 24.7 & 1 \\
\hline $6+$ thor & 10:53 & 52 & 60.3 & 41.4 & 35.6 & 71.8 & -11.93 & 52 & 165.8 & so & 2.69E-08 & -100.0 & 60.3 & 4 \\
\hline 10-rlov & $10: 35$ & 56 & 82.4 & 49.4 & 43.2 & 95.4 & -27.25 & 56 & 547.3 & 54 & $6.90 E-08$ & . 166.7 & 30.5 & 9 \\
\hline 13-Hov & 9.57 & 59 & 95.6 & 53.2 & 47.2 & 108.1 & -35.68 & 59 & 883.9 & 57 & 1.5IE-07 & 166.7 & 18.9 & 4 \\
\hline 17-Nov & 10:44 & 63 & 97.8 & 57.3 & 48.4 & 111.5 & -38.40 & 63 & 266.0 & 61 & 3.32E-08 & -216.7 & 81.5 & 3 \\
\hline 20-Nov & 10:18 & 66 & 82.1 & 57.5 & 48.4 & 82.9 & -27.38 & 66 & 539.9 & 64 & 9.04E-08 & 50.0 & 9.3 & 6 \\
\hline 25-Nov & 10:08 & 71 & 80.4 & 80.7 & 70.1 & 106.2 & -44.00 & 71 & 1248.1 & 68 & $1.25 E-07$ & 183.3 & 14.7 & 5 \\
\hline 4-Dec & $10: 00$ & 80 & 60.1 & 36.5 & 32.8 & 71.5 & -9.88 & 80 & 768.3 & 75 & 4.27E-08 & -250.0 & 32.5 & 2 \\
\hline 18-Dec & $10: 00$ & 94 & 60.1 & 36.3 & 32.8 & 71.5 & -9.88 & 94 & 445.6 & 87 & $1.57 E-08$ & 0.0 & 0.0 & ו- \\
\hline 23-Dec & $10: 00$ & 99 & 60.1 & 36.5 & 32.8 & 71.5 & -9.88 & 99 & -668.0 & 96 & $-6.87 E-08$ & 0.0 & 0.0 & -1 \\
\hline 31-Dec & 10:00 & 107 & 60.1 & 36.5 & 32.8 & 71.5 & -9.88 & 107 & 461.5 & 103 & $2.88 E-08$ & 0.0 & 0.0 & 2 \\
\hline 8-bn & $10: 00$ & 115 & 60.1 & 36.5 & 32.8 & 71.5 & -9.88 & 115 & 600.8 & 111 & 3.70E-08 & 233.3 & 38.8 & \\
\hline
\end{tabular}




\begin{tabular}{|c|c|c|c|c|c|c|c|c|}
\hline \multicolumn{9}{|c|}{$\begin{array}{l}\text { CALCOLATION SHEET FOR HYDRAULC CONOUCTIVIT } \\
\text { WFR TRONETER D-1 (E-S) }\end{array}$} \\
\hline 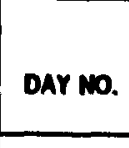 & $\begin{array}{c}x 10-7 \\
1 \\
(\mathrm{~cm} / \mathrm{sec})\end{array}$ & $\begin{array}{c}\text { WATER } \\
\text { OEPTH } \\
\text { (b) }\end{array}$ & $\begin{array}{c}\text { W. FRONT } \\
\text { DEPTH } \\
\text { (in) }\end{array}$ & GRADENT & Dar mo. & $4 \%$ & $\begin{array}{c}\text { x10-7 } \\
\text { sweul } \\
1 \\
(\mathrm{~cm} / \mathrm{sec})\end{array}$ & 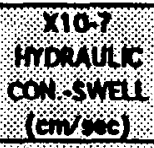 \\
\hline 1 & - & 11.75 & - & - & 1 & 8 & - & 8 \\
\hline 2 & 2.4 & 11.75 & 3.33 & 4.53 & 2 & 03 & 2.42 & 0.93 \\
\hline 3 & $\cdot$ & 11.75 & • & *REFI & 3 & \% & - & 1.\% \\
\hline 4 & 2.3 & 11.63 & 6.11 & 2.90 & 4 & $8 \%$ & 2.29 & 019 \\
\hline 6 & 2.2 & 11.50 & 9.26 & 2.24 & 6 & 10 & 2.21 & 0.98 \\
\hline 7 & 2.3 & 11.50 & 2.71 & 5.24 & 7 & 18 & 2.32 & 0,1 \\
\hline 8 & 3.0 & 11.50 & 3.02 & 4.81 & 8 & 86 & 2.98 & 0.62 \\
\hline 9 & 1.5 & 11.63 & 3.41 & 4.41 & 9 & 03 & 1.54 & $\mathbf{\alpha s}$ \\
\hline 10 & 2.7 & 11.75 & 3.83 & 4.07 & 10 & $0 \%$ & 2.69 & 066 \\
\hline 11 & 2.3 & 11.88 & 4.14 & 3.87 & 11 & 80 & 2.29 & 059 \\
\hline 14 & 2.0 & 12.00 & 5.31 & 3.26 & 14 & 06 & 1.97 & 060 \\
\hline 15 & 2.1 & 11.88 & 5.69 & 3.09 & 15 & $0 \%$ & 2.13 & 0,69 \\
\hline 16 & 1.7 & 11.75 & 6.09 & 2.93 & 16 & 0.6 & 1.75 & 0.60 \\
\hline 17 & 1.6 & 11.75 & 6.43 & 2.83 & 17 & 06 & 1.58 & 056 \\
\hline 21 & 1.4 & 12.38 & 7.88 & 2.57 & 21 & 03 & 1.35 & 0.53 \\
\hline 24 & 1.5 & 13.13 & 4.82 & 3.72 & 24 & $0 \%$ & 1.50 & 0.40 \\
\hline 28 & 0.7 & 13.25 & 5.61 & 3.36 & 28 & 02 & 0.66 & 019 \\
\hline 31 & 1.0 & 12.25 & 6.19 & 2.98 & 31 & 00 & 1.03 & 0.36 \\
\hline 35 & 0.5 & 11.88 & 7.01 & 2.69 & 35 & $8 \%$ & 0.48 & 098 \\
\hline 38 & 1.1 & 11.75 & 7.64 & 2.54 & 38 & 01 & 1.14 & 0,1 \\
\hline 42 & 0.9 & 11.60 & 8.41 & 2.38 & 42 & $0 \%$ & 0.88 & 037 \\
\hline 45 & 0.9 & 11.48 & 9.02 & 2.27 & 45 & 09 & 0.91 & 0.40 \\
\hline 49 & 0.3 & 11.63 & 9.79 & 219 & 49 & $0 \%$ & 0.27 & 0.12 \\
\hline 52 & 0.3 & 11.88 & 10.41 & 2.14 & 52 & 01 & 0.27 & 0.13 \\
\hline 56 & 0.7 & 11.88 & 11.21 & 2.06 & 56 & 03 & 0.69 & 033 \\
\hline 59 & 1.5 & 12.00 & 11.80 & 2.02 & 59 & 07 & 1.51 & $0 \%$ \\
\hline 63 & 0.3 & 12.00 & 12.61 & 1.95 & 63 & 02 & 0.33 & 0.17 \\
\hline 66 & 0.9 & 11.88 & 13.21 & 1.90 & 66 & 03 & 0.90 & 0.48 \\
\hline 71 & 1.3 & 12.00 & 14.21 & 1.84 & 71 & 07 & 1.25 & 0.66 \\
\hline 80 & 0.4 & 11.88 & 16.00 & 1.74 & 80 & 02 & 0.43 & 025 \\
\hline 94 & 0.2 & 11.88 & 18.80 & 1.63 & 94 & 01 & 0.16 & 010 \\
\hline 99 & -0.7 & 12.00 & 19.80 & 1.61 & 99 & 04 & -0.69 & 043 \\
\hline 107 & 0.3 & 12.00 & 21.40 & 1.56 & 107 & 02 & 0.29 & 018 \\
\hline 115 & 0.4 & 12.38 & 23.00 & 1.54 & 115 & 0.2 & 0.37 & 0.24 \\
\hline
\end{tabular}

